(1)

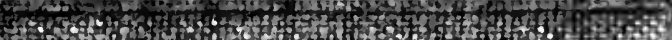



Frank, Vinsters 




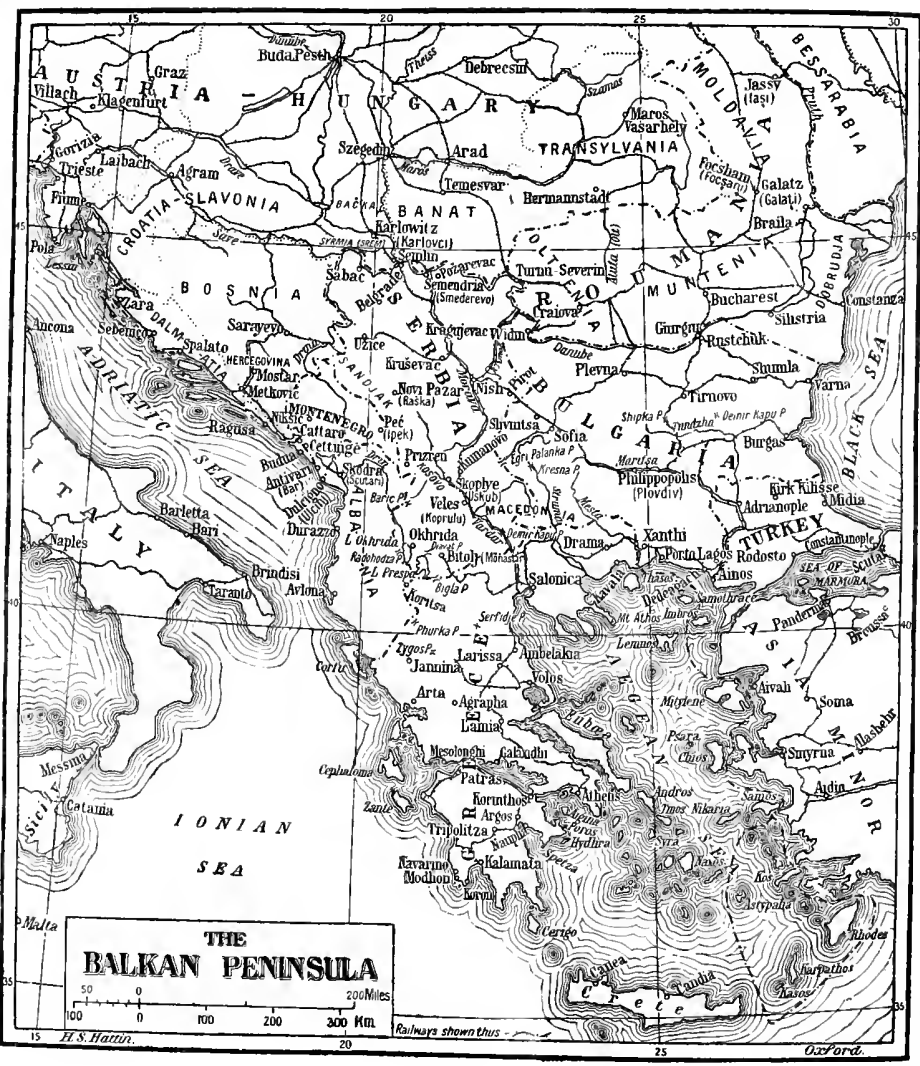




\title{
THE
}

\section{EASTERN QUESTION}

AN HISTORICAL S'TUDY

IN

\section{EUROPEAN DIPLOMACY}

BY

\author{
J. A. R. MARRIO'T'T
}

FELLOW OF WORCESTER COLLEGE, OXFORD; M.P. FOR THE CITY OF OXFORI

OXFORD

A'T 'THE CLARENDON PRESS

1917 


\section{OXFORD UNIVERSITY PRESS \\ LONDON EDINBURGH GLASGOW NEW YORK \\ TORONTO MELBOURNE CAPE TOWN EOMBAY \\ HUMPHREY MILFORD \\ PUBLISHER TO THE CNIVERSITY}




\section{PREFACE}

'The Eastern Question has by degrees assumed such large proportions that no one can be surprised at the space it occupies in all public discussions whether of the tongue or of the pen.' So Lord Stratford de Redcliffe wrote to The Times on September 9, 1876. His words testified to a notorious fact. The fact has not become less notorious during the forty years since the words were written nor have the proportions assumed by the Eastern Question become less ample. In view of these facts it is the more surprising that English Historical Literature should still lack any systematic and continuous accomt of the origin and development of the Eastern Question.

Monographs exist in plenty on special aspects of the problem, and many general Histories of Europe contain useful chapters on the subject, but I do not know of any book in English which attempts the task which in the present work I have set before myself.

The main lines of this book were laid down many years ago ; the subject has formed part of my academic teaching; for this purpose my material has been under constant revision, and some of it has been utilized for articles recently contributed to the Edinburgh Review, the Fortnightly Review, and the Nineteenth Century and After. To the proprietors and editors of these Reviews I am indebted for permission to reproduce portions of my articles, but none of them are reprinted in extenso. Elsewhere, in the course of my protracted journey, I have come across traces of $\mathrm{my}$ own footsteps, indicating the route of previous historical excursions. In such cases I have not been careful to avoid them, and here and there I have incorporated whole para- 
graphs from earlier works, for I was long ago impressed by the warning that a man may say a thing once as he would have it said, but he cannot say it twice.

To each chapter I have suffixed a list of authorities which will I trust be found useful by students, by teachers, and by the 'general reader' who may desire further information on special topics which in a work like the present must needs be somewhat summarily dismissed. To stimulate such euriosity and to encourage more detailed research are among the main objects which I have had in view. But my primary purpose has been to provide for those who are in any degree charged with the responsibility for the solution of a most complex political problem an adequate basis of historical knowledge. A knowledge of the past is not in itself sufficient to solve the problems of the present; but no solution is likely to be effective or enduring which is not based upon such knowledge. Least of all in the case of a problem which, like that of the Near East, includes numerous factors which are intelligible only in the light of past events, many of them remote, and most of them obscure.

Especially obscure are the facts of the political geography of the Balkans. My numerous maps are intended to elucidate them, and if they are found to fulfil their purpose at all adequately it is mainly owing to the kind help of my friend and colleague Mr. C. Grant Robertson, M.A., C.V.O., of All Souls College, and to the extraordinary patience and care bestowed upon their preparation by the Assistant Secretary to the Delegates of the Press. But every student of historical geography will acknowledge the difficulty of the task. Among the maps will be found one on Balkan Ethnography which no one should consult without taking heed to Sir Charles Eliot's warning: 'every Ethnographic map of the Balkan Peninsula gives a different view of the arrangement of the populations.' In truth precision is unattainable, and the map must be accepted only as a rough indication of the distribution of races. 
In the accomplishment of my task I have incurred many obligations to friends which it is a duty and a pleasure to acknowledge. Sir Arthur Evans kindly allowed me to consult him on one or two geographical points ; Dr. Holland Rose of Cambridge and Professor Alison Phillips of Dublin were good enough to reply in some detail to questions addressed to them, while to Dr. R. W. Macan, Master of University College, and to Mr. Grant Robertson I owe a debt which I find it difficult to acknowledge in terms which shall be at once adequate to my own sense of gratitude and not repugnant to them. Both these distinguished scholars have subjected my proof sheets to the most careful revision, and from both $\mathrm{I}$ have received invaluable suggestions. My obligations to writers who have covered parts of the same ground are, it is needless to add, exceedingly numerous, but I trust that they have been acknowledged in the foot-notes and bibliographies. For any macknowledged or unwitting appropriation I crave pardon. To the modern school of French historians my debt is particularly heavy, and I desire to pay my respectful homage to the skill with which they combine massive erudition with a brilliance of exposition which none may hope to rival. Neither in French, however, nor in any other language have I come across any book which is identical in scope and purpose with my own, and though no one can be more conscions than myself both of the inadequacy of my equipment and the imperfection of my execution, yet I have no misgivings as to the importance or the timeliness of the task I have essayed. The author may have dared too much; but the book itself was overdue.

\section{J. A. R. MARRIOTT.}

OXFORD,

Easter Eve (April †), 1917. 



\section{CONTENTS}

CHAP.

PAGE

I. INTroductory. The Problem of the Near East 1

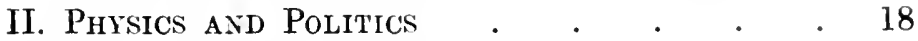

III. The Advent of the Ottomans. Conquests in Europe . $\quad . \quad$. $\quad . \quad$. $\quad$. 37

IV. The OtTouAn Enpire: its Zenith, 1453-1566. Suleiman the Magnificent . . . . $\quad 66$

V. The Decadence of the Ottoman EMrire. Contest with Venice and the Habsburgs . . 95

VI. The Easteri Question in The Eighteenth

Century. Russia and Turkey, 1689-1792.

1. From the Treaty of Carlowitz to the Treaty of Belgrade, 1699-1739 . . . . . 116

2. From the Treaty of Belgrade to the Treaty of Kutschuk-Kainardji, 1739-1774 . . . 128

3. Austro-Russian Alliance, 1775-1792 . . 138

VII. Napoleon and the Near Eastern Problem.

1. West and East, 1797-1807 . . . . . 148

2. The Ottoman Empire and the Resurrection of Serbia . . . . . . . 159

3. Napoleon and Alexander . . . . 164

VIII. The Strugale for Hellenic Independence • 173

IX. The Powers and The Eastern Question, 18301841. Mehemet Ali of Egypt. . . . 201

X. The Crimean War . . . . . . . 222

XI. The Making of Roumania $\quad$ • • • • 253

XII. The Balkan Ixsurrections. The Southern

Slavs. The Russo-Turkish War. The Powers and the Eastern Question, 1856-1878 • . : 274 
CHAP.

XIII. The Balkan States, 1878-1898. The Making of Bulgaria. Modern Greece (1832-1898). The Cretan Problem

XIV. A New Factor in the Problem. German Policy in the Near East, 1888-1908

XV. The Macedonian Problem. Habsburg Policy in the Balkans. The Young Turk Revolution

XVI. The Balkan League and the Balkan Wars 386

XVII. Epilogue, 1914-1916

Appendix A: List of Ottoman Rulers . . . 445

Appendix B: Genealogies . . . . . . . 446

Appendix C: Shrinkage of the Ottoman Empire in Europe, 1817-1914 . . . . . . . 449

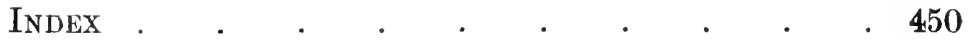

\section{LIST OF MAPS}

The Balgans: Physical Features . . . . 23

The Balkans : Roman Empire . . . . . 28

Balikan Railways, 1914 . $\quad . \quad$. $\quad$. $\quad$. 29

The Otтoman Empire, except the Arabian and African Provinces . . . . . . . . . . 36

The Balkan Peninsula: Ethnological . . . 40

Mediaeval Bulgaria. A. D. 900-1019 . . . . 48

Mediaeval Kingdom of Serbia. Stephen Dushan . 50

Frontiers of States in 1912 ; Aspirations of

Roumania, Bulgaria, Serbia, and Greece • 387

Balkan States, 1878-1914, showing acquisitions of

Montenegro, Roumania, Bulgaria, Serbia, and

Greece, 1913, and the territory ceded to Bulgaria and retroceded to Turkey, 1913 . . . . 


\section{CHAPTER I}

\section{INTRODUCTORY}

\section{The Problem of the Near East}

' That shifting, intractable, and interworen tangle of conflicting interests, rival peoples, and antagonistic faiths that is veiled under the easy name of the Eastern Question.'-JoHx MorLEY.

Frox time immemorial Europe has been confronted with The an 'Eastern Question'. In its essence the problem is un- problen changing. It has arisen from the clash in the lands of SouthEastern Europe between the habits, ideas, and preconceptions of the West and those of the East. But although one in essence, the problem has assumed different aspects at different periods. In the dawn of authentic history it is represented by the contest between the Greeks and the Persians, the leroic struggle enshrined in the memory of Marathon, Thermopylae, and Salamis. To the Roman the 'Eastern Question' centred in his duel with the great Hellenistic monarchies. In the early Middle Ages the problem was represented by the struggle between the forces of Islam and those of Christianity. That struggle reached its climax, for the time being, in the great battle of Tours (732). The chivalry of Western Europe renewed the contest, some centuries later, in the Crusades. The motives which inspired that movement were curiously mixed, but essentially they afforded a further manifestation of the secular rivalry between Cross and Crescent ; a contest between Crusaders and Infidels for possession of the lands hallowed to every Christian by their association with the life of Christ on earth.

With none of these earlier manifestations of an immemorial antithesis is this book concerned. Its main purpose is to sketch the historical evolution of a problem which has baffled the ingenuity of European diplomatists, in a general sense, for more than five hundred years, more specifically 
and insistently for about a century. In the vocabulary of English diplomacy the Eastern Question was not included until the period of the Greek War of Independence (1821-9), though the phrase is said to be traceable at least as far back as the battle of Lepanto (1571). A definition of the 'Question', at once authoritative and satisfactory, is hard to come by. Lord Morley, obviously appreciating the difficulty, once spoke of it, with characteristic felicity, as 'that shifting, intractable, and interworen tangle of conflicting interests, rival peoples, and antagonistic faiths that is veiled under the easy name of the Eastern Question'. A brilliant French writer, II. Édouard Driault, has defined it as Le problème de la mine de la puissance politique de l'Islam. But this definition seems unnecessarily broad. Dr. Miller, with more precision, has explained it thus: 'The Near Eastern Question may be defined as the problem of filling up the vacuum created by the gradual disappearance of the Turkish Empire from Europe.' But though this definition is unexceptionable as far as it goes, our purpose seems to demand something at once more explicit and more explanatory. Putting aside the many difficult problems connected with the position of Ottoman power in Asia and Africa, the 'Eastern Question' may be taken, for the purpose of the present survey, to include :

First and primarily: The part played by the Ottoman Turks in the history of Europe since they first crossed the Hellespont in the middle of the fourteenth century ;

Secondly: The position of the loosely designated Balkan States, which, like Greece, Serbia, Bulgaria, and Roumania, have gradually re-emerged as the waters of the Ottoman flood have subsided; or, like Montenegro, were never really submerged; or, like Bosnia, the Herzegovina, Transylvania, and the Bukovina, have been annexed by the Habsburgs ;

Thirdly : The problem of the Black Sea ; egress therefrom, ingress thereto; the command of the Bosphorus and the Dardanelles, and, above all, the capital problem as to the possession of Constantinople;

Fourthly: The position of Russia in Europe; her natural 
impulse towards the Mediterranean; her repcated attempts to secure permanent access to that sea by the narrow straits ; her relation to her co-religionists under the sway of the Sultan, more particularly to those of her own Slavonic nationality ;

Fifthly: The position of the Habsburg Empire, and in particular its anxiety for access to the Aegean, and its relations, on the one hand, with the Southern Slars in the annexed provinces of Dalmatia, Bosnia, and the Herzegovina, as well as in the adjacent kingdoms of Serbia and Montenegro ; and, on the other hand, with the Roumans of Transylvania and the Bukorina; and

Finally: The attitude of the European Powers in general, and of England in particular, towards all or any of the questions enumerated above.

The primary and most essential factor in the problem is, The then, the presence, embedded in the living flesh of Europe. Ottoman of an alien substance. That substance is the Ottoman Turk. Akin to the European family neither in creed, in race, in language, in social customs, nor in political aptitudes and traditions, the Ottomans have for more than fire hundred years presented to the other European Powers a problem, now tragic, now comic, now bordering almost on burlesque, but always baffling and paradoxical. The following pages, after sketching the settlement of this nomad people in Anatolia, will describe their momentous passage from the southern to the northern shore of the Hellespont; their encampment on European soil ; their gradual conquest of the Balkan peninsula ; their overthrow of the great Serbian Empire; their reduction of the kingdom of Bulgaria; and finally, by a successful assault upon Constantinople, theil annihilation of the last feeble remnant of the Roman Empire of the East.

From Constantinople we shall see the Ottomans advancing Conquests to the conquest of the whole of the Eastern basin of the in Europe Mediterranean : the Aegean islands, Syria, Egypt, and the northern coast of Africa. The zenith of their power was attained with remarkable rapidity. Before the end of the 
sixteenth century it was already passed. The seeds of decay were indeed sown, even if they were not yet discernible, during the reign of Suleiman the Magnificent (1520-66), a period generally accounted the noontide of Ottoman greatness and prosperity. Within five years of Suleiman's death the great naval disaster at Lepanto (1571) had revealed to an astonished world the obvious weakening of Ottoman morale and the waning of their power at sea.

Decadence.

Political decay was temporarily arrested during the following century. But for any success achieved by the Turks the Sultans were no longer personally responsible. Not one of the Sultans of the seventeenth century, nor for that matter of the eighteenth, left any impress upon the page of Ottoman history. The revival of Turkish prestige in the seventeenth century was due to a remarkable Albanian family, the Kiuprilis ; but that revival rested upon no substantial foundations, and its evanescent character was clearly manifested before the century had drawn to a close. The failure of the Moslems to take adrantage of the distractions of their Christian enemies during the Thirty Years' War (1618-48) was in itself symptomatic of a loss of energy and initiative. Still more significant were the reverses sustained by Turkish arms. At the great battle of St. Gothard (1664) Montecuculi proved that the Ottomans were no longer invincible on land, as Don John had demonstrated at Lepanto that they were no longer invincible by sea.

Twenty years later the Vizier, Kara Mustapha, did indeed carry the victorious arms of Turkey to the gates of Vienna. But the Polish King, John Sobieski, snatched from him the supreme prize; saved the Austrian capital; and relieved Europe from the nightmare by which it had long been oppressed.

From that moment (1683) the Turks ceased to be a menace to Christendom. The Habsburgs inflicted a series of crushing defeats upon them in the north; the Venetians conquered the Morea; while France was so decply involved in Western Europe that she could do little to help the Power with whom she had so long been allied in the East. The Treaty of Carlowitz, concluded in 1699 between the Habsburgs 
and the Turks, supplemented by that of Azov, dictated by Russia in 1702, afforded conclusive evidence that the tide had turned. For two and a half eenturies the Ottomans had been the scourge of Christendom and had seriously threatened the security of the European polity. The menace was now dissipated for ever. John Sobieski's brilliant exploit was in this sense decisive. The advance of the Moslem was finally arrested, and the first phase of the Eastern Question had closed.

Only, howerer, to give place to another less alarming but Change in more perplexing. Ever since the early year's of the eighteenth of the century Europe has been haunted by the apprehension of rroblem. the consequences likely to ensue upon the demise of the sick man, and the subsequent disposition of his heritage. For nearly two hundred years it was assumed that the inheritance would devolve upon one or more of the Great Powers. That the submerged nationalities of the Balkan peninsula would ever again be in a position to exercise any decisive influence upon the destinies of the lands they still peopled was an idea too remote from actualities to engage even the passing attention of diplomacy. From the days of Alberoni ingenious diplomatists in long suceession have amused themselves by devising schemes for the partition of the Ottoman Empire, but none of these schemes paid any heed to the claims of the indigenous inhabitants. It would, indeed, have been remarkable if they had; for from the fifteenth eentury to the nineteenth nothing was heard and little was known of Bulgar, Slav, Rouman, or Greek. The problem of the Near East coneerned not the peoples of the Balkans, but the Powers of Europe, and among the Powers primarily Russia.

In its second phase (1702-1820) the Eastern Question might Relations indeed be defined as the Relations of Russia and Turkey. of $\mathrm{P}$ The Habsburgs were frequently on the stage, but rarely in Turkes. the leading rôle, and the part they played became more and more definitely subsidiary as the eighteenth eentury adranced. From the days of Peter the Great to those of Alexander I Europe, not indeed without spasmodic protests from France, acquiesced in the assumption that Russia might 
fairly claim a preponderant interest in the settlement of the Eastern Question. This acquiescence seems to a later generation the more remarkable in view of the fact that Russia herself had so lately made her entrance upon the stage of European politics. Perhaps, however, this fact in itself explains the acquiescence. Russia was alreadypushing towards the Black Sea before Western Europe recognized her existence. By 1774 her grip upon the inland sea was firmly established, and she was already looking to the possibilities of egress into the Mediterranean. The Treaty of Kainardji, concluded in that year, not only provided ample excuse for subsequent interference in the Balkans, but gave Russia the right of establishing a permanent embassy at Constantinople. The Treaties of Jassy (1792) and Bucharest (1812) carried her two stages further towards her ultimate goal. But by this time new factors in the problem were beginning to operate.

France and the

Near

East.
English Policy.
France had never been ummindful of her interests in the Eastern Mediterranean. By the capitulations of 1535 Francis I had obtained from Suleiman the Magnificent considerable trading privileges in Egypt. D'Argenson, in 1738, published an elaborate plan for the construction of a canal through the Isthmus of Suez and for restoring, by the enterprise of French traders and the efforts of French administrators, political order and commercial prosperity in Egypt. In the negotiations between Catherine II and the Emperor Joseph for the partition of the Ottoman dominions the interests of France were recognized by the assignment of Egypt and Syria to the French monarch.

But it was Napoleon who first concentrated the attention of the French people to the high significance of the problem of the Near East. The acquisition of the Ionian Isles ; the expedition to Egypt and Syria ; the grandiose schemes for an attack on British India ; the agreement with the Tsar Alexander for a partition of the Ottoman Empire-all combined to stir the imagination alike of traders and diplomatists in France.

And not in France only. If Napoleon was a great educator of the French, still more was he an educator of the English. For some two hundred years English merchants had been. 
keenly alive to the commercial value of the Levant. The politicians, however, were curiously but characteristically tardy in awakening to the fact that the development of events in the Ottoman Empire possessed any political significance for Eugland. The statesmen of the eighteenth century observed with equal unconcern the decrepitude of the Turks and the advance of the Russians. The younger litt was the first and only one among them to display any interest in what, to his successors in Downing Street, became known as the Eastern Question. With a prescience peculiar to himself he perceived that England was supremely concerned in the ultimate solution of that problem. His earliest diplomatic achierement, the Triple Alliance of 1788, was designed largely, though not exclusively, to circumscribe Russian ambitions in the Near East. But his apprehensions were not shared by his contemporaries. Few English statesmen have commanded the confidence and the ear of the House of Commons as Pitt commanded them. Yet even Pitt failed to arouse attention to this subject, and when in 1790 he proposed a naval demonstration against Russia he suffered one of the few checks in his triumphant parliamentary career. The enemies of England were less slow to perceive where her vital interests lay. 'Really to conquer England,' said Napoleon, 'we must make ourselves masters of Egypt.'

Hence the importance attached by General Bonaparte, at the very outset of his political career, to the acquisition of the Ionian Isles. Corfu, Zante, and Cephalonia were, he declared in 1797, more important for France than the whole of Italy. They were the stepping-stones to Egypt ; Egypt was a stage on the high road to India. Hardly a generation had elapsed since Clive, stremuously seconded by the elder Pitt, had turned the French out of India. To Egypt, therefore, the thoughts of Frenchmen naturally turned, not only as affording a guarantee for the maintenance of French commercial interests in the Near East, but as a means of threatening the position so recently acquired by England in the Further East. These ideas constantly recur in the reports of French ambassadors at the Porte, and Talleyrand, on taking office, found, as he tells us, his official portfolio bulging with schemes for 
the conquest of Egypt. ${ }^{1}$ Napoleon, therefore, in this as in other things, was merely the heir and executor of the traditions of the Ancien régime. He brought, however, to the execution of these schemes a vigour which, of late years, the old monarchy had conspicuously lacked. But even Napoleon was only partially successful in arousing the attention of the English people to the importance of the Eastern Mediterranean. The decrepitude of the Turk, the advance of Russia, the ambitions of France were all regarded as the accentuation of a problem that was local rather than European.

The Not until the events which followed upon the insurrection

Greek Revolution. of the Greeks in 1821 did the English Foreign Office, still less did the English public, begin to take a sustained interest in the development of events in South-Eastern Europe.

The Greek Revolution was indeed sufficiently startling to arouse the attention even of the careless. For more than four hundred years the Greeks, like the Bulgarians and the Serbians, had been all but completely submerged under the Ottoman flood. To the outside world they had given no sign whatever that they retained the consciousness of national identity, still less that they cherished the idea of ever again achieving national unity. There had indeed been a rising in Serbia in 1804, and by the Treaty of Bucharest the Serbians had obtained from the Porte a small measure of internal antonomy, but all the strong places were garrisoned by Turks, and the step towards independence was of insignificant proportions. Besides, Europe was preoccupied with more important matters; Balkan affairs were of merely local interest.

The Greek rising was in a wholly different category. When Prince Alexander Hypsilanti unfurled the flag of Greek independence in Moldavia, still more when the insurrection spread to the Morea and the islands of the Aegean archipelago, even the dullards began to realize that a new force was manifesting itself in European politics, and that an old problem was entering upon a new phase. The Greek rising meant an appeal to the sentiment of nationality: Panhellenism-the achievement of Hellenic unity and the 1 C. de Freycinet, La Question $d$ Égypte, p. 2. 
realization of Hellenic identity - was the motto inscriberl upon their banner. Plainly, a new factor had entered into the complex problem of the Near East. But the nationality factor was not the only one disclosed to Europe by the Greek insurrection. Hitherto, the Eastern Question had meant the growth or the decline of Ottoman power; a struggle between the Turks on the one hand and Austrians and Venetians on the other. More lately it had centred in the rivalry between the Sultan and the Tsar. Henceforward it was recognized, primarily through the action of Russia and the newly aroused sympathies of England, as an international question. The more cautious and more disinterested of European statesmen have persistently sought to 'isolate' the politics of the Near East. They have almost consistently failed. The Greek insurrection struck a new note. It refused to be isolated. The Tsar Alexander, though deaf to Hypsilanti's appeal, had his own quarrel with Sultan Mahmud. There was, therefore, an obvious probability that two quarrels, distinct in their origin, would be confused, and that the Tsar would take advantage of the Greek insurrection to settle his own account with the Sultan.

To avoid this confusion of issues was the primary object of England English diplomacy. C'astlereagh and C'anning were fully alive and the to the significance of the Hellenic movement, alike in its Revoluprimary aspect and in its secondary reaction upon the general diplomatic situation. And behind the statesmen there was for the first time in England a strong public opinion in favour of determined action in the Year East. The sentiment to which Byron and other Philhellenist enthusiasts appealed with such effect was a curious compound of classicism, liberalism, and nationalism. A people who claimed affinity with the citizens of the States of ancient Hellas; a people who were struggling for political freedom ; who relied upon the inspiring though elusive sentiment of nationality, made an irresistible appeal to the educated classes in England. Canning was in complete accord with the feelings of his countrymen. But he perceived, as few of them could, that the situation, unless dexterously handled, might lead to new and dangerous derelopments. Consequently, he spared no 
efforts to induce the Snltan to come to terms with the insurgent Greeks lest a worse thing should befall him at the hands of Russia.

The Porte was, as usual, deaf to good advice, and Canning then endeavoured, not without success, to secure an understanding with Russia, and to co-operate cordially with her and with France in a settlement of the affairs of South-Eastern Europe. That co-operation, in itself a phenomenon of high diplomatic significance, was in a fair way of achieving its object when Canning's premature death (1827) deprived the new and promising machinery of its mainspring. Owing to untimely scruples of the Duke of Wellington England lost all the fruits of the astute and far-seeing diplomacy of Canning; the effectiveness of the Concert of Europe was destroyed, and Russia was left free to deal as she would with the Porte and to dictate the terms of a Treaty, which, by the Duke's own admission, 'sounded the death-knell of the Ottoman Empire in Europe'. Bnt, although the Treaty of Adrianople represented a brilliant success for Russian policy at Constantinople, Great Britain was able to exercise a decisive influence on the settlement of the Hellenic question. By the Treaty of London (1832) Greece was established as an independent kingdom, under the protection of Great Britain, Russia, and France.

Mehemet The tale of the Sultan's embar'rassments was not completed Ali. by the Treaties of Adrianople and London. The independence of Greece had not only made a serious inroad upon the integrity of the Ottoman Empire in Europe, but had precipitated a disastrous conflict with Russia. Worse still, the effort to avert the disruption of his Empire had induced the Sultan to seek the assistance of an over-mighty vassal. If there is anything in politics more dangerous than to confer a favour it is to accept one. Mehemet Ali, the brilliant Albanian adventurer, who had made himself Pasha of Egypt, would, but for the intervention of the Powers, have restored Greece to the Sultan. The island of Crete seemed to the vassal an inadequate reward for the service rendered to his Suzerain. Nor was the revelation of Ottoman weakness and incompetence lost upon him. He began to aspire to an independent 
rule in Egypt ; to the pashalik of Syria ; perhaps to the lordship of Constantinople itself. The attempt to realize these ambitions kept Europe in a state of almost continuous apprehension and unrest for ten years (1831-41), and opened another chapter in the history of the Eastern Question.

To save himself from Mehemet Ali the Sultan appealed to the Powers. Russia alone responded to the appeal, and as a reward for her serrices imposed upon the Porte the humiliating Treaty of Unkiar-Skelessi (1833). By the terms of that Treaty Russia became virtually mistress of the Bosphorus and the Dardanelles. The Tsar bound himself to render unlimited assistance to the Porte by land and sea, and in return the Sultan undertook to close the Straits to the ships of war of all nations, while permitting free egress to the Russian fleet. To all intents and purposes the Sultan had become the vassal of the Tsar.

Thus far England, as a whole, had betrayed little or England no jealousy of the Russian advance towards the Mediter- and Russiz. ranean. Canning, though not unfriendly to Russia, had indeed repudiated, and with success, her claim to an exclusive or even a preponderant influence orer Turkey. But by the Treaty of Unkiar-Skelessi that claim was virtually admitted. Russia had established a military protectorship orer the European dominions of the Sultan.

The Treaty of Unkiar-Skelessi inaugurates yet another phase in the evolution of the Eastern Question. From that time down to the Treaty of Berlin (1878) the primary factor in the problem is found in the increasing mistrust and antagonism between Great Britain and Russia. Lord Palmerston, inheriting the diplomatic traditions of Pitt and Canning, deeply resented the establishment of a Russian protectorate over Turkey, and determined that, at the first opportunity, the Treaty in which it was embodied should be torn up. Torn up it was by the Treaties of London (1840 and 1841), under which the collective protectorate of the Western Powers was substituted for the exclusive protectorate of Russia. After 1841 the Russian claim was never successfully reasserted.

That Great Britain had a vital interest in the derelopment 
England and the Near East.

The Crimean War and after.

of events in South-Eastern Europe was frankly acknowledged by Russia, and the Tsar Nicholas I made two distinct efforts to come to terms with Great Britain. The first was made in the course of the Tsar's visit to the Court of St. James's in 1844 ; the second occurred on the eve of the Crimean War, when the Tsar made specific though informal proposals to Sir Hamilton Seymour, then British Ambassador at St. Petersburg. Neither attempt bore fruit. The overtures were based upon the assumption that the dissolution of the Ottoman Empire was imminent, and that it was the duty, as well as the obvions interest, of the Powers most closely concerned to come to an understanding as to the disposition of the estate. British statesmen refused to admit the aceuracy of the Tsar's diagnosis, and questioned the propriety of the treatment prescribed. The 'sick man' had still, in their opinion, a fair chance of recovery, and to arrange, before his demise, for a partition of his inheritance, seemed to them beyond the bounds of diplomatic decency. Lord Palmerston, in particular, was at once profoundly mistrustful of the designs of Russia, and singularly hopeful as to the possibilities of redemption for the Ottoman Empire. The advances of the Tsar were, therefore, rather curtly declined.

However distasteful the Tsar's proposals may have been to the moral sense or the political prejudices of English statesmen, it cannot be denied that they were of high intrinsic significance. Had they found general acceptance-an extravagant assumption-the Crimean War would never have been fought; Russia would have become virtually supreme in the Balkans and over the Straits, while England would have established herself in Egypt and Crete. The refusal of the Aberdeen Cabinet even to consider such suggestions formed one of the proximate causes of the Crimean War.

That war, for good or evil, registered a definite set-back to the policy of Russia in the Near East. It has, indeed, become fashionable to assume that, at any rate as regards the British Empire, the war was a blunder if not a crime. How far that assumption is correct is a question which will demand and receive attention later on. For the moment it is sufficient to 
observe that the Crimean War did at any rate give the Sultan an opportunity to put his house in order, had he desired to do so. For twenty years he was reliered of all anxiety on the side of Russia. The event proved that the Sultan's zeal for reform was in direct ratio to his anxiety for self-preservation. To relieve him from the one was to remove the only incentive to the other. Consequently, his achievements in the direction of internal reform fell far short of his professions.

Little or nothing was done to ameliorate the lot of the Unrest subject populations, and in the third quarter of the nineteenth in the century those populations began to take matters into their own hands. Crete, the 'Great Greek Island', had been in a state of perpetual revolt erer since it had been replaced, in 1840, under the direct government of the Sultan. In 1875 the umrest spread to the peninsula. It was first manifested among the mountaineers of the Herzegovina; thence it spread to their kinsmen in Bosnia, Serbia, and Montenegro. The insurrection among the Southern Slars in the west found an echo among the Bulgars in the east. The Sultan then let loose his Bashi-Bazouks among the Bulgarian peasantry, and all Europe was made to ring with the tale of the atrocities which ensued. The Powers could not stand aside and let the Turk work his will upon his Christian subjects, but mutual jealousy prerented joint action, and in 1877 Russia was compelled to act alone.

An arduous but decisire campaign brought her within Treaties striking distance of Constantinople, and enabled her to of San dictate to the Porte the Treaty of San Stephano. The terms and of that famous Treaty were highly displeasing, not only to Austria and Great Britain, but to the Greeks and Serbians, whose ambitions in Macedonia were frustrated by the creation of a Greater Bulgaria. Great Britain, therefore, demanded that the Treaty should be submitted to a European Congress. Russia, after considerable demur, assented. Bismarck undertook to act as the 'honest broker' between the parties, and terms were ultimately arranged under his presidency at Berlin. The Treaty of Berlin (1878) ushers in a fresh phase in the erolution of the Eastern Question. 
The nationality principle. aspirations and claims of the indigenous inhabitants of the Balkan peninsula. The Slavs and Bulgars were indeed only in one degree more indigenous than the Turks themselves. Roumans, Albanians, and Greeks might claim by a more ancient title. But all alike had at any rate been established in the lands they still continue to inhabit many years before the arlvent of the alien Asiatic power. For centuries, however, all, save the hillsmen of Albania and the Black Mountain, had been more or less completely submerged under the Ottoman flood. When the tide turned and the flood gare signs of receding, the ancient nationalities again emerged. The rebirth of Greece, Roumania, Serbia, and Bulgaria represents in itself one of the most remarkable and one of the most characteristic morements in the political history of the nineteenth century. Incidentally it introduced an entirely new factor, and one of the highest significance, into the already complex problem of the Near East. The principle of nationality is itself confessedly elusive. But whatever may be its essential ingredients we must admit that the principle has asserted itself with peculiar force in the Balkan peninsula. Nor have the peoples of Western Europe been slow to manifest their sympathy with this new and interesting derelopment. The official attitude of Great Britain during the critical years 1875-8 might seem to have committed the English people to the cause of reaction and Turkish misgovernment. Whatever may have been the motives which inspired the policy of Lord Beaconsfield it is far from certain that, in effect, it did actually obstruct the derelopment of the Balkan nationalities. Two of them, at any rate, have reason to cherish the memory of the statesman who tore up the Treaty of San Stephano. Had that Treaty been allowed to stand, both Greece and Serbia would have had to renounce their ambitions in Macedonia, while the enormous accessions of territory which it secured for Bulgaria might ultimately have proved, even to her, a doubtful political advantage.

Since 1878 the progress of the Balkan nations has been rapid, and with that progress the concluding portion of this 
book will be mainly concerned. It will also have to chronicle the appearance of yet another factor in the problem. At 110 time could the Habsburgs regard with unconcern the development of events in South-Eastern Europe, but between 1848 and 1878 they had much to engage their attention elsewhere. They played a shrewd and calculating game between 18.53 and 1856, and not without success ; but their conduct during the Crimean crisis was hotly resented in Great Britain, and it may perhaps account for the lack of sympathy with which the English people regarded the misfortunes of the Austrian Empire during the next ten years. Prussia, too, was busy elsewhere, and as long as Bismarck remained in power Prussia disclaimed any interest in the problem of the Near East.

Nothing differentiates more clearly the policy of the Germany Emperor William II from that of Bismarck than the in- and the creasing activity of German diplomacy in the Balkans. The growing intimacy of the relations between Berlin and Viemna, still more between Berlin and Buda-Pesth, must in any case have led to this result. The virtual annexation of Bosnia and the Herzegovina to the Austrian Empire was Bismarck's acknowledgement of the obligations which in 1870 he had incurred to Habsburg neutrality. But the gift bestowed upon Anstria caused the first serious breach in the good relations between Berlin and St. Petersburg. The wire between those capitals was nerer actually cut so long as Bismarck controlled the German Foreign Office ; but his successor found himself compelled to choose between the friendship of Austria and that of Russia, and he deliberately preferred the former.

That choice inevitably involved a change in the attitude of Germany towards the Near Eastern Question. Austria made no secret of her ambition to secure access to the Aegean. Germany not only identified herself with this ambition, but she developed similar ambitions of her own. If Salonica was the obvious goal for Austrian activities, those of her ally might naturally be directed towards Constantinople, and from Constantinople onwards to Bagdad and Basra. From such grandiose designs Bismarck instinctively recoiled; but to the very differently constituted mind of William II their appeal was irresistible. Consequently, in the Near East as elsewhere, 
German diplomacy has followed since 1890 a perfectly consistent and undeviating path. In every conceivable way the Turk was to be caressed. Not even the massacre of the Armenian Christians was allowed to interrupt the growing intimacy between Berlin and Constantinople. The moment when the rest of the Powers shrank in horror from the perpetrator of those massacres was selected by the Kaiser to demonstrate his unalterable friendship for his new ally. From 1904 onwards the Triple Alliance was enlarged to include the Ottoman Turk. Not, indeed, without embarrassment to one of the original partners. Berlin was continually engaged in the delicate task of preventing a rupture between Rome and Viemna on questions connected with the Near East, and for the time her diplomacy succeeded. The Alliance was still further strained by the Turco-Italian War in 1911 ; but for three more years it remained nominally intact. Not until 1914 was it finally broken.

German policy in the Near East had in the meantime sustained more than one check. Depending, as it did, largely on a personal equation; the deposition of Abdul Hamid and the triumph of the 'Young Turks' threatened it with ruin. But the danger passed; the Young Turks proved no less amenable than Abdul Hamid to the influence of Berlin; Germany was again supreme at Constantinople. Eren more serious was the formation, in 1912, of the Balkan League and its astonishing success in the field. All the arts known to German diplomacy were needed to avert disaster; but they did not fail. With consummate adroitness Serbia was pushed away from the Adriatic and compelled to turn southwards; the most extravagant demands of Greece were encouraged in Macedonia; Bulgaria was effectively estranged from its allies; a remnant of the Ottoman Power in Europe was salved; a German vassal still reigned at Constantinople.

One danger remained. Between Central Europe and its Drang nach Sïdosten there intervened Serbia; no longer the Serbia of 1878; no longer the client of Austria-Hungary; but a Serbia in which was reborn the ancient spirit of the Jugo-Slav race; a Serbia which believed itself destined to be the nucleus of a great Serbo-Croatian Empire; which 
should embrace all the lands in which their race was dominant : Croatia, Slavonia, Bosnia and the Herzegovina, Serbia, Montenegro, Dalmatia, with parts of Carniola, Carinthia, Istria, and Styria. The foundation of such an empire would mean not only the dismemberment of the Dual Monarchy, but the death-blow to the ambitions of Central Europe in the Near East. At all hazards, even at the hazard of a worldwar, such a danger must be arerted.

The Great War of 1914 was the outcome of this conviction. Once more had the Near East reacted upon the West; indeed upon the whole world. In order that Austria-Hungary might keep a road open to the Aegean; in order to prevent a change of gauge between Berlin and Basra, the world nust be flung into the crucible: Belgium, peaceful and unoffending, must be ruthlessly devastated; given over to arson, pillage, and abomination of every description; Poland must pay the last of many penalties; some of the fairest fields and most prosperous cities of France must be laid waste; the vast resources of the British Empire must be strained to the uttermost ; Canadians must pay the toll in Flanders; Australians and New Zealanders must make the last heroic sacrifice in Gallipoli ; Englishmen must perish in the swamps of the Euphrates; Indians must line the trenches in France; women and babes must perish on land and sea ; from London to Melbourne, from Cairo to the Cape, from Liverpool to Vancouver the whole Empire must fight for its life; the whole world must groan in pity and suffering.

If it be true that in its dealings with the Near East Western Europe has in the past exhibited a brutal and callous selfishness, the Near East is indeed arenged.

The end no man can see. But one thing is certain. The future will not be as the past, nor as the present. Yet in order to face the future fearlessly and to shape it aright nothing is more indispensable than a knowledge of the past. Nor can that knowledge safely be confined to the few who govern ; it must be diffused among the many who control. To diffuse that knowledge is the purpose of the pages that follow. 


\section{CHAPTER II}

\section{PHYSICS AND POLITICS}

'No other site in the world enjoys equal advantages nor perhaps ever will enjoy them.'-D. G. Hogarth (of Constantinople).

'It is the Empire of the world.'-NAPoLEon (on Constantinople).

"When the Turks threw themselves across the ancient paths in the fifteenth century A.D., a great necessity arose in Christendom for searching out new lines of approach to India. From that quest the history of moderm commerce dates.'-Sir W. W. Hunter.

'By whichever way we approach the problems before us we are brought back to the unique importance of the position occupied by Belgrade. It is in several ways the most commanding of any European city. . . . Belgrade lies at the only available gateway on the road to Salonica and the Piraeus as well as to Constantinople.'-Sir Arthur Evans.

Physical

conditions.

THIS book will be concerned, as the introductory pages should have made clear, primarily with Politics; with the history of the Near East as the home of man ; as the cockpit of nations, and as the arena of international rivalries. But there is no region in the world where physical conditions have played a more dominating part in shaping the destinies of individual men or of those political aggregations which we know as Nations and States. This is demonstrably true whether we have regard to the region as a whole, or to that segment of it with which this book is more particularly concerned, the lands which the geographers of the last generation described as Turkey in Europe, but for which political changes have compelled us to seek a new name. The name generally given to that segment is The Balkan Peninsula, or simply The Ballans. In strictness the description applies only to the lands to the south of the great Divide formed by the Shar mountains and the Balkan range. It excludes, therefore, a great part of Serbia and the Southern Slar provinces, and the whole of Roumania. In the following pages The Balkans will, however, be used as synonymous with the Turkey in Europe of our forefathers. 
Only a few words can be spared for the geographical the significance of the general region of the Near East. Nor, "Naart". indeed, is it necessary to labour a commonplace. A glance at a map of the world-more particularly of the known world of A.D. 1450-can hardly fail to carry conviction even to those who are not wont to cultivate the historical or geographical imagination. The lands which fringe the Eastern Mediterranean-roughly the region bounded on the west by the Adriatic and the island of Crete, to the north by the Danube, to the east by Asia Minor and Mesopotamia, and to the south by Syria and Egypt--have possessed a significance in world-history incomparably greater than any other. If it be objected that the definition excludes all the lands dominated by the Anglo-Saxon race it is sufficient to reply, first, that this statement refers to the past, not to the future; and, secondly, that indications are not wanting that, in the future, the region may play a part in determining the fate of worldempires hardly less important than that which it has played in the past.

Until the establishment of the Ottoman Empire the The old region thus defined formed the nerve-centre of the world's Trandecommerce. From time immemorial the trade between the East and the West has followed well-defined routes. The most ancient is the caravan route which, from the dawn of history down to the sixteenth century, was commanded by the Semites. From the Far East goods found their way to the head of the Persian Gulf, thence by caravan they ultimately reached the Syrian sea-board, and from Tyre and Sidon were distributed by the Phoenicians to the peoples of the West. Basra, Bagdad, and Jerusalem were the dominating stations on this trunk-line. The Mongol invasions of the thirteenth century gravely impaired the security of the Mesopotamia-Syria route, and proportionately increased the importance of the northern and southern routes. The former reached Europe by the Oxus, the Caspian, and the Black Sea, its outer gate being commanded, of course, by Constantinople; the latter came by way of the Indian Ocean, the Red Sea, and the valley of the Nile, debouching from 332 B. c. onwards at Alexandria. 
Every one of these Mediterranean outlets, Constantinople, Alexandria, and the Syrian coast, passed into the hands of the Ottoman Turks between 1453 and 1516. One after another the great trade-routes were blocked by a Power, inimical to commerce, and still more inimical to those Christian nations for whose benefit intercourse between East and West was mainly carried on. It will, therefore, be readily understood that the Ottoman conquest of the Near East constitutes one of the decisive events in world-history. After that conquest the Western world found itself confronted by three alternatives : to forgo the profits and conveniences of its trade with the East ; or to expel the Ottomans from the 'nodal-points', or to discover a new route to the East with the continuity of which the Ottomans could not interfere. Europe preferred the last. Hence the abnormal activity displayed at Cadiz, Bristol, and above all at Lisbon, in the latter half of the fifteenth century. Portugal, thanks to Prince Henry the Navigator, had indeed long been a centre of maritime activity and scientific research. It was fitting, therefore, that the first prize in the quest for a new route to the East should fall to the Portuguese explorers.

The new The rounding of the Cape of Good Hope by Vasco routes. da Gama in 1498 opened a sea-route to India which was successively dominated by the Portuguese, the Dutch, and the English. Columbus setting forth on a similar quest a few years earlier had stumbled upon the West Indies, and had thus opened to his Spanish patrons a path to Empire in Sonth America. The Cabots, sailing from Bristol, under the English flag, discovered and explored the coast of North America Plainly, then, the geographical renaissance of the later fifteenth century was due primarily, though not exclusively, to the advent of the Ottomans in South-Eastern Europe and the consequent blocking of the old established trade-rontes.

Results to The opening of the new route to the East Indies, together Europe. with the discovery of America and the West Indies, had a profound and far-reaching influence upon the European polity. The centre of gravity, commercial, political, and intellectual, rapidly shifted from the south-east of Europe to the north-west ; from the cities on the Mediterranean littoral 
to those on the Atlantic. Constantinople, Alexandria, Venice, Genoa, and Marseilles were deprived, almost at one fell swoop, of the economic and political pre-eminence which had for centuries belonged to them. Four of the five cities have regained a large measure of importance, and at least one of them may be destined to pre-eminence in the near future ; but for four centuries the Mediterranean, which had been the greatest of commercial highways, was reduced almost to the position of a backwater. Commercial supremacy passed to the Atlantic. The Thalassic Age, to adopt the terminology rendered classical by Sir John Seeley, was superseded by the Oceanic. To Western Europe, as a whole, and to England in particular, these changes were of the highest possible significance; but it is neither necessary, nor in this connexion pertinent, to elaborate a commonplace of historical generalization.

Towards the end of the nineteenth century the great The Suez enterprise of M. de Lesseps, the cutting of the Isthmus of Suez by a canal, restored in large measure the commercial significance of the Mediterranean. Hardly less important has been the influence excited in the same direction by the political reorganization and the economic development of Egypt under Lord Cromer. Genoa and Marseilles hare responded superbly to the new demands made upon them, Alexandria has regained much of its importance.

The twentieth century has witnessed the initiation of an The enterprise which, if it be carried through to a successful issue, Bagdedmay possibly have consequences, political and economic, hardly inferior to those which have accrued from the cutting of the Suez Canal. Just as at the close of the fifteenth century the Western Powers were intent upon securing for the eastern trade a route beyond the control of the Ottomans, so at the present day Mitteleuropa is straining every nerre to obtain command of a great trunk-line which, by the dominant sea-power of Great Britain, shall carry the commerce and the influence of the Teutonic Empires from the shores of the North Sea to the Persian Gulf undisturbed. The Bagdad railway is not yet completed, nor is it by any means certain that if and when it is completed the control will be 
vested in Berlin or Hamburg. But the mere initiation of the enterprise affords one more indication of the commanding geographical situation of the lands which still form part of the Ottoman Empire, and in particular the incomparable significance of Constantinople. The convergence of all the great trade-routes of the ancient and the mediaeval worlds upon the Eastern Mediterranean, the importanee attached in the modern world to Egypt, Syria, Mesopotamia, and Constantinople, are conclusive proof of the propositions advanced in the opening paragraphs of this chapter. England would not be in Egypt to-day, the German Emperor would not have courted the Sultan Abdul Hamid and Enver Pasha, had not the Near East retained all the significance which in all previous ages of world-history has been conferred upon it by a geographical situation pre-eminently and perhaps uniquely advantageous.

The Not less obvious is the influence which physics have Balkans: exereised upon the history of the Balkan lands. Before this features. proposition can be accepted it is necessary to discriminate with some nicety the outstanding geographical features of this region. For the first impression is one of almost hopeless eonfusion.

The The orographical relief is, indeed, singularly complex. At

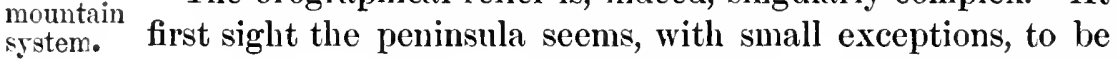
covered by a series of mountain ranges, subject to no law save that of caprice, starting from nowhere in partieular, ending nowhere in particular, now rumning north and south, now east and west, with no obvious purpose or well-defined trend. Closer scrutiny corrects the first impression, though not fundamentally. Still, where all had seemed chaotic, certain features emerge: the lower Danube basin, the two valleys of the Maritza, the plain of Thessaly, and the lower Vardar valley. These are the most obvious exceptions to the mountain ranges and the high uplands. Still eloser observation reveals a gap between the southern end of the Dinaric Alps and the northern terminus of the mountains of Albania. This 'Albanian Gap', ereated by the Drin river and extending on the Adriatic coast from Scutari to Alessio or S. Juan di Medua, has already played a cousiderable 
political rôle, and may be destined to play a much larger one. It is, indeed, hardly too much to say that the whole political future of Serbia depends upon the economic potentialities of this break in the coastal mountains. Another feature, of hardly less significance to Serbia, is the passage-way between the western coastal mountain chains and the central upland, a passage which opens at the northern end into the great

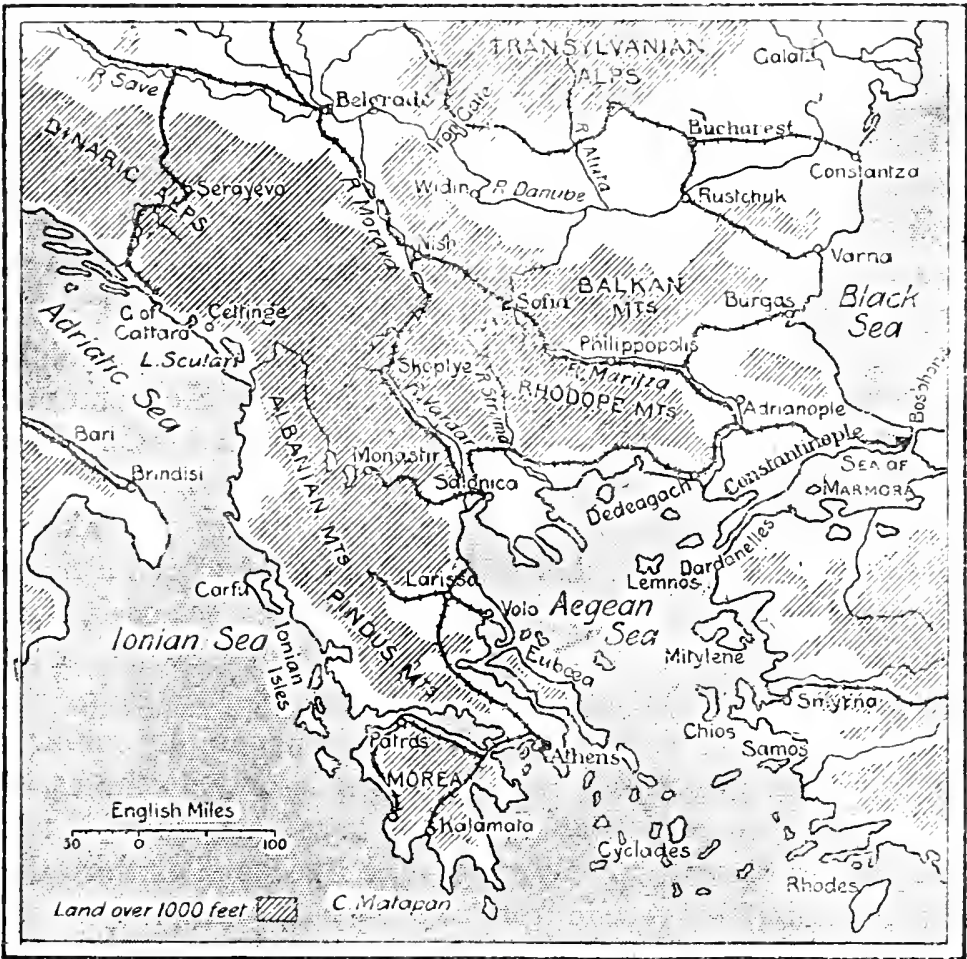

Hungarian plain, and at the southern into the lower Vardar valley, connecting, in fact, Belgrade and Salonica. 'Within this belt is concentrated', as a recent writer has admirably said, 'most of the drama and most of the tragedy of the peninsula.' 1

A third feature which disentangles itself from the confused

1 Newbiggin, Geographical Aspects of Balkan Problems, p. 9. 
mountainous mass is the Rhodope upland, a fairly defined central earth-block of triangular shape, based upon Salonica and Constantinople, and stretching in a north-westerly direction towards an apex at Belgrade. Along the sides of this triangular upland run the main lines of communication, with their junction at Nish (see maps, pp. 28, 29).

The west- The most pronounced features of the mountain system still coastal mountains. remain to be summarily noted. The first is the prolongation of the Alpine chain which, starting between Nice and Genoa, forms the northern boundary of the great Lombard plain, then sweeping round the head of the Adriatic begins to run down its eastern shore, first as the Julian and then as the Dinaric Alps. There is a fairly wide gap north-east of Fiume, and a well-marked one, already referred to, where the Drin has forced its way to the sea. Otherwise the coastal range runs almost continuously parallel with the shore, and, what is more important, generally close to it. These geographical facts are not without significance in relation to the claim put forward by Italy to the eastern shore of the Adriatic. The Venetian character of the Dalmatian cities is as indisputable as is the Slavonic blood of the vast majority of the inhabitants, and if it be true that a mountain range affords a more scientific frontier than a river bank or even a sea-coast line, geographical symmetry might seem to argue in favour of Italy's claim to the ancient Illyria and modern Dalmatia. But here, as elsewhere in the Balkans, ethnography conflicts sharply with geography, agreeing with it only so far as to assert that whoever 'the rightful claimant may be it is not the present occupant'. Once past the Bocche di Cattaro the coastal mountains recede from the sea-coast until they reach Valona. From Valona they have a south-westerly trend until, in the Pindus range, they form the spinal cord of Greece.

The From the west-coastal mountains there runs almost to the central watershed. Black Sea an horizontal range. It starts with the Shar mountains just south of the Albanian Gap; and broken once or twice, notably by the Belgrade-Salonica gangway, it continues as the Balkan range almost due east, stopping short of Varna on the Black Sea coast. This forms the great central water- 
shed of the peninsula. North of it all the rivers, such as the northern or white Drin, the Morava, the Isker, and the Vid, empty into the Danube ; south of it the Vardar, the Struma, and the great Maritza system all flow into the Aegean.

Finally, we have to note the position of the Carpathians. 'The CarThey belong, in a sense, rather to the Central European than pathians. to the Balkan system. But the Balkan range itself may almost as well be regarded as a continuation of the Carpathian folds as of the central watershed, and apart from this the Carpathians have a paradoxical significance of their own which cannot be ignored. In one sense they form an obvious and formidable barrier between the Hungarian plain and the basin of the lower Danube, which in its turn marks, from the Iron Gates almost to the Black Sea, the sonthern frontier of Roumania. But the physiographic frontier, in the case of the Danubian principalities, conflicts curiously with the ethnographic. If there are some nine million Roumanians dwelling to the east of the Carpathians, there are four million people of the same race to be found on the western side of the mountains. In this fact lies the core of the political problem of Roumania, a problem deliberately created, it would seem, by a capricious but obstinate geography.

Caprice is, indeed, the obtrusive characteristic of Balkan The river physiography. If anything could be more confusingly capricious than the orographical relief, it is the river system of the peninsula. Why does the Danube, after a prolonged, regular, orthodox, west to east course from Belgrade to beyond Silistria, take a sudden tilt due north as far as Galat' before it is content to empty itself into the Black Sea? Its only purpose seems to be the purely malicious one of involving Roumania and Bulgaria in disputes over the unattractive marshes of the Dobrudja. If the Danube had only persevered a little longer in its eastward course and reached the sea -as the railway line from Bucharest does-at the port of Constanza, there would be practically nothing to prevent unbroken amity between the Roumanians and their Bulgarian neighbours. But that again would be so contrary to every Balkanic principle and tradition that perhaps, after all, the Danube, under an onter cloak of perversity, is only attempt- 
ing to preserve spiritual conformity with the circumstances of its political environment.

Further south, the Maritza plays us an almost identical trick with political results hardly less embarrassing. This great river drains the valley which intervenes between the Balkans and the Rhodope block of central uplands ; it maintains a south-easterly course from Philippopolis to Adrianople, and then, instead of continuing its orthodox course to the Black Sea, or even to the Sea of Marmora, it takes a sudden turn to the south and finally, by a course decidedly southwesterly, reaches the Aegean at Enos. The curious deflection of this great river system is due to the geological process known as 'river capture'. The sinking of land below what is now the surface of the Aegean Sea-a process the incompleteness of which is manifested by the existence of the Aegean archipelago-has increased the relocity and therefore the erosive power of the streams flowing southward to such a degree that the watershed has been thrust northward, and the Aegean streams have 'captured' the head-waters of systems which did not originally belong to them. Geologically the Aegean has thus excited a very powerful attractive force. The Maritza, the Mista, the Struma, to say nothing of the Vardar and the Vistritza, all flow into the Aegean. Politics have followed the lead of Physics. Men, like streams, have been attracted towards the Aegean littoral, and thus Macedonia has become the 'key to the history of the whole peninsula'.1 Nowhere in the Balkans has physiography more obriously dictated the course of history than in this difficult and debatable region. Macedonia consists of a string of basins more or less comnected by the threads of the Vardar and the Vistritza. But here, as in Roumelia, geography has made it much easier for the northern peoples to come south than for the southern peoples to go north. ${ }^{2}$ Therein lies, perhaps, the primary cause of the outbreak of the Second Balkan War in 1913, though the monitions of nature were in that case powerfully assisted by the promptings of diplomacy.

1 Newbiggin, op. cit., p. 10. On the whole subject of 'rirer' capture' ef. chap. $\mathrm{v}$ in the same illuminating work.

2 Hogarth, Nearer East, pp. 170-1. 
Apart, howerer, from this particular instance history shows the continuous attraction of the Aegean littoral for the several peoples of the peninsula.

Closely connected with the geological process to which reference has been made is the uncertainty of the watershed between the upper waters of the Vardar and those of the Morava. That physical phenomenon finds its political reflection in the position of the Southern Slars. By which route will they ultimately obtain access to the sea? By the Vardar valley to the Aegean or by the Albanian Gap to the Adriatic? But for the malicious interposition of the Central European Powers the Serbians would, without question, be on the Adriatic to-day. Whether that or the Aegean is their ' natural' destiny is a point upon which nature has not very decisively pronounced. It is, however, worthy of note that there is no such 'pull' to the Adriatic as there is to the Aegean. To Italy the strategical value of the Dalmatian and Albanian coast is unquestionable. It has still to be demonstrated that it is for the Southern Slavs a 'natural' outlet either in a commercial or in a political sense. If the dictates of ethnography are to be accepted as final the award cannot be in doubt. The elaim of the Southern Slars is indisputable. But race is not the only factor of which account must be taken.

A conspectus of the physical features of the peninsula seems, indeed, to suggest the conclusion that the main structural lines are not horizontal but vertical. The general trend is north to south, not east to west nor west to east. ${ }^{1}$ It would be unwise to lay exaggerated emphasis upon this physiographic tendency. To do so might supply a physical justification for the Drang nach Sïdosten of the Central European Empires. But it may not, on this account, be ignored. The conclusions suggested by the main lines of communication are indeed irresistible.

In a country such as has been described above it would be Roads ant ridiculous to look for elaborate means of communication. In Railways. the Balkans, at any rate, they will be looked for in vain.

1 Cf. Evans, The Adriatic Slars. 


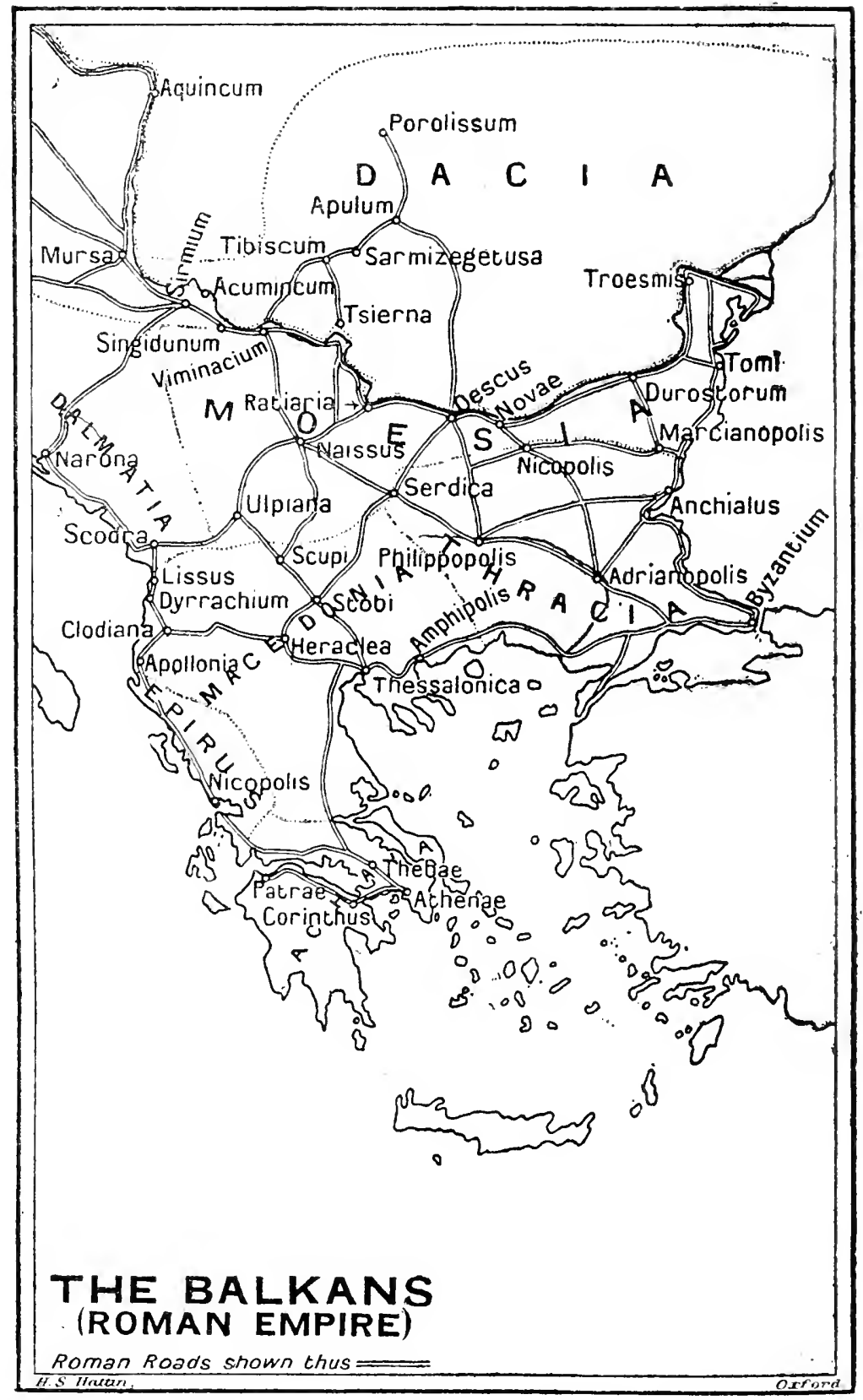




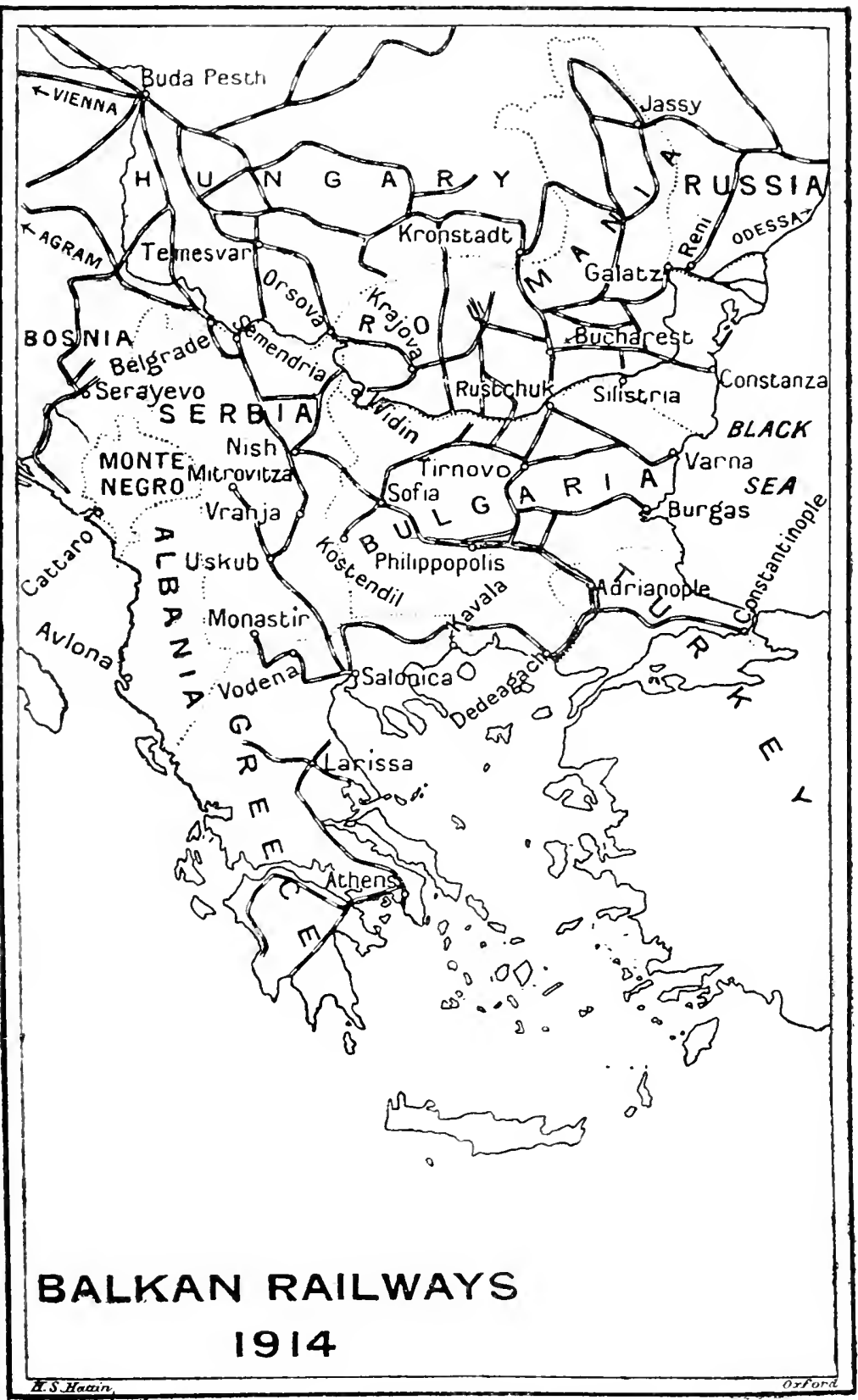


Neither by road nor rail is communication easy. The difficulties interposed by nature may be gauged by a comparison, extraordinarily suggestive, between the Roman road map and a modern railway map of the peninsula. A glance at the maps on pp. 28 and 29 will show that only in one respect is there any conspicuous divergence between the two. The primary purpose of the Roman roadmaker was to secure a direct line of communication between the old Rome on the Tiber and the new Rome on the Bosphorus. This purpose was achieved by the construction of the famous Via Egnatia, which, starting from Durazzo on the Adriatic, ran by way of Lake Ochrida to Monastir and thence to Salonica. From Salonica it ran parallel to, but at some little distance from, the Aegean littoral to Kavala, and thence down to the shore at Dedeagatch, from which point it made straight for Constantinople. A second trunk-road from Belgrade to Constantinople via Nish, Sofia, Philippopolis, and Adrianople-the precise route of the line now traversed by the Berlin to Constantinople express. A third, starting from Metkovitch, followed the stream of the Narenta, and thence ran up to Serajero, and linked Serajero with Salonica by way of Novi Bazar, the plain of Kossovo, and Uskub. Subsidiary roads connected Scutari with the Danube via Nish, and Monastir with the Danube via Sofia.

The modern lines of communication are, with one exception, far less systematic. Bucharest now is connected by different lines with the Roumanian port of Constanza, the Bulgarian port of Varna, with Sofia, and, via Philippopolis, with Constantinople. Otherwise, the advantage lay with the Roman roads. Besides the trunk-line already mentioned between Belgrade and Constantinople, a second connects Belgrade with Nish, Uskub, and Salonica, and a branch line runs from Salonica to Constantinople. But, with the exception of a line from Ragusa to Serajevo, there is not a single railway running westward from or eastward to the Adriatic. There is nothing to connect either Durazzo or Valona with Monastir and Salonica; nor Serajero with anything to the south of it. The outbreak of the European War interrupted various projects for supplying the more obvious of these 
deficiencies, but many repairs will have to be effected before any large schemes of construction are likely to be resumed. Meanwhile, the main lines of communication remain much as the Romans left them. Now, as then, they are dictated by the triangular central upland which, based upon Constantinople and Salonica, reaches its apex at Belgrade. Now, as then, these three cities hold the keys of the peninsula.

The foregoing survey of the geographical features of the l'olitical Balkans, summary as it has been, is sufficient to indicate the cleducexceptional degree of influence which in this interestiug impossiregion Physics has exercised upon Politics. In such a country lility of it would be vain to expect the establishment of a strong tion. centralized State, such as was possible in England, and still more obviously in France. Nor, in fact, has there ever been such a State in the Balkans. The Greek city States represent the antithesis of centralization, and neither Macedon nor Rome was foolish enough to attempt the impossible. The Ottoman Empire, though in a sense despotic, has never been a centralized despotism. Subsequent chapters will make it clear that in practice a very considerable amount of local autonomy was permitted to the conquered peoples even throughout the most oppressive periods of Ottoman dominion. Centralization is indeed prohibited by nature.

Even a closely knit federal State would seem to be outside Kleinthe realm of possibilities for the Balkans. Nature points imperiously to a congeries of relatively small States, and the geographical presuppositions are re-enforced by the principle of ethnography. The present distribution of States and races is, on the whole, tolerably scientific. As usual, however, nature has done her political work in a slovenly fashion, and has left a number of very ragged edges. Or perhaps it would be more modest and more true to say that man has been too stupid to interpret with precision the monitions of natmre. But wherever the blame lies, the fact remains that there are in the Balkans a good many intermediate or debatable districts, the political destiny of which cannot easily be determined. As we have already seen nature has not made it quite clear whether she means Serbia to expand towards the Adriatic or towards the Aegean. Politically, the former 
alternative would be the less inconvenient, for it might untie one of the many knots in which the Macedonian problem is involved.

Inter- Of all the debatable areas Macedonia is the most con-

State rivalry. spicuous. If the Moslems are to evacuate it, upon whom is the inheritance to devolve? Upon Greece, Serbia, or Bulgaria? If upon all three, how will the lines of a satisfactory frontier be drawn? That Bulgaria cannot be permanently content with the present arrangement is frankly admitted by the most prescient of Greek statesmen. But if Greece makes room for Bulgaria at Kavala, ought Serbia to keep Monastir? Does not the road system of the Romans, however, suggest a connexion between Monastir and Durazzo? Again, is not Salonica the obvious port of Belgrade? Or possibly, horresco referens, of Buda-Pesth, or even of Berlin? It is much easier to ask these questions than to answer them. And they are far from being exhaustive. They may serve as samples of the problems propounded by Physics to Politics in the Balkans.

Two conclusions would seem, however, to emerge with tolerable clearness, and there is some danger of our being compelled to accept a third. It will always be difficult to maintain in the Balkans a single centralized State ; unless, therefore, the ingenuity of man can triumphantly overcome the dispositions of nature there will always be a congeries of relatively small States. Must we also conclude that these States will remain to all time in a condition of rivalry; is an armed peace the best that is to be hoped for in the Balkans? This question cannot in any case be disposed of summarily, and an attempt at a considered answer may conveniently be deferred to a later chapter. But this much may be said at once. It would be hazardous to draw conclusions either from the 'miracle' of 1912 or from the grotesquely disappointing sequel of 1913. Grossly exaggerated were the hopes founded upon the formation of the Balkan League; perversely pessimistic were the opposite conclusions derived from its melodramatic dissolution.

Con- Two inferences seem to be justified by recent events. federation First, that the utmost degree of centralization which may be 
reasonably looked for in the Balkans is a somewhat loose con- v. Federalfederation of the Christian States. Unification is prohibited ism. alike by geography and by ethnography. Even federalism presupposes the existence of unifying forces which have not as yet manifested themselves in this region. Things being as they are, a Stactenbund would therefore be preferable to a Bundesstaat: Switzerland is a model more appropriate to the Balkans than Germany or the Australian Commonwealth ; and the Switzerland ante 1848 rather than that of to-day. Secondly, even this measure of union is unattainable without a thorough territorial readjustment. No confederation, however loose in structure, could be expected to endure for six months, unless a fairly satisfactory settlement of outstanding difficulties can be previously effected. And that settlement must come from within. The Treaties of London and Bucharest (May and August, 1913) are a sufficient warning against the futility of European intervention in Balkan affairs. Even assuming complete disinterestedness and goodwill, the event is only too likely to defeat benevolent intentions; where, as at Bucharest, such an assumption is forbidden by notorious facts, intervention can issue only in disaster.

The above reflections suggest irresistibly a further conclu- Europe sion. Physiography, as we have seen, denies to the Balkan Near lands any pre-eminent importance from the productive point East. of view. In this respect the Danubian principalities are the most favourably circumstanced among the States of the peninsula. The external commerce of Roumania is approximately equal to that of the rest of the States put together, and Roumanian oil and cereals have undoubtedly a great future in the European markets. But only on one conditionthat the egress of Roumanian merchandise through the narrow straits is unimpeded. The future of Constantinople is therefore of vital consequence to Roumania. Bulgaria, with an Aegean sea-board, is obviously less interested, but only in one degree. Bulgaria, like Roumania, is giving evidence of improvement in the methods of cultivation by the exportation of cereals. Nor are the exports of Greece and Serbia insignificant, though Greece ministers chiefly to luxuries.

It is not, however, in its productive capacity that the 
economic importance of the Near East consists. That is to be sought in its general geographical situation regarded from the point of view of Weltpolitik and Weltökonomie. Throughout the ages this region has possessed an incomparable importance in relation to the commercial lines of communication. Temporarily diverted by the discovery of America and of the Cape ronte to India, commerce, always conservative in its instincts, has lately regained the accustomed paths. The Balkans, Egypt, Mesopotamia, are again to-day, what from the dawn of history they have been, objects of jealous desire to all economically minded peoples. Less from the point of view of occupation than of control; less for their intrinsic importance than as a means of access to other lands. Hence the concentration of international rivalries upon the lands which fringe the Eastern Mediterranean. That rivalry has not exhausted itself during the last twenty centuries; on the contrary, it seems possible that we may be about to witness its manifestation on a scale without precedent in the history of the world. Nor can there be any doubt that the lands which form part, or until recently did form part, of the Ottoman Empire will provide the arena. Enough has been already said on the importance of Egypt, Syria, and Constantinople as guarding the lines of communication, but we must not fail to notice that the geographical formation of the peninsula itself has rendered it exceptionally open to incursions. Unlike the Iberian peninsula, that of the Balkans is widest where it joins the European continent. Neither to the north-east nor to the north-west is there any natural line of separation, still less is there any substantial obstacle to the advance of a hostile incursion. ${ }^{1}$ Over and over again has Roumania offered a convenient high road for the passage of invading hosts : Goths, Huns, Lombards, Avars, and Slavs traversed it in turn, though only the last tarried in Roumania itself. Between Bucharest and Constantinople there is no serious impediment, still less between Belgrade on the one hand and either the A egean or the Bosphorus on the other.

Relatively small and weak as the States of the Balkans

1 Cf. Newbiggin, op. cit., p. 15. 
are, and must necessarily be, what hope is there of their being able to offer any effective resistance to similar incursions in the future? There would secm to be none except in the adoption of safeguards similar to those which for more than a century have maintainerl inviolate the neutrality and independence of the Swiss Confederation: constitutional readjustment, neutralization under an international guarantee, and a confederate citizen army, well trained and well equipped, and prepared, if need be, to extort the respect of powerful neighbours. Before these conditions can be attained there will have to be a good deal of give and take among the Balkan States ; irreconcilable claims in Macedonia and elsewhere will have to be compromised. This will be no easy task, but it may perhaps be accomplished if once the contending parties can be conrinced that there are only two other alternatives. Either the peninsula will, in the future as in the past, be the prey of any sufficiently powerful invader, or it will find protection by common subordination to an alien empire, drawing upon resources external to the peninsula, and imposing its will by irresistible military strength. These alternatives to a domestic accommodation are not attractive, but they are exhaustive. Physiography excludes a third.

For further reference: D. G. Hogarth, The Near East; Miss Newbiggin, Geographical Aspects of the Balkan Problem; Sir W. W. Hunter, History of British India, rol. i; E. Himly, La formation territoriale; E. A. Freeman, Historical Geography of Europe; Sir Arthur Evans, The Adriatic Slar's and the Overland Route io Constantinople. 


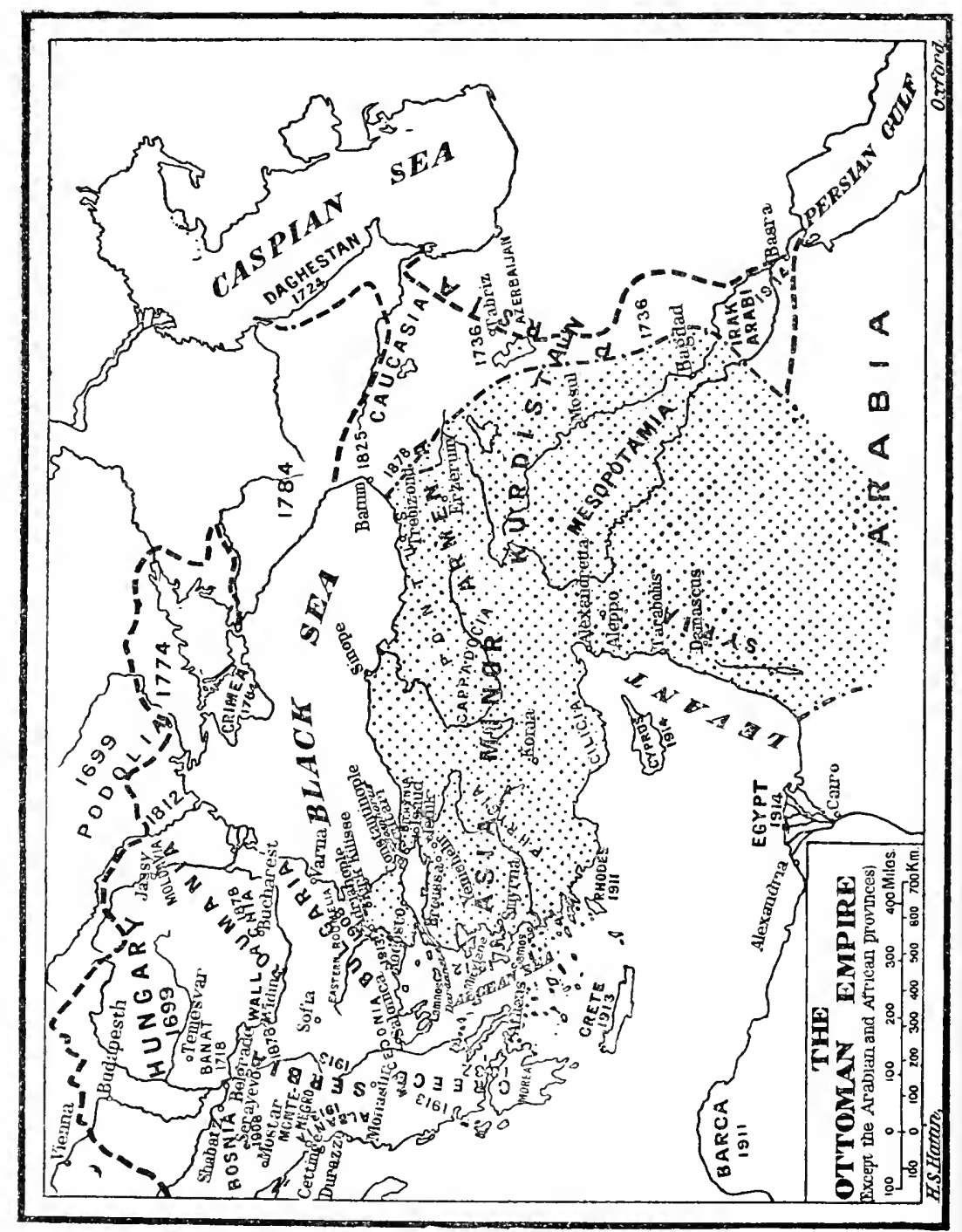




\section{CHAPTER III}

\section{THE ADVENT OF THE OTTOMANS}

\section{Conquests in Europe}

'Modern history begins under the stress of the Ottoman Conquest.'LORD ACTON.

'Il n'y a point de nation turque, mais seulement des conquérants campés au milieu de populations hostiles; les Tures ne forment point un État, mais une armée qui ne vaut que pour la conquête et tend à se dissoudre dès qu'elle est contrainte de s'arrêter.'-ALBERT SoREL.

The origins of the Turkish tribe, subsequently known as The the Osmanlis, Othmans or Ottomans, are shrouded in baffling Ottomans obscurity. The highly coloured pictures drawn by their own historians are, by common consent, entirely untrustworthy. But if little can be learnt authoritatively, perhaps it is because there is little to learn. It is still more probable that we have a good deal to unlearn. We are bidden, for example, to discard the commonly accepted tradition of a westward migration on an imposing scale; of a great struggle between the Ottoman and Seljukian Turks ; of the dramatic overthrow of the Seljuk Empire; of the establishment of a powerful Ottoman Empire in Asia Minor and the advance of the conquerors upon South-Eastern Europe. This book is not, however, a history of the Ottomans, and the critical discussion of these and similar questions must not therefore be permitted to detain us. Let it suffice to say that the Ottomans emerge into the realm of authentic history in the thirteenth century. We first see them as one of innumerable bands of nomads, warriors, and herdsmen, flying from the highlands of Central Asia before the fierce onset of the Moguls. A picturesque but exceedingly doubtful legend tells how Ertogrul, chief of a tribe of some four hundred families, found himself in a position to perform a signal service to Alaeddin, Sultan of the Seljukian Turks. The Seljuks had 
established a powerful empire in Asia Minor in the course of the elerenth and twelfth centuries, but by the thirteenth their power was manifestly in decay. To the Seljuk Empire there was no immediate successor. The story of its overthrow by the Ottomans camot be accepted. All that we know is that Ertogrul and his small band of followers established themselves, towards the middle of the thirteenth century, in the north-western corner of Asia Minor, in the plain between Brusa and Nicaea, with a 'capital' at Yenishehr.

0.man (12)81326).

Orkhan (13:36$13391 \%$
To Ertogrul there succeeded in 1288 his son Osman or Othman, from whom the tribe, destined to fame as the conquerors of Constantinople and inheritors of the Byzantine Empire, took their name. ${ }^{1}$ Osman extended his modest heritage partly at the expense of other Turkish Emirs but mainly at the expense of the Greek Empire in Asia Minor, and, upon the extinction of the Seljuk Empire, he assumed the title of Sultan (circ. 1300). In 1301 he won his first notable rictory over the Greeks at Baphaeon, in the neighbourhood of Nicomedia, and during the next few years he pushed on towards the Black Sea, and thus hemmed in the strong Greek cities of Nicomedia, Brusa, and Nicaea. On his death-bed (1326) he learnt that Brusa had fallen to his son Orkhan, and though the great prize of Nicaea was denied to him, Osman died 'virtual lord of the Asiatic Greeks'.

His son and successor Orkhan not only rounded off Osman's work in Asia Ninor, but obtained a firm foothold upon the European shores of the Hellespont. Nicomedia, the ancient capital of the Emperor Diocletian, fell to him in the first year of his reign, and was renamed Ismid. $\mathrm{A}$ few years later lie crowned his rictories over the Byzantine Empire in Asia Ninor by the capture of Nicaea, the second city of the Empire. By this time the Eastern Empire was, as we shall see later, tottering to its fall, not only in Asia Minor but in Europe. Towards the middle of the fourteenth century the pitiful remnant of it was distracted by ciril war between the

1 Only to Europeans are the Ottomans known as 'Turks'-a name, among themselves, of contempt, see H. A. Gibbons, Ottoman Empire, p. 29 ; Hogarth, Balkans, p. 319, \&c.

2 Hogarth, op. cit., p. 325. 
Palaeologi and John Cantacuzenos, who in 1341 had crowned himself Emperor at Demotika. Both parties appealed to Sultan Orkhan for help. Orkhan went to the assistance of Cantacuzenos in 1345, and was rewarded by the hand of Theodora, daughter of Cantacuzenos and granddaughter of the Bulgarian Tsar. This marriage may be regarded as the first step towards the establishment of an OttomanByzantine Empire in Europe. In 1349 Orkhan's assistance was again invoked by his father-in-law, to help in repelling the attacks of the Serbians, now at the zenith of their power, upon Macedonia. Orkhan's response was suspiciously prompt, and again a large body of Ottoman warrior's feasted their eyes with a vision of the promised land.

Hitherto the Ottoman horsemen, once their mission was ac- Percomplished, had duly withdrawn to their home on the Asiatic shore. But we are now on the eve of one of the cardinal events in world-history. That event was in one sense only the natural sequel to those which immediately preceded it; nevertheless it definitely stands ont as marking the opening of a new chapter. In 1353 Cantacuzenos once more appealed for the help of the Ottoman Sultan agaiust the Serbiaus : accordingly, Orkhan sent orer his son Suleiman Pasha, by whose aid the Serbians were defeated at Demotika and the Greeks recaptured the Thracian capital Adrianople. In acknowledgement of these signal services Suleiman Pasha received the fortress of Tzympe, and there the Ottomans effected their first lodgment on European soil. Much to the chagrin of the rival emperors Gallipoli fell before the Ottoman assault in the following year (1354), and a few years later Demotika also was taken. By this time the breach between Orkhan and his father-in-law was complete, and henceforward the Osmanli horsemen fought in Europe no longer as auxiliaries but as principals. Suleiman Pasha was killed by a fall from his horse in 1358, and a year later his father followed him to the grave. But the grip which they had got upon the European shore of the Dardanelles was never afterwards relaxed.

Before proceeding to describe the wonderful achievements Condition of Ottoman arms during the next hundred years it seems of Sonth- 


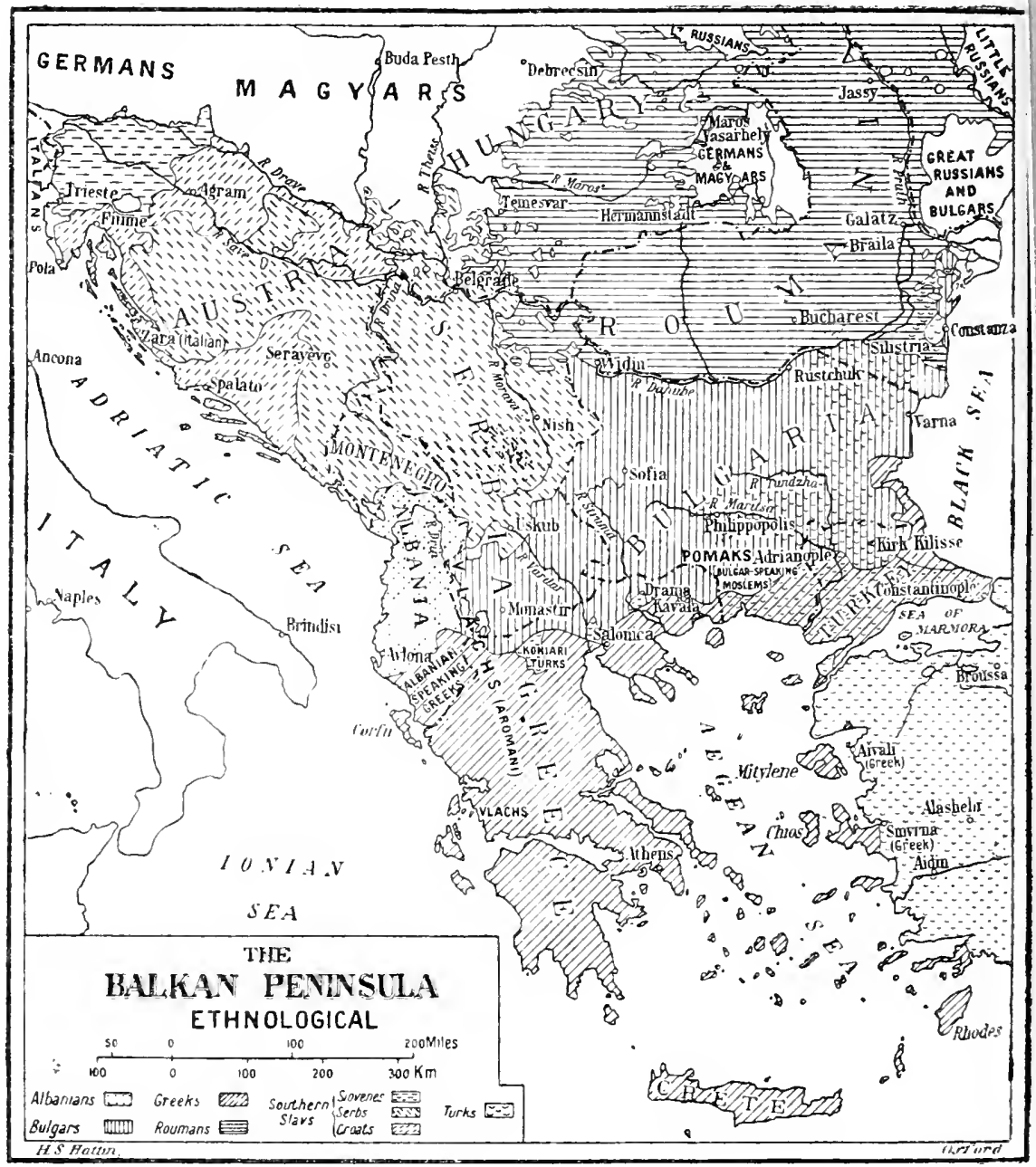


desirable to get some clear idea of the political conditions Europe which prevailed in South-Eastern Europe. in the

The Empire of the East, known indifferently as the Greek teenth or Byzantine Empire, had by this time reached the last stage of emasculate decay. The life of the Roman Empire had The been prolonged for more than a thousand years by the epoch- Empire. making resolution of the Emperor Constantine. But it was now ebbing fast. For three hundred years after Constantine's removal of the capital to Byzantium (330 A.D.) the Empire continued to be essentially Roman. With the reign of Heraclius (610-41) it became as definitely Greek. Under Leo III (the Isaurian, 716-41) Greek became the official language of the Empire, though its subjects still continued, until the advent of the Ottomans and beyond it, to style themselves Romaioi. Many hard things have been said of the Eastern Empire, but this at least should be remembered to its credit. For nearly a thousand year's it held the gates of Europe against a series of assaults from the East, until in turn it was itself partly orerwhelmed and partly absorbed by the Ottomans. Not that the Ottomans were the earliest of the Turkish tribes to threaten the Greek Empire. Towards the end of the eleventh century the Seljuks overran Asia Minor, drove the Emperor out of his Asiatic capital, Nicaea, and assumed the title of Sultans of Roum. The Emperors of the House of Comnenos pushed back the Seljuks from Nicaea to Iconium (Konia), but in the latter part of the twelfth century the Eastern Empire again showed symptoms of decrepitude, and at the opening of the thirteenth century it suffered an irreparable blow.

The fourth crusade (1200-4) has generally been accounted The Latin one of the blackest crimes in modern history 1 The immediate Empire at result of it was to establish a Latin or Frankish Empire, under nople Baldwin, Count of Flanders, in Constantinople; more re$(1204-61)$ motely it may be held responsible for the Ottoman conquest of South-Eastern Europe. It lasted little more than half a century (1204-61); but during those years the work of

1 See e.g. Sir Richard Jebb, Modern Greece, p. 30 ; Sir Edwin Pears, Conquest of Constantinople; the famous chapters in Gibbon's Decline and Fall; and Milman's Latin Christianity. 
disintegration proceeded apace in the Balkan lands. The Slavonic kingdoms firmly established themselves in the northern parts. Boniface of Montferrat proclaimed himself King of Salonica. Greece proper was divided up into various Frankish principalities, while the Aegean islands passed, for the most part, under the flag of the maritime Republic of Venice. Meanwhile, the Greek Empire, dethroned at Constantinople, maintained itself, in somewhat precarious existence, at Nicaea. Not less precarious was the hold of the Latin Empire upon Constantinople. The latter was purely a military adventure. It never struck any roots into the soil, and in 1261 Michael Palaeologus, Emperor of Nicaea, had little difficulty in reconquering Constantinople from the Latins. The restored Byzantine Empire survived for nearly two centuries, but its prestige had been fatally damaged, its vitality had been sapped, and it awaited certain dissolution at the hands of a more virile race. There can indeed be little doubt that only the advent of the Ottomans prevented Constantinople itself from falling into the hands of the Southern Slavs. The condition of the Byzantine Empire during this last period of its existence presents a curious analogy to that of the Ottoman Empire in the nineteenth. 'It is', writes a penetrating critic, 'the story of an uninterrupted succession of bitter internal quarrels, of attacks by former vassals upon the immediate frontiers of its shrunken territory, of subtle undermining by hostile colonies of foreigners whose one thought was commercial gain, and of intermittent, and in almost all cases selfishly inspired, efforts of Western Europe to put off the fatal day.' 1

Territorially, the Greek Empire had shrunk to the narrowest limits, little wider, in fact, than those to which the Ottoman Empire in Europe is reduced to-day. The Empire of Trebizond represented the remnant of its possessions in Asia, while in Europe, apart from Constantinople and Thrace, it held only the Macedonian coast with the city of Salonica and the Eastern Peloponnesus. Hungary, Transylvania, Wallachia, Croatia, and Bosnia owned the sway of Lewis the Great; the

1 H. A. Gibbons, op. cit., p. 36. 
Serbian Enpire stretched from Belgrade to the Gulf of Corinth, from the Adriatic to the Aegean ; Bulgaria held what we know as Bulgaria proper and Eastern Roumelia ; Dalmatia, Corfu, Crete, and Euboea were in the hands of Venice; the Knights of St. John were in possession of Rhodes, while the Franks still held the kingdom of Cyprus, the principality of Achaia, the Duchies of Athens, Naxos, and Cephalonia, not to speak of many of the Aegean islands. Little, therefore, was left to the successors of the Caesars in Constantinople.

When the Romans first made themselves masters of South- IllyrianEastern Europe they found three great races in possession : and Tians. the Illyrians, the Thracians, and the Hellenes. The Illyrians, who had established the kingdom of Epirus in the fourth century B.c., were represented in the thirteenth century, as they are still, by the mountaineers of Albania. The Thracians, dominant during the Macedonian supremacy, mingled with Trajan's colonists in Dacia to form the people represented by the modern Roumanians. But neither of these aboriginal races would, perhaps, have preserved, through the ages, their identity but for the existence of the third race, the Greeks. It was the Greeks, who, by their superiority to their Roman conquerors in all the elements of cirilization, prevented the absorption of the other races by the Romans, and so contributed to that survival of separate nationalities which, from that day to this, has constituted one of the special peculiarities of Balkan politics. Of the Illyrians in Albania little need, in this place, be said, except that they have successfully resisted absorption by the Turks as they had previously resisted similar efforts on the part of Romans, Byzantines, and Slars.

The Albanians have never contributed an important factor to the Balkan problem. Like the Slars, but in even greater degree, " they were devoid of cohesion and political sentiment, and have at no time been more than an aggregate of tribes, mostly occupied with internal quarrels,' 1 though, as we shall see, they have more than once produced a man of virile and commanding personality. 
Moldavia and Wallachia.

Far different has been the history of the Thracians in the Danubian principalities. That history is largely the outcome of geography. Their geographical situation, as was explained in the preceding chapter, though suggesting a highway to westward-bound invaders rendered them immune from conquest, and, as a fact, they have never actually submitted to a conqueror. Least of all to the Ottomans, who, as we shall see later, never made any serious or sustained attempt to absorb them into their Empire.

The modern Roumanians are commonly supposed to be descendants of the Roman colonists settled (circ. A.D. 101) by the Emperor Trajan in the province of Dacia for the proteetion of the Roman Empire against the northern barbarians. This account of their origin was disputed, however, by Dr. Freeman, who held that they represented 'not specially Dacians or Roman colonists in Dacia, but the great Thracian race generally, of which the Dacians were only a part'. 1 'The question is not one which can be permitted to detain us. It must suffice for our present purpose to say that just as the Hungarians represent a great Magyar wedge thrust in between the Northern and the Southern Slavs, so do the Roumanians represent a Latin wedge, distinct and aloof from all their immediate neighbours, though not devoid, especially in language, of many traces of Slav influences. Towards the close of the third century (circ. A.D. 271) the Emperor Aurelian was compelled by barbarian inroads to abandon his distant colony, and to withdraw the Roman legions, but the colonists themselves retired into the fastnesses of the Carpathians, only to emerge again many centuries later, when the barbarian flood had at last subsided.

For nearly a thousand years, reckoning to the Tartar invasion of 1241, Dacia was nothing but a highway for successive tides of barbarian invaders, Goths, Huns, Lombards, Avars, and Slavs. But, except the last, none of the invaders left any permanent impress upon the land. Still, the successive tides followed each other so quickly that the DacoRomans themselves were completely submerged, and for a thousand years history loses sight of them.

\section{E. A. Freeman, Ottoman Power in Europe, p. 51.}


But though submerged they were not dissipated. 'The possession of the regions on the Lower Danube', writes Trangott Tamm, 'passed from one nation to another, but none endangered the Roumanian nation as a national entity. "The water passes, the stones remain"; the hordes of the migration period, detached from their native soil, disappeared as mist before the sun. But the Roman element bent their heads while the storm passed over them, elinging to the old places until the advent of happier days, when they were able to stand up and stretch their limbs.' 1 The southern portion of what is now Roumania emerged, towards the close of the thirteenth century, as the principality of Wallachia (or Muntenia, i. e. mountain-land); the northern, a century later, came to be known as the Principality of Moldavia. Both principalities were founded by immigrant Rouman nobles from Transylvania, and, as a consequence, Roumania has always been distinguished from the other Balkan provinces by the survival of a powerful native aristocracy. In Serbia the nobles were exterminated; in Bosnia they saved their property by the surrender of their faith ; in Roumania alone did they retain both.

Such was the position of the Danubian principalities when the Ottomans began their career of conquest in South-Eastern Europe. The principalities had nerer been in a position, like their neighbours to the south and west of them, to aspire to a dominant place in Balkan politics. Nor were they, like those neighbours, exposed to the first and full fury of the Ottoman attack. Still, under its famous Voivode Mireaea the Great, Wallachia took part against the Ottomans in the great Slavonic combinations, which were dissolved by the Turkish victories at Kossovo (1389) and Nicopolis (1396).

Early in the fifteenth century the Ottomans crossed the Danube, and in 141.2 Wallachia was reduced to a state of vassaldom. But it was never wholly absorbed like Serbia, Bulgaria, Greece, Macedonia, and Thrace into the Ottoman Empire. Nor was Moldavia, which, for obvious geographical reasons, managed to maintain its independence for a hundred

1 Quoted by D. Mitrany, The Balkans, p. 256. 
years longer than Wallachia. In 1475 Stephen the Great, Voivode of Moldavia, won a resounding victory over the Turkish army at Racova. In 1512, howerer, his son Bogdan, weakened by the attacks of Poland and Hungary, made a voluntary submission to the Ottomans. He agreed to pay tribute to the Sultan and to assist him in time of war, but Moldavia was to continue to elect its own prince, and no Turk was to be permitted to settle in the principality. These terms were confirmed, in 1536, by Suleiman the Magnificent, and formed the basis of the relations which subsisted between Constantinople and the two Danubian principalities down to the eighteenth eentury.

Bulgaria. South of the Danube and between that river and the Aegean lay the district known as Bulgaria. The ThracoIllyrian race by which it was originally inhabited was conquered by the Slavs who, from the beginning of the sixth century onwards, inundated the peninsula. By the middle of the seventh century the Slav penetration of the Balkans was complete ; from the Danube to the Maritza, from the Adriatic to the Black Sea the Slavs formed a solid mass, broken only by Albania and Southern Thrace; Greeks held the A egean eoast and most of the towns-Athens, Corinth, Patras, Larissa, and Salonica : but even in the interior of the Morea there was a eonsiderable infusion of Slavs. Upon the heels of the Slavs came the Bulgars. The latter belong to a Turanian race, akin to the Avars, Huns, Magyars, and Finns. Coming like other Mongol races from Eastern Asia, they settled on the Volga, where the Greater or White Bulgaria eontinued to exist down to the sixteenth century. Thence they made various predatory iuroads into the Balkan peninsula, in the latter part of the sixth and first half of the seventh eentury, and eventually in 679 subjugated the Slars of Moesia and effected a definite and permanent settlement in the land between the Danube and the Balkan mountains. After their settlement, however, they were completely assimilated in language and in civilization to the conquered Slavs, and to-day they are commonly accounted a Slavonic people. Yet despite identity of speech, and despite a very large infusion of Slav blood, the Bulgar has 
developed a distinct national self-consciousness which has constantly come into conflict with that of the Southern Slavs.

The antagonism between these near ncighbours has been accentuated in recent years by the establishment of an independent Bulgarian Exarchate. That exceedingly important step was taken in 1870 , precisely one thousand years after the fateful decision by which the Bulgarian Church was placed under the Patriarch of Constantinople. Prince Boris of Bulgaria had been converted to Christianity in 865 , but for the first few years it was uncertain whether the infant Bulgarian Church would adhere to Constantinople or to Rome. In 870, during the reign of the Emperor Basil I, the victory, pregnant with consequences for Bulgaria, was assured to Constantinople.

It was under Simeon the Great (893-927), the son of Boris, First that Bulgaria attained to the position of a great Power. Bulgarian Simeon himself adopted the style of 'Tsar and Autocrat of (893-972). all Bulgars and Greeks', and the territorial expansion of his kingdom, the widest as yet achieved by Bulgaria, went far to sustain his titular pretensions. The Byzantine emperors could command the allegiance only of Constantinople, Adrianople, Salonica, and the territory immediately adjacent thereto, and were compelled to pay tribute to the Bulgarian Tsar. Simeon's empire stretched at one time from the Black Sea almost to the Adriatic, and included Serbia and all the inland parts of Macedonia, Epirus, and Albania.

But the first Bulgarian Empire was shortlived. The Serbs reasserted their independence in 931 ; domestic feuds led to the partition of Bulgaria itself into Eastern and Western Bulgaria in 963 ; ecclesiastical schism, due to the spread of the curious Bogomil heresy, accentuated civil strife; while the Emperor Nikephoros Phokas (963-9) renounced in 966 the tribute paid to the Bulgarian Tsar, and, shortsightedly invoking the assistance of the Russians, inflicted a crushing defeat upon Bulgaria. It was, indeed, easier to introduce 


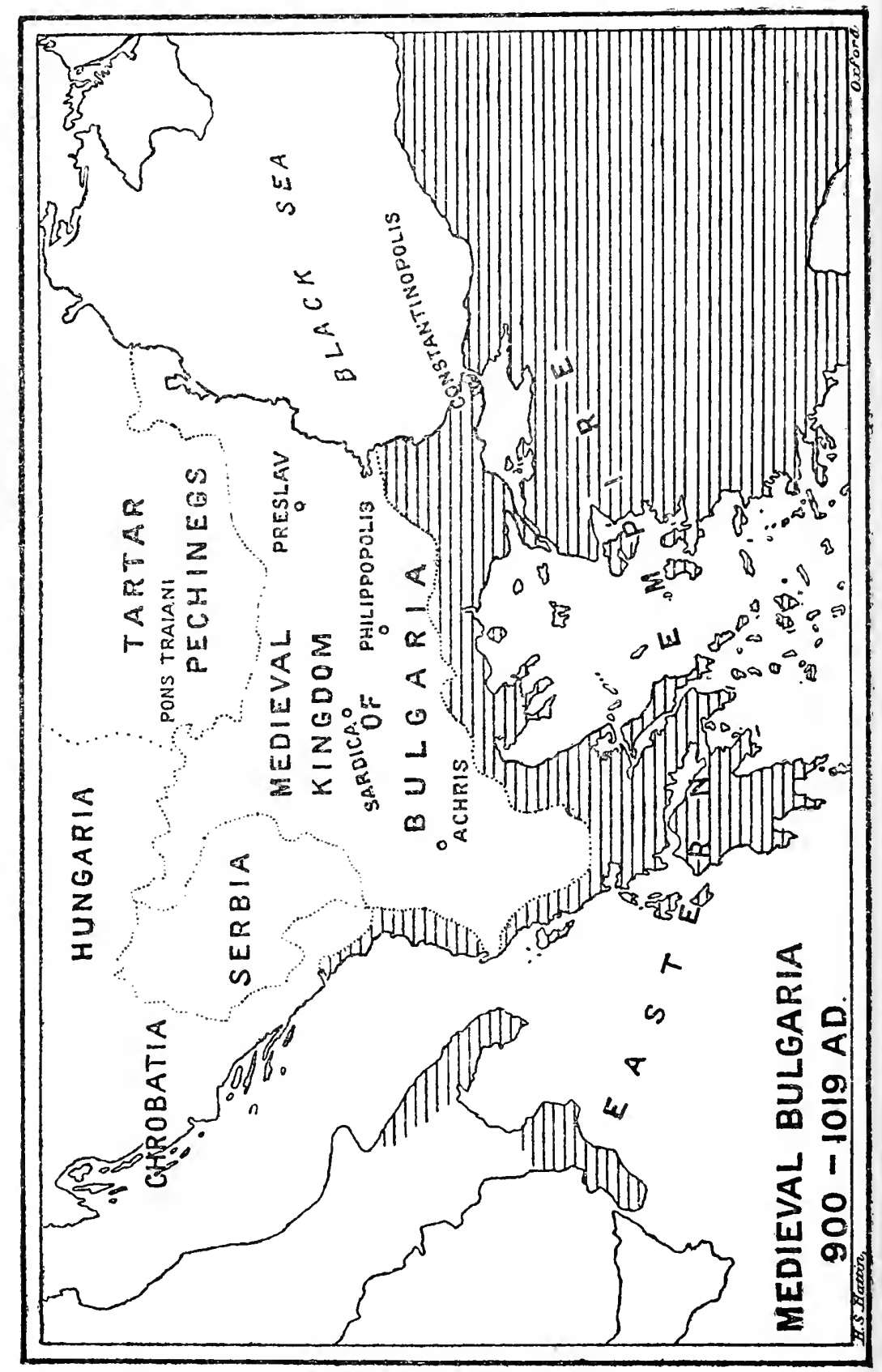


the Russians into the Balkans than to get rid of them. But the latter feat was at length accomplished by the Emperor John Tzimisces - a brilliant Armenian adventurer-and Eastern Bulgaria was merged, for the time, into the Byzantine Empire (972).

Western Bulgaria, with its capital at Okhrida, and including at one time Thessaly, Macedonia, Albania, Montenegro, Herzegovina, and parts of Serbia and Bulgaria proper, survived for another thirty years. But it in turn fell before the longsustained attack of the Emperor Basil II (976-1025), known to fame as Bulgaroktonos, 'slayer of the Bulgarians.' A succession of victories culminated in 1016 in the capture of Okhrida, and the Western Bulgaria, like the Eastern, ceased to exist. Once more the authority of the Byzantine emperor was reasserted throughout the peninsula.

For more than a century and a half the history of Bulgaria The is a blank. Its revival dates from a successful rerolt headed $\begin{aligned} & \text { Second } \\ & \text { Bulgarian }\end{aligned}$ in 1186 by John Asen-a Vlach shepherd-against the tyranny Empire, of the Emperor Isaac Angelus. The capital of this second (1187or Vlacho-Bulgarian Empire was at Tirnovo where, in 1187, John Asen was crowned. It included, at one time, besides Bulgaria proper, most of Serbia, with parts of Thrace, Macedonia, Thessaly, and Epirus, but the murder of John Asen II in 1257 brought the Vlach dynasty and the Vlacho-Bulgarian Empire to an end. Most of its provinces had already been lost to it, and the remnant was held in vassaldom to Serbia. For the Serbs had by this time become the dominant power in the peninsula, and it was, as we have seen, to combat the insistent menace of this people that Catacuzenos, in the middle of the fourteenth century, invoked the aid of the Ottomans. The place of the Southern Slars in the Balkan polity of the fourteenth century must, therefore, be our next concern.

Of the coming of the Slars into the Balkan Peninsula Serbia something has been already said. By the middle of the and the seventh century the peninsula had become predominantly Slavs. Slavonic, and the lines of the chief Slav States had already been roughly defined. Of Bulgaria no more need be said. The other three were inhabited by Serbs, Croatians, and 


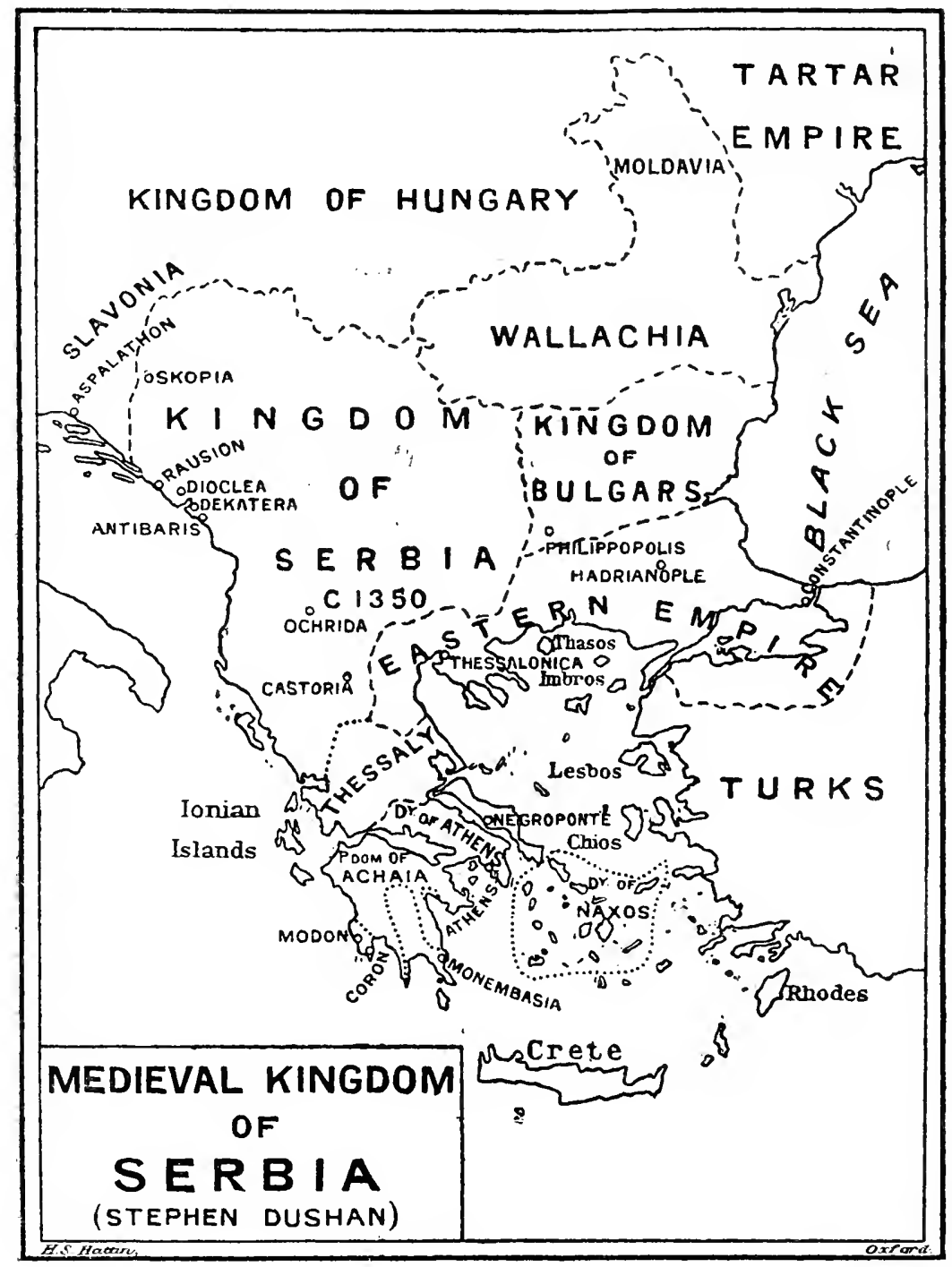


Slovenes respectively. The last occupied what we know as Carniola and Southern Carinthia; the Croats held Croatia with parts of Bosnia, Herzegovina, and Dalmatia; the Serbs held the remaining portions of the three last-named provinces together with Montenegro and practically everything which was assigned to Serbia by the Treaty of Bucharest (1913), i. e. Serbia proper, old Serbia, and the northern part of Macedonia. The Southern Slavs have always been more devoted to independence than to discipline, more conspicuous for valour than for organizing capacity. From the first they were, in a political sense, loosely knit, lacking in coherence or in the power of continuous combination. They were bound to the soil, not by serfdom, but by the affectionate ties of cultivating proprietors. Such governmental machinery as they devised was local rather than central ; they organized themselves in agricultural village-conmunities, and showed a marked aversion, in strong contrast with the Greeks, to city life. Originally they had neither kings, nor priests, nor even slaves, but settled down in free communities of peasant owners and organized their social and economic life on 'a system of family communism'.' Freedom-loving and brave, they had the defects of their qualities. Their lack of discipline, subordination, and political coherence, not less than the physical characteristics of their country, made it difficult to weld them into a powerful State, while their jealous devotion to the soil disposed them to local feuds of a peculiarly ferocious character.

Torn by internal dissensions the Serbs have always lacked, except towards the north, natural and definable frontiers. Still more unfortunate has been their lack of coast-line. They have never reached the Aegean, and only for a short period were they established on the Adriatic. The Greeks headed them off from the former; the Venetians and Hungarians, after the fall of Rome, generally kept a jealous hold upon the latter.

The Serbs embraced Christianity towards the end of the ninth century, but in ecclesiastical as in political affairs the 
Southern Slavs found it difficult to agree; for while the Serbs adhered to Constantinople the Croats acknowledged the authority of Rome. Temporal allegiance tended to follow the same direction. From the ninth century to the twelfth the Serbs were for the most part under the suzerainty of the Bulgarian or the Byzantine Empires; the Croats were subject to Hungary or Venice.

'The

Serbian Empire.

The great period in the mediaeval history of Serbia extends from the middle of the twelfth to the close of the fourteenth century. Under the Nemanya dynasty (1168-1371) Serbia managed to compose, in some degree, her internal quarrels, and so gave herself, for the first time, a chance of attaining to a dominant position in Balkan politics. Stephen Nemanya, the first of the new line, succeeded in uniting most of the Serbian countries-Serbia proper, Montenegro, and Herzegovina, and though forced to make submission to the Emperor Mannel I Comnenus, he renewed his career of conquest on the latter's death, 1180, and when, in 1196, he resolved to abdicate, he handed over to his second son, Stephen Urosh (1196-1223), a kingdom tolerably homogeneous, and, in extent, indubitably imposing.

Stephen The new ruler was, on his accession, confronted by diffiUrosh (1196culties which have recurred with ominous regularity in every period of Serbian history. These difficulties arose from three main causes : dynastic disunion ; the jealousy of Bulgaria; and the unremitting hostility of the Magyars of Hungary. The chagrin of an elder brother, passed over in the succession, was mollified by the tact of a younger brother, a monk, the famous St. Sava. The same tactful intermediation secured for the Serbian Church internal autonomy and independence of the Patriarchate of Constantinople. Against the jealousy of Bulgaria St. Sava was less successful, for the Bulgarians, seizing the opportunity of Serbian disunion, made themselves masters of a large part of Eastern Serbia, including the important towns of Belgrade, Nish, and Prizren. The hostility of Andrew II of Hungary had, for the time being, little definite result, but its existence supplies one of those constant factors which give something of unity and consistency to the confused annals of the Southern Slars. If at any time there has been 
any special manifestation of national self-consciousness on the part of the Sonthern Slars, Buda-Pesth has immediately responded by a marked exhibition of its $\mathrm{mn}$. ceasing vigilance and its ineradicable jealousy. Nor is it possible to deny that the antagonism between the two peoples is due to a direct conflict of interest. The Magyars have always striven to obstruct the progress of the Southern Slavs towards the Adriatic; the Serbians still block the access of the Magyars to the Aegean. Notwithstanding these initial difficulties the reign of Stephen Urosh was exceptionally prosperous. He himself was the first of Serbia's kings to receire the consecration of a solemn coronation, and so skilful was his diplomacy in playing off Rome against Constantinople, and Nicaea against both, that he secured the recognition of Serbian independence, both civil and ecclesiastical, not only from the Pope but from the Latin and Greek cmperors. ${ }^{1}$

We must pass over with scant notice the century which elapsed between the death of Stephen Urosh (1223) and the accession of the most renowned of all Serbian rulers, Stephen Dushan (1331). Serbian annals have little else to record during this period but a monotonous tale of domestic quarrels and military expeditions, conducted with varying success, against immediate neighbours. A crushing defeat inflicted upon a combination of Greeks and Bulgars by Stephen VII ${ }^{2}$ (1321-31) is perhaps worthy of record, since it prepared the way for the brilliant success achieved by his son. It should be noted also that by this time the Serbians had already come into contact with the Turks.

The reign of Stephen VIII, 'Dushan,' 3 demands more $\begin{gathered}\text { Stephen } \\ \text { Dushan }\end{gathered}$ detailed consideration, for it marks the meridian of Serbian $\begin{gathered}\text { Dushan } \\ \text { (1331- }\end{gathered}$ history. Cut off at the early age of forty-six, perhaps by 50). poison, he yet lived long enough to establish his fame both as lawgiver and conqueror. His code of laws published in

1 The Latin Empire was established at Constantinople in 1204, see supre, p. 41.

2 It should be noted that the numeration of kings and the chronology of their reigns are alike uneertain.

${ }^{3}$ Dushan = the strangler, and according to one, but not the only, version Stephen VIII strangled his father. 
1349, not less than his encouragement of literature and his protection of the Church, has given to Dushan a place in the history of his own land analogous to that of King Alfred in our own. It is, however, as a mighty conqueror that his memory lives most vividly in Balkan history.

Conquests His first military success was achieved against the Emperor of Stephen Andronicus III. He invaded Thessaly, defeated the forces of the emperor, and by a treaty dictated in 1340 Serbia was recognized as the dominant power in the peninsula. Bulgaria, the sister of whose king Dushan married, formally recognized his supremacy, and in 1345 Stephen was crowned at Uskub, which he made his capital, Tsar of the Serbs, Bulgars, and Greeks. So formidable was Dushan's position in South-Eastern Europe that in 1353 the Pope, Innocent VI, deemed it prudent in the interests of Western Christendom to incite Lewis, King of Hungary, to an attack upon the Serbian Tsar. The Magyars, as we have seen, were never backward in such enterprises; but, in this case, their intervention recoiled upon their own heads. The city of Belgrade, and the provinces of Bosnia and Herzegovina rewarded the victorious arms of Dushan. The extent of his empire was now enormous. It extended from the Save and Danube in the north almost to the Aegean in the south; from the Adriatic in the west almost to the Lower Maritza in the east. It thus comprised Serbia, Montenegro, Albania, Southern Dalmatia, Bosnia and Herzegovina, Northern Macedonia, and a great part of Greece.

The South Slavonic lands of Croatia, Slavonia, and Northern Dalmatia were still outside the Serbian Empire, nor did it even include Salonica, still less the imperial city itself. Not that Constantinople was beyond the range of Dushan's ambition. The distracted condition of the Eastern Empire seemed indeed to invite an attack upon it. In the domestic dissensious which so grievously weakened the Byzantine emperors in their incipient duel with the Ottomans, Dushan espoused the side of the Empress Anna against Cautacuzenos, and with marked success. In 1351 Dushan organized a great crusade 
against the decadent Empire of Constantinople with the hope of re-establishing the imperial city as a barrier against the advancing power of the Ottomans.

Cantacuzenos, as we have seen, had not hesitated, again and again, to inroke the aid of Sultan Orkhan against the redoubtable Dushan. In 1353 the Serbians were defeated by the Ottomans at Demotika and Adrianople, and Thrace and parts of Macedonia were thus recorered for the Byzantine Empire. Dushan was great enough both as statesman and strategist to see that, if South-Eastern Europe was to be sared from the Asian menace, Constantinople itself must be held by a national Power, more virile than that of the decadent Byzantines. Under the circumstances that Power could be none other than Serbia. Adrancing in 1355 to the accomplishment of this great enterprise, Stephen Dushan was suddenly and prematurely cut off. That poison should have been suspected was inevitable, and the suspicion may be justified.

The death of the Tsar Dushan may fitly close our prolonged parenthesis.

The object of that parenthesis has been to enable the reader to grasp the main features of the general political situation in the Balkans at the moment when a new Power intervened in European affairs. The close of it tempts to speculation. Is it idle to conjecture what might have happened had the Ottomans declined the invitation of Cantacuzenos and elected to remain an Asiatic Power? What, under those circunstances, would have been the fate of SouthEastern Europe? The Greek Empire, undeniably damaged in prestige by the Latin episode, had itself fallen into a state of decrepitude which forbad any possible hope of redemption. Could a suitable successor hare been found among the other Balkan 'States'? The autochthonous Illyrians, now settled in Albania, might perhaps have kept a hold on their mountain fastnesses, but they could nerer hare hoped to do more. The Daco-Roumans, representing the other indigenous race, were geographically too remote from any one of the three keys of the Balkans-Belgrade, Salonica, and Constantinople - to assume at this stage a leading rôle. The Greeks were 
politically successful only so long as they remained within sight and smell of the sea. The subjection of a hinterland has always seemed to be beyond their powers. By a process of exclusion we reach the Bulgarians and the Serbs, and judging from the experience of the recent past the future seemed to belong to one or other of these peoples, or still more certainly, if they could compose the differences which divided them, to both. Twice had the former attained to clear pre-eminence, if not to domination. But the empires of Simeon and Asen were matched if not surpassed by that of Stephen Dushan. And to Serbia came the 'psychological' chance. Her supremacy in Balkan politics coincided with one of the great moments in human history. Tremendous issues hung in the balance when Stephen Dushan was suddenly smitten with mortal illness, as he was advancing on Constantinople; when, from the Danube almost to the Aegean, from the Black Sea to the Adriatic, Serbian suzerainty was virtually unchallenged; when the Ottomans were effecting their first lodgment on European soil.

The history of the Southern Slavs had already revealed congenital weaknesses; it would be idle to pretend that more recent experience has proved that during the dark days of adversity and oblivion they have been entirely overcome. But whatever the explanation the fact remains that, in the middle of the fourteenth century, the Balkan Slavs had a chance such as comes to few peoples; and they missed it. As a result the history of South-Eastern Europe belongs for the next five hundred years not to the Slavs, nor to the Greeks, but to their Ottoman masters.

Ottoman To the story of the Ottomans we must, therefore, after conquests in Europe. a long but necessary diversion, return. It was against the Serbs, not against the Greeks, that the Ottoman arms in Europe were first directed-a point on which a recent historian has laid considerable enphasis. The result was to involve the Ottoman invaders 'in a tangle of Balkan affairs from which they only extricated themselves after forty years of incessant fighting'. ${ }^{1}$ Nevertheless it was upon the 
Thracian Chersonese that the invaders first fastened. Cantacuzenos was not slow to perceive the blunder he had made. An appeal to Orkhan to quit his hold was met by a courteous but firm refusal. Whereupon the wretched emperor so far humiliated himself as to beg for the assistance of the Bulgars and Serbs. On their refusal his position in Constantinople became desperate. His subjects recalled John Palacologus, and Cantacuzenos abdicated his uneasy throne and withdrew into a monastery (1354).

Four years later Sultan Orkhan, his son-in-law, died. The Murad I reign of his son, Murad I, was one of the most splendid in the ${ }_{89)}^{(1359-}$ ammals of the Ottomans. It opened auspiciously with a long and successful campaign in Thrace (1360-1) which finally assured the foothold of his people on the soil of Europe. One after another the important strategic points in Thrace fell into their hands, until at last, by the capture of Adrianople and Philippopolis, they confined the Greek Empire to Constantinople. The Emperor, John V, bowed to the inevitable, recognized the Ottoman conquest of Thrace as definitive, and agreed to become the vassal of the Sultan (1363).

By this time the Christian States were awakening to the gravity of the situation, and in 1363 Lewis the Great of Hungary led a crusading expedition of Hungarians, Serbians, Bosnians, and Wallachians against the successful infidel. Very little, however, was achieved by the enterprise, which came to a disastrous, if not a disgraceful, end in a crushing defeat on the banks of the Maritza.

In 1366 Sultan Murad took a step of high significance; he Conquest established his capital at Adrianople, and, turning his back of the upon the imperial city, devoted hinself for the remainder of Peninsula. his life and reign - twenty-three years - to the conquest of the Balkan Peninsula. Sisman of Bulgaria was, in 1379, reduced to vassaldom ; the Serbs were decisively defeated at Taenarus, and the Nemanya dynasty came to an end. With the extinction of the dynasty to which Dushan had given distinction Serbia's brief day was over. Little hope now remained to the Byzantine emperor. Frantic appeals were once more addressed to the Christian princes; the emperor himself undertook a special pilgrimage to Rome, but no help was forthcoming 
from a distracted and divided Christendom, and in 1373 John $\mathrm{V}$ definitely accepted the suzerainty of the Ottoman conqueror; undertook to render him military service; and entrusted to his custody his son Manuel as a hostage for the punctual performance of his promises.

Meanwhile Murad made rapid progress in the subjugation of the peninsula : Eastern Macedonia, up to the Vardar river, was conquered in 1372 ; the rest of Macedonia was occupied in 1380 ; the Ottomans established themselves in Prilep and Monastir, and, a few years later, in Okhrida. Murad then turned to complete the subjection of Bulgaria and Serbia. Sofia was taken in 1385, and a year later Nish also fell.

Battle of Kossovo, June 15, 1389 .
One last and desperate effort was now made by the Slavs to avert their impending doom. A great combination was formed between the Southern Slars of Serbia and Bosnia, the Bulgars, the Vlachs, and the Albanians. On June 15, 1389 , one of the most fateful battles in the history of the Near East was fought on the historic plain of Kossovo. The arms of the Ottoman were completely victorious, and the Slav confederacy was amnihilated. The assassination of the Sultan Murad by a pretending Serbian traitor, Milosh Obilic, adds a touch of tragedy to sufficiently impressive history. But the tragedy did not affect the issue of the day. Murad's son, Bajazet, rallied his troops and pressed the victory home. Lazar, the last Serbian Tsar, was captured and executed, and his daughter, Despina, became the wife of the rictorious Sultan. The memory of the battle of Kossovo Polye-the Field of Blackbirds-has been preserved in the ballad literature of a freedom-loving peasantry. Not until 1912 did the memory cease to rankle; not until then was the defeat avenged, and the bitterness it had engendered even partially assuaged.

For five hundred years after Kossovo the Serbs never really rallied. Many of them took refuge in the mountains of Montenegro, and there maintained throughout the ages a brave fight for freedom ; many more migrated to Bosnia, and even to Hungary. But as an independent State Serbia was blotted out. 
Four years after the overthrow of the Sonthern Slars at Conquest Kossoro Bulgarian independence suffered a similar fate. of BulThe Turks had already taken Nikopolis in 1388, and in 1393 they destroyed the Bulgarian capital, Tirnovo. The Bulgarian Patriarch was sent into exile; the Bulgarian Church was, for just five hundred years, reduced to dependence on the Greek Patriarchate at Byzantium; the Bulgarian dynasty was extinguished, and the Bulgarian State was absorbed into the Empire of the Ottomans.

From the conquest of Bulgaria Bajazet turned to Hungary. Battle of He had already, in 1390, carried out a series of snccessful $\begin{aligned} & \text { Nikopolis } \\ & (1396) \text {. }\end{aligned}$ raids into that country ; he now aspired to more permanent conquest. Sigismmd, who had succeeded to the throne of Hungary in 1387, was fully conscious of the impending peril. He made a strong appeal to the other Christian princes of Europe, and in 1394 Pope Boniface IX proclaimed a crusade. One hundred thousand Paladins, the flower of the chivalry of France and Germany, nobles not a few from England, Scotland, Flanders, and Lombardy, and a large body of the Knights of St. John responded to the papal call, and enlisted under the banner of Sigismund. In the battle of Nikopolis (1396) the forces of Christendom were overthrown by the Ottomans. The larger part of Sigismund's followers were slain or driven into the Danube to be drowned; no fewer than four French Princes of the Blood and twenty sons of the highest nobility in France were among Bajazet's prisoners; of the Knights of Rhodes only the Grand Master survived, while Sigismund himself escaped with difficulty down the river, and thence by sea returned to Hungary. After the battle a force of Turks invaded Hungary, destroyed the fortresses, and carried off sixteen thousand Styrians into captivity. The triumph of the Ottomans was complete.

The effort of Christendom was unfortunately premature. C'ould they harc waited another six years, and then have struck hard when Bajazet was himself a prisoner in the hands of Tamerlane, the whole future course of European history might have been profoundly affected. When the chance did come in the first years of the fifteenth century, Christian Europe was too hopelessly distracted by 
the Great Schism and other quarrels to take advantage of it.

Conquest After his victory at Nikopolis Bajazet turned southwards. of Greece.

Hitherto Greece proper had been spared ; but between 1397 and 1399 Bajazet conquered Thessaly, Phocis, Doris, Locris, part of Epirus, and Southern Albania. Thus the conquest of the Balkan Peninsula was all but complete. Athens and Salonica remained in Christian hands, ${ }^{1}$ but the emperor himself retained nothing but the extreme south of the Morea and Constantinople.

Could even this remuant be saved? At the end of the fourteenth century it seemed more than donbtful; at the beginning of the fifteenth it appeared at least to be possible; for the whole situation was temporarily transformed by the bursting over Western Asia of a storm which for some years had been gathering in the East.

Tamer- Born in Bokhara in 1336, Timour 'the Tartar' had in the lane. latter half of the fourteenth century made himself master of a vast-stretching territory between the Indus and Asia Minor. From Samarkand to Khorassan, from Khorassan to the Caspian; northwards from the Volga to the Don and the Dnieper ; southwards to Persia, Mesopotamia, Armenia, and Georgia-all acknowledged him as lord. In 1398 he invaded India, and was proclaimed Emperor of Hindustan; then, westwards again, he made himself master of Bagdad, Aleppo, and Syria. Finally, in 1402, he challenged the Ottoman Sultan in Anatolia. With the Ottoman Empire in Asia this book is not primarily concerned; but it is essential to remember that, coincidently with their ceaseless activity in Europe, the Ottomans had gradually built up, partly at the expense of the Greek emperors, partly at that of the Seljukian Turks, partly at that of smaller Turkish emirs, an imposing empirc in Asia Minor.

At the beginning of the fifteenth century the whole of their hardly-won empire was threatened by the advent of the mighty conqueror Tamerlane. In 1402 Tamerlane inflicted

1 Gibbons, op. cit., p. 231, seems to have established his point that Salonica was not taken until 1430 , and that Athens survived the capture of Constantinople; but it is not certain. 
a crushing defeat upon the Ottomans at Angora, and took the Sultan Bajazet prisoner. Later on he captured Brusa and Smyrna, and overran the greater part of Asia Minor. But then, instead of advancing into Europe, he again turned eastwards, and in 1405 he died. The cloud dispersed almost as quickly as it had gathered.

Sultan Bajazet died in captivity in 1403. The battle of Angora is memorable for the fact that it resulted not only in a crushing military defeat but in the capture of an Ottoman Sultan. Never had this happened before; never has it happened since. But apart from this, the defeat of Bajazet at Angora had curiously little significance. The remnant of the Byzantine Empire did, indeed, get a temporary respite ; the imperial city was saved to it for half a century; and there ensued among the Ottomans a decade of confusion, civil war, and interregnum.

Yet during this period of confusion no attempt was made either by the Greek emperor or by the Slar peoples in the peninsula, or by interested competitors such as the Venetians or Genoese, or by Sigismund of Hungary, or by the Pope as representing Christendom, to repair the damage wrought in the last half century by the infidel. What is the explanation of this astounding neglect of a unique opportunity? Christendom had, it is true, plenty on its hands. The Great Schism rendered nugatory any action on the part of a Pope. Sigismund, too, was preoceupied. But the essential reasons must be sought elsewhere. It is clear, in the first place, that the Greek Empire was sunk beyond hope of redemption; secondly, that the Balkan 'peoples' were umready to take its place; and finally, that the Ottoman Emperors, Orkhan, Murad, and Bajazet, had builded better than they knew. It is, indeed, a remarkable testimony to their statesmanship that the infant empire should have passed through the crisis after Angora practically unscathed. The ten years' anarchy was ended in 1413 by the recognition of Mohammed I (1413-21) as sole Sultan, but his brief reign did little to repair the havoc. That task he bequeathed to his son.

For thirty years Murad II devoted his great energy and Murad II ability to its accomplishment. His first effort was directed ${ }^{(1421-51)}$. against Constantinople; but the great prize was snatched 
from his grasp, as all men then believed, by the miraculous apparition of the Virgin on the walls of the beleaguered city, or possibly by an urgent call from Asia Minor. To Asia Minor, at any rate, he went, and having effectually restored his authority there, he returned to Europe in 1424. The attack upon Constantinople was not resumed, but in 1430 Salonica was for the first time taken by the Ottomans, and Murad's victorious army advanced into Albania.

John Corvinus Hunyadi

But the main work of Murad lay elsewhere. In 1440 he was confronted by a great confederacy in the north. The Turkish victory at Nikopolis owed not a little to the help of Serbia, who, as a reward, was reinvested with Belgrade. In 14:7, howerer, the lordship of the Serbians passed to George Brankovic, whereupon Murad immediately declared war, and Brankovic was compelled to surrender Nish to the Turks and Belgrade to the Magyars. But he built, lower down the Danube, the great fortress of Semendria, which remained, until the nineteenth century, the Serbian capital. Shortly afterwards the Ottomans were threatened by the rise of a great leader among the Magyars. Of all the foes whom the Turks encountered in their conquest of the Balkans, the most brilliant, perhaps, was John Corvinus Hunyadi, Voivode of Transylvania, and celebrated by Commines as 'le chevalier blanc des Valaques'. Under his banner Magyars, Czechs, Vlachs, and Serbians united in an attempt to stem the Ottoman tide. The first encounter between Hunyadi and the Turks was in 1442 at Hermannstadt in Transylvania, when he inflicted a crushing defeat upon the Ottoman general. An attempt to avenge this defeat ended in an even more decisive victory for the arms of Hunyadi. In the summer of 1443 Hunyadi again led an imposing host against the Ottomans. Crossing the Danube near Semendria, he marched up the valley of the Morava, and on November 3 defeated the Turks at Nish. He then took Sofia, forced the passage of the Balkans, and having won another great victory in the valley of the Maritza, found hinself within striking distance of Constantinople.

Treaty of Sultan Murad, beaten to his knees, begged for peace, which Szegeddin. was solemnly concluded at Szegeddin (July 12, 1444). There 
was to be a truce for ten years; Serbia and Herzegovina were to be restored to George Brankovic in complete independence, and Wallachia was to pass under the suzerainty of Hungary. Ladislas, King of Hungary, swore upon the Gospels, the Sultan swore upon the Koran, that the terms should be faithfully observed.

Hardly was the ink dry upon the treaty when Ladislas, on yielding to the combined and perfidious persuasion of the Papal Legate, Cardinal John Cesarini, and the Greek Emperor, determined to break it. Hunyadi, bribed by a promise of the throne of Bulgaria, reluetantly consented, and on September 1 the Hungarian army marched into Wallachia, and in less than two months found themselves in front of Varna. The surrender of Varna, however, put a term to the triumph of the Hungarians.

Secure in the oath of a Christian, Sultan Murad had gone Pattle of into retirement after the Treaty of Szegeddin, and had sent Yarna, his army into Asia Minor. The news of the Hungarian 144. advance recalled both the Sultan and his army. Transported from Asia by a heavily bribed Genoese fleet, the Turks reached Varna, and there on November 10, 1444, inflicted a crushing and merited defeat upon their foes. The King of Hungary, the Papal Legate, and two bishops paid for their perfidy with their lives upon the field of battle.

Hunyadi, howerer, escaped, and four years later he again led a great army across the Danube. The Turks met him on the historic field of Kossovo (October 17, 1448), and there, after three days battle, aided by the defection of George Brankovic, they won, for the second time, a decisive victory.

Thus was the infant empire of the Ottomans saved at last from one of the greatest dangers that ever threatened it. In the same year the Emperor John VIII died, and the rival claimants appealed to Sultan Murad, who designated Constantine as his successor. In 1451 Murad himself died, and was succeeded by his son, Mohammed II.

Mohammed, a young prince of one and twenty, lost no time Irohamin plunging into the task with the accomplishment of which "the II, his name will always be associated. Having hastily renewed queror' all his father's engagements with Hungary, Serbia, Wallachia, 
the republics of Ragusa, Venice, and Genoa, he promptly declared war upon the Greek emperor and advanced to the siege of the imperial city. On May 29, 1453, Constantinople was carried by assault, and the last Greek emperor died fighting in the breach.

Fall of The last Greek emperor died, but his empire survived. nople: the It has been recently argued that modern critics have Byzantine attached to the conquest of Constantinople an importance

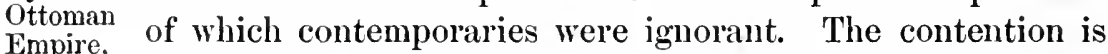
partly true. Contemporaries, however, are not the best judges of the historical perspective of the events they witness. To the people of that day the capture of Constantinople was merely the inevitable climax of a long series of Ottoman victories on European soil. The Sultan was already sovereign of the Greek Empire; the emperor was his vassal; the taking of the imperial city was merely a question of time.

Nevertheless, the fall of Constantinople is in the true historical sense 'epoch marking'. Of its significance in an economic and commercial sense, and its relation to the geographical Renaissance, mention has been already made. Hardly less direct was its relation to the Humanistic Renaissance. Learning fled from the shores of the Bosphorus to the banks of the Arno. From Florence and Bologna and other Italian cities the light of the new learning spread to Paris and to Oxford. The Oxford lectures of John Colet, the Novum Instrumentum of Desiderius Erasmus, perhaps even Luther's historic protest at Wittenberg, may be ascribed, in no fanciful sense, to the Ottoman conquest of Constantinople. But most important of all its consequences, from our present standpoint, was the foundation of a new empire. That empire was not exclusively Turkish; still less was it purely Byzantine. It was a fusion and combination of the two. The Ottomans were in truth not merely the conquerors of the Balkans but the heirs of the Graeco-Roman Empire of the East.

For further reference: H. A Gibbons, The Foundations of the Ottoman Empire (with an elaborate bibliography for the period prior to 1403); E. A. Freeman, The Ottoman Power in Europe (London, 1877); S. Lane Poole, Turkey (1250-1880), (London, 1888); D. S. Margoliouth, Mohammed and the Rise of Islam (London, 1905); Sir W. Muir, The Caliphate, its Rise, 
Decline, and Fall (London, 1ns1; A. Wirth, Grschirhte der T'ürken; 1I. I. Tozer, The Churele and the Eastern Empire (1888); I. von Ranke, IIstory of Servir (Lng. trans. 1858); Lavisse et Ramband, Histoive Generale, vol. iii (with excellent bibliography for this period); Sir W. M. Ransay, Historical Geography of Asia Minor (1890); W. Miller, The Balkans (1896), The Latins in the Levant: " History of Frankish Greece (1905); Vto A. de la Jonquière, Histoire de l'Empire Ottoman, 2 rols. (new ed. 1914); E. Creasy, History of the Ottoman Turks; J. von Hammer, Gesch. des Osmanischen Reichs, 10 vols.; E. Gibbon, Decline and Fall of the Roman Empire; J. H. Newman, The Ottoman Turk; J. W. Zinkeisen, Gesch. des Osmanischen Reichs in Europa, 7 rols. (rol. i); Sir E. P'ears, Destruction of the Greek Empire (1903) ; C. Onan, Byzantine Empire; W. H. Hntton, Constantinople. 


\title{
CHAPTER IV
}

\section{THE OTTOMAN EMPIRE: ITS ZENITH}

\author{
$14.53-1566$
}

\section{Suleman the Magnificent}

'The peculiarity of the Turks is at onee apparent when we observe that their history is almost exclusively a catalogie of names and battles.'-Odysseus (Sir Charles Eliot).

'The failure of the Turks is due to Byzantinism. . . . The deeadenee of the Turk dates from the day when Constantinople was taken and not destroyed.'-_ Diplomatist,' Nationalism and War in the Near East.

THE events recorded in the preceding chapter demonstrated conclusively one fact of supreme significance : a new nation had definitely planted itself on European soil; the Osmanlis had come to stay.

Down to the capture of Constantinople some doubts upon this point might have lingered; after it there could be none. The Osmanlis were now plainly something more than brilliantly successful adventurers. The taking of Constantinople fundamentally altered their position. It is true that in its declining year's the Byzantine Empire enjoyed, as it deserved, little prestige; yet the mere possession of the imperial city did confer upon its conquerors, altogether apart from questions of strategic or commercial advantage, a quasi-constitutional authority such as they could not otherwise have obtained.

And the Sultan Mohammed clearly recognized the significance of the change. Hitherto his followers had been merely an army of occupation in a conquered land. They have always been that and, according to one reading of their history, they have never been anything more. How far that reading is accurate the following pages will show; a point of more immediate significance is that after 1453 Sultan Mohammed initiated the attempt to devise a polity for the new nation. 
To what extent could he rely upon the essential charac- Characteristies of his people? Nany contradictory attributes have of the thes been predicated of the Ottoman Turks. They have been Ottoman delineated by friends and by foes respectively as among the Empire. most amiable, and unquestionably the most detestable of mankind; but on one point all observers are agreed. The Turk never changes. What he was when he first effected a lodgement upon European soil, that he remains to-day. Essentially the Ottoman Turk has been from first to last a fighting man, a herdsman, and a nomad.

'In the perpetual struggle', writes one, 'between the herdsman and the tiller of the soil, which has been waged from remote ages on the continents of Europe and Asia, the adrance of the Ottomans was a decisive victory for the ehildren of the steppes. This feature of their conquest is of no less fundamental importance than its victory for Islam.'

'The Turks', writes another, 'never outgrew their ancestral eharacter of predacious nomads; they take much and give little.' ${ }^{2}$

Thus, to close observers, the Turks have always given the impression of transitoriness; of being strangers and sojourners in a land that is not their own. 'Here', they have seemed to say, 'we have no abiding eity.' 'A band of nomadic warriors, we are here to-day; we shall be gone to-morrow.'

But the sense of temporary oecupation was not inconsistent Heirs of with a rigid conservatism as long as the occupation might ${ }_{\text {tines. }}^{\text {the Byzan- }}$ last. And in nothing have the Ottomans shown themselves more conservative than in fulfilment of the obligations which they inherited from their predecessors. No sooner were they masters of the imperial city than they made it plain to the world that they regarded themselves as the legitimate heirs of the Byzantine Empire. No Greek could have exhibited more zeal than Sultan Mohrammed in resisting the encroachments, whether territorial or ecelesiastical, of the Latins. Venetians, Genoese, and Franks were alike made to realize that the Turk was at least as Greek as his

${ }^{1}$ J. B. Bury ap. C.M.H. 2 Eliot, Turkey in Europe. 
predecessor in title. Most clearly was this manifested in his dealings with the Orthodox Church.

The Some of the more fanatical adherents of that Church had

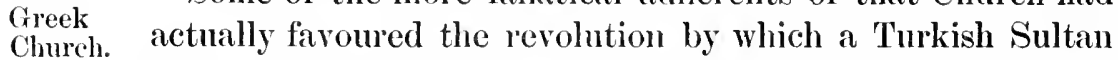
had replaced a Greek Basileus who was known to approve of reunion with Rome. They had their reward. At the moment when Constantinople was taken the patriarchal throne happened to be racant. Within three days Sultan Mohammer had given order's that a new Patriarch should be elected and consecrated with all the accustomed rites. After his election the Patriarch was treated with the deepest personal respect, and received from the Sultan a solemn guarantee for all the rights and immunities of his Church; in particular, there was to be complete freedom of worship for the Greek Christians. In every way the Orthodox Church was encouraged to look to the Sultan as its protector against the pretensions of the rival Rome. Thus the Patriarch became in effect the Pope of the Eastern Church. He was invested, indeed, with extraordinary privileges. After the conquest, as before, he was permitted to summon periodical synods, to hold ecclesiastical courts, and to enforce the sentences of the courts with spiritual penalties. ${ }^{1}$

The Pha- Nor was the favour shown to the Greeks confined to nariotes. ecclesiastics. On the contrary the Sultans developed among the Greek laymen a sort of administrative aristocracy. Known as Phanariotes from the Phanar, the particular quarter which they inhabited in Constantinople, these shrewd and serviceable Greeks were utilized by the Turks for the performance of duties for which the conquerors had neither liking nor aptitude. The Turk is curiously devoid of that sense which the ancient Greeks described as political. He desires neither to govern nor to be governed. He, is a polemical not a 'political animal'. To conquer and to enjoy in ease the fruits of conquest has always been his ideal of life. With the dull details of administration he has never cared to concer'n himself. 'That was the work of 'slaves', and as a fact, though none but a Moslem could in theory

1 Hutton, Constantinople, p. 156. 
aspire to the highest arministrative posts, the actual work of administration was confider to the Phanariotes. Whether this practice, in the long run, contributed either to the wellbeing of Christianity in the dominions of the Porte, or to the better government of the Greek population, is a moot point to which we may recur. For the moment it must suffice to say that while the Higher Clergy of the Orthodox Church became almost wholly dependent upon the State, the parish priests laboured with extraordinary devotion to keep alive among their flocks the flame of nationality even more perhaps than the tenets of Orthodoxy. To their efforts, maintained with remarkable perseverance thronghout a period of four and a half centuries, the success of the Greek revival, in the early nineteenth century, was largely due.

The attitude of the Ottomans towards the Greek Christians Tolerance was inspired by a mixture of motives. It was due partly to and ${ }_{\text {indence. }}$ an immate tendency towards toleration, and still more perhaps to invincible indolence. In view of the hideons massacres perpetrated by Abdul Hamid it is not easy to insist that religions toleration is one of the cardinal virtues of the Turk. ${ }^{1}$ Yet the fact is incontestable. Although the Ottoman State was essentially theocratic in theory and in structure, although the sole basis of political classification was ecclesiastical, ${ }^{2}$ the Turk was one of the least intolerant of rulers. He was also one of the most indolent. So long as his material necessities were supplied by his subjects the precise methods of local government and administration were matters of indifference to him. This had its good and its bad side. It often left the conquered peoples at the mercy of petty tyrants, but where the local circumstances were unfavourable to tyrannies it left the people very much to themselves. Hence that considerable measure of local autonomy which has frequently been noted as one of the many contradictory features of Ottoman govermment

1 Cf. a recent writer: "The Osmanlis were the first nation in modern history to lay down the principle of religions freedom as the corner-stone in the building up of their nation.' Gibbons, op. cit., and ef. an interesting note on the Armenian massacres, p. 74.

"The Ottoman government took no account of 'nationalities'. If a 'T'urkish subjeet was not a Moslem, he was a 'Greek'. 
in Europe, and which largely contributed, when the time came, to the resuscitation of national self-consciousness among the conquered peoples.

No assimi- The traits already delineated may perhaps account for lation between conquerors and conquered.

another marked characteristic of Ottoman history. Whether it be due to pride or to indolence, to spiritual exclusiveness or to political indifference, the fact remains that the Turks have neither alssorbed nor been absorbed by the conquered peoples; still less have they permitted any assimilation among the conquered peoples. Mr. Freeman put this point, with characteristic emphasis, many years ago:

'The Turks, though they have been in some parts of Turkey for five hundred years, have still never become the people of the land, nor have they in any way become one with the people of the land. They still remain as they were when they first came in, a people of stranger's bearing rule over the people of the land, but in every way distinct from them.'

The original Ottoman invader's were relatively few in numbers, and throughout the centuries they have continued to be 'numerically inferior to the aggregate of their subjects'. But for two considerations it is almost certain that like the Teuton invaders of Gaul they would have been absorbed by the peoples whom they conquered. The Tenton conquerors of Gaul were pagans, the Turks, on the contrary, brought with them a highly developed creed which virtually forbade assimilation. Under the strict injunctions of the Koran the infidel must either embrace Islamism; or suffer death; or purchase, by the payment of a tribute, a right to the enjoyment of life and property. Only in Albania was there any general acceptance of the Moslem creed among the masses of the population. In Bosnia, and to a less degree in Bulgaria, the larger landowners purchased immunity by conversion ; but, generally speaking, the third of the alternatives enjoined by the Koran was the one actually adopted. Christianity consequently survived in most parts of the Turkish Empire. And the Turk, as we have seen, shrewdly turned its survival to his own advantage. The second pertinent consideration is that the conquered peoples were 
hopelessly divided amougst themselves. Before the coming of the Turk, the Bulgarians, as we have seen, had been constantly at the throats of the Serbians, and both at those of the Greeks. This antagonism the Turk set himself sedulonsly to cultivate, and with conspicuous suceess. As a close and discriminating observer has justly said: 'they have always done and still do all in their power to prevent the obliteration of racial, linguistic, and religions differences', with the result that 'they have perpetuated and preserved, as in a museum, the strange medley which existed in SouthEastern Europe during the last years of the Byzantine Empire'. 1

If the Turk was not, in the Aristotelian sense, a 'political Neglect animal', still less was he an 'economic man'. He adhered of comfaithfully to his primitive nomadic instincts. There is a proverbial saying in the East: where the Turk plants his foot the grass never grous again. To a nomad it is a matter of indifference whether it does. He is a herdsman, not a tiller of the soil. Agriculture and commerce are alike beneath his notice, except, of course, as a source of revenue. Here, as in the lower ranks of the administrative hierarchy, the Greek could be pre-eminently useful to his new sovereign. Consequently the Greek traders in Constantinople, for example, and Salonica and Athens, were protected by a substantial tariff against foreign competition. In the sixteenth century the expulsion of the Moors from Grenada led to a considerable influx of Moors and Spanish Jews into Salonica, where they still predominate, and even into Constantinople. In them and also in the Armenians the Greeks found powerful competitors, both in finance and in commerce. For the governing Turks these matters had no interest except in so far as they affected the contributions to the imperial

1 Eliot, op. cit., p. 16. Cf. MI. Rambaud, ap. Hist. Générale, iv. 751 : 'L'assimilation, l'absorption de l'un des deux éléments par l'autre était impossible grâce à l'opposition du Koran à l'Évangile, du croissant à la croix. Plus d'une fois les Osmanlis ayant conscience de leur infériorité numérique s'inquiétèrent de cette situation grosse de périls pour l'arenir de leur puissance.' 
treasury. So long as that was full it mattered nothing to the Turks who were the contributors, or whence their wealth was derived.

Such were some of the outstanding characteristics of the people who in the fifteenth century established themselves permanently in South-Eastern Europe. But though they were permanently established by 1453 , they had by no means reached the final limits of political ascendaney or of territorial conquest and expansion.

Progress of Ottoman conquests.

Extinction of Southern Slav independence.

Montenegro.

Albania. Almost the same is true of Albania, though in the middle of the fifteenth century the sombre story of the Albanian mountaineers was illuminated by the brief but brilliant episode of a famous adventurer known as Seanderbeg or 
Iskendar Bey. George Castriotis, 'the dragon of Albania', was brought up as a Moslem at the court of Murad II and served in the Ottoman army, but at the age of forty he was converted to Christianity, abjured his allegiance to the Sultan, and initiated, in his native mountains, a guerrilla warfare against the Turks. This war was maintained with extraordinary success during the remaining years of Scanderbeg's life (1443-67); one Turkish army after another was thrown into Albania only to be repelled by the indomitable courage of Scanderbeg and his compatriots, seconded by the inaccessible nature of their fastnesses. In 1461 Mohammed II came to terms with Scanderbeg, acknowledging the independence of Albania and the lordship of Castriotis orer Albania and Epirus. $A$ few years later, however, the struggle was renewed, but with no better success for the Turks. Castriotis died still unconquered in 1467, and after his death many of his followers migrated to Italy. Of the rest a large number embraced Mohammedanism; not a few entered the service of the Porte; and some, notably the Kiuprilis, rose to eminence in that service. But the comtry itself has never really been subdued by the foreigner, and only at rare intervals has it been mited in submission to one of its own native chieftains. Geography has indeed prohibited both union and subjection ; both commercial and political development. Bands of brigands, with little or no mutual cohesion, have, throughout the centuries, maintained a precarions existence by preying on each other or on their neighbours. That the race has virility is proved by the men it has spasmodically thrown up-a Castriotis, a Kiuprili, an Ali Pasha of Janina, and, most notable of all, the famous soldier and statesman who played in the nineteenth century so great a part in the history of Egypt and indeed of Europe, Mehemet Ali. But apart from individuals such as these, and the episodes connected with one or two of them, Albania from the end of the fifteenth century mutil the end of the nineteenth played no appreciable part in Balkan politics. In recent years European diplomacy has, for its own purposes, discovered an 'Albanian Question', but it is not cynical to suggest that the discovery is due to the existence of two 
harbours on the Albanian eoast, Durazzo and Valona. The significance of the discovery must engage attention at a later stage of our inquiry. For at least four centuries after the death of Scanderbeg, as a factor in the problem of the Near East, Albania may be ignored.

Conquest The Morea and Greece proper were, as we saw, distributed, of Greece at the time of the Ottoman invasion, among a number of
proper. principalities, Byzantine, Frankish, and Venetian. After the eonquest of Constantinople these were gradually reduced to submission. The Florentine dynasty in $A$ thens was finally expelled in 1456 ; Corinth capitulated in 1458 ; the two Palaeologi, whose rule in the Morea had long been a public scandal, were dethroned in 1459, and the Morea itself was finally annexed to the Ottoman Empire.

War with Aegina and some half-dozen coast towns, not to mention Venice and Genoa. the great majority of the Aegean islands, still remained in the hands of the Venetians. Between the Turks and the Venetian Republic there was intermittent war for nearly twenty years. In 1463 Venice attempted to rouse Western Europe to a sense of the gravity of the Ottoman peril. But only with partial success. A league was formed between the Republic, the Pope, the Duke of Burgundy, and the King of Hungary, but though a considerable force assembled at Ancona it lacked organization, and Venice was left to fight the battle of Christendom alone. She fought bravely but without success. Argos was taken by the Turks in 1463, and in 1467 Euboea was attacked in force by land and sea. Its conquest, in the following year, was the death-blow to the Venetian Empire in the Near East. Joined by Pope Sixtus IV, by Naples, and by the Knights of St. John, Venice then attempted a diversion in Asia Minor. Their combined fleets attacked and captured Smyrua, and an attempt was made to incite Karamania to revolt against the Turks. But little was actually accomplished. Nearer home Scutari was held by the Venetians against repeated sieges, but in 1478 the Turks took Kroia, the Albanian fortresses, and thence advanced again upon Scutari. Deserted by her allies Venice then determined to treat, and in 1479 the Treaty of Constantinople was concluded. The Doge surrendered to the Turks Lemnos, 
Euboea, and Scutari, and agreed to pay an indemnity of 100,000 ducats and an annual tribute of 110,000 . In return Venice was to have the privilege of a consular establishment in Constantinople, and to enjoy freedom of trade thronghout the Ottoman dominions.

Meanwhile the Turks had been making rapid progress on supreboth shores of the Black Sea. In 1461 Amastris, in the north macy in of Anatolia, was taken from the Genoese; in the same year Euxine. Sinope and Paphlagonia were eaptured from one of the Turkish emirs; and-greatest prize of all-Trebizond, the last refuge of the Greek emperors, fell into the hands of Mohammed. A few years afterwards the Emperor, David Comnenus, and all his kinsmen were strangled. Thus perished the last of the Roman emperors of the East. The Seljukian Empire survived that of Byzantium only a few years. In 1471 Karamania, the last Seljukian principality, was annexed by Mohammed, and two years later a terrific contest between Mohammed and Ouzoun Hassan, the Turcoman ruler of Persia and part of Armenia, ended in the decisive defeat of the latter. Thenceforward the Turks were undisputed masters of Anatolia. Finally, in 1475 Azov and the Crimea were taken from the Genoese, and the Tartars accepted the suzerainty of the Sultan. This completed Turkish supremacy on both shores of the Black Sea. Not until the latter part of the eighteenth century was it ever again questioned.

The career of Sultan Mohammed, now nearing its close, had Death of been one of almost uninterrupted success. One last ambition IIohamwhich he cherished was destined to remain unfulfilled. He Conhad already conquered most of the Aegean islands, Lemnos, queror'. Imbros, Thasos, and Samothrace; but the island of Rhodes was still held by the Knights Hospitallers. A great armament was accordingly dispatched from Constantinople in 1480 to effect its conquest, but after besieging it for two months the Turks were beaten off with heary loss. Mohammed, nettled by this reverse, determined to take command of the next expedition in person, but just as it was starting the Sultan suddenly passed away (May 3, 1481). He well deserves the name by which in Turkish history he is distinguished; among a long 
line of brilliant soldiers he was pre-eminently 'the Conqueror'. A few ontlying portions of the Byzantine Empire, each important in a strategic sense, were nerertheless denied to him: Belgrade in the north; Crete, Cyprus, and Rhodes in the south; but apart from these hardly an ambition of his life was infulfilled, and to his snecessor he bequeathed an empire which extended from the Danube to the Euphrates.

Bayezirl II (14811512).

That successor was destined to a more chequered fortune. One distinguished critic has held that the seeds of the decay of the Ottoman Empire began to be sown as early as the reign of Bayezid II. Be that as it may, his career was certainly less consistently successful than that of his predecessor. To begin with, the succession was not undisputed. His halfbrother Djem proposed partition: that Bayezid should keep the European dominions, while 1)jem should rule Asiatic Turkey with Brusa as his capital. Bayezid declined the offer, and in one decisive battle, at Yenisher, disposed of his brother's pretensions. Supported by the Mameluke Sultan, with whom he took refuge in Cairo, Djem had the temerity to repeat the proposal, only to meet with an equally decided rebuff. Djem then fled for refuge to the Knights of St. John, by whom he was sent on to France, whenee, six years later, he passed to his final captivity at the Vatican. So long as he lived (until 1495) he was a source of some disquietude to Sultan Bayezid, and a pawn of some potential value in the hands of the Christians, but the effective use they made of him was not great. War with Of Bayezid's numerous wars the most important was that (1498$1502)$. with the Tenetian Republic. The progress made by the Venetians in the Aegean, more particularly the taking of Cyprus, had seriously alarmed the Sultan. Further stimulated,perhaps, by the Italian rivals of the Republic, he declared war upon it in 1498. The Turkish fleet won a great victory at Lejanto, but in the Morea, where most of the land fighting was concentrated, the fortunes of war were very uncertain. Hungary, the Papacy, and other Western Powers sent some assistance to the Republie, and their combined fleet inflicted a severe defeat upon the Turkish nary, raided the coast of Asia Minor, and seized the island of Santa Manma. Bayezid, 
therefore, concluded peace with Venice in 1502 and with Hungary a year later. The Sultan recovered Santa Maura, and retained all his conquests in the Morea, while Cephalonia was retained by the Republic.

The next twenty years (1503-20) formed a period, as far as Europe was concerned, of unusual tranquillity. The Turkish Sultan was busy elsewhere. The rise of the Safarid dynasty in Persia led to a struggle between Persia and the Ottomans; there was a war also, not too successful, with the Mamelukes; and, worst of all, Bayezid had serious trouble with his own house. So serious, indeed, did it become that in 1512 Sultan Bayezid was compelled by Selim, the youngest of his three sons, to abdicate, and shortly after his abdication he died, probably by poison.

Entirely devoid of pity or scruples the new Sultan began Selim I, his reign by the murder of his two brothers and eight nephews. 'the In-' Still his reign, though brief, was brilliant. Perpetually at war (1512-20). he never crossed swords with a Christian. But his wars and conquests in the East were on such an imposing scale that in less than eight years he nearly doubled the size of the Ottoman Empire.

A three years' war with the Shah Ismail of Persia resulted Conquest in the acquisition of Northern Mesopotamia ; Egypt, Syria, of Northand Arabia were successively conquered, and, to crown all, potamia, the Khalifate was transferred to the Ottoman Sultan, who Enypt, became henceforward the protector of the holy places and the Arabia. spiritual head of Mohammedanism throughont the world. The conquest of Egypt rendered the continued occupation of Rhodes by the Knights Hospitallers increasingly galling to the masters of Cairo and Constantinople. But to Selim, as to his grandfather, this prize was denied. Like Mohammed he was preparing for an expedition against the Kinights when he was overtaken by death.

Few reigns in Ottoman history have been shorter; none has been more crowded with notable events. Of these by far the most significant, apart from the territorial expansion of the empire, was the assumption of the Khalifate-significant but sinister. For, as an acute critic has said, 'it marked the supersession of the Byzantine or European ideal 
by the Asiatic in Osmanli policy, and introduced a phase of Ottoman history which has endured to our own time.'

Sulei- The Khalifate and the Sultanate passed withont dispute, man I, thanks to the sanguinary precautions of Sultan Selim, to his "the Mag- only son Suleiman, known to European contemporaries as (1520-66). ' the Magnificent', to his own people as the 'lawgiver'.

In the reign and person of Suleiman the history of his nation reaches its climax ; as warrior, as organizer, as legislator, as man he has had no superior, perhaps no equal, among the Ottoman Turks. Physically, morally, and intellectually Suleiman was richly endowed : a man of great strength and statmre; capable of enduring immense fatigue; frank, generous, amiable in character; indefatigably industrious; a capable administrator, and no mean scholar. But despite his brilliant gifts, sedulously cultivated, the reign of Suleiman is, by general consent, taken to mark not only the zenith of Ottoman greatness, but the beginnings, though at first hardly discernible, of decline.

Conquest The opening of the reign was extraordinarily auspicious. of Bel- mis predecessor bequeathed to Suleiman a vast empire; but Rhodes. in that empire there were two points of conspicuous weakness. In the north, the Turkish frontier was insecure so long as the great fortress of Belgrade remained in the hands of Hungary ; in the south, the presence of the Knights Hospitallers in Rhodes constituted a perpetual menace to the safety and continuity of communication between Cairo and Constantinople. Within two years of Suleiman's accession both these sources of weakness had been removed. Belgrade and Sabacz were conquered from Hungary in 1521; Rhodes at least fell before the Ottoman assanlt in 1522. The Knights found a temporary refuge in Crete, and in 1530 settled permanently in Malta. Belgrade remained continuously in the hands of the Ottomans until the end of the seventeenth century. Conquest The acquisition of this great frontier fortress opened the gary. way for the most conspicuous military achievement of the reign. With Belgrade in his hands Suleiman could safely 
embark upon a more ambitions enterprise, the conquest of Hungary itself.

That enterprise initiates a new phase in the history of The the Ottoman Empire in Europe. The Turks had now been Ottoman 'encamped' upon European soil for nearly two centuries; the Eurobut though in Europe they were not of it. They were Poan pariahs, with whom no respectable prince, except surreptitiously, would hold converse. The reign of Suleiman marks, in this respect, a notable change, a change mainly due to the new political conditions which were beginning to prevail in Western Europe. The States-system of modern Europe only came into being in the sixteenth century, and the first manifestation of the new system was the prolonged and embittered rivalry between the kingdom of France and the Habsburg Empire. The contest between Charles V and Francis I for the imperial crown (1519) brought that rivalry to a head. The success of Charles $\mathrm{V}$ opened a chapter which did not close until, at the beginning of the eighteenth century, Louis XIV put his grandson on the throne of Spain. The first bout of this prolonged contest ended with the utter defeat of Francis I in the battle of Pavia (1525). Pavia was a great day not only for the Habsburgs but for the Turks. Francis I had begun his reign with a fervent reaffirmation of the traditional policy of his house. Fresh from the glory achieved at Marignano he would lead a great crusade of all the powers of the West against the intruding Ottoman. That crusade was a main plank of his platform in the contest for the empire. He promised that if elected he would, within three years, either be in Constantinople or in his coffin. His failure to obtain the imperial crown somewhat tempered his crusading zeal, and after his humiliating defeat at Pavia, Francis, while yet a prisoner in the hands of his rivals, made overtures to the Ottoman Sultan. The alliance that ensued between Turkey and France was destined to supply one of the most important and one of the most continuous threads in the fabric of European diplomacy for more than three hundred years to come.

The overtures of a French king, even in eaptivity, could Battle of not fail to canse gratification at Constantinople, and the $\begin{gathered}\text { Mohacz } \\ (1526)\end{gathered}$ 
response was prompt. In April, 1526, the Sultan started from Constantinople at the head of a magnificent army of 100,000 men. Crossing the Danube he took Peterwardein in July, and on August 28, 1526, he met and defeated on the plain of Mohacz the flower of the Hungarian nobility. Lewis, the last Jagellon King of Hungary and Bohemia, the brotherin-law of Ferdinand of Austria, was drowned in his flight from the field. Nothing could now arrest the advance of Suleiman upon Buda, the Hungarian capital, which he occupied on September 10. But after a fortnight's stay he was recalled to Constantinople, leaving the fate of Hungary undeeided. For the next two years Suleiman's energies were fully oecupied with the affairs of his empire in Asia Minor.

Third ex- Meanwhile, there was acute dissension in the two kingdoms pedition into where the Jagellons had ruled. To Bohemia, Ferdinand of Hungary Austria made good his claim, but in Hungary he eneountered $(1529)$. a serious rival in John Zapolya, the Voyvode of Transylvania. Favoured by Suleiman the latter was crowned king in 1526, but in 1527 he was driven back by Ferdinand into Transylvania. Both parties then appealed for help to the Ottoman Sultan. Accordingly, Suleiman again set out for Hungary in 1529, and in August of that year again found himself on the plain of Mohacz. There he was joined by Zapolya, and together they advanced on Buda. Buda offered little resistance, and Suleiman then determined to attack Vienna itself.

Siege of Exclusive of the Hungarian followers of Zapolya the Vienna (1529). Turkish army numbered 250,000 men, and had 300 guns. The garrison consisted of only $16,000 \mathrm{men}$, but they defended the city with splendid gallantry. In view of the menace to Christendom Lutherans and Catholics closed their ranks, and large reinforcements were soon on their way to the capital. After a fruitless siege of twenty-four days Suleiman, therefore, decided to retire (October 14).

The failure of the greatest of the Sultans to take Vienna, and his withdrawal in the autumn of 1529 , mark an epoch in the history of the Eastem Question. A definite and, as it proved, a final term was put to the advance of the Ottomans towards Central Europe. The brave garrison of Vienma had 
rendered an incomparable service to Ciermany and to Christendom. Here at last was a barrier which eren Sulciman could not pass.

Three times more at least did Suleiman lead expeditions into Hungary : in 1532 , in 1541 , and finally in the very last year of his reign and life, 1566. But never did he renew the attempt upon Vienna. The failure of 1529 was accepted as final.

It would be tedious to follow in detail the fortunes of Suleiman's Hungarian enterprises ; nor is it pertinent to the purpose of this book. The expedition of 1532 was on a rery imposing scale. Suleiman left Constantinople at the head of a force of 200,000 men, and was joined at Belgrade by 100,000 Bosnians and 15,000 Tartars. But the Turkish host suffered a serious cheek at the little town of Güns, and after taking it Suleiman, instead of advancing on Viemna, contented himself with laying waste a great part of Styria and Lower Austria. Nothing of importance had been effected, and in Jume, 1533, a treaty-memorable as the first between the House of Austria and Turkey - was concluded.

The expedition of 1541 had more permanent results. JncorZapolya had died in July, 1540, and though Suleiman poration espoused the cause of his widow and infant son, the interests gary and of the Zapolya family were virtually set aside. What the Trania in Sultan now conquered he conquered for himself. Buda Ottoman again fell into his hands in $15+1$, not to be surrendered for ${ }_{(1517) \text {. }}^{\text {Empire }}$ nearly a century and a half. Another expedition in 1543 confirmed the Turkish possession of Hungary and Transylvania which, except for a strip retained by Ferdinand, was definitely incorporated as the pashalik of Buda in the Ottoman Empire. The country was divided into twelre sanjalis, in each of which a regular administrative and financial system was established. Negotiations between the Habsburgs and the Turks continued for several years, but at last, in 1547 , the former acepted the inevitable and a fire years' armistice was concluded. Ferdinand then agreed to pay to the Porte an anmual tribute of 30,000 ducats for the strip of Hungary which he was permitted to retain. The truce was imperfectly observed on both sides and in 1551 the war was resumed. 
With short intervals of inaetivity it continued, without essentially modifying the situation on either side, until 1562, when a treaty was concluded between the veteran antagonists. Ferdinand died two years afterwards (1564), but in 1566 war was renewed between his successor, the Emperor Maximilian II, and the Ottomans. It was in the course of this campaign, which he led in person, that the great Sultan Suleiman passed away. Persian The wars against the Habsburgs, extending with brief acquisitions in Asia. intervals from the first year of Suleiman's reign to the last, constitute the most important as well as the most continuous preoccupation of that monarch's career. But these wars did not stand alone, nor were the Sultan's activities confined to the Hungarian expeditions. Six campaigns at least did he undertake in person against the rival Mohammedan Power of Persia with the result that large portions of Armenia and Mesopotamia, including the city of Bagdad, were added to the Asiatic dominions of the Ottomans. Suleiman went indeed even further afield. Thanks to his omnipotence at sea he was able to effect a permanent occupation of Aden, which was strongly fortified, and to make himself master of much of the coast of Arabia, Persia, and even North-Western India.

Ottoman Even more conspicuous was the superiority of Ottoman seapower. sea-power in the Mediterranean. Great as was the terror inspired in Europe by the military prowess of Suleiman, that inspired by the exploits of the Turkish nary was hardly less. For this reputation Suleiman was largely indebted to the genius of one of the most remarkable seamen of the sixteenth century. In that age of buccaneers Khaireddin Barbarossa fills a conspicuous place. He did not, like Frobisher or Drake, add to knowledge, but his seamanship was unquestioned, and to the Spaniards his name was hardly less terrible than that of Drake. Born in Mitylene after the conquest of that island by the Turks he was by birth an Ottoman subject. About the year 1516 he and his brother established themselves in Algiers, whence they carried on a perpetual and harassing contest with the naval forces of Spain. Recognized by Suleiman as Beyler Bey of Algiers, Barbarossa placed his serrices at the disposal of his suzerain, and in the year 1533 
was appointed admiral in chief of the Ottoman navy, then at the zenith of its reputation.

About the same time he undertook a series of voyages, Barlaseven in all, from Algiers to the Andalusian coast, in the rossa and course of which he transported 70,000 Moors from Spain to Algiers. By this remarkable feat he not only consolidated his own corsair kingdom on the African coast, but rescued a large number of persecuted Moslems from the tender mercies of the Inquisition. In 1533 he was employed by the Sultan to drive off Andrea Doria, the famous Genoese sailor who commanded the imperial fleet in the Mediterranean. Doria had lately scized. Coron, Patras, and other fortified coast-towns belonging to the Ottomans, and Barbarossa's intervention was as opportune, therefore, as it was effective. In 1534, at the head of a powerful and well-equipped fleet, Barbarossa attacked and plundered the coasts of Italy, and later in the year conquered Tunis and added it to his Algerian principality. But his triumph in 'Tunis was shortlived. Muley Hassan, the representative of the Arabian family who had ruled for centuries in Tunis, appealed to the Emperor Charles V. The latter, seriously alarmed by Barbarossa's activity in the Western Mediterrancan, collected a large army and a powerful fleet, and in 1535 sailed from Barcelona for the Tunisian coast. He reconquered the principality, and having put the capital to the sack with a barbarity which no Turk could rival, he drove out Barbarossa and reinstated Muley Hassan.

In the same year, 1535, the war between the Habsburg FrancoEmperor and Francis I was renewed, and the latter turned for assistance to the Sultan Suleiman.

The treaty then concluded between the French monarch and the Ottoman Sultan is of the highest possible significance. It is indicative of the position to which the Turks had by now attained that even a French writer should describe the convention as 'less a treaty than a concession'.' The Sultan now extended throughout the Ottoman Empire the privileges accorded, in 1528, to the French in Egypt. Frenchmen were

1 Albin, Les Grands Traités politiques, p. 128.

G 2 
to enjoy complete freedom of trade and navigation in all Turkish ports, subject to a uniform duty of 5 per cent. ; no foreign vessel might sail in Turkish waters except under the French flag; French traders were to be under the exchusive jurisdiction, both civil and criminal, of their own consuls, and the Turkish officials guarantecd the execution of all judgements in the consular courts; French settlers in the Ottoman Empire were to enjoy peculiar privileges in respect of the transmission of property by will and eren of intestate estates; they were to have not only complete religious liberty for themselres, but also the custody of the Holy Places, and thus to exercise a species of protectorate over the Christian subjects of the Porte. The King of France, alone among the European sovereigns, was regarded and treated as an equal by the Sultan, being henceforward described in official documents as Padishah, instead of $B c y$.

The privileges thus accorded, in the Ottoman Empire, to France were not only extraordinarily valuable in themselves; they established, on firm fomdations, a diplomatic friendship which operated powerfully, in the sixteenth century, against the dominance of the Habsburgs, and for more than three hundred years continued to be an essential factor in French diplomacy. ${ }^{1}$

Its inmediate significance was far from negligible. France was at war with the Habsburgs, with very brief intervals, from 1535 to 1559 , and not until 1598 was peace finally concluded. Throughont the whole of that period, and indeed much beyond it, France conld count upon the loyal co-operation of the Turks. It must, indeed, be confessed that the loyalty of the Turks to the alliance was a good deal more constant and continuous than that of the French. The latter were glad enough to take advantage of it whenerer and for so long as it suited their purpose; but they did not hesitate to come to terms with the adversaries of the Turk when their own interests dictated the step. Nevertheless, the alliance confirmed in 1535 forms a guiding thread in a tangled diplomatic skein.

1 Cf. injra, chap. vi. 
In that year war was resumed between Francis I and the Naval war emperor. Barbarossi, far from discouraged by the loss of between Tunis, was ready to embarrass Charles $V$ in the Mediter-and ranean. Secure in the possession of Algiers he was still in Venice a position to attack with effect, and in the sprace of a few months he plundered the island of Minorca, sacked the coasts of Apulia and Calabria, and recovered Coron. In 1537 Suleiman, in response to an appeal from France, declared war upon the Venetians, who were staunch in their alliance with the emperor. Sailing from Valona he laid siege to the island of Corfu, while Barbarossa seized the opportunity to conquer for his master most of the Aegean islands which still flew the flag of the Republic. In 1538 the Pope and King Ferdinand joined with the emperor and Venice in a Iloly League against the Turks, and in the same year Francis I concluded with Charles $V$ the Truce of Nice. The Venetians, howerer, found themselves ill-supported in their contest with the Turks by their Holy allies; the latter suffered a tremendous reverse at the hands of Barbarossa off' Prevesa in September, 1538, and in 1539 negotiations were opened between the Republic and the Porte. A three months' truce was arranged, and in 1.540 a definite peace was concluded. The Republic agreed to pay to the Sultan an indemnity of 300,000 ducats, and to surrender various points on the Dalmatian coast, and all claims to the recovery of the Aegean islands which had been captured by Barbarossa. The triumph of the Ottoman Sultan was complete.

Neither the conchusion of the Truce of Nice between the Continued French king and the Habsburgs nor the definitive treaty war with between the Republic and the Porte was permitted to inter-emperor. rupt the contest between the Sultan Suleiman and the Emperor Charles V. Barbarossa's continued possession of Algiers was a perpetnal menace to the Spanish and Italian dominions of the emperor. In 1541, therefore, Charles V fitted out another expedition with the object of finally expelling Barbarossa from his corsair kingdom. The expedition was a complete fiasco. Francis I renewed his contest with Charles $\mathrm{V}$ in 1542 , and in the following year a French fleet, commanded by the Duc dEnghien, combined with that of 
Barbarossa to effect a capture of the town of Nice which was sacked and burnt by the Ottomans. The accord between Barbarossa and the French was far from perfect, but the latter gave proof of their friendship by handing over the harbour of Toulon to their allies. But in 1544 Francis and Charles again made peace at Crespy, and again the Turks and the Habsburgs were left confronting each other both in the Mediterranean and on the Hungarian plain.

Death of In 1546 Suleiman suffered a great loss by the death of his Barbarossa (15 16$)$. brilliant admiral, Barbarossa. The genius of the corsair had not merely added materially to the Empire of the Ottomans, but had secured for their navy in the Mediterranean, in the Red Sea, and in the Indian Ocean an ascendancy which it never again enjoyed. The death of Barbarossa, following closely upon the desertion of France, inclined Suleiman to peace with the emperor, and in 1547 , as we have seen, ${ }^{1}$ a five year's truce was concluded at Constantinople.

Henry II The death of Francis I in the same year was of much less conand Suleiman. sequence than that of Barbarossa, for the alliance between him and Suleiman was cemented and perhaps more consistently maintained by his son. In 1556, however, the Emperor Charles $\mathrm{V}$, in view of his impending abdication, concluded with France the Truce of Vaucelles, and at the same time recommended his brother Ferdinand to come to terms with the Turks. The French king was at pains to explain to his Ottoman ally that the truce concluded with the emperor involved no weakening of his hereditary friendship, and Suleiman graciously aceepted the assurance. The truce did not endure; in 1557 the French suffered a severe defeat at St. Quentin, and Henry II was more than ever anxious for the assistance of the Sultan; and that in more than one form. He begged Suleiman to attack the Habsburgs in Hungary, to send an expedition to Naples, to maintain their fleet on a war footing, even throughout the winter months, in the Mediterranean, and, finally, to accommodate him with a considerable loan. As to the last, the Sultan replied, not without dignity, that 'the Ottomans were wont to succour their friends with their persons and 
not with their purses, since their religion forbade money loans to the enemies of their faith'. Naval assistance in the Mediterranean was, howerer, readily promised. As a fact, there had been no cessation of naval hostilities throughout all these years. Even the conclusion of the Peace of Prague ${ }^{1}$ between the Sultan and the Habsburgs did not interrupt them, for Spain was not included in the peace. Soon after his accession (1556) Philip II of Spain had endeavoured to rid himself of the perpetual embarrassment of the naval war ; but his effort was fruitless, and the contest in the Mediterranean dragged its wearisome length along. On both sides it was largely irregular and almost piratical in character ; sustained on the one hand by Thorgond, the successor of Barbarossa in Algiers, and on the other by the Knights of St. John.

The Knights, driven by Suleiman from Rhodes, had estab- Ottoman lished themselves in Malta. The possession of that island is, attack on and always has been, deemed essential to naval supremacy in the Mediterrancan. Apart from the shelter it afforded the buccaneering. Knights it offered tempting advantages to the Turks in their contest with the Sovereign of spain. In 1565 Snleiman determined to make a strenuons effort to eapture the island In the spring of that year, therefore, he dispatched from Constantinople a magnificent fleet, numbering not less than one hundred and ninety ships, with an army, on board, of 30,000 men, under the command of Mustapha Pasha. The fort of St. Elmo was taken but with very heavy loss to the Turks, and the Castles of St. Angelo and St. Michel resisted all their efforts. Again and again the assault was renewed, but after four months of fruitless fighting Mustapha, having lost two-thirds of his army, decider to abandon the attempt. What the Turks could not do in the sixteenth century no one else ventured to attempt, and the Knights were left undisturbed until the Napoleonic wars.

The great Sultan's course was now nearly run. It had Death of been attended, in the main, with extraordinary success, yet $\underset{(1566) \text {. }}{\text { Suman }}$ the failure to take Malta was not the only shadow which fell over his declining year's. 
Roxalana. Like other men who present to the world an adamantine front Suleiman was not proof against the cajolery of a fascinating woman. A Russian slave, named Khoureem, better known as Roxalana, ${ }^{1}$ had in his early years aequired an extraordinary influence over her lord, who was persuaded to enfranchise her and to make her his wife. All the Sultana's efforts were then directed to securing the succession for her son, Prince Selim. An elder son, Prince Mustapha, born to the Sultan by another wife, had already shown extraordinary promise, and had won, among his father's subjects, a fatal measure of popularity. The intrigues of Roxalana turned that popularity to his destruction, and the prince was murdered in his father's presence. After Roxalana's death, which preceded that of the Sultan by eight years, her second son, Prince Bayezid, with his children, was murdered, at his father's instance, by the Persians. The purpose of all these sordid tragedies was to clear the succession for Roxalana's elder and favourite son Selim, 'the Sot'.

It seems at first sight paradoxical that these rerolting murders should have been instigated by a sovereign famed, and justly famed, for magnanimity, generosity, kindliness, and courtesy. Tet the contradiction is not peculiar to great rulers, or ereu to great men. Suleman, perhaps the most brilliant of the Ottoman Sultans, certainly one of the greatest among contemporary sovereigns, was as wax in the hands of the woman to whom he gave his heart. Whether that complaisance affected in any degree his policy or eapacity as a ruler is open to question; but two things are certain: on the one hand that the Ottoman Empire attained, in the days of Suleiman, the zenith of splendour and the extreme limits of its territorial expansion; and, on the other, that the seeds of decay were already sown and were begiming, thongh as yet imperceptibly, to germinate.

Extent of Estimates of population are notoriously untrustworthy, but Sulei-
man's it seems probable that at a time when Henry VIII ruled over empire. about $4,000,000$ people the subjects of the Sultan Suleiman numbered 50,000,000. These included not less than twenty

I A corruption or emendation of La Rossa, the Russian woman. 
distinct races: Ottomans, Slaws, Greeks, Magyar's, Rommans, Armenians, Arabs, Copts, and Jews, to mention only a few. The empire extended from Buda to Basra ; from the Cispian to the Western IIediterrancan; and embraced many linds in Europe, Asia, and Africa. To the north the walls of Azov guarded the frontiers of the Turkish Empire against Russia; to the south "the rock of Aden secured their authority over the southern coast of Arabia, invested them with power in the Indian Ocean, and gave them the complete command of the Red Sea.... It was no vain boast of the Ottoman Sultan that he was the master of many kingdoms, the ruler of three continents, and the lord of two seas' ${ }^{1}$

This vast-stretching empire was organized by suleiman in twenty-one goveruments, which were subdivided into two hundred and fifty sanjaks, each under its own Bey. Land tenure and local govermment were alike assimilated to the feudalism of the .West; but it was feudalism devoid of its disintegrating tendencies, for all power was ultimately concentrated in the Sultan, who was at once Betsileus and Khalif, Emperor, and Pope.

The scope of this work does not permit of the discussion of the details of domestic administration. It is concerned with the Ottoman Empire only as a factor, though a very important factor, in the problem of the Near East, as marking a stage in the evolution of the Eastern Question. Yet there is one domestic institution to which a passing reference must be made.

Many things contributed to the astonishing success of the The Janisearly Uttomans and the rapid extension of their empire : the saries. hopeless decrepitude of the Greek Empire; the proverbial lack of cohesion among the slar peoples; the jealousies and antagonisms of the Western Powers ; the Babylonish captivity at Avignon and the subsequent schism in the l'apacy; the military prowess and shrewd statesmanship of many of the earlier Sultans. But, after all, the main instrument in the hands of the Sultan was his army, and in that army a unique feature was the corps d'elite, the Janissarics. 
As to the origin of this famous corps there has been much controversy. It is, however, generally agreed ${ }^{\mathbf{1}}$ that the beginnings of the institution must be ascribed to Alaeddin, brother of Orkhan, and first vizier of the Ottomans, and dated about the year 1326. But if Orkban initiated, Murad I perfected, the organization. Every four years ${ }^{2}$ the agents of the Sultan took toll of his Christian subjects; one in five of all the young boys, and always, of course, those who gave most promise of physical and mental superiority, were taken from their parents and homes, compelled to accept the Moslem faith, and educated, under the strictest discipline, as the soldier-slaves of the Sultan. Cut off from all human intercourse save that of the camp, withont parents, wives, or children, the Janissaries ${ }^{3}$ formed a sort of military brotherhood: half soldiers, half monks. Owing implicit obedience to their master, intured to every form of toil and hardship from earliest youth, well paid, well tended, they soon became one of the most potent instruments in the hands of the Sultan.

Originally one thousand strong the force increased rapidly, and may have numbered 10,000 to 12,000 under Mohammed the Conqueror, and anything between 12,000 and 20,000 in Suleiman's day. It was recruited from all parts of the Ottoman Empire in Europe, but mainly from Bosnia, Bulgaria, and Albania. The child-tribute has been commonly regarded as a peculiarly repulsive illustration of the cruelty and ingenuity which characterized the rule of the Ottonan Turks. It is far from certain that it was so regarded by the Christians of the Empire. The privileges of the corps were so great, and their prestige so high, that the honour may well have outweighed the ignominy in many minds. There seems, at any rate, to have been little need of compulsion, and one

1 The latest authority on the early history of the Ottomans, Mr. Giblons (op. cit., p. 118), dissents on this, as on many other points, from the hitherto accepted view, and here as elsewhere gives reasons for his dissent.

$2 \mathrm{Or}$, as some say, every five. There is infinite variety, among authorities, in regard to this and other details.

3 'The name is generally derived from Yeni-Tscheri $=$ new or young troops. 
distinguished authority has gone so far as to assert that the Greek clergy' 'tacitly acquiesced in the levy of tributechildren'. Be this as it may, there can be no question as to the importance of the part played by this corpss in the building up of the Ottoman Empire.

The institution of the Janissaries fulfilled a dual purpose. On the one hand, it provided the Sultan with a body of picked troops on whose loyalty and discipline he could implicitly rely. On the other, it represented a perpetual drain upon the young manhood of the peoples who obstinately refused to accept the creed of their conquerors. It may be that the extent of the debt which the earlier Sultans owed to the Janissaries has been exaggerated, no less than the resentment of those upon whom the tribute was levied. This, however, is certain, that the advance of the Ottomans synchronized with the period during which the corps was maintained in its pristine simplicity, and that the change in the position of the Janissaries coincided with the begimnings of the political decadence of the empire.

Early in his reign (1526) Suleiman was faced by a mutiny of the Janissaries. The mutiny was stamped out with salutary severity, but the hint was not lost upon the shrewd Sultan. He perceived that constant employment on warservice was absolutely essential to discipline; nor did he fail to provide it. But the loyalty of the army was given not to a political institution but to a personal chief. Consequently, as the Sultan tended to withdraw from active service in the field and to yield to the seductions of the harem, the Janissaries manifested similar inclinations'

The whole position of the corps was rerolutionized when, Changes in 1566 , its members were permitted to marry. The next in the step, an obvious one, was to admit their children to a body of the which thus in time became to a large extent hereditary. JanisThe hereditary principle soon led to exclusiveness. The (1566Janissaries began to regard with jealousy the admission of 1676). the tribute-children, and after 1676 the tribute ceased to be levied. A step, not less fatal to the original conception of a military order, was taken when members of the corps were allowed to engage in trade, and even to pay substitutes 
for the performance of their military duties. 'Throughout the seventeenth and eighteenth centuries this praetorian guard became more and more highly privileged; more and more insolent in the exercise of power; more and more the masters instead of the serrants of the nominal sovereigns, who reigned on sufferance. At last, but not until the nineteenth century, there came to the throne a Sultan who was strong enough to deal with what had long since become the most flagrant scandal and the most corroding weakness in a govermment which was rapidly dissolving into anarchy. In 1826 Sultan Mahmud exterminated the whole caste of the Janissaries and razed to the ground the quarter of Constantinople which they had appropriated. The treatment was drastic; but no one conld donbt that it was an indispensable preliminary to political reform.

Symptonss of decay.
But we anticipate events. The change in the position of the Janissaries was in part the canse, in part the consequence, of the general decrepitude in Ottoman administration. The general causes are not difficult to discern. The most important was the deterioration in personnel. In an autocracy everything depends on the efficiency of the autocrat. After Suleiman the Magnificent the Sultans exhibited symptoms of astonishingly rapid deterionation. Between the death of Sulciman (1566) and the accession of Mahmud II (1808) there was not a single man of mark among them. Few of them enjoyed any considerable length of days: there are twelve accessions in the seventeenth century as against six in the sixteenth. The deficiency of character among the serenteenth-century sultans was to some extent supplied by the emergence of a remarkable Albanian family, the Kinprilis, who provided the Porte with a succession of brilliant viziers; but a great vizier is not the same thing in Turkey as a great Sultan, and eren this resource was lacking in the eighteenth century.

The inefficiency of the dynasty was reflected in that of the armed forces of the Crown. The soldiers and sailors of the Crescent continued to fight, but they no longer conquered. The only permanent conquests effected by the Porte after the death of suleiman were those of Cyprus and Crete. 
Ceasing to advance the Turkish power rapidly recerled. Victory in the field was as the breath of life to the Ottomans; success in arms was essential to the vigour of domestic administration.

So long as the Turks were a conquering race their government was not merely tolerable but positively good. There was no kingdom in Europe better administered in the sixteenth century than that of Suleiman. That great Sultan was, as we hare seen, known to his own people as 'the legislator'; and his legislation was of the most enlightened character. Entirely based upon the Koran Turkish law is not susceptible of expansion or reform; but there, as elsewhere, everything depends on interpretation and administration, and, under Suleiman, these left little to be desired. Nor did he fail of the appropriate reward. Taxation was light, but the revenne was prodigions, amounting, it is reckoned, to between $7,000,000$ and $8,000,000$ ducats, more than half of it being derived from Crown lands. Under Suleiman's successor corruption set in, and spread with fatal rapidity from the heart to the members. The taxes were farmed out to the Jews and Phanariote Greeks; with the ineritable consequences: the grinding oppression of the taxpayer and an habitually imporerished treasury.

For one sonrce of increasing weakness Suleiman himself may be held indirectly responsible. No antocracy could be expected permanently to sustain the burden of an empire so extended as his. The more distunt conquests meant a drain upon resources without any corresponding accession of strength. Even the incorporation of Humgary has not escaped criticism. It has been argned, and with some show of reason, that in a military sense the Porte would have been better without it. Economically, the Hungarian plain must always have been raluable, but strategically Belgrade is a better frontier fortress than Buda.

Still, when all criticisms have been weighed and all deductions effected, Suleiman was a great ruler, and his reign was incomparably the most brilliant epoch in the history of the Ottoman Empire. If, after his death, decay supervened with suggestive rapidity, we must not hastily 
assume that it could not have been arrested had competent suecessors been forthcoming. Subsequent ehapters will show how little that condition was fulfilled.

For further reference sce libliography to chapter iii, and Appenilix. General Worls. Cf. also L. von Ranke, The Ottoman and Spanish Empires in the Sixteenth and Seventeenth Centuries (Eng. trans. 1854); J. de la Gravière, Doria ot Barberousse; J. B. Zeller, La Diplomatie française vers le milieu du xvI siècle. 


\title{
CHAP'TER V
}

\section{THE DECADENCE OF THE OTTOMAN EMPIRE}

\author{
$1560-1699$
}

\section{Contest with Venice and the Habsburgs}

'My last judgment is that this Empire nay stand, but never rise again.'Sir Thomas Roe (1628).

Thus far the main factor in the problem of the Near East Change has been the advent and progress of the Ottoman Turk. To in chaan analysis of that factor the two preceding chapters have problem. been deroted. We now enter upon a new period, which will disclose a considerable modification in the conditions of the problem. When the Sultan Suleiman passed away in 1566 the Ottoman Empire had already reached and passed its meridian. In the seventeenth century the symptoms of decay are manifest. Sultan succeeds Sultan, and, as one brief reign gires place to another, the decadence of the ruling race becomes more and more obvions. Anarchy reigns in the capital, and corruption spreads from Constantinople to the remotest corners of the empire. Lepanto has already announced that the Turks are no longer invincible at sea; Montecuculi's great victory at St. Gothard, the failure to capture Viemna in 1683, Prince Eugène's victory at Zenta in 1697 , combine to prove that the army is going the way of the navy. The Treaties of Carlowitz, Azor, and Passarowitz afford conclusive eridence that the Eastern Question has entered upon a new phase ; that the problem presented to Christendom will no longer be how to arrest the advance of the Ottomans, but how to provide for the snccession to his inheritance.

The main interest of the period under review in the Contest present chapter concentrates upon the prolonged duel with between the Turks and the Habsburgs for supremacy in and the the valleys of the Danube and the Save. By the end of Hats- 
the period the issue of that duel is no longer in doubt. Hardly secondary is the interest attaching to the contest with the Venetian Republic. In the latter, fortume inclines now to this side now to that; nor is this remarkable, for it is a struggle between combatants both of whom have passed their prime.

The suc- The most palpable symptom of Ottoman decadence is cessors of Suleiman. afforded by the deterioration in the personal character of the Sultans. Mustapha, the idiot son of Mohammed III, was declared incapable of reigning when in 1617 he succeeded to the throne. Excluding Mustapha no less than thirteen sovereigns occupied the throne between 1566 and 1718. Of these only two, Murad IV (1623-40) and Mustapha II (1695-1703) showed any anxiety to effect reform and to arrest the decrepitude of the empire. One out of the thirteen was murdered, three others were dethroned. Not one led an army to victory; most of them devoted all the time they could spare from the neglect of their duties to the pleasures of the harem. The son, for whom Roxalana had intrigned and Suleiman had murdered, was known as Selim, 'the Sot' (1566-74). His son and successor, Murad III (1674-95), spent the twenty-one years of his reign in his harem. He began it by strangling his five brothers, and was otherwise remarkable only for the number of his ehildren. Of the 103 who were born to him 47 surviced him. As twenty of these were males, his successor, Mohammed III (1595-1603), had to better his father's example by the simultaneous slaughter of no less than nineteen brothers. The next Sultan, Achmet I (1603-17), was a lad of fourteen when he succeeded, and died at the age of eight-and-twenty. His brother Mustapha was declared incapable of reigning owing to mental deficiency, and the throne accordingly passed to another minor, Othman II, whose brief reign of four years (1618-22) was only less disturbed than that of his successor, Mustapha I (1622-3), whose reign of fifteen months was the shortest and perhaps the worst in Ottoman history. His son, Murad IV (1623-40), was unspeakably eruel, but by no means devoid of ability, and he made a real effort to carry out much needed 
reform. But all the ground gained under Mrurad was lost under Ibrahim I, whose reign of eight years (1640-8) was brought to a close by a revolution in the capital and the violent death of the Sultan. His son, Mohammed IV (1648-87), was a child of six at the time of his father's murder. The anarchy which prevailed during the first years of the reign was unspeakable, but it was dissipated at last by the emergence (1656) of the Kiuprili 'dynasty', who throughout the rest of the century provided the distracted empire with a succession of remarkable grand viziers.

The Kiuprilis might provide rulers, but they could not secure a succession of even tolerably efficient Sultans, and in the absence of the latter no permanent reform of Ottoman administration could be effected. Mohammed IV was dethroned in 1687, and was succeeded by two brothers, Suleiman I (1687-91), who at the age of forty-six emerged from his mother's harem to assume an unwelcome crown; and Achmet II (1691-5), who was a poet and a musician, and would have liked to be a monk. In 1695 the throne fell to Mohammed's son, Mustapha II, who in his reign of eight years (1695-1703) made a real effort to recall the virtues of the earlier Sultans, but was dethroned in 1703. The same fate befell his successor, Achmet III, in 1730.

This tedious and catalogic enumeration will suffice to show that the student of the Eastern Question need not concern himself overmuch with the Ottoman Sultans of the seventeenth century. Until the accession of the Kiuprilis the internal history of the empire presents one monotonous rista of anarchy and decay. To follow it in detail would mean the repetition of features which become tiresomely familiar as one incompetent Sultan succeds another. Fortunately, there is no reason for inflicting this tedium upon the reader.

The interest of the period, as already stated, centres in the contests between the Ottomans on the one hand, and, on the other, the Venetian Republic and the Habsburg Empire. From the moment when the Ottoman Turks obtained 1984 
Venice command of the great trade-routes ${ }^{1}$ the ultimate fate of and the Turks.

Venice as a commercial power was sealed. She had already lost to the Turks many of her possessions on the mainland of the Peloponnese and in the Aegean archipelago, but the Republic still carried her head proudly, and still held a position which was in many ways threatening to the Ottoman Empire. Planted in Dalmatia she headed off from the Adriatic the Turkish provinces of Bosnia and Herzegovina; mistress of the Ionian isles she threatened the security of the coasts of the Morea; while the continued possession of Crete and Cyprus not only rendered precarious the Ottoman hold on the Levant, but offered a convenient naval base to the Knights of St. John and the other Christian pirates who infested the Mediterranean.

One of the first exploits of the Sultan Suleiman was, as we have seen, the conquest of Rhodes; one of the last was the capture of Chios (1566). A year later Naxos fell to his son Selim, who then proceeded to demand from Venice the cession of Cypius.

The moment seemed favourable for the enterprise. The destruction by fire of her naval arsenal had just maimed the right hand of Venice (September, 1569), while the Sultan had freed his hands by concluding a truce with the Emperor Maximilian (1569) and completing (1570) the conquest of Yemen. The grand vizier, Mohammed Sököli, had lately conceived the idea of cutting a canal through the Isthmus of Suez and thus strengthening the strategical position of the empire. The outbreak of a revolt in Arabia deferred the execution of this interesting project and led to the conquest of Yemen. This accomplished, the Turks were firee to turn their attention to Venice.

The Holy The Republic, gravely perturbed by the insolent demand

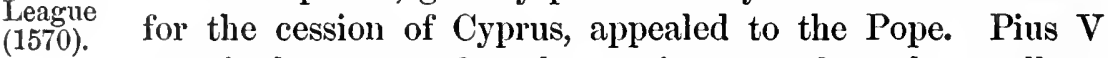
promised to pay for the equipment of twelve galleys, sanctioned the levy of a tithe on the Venetian clergy, and appealed for help not only to the Christian princes but to the Persian Shah. The emperor's hands were tied by his

1 See supra, chap. ii. 
recently concluded truce, but Philip II of Spain, Cosmo de Medici, Duke of Tuscany, and the States of Parma, Mantua, Lucca, Ferrara, and Genoa joined Venice and the Papacy in a Holy League against the Ottomans. The command of the combined armada was entrusted to a brilliant young sailor, Don John of Austria, a natural son of the Emperor Charles V.

The two fleets, each with a large and well-equipped army Battle of on board, met near the entrance of the Gulf of Patras, and Lepanto, there, on the 7th of October, 1571, Don John fought and won 1571.' the great battle of Lepanto. The battle was stubbornly contested, and the losses on both sides were enormous. ${ }^{1}$ The victory of the Holy Allies resounded throughout the world; Te Deums were sung in every Christian capital; the Pope preached on the text, "There was a man sent from God whose name was John', but the actual fruits of a gigantic enterprise were negligible. The Turks, though hopelessly defeated in battle, retained command of the sea ; a new and splendid fleet was rapidly built and equipped ; the conquest of Cyprus was completed, and in May, 1573, Venice concluded peace with the Ottoman Empire. The terms of that peace reflected the issue of the campaign, not that of Don John's brilliant sea-fight. The Republic agreed to the cession of Cyprus; to the payment of a war indemnity of 300,000 ducats ; to increase her tribute for the possession of Zante from 500 to 1,500 ducats, and to re-establish the status quo ante on the Dalmatian and Albanian coasts.

The terms were sufficiently humiliating to the victors at Lepanto. Yet the victory itself was by no means devoid of significance. Coming, as it did, so soon after the great days of Suleiman and Barbarossa, it was interpreted as a sign that the Turks were no longer invincible, and that their political decadence had set in. Nor was the interpretation wholly at fault.

The truce concluded in 1569 between the Emperor Maxi- The Habsmilian and the Turks lasted, mirclile dictu, for nearly burgsand a quarter of a century. But the truce between the rulers the Turks. 
did not deprive the local chieftains on either side the artificial frontier from perpetual induggence in the pastime of irregular war. Nominally, however, the truce was not broken till 1593. The breach of it was followed by thirteen years of war; the Turks achieved one brilliant victory, but much of the fighting was of a desultory character, and the rassal rulers of Moldavia, Wallachia, and Transylrania allied themselves with the enemy of their suzerain ; the war went, on the whole, decidedly in farour of the Habsburgs; it became clear that the Turks had reached the limits of expansion beyond the Danube. Peace was accordingly concluded, in 1606, at Sitvatorok. The Sultan renounced his suzerainty orer Transylrania, and in exchange for a lump sum surrendered the annual tribute of 30,000 ducats which ever since 1547 the emperor had paid in respect of that portion of Hungary which he had then been permitted to retain. Thenceforward there was no question, on either side, of superiority. Sultan and emperor were on a footing of formal equality.

The

Thirty

Years'

War (1618-48).

Fortunately for the Habsburgs, and indeed for Western Christendom, the half century which followed upon the Peace of Sitvatorok was, as we have seen, a period of anarchy and corruption in the Ottoman Empire. Were other proof lacking, sufficient evidence of the degeneracy of the Sultans would be found in their neglect to take advantage of the embarrassments of their chief opponent. From 1618 until 1648 the empire was in the throes of the Thirty Years' War; the Habsburg dynasty did not finally emerge from the contest until 1659. In one sense, indeed, the fight did not cease until Louis XIV had 'erased' the Pyrenees and put a Bourbon on the throne of Spain. The preoccupation of the Habsburgs ought to have been the opportunity of the Turk. Had the latter advanced from Buda to Vienna when the Habsburgs were engaged with the recalcitrant Calrinists of Germany; with Demmark, Sweden, or France, the Austrian capital could hardly have failed to fall to them. But the Turk let all the chances slip, and when, in 1648, the Treaties of Westphalia were concluded, the conditions of the secular contest were essentially altered.

The Thirty Year's' War fatally weakened the Holy Roman 
Empire, but out of the welter the House of Austria emerged as a first-rate European Power. The Treaty of Westphalia, even more definitely than that of Prague (1866), marks the real beginning of the new orientation of Habsburg policy: the gravitation towards Buda-Pesth had begun. The Holy Roman Empire belonged essentially to the Western States-system; the interests of Austria-Hungary have drawn her irresistibly towards the East. This gravitation has necessarily accentuated the antagonism between the Habsburgs and the Ottomans, and the second half of the serenteenth century is largely occupied by a contest between them for supremacy in the Danube and the Save valleys.

Before we pass to the details of that contest it will conduce Turkey to lucidity if we dismiss briefly the subsidiary, but at times $\stackrel{\text { and }}{\text { Venice }}$ interdependent, war between the Turks and the Venetian (1645Republic. So long as the latter retained Crete Ottoman 1718). supremacy in the Eastern Mediterranean lacked completeness. In 1645 the Sultan Ibrahim roused himself to the task of putting the coping stone upon the edifice. A pretext was soon found. In 1638 the Venetians, in pursuit of some Barbary pirates, had bombarded Valona on the Albanian coast. In 1644 a buccaneering raid was made by some galleys upon a valuable Turkish merchant fleet in the Levant. The successful assailants came, indeed, from Malta, but it sufficed that they found a refuge in a Cretan harbour. The disastrous faihure, in 1565, of the last Turkish attack upon the Knights Hospitallers in Malta, had made the Sultan shy of renewing the attempt. The Venetian Republic seemed to be a less redoubtable enemy and Crete a more important prize. Against Crete, accordingly, the attack was delivered in 1645, and Candia was besieged. The town held out for just a quarter of a century, in the course of which the Venetian sailors managed to inflict more than one humiliation upon the Turks. The Ottoman fleet suffered an important reverse in the Aegean in 1649, and in 1656 Mocenigo, an intrepid Venetian admiral, won a great victory in the Dardanelles, captured Lemnos and Tenedos, and threatened Constantinople.

The brilliant success of the Venetian fleet, combined with The the degeneracy of the Sultans and the complete corruption Kiuprilis. 
of Ottoman administration, seemed to threaten the imminent dissolution of the Turkish Empire. The nadir of its fortunes was reached, however, in 1656, and in the same year there was initiated a remarkable revival. The revival was due to the stupendous energy and splendid ability of one man, Mohammed Kiuprili. To him the mother of the young Sultan turned, in the hour of the empire's deepest need. Belonging to an Albanian family which had long been resident in Constantinople, Mohammed Kinprili was, in 1656, an old man of serenty, but he agreed to attempt the task demanded of him, on one condition. He stipulated that he should be invested with absolute authority. The condition was accepted, Kinprili became grand vizier, and entered forthwith upon his work.

The strong hand upon the reins was felt at once, and the high-mettled steed immediately responded to it. The Janissaries were taught their place by the only method they could now appreciate-the simultaneous execution of 4,000 of their number; the administration was purged of the corrupting and enervating influences to which it had long been a prey; chaos gave way to order in the finances, and discipline was promptly restored in the army and navy.

In no sphere were the effects of the new régime more quickly manifested than in the prosecution of the war. Within twelve months the Venetian fleet was chased from the Dardanelles; the guardian islands, Lemnos and Tenedos, were recovered by the Turks; the operations against Crete were conducted with new vigour; and in 1658 the grand vizier undertook in person, despite his years, a punitive expedition against George Rákóczy II, the Voyvode of Transylvania. Rákóczy himself was deposed, and two years later was killed ; Transylvania had to pay a large war indemnity and an increased tribute to the Porte.

Achmet Mohammed Kiuprili died in 1661, but was immediately Kiuprili $(1661-76)$. succeeded by his son Achmet, a man of a vigour and ability not inferior to his own. After an expedition into Hungary, to which reference will be made presently, Achmet, in 1666, assumed personal control of the operations against Venice. In 1669 Louis XIV, in order to a renge an insult offered to 
the French ambassador in Constantinople, sent a force to the help of the Republic, but at last, after a siege which had dragged on, with intervals, for twenty-five years, Candia capitulated in 1669, and the whole island of Crete-except the three ports of Suda, Carabusa, and Spina-Lurga-passed into the hands of the Turks. The conquest of the great Greek island was doubly significant: it was the last notable conquest made in Europe by the Ottomans, and marked the final term of their adrance; it marked also the complete absorption of the last important remnant of the Greek Empire. Not until 1913 did the Hellenes formally recover an island by which they have always set exceptional store.

The capitulation of Candia was immediately followed by Renewal the conclusion of peace between the Porte and the Republic. of war But, after the disaster to Turkish arms before Vienna in 1683, Venice the Venetians again determined to try their fortunes against (1684). their old enemies. A Holy League, under the patronage of the Pope, was in 1684 formed against the infidel. Austria, Venice, Poland, and the Knights of Malta were the original confederates, and in 1686 they were joined by Russia. The Venetians invaded Bosnia and Albania, and a little later, under Francesco Morosini, they descended upon the Morea. Brilliant suceess attended the expedition; Athens itself was taken in September, 1687, and though it was restored by the Treaty of Carlowitz (1699), the whole of the Morea, exeept Corinth, together with the islands of Aegina and Santa Mamra and a strip of the Dalmatian coast, were retained by the Republic.

Venetian rule in the Morea was not popular. The Venetians did something to improve education, and much of the lost trade between the Levant and Western Europe was, during the period of their occupation, recovered. But their domination was almost as alien as that of the Turks, and the Greeks gained little by the change of masters. When therefore the Turks, in 1714, declared war against the Venetians, they were able in some sort to pose as the liberators of the Morea. In places they were indubitably weleomed as such, and the progress of their arms was consequently rapid. But in 1716 Austria intervened in the war, and in 1718 the Porte was 
glad enough to conclude a peace by which she regained the Morea, though Venice retained her conquests in Dalmatia, Albania, and Herzegovina. If the Ottoman Empire was decadent, the Republic too had fallen from its high estate.

Hungary For the sake of lucidity we have anticipated the progress and Tran- of events; we must now retrace our steps and follow the course of the struggle on the northern frontiers of the empire. For more than a century the Sultan had been direct sovereign of the greater part of Hungary, and had claimed a suzerainty, not always conceded, over Transylvania. By the middle of the serenteenth century it seemed possible that the latter principality, after many vicissitudes, might become hereditary in the house of Rákóczy. That possibility was dissipated, as we have seen, by the vigorous action of Mohammed Kiuprili. On the death of George Rákóczy II (1660), the Transylvanian nationalists elected John Kamínyi as Voyrode, while the Turks nominated a candidate of their own, Apafy. Kaminyi appealed to the Emperor Leopold, who sent a force under Montecuculi to his assistance. The succour did not, however, prove effective, and in 1662 Kaminyi was killed. Apafy, mistrustful of the disinterestedness of his patrons, sought, in his turn, help from the emperor. Meanwhile, Achmet Kiuprili collected a force of 200,000 men, and in 1663 crossed the Danube at their head. He captured the strong fortress of Neuhäusel, ravaged Moravia, and threatened Vienna. Smarting under the diplomatic insult to which reference has been made, Louis XIV dispatched a force to the assistance of the emperor, and at St. Gothard, on the Raab, Montecuculi, commanding the imperial forces, inflicted, with the aid of the French, a decisive defeat upon Kiuprili.

Treaty of St. Gothard was the most notable victory won by the arms Tastar (1664). of Christendom against those of Islam for three hundred years. But the emperor, instead of following it up, suddenly concluded a truce for twenty years with the Turks. The terms obtained by the latter, and embodied in the Treaty of Vasvar, were unexpectedly favourable. The emperor agreed to pay an indemnity of 200,000 florins; the Turks retained Grosswardein and Neuhäusel, and thus actually strengthened 
their position in Hungary, while their suzerainty over Transylvania was confirmed. The concession of such terms after such a victory as that of St. Gothard evoked resentment in some quarters, and astonishment in all. The explanation of the paradox must be sought in the repercussion of Western politics upon those of the East, and in the dynastic preoccupation of the Habsburg emperor. Philip IV of Spain was on his death-bed ; the succession to the widely distributed dominions of the Spanish crown was a matter of great uncertainty; French help in Hungary, though acceptable at the moment, might well prove to have been too dearly purchased; and it was intelligible that the emperor should desire to hare his hands free from embarrassments in the East, in view of contingencies likely to arise in the West.

For the time being, howerer, his enemies were even more Turkish deeply involved than he was. The Venetian War was not Woland ended until 1669, and three years later the Turks plunged (1672-6). into war with Poland.

The lawlessness of the border tribes to the north of the Euxine had already threatened to bring the Ottoman Empire into collision with the Russian Tsars. Towards the end of Ibrahim's reign (1640-8) the Tartars of the Crimea had pursued their Cossack enemies into Southern Russia and had brought away 3,000 prisoners. The Russians in turn advanced against Azov but were badly beaten, with the result that the Tartars sent 800 Muscorite heads as a trophy to Constantinople.

There were similar troubles on the side of Poland. In 1672 the Cossacks of the Ckraine, stirred to rerolt by the insolence of the Polish nobles and the extortions of their Jewish agents, offered to place themselres under the suzerainty of the Suitan in return for assistance against their local oppressors. Achmet Kiuprili, nothing loth, deelared war upon Poland, and, accompanied by the Sultan, Mohammed IT, led a strong force to an assault upon Kaminiec, the great fortress on the Dniester, which strategically commanded Podolia. Kaminiec, though hitherto deemed impregnable, quickly yielded to the Turks, and the Polish King Michael hastily concluded with the Sultan a treaty, 
which involved the payment of an annual tribute and the surrender of Podolia and the Ukraine. The Polish Diet, however, refused to ratify the treaty, and entrusting the command of their forces to John Sobieski, they waged for four years an heroic struggle against the Ottomans. Thanks to the commanding character and the military genius of Sobieski, the Poles not only rallied their forces, but inflicted a crushing defeat upon the Turks at Khoczim (Novenber, 1673). In 1674 the victorious general was elected to the Polish throne, and in the following year he again defeated the Turks at Lemberg. But despite this defeat the Turks steadily persisted and maintained their hold upon Podolia, and in 1676 both sides were glad to conclude the Peace of Zurawno. Under the terms of this treaty the Turks retained Kaminiec and the greater part of Podolia, together with a portion of the Ukraine, but agreed to forgo the tribute promised by King Michael.

The Peace of Zurawno may be regarded as a further triumph for Achmet Kiuprili, but it was his last. In the same year he died, having substantially advanced the border's of the empire at the expense of Austria-Hungary, of Poland, and of Venice. He was succeeded, as grand vizier, by his brother-in-law, Kara Mustapha, who almost immediately found himself involved in war with Russia.

Russo- The war brought little credit to the new vizier, and Turkish nothing but disastel to his country. Kara Mustapha led (1675-81). a large army into the Ukraine, but he was driven back across the Danube by the Russians, and in 1681 the Porte was glad to conclude a peace by which the district of the Ukraine, obtained from Poland in 1676, was ceded to Russia, and the two Powers mutually agreed that no fortifications should be raised between the Dniester and the Bug.

East and Kara Mustapha had more important work on hand. Lacking both character and ability he was nevertheless devoured by ambition. He determined to associate his name with the conquest of Vienna and the extension of the Ottoman Empire to the Rhine. The moment was not unfavourable to such a design. The attention of Western Europe was concentrated upon Louis XIV, who had now reached the zenith 
of his power. War had succeeded war and treaty had followed treaty, and from all France had cxtracted the maximum of advantage. By the Treaty of Westphalia, supplemented by that of the Pyrenees (1659), Louis XIV had gone some way towards realizing the dream of all patriotic Frenchmen, the attainment of les limites nuturelles: the Rhine, the Alps, the Pyrenees, and the Ocean. France pushed her frontier to the Pyrenees and got a firm grip upon the middle Rhine; Pinerolo guarded her frontier towards Saroy, and, on the north-east, a large part of Artois passed into her hands. Louis's marriage with Marie Louise, eldest daughter of Philip IV of Spain, opened out a still larger ambition. The War of Devolution gave him an impregnable frontier on the north-east, and ten years later, by the Treaty of Nimeguen (1678), he obtained the 'Free County' of Burgundy, and made the Jura, for the first time, the eastern fronticr of France. His next annexation was the great fortress of Strasburg (1681), and in 1683 he threatened Luxemburg.

The emperor could not remain indifferent to these assaults The upon the western frontiers of the empire; but as Archduke Habsof Austria and King of Hungary he had troubles nearer home. Hungary. The Turks were still, it must be remembered, in possession of by far the larger part of Hungary-the pashalik of Buda. In Austria-Hungary, moreover, there had long been much discontent with Habsburg rule. The Emperor Leopold, like his predecessors, was much under the influence of his Jesuit confessors, and his hand was heavy on the Hungarian Protestants, who looked with envy upon the lot of their brethren living under the tolerant rule of the Ottoman Turks.

Nor was religions persecution their only ground of complaint against the Habsburgs. The proud Magyar aristocracy denounced the Treaty of Vasrar as a craven betrayal of Hungarian interests on the part of a ruler by whom Hungary was regarded as a mere appendage to Austria. Their nationalist instincts were further offended by the attempt of the Emperor Leopold to administer his Hungarian kingdom through German officials responsible solely to Vienna. So bitter was the feeling that in 1666 a widespread conspiracy was formed under the nominal leadership of Francis Rákóczy; 
a son of the late Prince of Transylvania. The plot was betrayed to the Viennese Government. Louis XIV had lately concluded a secret agreement with the Emperor Leopold in regard to the Spanish succession, and hence was not, at the moment, disposed to help the Hungarian malcontents; abore all, the Turks were busy in Crete. The morement, therefore, collapsed; Rákóczy was treated with contemptuous lenity, but the rest of the leaders were punished with pitiless severity, and the yoke of the Habsburgs was imposed with tenfold rigour upon what was now regarded as a conquered province. The office of Palatine was abolished ; the administration was entrusted exclusively to German officials; the Hungarian aristocracy were exposed to every species of humiliation and crushed under a load of taxation; the Protestant pastors were sent to the galleys or driven into exile.

Hun- The reign of terror issued, in 1674, in a renewed revolt garian revolt under Tököli (1674). under the patriotic and devoted leadership of a Magyar aristocrat, Emmerich Tököli. The moment was propitious. The emperor was now at war with Louis XIV, who, in 1672, had launched his attack upon the United Provinces. Louis was, it is true, too much engaged on his own account to send help to the Hungarian nationalists, but he used his influence at Warsaw and Constantinople on their behalf. Not that either Poles or Turks engaged in fighting each other (1672-6) could at the moment do much for the Magyars. Kara Mustapha, however, promised that he would send help immediately his hands were free of the Polish War. But, as we hare seen, that war was no sooner ended than the Turks were involved in war with Russia. The latter war ended, in its turn, in 1681, and at last Kara Mustapha was in a position to embark upon the larger designs which from the first he had entertained.

Promptly, the emperor attempted to conciliate the Hungarian nationalists. The administrative system was remodelled in accordance with their wishes; the governor-generalship was abolished ; the German officials were withdrawn; the more oppressive taxes were repealed; the rights of citizenship were restored to the Protestants, both Calvinists and 
Lutherans, who were to enjoy liberty of conscience and of worship; the chief administrative offices were confided to natives; and the dignity of Palatine was rerived in farour of Paul Esterhazy.

Concession could hardly have gone further, but the emperor's change of front was suspiciously coincident with the modification of the external situation. Emmerich Tököli refused to be beguiled into the acceptance of conditions so obviously inspired by prudential considerations. On the contrary, he entered into closer relations with the enemies of the emperor. He married the widow of Francis Rákóczy, and so strengthened his position on the side of Transylrania, and at the same time proclaimed hinself Prince of Hungary under the suzerainty of the Sultan.

In 1682 Mohammed IV advanced to the support of his Austrovassal. He led from Adrianople a magnificent army of 200,000, Wurkish amply supplied with guns and siege trains. At Belgrade he (1683). surrendered the command to the grand vizier, who, having effected a junction with Tököli, adranced in 1683 towards Vienna.

The Emperor Leopold, isolated by the diplomacy of John Louis XIV in Western Europe, and eren in the empire itself, turned for help to Poland, and, thanks to the king, not in rain. Sobieski undertook, notwithstanding an appeal from Louis XIV, to come with a force of 40,000 men to the rescue of the emperor and of Christendom.

Meanwhile Kara Mustapha was marching with leisurely confidence upon Vienna. The emperor and his court retired in haste to Passau, and Charles IV, Duke of Lorraine, the commander of the imperialist forces, having entrusted the defence of the eapital to Count Stahremberg, withdrew to await the arrival of Sobieski and the Poles. Stahremberg proved equal to one of the heaviest responsibilities ever imposed upon an Austrian general. He burned the suburbs to the ground, and did his utmost to put the city itself into a posture of defence. The fortifications were in a most neglected condition; the walls were in no state to resist an assault; the garrison consisted of no more than 10,000 men ; while the defence was hampered by crowds of 
peasants who had fled for refuge to the city before the advance of the Ottomans.

Siege of

Vienna.

Stahremberg, however, kept a stont heart, and inspired the garrison with his own grim determination. On July 14 the Ottoman host encamped before the walls, and proceeded to invest the city. The siege lasted for 60 days, and the beleaguered garrison was reduced to the last extremity. On September 5 Sobieski had joined the Duke of Lorraine, and had assumed command of their combined forces; on the 9th a message reached him from Stahremberg that unless succour arrived immediately it would be too late; on the 11th the relieving army took up its position on the Kahlenberg, the hill which overlooks the capital; on the 12 th it advanced to the attack upon the besiegers.

At the first charge of the Poles the Turks were seized with panic, and, before they could recover, Sobieski flung his whole force upon them. The great host was routed; Vienna was saved'; 10,000 Turks were left dead upon the field ; 300 guns and an enormous amount of equipment and booty fell into the hands of the victors. Two days later the emperor returned to his capital to greet the saviour of Christendom.

Sobieski, howerer, started off at once in pursuit of the Turks, defeated them near Parkan in October, at Szecsen in November, and drove them out of Hungary. Kara Mustapha fled to Belgrade, and there on Christmas Day paid with lis life the penalty of his failure.

The significance of that failure can hardly be exaggerated. Had Kara Mustapha's ability been equal to his ambition and superior to his greed, Vienna must have fallen to an assault. Had Vienna fallen, the Ottoman Empire might well have been extended to the Rhine. In view of the decadence of the Sultans and the corruption which had already eaten into the vitals of their empire, it is more than doubtful whether the advance could have been maintained ; there is, indeed, ground for the belief that even the absorption of Hungary was a task beyond their strength, and that the Danube formed their 'natural limit' towards the north. But even the temporary occupation of Vienna, still more the annexation, howerer transitory, of lands wholly 
Teutonic in race and essentially 'western' in their political connexions, could not have failed to administer a severe moral shock to Christendom. That shock was averted by the valour and intrepidity of Sobieski, the Pole. The 'most Christian King', Louis XIV of France, so far from stirring a finger to save Christendom, regarded the advance of the Turks as a welcome military diversion; he exhausted all the unrivalled resources of French diplomacy to assure the success of their enterprise, and anuihilate the only Power in Europe which seemed, at the moment, capable of circumscribing the ambition of the Bourbons. ${ }^{1}$ It was five years later that the English Revolution gave to the Dutch stadholder the chance, which he did not neglect, of saving Europe from the domination of France.

Meanwhile, the war between the Habsburgs and the Turks Reconcontinued for fifteen years after the raising of the siege of quest of Vienna. Sobieski, having successfully accomplished the task \&u. which has won him imperishable fame, soon retired from the war. The French party reasserted itself at Warsaw ; domestic difficulties, ever recurrent in Poland, demanded the personal intervention of the king, and in 1684 he surrendered the command of the imperialist forces to Charles of Lorraine. The formation of the Holy League, in that same year, gave to the war against the Turks something of the nature of a crusade, and volunteers flocked to the standard of the emperor from many countries besides those which actually joined the League."

Led by Charles of Lorraine, by the Margrave Lewis of Baden, by the Elector of Bavaria, by Prince Eugène of Savoy, and other famous captains, the imperialists won a succession of significant victories against the Turks. They stormed the strong fortress of Neuhäusel, and drove Tököli and the Hungarian nationalists back into Transylvania in

I Voltaire suggests (Le Siècle de Louis XIV, chap. xiv) that the French king was only waiting for the fall of Vienna to go to the assistance of the empire, and then, having posed as the saviour of Europe, to get the Dauphin elected king of the Romans. The idea may well have been present to Louis's mind.

2 See supra, p. 103. 
1685, and in the following year they retook Buda, which for 145 years had formed the capital of Turkish Hungary. The Habsburg emperor, now master of the whole of Hungary, proceeded to deal with his rebellious subjects. A reign of terror ensued, and the embers of the insurrection were quenched in blood. Important modifications were introduced into the constitution. The Hungarian Crown, hitherto nominally elective, became hereditary in the House of Habsburg, and in 1687 the Austrian Archduke Joseph was crowned king.

Second battle of Mohacz (1687).

Fall of Belgrade (1688).
In that same year the imperialist forces met the Turks on the historic field of Mohacz, and by a brilliant victory wiped ont the memory of the defeat sustained at the hands of Suleiman the Magnificent 161 years before. The second battle of Mohacz was followed by the reduction and recovery of Croatia and Slavonia. This prolonged series of defeats in Hungary led to the outbreak of disaffection in Constantinople. The Janissaries demanded a victim, and in 1687, as we have seen, Sultan Mohammed IV was deposed. But the change of Sultans did not affect the fortunes of war. In 1688 the imperialists invaded Transylvania, and the ruling Prince Apafy exchanged the suzerainty of the Ottomans for that of the Habsburgs. Henceforward Transylvania became a rassal state under the crown of Hungary.

But a much more important triumph awaited Austrian arms. In September, 1688, the great fortress of Belgrade was stormed by the imperialists, and for just half a century was lost to the Turks. From Belgrade the conquering Tentons advanced into Serbia and captured Widdin and Nish.

Once more, however, the repercussion of Western politics was felt in the East, and, in 1688, the outbreak of the war of the League of Augsburg and the French invasion of the Palatinate, relieved the pressure upon the Turks. But this advantage was cancelled by the appearance of a new antagonist. In 1689 Peter the Great of Russia invaded the Crimea, and in 1696 captured the important fortress of Azor. ${ }^{\mathbf{1}}$ Meanwhile, for the Turks the situation was temporarily redeemed

1 See, for further details, infra, p. 119. 
by the appointment as grand vizier of a third member of the famous Albanian family which had already done such splendid service for the State. Mustapha Kimprili (III) was the brother of Achmet; he was in office only two years (1689-91), but the effect of a strong hand at the helm was immediately manifested : the finances were put in order ; the administration was purified, and new vigour was imparted to the conduct of the war.

The death of Apafy, Prince of Transylvania (April, 1690), gave Mustapha a chance of which he was quick to avail himself. Master of Hungary, the Emperor Leopold was most anxious to absorb Transylvania as well, and to this end endeavoured to secure his own election as suecessor to Apafy. The separatist sentiment was, however, exeeedingly persistent among the Roumans of Transylrania, and, with a view to encouraging it, the vizier nominated as voyvorle Emmerich Tököli. With the aid of Turkish troops Tökioli temporarily established himself in the principality, thongh his position was threatened by the adrance of an imperialist army under Lewis, Margrave of Baden.

Meanwhile, Kiuprili himself marched into Serbia, retook Widdin and Nish, and adranced on Belgrade. That great fortress fell, partly as the result of an aceidental explosion, into the hands of the Turks, who, in 1691, adranced into Hungary. Recalled from Transylvania to meet this greater danger, Lewis of Baden threw himself upon the advancing Turks at Salan Kemen, and inflicted upon them a erushing defeat (August 19, 1691). 28,000 Turks were left dead upon the field, and 150 guns fell into the hands of the rictors. The grand vizier himself was among the killed. With him perished the last hope of regeneration for the Ottoman Empire.

After the defeat and death of Kiuprili III, Tököli conld Conquest no longer maintain his position in Transylvania, and the of TranDiet came to terms with the emperor (December, 1691). Local privileges were to be respected, but the emperor was to become voyvode and to receive an annual tribute of 50,000 ducats. Transylvania thus virtually took its place as a province of the Habsburg Empire. 
For the next few years the war languished. England and Holland tried to bring about peace in Eastern Europe, while Louis XIV, for reasons equally obvious, did his utmost to encourage the prolongation of the war. But in 1697 Louis XIV himself came to terms with his enemies in the Treaty of Ryswick, and thus the emperor was once more free to concentrate his attention upon the struggle in the Near East.

Battle of In 1697 Prince Engène of Savoy assumed command of Zenta, Sept. 11, 1697. the imperialist forces, and in the autumn inflicted upon the Turks at Zenta on the Theiss the most crushing defeat their arms had sustained since their advent into Europe. The grand vizier and the flower of the Ottoman army, 20,000 in all, were left dead upon the field; 10,000 men were wounded, and many trophies fell into the hands of the victors. Carlyle's comment on this famous victory is characteristic: 'Engène's crowning feat; breaking of the Grand Turk's back in this world; who has staggered about less and less of a terror and outrage, more and more of a nuisance, growing unbearable, ever since that day.'

Treaty of A fourth Kiuprili, who succeeded as grand vizier, made Carlowitz, a gallant effort to redeem the situation; he raised a fresh 1699 . army and drove the Austrians back over the Save; but the battle of Zenta was decisive, it could not be reversed, and in January, 1699, peace was concluded at Carlowitz.

The terms were sufficiently liumiliating for the Porte. The advantages secured by the Venetian Republic have already been enumerated. 'To the emperor the Turks were obliged to cede Transylvania, the whole of Hungary except the Banat of Temesvar, and the greater part of Slavonia and Croatia. Poland retained the Ukraine and Podolia, including the great fortress of Kaminiec. The peace with Russia was not actually signed until 1702 , when she secured the fortress and district of Azov.

No such peace had ever before been concluded by the Turk. The tide had ummistakably begun to ebb. The principalities of Moldavia and Wallachia remained subject to the sultan for a century and a half to come, but otherwise the boundary of the Ottoman Empire was fixed by the 
Drave, the Save, and the Danube. Never again was Europe threatened by the Power which for three centuries had been a perpetual menace to its security. Henceforward the nature of the problem was changed. The shrinkage of the Ottoman Empire created a vacuum in the Near East, and diplomacy abhors a vacumm. How was it to be filled?

The succeeding chapters of this book will be largely concerned with the attempts of Europe to find an answer to that question.

For further reference ef. chapter iii; General Works (Appendix); and also L. Léger, L'Autriche-Hongrie; Rambaud, History of Russica (Eng. trans.) ; Himly, La formation territoriale; Freeman, Historical Geography. 


\title{
CHAPTER VI
}

\section{THE EASTERN QUESTION IN THE EIGHTEENTH CENTURY}

\author{
Russia and Turkey, 1689-1792
}

'Pour la Russie toute la fameuse question d'Orient se résume dans ces mots: de quelle autorité dépendent les détroits du Bosphore et des Dardanelles? Qui en est le détenteur?'-Sfrat Goriainow.

'Tout contribue à développer entre ces denx pays l'antagonisme et la haine. Les Russes ont reçı leur foi de Byzance, c'est leur métropole, et les Turcs la souillent de leur présenee. Les Tures oppriment les coreligionnaires des Rinsses, et chaque Rnase considère comme une œuvre de foi la délivrance de ses frères. I es passions populaires s'accordent ici arec les conseils de la politique: c'est vers la mer Noire, vers le Danube, vers Constantinople que les sonverains russes sont naturellement portés à s'étendre: délivrer et conquérir deviennent pour eux synonymes. Les tsars ont cette rare fortune que l'instinct national soutient leurs calculs d'ambition, et qu'ils peuvent retoumer contre l'empire Ottoman ce fanatisme religienx qui a précipité les Tures sur l'Europe et rendait naguère leurs invasions si formillalles.'-Azbert Sorez.

'L'introduction de la Russie sur la scène européenne dérangerait aussi le système politique du Nord et de l'Orient tel que l'avait composé la prudence de nos rois et de nos ministres.'-VANDAL.

\section{§ 1. From the Treaty of Carlowitz to the Treaty of Belgrade, 1699-1739}

The new factor in the problem.

Throughout the sixteenth and seventeenth centuries it was, as we have seen, the Habsburg emperors who, with the fitful aid of the Venetian Republic, bore the brunt of the struggle against the Turks. The prize for which they contended was domination in the Save and the Middle Danube valleys.

With the opening of the eighteenth century, just, indecd, before the close of the seventeenth, a new factor makes its appearance in the problem of the Near East. Russia comes more and more prominently forward as the protagonist. She challenges Turkish supremacy in the Black Sea, and 
begins to interest herself in the fate of her co-religionists in the Ottoman Empire. Connected with many of them by ties not merely of religion but of race, she stands forth as the champion of the Slav nationality no less than as the protector of the Greek Church. To her Constantinople is Tsargrad. She poses as the legitimate heir to the pretensions of the Byzantine emperor's. But Constantinople is more than the imperial city. It is the sentinel and custodian of the straits. In alien hands it blocks the access of Russia to European waters. Without the command of the straits Russia can never become, in the full sense, a member of the European polity. Persistently, therefore, she looks towards the Bosphorus. Her ulterior object is to obtain unrestricted egress from the Black Sea into the Mediterranean. But a prior necessity is to get access to the shores of the Black Sea.

When Peter the Great, in 1689, took up the reins of Peter the government Russia had little claim to be regarded as a creat European Power. She had no access either to the Baltic 1725). or to the Black Sea. The former was a Swcdish lake; the latter was entirely surrounded by Turkish territory. With the opening of the 'window to the west' this narrative is not concerned, though it is noteworthy that the prospect from St. Petersburg, like that from Azov, is a singularly contracted one, unless the tenant has the key of the outer door in his own pocket.

Since 1453 there had been no attempt to force the door Russia of the Euxine from either side. But the rapid rise of the and the Russian Empire in the seventeenth and eighteenth centuries rendered it certain that the attempt would not be indefinitely postponed. The first contact between the two Powers, which were destined to such acute rivalry in the Near East, dates from the year 1492, when the Tsar, Ivan III, protested against the treatment to which certain Russian merchants had been subjected by the Turks. The result of the protest was the opening of diplomatic relations between Moscow and Constantinople. The same Ivan, on his marriage with Sophia, niece of the Emperor Constantine XIII and the last princess of the Byzantine House, assumed the 
cognizance of the two-headed eagle, the symbol of the Eastern Empire. Already, it would seem, the ambitions of the Muscovite were directed towards the city and empire of Constantine. The reign of Ivan the Terrible (1533-84) is memorable for the first armed conflict between the Russians and the Turks. Sököli, the grand vizier of Selim the Sot, lad conceived the idea of strengthening the strategical position of the Ottoman Empire in regard to that of Persia by cutting a canal to unite the Don with the Volga. A necessary preliminary was the occupation of Astrakhan. Not only was the attempt to seize that city successfully resisted by the Russian garrison, but a serious defeat was inflicted by the Muscovite forces upon another Turkish army near Azov (1575). Thus the Russians had drawn first blood, and Sököli's enterprise was abandoned.

Not for a century did the two Powers again come into direct conflict. In the meantime, however, they were frequently in indirect antagonism in connexion with the perpetual border warfare carried on by the Cossacks and the Tartars on the northern shores of the Black Sea. A raid of the Tartars into southern Muscovy would be followed by a Cossack attack upon Azov. The Sultan would disavow the action of his Tartar vassals; the Tsar would protest that he could not be held responsible for the lawlessness of the Cossacks, 'a horde of malefactors who had withdrawn as far as possible from the reach of their sovereign's power, in order to escape the punishment due to their crimes'. The protestations were on neither side wholly sincere; but if they had been it would have made little difference to the conduct of the fierce tribesmen on the frontiers.

In 1677, as we have seen, ${ }^{1}$ the relations between the Poles and the Cossacks of the Ukraine involved the outbreak of formal war between Russia and Turkey. A peace was patched up in 1681, but Russia joined the Holy League in 1686, and from that time until the conclusion of the Treaty of Carlowitz (1699) the two Powers were intermittently at war. 
From the outset of his reign Peter the Great was firmly Peter's resolved to obtain access to the Black Sea. With that conquest object he organized a great expedition against Azov in 1695. He himself led an army of 60,000 men against the fortress. Thrice did he attempt to storm it, and thrice was he repelled, but failures only stimulated him to further efforts. During the winter of 1695-6 25,000 labourers, headed by the Tsar himself, worked night and day on the building of a vast flotilla of vessels of light draught. In 1696 the attempt was renewed with fresh forces and with the assistance of this newly-built fleet, and on July 28 Azov surrendered. No sooner had the fortress passed into his hands than Peter proceeded to improve the fortifications, to enlarge the harbour, and to make all preparations for converting the conquered town into a great naval base. Two years later a Russian Tsar and an Ottoman Sultan were for the first time admitted to a European congress. By the treaty arranged at Carlowitz the Porte agreed to cede Azor and the district-about eighty miles in extent-which the Russians had conquered to the north of the Sea of Azor.

But ten years later the Turks turned the tables upon the Charles Tsar. In 1709 the greatness of Sweden as a European power was XII and destroyed at a single blow by the rash policy of Charles XII. Perhaps persuaded by the subtle diplomacy of Marlborough to turn his arms against the 'T'sar; certainly lured by Mazeppa, the Cossack chieftain, to embroil himself in his quarrels, Charles XII led the army of Sweden to its destruction on the fateful field of Pultawa (July, 1709). After the amnihilation of his army at Pultawa the Swedish king, accompanied by Mazeppa, took refuge in 'Turkey, and the Tsar's demand for their surrender was firmly refused by the Sultan. Urged to a renewal of the war with Russia by Charles XII, and still more persistently by his vassal, the Khan of the Crimean Tartars, Sultan Achmet, rather reluctantly consented, and in November, 1710, war was declared.

The Russian conquest of Azov, and the resounding victory The capiover the Swedes at Pultawa, had created no small measure tulation of unrest among the Christian subjects of the Ottoman Treaty Empire. The Slavs in the west, the Greeks in the south, of the 
and even the Latins in the north-east of the peninsula, began to look to the Tsar as a possible liberator, and the excitement among them was great when, in the summer of 1711 , the Russian army crossed the Pruth. Peter, however, repeating the blunder which had led to the overthrow of the Swedish king at Pultawa, pushed on too far and too fast, found himself surrounded by a vastly superior force of Turks, and was compelled to sue ignominiously for peace. Despite the remonstrances of the Swedes and Tartars the Turkish vizier consented to treat, and on July 21, 1711, the terms of the capitulation were arranged. By this Treaty of the Pruth Azov and the adjacent territory were to be restored to the Ottomans; the Tsar undertook to raze to the ground the fortress of Taganrog lately built on the Sea of Azov; to destroy other fortifications and castles in the neighbourhood; to surrender the guns and stores; to withdraw his troops from the Cossack, and not to interfere in the affairs of Poland or the Ukraine. The Russians were no longer to have an ambassador at Constantinople; they were to give up all Moslem prisoners in their custody; to afford Charles XII, the guest of the Ottoman Empire, free and safe passage to his own kingdom, and not to keep a fleet in the Black Sea. No surrender could have been more complete, but it is generally agreed that the vizier, either from weakness or something worse, made a fatal blunder in accepting it. Such an opportunity for amnihilating the power of the Muscovite Tsar might never recur. Such was emphatically the opinion of contemporaries. The indignation of Charles XII knew no bounds, and he refused to leave the Ottoman dominions; the vizier was deposed, and his two subordinate officers were exeented, but thanks mainly to the mediation of English and Dutch envoys, a definitive peace, on terms corresponding to those of the capitulation, was finally concluded in 1713. Not for a quarter of a century did war break out again between Russia and Turkey.

Renewal of war against Venice and Austria.
The Turks, however, were at war again with the Venetian Republic in 1715. They had never acquiesced in the loss of the Morea, where Venetian rule, thongh favourable to commerce and education, did not prove popular among the 
mass of the people. In 1715, therefore, the Turks fell upon the Morea, with overwhelming forces, both by land and sea, and in the course of a few months the Venetians were expelled from the Morea and from all the islands of the Archipelago. The victors then prepared to follow up their success in the Adriatic; but in 1716 Austria intervened, accused the Porte of a gross violation of the Treaty of Carlowitz, and concluded an alliance with the Republic. Prince Eugène won a great victory over the Turks at Peterwardein (August 13, 1716), and in November the city of Temesvar, the last fortress left to the Turks in Hungary, was compelled to surrender.

Prince Eugène's campaigu against the Turks possessed Capture of political as well as military significance. Since the over- Belgrade. throw of the Slars on the fatal field of Kossoro, ${ }^{1}$ Serbia, as a political entity, had virtually been obliterated, but at the opening of this campaign Eugène appealed to the Serbians to seize the opportunity of throwing off the yoke of the Turks, and more than a thousand of them enlisted under his banners. Could they have looked into the future they might have shown less eagerness to help the Austrians to the possession of Belgrade.

The capture of that great fortress was the object and culmination of the campaign of 1717 . The city was held by a garrison of 30,000 men, who for two months (June-Augnst) resisted all the efforts of Eugène's besieging force. Early in August an army of 150,000 Turks marched to the relief of the beleaguered fortress, and Eugène was in turn besieged. On August 16, however, he attacked, and, with greatly inferior numbers, routed the relieving force. Two days later Belgrade surrendered.

The Porte now inroked the mediation of Great Britain Treaty of and Holland. The emperor, anxious to have his hands free $\frac{\text { Passaro- }}{\text { witz }}$ for dealing with a complicated situation in the West, con- (1718). sented to treat, and peace was signed at Passarowitz (July 21, 1718). The Sultan accepted terms from the emperor, but dictated them to Venice. The Republic had to acquiesce in the loss of the Morea and the Archipelago, and henceforward retained only the Ionian isles and a strip of the Albanian

1 Supra, p. 58. 
coast. Her sun was setting fast. For the Habsburgs, on the other hand, the Treaty of Passarowitz marks the zenith of territorial expansion in the Near East. By the acquisition of the Banat of Temesvar they completed the recovery of Hungary ; by the cession of Little Wallachia they made a serious inroad upon the Danubian principalities; while by that of Belgrade, Semendria, a portion of Bosnia, and the greater part of Serbia they advanced towards both the Adriatic and the Aegean. It will not escape notice that the populations thus transferred from the Sultan to the emperor were not Ottomans, but, on the one hand, Roumanians, and on the other, Southern Slavs. The significance of that distinction was not, however, perceived at the time; it has, indeed, only recently been revealed.

'The

Danubian principalities.

A change of more immediate consequence to the Roumanians had been effected a few years before the Treaty of Passarowitz. Down to the year 1711 the Danubian principalities had, in accordance with an arrangement concluded with Suleiman the Magnificent, ${ }^{\prime}$ been permitted to remain under the rule of native hospodars. The progress of Russia to the north of the Euxine, and the dubious attitude of one or more of these hospodars during the recent wars between Russia and Turkey, seemed to render desirable a strengthening of the tie between the principalities and the bureaucracy of Constantinople. The hospodarships were, therefore, put up to auction, and for 110 years were invariably knocked down to Phanariote Greeks. The tenure of each Phanariote was brief, for the more rapid the succession the greater the profit accruing to the Porte. Consequently each Phanariote had to make his hay while the sun shone, and it was made at the expense of the Roumanians. ${ }^{2}$

liussia The capitulation of the Pruth was a humiliating, and for and 'Turkey the time being a disastrous, set back to the advance of (1711-36). Russia. But its significance was merely episodical. Russia, notwithstanding the signature of a treaty of 'perpetual' peace with the Porte in 1720 , nerer regarded it as anything

1 In 1536.

2 Between 1711 and 1821 there were 33 hospodars in Moldavia and 37 in Wallachia. 
more than the temporary adjustment of an embarrassing situation. Least of all did she forgo for an instant her ambitions in regard to the Black Sea in general and Azov in particular. Nor were any of the outstanding difficulties between Russia and Turkey really settled. The Tartars of the Crimea, encouraged by the retrocession of Azov, were more persistent than ever in their incursions into South Russia; the quarrels between them and the Cossacks were unceasing and embittered ; occasional co-operation between Russians and Turks against the Empire of Persia did nothing to adjust the differences between them in the Kuban district in Kabardia, and in the other disputed territories which lay between the Black Sea and the Caspian. Most insistent of all, however, was the problem of the Black Sea. It still remained a Turkish lake, and into this Turkish lake poured all the waters of the great Russian rivers, the Kuban, the Don, the Dnieper, the Bug, and the Dniester. These were and are the natural highways of Russia; so long as the Black Sea was a Turkish lake they were practically useless for purposes of trade. From the moment that Russia achieved something of political unity, from the moment she realized her economic potentialities, the question of access to the Black Sea, of free navigation on its waters, and free egress from them into the Mediterranean became not merely important but paramount. To have accepted as final the terms extorted in 1711 would have meant for Russia economic strangulation and political effacement. Without access to the Black Sea she could never become more than a secondclass Power; without command of the narrow straits which stand sentinel over the outer door she can never fulfil her destiny as one of the leaders of world-civilization.

How far did the general diplomatic situation lend itself to The diplothe realization of Russian ambitions? Upon whom could matic she count as a steadfast ally? With whose enmity must she reckon?

For 200 years the permanent pirot of continental politics Bourbonhad been the antagonism between France and the House Habsburigr of Habsburg. In order to secure her own diplomatic interests France had cultivated close relations with Stock- 
holm, with Warsaw, and, above all, with Constantinople. Nor were the ambitions of France exclusively political. Her commercial prosperity was derived mainly from the trade with the Levant, which was one of the by-products of the Franco-Turkish alliance.

The wars of Louis XIV, however flattering to French prestige, had imposed a terrible strain upon the economic resources of the country, and under Louis XV France was compelled to trust rather to diplomacy than to war for the maintenance of her pre-eminent position in Europe. ${ }^{1}$ It was more than ever important for her to maintain her ascendancy at Constantinople. Originally an outcome of her rivalry with the Habsburgs, that ascendaney now involved her in prolonged antagonism to the ambitions of Russia. It was to France, then, that Turkey naturally looked for guidance and support, as did Poland and Sweden.

Between England and Russia there had as yet arisen no occasion of conflict, but England, if a friend, was a distant one. Prussia had hardly as yet attained the position of a second-class Power, though she was on the eve of attaining something more; Austria, therefore, was the only great Power upon whose friendship Russia, in pursuit of her Near Eastern policy, could at all confidently rely. The Habsburgs had been fighting the Turks for two centuries; the centre of gravity of their political system was still in Viemna ; the ideas of Pan-Slavism and Pan-Germanism were yet unborn; the conflict between them was still in the distant future. To Austria, therefore, Russia now turned, and, in 1726, concluded with her a close alliance which, with occasional and brief interruptions, endured for more than a century, and proved of incomparable advantage to Russia.

Russo'T'urkish War $(1736-9)$.

Ten years later the long period of patient preparation, military and diplomatic, came to an end, and Russia plunged into war with Turkey. The trouble began, as it so often did, in Poland. In 1732 France offered her friendship to Russia on condition that the latter would support the candidature

1 Not that France refrained from war. Far otherwise. But (i) the energies of France were largely divertel to India and North America; and (ii) her arms were by no means so potent as under Louis XIV. 
of Stanislaus Leczynski, the father-in-law of Louis XV. Osterman, the brilliant minister of the T'sarina Anne, declined the offer, and agreed to support the Saxon candidate, who afterwards became king as Augustus III. France then turned to Turkey, and reminded the Porte that it was by treaty bound to safeguard the independence of Poland, now menaced by the interference of Russia and Austria. The socalled War of the Polish Succession broke out in 1733. Two years later Russia declared war upon the Porte, and, in 1736, Azov was recaptured; the whole of the Crimea was overrun by Russian troops, and Bagchaserai, the capital of the Tartar khan of the Crimea, was destroyed. The Russian triumph was complete, but it was purchased at enormous cost. Austria then offered her mediation, and Russia agreed to accept it-on terms. She demanded, as the price of peace, the whole of the territory encircling the Black Sea between the Caucasus and the Danube; she required the Porte to acknowledge the independence of the frontier provinces of Moldavia and Wallachia under the suzerainty and protection of Russia; and she insisted that Russian ships should be free to narigate the Black Sea and to pass into and from the Mediterranean through the narrow straits. Austria's disinterested friendship was to be rewarded by the acquisition of Novi-Bazar and a further slice of Wallachia.

The Porte naturally refused these exorbitant demands, and Austria consequently marehed an army into Serbia and captured Nish. Encouraged by the Marquis de Villeneuve, the French ambassador at Constantinople, the Turks then took the offensire, marched down the Morava valley, eaptured Orsova, and besieged Belgrade. Ontside Belgrade Villeneure himself joined them, promptly opened direct negotiations with the Austrian general, Neipperg, and on September 1, 1739, the Treaty of Belgrade was signed.

Austria agreed to abandon all the acquisitions which had the been secured to her in the last war by the brilliant strategy 'Treaty of of Prince Eugène of Savoy. She restored Belgrade and (1739). Orsova and Sabacz to the Porte, and evacuated Serbia and Little Wallachia.

The news of the signature of this astonishing treaty came 
as a bitter surprise to Marshal Muinnich, the commander of the Russian forces. The Russian part in the campaign had been as successful as that of Austria had been the reverse. The Russians had captured the great fortress of Oczakov in 1738, that of Choczim, on the Dniester, in 1739, and ten days after Austria had signed a separate peace at Belgrade they crossed the Pruth and entered the Moldavian capital. But, deserted by their ally, they had no option but to conclude a peace on the best terms they could. They recovered Azov, but only on condition that the fortifications were destroyed, and that the district immediately surrounding it should be cleared of all works ; they were to be allowed to trade on the Sea of Azov and the Black Sea, provided, however, that all their goods were carried in Turkish vessels.

The Treaties of Belgrade were a grievous disappointment to the Russians, a humiliation for Austria, a notable success for the Turks, but, above all, a brilliant triumph for the diplomacy of France. French historians may well exalt the skill of the Marquis de Villeneuve. It cannot be denied. They may well derive legitimate satisfaction from the testimony afforded by these treaties to the prestige of France, and to her controlling influence upon the politics of the Near East. But these things are insufficient, by themselves, to account for the astonishing surrender of Austria. The explanation is to be found in the consuming anxiety of the Emperor Charles VI, now nearing his end, to secure for his daughter, Maria Theresia, the succession to the hereditary dominions of his house, and for her husband the crown of the Holy Roman Empire. But whatever the explanation may be, the fact remains that the intervention of France had obtained for the Ottoman Empire a respite on the side of Russia, and a signal revenge upon Austria.

France and the Near East.
Cardinal Alberoni might mitigate the tedium of political exile by drafting schemes for the partition of the Ottoman Empire. But Montesquieu diagnosed the situation with a shrewder eye: 'L'Empire des Turcs est à présent à peu près dans le même degré de foiblesse où étoit autrement celui des Grecs ; mais il subsistera longtemps. Car si quelque prince que ce fût mettoit cet empire en péril en pour- 
suivant ses conquêtes les trois puissances commerçantes de l'Europe comnoissent trop leur affaires pour n'en pas prendre la défense sur-le-champ.' ${ }^{1}$ As regards England, Montesquien, writing in 1734, was considerably ahead of his time; bot his words made an obvious impression upon the younger Pitt, who referred to them in the House of Commons, when, in 1791, he vainly attempted to excite alarm on the subject of Russia's progress in South-Eastern Europe. There was no need to excite it among French statesmen. Jealousy of Russia's influence in the Near East had long since become one of the fixed motives of French diplomacy. France was definitely committed to the defence of the integrity and independence of the Ottoman Empire many years before that famous phrase had ever been heard in England.

Nor are the reasons far to seek. Apart from the secular rivalry between France and the Habsburgs; apart from all questions of balance of power, France was vitally interested, from commercial considerations, in the Near East. French trade with the Levant was, for those times, on a most imposing scale. 'En matière de commerce,' as a French historian has put it, 'l'Orient nous rendait tous les services d'ume vaste et florissante colonie.' 2 The Capitulations originally conceded to France by Suleiman in $1535^{3}$ had been rencwed in 1581,1597 , and 1604 .

It was natural after the signal service rendered by Vil- The leneuve to the Ottoman Empire that the Capitulations Capitulashould have been re-enacted with special formality and par- 1740 . ticularity, and should have been extended in several important directions. Extraordinary and exclusive privileges were, in 1740, conferred upon French traders in the Ottoman dominions, and special rights were granted to Latin monks in the Holy Land, to French pilgrims, and in general to Roman Catholics throughout the Turkish Empire." It was to these Capitulations that Napoleon III appealed when, on

1 Grandeur et Décadence des Romains, chap. 23.

2 M. Vundal, ap. Histoire Générale, vii. 145.

3 See supra, p. 83.

4 The text will be found in Allin, Les Grands Traités politiques, pp. 128 sqq. 
the eve of the Crimean War, he attempted to reinstate Latin monks in the guardianship of the Holy places in Palestine.

\section{§2. From the Treaty of Belgrade to the Treaty of Kutschuk-KainardJi, 1739-74}

Interlude To France, then, the Ottoman Empire owed the new lease (1739-68). of life which it obtained in 1739. The actual duration of the lease was about thirty years, and it was the action of France which at the close of that period determined it.

European During the interval the Porte was relieved of all pressure Wars
$(1740-63)$, on the side either of Russia or of Austria-Hungary. Like the rest of the Great Powers they were preoccupied with other matters. Between 1740 and 1763 two great questions were in the balance: first, whether Anstria or Prussia was to be the dominant power in Germany; secondly, whether France or England was to be supreme in India and North America.

The death of Frederick William I of Prussia in May, 1740, followed in October by that of the Emperor Charles VI, opened a new chapter in German history-a chapter that was not finally closed until, in 1866, on the fateful field of Königgrätz (Sadowa), the question of German hegemony was set at rest for erer. Almost simultaneously there opened in India and in America, between England and France, or rather, between England and the French and Spanish Bourbons, the war which was destined to determine the future of a great part of the world. Hardly was Frederick the Great seated on the Prussian throne when he snatched the Silesian duchies ont of tle hands of Maria Theresia. Great Britain supported Maria Theresia ; France was on the side of Frederick. The Peace of Aix-la-Chapelle (1748) left Frederick in possession of Silesia, while France and England restored the conquests they had respectively made in India and North America.

Between the conclusion of the so-called War of the Austrian Succession in 1748 and the renewal of war in 1756 there was a curious reversal of alliances. The rivalry of Austria and Prussia on the one hand, and of France and England on the 
other, remained unchanged and unabated. But Frederick reluctantly joined England on the question of the neutralizaltion of Hanover, and thus France was compelled to accept the proffered friendship of Austria. The detachment of France from Prussia was a conspicuous triumpl for the diplomacy of the Austrian minister, Kaunitz; the wisdom of the change from the French point of view is much more questionable. It might have been argued that, on a long view, it could not be to the interest of France to contribute towards the aggrandizement of the Hohenzollerm. But such an argument would, in 1756, have implied unusual prescience. The point which impressed itself upon contemporaries was that France surrendered in an instant the influence which for two hundred years she had exercised in Poland and at Constantinople. For friendship with Austria involred alliance with Russia.

The significance of this fact, obrious enough during the The Seven Years' War, became much more startlingly apparent, Polish when, after 1763, the attention of the Eastern Powers was concentrated upon Poland. In 1762 one of the ablest rulers that ever sat upon a European throne succeeded to that of Russia. Catherine II did not lose a moment in picking up the threads of the ambitious foreign policy initiated by Peter the Great.

Marshal Muinnich, the hero of the last Turkish War, used Policy of all his influence with the young Tsarina to induce her Catherine promptly to espouse the cause of the Greeks and Slars in the Ottoman Empire. In the war of 1736 Miinnich had assured the Tsarina Anne that Greeks, Slars, and Roumanians alike looked to her not only as their protectress but as their legitimate sovereign; he had begged to be allowed to take advantage of their enthusiasm for the Russian cause, and to carry the war to the gates of Constantinople. The signature of the Treaty of Belgrade had for the moment interrupted his plans, but he now urged the same policy upon Catherine II.

No scheme of foreign policy was too grandiose to command the assent of the Tsarina, but she thought it prudent to secure at least one trustworthy ally. France had been 
compelled, by her alliance with Austria, to surrender her interests at Warsaw and Constantinople. But the divergenee from the traditional path of French policy was only temporary; France, therefore, had to be reckoned as an opponent. Great Britain, though friendly enough to Russia, had already acquired the reputation of fickleness in diplomacy, and Catherine preferred a power whose interests were more definitely eompatible, if not identical, with her own. That could not be said of Austria, and Catherine, therefore, turned to Frederick of Prussia.

The accession of the Tsar Peter III in 1762 had saved Frederick II at the most critical moment of the Seven Year's' War, and, indeed, of his whole eareer. Catherine II was not at all unwilling to trade upon the good will acquired by her unfortmate husband. Prussia had no interests which could by any possibility conflict with her own in the Balkan peninsula, and their interests in Poland were, up to a point, identical.

Russo- Augustus III, the Saxon King of Poland, died on October 5, intrigues 1763 , and it became immediately necessary to look out for in'Poland a successor. A group of Polish patriots, led by the Czartoryskis, were anxious to seize the opportmity of effecting a radical reform of 'the most miserable eonstitution that ever enfeebled and demoralized a nation'. In particular they desired to make the crown hereditary, and to abolish the ridiculous privilege-the liberum veto-which permitted any single noble to veto legislation and obstruct reform. But the last thing desired either by Frederick or by Catherine was a reform of the Polish Constitution. They accordingly intervened to perpetuate the prevailing anarchy, and in April, 1764, agreed to procure the election to the Polish throne of Stanislas Poniatowski, a Polish nobleman of blemished reputation and irresolute character, and one of the discarded lovers of the Russian Empress. Stanislas was duly seated on the throne, and in 1768 a Diet, elected under the influence of a Russian army of occupation, declared the liberum reto and other intolerable abuses to be integral, essential, and irrevocable parts of the Polish Constitution, and placed that Constitution under the guarantee of Russia. 
The Polish patriots made one more effort to escape from the toils of their ambitions neighbours, and formed the Confederation of Bar. The object of the Confederation was to put an end to Russian domination and to restore the supremacy of Roman Catholicism. Austria and France cordially supported the patriots. France, indeed, would gladly have done more, but erippled, both in a military and in a financial sense, by the prolonged and unsuccessful war with England, she was compelled to rely entirely upon diplomatic methods.

Choiseul had returned to power in 1766 eager for revenge Turkey upon England. $\Lambda$ s a preliminary to that revenge France and must, however, recover her position upon the Continent, and for that purpose Choisenl tried to cement the recent alliance with Austria, and to renew the ancient ties of France with Sweden, Poland, and, above all, with the Ottoman Empire. 'To Vergemes, the French ambassador at Constantinople, he wrote: "We must at all costs break the chain fastened upon the world by Russia. ... The Ottoman Empire is the best instrument for doing it, and most interested in the success of the operation. True, the Turks are hopelessly degenerate, and the attempt will probably be fatal to them, but that does not concern us so long as we attain our objects.'

The immediate objects of French diplomacy were to rescue Poland from the grip of Catherine II and Frederick II, and to arrest the progress of Russian propaganda in the Balkans.

Catherine's pact with the King of Prussia (1764) had pro- Russia vided for common action at Constantinople with a view to ${ }_{\text {'Turkey. }}^{\text {and }}$ averting Turkish intervention in Poland. The simplest way to effect this end was to keep the Turks busy at home. Accordingly, thronghout the year's $1765-7$, Russian agents were constantly at work in Greece, Crete, Bosnia, and Montenegro. Both Greeks and Slavs were led to believe that the day of their deliverance was at hand ; that the ancient prophecy that 'the Turkish Empire would one day be destroyed by a fair-haired people' was at last about to be fulfilled. Vergemnes, on his part, lost no opportunity of emphasizing the significance of the ferment among the subject peoples, and of urging upon the Porte the necessity of a counter-attack. 
Turkey declares war on Russia (1768).

A pretext was found in the violation of Turkish territory by Russian troops who had pursued some fugitive Poles into Tartary. Accordingly, in 1768, the Porte demanded that the Russian troops should immediately evacuate Poland. Russia hesitated to comply; the Porte declared war (October 6), and, on the advice of Vergennes, issued a manifesto to the Powers. The Sultan, so it ran, had been compelled to take up arms against Russia in defence of the liberties of Poland, grievously compromised by the recent action of the Empress Catherine: 'she had forced upon the Poles a king who was neither of royal blood nor the elect of the people; she had put to the sword all who had opposed her will and had pillaged and laid waste their possessions.' Turkey, in fact, stood forth as the guardian of international morality and the champion of small nationalities.

'War', wrote Vergennes, 'is declared. I have done my master's bidding. I return the three millions furnished to me for my work. There was no need of the money.' 1 Thus, as Sorel pithily puts it: 'La France essaya de soutenir les confédérés catholiques arec les armes des Musulmans.'

Catherine The methods employed by France did not save Poland, II and and they brought destruction upon Turkey. The Turkish Frederick attack upon Russia served only to precipitate the partition of Poland. Catherine would much have preferred the maintenance of the status quo in Poland. Attacked on the flank by Turkey she was the more disposed to listen to the voice of the Prussian tempter. Frederick was profoundly impressed by the rapid development of Russia, and he dreaded in particular a renewal of that alliance between Russia, Austria, and France, which had so nearly proved fatal to Prussia in the Seven Year's' War. How was he to retain the friendship of Russia ; to remove from Austria the temptation to fling herself into the arms of either Russia or of France, and at the same time avert the threatened amnihilation of the Ottoman Empire? Of these objects the last was not the least important in Frederick's eyes. It was, in his riew, entirely opposed to the interests of Prussia that Turkey

1 Sorel, La Question dOrient au diă-huitième Sicle, chap. ii. 
should be wiped out of the map of Europe, for circumstances might well render her a valuable counterjoise against the designs either of Russia or of Austria. ${ }^{1}$ The problem was by no means simple, but the solution of it was found, for the time being, in the partition of Poland.

Early in 1769 that partition was informally suggested by Frederick to his ally at St. Petersburg. Almost simultaneously, Austria, alarmed by the outbreak of war between Russia and Turkey on her immediate frontier, deemed it prudent to reoccupy the county of Zips which had been mortgaged by Hungary to Poland in 1412. Maria Theresia was probably perfectly sincere when, two years later, she protested unalterable friendship for Poland, and repudiated the idea of partition. Nevertheless, the seizure of Zips had its place in the coil which was winding itself round the devoted kingdom. In 1772 the first partition was accomplished, and Maria Theresa accepted her share of the spoil.

Meanwhile, things were going badly for the Turks. In Russo1769 a Turkish army was surprised on the Dniester, and fled Turkish in panic before the Russians, who then oceupied Jassy and (1769-74) Bucharest.

In 1770, Catherine II, relying upon the reports of discon- Russia tent among the subject populations in the Balkans, and and particularly among the Greeks, made a determined effort to rouse them to insurrection against the Sultan. A Russian fleet, under the command of Admiral Elphinstone, formerly in the English serrice, issued from the Baltic and made its way round to the Mediterranean. Choiseul wished to arrest its progress, and in no other way could France have rendered so signal a service to her Turkish allies. But England firmly intimated to both France and Spain that any attempt to arrest the progress of the Russian fleet would be regarded as a casus belli, and it was permitted, therefore, to go on its way unmolested.

In the Mediterranean, Alexis Orloff, one of the murderers of Peter III, assumed the supreme command, and made a descent upon the coasts of the Morea. Great excitement was

1 Frederick II Mémoires, vi, p. 25, ap. Sorel, op. cit., p. 49. 
aroused among the Greeks in the Morea, and it extended to the Serbs and even to the Rommanians. The hour of their deliverance appeared to be at hand. But the Russian scheme miscarried. Orloff, with a small force, attacked Tripolitza, but was badly supported by the Greeks, and fell back before the Turks. The latter exacted a terrible vengeance from the unhappy Greeks, both in the Morea and in the islands of the Arehipelago, and the Greeks, disillusioned and disappointed, cursed the fickle allies who had first roused them to rebellion and had then abandoned them to their fate.

Naval Meanwhile Orloff, aided by some luck and still more by the victory of English officers under his command, won a notable success at sea. He attacked the Turkish fleet near Chios, inflicted heavy losses upon them, and eompelled them to take refuge in the harbour of Tchesmé. Elphinstone then suggested a brilliant manoeure. The whole Turkish fleet, cooped up in harbour, was destroyed by a fireship, almost without another shot. Elphinstone was anxious to follow up the victory by an immediate attack upon Constantinople; but Orloff delayed, and though the English admiral took a few ships with him to the Dardanelles, no decisive operations could be attempted. Constantinople was quickly put in a posture of defence, and Orloff contented himself with the seizure of some of the islands in the Levant. But although the greater prize was denied to the English admiral, the appearance of a Russian fleet in the Mediterranean and the damage inflicted upon the Turkish navy created an immense sensation not merely in the Ottoman Empire but throughout the world. It seemed to presage the final overthrow of the power of the Turks.

Russian Nor were the disaster's at sea redeemed by success on land. victories on land.

The Crimea was conquered by Russia ; the Turkish fortresses on the Dniester and the Danube fell one after another before the Russian assault; and before the end of 1771 Catherine was in undisputed occupation of Moldavia and Wallachia.

Austrian Meanwhile Austria, serionsly alarmed by the rapid success interven- of Russia, had, on July 6, 1771, signed a secret treaty with
tion. Turkey. If the Russians crossed the Damube Austria under- 
took to mareh an army to the assistance of the Sultan. An intimation to this effect was sent to St. Petersburg and Berlin. Frederick was gravely perturbed by the news. In two interviews with Joseph II in 1769 and 1770 at Neisse and Neustadt respectively he had brought the emperor orer to his views on the Polish question. The whole seheme would be ruined if war were now to break out between Russia and Austria. But the partition itself, if promptly effected, seemed to offer a way out of the Balkan difficulty. Negotiations were hastily resumed, and in 1772 the partition was finally agreed upon. Catherine consented to surrender. her conquests on the Pruth and the Danube in return for a large slice of Poland: Turkey was saved from disruption, and war between Russia and Austria was arerted.

The Russo-Turkish War still dragged on, but although Catherine continued to win victories in the field, she was disposed towards peace by the outbreak of a formidable insurrection among the Cossacks of the Don, and in July, 1774, the Treaty of Kutschuk-Kainardji was signed. ${ }^{1}$

Of the many treaties concluded during the last two cen- Treaty of turies between Russia and Turkey this is the most funda- Kutmental and the most far-reaching. A distinguished jurist Kainardji, has indeed asserted that all the great treaties exeeuted July 15 , by the two Powers during the next half century were but commentaries upon this text. Its provisions, therefore, demand close investigation. Apart from those of secondary or temporary importance three questions of pre-eminent signifieance are in rolved.

Russia restored to the Porte most of the territories she $(a)$ Terrihad recently occupied : Bessarabia, Moldaria, Wallachia, and jorial adthe islands of the Archipelago ; but only, as we shall see, on and the condition of better treatment. For herself Russia was to Black Sea. retain Azor, Jenikale, and Kertsch, with the districts adjacent thereto; also Kinbur'n at the mouth of the Dnieper, and, provided the assent of the Khan of Tartary could be obtained, the two Kabardas. By these aequisitions Russia obtained

1 An admirable commentary uron this most important treaty, together with the full text, will be found in Holland's Treaty Relations betreen Russia and Turkey. 
for the first time a firm grip upon the northern shore of the Black Sea; she controlled the straits between the Sea of Azov and the Black Sea; while the possession of the two Kabardas gare her a footing on the eastern shore. The Tartars to the east of the Bug were at the same time declared independent of the Porte, except in ecclesiastical matters-a further blow to the position of the Turks on the Euxine. Thus Turkish territory, instead of encircling the Black Sea, was henceforward to be bounded on the northeast by the river Bug. To develop her trade, Russia was to be allowed to establish consuls and rice-consuls wherever she might think fit; she was to have the right of free commercial navigation in the Black Sea; and the subjects of the Tsarina were to be allowed to trade in the Ottoman dominions ' by land as well as by water and upon the Danube in their ships . . . with all the same privileges and advantages as are enjoyed by the most friendly nations whom the Sublime Porte favours most in trade, such as the French and English. Reciprocal adrantages were granted to Ottoman subjects in Russia'. (Art. xi.)

(b) Russia Not less significant was the diplomatic footing which and the Orthodox Chureh in the Ottoman Empire. Russia obtained in Constantinople. Henceforward Russia was to be represented at the Porte by a permanent Embassy ; she was to have the right to erect, in addition to her minister's private chapel, 'a public church of the Greek ritual', which was to be under the protection of the Russian minister. The Porte further agreed to permit Russian subjects, 'as well laymen as ecclesiastics', to make pilgrimages to Jerusalem and other Holy places, and the Sultan undertook 'to protect constantly the Christian religion and its churches'. The Porte also allowed 'the ministers of the imperial court of Russia to make, upon all occasions, representations as well in farour of the new church at Constantinople as on behalf of its officiating ministers, promising to take such representations into due consideration as being made by a confidential functionary of a neighbouring and sincerely friendly power'.

The clauses (Articles xii and xir) in which these terms were embodied deserve the closest scrutiny, for upon them were 
founded the claims to a formal protectorate over the Greek Christians put forward by Russia on the eve of the Crimean War. ${ }^{1}$ Lord Clarendon then declared that the interpretation which Russia sought to place upon these clauses was inadmissible. But however ambiguous, perhaps studiously ambiguous, they may have been, it cannot be denied that the provisions which defined the relations of Russia to the Greeks $^{2}$ in Turkey registered a signal triumph for Russian diplomacy. Thugut, who was then Austrian minister at Constantinople, truly described the whole treaty as 'un modèle d'habileté de la part des diplomates russes, et un rare exemple d'imbécillité de la part des négociateurs turcs '.3

In regard to the territories lately occupied by Russia and now restored to the Ottoman Empire the stipulations were Danubian even more specific. The Danubian principalities, the islands palities, of the Archipelago, and the provinces of Georgia and Mingrelia were restored only on condition of better govermment in general, and of particular privileges in regard to 'monetary taxes', to diplomatic representation, and above all to religion. The Porte (Arts. xri, xvii, and xxiii) definitely promised 'to obstruct in no manner whatsoever the free exercise of the Christian religion, and to interpose no obstacle to the erection of new Churches and to the repairing of old ones'.

From these stipulations Russian publicists hare deduced, and not unnaturally, a general right of interference in the domestic concerns of the Ottoman Empire. 'De là,' as M. Sorel says, 'pour la Russie l'obligation de s'immiscer' dans les affaires intérieures de la Turquie, chaque fois que les intérêts des chrétieus l'exige.' *

Such was the famous Treaty of Kutschuk-Kainardji: not the term but the real starting-point of Russian progress in the Near East.

The next step toward the dismemberment of the Ottoman The Empire was taken, howerer, not by Russia but by Austria.

Bukovina.

I Infra, chap. x.

2 It must not be forgotten that the term Greek at that time included all non-Mussulmans in Turkey. Creed not race was the differentia.

3 Sorel, op. cit., p. 263.

4 Op. cit., p. 262. 
The Turks, declared Kaunitz, thoroughly deserved their misfortunes, as much by their feebleness in war as by their ' lack of confidence in those Powers which, like Austria, were disposed to help them out of their difficulties'. Austria's method of doing this was characteristic. She was far from satisfied with her share, though in point of population and extent of territory it was the giant's share, in the partition of Poland. Accordingly, directly after the conclusion of the Treaty of Kainardji, she helped herself to the Bukovina; and the Turks were constrained to acquiesce. The formal treaty of cession was signed on May 7, 1775. Thus by a simple act of brigandage Austria obtained, in territory, far more than Russia had acquired by a prolonged and strenuous war: Nor did she gain only in territory. The acquisition of the Bukovina forged a fresh link in the chain of friendship between Viemna and St. Petersburg.

\section{§. Austro-Russian Alliance, 1775-92} Catherine That friendship became even more intimate after the Joseph II death, in 1780, of Maria Theresia. The Emperor Joseph II succumber entirely to the seductive and dominating personality of the Tsarina Catherine, and cordially supported her ambitious policy in the Near East.

Catherine was, in respect of that policy, in direct apostolical succession to Peter the Great. It is a suspicious fact that the Political Testament of Peter the Great was first published in Paris at the moment when Napoleon, in preparation for his expedition to Moscow, was anxious to alienate sympathy from and excite alarm against the 'colossus of the north'. 'That famous document was probably an apocryphal forgery, but there can be no question that it accurately represented the trend and tradition of Russian poliey in the eighteenth century. Constantiuople was clearly indicated as the goal of Russian ambition. The Turks were to be driven out of Europe by the help of Anstria; a good understanding was to be maintained with England ; and every effort was to be made to accelcrate the dissolution of Persia and to secure the Indian trade. Whether inherited or 
original these were the principles which for nearly forty years inspired the policy of Peter the Great's most brilliant successor on the Russian throne.

To the realization of Catherine's dreams one thing was Russoindispensable-the cordial support of the Habsburg emperor. Alliance. One or two personal interviews sufliced to secure it, and in June, 1781, an agreenicnt between the two sorereigns was embodied in private correspondence. $A$ technical question of precedence alone prevented a more formal engagement. Catherine and Joseph were thus mutually pledged to support each other in the Near East.

In September, 1782, the Tsarina laid before her ally a Cathespecific plan for the complete reconstruction of the map of rine's the Balkan peninsula, and the lands, seas, and islands adjacent thereto.

The governing presupposition of the whole scheme was the expulsion of the Ottoman Turks from all their European territories. Once the Turks were expelled, partition would not be difficult. The direct acquisitions of Russia were conceived on a moderate scale: she was to get only Oezakor and the territory, known as Lesser Tartary, which lay between the Bug and the Dniester, with the addition of a conple of the Aegean islands to be ntilized as naral bases. Moldaria, including Bessarabia, and Wallachia were to be erected into the independent kingdom of Dacia, and a crown was in this way to be provided for Catherine's favourite and minister, Potemkin. Austria's share of the spoil was to consist of Serbia, Bosnia, Herzegovina, and Dalmatia, while Venice was to be compensated for the loss of Dalmatia by the acquisition of the Morea, Cyprus, and Crete. Catherine did not apparently apprehend any opposition except from France, and that was to be averted by a timely offer of Egypt and Syria. The crowning feature of this wonderfully comprehensive scheme remains to be disclosed. The Greek Empire, with Constantinople itself, Thrace, Macedonia, Bulgaria, northen Greece, and Albania was to be reserved for Catherine's second grandson. The boy, with sagacious prescience, had been christened Constantine; he was always dressed in the Greek mode, surrounded by Greek nurses, and instructed in the tongue of his 
future subjects. That no detail might be lacking which foresight conld devise, a medal had already been struck, on one side of which was a representation of the young prince's head, and on the other an allegorical device indicating the coming triumpl of the Cross over the Crescent. Against the possible union of the Greek and Russian Empires the Tsarina was prepared to offer ample guarantees.

Catherine's proposals were not entirely to Joseph's liking. To a modern critic the most curious and significant feature of the scheme is the total lack of any recognition of the nationality principle; the complete absence of any consideration for the likes and dislikes, the affinities and repulsions, of the peoples immediately concerned. That was, however, the way of the eighteenth century, and no criticism on that score was to be expected from the Habsburg emperor. Joseph's objection was of another kind. His own share was insufficient. He wanted not only Dalmatia but Istria, not only Serbia but Little Wallachia; nor did it please him that the rest of the Danubian principalities should be torn from the Ottoman Empire only to pass into the control of Russia. But these were, relatively, details, and were not sufficient to cause a breach of the friendship existing between the angust allies.

Annexation of the Crimea,

The grandiose scheme of 1782 was not destined to realization. But in the following year Catherine resolved to put an end immediately to an embarrassing situation in the Crimea. By the Treaty of Kainardji the Porte had been deprived of its suzerainty orer the Tartars in political affairs, though the Khalifal authority of the Sultan remained inviolate. Difficulties naturally arose from this contradietory arrangement, and in 1759 a Concention explicative defined the Turkish supremacy over the Tartars as purely spiritual. This virtually meant that political supremacy was transferred to Russia, and in 1783 Catherine resolved any remaining ambiguity by annexing the khanate of the Crimea. The administration of the new Russian provinee was confided to Potemkin, and, thanks to his energy, was rapidly transformed by Russian engineers and eultivators; it began to bristle with fortresses and arsenals, and to yield a rich harrest of agricultural produce. 
In 1787 the Tsarina, accompanied by the Emperor Joseph, Cathemade a magnificent progress through her new clominions. rine's She sailed down the Dnieper to Kherson, where she passed in the under a triumphal arch bearing the inscription, 'The Way south. to Byzantium '; she had the more solid satisfaction of witnessing, in company with her ally and the ambassadors of the Great Powers, the launch of three battleships from the newly constructed dockyard; and then from Kherson she passed on to the Crimea, where she inspected Potemkin's crowning achievement, the new naval arsenal of Sevastopol. There was a touch of the theatrical, not to say the melodramatic, in the whole proceedings, but they did not lack real substance and significance.

It was not to be expected that the Porte would riew with Attitude unconcern the rapid strides which Russia was making towards of the supremacy in the Black Sea : the annexation of the Tartars; the fortification of the Crimea ; the economic derelopment of the southern provinces; above all, the striking progress of Russian sea-power. Sebastopol was within two days' sail of Constantinople; Varna, where Catherine had insisted upon establishing a consulate, was within 120 miles of it. Moreover, Russian agents had been busy of late in stirring up discontent among the Greeks, Slavs, and Roumanians; they had even extended their intrigues to Egypt. Sultan Abdul Hamid had, therefore, ample ground for disquietude.

Disquietude gave place to indignation when Catherine formulated her immediate demands. The Sultan was required to renounce his sovereignty over Georgia, to surrender Bessarabia to Russia, and to permit the establishment of hereditary governors in Moldaria and Wallachia. The cup of Abdul Hamid's anger was now full. He had already issued a manly manifesto to the true believers, calling attention to the treacherous advance of Russia, and in particular to the seizure of the Crimea in time of peace. He now demanded its immediate restoration, and followed up the demand by a declaration of war against Russia (August, 1787).

As to the wisdon of this move there are diversities of Turkey opinion among modern critics. Professor Lodge attributes and ${ }_{\text {Russia. }}$ 
the action of the Sultan to 'passion rather than policy'. Dr. Holland Rose sees in it a 'skilful move'," in view of the reasonable probability that Prussia and Sweden would come to the assistance of the Porte. Catherine herself was deeply chagrined, and attributed the bold action of the Sultan to the perfidious encouragement of Pitt. For this suspicion there was not, as we shall see, a scintilla of justification.

Interven- Faithful to his alliance Joseph II declared war against the tion of Austria.

Sultan in February, 1788, but the Austrians contributed little to the success of the campaign. Not that the Turks were making much of it. In October, 1788, Suraroff, the Russian veteran, beat off with great loss a Turkish attack on Kinburn, the fortress which confironted Oczakov and commanded the estuary of the Dnieper and the Bug. Catherine, however, was on her side compelled to withdraw a considerable portion of her forces in order to repel the advance of Gustavus III of Sweden upon St. Petersburg. The Swedish attack, like that of the Turks, was set down by Catherine to English diplomacy. 'As Mr. Pitt', said the Tsarina, 'wishes to chase me from St. Petersburg, I hope he will allow me to take refuge at Constantinople.' There is no more ground for the one insinuation than for the other. Nevertheless, it cannot be denied that from the Turkish point of view the intervention of Gustavus was exceedingly opportune. It probably saved the Ottoman Empire from immediate amihilation.

Gustarus conld not, however, secure the Turks from all damage. Before the close of the year 1788 Potemkin had made himself master of the great fortress of Oczakov and the surrounding district, and in 1789 the Austrians, after taking Belgrade and Semendria, made an incursion into Bosnia.

The

Powers and the Eastern Question.

The days were, however, drawing to a close when a war between the Ottoman Empire and its immediate neighbours could be regarded as a matter of concern only to the belligerents. It had never been so regarded by France, and the ablest ministers of the last period of the Ancien Régime, Choiseul, for example, and Vergennes, were entirely faithful to the traditions of French diplomacy in the Near East.

1 Ap. Cambridge Modern History, viii. 316.

2 Pitt and the National Revival, p. 488. 
Brandenburg-Prussia cannot be said to have had a diplomatic system before the eighteenth century, while England had so far been cmiously unconcerned as to the development of events in Eastern Europe. But the period of aequiescence was nearly at an end. A new phase of the Eastern Question was clearly opening.

The Triple Alliance concluded, in 1788, between Great The Britain, Prussia, and the United Provinces was not concerned 'Triple primarily with the affairs of the Near East. But among its objects was that of holding in check the ambitious designs of Russia and Austria in that direction. Prussia, in particular, was anxious to use the machinery of the alliance for sustaining the resistance of the Turks to the aggressions of their neighbour's. Not that Prussia's policy in the matter was free from ambiguity and vacillation. In May, 1789, the Prussian minister, Herzberg, propounded an ambitious project by which Prussia was to secure her heart's desire, Dauzig and Thorn. Poland was to be compensated by the recovery of Galicia from Austria, while the latter was to be permitted to add Moldavia and Wallachia to Transylvania and the Bukovina.

Pitt, however, had not formed the Triple Alliance to further England the ambitions of Prussia, but to save Belgium from France, $\frac{\text { and the }}{\text { Eastern }}$ and above all to preserve the peace of Europe. He frowned, Question. therefore, upon proposals which were likely to provoke a general European war. He willingly combined with Prussia in bringing effective pressure to bear upon Denmark, when the latter, at the bidding of the Tsarina Catherine, attacked Gustavus III of Sweden. But only very gradually and reluctantly was he driven to the conriction that it was incumbent upon Great Britain to offer more direct resistance to the adrance of Russia in South-Eastern Europe.

Hitherto England had not manifested any jealonsy towards England the remarkable progress of Russia. On the contrary, she had Russia. welcomed Russia's advent into the European polity : politically, as a possible counterpoise to the dangerous pre-eminence of France; commercially, as an exporter of the raw materials required for naval construction, and as a considerable importer of English goods, and of 'colonial produce' carried to her 
ports in English bottoms. The elder Pitt was a strong advocate of a Russian alliance. 'I am quite a Russ,' he wrote to Sherburne in 1773 ; 'I trust the Ottoman will pull down the House of Bourbon in his fall.' In regard to Russia Fox inherited the views of Chatham. He was in office when Catherine annexed the Crimea and cordially approved of it, and, like Chatham, he would gladly have formed a close alliance with Russia and the northern powers.

Pitt and The younger Pitt was the first English statesman to the

Eastern appreciate the real and intimate concern of Great Britain Question. in the affairs of the Near East, and to perceive that those interests might be jeopardized by the dissolntion of the Ottoman Empire, and the access of Russia to Constantinople. And the truth, as we have seen, dawned only gradually upon him. So late as 1790 he warned Herzberg that the armed mediation which Prussia proposed in the interests of the Porte was outside the scope of the Triple Alliance. ${ }^{1}$ He did, however, go so far as to press Austria to come to terms with the Porte and so avoid the threatened rupture with Prussia.

Close of Meanwhile, a combination of events disposed the bellithe war. gerents to peace. In April, 1789, Abdul Hamid I died, and was succeeded by Selim III, a ruler who was as feeble and reactionary as Abdul Hamid had been vigorous and enlightened. The death of the Emperor Joseph (February 28, 1790) and the accession of his sagacious brother, Leopold, gave a new turn to Austrian policy. Above all, the development of the revolutionary movement in France was compelling the strained attention of every monarch and every government in Europe. In face of this new source of disturbance the emperor and the King of Prussia accommodated their differences, and in June, 1790, concluded the Convention of Reichenbach. Prussia surrendered, for the moment, the hope of acquiring Danzig and Thorn. Leopold agreed to make peace with the Turks on the basis of the stutus quo conte.

England Pitt now assumed a firmer tone towards Catherine II. In and Russia. November, 1790, he demanded that she should surrender

$$
1 \text { Rose, op. cit., p. } 521 .
$$


Oczakov, and in the following March the Cabinet agreed that an ultimatum should be dispatched to Russia in that sense. But subsequent debates, both in the House of Lords and in the Commons, showed that public opinion, as represented there, was not yet prepared for a reversal of the traditional policy which had hitherto governed the relations of Russia and England. On March 28 the king sent a message to both Houses recommending 'some further' augmentation of his naval force' in riew of the failure of his ministers to 'effect a pacification betw'een Russia and the Porte'. The ministers carried their reply in the Lords by 97 to 34 , and in the Commons by 228 to 135 . But although the ministerial majorities were substantial, the rotes did not reflect either the temper of Parliament or the tone of the debate. Hardly a roice was raised in either House in farour of Pitt's proposed demonstration. Lord Fitzwilliam opposed it on the ground that 'no ill consequence was likely to arise from Russia's keeping in her hands Oczakov and Akerman'. Burke rehemently protested against a demonstration of friendship or support for 'a eruel and wasteful Empire' and a nation of 'destruetive sarages'. Fox insisted that Russia was our 'natural ally', that we had always looked to her to counterbalanee the Bourbons, that we had encouraged her 'plans for raising her aggrandisement upon the ruins of the Turkish Empire', that to oppose her progress in the Black Sea would be sheer madness, and that it would not hurt us if she emerged into the Mediterranean. Pitt urged that 'the interest which this eountry had in not suffering the Russians to make eonquests on the coasts of the Black Sea were of the utmost importance', but his reply as a whole was singularly uneonvincing and even perfunctory. In regard to the proposed armament Pitt wisely deferred to an umistakable expression of public opinion, and promptly

1 Hansard, Parliamentury History (rol. xxix), for the debates which are supremely interesting in riew of the subsequent policy of England. It is noteworthy that Pitt's speech on this occasion is not included in Hathawar's edition of his speeches, and from the eritical point of view Hathaway was right. It is less remarkable that it should have been omitted from Mr. Coupland's reeent edition of the Irar speeches. 
effected a somewhat humiliating but exceedingly prudent retreat. Catherine II had her way about Oczakov, without molestation from the English fleet. But it is pertinent to remark that though Oczakov is now merely an historical memory, Odessa is not.

Treaties of Sistova and Jassy.

In August, 1791, Austria concluded peace with the Porte at Sistova. Serbia was handed back to Turkey, and the status quo ante was restored. On Jammary 9, 1792, a ' treaty of perpetual peace' was signed by Russia and Turkey at Jassy. The Treaty of Kainardji, the Convention Explieative of 1779 , and the Commercial Treaty of 1783 were confirmed; the Porte recovered Moldavia, but again on condition that the stipulations contained in the preceding treaties were fulfilled ; the Russian frontier was advanced to the Dniester (Oczakor being thus transferred), and the Porte agreed to recognize the amnexation of the Crimea.

The close The Treaty of Jassy brings to a close one of the most chapter. important phases in the history of the Eastern Question, and one of the lengthicst chapters in this book. When it opened Russia had hardly begun to play a part as a European Power; the Black Sea was a Turkish lake. As it closes, Russia is firmly entrenched upon the shores of the Euxine, and is already looking beyond them. Kherson and Sebastopol have been transformed into great naval arsenals ; Kinburn and Oczakov, not to mention Taganrog, Azov, and the Kabardas, are secure in Russian keeping. To the north of the Euxine Turkish territory ends at the Dniester, and the border provinces between the Dniester and the Damube are retained only on sufferance. Upon the lands to the south of the Euxine the Turkish hold is already loosening. 'I came to Russia', said Catherine, 'a poor' girl ; Russia has dowered me richly, but I have paid her back with Azov, the Crimea, and the Ukraine.' Proudly spoken, it was less than the truth.

For further reference see chapter iii and Appendix B; also Serge Goriainow, Le Bosphore et les Dardanelles (a valuable study in diplomacy with close reference to the documents); Cardinal Alberoni, Scheme for reducing the Trurkish Empire (Eng. trans. 1736); A. Sorel, La Question dOrient au XVIII siccle; T. E. Holland, Treaty Relations of Russia and Turkey (with texts of important treaties); W. E. H. Lecky, History of 
England in the Eighteenth Century; J. Holland Rose, Pitt and the National Revival; Paganel, Histoire de Joseph II; J. F. Bright, Joseph II; Vandal, Lonis XV et Elisabeth de Russie, Une ambassade frangaise en orient, La mission de Villeneuve: R. Waliszewski, Le roman d'une imperatrice (Catherine II); A. Rambaud, Histor?l of Russia. 


\section{CHAPTER VII}

\section{NAPOLEON AND THE NEAR EASTERN PROBLEM}

'Tieally to ruin England we must make ourselves masters of Egypt.'NApoleon to the Directory, Aug. 16, 1797.

'Egypt is the keystone of English ascendancy in the Indian Ocean.'Paul Rohrbach (1912).

'Le personnage de Napoléon, en Orient comme ailleurs, domine les premières années dn XIX ${ }^{\text {e }}$ siècle ... certes il serait excessif d'affirmer que la question d'Orient fût le noend de sa politique ... mais c'est précisément par l'Orient qu'il pensa atteindre son inabordable ennemie, et, par snite, il ne le quitta jamais des yeux; il y édifia ses combinaisons politiques les plus aventureuses sans doute, mais anssi les plus géniales. Il y porta ses vues dès ses premières victoires en Italie; il y poursuivit les Anglais à travers l'ancien continent; il y brisa sa fortune. C'est en ce sens qu'il put concevoir un moment l'idée de la domination universelle; c'est bien à Constantinople qu'il plaça le centre du monde.'-Édouard Driault, Question dorient.

\section{§1. WeST AND EAST, 1797-1807}

The The Treaty of Jassy closed one important chapter in the advent of history of the Eastern Question. The next opens with Napoleon. the advent of Napoleon. By the year 1797 he had begun to arrive not only in a military but in a political sense. During the five years which elapsed between the Treaty of Jassy (1792) and that of Campo Formio the Eastern Question, as in this work we understand the term, was permitted to rest. This brief interval of repose was due to several canses, but chicfly to the fact that the year which saw the conclusion of the war between Russia and Turkey witnessed the opening of the struggle between the German Powers and the French Revolution.

The

Frencli

Rerollttion and the Partitions of Poland.

Catherine's ambition in regard to Poland had been whetted rather than sated by the partition of 1772. But between 1772 and 1792 she was, as we have seen, busy elsewhere. Poland seized the opportunity to put what remained of its house in order-the last thing desired by Catherine. But in 1792 her chance came. She had been 'cudgelling her' 
brains to urge the Courts of Vienna and Berlin to busy themselves with the affairs of France' so that she might have 'her own elbows free'. The German Courts played her game for her, and by the summer of 1792 her elbows were free. In 1793 the second partition of Poland was carried ont. Prussia and Russia divided the spoil; Austria got nothing. But in the third and final partition of 1795 Austria was admitted to a share. In the same year Prussia concluded peace with France at the expense of the empire; two years later Austria followed suit.

Prussia had made her peace with the Directory. With Austria the peace was negotiated directly by the young general who had commanded the French army in the great campaign of 1796-7. And General Bonaparte had already begm to comport himself as an independent conqueror. 'Do you suppose', said he to Miot de Mélito, 'that I have been wimning victories in Italy to enhance the glory of the lawyers of the Directory--Barras and Carnot? Do you suppose that I mean to establish the Republic more securely? . . The nation wants a chief, a supreme head covered with glory.' In Bonaparte's view they had not very far to look for him. Nor was the chief in any doubt as to his real antagonist. From the outset his eyes were fixed upon England, and upon England not merely or mainly as a unit in the European polity, but as a world-power, and above all as an Oriental power.

Before the Treaty of Campo Formio was actually signed The Bonaparte had written to the Directors (August 16, 1797): Ionian 'Corfu, Zante, and Cephalonia are of more interest to us than all Italy.' 'Corfu and Zante', he said to Talleyrand, ' make us masters both of the Adriatic and of the Lerant. It is useless to try to maintain the Turkish Empire; we shall see its downfall in our lifetime. The occupation of the Ionian Isles will put us in a position to support it or to secure a share of it for ourselves.' Amid the much more resounding adrantages secured to France in 1797-Belgium, the Rhine frontier, and so on-little significance was attached to the acquisition of these islands. But Bonaparte was looking ahead. To him they were all important. Might they not serve as stepping- 
stones to Egypt.' To Choiseul Egypt had seemed the obvious compensation for the loss of the French Empire in India. Napoleon regarded the occupation of the first as a necessary preliminary to the recovery of the second. Volney, whose book, Les Ruines, had a powerful influence upon him, had written in 1788, 'Par l'Égypte nous toncherons à l'Inde ; nous rétablirons l'ancienne circulation par Suez, et nous ferons déserter la route du cap de Bonne-Espérance.'

Nor was Napoleon without warrant from his nominal masters. On October 23, 1797, the Directors had indited all elaborate dispatch commending to his consideration the position of Turkey, the interests of French commerce in the Levant, and indicating the importance they attached to the Ionian Isles and Malta. ${ }^{1}$ The views of the Directors coincided with his own. It is safe to assume that if they had not done so they would not have found an agent in General Bonaparte. But alike to the Republicans and to the future emperor they came as a heritage from the Ancien Régime. French policy in the Near East has been, as we have repeatedly seen, singularly consistent. So far as Napoleon initiated a new departure, it was only in the boldness and originality with which he applied traditional principles to a new situation.

Egypt. In the summer of 1797 Napoleon had already made overtures to the Mainotes, the Greeks, and the Pashas of Janina, Scutari, and Bosnia. In regard to the Greeks of the Morea he was particularly solicitous. 'Be careful', he wrote to General Gentili, whom he sent to ocenpy the Ionian Isles, ' in issuing your proclamations to make plenty of reference to the Greeks, to Athens, and Sparta.' He himself addressed the Mainotes as 'worthy descendants of the Spartans who alone among the ancient Greeks know the secret of preserving political liberty'. But it was on Egypt that his attention was really concentrated, and on Egypt mainly as a means to the overthrow of the Empire of England. Talleyrand represented his views to the Directory: 'Our war' with this Power (England) represents the most favourable opportunity for the invasion of Egypt. Threatened by an imminent landing on

1 Sorel, L'Europe et la Fiérolution, r. 253. 
her shores she will not desert her coasts to prevent our enterprise (in Egypt). This further offers us a possible chance of driving the English out of India by sending thither 15,000 troops from Cairo ria Suez.' 1

It was, however, to the command of the Army of England The that Bonaparte was gazetted in Norember, 1797. He Army of accepted it not without an crrière-pensée. 'This little Europe', he said to Bourriemne, 'offer's too contracted a field. One must go to the East to gain power and greatness. Europe is a mere mole-hill; it is only in the East, where there are $600,000,000$ of human beings, that there have crer been rast empires and mighty rerolutions. I am willing to inspect the northern coast to see what can be done. But if, as I fear, the success of a landing in England should appear doubtful, I shall make my Army of England the Army of the East and go to Egypt.' 2

A visit to the northern coast confirmed his view that the The blow against England should be struck in Egypt. The French Egyptian navy was not in a condition to attempt direct invasion. tion Besides, he had his own career to consider. He must 'keep (1798). his glory warm', and that was not to be in Europe. He persuaded the Directors to his riews, and in April, 1798, he was nominated to the command of the army of the East. His instructions, drafted by himself, ordered him to take Malta and Egypt, ent a channel through the Isthmus of Snez, and make France mistress of the Red Sea, maintaining as far as possible good relations with the Turks and their Sultan. But the supreme object of the expedition was nerer to be lost sight of. 'You', he said to his troops as they embarked at Toulon, 'are a wing of the Army of England.'

The preparations for the expedition were made with a thoroughness which we have been too apt of late to associate with the Teutonic rather than the Latin genius. On Napoleon's staff were at least a dozen generals who subsequently attained renown; but not generals only. Egypt was to be transformed under French rule; the desert was to be made to

1 Jonquière, L'Expédition d'Égypte, i. 161 (cited by Fournier).

2 I combine two separate eowersations, both with Bourrienne, but, of course, without altering the sense and merely for the sake of brevity. 
blossom as the rose. To this end Napoleon took with him Berthollet, the great chemist, Monge, the mathematician, engineer's, architects, archaeologists, and historians.

The expedition sailed from Toulon on May 19, 1798. Nelson had been closely watehing the port, though quite ignorant of Napoleon's destination. But he was driven out to sea by a storm, and before he conld get back the bird had flown. Meanwhile, Napoleon occupied Malta without resistance from the Knights of St. John (June 13); the French troops landed in Egypt on July 1 ; took Alexandria on the 2nd, fought and won the battle of the Pyramids on the 21st, and on the next day occupied Cairo. Three weeks had sufficed for the conquest of Lower Egypt. But Nelson and the English fleet, though successfully eluded during the royage, were on Napoleon's track, and on the 1st of August they came up with the French fleet lying in Abonkir Bay, and, by a manœuvre conceived with great skill and executed with superb courage, they sneceeded in completely annihilating it. Nelson's vietory of the Nile rendered Napoleon's position in Egypt exceedingly precarious. Cut off from his base, deprived of the means of transport and supply, a lesser man would have deemed it desperate. Napoleon was only stimulated to fresh efforts.

Expedition to Syria (1799).
The attack upon Egypt was, as we have seen, directed primarily against England. But the lord of Egypt was the Sultan, and to him the French conquest was both insulting and damaging. Encouraged by Nelson's success Sultan Selim plucked up courage to declare war upon France on September 1, and prepared to reconquer his lost province. Napoleon thereupon determined to take the offensive in Syria. He took by assault El Arisch, Gaza, and Jaffa, laid siege to Acre (March, 1799), and on April 16 inflicted a crushing defeat upon the Turks at Mount Tabor.

Acre, thanks to the support of the English fleet under Sir Sydney Smith, sustained its reputation for impregnability ; the sufferings of Napoleon's army were intense ; their general, reluctantly resigning his dream of an advance through Asia Minor upon Constantinople, was compelled to withdraw to Egypt. Instead of conquering Constantinople, and from Constantinople taking his European enemies in the rear, he 
found himself obliged to defend his newly conquered province against the assault of its legitimate sovereign.

Convoyed by the English fleet a Turkish expedition reached Egypt in July, but Napoleon flung himself upon them and drove them headlong into the sea (July 25). This second battle of Aboukir firmly established Napoleon's supremacy in Egypt. But the victory, though militarily complete, was politically barren. News from France convinced Napoleon that the pear was at last ripe, and that it must be picked in Paris. Precisely a month after his victory over the Turks at Aboukir he embarked with great secrecy at Alexandria, leaving his army under the command of Kléber. The Mediterranean was carefully patrolled by the English fleet, but Napoleon managed to elude it, landed at Fréjus on October 9, and precisely a month later (18th Brumaire) effected the coup d'état which made him, at a single blow, master of France.

During Napoleon's absence in Egypt events had moved The war rapidly in Europe. Great Britain, Russia, Prussia, Naples, of the Portugal, and Turkey had united in a second coalition against Coalition France. So long as Napoleon was away the war went in the 1891 main against France, but his return was signalized by the victories of Marengo (June) and Hohenlinden (December, 1800), and early in 1801 Austria was obliged to make peace.

Napoleon had already, without much difficulty, detached Napoleon the Tsar of Russia ${ }^{1}$ from the coalition. Alienated from Eng- ${ }_{\text {Tsar }}$ land by the rigidity with which she interpreted the rules of Paul I. International Law at sea, Paul I gladly came to terms with the First Consul, for whom he had suddenly conceived a ferrent admiration. The bait dangled before the half-crazy brain of the Russian Tsar was a Franco-Russian expedition against British India. ${ }^{2}$ A large force of Cossacks and Russian regulars were to march by way of Turkestan, Khiva, and Bokhara to the Upper Indus valley, while 35,000 French troops, under Masséna, were to descend the Danube, and, going by way of the Black Sea and the Caspian, were to make

I He succeeded Catherine in 1796.

2 A Freneh historian speaks of this scheme as 'une éclatante lumière jetée sur l'avenir', Driault, op. cit., p. 78 . 
an attack on Persia, take Herat and Candahar, and then unite with the Russians on the Indus. The details of the scheme were worked out to an hour and a man; twenty days were to suffice for reaching the Black Sea; fifty-five more were to see them in Persia, and another forty-five in India. Towards the end of Jume, 1801, the joint attack would be delivered upon India. Towards the end of February, 1801, a large force of Cossacks did actually eross the Volga; but on March 24 the assassination of the Tsar Paul put an end to the scheme.

Treaty of The projected expedition into Central Asia was not without Amiens (1802). its influence upon subsequent schemes entertained by Napoleon, but it did nothing to relieve the immediate situation in Egypt. Great Britain, by the taking of Malta (September, 1800), had made herself undisputed mistress of the Mediterranean, and she had also thrown a large army, including 10,000 Sepoys, into Egypt. Sir Ralph Abercromby won a great victory at Alexandria in Mareh (1801); Cairo eapitulated in June, and in September the French agreed to evacuate Egypt, which was forthwith restored to the Sultan. There was no longer any obstacle to the conclusion of peace, and in March, 1802, the definitive treaty was signed at Amiens. England undertook to restore Malta to the Knights, and the Ionian Isles were erected into a sort of federal republic under the joint protection of Turkey and Russia.

The The truce secured to the two chief combatants by the Sebastiani Treaty of Amiens proved to be of short duration. Napoleon
Mlission. was angered, not umnaturally, by the refusal of England to evacuate Malta. England was ready to restore the island to its legitimate owners, but only when they could guarantee its security from Napoleon, against whom she had her own grievances. Among many others were the continued intrigues of Napoleon in Egypt and the Levant. In the autumn of 1802 he sent a Colonel Sebastiani on a commercial mission to the Near East. Sebastiani, who hardly disguised the political and military purpose of his journey, was, aceording to the French authorities, received with boundless enthusiasm in Tripoli, Alexandria, Cairo, and not less when he passed on to 
Acre, Smyrna, and the Ionian Isles. ${ }^{1}$ On his return to France he presented a Report, which was published in the Moniteur. Officiel for January 30, 1803. The publication gave deep, offence in England, and well it might, for it diseussed with complete frankness the military situation in the Near East; it declarerl that, in view of the hostility between the Turks and the Mamelukes and the latter's sympathy with France, 6,000 French troops would suffice for the reconquest of Egypt, and it affirmed that the Ionian Isles only awaited a farourable moment to declare for France.

Sebastiani's Report had, before publication, been largely retouched, if not fundamentally altered, by Napoleon, and was published with the express purpose of goading England into a declaration of war. It succeeded, and in May, 1803, war was declared. Russia also, alarmed by the Sebastiani Report, strengthened her garrison in Corfu. Austria, moreover, discovered that Napoleon was again intriguing in the Morea, with the Senate of the little Republic of Ragusa, and with the Bishop of Montenegro, who had consented to hand orer the Gulf of Cattaro to France.

The young Tsar Alexander, who, on the assassination of Russia his father, had succeeded to the throne in 1801, was disposed Balkans. to resort to the policy of the Empress Catherine in regard to Turkey. According to the Memories of Prince Adam Czartoryski, now Foreign Minister of Russia, 'the European territories of Turkey were to be divided into small States united among themselves into a federation, over which the Tsar would exercise a commanding influence. Should Austria's assent be necessary she was to be appeased by the acquisition of Turkish Croatia, part of Bosnia, and Wallachia, Belgrade, and Ragusa. Russia would have Moldavia, Cattaro, Corfu, and above all Constantinople and the Dardanelles.' ${ }^{2}$

Russia and Austria both joined the fresh coalition formed 'The'Third by Pitt in 1805 , but their combined armies suffered a terrible Coalition.

1 e.g. Driault, op. cit., p. 82, but contra, see Fournier (Napoleon, i. 316), who declares, on the authority of Sebastiani himself, that the French mission so far from being welcomed in Egypt had been obliged to seek shelter from the mob in Cairo.

2 Cited by Fournier, op. cit., i. 347. 
reverse at Napoleon's hands at Austerlitz (December 2, 1805), and before the close of the ycar Austria was compelled to conclude peace at Pressburg. The terms of the treaty were disastrons both to her pride and her territorial position. Napoleon took his reward in the Adriatic: Venetia, Istria (cxecpt the town of Trieste), and Dahmatia being anmexed to the new kingdom of Italy. Talleyrand shrewdly advised the emperor to compensate Austria with the I)anubian principalities and northern Bulgaria, and so interpose a stout barrier between Russia and Constantinople, and by that means turn the ambitions of Russia towards Asia, where she must needs come into collision with Great Britain. This suggestion anticipated by nearly a century the policy of Bismarck, but it is far from certain that Austria would have accepted the offer, cren could Napoleon have bcen induced to make it. ${ }^{1}$

Auster- Austerlitz put Austria ont of play for four years. But litz, Jena, Frederick William III of Prussia chose this singularly unpro'Trafalgar. pitions moment for breaking the nentrality which for ten shameful years Prussia had maintaincd. Prussia, therefore, was crushed at Jena and Auerstiidt, and Napoleon oceupied Berlin. Russia, however, still kept the field, while England had strengthened her command of the sea by the great victory off Cape Trafalgar.

The Con- Nelson's victory compelled Napoleon to play his last cardtinental the continental blockade. England was still the enemy; she
Blockade. could not be reached by an army from Boulogne; she had proved herself irresistible at sea. What remained? She must be bronght to her knees by the destruction of her commerce. To this end every nation on the European Continent must be combined into his 'system', and the whole of the coast from Archangel to the Crimea must be hermetically sealed against English shipping and English trade. Such was the meaning of the decree issned in November, 1806, by Napoleon from Berlin.

Napoleon A month later the intrigues of Napoleon at Constantinople Turks.

1 Lefebvre, Hist. des Cubinets de l'Europe, ii. 235, and Vandal Napoléon et Alexandre, i, p. 9. 
issued (December, 1806) in a declaration of war by the Porte upon England and Russia.

After the conclusion of the Treaty of Pressburg the place of the ()ttoman Empire in the general scheme of Napoleonic policy becomes increasingly apparent. The annexations in the Adriatic were an essential part of a deliberate plan. 'The object of my policy', he wrote in May, 1806, 'is a triple alliance between mysclf, the Porte, and Persia, indirectly aimed at Russia. 'The constant study of my ambassador' should be to fling defiance at Russia. We must close the Bosphorus to the Russians.' 1

The closing of the straits was, indeed, of high consequence to Napoleon's ambitions in the Adriatic, for Russia had taken advantage of her alliance with Turkey to send large Russian reinforcements to the Ionian Isles. She had also, to the indignation of the Turk and the chagrin of Napoleon, utilized the arljacent mainland of Albania as a recruiting ground for her garrison in the islands.

In the summer of 1806 Sebastiani was sent by Napoleon as Russia ambassador extraordinary to Constantinople, charged with the and the special task of effecting a breach between Turkey on the one palities. hand and Russia and Great Britain on the other. A hint of Russian intrigues in the principalities sufficed to persuade Sultan Selim, in direct violation of his treaty engagements with the Tsar, to depose the hospodars of Moldavia and Wallachia, Prince Moronzi and Prince Hypsilanti. To this insult the Tsar promptly responded by sending 35,000 men across the Pruth, and before the end of the year the Russian army was in undisputed occupation of the principalitics. The Sultan thereupon declared war on Russia. An English fleet under Admiral Duckworth then forced the Dardanelles, destroyed a Turkish squadron in the Sea of Marmora, and threatened Constantinople. The defences of the city were in a ruinons condition, and had an attack been delivered forthwith Constantinople would almost certainly have fallen. But Duckworth wasted precions months in negotiation; Constantinople was rapidly put into a state of defence by

1 'To Eugène Beanharnais, ap. Sorel, op. cit., vii. 53-t. 
French engineers; the English fleet was compelled to withdraw from the Sea of Marmora, and, after sustaining considerable losses, repassed the Dardanelles on March 3, 1807.

Napoleon To Napoleon Constantinople was not the term but the and India. starting-point of adventure. He looked beyond Constantinople to Persia, and beyond Persia to the ultimate goal of India. The destruction of British Power in the Far East was fast becoming an obsession with the emperor.

A few weeks later Admiral Fraser landed a force in Egypt and took Alexandria. But Egypt was now in the capable hands of Mehemet Ali, the Albanian adventurer, destined to play so prominent a part in later developments of the Eastern Question. The Sultan Selim had sent Mehemet Ali at the head of a force of Albanians to Egypt in order to bring back the Mamelukes to their allegiance. The latter consequently inclined towards the English invaders, but Mehemet Ali had the situation well in hand, and nothing came of Fraser's intervention.

Meanwhile, Napoleon was revolving larger schemes upon a more extended field. To him an alliance with Turkey was only a step towards Asiatic conquest. The call of the Far East was to a man of Napoleon's temperament irresistible. India, as he subsequently confessed, was now occupying more and more of his thoughts. England, as an insular State, might be impregnable, but her dominion in the Far East was continental. On the Continent there was nothing which a French army could not reach, and anything which a French army could reach it could conquer. But between Europe and India lay Persia. To Persia, therefore, he first turned lis attention.

Treaty of Ever since the Tsarina Catherine had conquered the Finkenstein, April, 1807 . Caucasus there had been intermittent war between Russia and Persia. The Shah was, therefore, only too ready to receive the adrances of Napoleon. During the year 1806 no less than three French agents were sent to Teheran. 'Persia', wrote the emperor to Sebastiani, 'must be roused, and her forces directed against Georgia. Induce the Porte to order the Pasha of Erzeroum to march against this province with all his troops.' In April, 1807, a Persian envoy met the 
emperor in Poland, and the Treaty of Finkenstein was concluded. Napoleon promised to supply guns and gunners to the Shah, and to compel Russia to evacuate Georgia. The Shah on his part was to adhere to the continental system, to break off his relations with Great Britain, confiscate all British goods, exclude British shipping from his ports, stir up the Afghans against British India, afford free passage to a French army through Persia, and himself join in the attack against British Power in Asia. ${ }^{1}$

\section{§2. The OtToman Empire and the Resurrection of Serbia}

For all these adventures, however, Constantinople was the Condition starting-point. For the moment, therefore, the stability of of the the Ottoman Empire was a matter of considerable concern Empire. to Napoleon. How far could he depend upon it?

The Sultan, Selim III (1789-1807), who, as we have seen, had come to the throne in the midst of the war with Russia and Austria, had made a real effort to carry out much needed reforms in his distracted empire. His success had not been equal to his zeal, and the situation had now become so grave that the Sultan could give little effective aid to his exacting ally. In Egypt the Mamelukes virtually repudiated the authority of their nominal sovereign, and were held in check only by the dangerous device of setting a poacher to watch the game. In Syria, Djizzar Pasha exercised his tyranny in virtual independence of the Sultan. The Wahabites had conquered the Holy cities of Mecca and Medina in 1802 and were now masters of the whole of Arabia. Nearer home, the Suliotes and other tribes in northern Greece and Epirus were bound by the loosest of ties to Constantinople; Ali, Pasha of Janina, had carved out for himself an independent chieftainship in Albania; the Montenegrins had wrung from the Sultan an acknowledgement of the independence which they had always in practice enjoyed; while on the Danube, Passwan Oglon, one of the many Bosnian nobles who had

I Fournier, op. cit., 1. 449; Driault, La Politique orientale de Napoléon (passim). 
accepted Mohammedanism, was already master of Widdin, Sofia, Nikopolis, and Plevna, and was dreaming of a revival of the Bulgarian Tsardom with Constantinople itself as his capital.

Serbia. Most threatening of all was the position of affairs in Serbia. There, as in other provinces of the empire, the central government of Constantinople had ceased long since to exercise any real control over its nominal subordinates. The government of Serbia was in the hands of the Janissaries of Belgrade, who maintained their authority alike over the Moslem Spahis, or feudal landowners, and over the native peasantry by methods of revolting cruelty and tyranny.

Among the peasantry, however, the traditions of past greatness and independence, murtured on popular ballads and encouraged by the Orthodox clergy, had somehow managed to survive through the long centuries of Ottoman oppression. The frequent change of masters, resulting from the wars of the eighteenth century, had tended to revive a spirit of hopefulness among the native Slavs. Whatever change war might bring to them could hardly be for the worse. At one time they looked with some expectation to Viema. They were now turning, less unwarrantably, to their brothers in blood and creed, who were the subjects of the Russian Tsar.

Yet, in truth; the Serbians could count upon little effective assistance from any external Power. Fortunately, perhaps, they were compelled, by their geographical situation, to rely entirely upon themselves. Cut off, first by Venice and afterwards by Austria, from access to the Adriatic, they could obtain no help from the maritime Powers. Between themselves and their potential allies in Russia there interposed the Danubian principalities. Nor had they, like the Bosnians and Roumanians, any indigenous nobility to which they could look for leadership. Salvation, therefore, must come, if at all, from the peasantry. In the wars of the eighteenth century that peasantry had learnt to fight; and when, in 1791, Serbia was restored to the Porte, the agents of the Sultan were quick to note the change in their demeanour. 'Neighbours, what have you made of our rayahs?' asked a Turkish 
Pasha of an Austrian official, when a regiment of native Serbs paraded before him. On the restoration of Turkish authority the Serbian troops were disbanded, but the lessons which the peasants had learned were not forgotten. ${ }^{1}$

The fact was proved in 1804. The Serbian rising of that Serbian year marks an epoch of incomparable significance in the Insurrechistory of the Eastern Question. For four hundred years (1804-17). the spirit of Slav nationality had been completely crushed under the heel of the Ottomans. That it had not been eradicated events were soon to prove. But its continued existence was little suspected. Still it was something that the Serbian peasants had learnt to fight. Napoleon had taught the same invaluable lesson to his Italian subjects. But the Serbians had not yet learnt to fight for an idea. The seed of the new idea came from the Revolution in France. It fell into the fertile soil of the Balkans: it fructified in the insurrection of 1804.

It is one of the paradoxes of which the recent history of the Near East is compact that this insurrection should have been directed in the first instance not against the Turkish Government, but against its rebellious servants the Janissaries of Belgrade. The tyranny of the latter was as intolerable to the Serbians as was their disloyalty to the Sultan and his officials. Selim accordingly determined to dislodge them.

Expelled from Belgrade the rebels joined forces with Passwan Oglou, and together they invaded Serbia. Responding to the appeal of the Turkish Pasha of Belgrade, the Serbians rose in defence of their country and repelled the invasion. Thereupon the Janissaries of Constantinople and the Moslem hierarchy compelled Sultan Selim to restore the Janissaries at Belgrade, and Serbia was virtually reoccupied by official Mohammedanism and given over to a reign of terror. The Sultan vainly endeavouring to restrain his agents only added fuel to the flames of vengeance by an obscure hint that unless they mended their ways 'soldiers should come among them of other nations and of another creed'. The Janissaries determined that the alien soldiers should not be Slavs.

1 Ranke, Serbia, p. 84. 
Kara To avert literal extermination the Serbs organized what George. was in truth the first national rising in the modern history of the Balkans, and elected as their Commander-in-Chief a peasant pig-merchant, George Petrovitch, or Kara (Black) George.

Kara George had served in the Serbian Volunteer Corps in the Austrian war of 1788-91, and now led the national insurrection with conspicuous courage and skill. So great was the success of the peasant army that in a very brief space of time the Janissaries were confined to Belgrade, and a few other fortresses. Unofficial Mohammedanism went to the assistanee of the Janissaries, but the Pasha of Bosnia, acting upon instructions from Constantinople, put himself at the head of the Serbian nationalists. The strange combination of official Turk and Serb peasant again proved irresistible, and in the event the power of the Janissaries was annililated.

Official Turkey had now to deal with its formidable allies. The latter refused to be disarmed, and in August, 1804, applied for help to Russia. The Tsar was sympathetic, but advised the Serbians to apply for redress, in the first instance, to their own sovereign. In 1805, accordingly, a mission was sent by the Serbians to Constantinople to demand that, in view of their recent exertions and sufferings, all arrears of tribute and taxes should be remitted, and that all the strong places in their land should be garrisoned by native troops.

Almost simultaneously the Sultan was confronted by a demand from Russia, now on the eve of war with France, that the Porte should enter into a strict offensive and defensive alliance with Russia, and that all its subjects professing the Orthodox faith should be placed under the formal protection of the Tsar.

Threatened on one side by the insurgent Janissaries, on a second by the Serbian rayahs, on a third by Russia, Sultan Selim found himself involved in the most serious crisis of a troublesome reign. He dealt with it in characteristic fashion by temporizing with the Russian envoy, while he attempted to crush the Serbians.

The Serbian nationalists, magnificently led by Kara George, 
defended themselves with energy against the Sultan's troops, and in the brilliant campaign of 1806 practically achieved their independence, without any external assistance whatsoever. At the end of the same year Turkey, as we have seen, was forced by Napoleon into war with Ruesia, and the Serbian forces united with those of Russia on the Danube ; in May, 1807, Sultan Selim was deposed by a palace revolution, and in July, 1808, both he and his successor, Mustapha IV, were killed, and there succeeded to the throne the only surviving male descendant of Othman, and one of the greatest of his successors, the Sultan known to history as Mahmud II.

The sequel of the Serbian insurrection may be briefly told. Fighting came to an end after the conclusion of the Treaty of Tilsit, and as soon as they ceased fighting the Turks, the Serbs began to fight each other. The Turks offered to Serbia an administration similar to that of the Danubian principalities.

The sudden death of Milan Obrenovitch, the leader of the Russophils, gave an occasion for the usual insinuations of foul play against Kara George, who led the Nationalists. This insinuation naturally intensified the bitterness between the two parties. Nor was this feeling diminished when the Pro-Russians procured the rejection of the Sultan's terms under which Serbia would have been placed on the same footing as the Danubian principalities. The terms procured at Bucharest (1812) were, as we shall sce, decidedly less favourable. ${ }^{1}$

Nor were they observed. In 1813 the Turks relieved from Milcsh all fears of foreign intervention reconquered the country, Obrennand administered it with such brutality that in 1815 a fresh insurrection broke out. Its leader, Milosh Obrenovitch, the half-brother of Milan, conducted it with a mixture of courage and craft to a successful issue. In 1817, however, Kara George, who had been interned in Hungary whither he had fled after the reconquest of his country, returned to Serbia. His presence was as unwelcome to Obrenovitch as it was to the Turks. They combined to procure his assassination (July 26, 1817), and his head was sent by Obrenoviteh as a trophy to Constantinople. Such was the real beginning 
of the bitter blood-feud between the two dynasties, which have divided the allegiance of the Serbian people from that day until the consummation of the tragedy of 1903.

In November, 1817, a National Assembly was held at Belgrade, and, with the sulky assent of the Turks, Obrenovitch was elected hereditary prince of Serbia. A limited amount of local government was at the same time conceded to the province, though the sovereignty of the Sultan remained nominally unimpaired.

'I'reaty of The Greek war of independence led to a further concession. Akerman By the convention of Akerman, concluded between Russia
(1826). and the Porte in 1826, the latter recognized a Russian protectorate orer Serbia, and at the same time conceded to the Serbians almost complete autonomy.

T'reaty of The terms agreed upon in 1826 were confirmed by the Anrianople (1829). Treaty of Adrianople, and by 1830 Serbia's autonomy was definitely achieved. Milosh Obrenovitch was recognized by the Porte as hereditary prince of a district (now the northern part of the modern kingdom) bounded by the rivers Dvina, Sare, Danube, and Timok. No Turk was to be permitted to live in the principality, except in one or other of eight fortified towns which were still to be garrisoned by the Turks. The Serbs were to enjoy complete local autonomy, though remaining under the suzerainty of the Sultan to whom they were to continue to pay tribute. They were to be allowed to erect churches and schools, to trade freely, and to print books in the vernacular. In a word, but for the Turkish garrisons, they were to be free to work out their own salvation in their own way.

\section{§3. Napoleon and Alexander}

The

Treaty of Tilsit.

After this prolonged parenthesis it is time to resume the main thread of the story with which this chapter is concerned.

We left Napoleon in Poland conducting the war against Russia and Prussia, but finding time, in the midst of an arduous campaign, for the negotiation of a treaty which had as its ultimate object the annihilation of British power in India (April, 1807). The Treaty of Finkenstein was, indeed, no sooner signed than Napoleon dispatched to Teheran 
General Gardane to devise a detailed scheme for the invasion of India. But though primarily directed against Great Britain the Franco-Persian alliance would serve if required against Russia as well.

From that point of view it proved to be otiose. On June 14 Napoleon brought the campaign in East Prussia to an end by a decisive victory over the Russians at Friedland (June 14, 1807). After that battle the Tsar applied for an armistice, which was readily granted, for Napoleon had already decided upon a volte-face. The real enemy was not Russia nor even Prussia. Prussia must incidentally be amnihilated, but if Alexander was prepared to abandon his alliance with England, and to join forces with France, the two emperors might divide the world between them.

The Tsar was not indisposed to listen to the tempter ; but before the conspirators met at Tilsit to arrange terms, the Prussian minister Hardenberg laid before the two emperors a scheme by which the attention of Napoleon might be diverted from the amnihilation of his enemy Prussia to the spoliation of his ally, the Ottoman Sultan.

According to Hardenberg's scheme Russia was to get Wallachia, Moldavia, Bulgaria, and Roumelia, together with the city of Constantinople, the Bosphorus, and the Dardanelles; France was to have Greece and the islands of the Archipelago; Austria to acquire Bosnia and Serbia ; a reconstituted Poland might go to the King of Saxony, who should in turn cede his own kingdom to Prussia. The idea was highly creditable alike to the courage and to the ingenuity of the Prussian statesman, and his plan had the merit of completeness. But Napoleon was in no mood to negotiate, on this or any other basis, with a defeated and despised foe. If Prussia were permitted to survive at all it must be on terms dictated by the conqueror.

In order to ensure complete secrecy the two emperors met in a floating parilion which was moored in mid-stream in the Niemen. With most of the detailed questions discussed between them this narrative is not concerned; enough to note that the emperors decreed that Prussia should be dismembered-but for the scruples of the Tsar it would have been completely wiped out; the British Empire must be 
amnihilated. The latter consummation was to be attained in two ways: by the ruin of English commerce through the enforcement of the continental blockade, and by an attack upon Iudia. Napoleon had come to the conclusion that on the whole it was easier for him to transport an army from Paris to Delhi than from Boulogne to Folkestone. Never, in our whole history, has the significance of irresistible sea-power been more amply vindicated or more brilliantly illustrated. But the latter part of the scheme was still locked in the breast of Napoleon. Enough for the moment that an avaricions nation of shopkeepers should be compelled to concede the "freedom of the seas', and to share their commercial gains with equally deserving but less favoured peoples. For the ammihilation of her two allies, Russia was to find her compensation in the acquisition of Finland and the partition of the Ottoman Empire.

Tilsit and According to the secret articles of the Treaty of Tilsit the Near East. France was to have the Bocche di Cattaro, and it was further stipulated that, failing the conclusion of a peace between Russia and the Porte within three months, Napoleon would join the Tsar in expelling the Turks from the whole of their European dominions except the city of Constantinople and the province of Roumelia. ${ }^{1}$ How the provinces of European Turkey were to be apportioned was not specified, though it was taken for granted that Russia would retain Moldavia and Wallachia. But the Danubian principalities, even if their cession were procured by Napoleon-a large assumption-were an inadequate recompense for the desertion of allies; and the Tsar intimated to Napoleon that he would not ultimately be satisfied with anything short of the possession of Constantinople. For Constantinople, as Alexander urged with unanswerable logic, was the 'key of his house'. The suggestion is said to have provoked from Napoleon an angry retort: 'Constantinople! never; that would mean the empire of the world.' The truth of the matter is that at Tilsit, as elsewhere, Napoleon had only one object in view : to engage

1 See A. Vandal, Napoléon et Alexandre $I^{e r}$, where the full text of the Treaty of Tilsit will be found in the Appendix to vol. $i$. 
Europe at large in his contest $\grave{a}$ outrance against Great Britain.

As for the Near East Napoleon's policy was palpably opportunist. The gradual publication of memoirs and documents has made it abundantly clear that Napoleon was merely amusing Alexander with hopes of rich spoils in South-Eastern Europe. For himself he had by no means made up his mind whether he would plump for the integrity of the Ottoman Empire or for its annihilation. His own preference was in favour of the former policy, a policy which, as we have seen, accorded with the unbroken traditions of monarchical France. ${ }^{1}$ The latter accorded more precisely with the views of his ally, and Alexander was an important asset in his diplomatic balance-sheet. For the English Foreign Office had lately passed into the rigorous hands of Canning, and English policy showed signs of unwonted promptitude and energy. Hardly was the ink dry on the Tilsit Treaty when the whole conspiracy was countermined by Great Britain's seizure of the Danish fleet and her prompt succour to Portugal and Spain. More than ever Napoleon was in need of his Russian ally. Grandiose schemes of policy in the East must therefore be dangled before the eyes of the Tsar. There was talk of a joint attack, French, Austrian, and Russian, upon Constantinople, which was to be the base of an expedition to India. The Tsar was prudent enough to wish to make sure of Constantinople before going further: the Ottoman Empire must first be disposed of: France might have Bosnia, Albania, and Greece; Austria's share was to be Serbia and Roumelia, with possession of Salonica as a strategical and commercial base on the Aegean ; Russia was to have the Danubian principalities, Bulgaria, and Constantinople, with command of the Straits.

Coulaincourt, who succeeded Savary as French ambas- Napoleon sador at St. Petersburg in December, 1807, was entrusted by and AlexNapoleon with these delicate and protracted negotiations. He insisted that if Russia took Constantinople France must have the Dardanelles, but Alexander justly observed that Constantinople was important to Russia, only so far as it

I Cf. Sorel, L'Europe et la Rérolution française, vol. i, passim, and Bourgeois, Hanuel de la Politique étrangère, vol. i. 
would give access to the Mediterranean. France was welcome to Egypt and Syria, but the key to the Straits must be in Russia's keeping. ${ }^{1}$

The whole of the negotiations between the Tilsit conspirators are of singular interest, both in themselves and in relation to the offer subsequently made by the Tsar Nicholas to Great Britain. ${ }^{2}$ They are, moreover, strongly confirmatory of the conclusion which M. Serge Goriainow, one of the most eminent of Russian publicists, has deliberately reached: 'Pour la Russie tonte la fameuse question d'Orient se résume dans ces mots: de quelle autorité dépendent les détroits du Bosphore et des Dardanelles ; qui en est le détenteur.' ${ }^{3}$

But while the eyes of Russia were fixed upon the Near East Napoleon preferred to avoid inconvenient details by pointing to the rich prize which awaited bold enterprise in the further East: Constantinople was the goal of the Tsar; Napoleon's supreme object was the humiliation of England.

'I'he Ionian Isles.

Negotiations at Erfurt.
Meanwhile, little came of the grandiloquent phrases and far-reaching schemes with which the two emperors had amused each other at Tilsit. Russia remained in occupation of the principalities; Napoleon resumed military control over the Ionian Isles, where the joint rule of Russia and Turkey had proved exceedingly unpopular. To the occupation of Corfu in particular Napoleon attached immense importance: "The greatest misfortune that could happen to me', he said, 'would be the loss of Corfu.' Corfu he did manage to retain until his abdication in 1814, but all the rest of the islands were captured between 1809 and 1814 by the British fleet. During those years Great Britain also occupied most of the islands off the Dalmatian coast, and Lissa proved very valuable to her as a naval base.

The two emperors met again at Erfurt in October, 1808. Napoleon's reception of his ally lacked nothing of pomp and magnificence; but the relations between the august allies were perceptibly cooler. The stern realities of the Peninsular campaign were already imparting more sober hues to Napoleon's

1 Tandal, op. cit., Appendix to vol. i.

2 Infra, chap. $\mathbf{x}$.

${ }^{3}$ Le Eosphore et les Dardanelles, p. 1. 
oriental dreams-all the larger schemes of partition were consequently put aside. The Danubian principalities were, however, guaranteed to the Tsar, who refused to evacnate them at the request of the Sultan. Accordingly, war was resumed between Russia and Turkey in 1809, and Russia, though by no means uniformly successful, took Silistria and other important fortresses from the Turks.

Relations between the Tsar and the Emperor of the French were, however, for reasons into which it is unnecessary to euter here, ${ }^{1}$ growing more strained every day. Turkey, therefore, became an increasingly inportant pawn in the diplomatic game. Russia made repeated efforts in 1811 to conclude peace with Turkey on the basis of the cession of the principalities. But in vain. The accession of Sultan Mahmud II had infused a new vigour and decision into the counsels of the Porte. Napoleon then made a desperate effort to secure the alliance of the Sultan. If Turkey would join France and protect Napoleon's right flank in the projected advance against Russia, not only should the Danubian principalities be definitely and finally secured to her, but she should recover the Crimea, Tartary, and all the losses of the last half century. It is not wonderful that the Sultan, besieged by suitors for his favour, should have been able to perceive the cynical effrontery of these orertures, and should have firmly rejected them. The more firmly, perhaps, because England had threatened to force the Dardanelles and burn Constantinople if they were accepted. As a fact, howerer, Napoleon was too late. Sultan Mahmud had already come to terms with Alexander, and on May 28, 1812, the definitive treaty of peace was signed at Bucharest.

Previous treaties were specifically confirmed, but Russia Treaty of obtained Bessarabia; her boundary was 'henceforward to be Buchathe Pruth, to its entrance into the Danube, and, from that point, the left bank of the Danube down to its entrance into the Black Sea by the Kilia mouth'. The great islands were to be left racant. The Treaties of Kainardji and Jassy, in reference to the better government of the principalities, were to be

1 They will be found briefly summarized in the present writer's Modern Europe, chap. $\mathrm{x}$. 
duly observed, and for the first time the liberties of Serbia were made the subject of treaty obligations between Russia and Turkey.

Serlia. Artiele VIII of the Treaty of Bucharest begins with the naïve recital that although 'it was impossible to doubt that the P'orte, in accordance with its principles, will show gentleness and magnanimity towards the Serbians, as a people long subject and tributary to it', yet it seemed just 'in consideration of the share which the Serbians have taken in the war, to make a solemn agreement for their safety'. The Porte aceordingly undertook, while continuing to garrison the fortresses, to allow the Serbians 'such liberties as are enjoyed by the islands of the Archipelago; and, as a token of its generosity, will leave to them the administration of their internal affairs'. ${ }^{2}$ The Serbians, it may be added, considered these terms as vague and unsatisfactory, and resented what they regarded as a base desertion at the hands of their powerful protector, the Tsar. ${ }^{2}$

The Congress of Vienna and the settlement of 1815 .

Austria and the Arlriatic.
In the stirring and pregnant events of the next three years the problem of the Near East had no place. The disastrous expedition to Moscow, the war of German Liberation, the Hundred Days-none of these was eoncerned with the Orient. Yet the settlement effected at Viemna had an important influence upon the future evolution of the Eastern Question.

The many schemes and violent perturbations of the Napoleonic period left the Ottoman Empire, in a territorial sense, almost unseathed. Bessarabia had, indeed, been alienated to Russia, but this represented a loss not so much to the Turkey of the present as to the Roumania of the future. For the rest, it was at the expense of Italy, or rather of Venice, that the neighbour's of the Turk were enriched.

Austria recovered Trieste, Gradisea, and Gorizia, together with Istria, Carniola, and Carinthia, which took their place in the eomposite empire of the Habsburgs as the kingdom of Illyria. She acquired also Venetian Dalmatia and the ancient

1 Holland, op. cit., pp. 16, 17.

2 Cf. Cimibert, Essai historique sur les Révolutions et l'Indépendance de la Serbre, cited by Creasy, op. cit., p. 491. 
Slav republic of Ragusa, the islands appurtenant thereto, and the Bocche di Cattaro. The Ionian Isles were formed into "The United States of the Ionian Islands, under the protectorate of Great Britain '. Had Great Britain known the things which belong unto her peace, she would never voluntarily have relaxed her hold upon islands, the strategical value of which was so clearly recognized by Napoleon. She also retained Malta, which greatly strengthened her naval hold upon the Mediterranean, and brought her, all unconscious, a step nearer to Egypt.

The net results of the wars, treaties, and negotiations of a quarter of a century appear disproportionately small. But it would be a fatal error to regard them as negligible.

The whole future of Austria, more particularly in relation to the Near East, was profoundly affected thereby. Crushed in the field again and again, Austria, nevertheless, emerged trimmphant at the Peace. Her emperor had cleverly got rid of the troublesome appanage of the Netherlands, and in return had secured two compact and invaluable kingdoms in the south. King of Lombardo-Venetia, Lord of Trieste, King of Illyria, master of the ports of Venice, Trieste, Pola, and Fiume, not to mention the Dalmatian littoral, Ragusa, the Gulf of Cattaro, and the Adriatic archipelago, he found himself in a most commanding position as regards the Eastern Mediterranean and the Balkan Peninsula. On the other hand, his rival the Tsar was, save for the acquisition of Bessarabia, no nearer to Constantinople than he had been in 1792. The long war with Persia had, indeed, left the Tsar in possession of Georgia, Tiflis, and the coast of the Caspian up to the Araxes, and had greatly increased his influence at Teheran, but as regards the solution of the problem with which this work is concerned the adrance of Russia was inconsiderable.

Infinitely the most important result of the period imme- The spirit diately under review was, howerer, one far too intangible to of Nationbe registered in treaties or documents. Subsequent events make it abundantly clear that, whether, as a direct consequence of the novel ideas disseminated by the French Revolution, whether in response to the principle of nationality 
so powerfully, if unconsciously, evoked by Napoleon, whether as a result of the general unrest, or from other causes too subtle for analysis, a new spirit had been awakened among the peoples of the Balkan Peninsula, so long inert and dumb beneath the yoke of the Ottoman Turk. It was stirring among the Latins of the Danubian principalities; it was clearly manifested in the insurrection of Serbia; above all, it was operating powerfully, though as yet silently, among the people destined, a few years later, to carve out of the European dominions of the Ottoman Sultan an independent commonwealth, and to add to the European polity a new sovereign State-the kingdom of the Hellenes.

With the making of the new State the next chapter will be concerned.

For further reference: Jonquière, L'Expédition d'Égypte; A. Sorel, Bonaparte et Hoche en 1797; Drianlt, La Question dOrient, L'Europe et la Rérolution irançaise; Vandal, Napoléon et Alexandre Ier ; Fournier, Life of Napoleon; Martens, Recueil des traités de la Russie avec les Puissances étrangères; E. Driault, La politique orientale de Napoléon; Tatistchef, Alexandre $I^{e r}$ et Napoléon. For Serbia sce infra. 


\section{CHAPTER VIII}

\section{THE STRUGGLE FOR HELLENIC INDEPENDENCE}

'Did I possess their (the Athenians) command of language an! their force of persuasion I should feel the highest satisfaction in cmploying them to incite our armies and our fleets to deliver Greece, the parent of eloquence, from the despotisn of the Ottomans. But we ought besides to attempt what is I think of the greatest monent, to influme the present Greeks with an ardent desire to emulate the virtue, the industry, the patience of their ancient progenitors.'-MILTON.

'It offers in detail a chequered picture of patriotism and corruption, desperate valomr and weak irrosolution, honour and treachery, resistanee to the Turk and feud one with another. Its records are stained with many acts of cruelty. And yet who can doubt that it was on the whole a noble stroke, struck for freedom and for justice, by a people who, feeble in numbers and resources, were casting off the vile slough of servitude, who derived their strength from right, and whose worst acts were really in the main lne to the masters, who had saddled them not only with a cruel, but with a most remoralizing, yoke?'-W. E. GLalstone, on the Greek War of Independence.

'As long as the litcrature and taste of the ancient Greeks continue to nurture scholars and inspire artists modern Greece must be an olject of interest to enltivated minds.'-FinLAY.

'... England ... sees that her true interests are inseparably connected with the independence of those nations who have shown themselves worthy of emancipation, and such is the case of Greece.'-Iord Byrox.

The Emperor Napoleon was at once the heir of the French The NaRevolution, and the product and agent of a powerful reaction against the principles which the Revolution had proclaimed. Of 'Liberty' he understood nothing ; at 'Fraternity' he scoffed ; 'Equality' he interpreted as 'equality of opportunity', the carriere ouverte aux talents. A chance was given not only to his subjects, but to two conntries which he conquered, and to some which he did not.

The ferment of ideas caused by the outbreak of the Revolution, the political unrest which followed on the conquests of Napoleon, and on the perpetual rearrangements of the map of Europe, produced important consequences in the principle. 
Near East. It is to the Balkan Peninsula that the political philosopher of to-day most frequently and most naturally turns for an illustration of the fashionable doctrine of nationality. Before 1789 the principle was unrecognized in those regions or elsewhere. In the great settlement of 1815 it was contemned or ignored. But in less than a decade after the Congress of Vienna it had inspired one of the most romantic episodes in the annals of the nineteenth century, and had presided over the birth of a new sovereign State.

'The

Hellenic revival.
The Holy Alliance.
The principle of nationality has defied definition and even analysis. Generally compounded of community of race, of language, of creed, of local contiguity, and historical tradition, it has not infrequently manifested itself in the absence or even the negation of many of these ingredients. But in the Hellenic revival, which by common consent constitutes one of the most conspicuous illustrations of the operation of the nationality principle, most of these elements may unquestionably be discerned.

In March, 1821, a bolt from the blue fell upon the diplomatic world. Many of the most illustrious members of that world happened, at the moment, to be in conference at Laibach, summoned thither by the Austrian minister, Prince Metternich, to discuss the best means of combating the spirit of revolution which had lately manifested itself in Spain, in Portugal, and in the Bourbon kingdom of the Two Sicilies.

In November, 1820, a formal protocol had been issued by the leading members of the Holy Alliance: Russia, Austria, and Prussia. The terms of this document are significant: 'States which have undergone a change of government due to revolution, the results of which threaten other States, ipso fucto cease to be members of the European Alliance, and remain excluded from it until their situation gives guarantees for legal order and stability.... If, owing to such alterations, immediate danger threatens other States the Powers bind themselves to bring back the guilty State into the bosom of the great alliance.' To this protocol, Louis XVIII of France, in general terms, assented, but Lord Castlereagh warmly insisted that the principle on which the allies proposed to act was 'in direct repugnance to the fundamental laws of' 
the United Kingdom'. Still stronger was his protest when the allies commissioned Austria to restore, by force of arms, Bourbon absolutism in Naples. "We could neither share in nor approve, though we might not be called upon to resist the intervention of one ally to put down internal disturbances in the dominions of another.' Castlereagh's protest, though consolatory to English liberalism, was quite ineffective as a restraint upon the Holy Allies.

Most disquieting, however, was the news which in the Rising in spring of 1821 reached the sovereigns and ministers in conMoldavia. ference at Laibach. They learnt with alarm, that Prince Alexander Hypsilanti, the son of a Phanariote Greek, Hospodar successively of Moldavia and Wallachia, had placed himself at the head of an insurrectionary movement in Moldavia, and harl unfurled the flag of Greek independence.

The local for the initial rising was singularly ill chosen, yet not without intelligible reasons. The malcontent Greeks had, as we have seen, received frequent encouragement from St. Petersburg in the latter part of the eighteenth century. The Tsar Alexander was known to be a man of enlightened views, a firm believer in the principle of nationality, and pledged, in his own words, "to restore to each nation the full and entire enjoyment of its rights and of its institutions'. So long ago as 1804 he had foreseen that the weakness of the Ottoman Empire, 'the anarchy of its régime and the growing discontent of its Christian subjects', must open a new phase in the history of the Eastern Question. ${ }^{1}$ The Tsar's foreign minister, Comnt Giovanni Antonio Capo d'Istria, was by birth a Greek and a member of the Philile Hetaireia. Hypsilanti, the chosen leader of the insurrection, was his aide-de-camp. What more natural than that the Greeks should have looked for assistance to Russia, or that in order to obtain it the more effectually the initial rising should have been planned to take place in Moldavia?

Nevertheless, the decision was a blunder. The Roumanians detested the Phanariote Greeks, whom they regarded as intrusive aliens and oppressors, and they neither felt nor

1 Ct. Alexander's instructions to Novosiltsov (180t), ap. Phillips, Confederation of Europe, p. 35. 
displayed any enthusiasm for the Hellenic cause. Nor did it secure the anticipated assistance of the Tsar Alexander. Hypsilanti, after crossing the Pruth on March 6, issued a proclamation calling upon the people to rise against Ottoman tyranny, and declaring that his adventure was sanctioned and supported by 'a Great Power'.

Alexander and Hypsi-

The statement was entirely unwarranted. The Tsar, from lanti. the first, frowned sternly upon Hypsilanti's enterprise. His political confessor was now Prince Metternich ; under Metternich's influence Alexander, rapidly discarding the slough of liberalism, was easily persuaded that the rising of the Phanariote Greeks supplied only one more manifestation of the dangerous spirit which had already shown itself at Madrid, Lisbon, and Naples-the spirit which the Holy Allies were pledged to suppress.

Any doubts which might have existed as to the attitude of the Tsar were promptly dissipated. He issued a proclamation which disavowed all sympathy with Hypsilanti, ordered him and his companions to repair to Russia immediately, and bade the rebels return at once to their allegiance to their legitimate ruler, the Sultan, as the only means of escaping the punishment which the Tsar would inflict upon all who persisted in aiding the revolt.

Collapse of the northern insurrection.

The firm attitude of Russia was fatal to the success of the rising in the Principalities. Hypsilanti himself betrayed a mixture of vanity, brutality, and incompetence; the Turks occupied Bucharest in force, and on June 19, 1821, inflicted a decisive defeat upon his forces at Dragashan, in Wallachia. Hypsilanti escaped into Hungary, where until 1827 he was, by Metternich's orders, imprisoned. He died a year later. Four days after the battle of Dragashan the Turks entered Jassy, and shortly afterwards the remnant of Hypsilanti's force was overwhelmed after a brief but heroic resistance at Skaleni.

The Moldavian rising was a mere flash in the pan: an enterprise unwisely conceived and unskilfully executed. Far otherwise was the movement in the Greek islands and in the Morea.

The outbreak has been described as a 'bolt from the blue'. So it appeared to the Holy Allies. In reality the motive 
forces which were behind it had been operating for a long Causes time, and if any one had given serious heed to the Greeks of the a national revival among them might have been foreseen.

But the racial movement was obscured beneath an ecclesiastical designation. To the Turks the social and political differentia has always been not race but religion. Every one who was not a Moslem, unless he were an Armenian or a Jew, was a Greek. 'After the Ottoman conquest', as Sir Charles Eliot has justly observed, 'the Greeks were not a local population, but a superior class of Christians forming a counterpart to the Turks. South-Eastern Europe was ruled by the Turks ; but until this century its religion, education, commerce, and finance were in the hands of Greeks.' ${ }^{1}$ Consequently, although the Greek Empire was annihilated, and the Greek nation was submerged, the Greek population survived, and a large number of individual Greeks rose to positions of great influence under the Ottoman Empire.

The truth is, and too much emphasis can hardly be laid upon it, that the Turk is a great fighter, but not a great administrator : the dull details of routine government he has always preferred to leave in the hands of the 'inferior' races. This fact must not be ignored when we seek the causes of the national revival among the Greeks and other Balkan peoples in the nineteenth century.

Largely as a result of this indifference the Greeks were Survival permitted to enjoy, in practice if not in theory, a considerable of local amount of local autonomy. The unit of administration has, erer since classical days, been small ; and in the rillage communities of the interior and the commercial towns on the sea-board the Greeks, throughout the long centuries of Ottoman rule, preserved the memory, and, to some extent retained the practice, of self-government. More particularly was this the case in the Greek islands of the Adriatic and the Aegean. These islands, inhabited by a race of shrewd traders and skilful mariners, had long been virtually independent, save for the payment of an aunual tribute to Constantinople, and in them the national morement found its most deroted and most capable adherents.

$$
1 \text { Op. cit., p. } 273 .
$$


Mariners and merchants.

Armatoli and Klephts.

The

Phanariote Greeks.

The Turkish navy had always been manned to a large extent by Greeks, and most of the commerce of the empire was in the same hands. Among the Greeks the joint-stock principle had developed with great rapidity in the eighteenth century, and a large number of trading companies had been formed. To this development a powerful stimulus was given by the victories of the Empress Catherine II, and the commercial advantages consequently conceded to Russia by the Porte. The provisions of the Treaty of Kainardji were supplemented in 1783 by a commercial convention under which the Greeks obtained the specific privilege of trading under the Russian flag. When, later on, the continental blockade and the British Orders in Council drove all shipping, save that of Turkey, from the sea, the Greeks were glad enough to resume the Turkish flag; and under the one flag or the other they not only amassed great fortumes, but practised the art of seamanship and cultivated the spirit of adrenture.

Among the Greeks of the mainland the fighting spirit was maintained partly by the Armatoli and partly by the Klephts. The former were members of a local Christian gendarmerie officially recognized by the Turkish Pashas, and permitted to bear arms for the purpose of keeping in order their more unruly neighbours, and in particular the Klephts, from whose ranks, however, they were not infrequently recruited. The Klephts may fairly be described as brigands dignified by a tinge of political ambition. At their worst they were mere bands of robbers who periodically issued from their mountain fastnesses and preyed upon the more peaceable inhabitants. At their best they were outlaws of the Robin Hood type. In either case they habituated the people to the use of arms and maintained a spirit of rough independence among the Greek subjects of the Sultan.

From the opposite pole the Phanariote Greeks contributed to the same end. These Phanariotes have, as Sir Charles Eliot truly observes, 'fared ill at the hands of historians. They are detested by all whose sympathies lie with Slavs or Roumanians, and not overmuch loved by Philhellenes.'

1 Op. cit., p. 283. 
Yet modern Greece owes to them a debt heavier than is generally acknowledged. Indolent in everything that does not pertain to war, the Turks, as we hare previously noted, ${ }^{1}$ soon found it to their advantage to delegate the work of govermment to the Greeks of the eapital, who were welleducated, supple, and shrewd. Employed, at first, mostly on humbler tasks, as clerks, interpreters, and so forth, the Greeks who generally inhabited that quarter of Constantinople assigned to the Patriarch and his satellites, known as the Phanar, rose rapidly to positions of great responsibility, and gradually came to fulfil the functions of a highly organized bureaucraey.

During the revival initiated by the Kiuprilis in the middle The of the seventeenth century a new office, the Dragoman of the Porte, was created in favour of a distinguished Phanariote, a Chiot named Panayoti; he was succeeded by a still more and the distinguished Greek, Alexander Marrocordatos, with the result that the office which these men successively adorned became Dragoman of the Porte Dragoman of the Fleet. virtually a Ministry for Foreign Affairs. Henceforward, the foreign relations of the Ottoman Empire were mainly conducted by Greeks. Later on, a Dragoman of the Fleet or Secretary of the Admiralty was similarly appointed to assist the Capitan Pasha, a great official who was at once Lord High Admiral and Governor of the Archipelago. This second Dragoman, generally a Phanariote, was thus brought into close official relations with the intensely Greek communities in the Aegean islands.

Early in the eighteenth century the hospodarships of the The Danubian principalities were, as we hare already seen, also Hospoentrusted to Greeks. Not infrequently the grand vizier himself was a Phanariote. These high officials naturally secured the appointment of compatriots to the subordinate posts, and in this way the Greeks began to dominate the whole official hierarchy. That this hierarchy was inspired by any feelings of national self-conscionsness it would be an affectation to suggest; still more that they maintained any close comnexion, except as tax-gatherers, with their kinsmen

1 Passim and supra, chap. iv. 
in the Morea and the Archipelago. But although Gordon speaks of them derisively as 'a fictitious and servile noblesse',' yet the large share of the Greeks in the actual administration was not without its influence upon the Hellenic revival.

The Even more important was the position of the Orthodox Orthodox Church. Nothing contributed more directly to the revival
Church. than the privileged relations between the Patriarch and the Sultan; and, in another sphere, the singular derotion displayed, alike in a pastoral and a political capacity, by the lower clergy.

Reference has already been made to the policy adopted by the conqueror Mohammed II, and his successors, towards the Byzantine Church ; the result being that the Greek Patriarch of Constantinople was not only respected as the representative of the Orthodox Church, but was utilized by the Ottoman Sultans as the official channel of communication between them and the conquered Greeks. So much was this the case that Finlay describes the Patriarch as 'a kind of under-secretary to the grand vizier for the affairs of the orthodox Christians'.? From the point of view of Greek nationalism the peculiar position thus occupied by the Greek Patriarch may have had its drawbacks as well as its advantages. The continuous exertions of the parish priests were, on the other hand, wholly to the good. It was mainly owing to their devotion that through the long night of darkness there was maintained a flicker of the national spirit among the Greeks of the islands and the Morea. 'The parish priests', writes Finlay, 'had an influence on the fate of Greece quite incommensurate with their social rank. The reverence of the peasantry for their Church was increased by the feeling that their own misfortunes were shared by the secular clergy.'

Literary To the causes of revival enumerated above, many of them of renaissance. long standing, must be added two more which began to operate only towards the end of the eighteenth century. The first was a literary revival of the Greek language, and the second was the outbreak of the revolution in France. Spoken Greek began to diverge perceptibly from the literary language of

1 History o, the Greek Revolution.

2 Greek Revolution, i. 21. 
classical days, in the fourth century, but until the eighth classical Greek was generally understood. After the Slavonic inroads a large infusion of Slav words took place, and from the twelfth century onwards a literature sprang up in the vernacular. This vernacular was afterwards largely overlaid with Slar, Turkish, Albanian, and Italian words. ${ }^{1}$

The Venetian occupation (1684-1718) did nothing for the language, but a good deal for education, in the Morea, and may to some extent have contributed to the marked literary revival in the latter years of the eighteenth century. That revival was partly the product, and still more the cause, of the rising sense of national self-consciousness.

Two writers of the period call, in this comnexion, for specific mention : Rhegas (1753-98) and Adamantios Koraes (17481833). The former, a Vlach, had studied in Paris, but his national songs sounded the first trumpet-note of the coming revolution. He was, however, more than a singer of songs. He was the founder of one of the secret societies out of which the Hetaireia subsequently developed, and he opened negotiations with other revolutionary spirits in various parts of the Balkans. Betrayed, when living in Hungary, to the Austrian police, he was handed over to the Turkish Government, and executed as a rebel at Belgrade in 1798. By the people, whose causc he served, he is commonly regarded as the proto-martyr of Greek independence. The great contribution made by Koraes to that cause consisted less in the political works of which he was the author than in his translation of the Greek classics into a purified and refined vernacular. By this means he performed a great service to the morement for linguistic reform which, at the close of the eighteenth century, succeeded in purging the spoken language of the Greeks from many of the impurities with which it had been infected. The work of Koraes did more. 'It gave an impetus to the wave of Philhellenism which did so much to solve the practical question of the liberation of Greece from Ottoman misgovernment; and it supplied to the infant State, born after

1 Modern Greece, by R. C. Jebb, p. 16. 
so much travail, a language and a tradition which linked it consciously with an inspiring past.' ${ }^{1}$

The

Philike

Hetai-

reia.

Not less inspiring to the Greeks was the example of revolutionary France. Under that example were founded a number of secret societies, the most famous of which was the Phililie Hetaireia. This 'Association of Friends' was founded at Odessa by four Greek merchants. The precise degree of significance to be attached to the influence of the Hetaireia has been very variously estimated, ${ }^{2}$ but it certainly secured the adhesion of most of the leading Greeks, both at home and abroad, and is said by 1820 to have enrolled 200,000 members. Its object was the expulsion of the Turks from Europe and the re-establishment of the Greek Empire; and, however questionable its methods, it indisputably gave coherence and unity of aim to a movement which, though powerful, was dispersed and hopelessly lacking in these qualities.

Ali Pasha The immediate opportumity for the outbreak of the Greek of Janina. insurrection was aftorded by the extraordinary success attained by Ali Pasha of Janina, one of the many ambitious and discontented viceroys of the Sultan. Ali Pasha had taken advantage of the general unrest caused by the Napoleonic wars, and of the frequent changes in the hegemony of the Adriatic, to carre out for himself a principality, imposing in extent, and virtually independent of Constantinople, upon the Albanian sea-board. The hill tribes of Albania and northern Greece were gradually reduced to subjection, and in 1817 the position of Ali was so far recognized by the protectress of the Ionian Isles that Great Britain handed over to him the excellent harbour and town of Parga. The conduct of Lord Castlereagh in this, as in other matters, has been hotly canvassed, but the choice he had to make was not an easy one. The Pargiotes had voluntarily surrendered their town to us, and had sought British protection against a ruffianly adventurer. But the adventurer had rendered a considerable service to us in the Napoleonic wars, and the retention of a town, little valued

1 Alison Phillips, ap. C. M. H., x. 17t-5.

2 e. g. by Finlay and Gordon respectively. 
for its own sake, might have led to embarrassments. So the 'Lion of Janina' went from triumph to triumph.

Not until 1820 did Sultan Mahmud take action against his audacions viceroy. But, at last, a large force under Kurshid Pasha was dispatched from Constantinople, and after two years of successful evasion and resistance the 'Lion' was trapped in Janina ; he was assassinated in the midst of a parley, and his head was sent as a trophy to the Sultan (Feb. 1822).

Meanwhile, encouraged by the preoccupation of the Porte, Rising the Hetairists had initiated the disastrous insurrection in in the Moldaria, and, before the northem rising collapsed, had April, lighted in the Morea and the islands a torch which was not 1821 . to be extinguished until a new nation had taken its place in the European polity.

The enthusiasm of Lord Byron, the knight errantry of Lord Cochrane, General Church, and other Philhellenist volunteers, cast over the ensuing war a glamour only partially deserved. Never, surely, did any movement display a more confused and perplexing medley of brutality and nobility, of conspicnous heroism and consummate cowardice, of pure-minded patriotism and sordid individualism, of selfsacrificing loyalty and time-serving treachery.

The initial uprising in the Morea was marked by terrible ferocity. It was avowedly a war of cxtermination. 'The Turk', sang the Moreotes, 'shall live no longer, neither in the Morea, nor in the whole earth.' In the Morea the threat was almost literally fulfilled. In April, 1821, a general massacre of Moslems began. Out of 25,000 Ottomans hardly one was suffered to remain outside the walled towns into which all who escaped the massacre had hastily fled for refuge. Within a month the Turkish domination of the Morea was at an end.

Meanwhile the massacre of Turks in the Morea was Turkish promptly followed by reprisals wherever Christians could be reprisals. taken at a disadvantage. In Constantinople itself Sultan Mahmud wrought a deed, the news of which startled and horrified Christendom. On the dawn of Easter Day (April 22, 1821) the Venerable Patriarch Gregorius was seized as he emerged from the celebration of mass, and, still 
clothed in his sacred vestments, he was hanged, and with him the Archbishops of Adrianople, Salonica, and Tirnovo. For three days the bodies hung outside the episcopal palace, and were then cut down and flung into the Bosphorus. The body of the Patriarch was picked up by a Greek trading ship and carried to Odessa, where it was interred with all the honour due to a martyr for the faith.

The murders in Constantinople gave the signal for a wholesale massacre of Christians. In Thessaly, Macedonia, and Asia Minor, Christian Churches were pillaged, the men were put to the sword, and the women sold into slavery.

Attitude The Powers could not look on at these things ummoved. of Russia. Least of all Russia. Metternich regarded the Greek insurrection with unfeigned alarm. To him it was merely one more manifestation of the revolutionary temper which was infecting a great part of Southern Europe. He would have left the Greeks to their fate, and did his utmost to restrain his august ally. But Alexander was not only the head of the Holy Alliance; he was the protector of the Orthodox Church and the hereditary enemy of the Sultan. His subjects, moreover, were deeply moved by the insult to their faith and the unhappy plight of their co-religionists.

Apart from the question of Greek independence, and the outrages upon the highest ecclesiastics of the Greek Church, the Tsar had his own grievances against the Porte. The Turks had insulted Russian ships in the Bosphorus, and had continued to administer the principalities, not perhaps unwarrantably but in defiance of Treaty obligations, by martial law. Accordingly, though Alexander' no less than Metternich 'discerned the revolutionary march in the troubles of the Peloponnese', the Russian ambassador at Constantinople was instructed, in July, 1821, to present the following demands and to require an answer within eight days :

(i) that the Greek Churches, destroyed or plundered, should be immediately restored and rendered fit for the celebration of Divine worship; (ii) that the Christian Religion should be restored to its prerogatives by granting it the same protection it formerly enjoyed, and by guaranteeing its inviolability for the future, to console Europe in some 
degree for the murder of the Patriarch ; (iii) that an equitable distinction should be made between the innocent and the guilty, and a prospect of peace held ont to those Greeks who should hereafter submit within a given time; and lastly (iv) that the Turkish Government should enable Russia, by virtue of existing treaties, to contribute to the pacification of the principalities of Wallachia and Moldavia.

The Porte was, at the same time, informed that immediate assent to these demands was 'the only means by which it would be able to avoid utter ruin'. The answer was not forthcoming within the specified time; the Russian ambassador demanded his passports, quitted Constantinople on July 27, and a Russo-Turkish war seemed imminent.

The rest of the Powers were, however, in no mood for the Attitude renewal of war. The restored Bourbons in France were pre- Powers. occupied with the congenial task of restoring legitimism and autocracy in Spain. Metternich was supremely anxious to avert the reopening of the Eastern Question in its larger aspects. Berlin echoed the voice of Vienna.

Lord Castlereagh was not indifferent to the fate of the Greeks, but, like Metternich, was primarily concerned to avoid a European conflagration. To that end he joined Metternich in putting pressure upon the Sultan to induce him to agree quickly with his powerful adversary. Capo d'Istria would have been glad to serve the cause of his people by engaging his master in a war with the Turks, but Alexander did not wish to push matters to extremities. Pacific counsels therefore prevailed. The Sultan was induced to yield a point and evacuate the principalities, and Metternich could congratulate himself upon having, for the time, averted war. In September, 1822, he met his allies at Verona in comparatively cheerful mood.

Meanwhile the Near East remained in a state of profound Campaign perturbation. The unrest was not appeased by the events of 1822. In February of that year the Albanian revolt was, as we have seen, extinguished, and thus the border provinces were preserved from Hetairist infection and secured to the Porte. Kurshid Pasha, fresh from his triumph over the Lion of Janina, then delivered his attack in force upon the insurgents 
of central Greece and the Morca. On July 16 a serious defeat was, owing partly to treachery and partly to mismanagement, inflicted upon a Greek force, and Marrocordatos withdrew to the shelter of Missolonghi. Missolonghi stood a siege for two months and then beat off its assailants; and before the end of the year the Greeks had recovered Athens, Nauplia, and Corinth.

The

The Greeks were equally successful at sea, but their mastery islands. was not established before the Turks had perpetrated terrible atrocities in Chios. On April 22, 1822, precisely a year after the murder of the Greek Patriarch, the Turks landed a force of 15,000 men in Chios, and put to the sword the whole population-priests and peasants, women and children, save some thousands of young girls who were carried off into slavery. Including the latter the Turks claimed, in Chios alone, some 30,000 rictims.

But their savage trimph was short-lived. The Greek fleet which, but for divided counsels, ought to have prevented the Turkish landing in Chios, presently appeared upon the scene and exacted a terrible though tardy rengeance. Employing a device familiar to the Greeks, Constantine Kanaris, their admiral, inflicted a crushing blow upon the Turks. On the night of June 18 he rammed, with a fireship, the Turkish admiral's flagship; and it was blown up with the admiral and a thousand men on board. This bold and skilful stroke cleared the Levant. The rest of the Turkish navy fled in terror and took shelter in the Dardanelles. On sea as on land the Greek cause seemed destined to a victory, speedy and complete.

A Greek Constitution.
Mean while the Greeks had taken a step of considerable political significance. On January 1, 1822, a national assembly met in a wood near Epidaurus, solemnly proclaimed the independence of Greece, and promulgated a constitution. There was to be an executive council of five members under the presidency of Alexander Marrocordatos, and a legislative assembly of fifty-nine members elected on a popular franchise and presided over by Demetrius, the brother of Alexander Hypsilanti. The formation of a new State, under a regularly constituted government, was thus officially announced to the world. 
For some time the Powers made no response. But to Great RecogniBritain and other maritime Powers the situation was highly ${ }_{\text {Greek }}^{\text {tion of }}$ inconvenient, and, as the Greek navy asserted its supremacy lrelligerin the Levant, became intolerable. The Greeks were still Great $_{\text {irey }}$ technically privateers. No redress for the outrages they Britain. committed could be obtained from Constantinople, nor under existing conditions could redress be sought from the provisional government in the Norea.

In August, 1822, the death of Lord Londonderry (Castle- C'aming. reagh) had opened the Foreign Office to George Canning. In regard to the Near East Canning accepted in principle the policy of his predecessor, but circumstances soon forced him to a much more active intervention than Castlereagh would have approved. In the first place, the injuries inflicted upon English commerce compelled him, on March 25, 1823, to recognize the Greeks as belligerents.

The rising tide of Philhellenism pushed him still further in Philhelthe same direction. The enthusiasm aroused in England, lenism in as among other progressive peoples, for the cause of the Greek insurgents was extraordinary. It was due partly to reverence for the past, partly to hope for the future. The mere name of Hellenes, heard once more upon the lips of men after centuries of complete oblivion, thrilled the hearts of those who owed to Greek philosophy, Greek art, and Greek literature a debt larger than they could acknowledge or repay. But Philhellenist sentiment did not derive its sustenance solely from the memories of the past. In England the long reign of the Tory party was drawing to a close. The peace of 1815 had been followed not by plenty but by a period of profound depression in agriculture, finance, and trade. Distress led to an epidemic of disorder ; disorder necessitated repression; repression stimulated the demand for reform. Liberalism not less than nationalism looked exultingly to Greece.

Of both sentiments Byron was the most impassioned repre- Byron and sentative, and in July, 1823, he started from Italy for Greece. He tarried in Cephalonia during the autumn, and in January, 1824, landed at Missolonghi.

During the last twelre months the outlook for the Greek 
nationalists had darkened. Distracted by internal feuds, gravely hampered, despite a generous loan from English sympathizers, by lack of money, the Greeks had nerertheless managed until 1824 to hold their own against the Turks.

Intervention of Ibrabim Pasha.

Conquest of Crete. reduced to submission. Ibrahim next exterminated the population of Kasos, while his Turkish allies dealt in similar fashion with Psara. Had there been anything approaching to unity in the counsels of the Greeks, had there been any co-ordination between the 'government', the soldiers and the sailors, Ibrahim might nerer have accomplished the short royage between Crete and the Morea. But thanks to the negligence of the Greek nary Ibrahim landed a large force at Modon in February, 182.5, and secured Navarino as Conquest a naval base. Bravely as they fought, the Greek irregulars rastation of the Morea.

Fall of Missolonghi. were no match for disciplined forces led by a skilled soldier. From Navarino Ibrahim advanced through the Morea 'harrying, derastating, and slaughtering in all directions'.

It seemed in 1825 as if no assistance, short of the official intervention of one or more great Powers, could avail to save the Greek cause. While the Egyptians attacked from the sonth-west, the Turks delivered their assault on the north-west. The two forces converged on Missolonghi where, on April 19, 1824, Byron had given the last proof of his derotion to the cause of Hellas.

In April, 1825, the Turks, under Reschid Pasha, inrested the town by land and sea. Again and again the assault was delivered; again and again it was repelled. Reschid himself was in danger of being cut off by the Greek fleet; but in November the Turkish forces were reinforced by Ibrahim. 
The efforts of the Egyptians were as vain as those of the Turks; the besiegers still repelled every assault. At last, after more than six months of siege, the assault was abandoned, and the combined force of the besiegers sat down to a blockade. The heroic defenders were starred out; and in April, 1826, after a close investment of exactly a year, the whole population determined to make a sortie. On April 22 every man, woman, and child - not physically disabled-assembled at the gates prepared for the last desperate sally; only the infirm were left behind. The ranguard cut their way through, and the gallant attempt seemed on the point of complete success, when, owing to a mistaken order, the force divided, part advanced, part retired ; some of the advancing party got through ; but the besiegers closed in upon the rest ; hardly a man of them escaped; most of them died sword in hand; the small remnant set fire to the magazines and perished in the flames. Some three thousand women and children, the sole survivors of the siege, were carried off into slavery.

From Missolonghi the victors marched on Athens; Athens Fall of in its turn was besieged, and on Jume 2, 1827, despite the Athens. efforts of the Greeks themselves, and despite the assistance of Lord Cochrane, General Church, and others, was compelled to surrender. The Greek cause seemed desperate. Unless help were forthcoming from outside the whole movement must collapse. In despair the Greeks formally placed themselves under British protection, and begged that Great Britain would send them a king. It was, of course, impossible to accede to the request, and Canning, though he received the Greek deputies with cordiality, made it clear to them that England could not depart from her attitude of strict, though benerolent, neutrality. This negotiation took place at the close of 1825 . Just about the same time an event happened which profoundly modified the whole European situation.

In December, 1825, the Tsar Alexander died suddenly Alexin the Crimea, and after a short interval of uncertainty ander I and confusion his brother Nicholas succeeded. Nicholas Nicholas was a man entirely opposed in taste and temper to his $\mathrm{I}$. 
predecessor. Alexander was a curious mixture of shrewdness and sentiment; Nicholas had none of his Western veneer, and cherished none of his illusions; he was brother's Russian to the core. For the Greeks he cared little; but he was indisposed to allow the Porte to play fast and loose with Russia. The questions at issue between the two Courts were no nearer a satisfactory settlement than when, four years earlier, Russia had broken off diplomatic relations with Constantinople. The British ambassador to the Porte had done all in his power to bring about a settlement of the dispute; but he had no sooner, with infinite labour, secured an adjustment on one point than another had been raised.

England On the accession of the new Tsar, Camning induced the and Russia. Duke of Wellington to undertake a special mission to St. Petersburg. His object was twofold: to adjust, if possible, the outstanding difficulties between Russia and the Porte, and thus to avert the war, which at any moment in the last four years might have been regarded as imminent; and to arrive at a common understanding with Russia on the Greek Question.

The For it was hardly possible that the great Powers could Power' and Greece. much longer hold aloof. Metternich, indeed, never wavered for an instant from the attitude which he bad from the first assumed: the Greeks were rebels against legitimate authority, and must be left to their fate. Prussia still adhered to the policy of Austria. In France, however, the Philhellenist sentiment was not powerless; and in England and Russia it might at any moment get beyond the control of the respective governments. More particularly was this the case after Ibrahim's devastating conquest in the Morea. Ibrahim has been described as a 'savage'; and if he was not that, it must, at least, be admitted that his methods of warfare were exceedingly repugnant to Western ideas. Noreover, an ugly rumour had got abroad that Ibrahim had formed a plan to carry off into slavery all the Greeks whom he did not exterminate, and having made of the Morea a desert to repeople it with submissive fellaheen. The Porte found it necessary to repudiate the report. But 
the report was more impressive than the repudiation. Nothing did so much to excite the sympathies of the Philhellenes in Western Europe, or to hasten the halting paces of diplomacy. Camning, indeed, regarded the rumour, first communicated to him by Prince Lieren, as incredible. But towards the end of 1825 he had appointed to the Embassy at Constantinople his cousin, Stratford Canning; a man destined to fame as Lord Stratford de Redcliffe. The first Reports sent home by the new ambassador' were a cautions confirmation of Prince Lieven's account. 'If the statements which had reached Mr. S. Canning were true, Ibrahim then acted on a system little short of extermination ... and there was room to apprehend that many of his prisoners had been sent into Egypt as slares, the children, it was asserted, being made to embrace the Mahommedan Faith.'

Stratford Camning was instructed to satisfy himself as to Camming's the facts, and, if they should correspond with the rumour, 'to declare in the most distinct terms to the Porte that Great Britain would not permit the execution of a system of depopulation'. More than that, a naval officer was to be dispatched from the Mediterranean fleet direct to Ibrahim, and to give 'the Pasha distinctly to understand that unless he should in a written document distinctly disavow or formally renounce... the intention of converting the Morea into a Barbary State, by transporting the population to Asia or Africa and replacing them by the population of those countries, effectual means would be taken to impede by the intervention of his Majesty's naval forces the accomplishment of so unwarrantable a project'.

Meanwhile the Duke of Wellington had, with some diffi- England culty, brought the Tsar Nicholas into line with Camning's and policy on the Greek Question; had secured his promise to 'co-operate with Great Britain to prevent the execution of the designs imputed to Ibrahim Pasha'; and on April 4, 1826, had concluded with him the Protocol of St. Petersburg.

By this treaty the two Powers, renouncing any 'augmenta- Protocol tion of territory, any exclusive influence', or any superior st. Peterscommercial advantages for themselves, agreed to offer their burg, 
April, mediation to the Porte. Greece, though continuing to pay 1826. tribute to the Porte, was to become a virtually independent State, to be governed by authorities chosen by itself, and to enjoy 'entire liberty of conscience and commerce'. 'To prevent collisions in the future the Turks were to evacuate Greece, and the Greeks were to 'purchase the property of the Turks ... on the Grecian continent or islands'.

Russia This protocol must be regarded as a conspicuous personal and Turkey. trimmph for Canning. And it went a long way to settle the Greek Question. But as to the outstanding questions between Turkey and Russia it did nothing: and on these the mind of the Tsar Nicholas was bent. Though professing his readiness to treat of the matter with Wellington, the Tsar had already (March 17, 1826) dispatched an ultimatum to the Porte. The ultimatum demanded the immediate evacuation of the principalities; the abandonment of the appointment of the 'Beshlis' or police; and the instant dispatch of plenipotentiaries to the Russian frontier.

These demands the Porte was not in a position to refuse. A critical moment in the domestic history of the Ottoman Empire had indeed arrived. The marvellous expansion of that empire in the fifteenth and sixteenth centuries had been largely due to the Corps of Janissaries. The decay of the empire in the seventeenth and eighteenth centuries had been coincident with their deterioration. Of late years the whilom defenders of the empire had degenerated into oppressive and obstructive tyrants. Without their concurrence no real reforms conld be effected, and that concurrence was invariably withheld.

Mahmud To Mahmud II, the greatest of the Sultans since Suleiman II and the the Magnificent, it seemed that the time had come to make extinction of the Janissaries.

a final choice; either he must be content to see the authority of the Sultan crumble and the empire perish, or he must by one bold stroke destroy the jealous military oligarchy which had become as ineffective in the field as it was obscurantist and tyrannical in domestic affairs. He had himself crushed the Wahabites; his vassal Mehemet Ali had exterminated the Mamelukes of Egypt; why should Mahmud hesitate to strike down the Janissaries? They were not, it seemed, 
equal even to the task of subduing the infidel insurgents in Greece. That Moslems could still fight when armed and disciplined on a European model Ibrahim had clearly demonstrated in the Morea. Small wonder that the contrast between his own troops and those of his vassal was too galling to Mahmud's pride to be endured, or that he resolved to remove the principal obstruction in the path of reform.

A great Council of State decreed that, in order to subdue the infidels, the military system of the empire must be completely reorganized. The Janissaries were ordered to submit to a new discipline. They refused; and broke out into rebellion.

Their mutiny had been foreseen, and every preparation had been made to quell it. A force of 14,000 artillerymen, splendidly equipped with guns, with a corresponding force of infantry drawn from Asiatic Turkey, had been assembled in the neighbourhood of the capital. The command of the artillery was entrusted to Ibrahim, a general of known devotion to the person of the Sultan, and of unquenchable resolution. Ibrahim, or Kara Djehennin ('Black Hell') as he came, after the great day, to be called, had made all necessary dispositions for street fighting of a severe character. As the Janissaries advanced on the palace they were mown down by the gunners: they then fled to their own barracks, which were battered with shell-fire until the whole body of the Janissaries of Constantinople had perished in the blazing ruins of the Etmeidan.

The blow struck in Constantinople was repeated in every city of the empire where there existed a body of Janissaries. Thus was the Sultan at last master in his own house and free to carry out the reforms indispensable to its preservation.

A comprehensive scheme of military reorganization was Mroltke's promptly initiated, and a great military critic has put on record opinion of his opinion that 'if'Turkey had enjoyed ten years of peace after reforms. the destruction of the Janissaries, Sultan Mahmud's military reforms might in that time have gained some strength; and, supported by an army on which he could depend, the Sultan might have carried out the needful reforms in the administration of his country, have infused new life into the dead 
branches of the Ottoman Empire, and made himself formidable to his neighbours'. ${ }^{1}$

'The 'Ten years of peace.' The war with Greece still continued ; Treaty of and, although Ibrahim's intervention had relieved the pressure
Akerman, Oct. on one side, it stimulated activity on the other. The new 7, 1826. Tsar would brook no delay. The last day permitted for a reply to his ultimatum was October 7 , and on that day the Convention of Akerman was signed. By that Convention the Sultan made, as we have already seen, large concessions in regard to Serbia and the principalities, and in all things submitted to the will of the Tsar.

Turkey As regards Greece, on the other hand, the Porte, in the and Greece. full tide of successful barbarity, showed no signs of accepting mediation mless backed by force. Greece had already formally applied for it. Accordingly, in September, 1826, Camning proposed to the Tsar common action to enforce mediation upon the Sultan. The two Powers agreed to intimate to the Sultan, if lie remained obdurate, that 'they would look to Greece with an eye of favour, and with a disposition to seize the first occasion of recognizing as an independent State such portion of her territory as should have freed itself from Turkish dominion'.

Every effort was made to bring the other Powers into line ; Metternich, however, left no stone unturned to frustrate Canning's policy, even to the extent of using backstairs influence to create mistrust between the Court and the Cabinet. Prussia followed Metternich's lead, but France concluded with Russia and Great Britain the Treaty of London (July, 1827).

The The public articles of the treaty were substantially Treaty of identical with the terms of the Protocol of St. Petersburg,
London (1827). in accordance with which an 'immediate armistice' was to be offered to the belligerents. A secret article provided that the Porte should be plainly informed that the Powers intend to take 'immediate measures for an approximation with the Greeks' ; and that if within one month 'the Porte do not accept the armistice ... or if the Greeks refuse to execute it' the High Contracting Powel's should intimate

1 Moltke, p. 456, quoted by Creasy, op. cit., p. 506. 
to one or both parties that 'they intend to exert all the means which circumstances may suggest to their prudence to obtain the immediate effect of the armistice ... by preventing all collision between the contending parties... without, however, taking any part in the hostilities between them'. It was further provided that 'instructions conformable to the provisions above set forth' should be sent 'to the admirals commanding their squadrons in the seas of the Levant'.

This treaty may be regarded as the crown of Camming's Camning's policy in regard to the Eastern Question. The principles of that policy are clear; the Powers could not ignore the struggle of Greece for independence: ' a contest so ferocious (as Canning wrote to Lieven), leading to excesses of piracy and plunder, so intolerable to civilized Europe, justifies extraordinary intervention, and renders lawful any expedients short of positive hostility.' On the other hand, they could not consistently interfere by force; nor must the Russian Tsar be permitted to utilize the Greek struggle, for which he cared little, to attain objects for which he cared much. This policy is clearly reflected in the terms of the Treaty of London; but its practical application was not free from difficulty and ambiguity. The Porte was notorious for sullen obstinacy. How were the 'high contracting parties', in the all too probable event of a refusal of an armistice by the Porte, to 'prevent all collision between the contending parties without taking any part in the hostilities'? Either the matter had not been clearly thought ont, or there was a deliberate intention to leave the Gordian knot to be cut by the Executive Officers of the Powers, i.e. 'the admirals commanding their squadrons in the seas of the Levant'. Canning was obliged to move warily; but that he himself contemplated the employment of force is clear from the Duke of Wellington's condemnation of the Treaty of London on the ground that 'it specified means of compulsion which were neither more nor less than measures of war'.

In August, 1827, the mediation of the three Powers was offered to the 'contending parties', was accepted by the Greeks, and refused by the Porte. 
The game now passed from the hands of diplomatists into those of sailors. The British fleet in the Levant was under the command of Sir Edward Corlrington. Codrington received his instructions on August 7 ; but, not being a diplomatist, he found them difficult of interpretation. How was he 'to intercept all ships freighted with men and arms destined to act against the Greeks, whether coming from Turkey or the coast of Africa', and, at the same time, prevent his measures from 'degenerating into hostilities'? In a word, was he, or was he not, to use force? Such was the blunt question which he addressed to our ambassador at Constantinople. Stratford Canning's answer was unequivocal : 'the prevention of supplies is ultimately to be enforced, if necessary, and when all other means are exhausted, by cannon shot.'

Battle of Navarino.

Meanwhile large reinforcements from Egypt had reached Ibrahim who was still in the Morea; and a squadron of Turkish and Egyptian ships was lying in Navarino Bay. Ibrahim was informed that not a single ship would be allowed to leare the harbour, and on making one or two attempts to sail he found that the admirals were determined to enforce their commands. Foiled in his attempt at naval operations, and instructed by the Porte to prosecute the war on land with all possible energy, Ibrahim proceeded to execute his orders with merciless severity. All who were found in arms were put to the sword, while the miserable survivors were to be starved into submission by the total destruction of every means of subsistence. 'It is supposed', wrote one eyewitness, Captain Hamilton, ' that if Ibrahim remained in the Morea, more than a third of its inhabitants would die of absolute starration.' Of these atrocities the allied admirals were all but eyewitnesses. 'Continual clouds of fire and smoke rising all round the Gulf of Coron bore frightful testimony to the devastation that was going on.' The admirals thereupon determined to "put a stop to atrocities which exceed all that has hitherto taken place', and for this purpose to sail into Navarino Bay, and there renew their remonstrances with Ibrahim. No hostilities were intended 'unless the Turks should begin'. The Turks, however, fired on a boat from the Dartmouth; the Dart- 
mouth and the French flagship replied; the battle became general ; and before the sun went down on October 20 the Turco-Egyptian ships 'had disappeared, the Bay of Navarino was covered with their wrecks'.

The news of the battle of Navarino was received with Reversal amazement throughout Europe, but by the English Govern- of Canment with something like consternation. The sailors had Policy. indeed cut the Gordian knot tied by the diplomatists, but they got no thanks in England for doing it. Canning had died two months before the battle of Nararino (August 8), and Wellington, who, after five months' interval, succeeded to his place, made no secret of his dislike of Canning's policy. The Turk, with consummate impudence, described Nararino as a 'revolting outrage', and demanded compensation and apologies. Eren Wellington was not prepared to go this length, but the king was made (January 29, 1828) to "lament deeply' that 'this conflict should have occurred with the naval forces of an ancient ally', and to express 'a confident hope that this untoward event will not be followed by further hostilities'.

The one anxiety of the new Govermment was to preserve Wellingthe independence and integrity of the Ottoman Empire. No ton's language could have been more nicely calculated to defeat this object. Turkey was, of course, encouraged to persist in her attitude towards Greece, and to renew her quarrel with Russia. Russia was permitted, and even compelled, to engage single-handed in war with the Turks. Thus all the fruits of years of diplomacy on Canning's part were carelessly dissipated in a few months by his successor's.

Sultan Mahmud had meanwhile denounced the Convention Russoof Akerman, and had declared a Holy War against the Turkish infidel (December 20, 1827). Russia, though with ample professions to the Powers of complete disinterestedness, accepted the challenge, and on April 26, 1828, the Tsar Nicholas formally declared war. In May, 1828, the Tsar himself took the field, crossed the Pruth at the head of an army of 150,000 men, and again occupied the principalities. About the same time the Russian flect entered the Dardanelles.

Neither France nor England was quite happy about the 
The action of the Tsar, nor disposed to confide the settlement of

Powers and

Greece. Near Eastern affairs to his hands exclusively. Consequently, in July, 1828, while the Turks, to the amazement of Europe, were holding the Russians in the Balkans, the two Western. Powers concluded a protocol, providing for immediate action against Ibrahim in the Morea. England, less jealous of. France than France was of her, confided the execution of the protocol to France. Accordingly, at the end of August, a French force of 14,000 men under the command of General Maison reached the Gulf of Corinth. The English consul offered some objection to their landing, on the ground that Sir Pulteney Malcohm, the English admiral, was, at that moment in Egypt, negotiating with Mehemet Ali for the withdrawal of the Egyptian forces from the Morea. Malcolm's mission was successful, and a convention was signed in Alexandria to that effect on August 6.

Meanwhile 14,000 French troops landed at Petalidi in the Gulf of Coron and arranged with Ibrahim for an immediate eracuation of the Morea. The good accord thus established between the French and the Egyptian Pasha was not, perhaps, without its influence on later events. ${ }^{1}$ Ibrahim had, however, surrendered the fortresses, not to the French, but to the Turks. The latter quitted them on the summons of the French general; Navarino, Coron, Patras, Tripolitza, and Modon were occupied by the French, virtually without resistance, and in a few days the Morea was entirely free of both Egyptian and Turkish forces.

A protocol concluded in London (November 16, 1828) placed the Horea and the islands under the protection of the Powers, and a further protocol (March 22, 1829) provided that Greece was to be an autonomous but tributary State, governed by a prince selected by the Powers, and that its frontier should rim from the mouth of the river Aspro, on the west coast, to the Gulf of Volo on the east.

Russia and Turkey.
Russia, meanwhile, was finding in the Porte a tougher antagonist than she had looked for. In the Cancasus, indeed, the Russians carried everything before them, but in Europe 
their progress in 1828 was very slow. Varna held them up for three months and Choumla for three more.

In 1829 Diebitsch was entrusted with the supreme command, and for the first time Russian troops crossed the Balkans. Leaning on his fleet, Diebitsch adranced with little resistance, by way of Burgas, upon Adrianople. Adrianople surrendered without firing a shot on August 14, and a month later the Treaty of Adrianople was signed.

In the long history of the Eastern Question the Treaty of Treaty of Adrianople is inferior only in importance to those of Kainardji Adriaand Berlin. Russia restored her conquests, exeept the 'Great Sept. 14, Islands' of the Danube; but her title to Georgia and the ${ }^{18 \% 9 .}$ other provinces of the Caucasus was acknowledged; all neutral vessels were to hare free narigation in the Black Sea and on the Danube; practical antonony was granted to the principalities of Moldaria and Wallachia under Russian protection; Russian traders in Turkey were to be under the exclusive jurisdiction of their own consuls, and, in regard to Greece, the Porte accepted the Treaty of London-thus virtually acknowledging Greek independence.

The actual settlement of the affair's of Greece was relegated The to a conference in London, and by the Protocol of London of the (February 3, 1830) Greece was declared to be an indepen- Hellenes. dent and monarchical State under the guarantee of the three Powers. This arrangement was confirmed and enlarged by the subsequent Convention of London (May 7, 1832), by which the Powers further undertook jointly to guarantee a loan of $60,000,000$ franes to the Greek kingdom. ${ }^{1}$

It was comparatively easy for the protecting Powers to declare that Greece should be a monarchical State; it was more difficult to find a suitable monareh, and most difficult of all to educate the Greek people in that purely exotic and highly exacting form of government known as 'constitutional monarchy'. The Crown having been successively deelined by Prince John of Saxony and, after a temporary acceptance, by Prince Leopold of Saxe-Coburg (afterwards King of the Belgians), was ultimately accepted by Prince Otto of Bavaria.

1 The texts of these important documents will be found in Hertslet, Map of Europe by Treaty, rol. ii, pp. 841 and 893 sq. 
Capo d'Istria, who, in March, 1827, had been recalled from voluntary exile in Switzerland, and had been elected President by a National Assembly in Greece, was assassinated in 1831, and the way was clear for the Bavarian princeling, who, at the age of seventeen, ascended the Greek throne on January 25, 1833.

The Treaties of Adrianople and London, and the accession of King Otto, mark the final achievement of Greek independence, and bring to a close one of the most significant chapters in the history of the Eastern Question. For the first time the principle of nationality had asserted itself in a fashion at once completely successful and striking to the historical imagination. For the first time the future of the Ottoman Empire was recognized as a matter of profound concern not merely to the Porte itself, to Russia and to Austria, but to Europe as a whole, and not least to Great Britain. For the first time an Ottoman Sultan of exceptional vigour and disposed to reform had been compelled to call to his aid an ambitious vassal, and despite that assistance to consent to terms of peace dictated by the Powers and involving the partial dismemberment of his European dominions. Plainly, Europe was face to face with all the perplexities, paradoxes, and contradictions which contribute to the tangle of the Eastern Question.

For further reference: T. Gordon, History of the Greek Revolution, 2 vols. (London, 1832); A. von Prokesch-Osten, Geschichte des Abfalls der Griechen vom türkischen Reiche im Jalire 1821, 6 vols. (Vienna, 1867); G. Finlay, History of Greece, 7 vols. (ed. Tozer) (Uxford, 1877); The History of the Greek Revolution (Edinburgh, 1861); G. Isambert, L'Indépendance grecque et l'Europe (Paris, 1900); W. A. Phillips, The Greek: Wrar of Independence (Lon ton, 1897); W. E. Gladstone, The Hellenic Factor in the Eastern Problem (Gleanings from Past Years, Series iv, Lonton, 1879); W. Miller, The Ottoman Empire (Cambridge, 1913); E. M. Church, Sir Richard Church in Greece and Italy (Edinburgh, 1895); L. Sargeant, Greece in the Nineteenth Century (London, 1897); Murray, Handbook to Greece. 


\section{CHAPTER IX}

\section{THE POWERS AND THE EASTERN QUESTION, $1830-41$}

\section{Menemet Ali of Egypt}

'L'Égypte vaut moins par elle-même que par sa situation. . . Q Qui touche à l'Egypte touche à la Turquie. Qui soulève la question d'Égypte soulève la question d'Orient, dans toute son ampleur et avee toutes ses conséquences.'-C. DE FreYcinet, La Question d'Égypte.

IT is proverbially dangerous in public affairs to confer a favour ; it is even more dangerous to accept one. Never has there been a more apt illustration of this truth than that afforded by the curious phase of the Eastern Question which it is the purpose of this chapter to disclose.

Had it not been for the intervention of the Powers, Mahmud Mehemet Ali of Egypt and Ibrahim Pasha would indubitably II and have rescued the Ottoman Empire from imminent dismember- Ali. ment. Such a service it was difficult for the recipient to requite, and still more difficult to forgive. Mehemet Ali, on his part, was not disposed to underrate the obligations under which he had placed his suzerain, and the cession of Crete seemed to him a wholly inadequate reward. In the disgust thus engendered we have one of the clnes to the intricacies of the period which intersened between the Treaty of Adrianople and the Treaty of London of 1841.

Recent events had, moreover, revealed the weakuess, military, naval, and political, of the Ottoman Empire. If Greece, an integral part of his European dominions, could so easily be detached from the sceptre of the Sultan, why not other parts of the empire, connected with Constantinople by a looser tie? Algiers, which still acknowledged the titular sovereignty of the Sultan, had been seized in 1830 by the French, who had proclaimed their purpose to deliver that 
promising land from the yoke of the Ottoman Sultan. If Algiers, why not other parts of Africa or of Asia?

Career of Mehemet Ali.

The extraordinary success already achieved by Mehemet Ali might well inspire that brilliant barbarian-half an illiterate savage, half a consummate statesman, wholly a genius-with ambitions even more far reaching.

Born in 1769 at Kavala, a small seaport in eastern Macedonia, Mehemet Ali was, like Ali Pasha of Janina, by race an Albanian. The son of a peasant cultivator he was himself a small trader, but Napoleon's invasion of Egypt in 1798 gave him his chance of carving out a career for himself. It was not neglected. As second-in-command of a regiment of Albanian irregulars, he took part in the Turkish expedition to Egypt, which began and ended so disastrously with the battle of Aboukir. Driven into the sea with his comrades he was picked up by the gig of the English admiral, Sir Sydney Smith, and two years later (1801) he returned to Egypt in command of his regiment.

Mehemet Ali was greatly impressed by the military superiority of troops trained on European models, and still more impressed of the career open, in such times, to a man of genius like Napoleon or himself. After the successive eracuations of the French and English Egypt was in a terrible condition of anarchy. The Mameluke Beys were as independent of their suzerain the Sultan as they were impotent to rule the Egyptians.

Pasha of In the prevailing confusion Mehemet Ali saw his chance; Egypt. he determined to stay in Egypt, and in 1805 was requested by the Sheiks of Cairo to become their Pasha. A little later the choice of the Sheiks was confirmed by the Sultan (July 9, 1805).

Nor was Mehemet Ali long in justifying it. The Sultan, in 1806, was forced by Napoleon to declare war upon the Third Coalition, and in 1807 England made the disastrous descent upon Egypt already described. ${ }^{1}$ The moment was not ill chosen. The Pasha was preoccupied with domestic difficulties, but on receiving news that the English had taken Alexandria, 
and were advancing upon Rosetta, Mehemet Ali did not lose an hour. He hastily collected his forces, marched northwards, and flung back the English, who were besieging Rosetta, with terrible loss upon Alexandria. The attempt to take Rosetta was repeated with equally disastrous results, and in September the English force was withdrawn. All traces of this humiliating episode are now erased; is the memory of it also eradicated?

'Few who nowadays drive by the Ezbekich garden are aware', writes Sir Auckland Colvin, 'that the space which it covers was hideous less than a century ago with the heads of British soldiers.' 1

Having repulsed the English attack, the new Pasha concentrated all his energies upon the accomplishment of his life-work in Egypt. That work owed much to French ideas and to French agents. Napoleon, when he went to Egypt in 1798 , was accompanied not only by great soldiers but by a brilliant staff of scientific experts, administrators, engineers, and financiers. Their work was less evanescent than that of their ehief. And no one knew better how to appreciate the skill of subordinates than the 'illiterate savage' who, between 1805 and 1849, was the real ruler of Egypt. Still, though Mehemet Ali utilized the technical skill of French soldiers, sailors, engineers, finaneiers, jurists, and agriculturists, the work aceomplished was his own, and bears in every detail the mark of a vigorous mind and a dominating personality.

There was no obscurity as to the objects which he meant objects of to attain. The first was to make himself master of Egypt: Melhemet

to annihilate ruthlessly every competing force or authority in the land; to concentrate in a single hand all the economic resourees of the country, and to make of the army and navy an instrument perfectly fashioned for the accomplishment of the task to which it was destined.

The task was threefold: to make Egypt supreme over the adjacent lands, the Soudan and Arabia; to render it virtually independent of the Sultan; and to use it as a stepping-stone to the conquest of Syria, perhaps of Asia Minor, and possibly 
of the Ottoman Empire as a whole. Was not the vigour of the Osmanlis exhausted; had not the time come to replace the house of Ottoman by a dynasty drawn from the virile races of Albania? But the question as to the future of Constantinople was not immediate. Mehemet Ali was enough of a diplomatist to realize the international advantages which for the time being he enjoyed as a vassal of the Sultan. Slight as was the connexion which bound him to his suzerain, it sufficed to ward off many inconveniences which might otherwise have arisen from the mutual jealousies of the Powers. His successors in the government of Egypt have sometimes made use of the same fiction to their advantage.

Military His first business, then, was to reorganize the army and and Naval navy. A brilliant French officer, Colonel Sèves, better known zation. as Suleiman Pasha, entirely reconstructed the Egyptian army: he introduced a new method of recruiting by which the army establishment was raised from 20,000 to 100,000 men; he set up special schools of military instruction; applied to Egyptian troops European discipline, and supplied them with arms and equipments of the most approved French pattern. The navy was similarly rebuilt by M. de Cérisy, a naral constructor imported from Toulon, while the armament was supplied and the sailors trained under the direction of a French engineer, M. Besson, of Rochefort. One fleet was stationed in the Mediterranean and another in the Red Sea, and at Alexandria a magnificent dockyard and arsenal were constructed.

Economic Nehemet Ali applied himself not less vigorously and and fiscal reforms. systematically to the work of economic reconstruction.

By an act of sheer confiscation the land was 'nationalized', the proprietors were expropriated, and Mehemet Ali himself became the sole owner of the soil of Egypt. Most of the principal products of the country were, in similar fashion, converted into State monopolies. New industries were established: under the scientific direction of M. Jumel cotton growing was developed in the Delta, and vast tracts of land yielded abundant crops of sugar, olires, and mulberries. Nor did raw products monopolize his attention. Factories were built, though with less remunerative results, and Egyptian 
youths were sent to western lands to extract from them the secrets of commercial and industrial success. The Mahmudiya Canal was constructed by the forced labour of the fellaheen to comnect Alexandria with the Nile. During the accomplishment of this useful but laborious task 20,000 workmen are said to have perished of dysentery, but of human life Mehemet Ali was prodigal. Not that he neglected sanitary science. It was part of the equipment of a modernized State, and must, therefore, find its place in his scheme of reform. Thus Alexandria was rebuilt and provided with a new water supply. Similarly in regard to education. Mehemet Ali is said not to have been able to read or write, ${ }^{1}$ but the modern State demanded education; Egypt, therefore, must have it. These things, as modern States have learnt to their cost, cannot be done without money, and the taxation imposed by Mehemet Ali was crushing. Combined with the system of State monopolies heavy taxation had the effect of raising prices to an almost incredible extent, ${ }^{2}$ and the sufferings of the fellaheen were consequently intense. It is, indeed, true of many of Mehemet Ali's economic reforms that they were more productive of immediate advantages to the ruler than conducive to the ultimate prosperity of his people; but not of all. Many works of permanent utility were carried out, and not until the British occupation did Egypt again enjoy an administration equally enterprising and enlightened.

Mehemet Ali's enterprise was, however, that of a savage Massacre despot. His dealing with the Mamelukes affords an illustra- of the tion of his ruthless temper. The Mamelukes had raised him lukes. to power, but they were now in his way and must be destroyed. With every circumstance of treachery and cruelty the deed was accomplished in 1811 ; the Mamelukes were wiped ont in a general massacre, and thus the last possible competitor's for political ascendancy were removed from the adventurer's path.

In the same year Mehemet Ali launched his expedition Conquest. against the Wahabites of Arabia. At the request of his of Arabia

1 Other authorities state that in midllle life he faught himself to read. Souclan.

2 Colonel Campbell, who was sent to Egypt as Consul-General in 1833, put the inerease as high as six to tenfold. 
suzerain he dispatched Ibrahim in 1811 to bring these troublesome schismatics to submission. Several years were devoted to the arduous task, but by 1818 it was accomplished : the Holy Cities of Mecca and Medina were recovered for the Sultan, and the remnant of the Wahabites were driven into the Nubian desert.

In 1821 his son Ismail penetrated to the confluence of the Niles and conquered the Soudan. Kordofan was annexed in 1822, and in 1823 were laid the foundations of Khartoum. From 1824 to 1829, as was explained in the last chapter, the military energies of Mehemet Ali were concentrated upon Europe.

For the services then rendered to Sultan Mahmud, and for the still greater service, which, but for the Powers, the Egyptian Pasha was prepared to render to his suzerain, the island of Crete was a recompense pour rive. To fulfil his promise in regard to the Morea was not within the Sultan's power; in regard to Syria it was. And Syria, at least, Mehemet Ali was determined to have.

Tbrahim 's A pretext for invasion was found in the refusal of Abdullah tion into Syria (1831-2) Pasha of Acre to surrender the Egyptian 'rebels' who had sought refuge with him. In November, 1831, a force variously estimated at 10,000 to 35,000 men was sent into Palestine under the command of the redoubtable Ibrahim. The great fortress of St. Jean d'Acre offered, as usual, an obstinate resistance, and, leaving a force to besiege it, Ibrahim occupied Jaffa, Gaza, and Jerusalem. On May 27, 1832, however, Acre was taken by storm, and on June 15 Damascus also was captured.

Tureo-

Eigrptian

Tiar

Ibrahim's progress naturally caused great alarm at Con$(1832-3)$. stantinople, but in reply to the remonstrances of the Sultan, Mehemet Ali protested his unbroken loyalty, and declared that the sole object of the expedition was to chastise the presumption of Abdullah Pasha who had 'insulted his beard whitened in the service of his sovereign'. No one was deceived by these assurances, but there were those about Sultan Mahmud, and not his least sagacious counsellors, who urged him to come to terms with his formidable vassal, and turn their combined arms against the infidel. Hatred of

I Hall, England and the Orleans Monarchy, p. 150. 
Mehemet Ali was, however, the master passion of Mahmud's declining years, and he decided, thongh not without hesitation, to send an army against him. In May, 1832, sentence of ontlawry was pronounced against both Mehemet Ali and Ibrahim, and Hussein Pasha, the destroyer of the Janissaries, was appointed to command the Turkish troops.

On July 9 Ibrahim routed the advanced guard of the Turks in the valley of the Orontes, entered Aleppo, which had closed its gates upon Hussein Pasha on July 16, and on the 29th inflicted a decisive defeat upon Hussein himself in the Beilan Pass. The Turks were thrown back in complete confusion into the Taurus Mountains, and Asia Minor was open to Ibrahim.

A second army was then dispatched from Constantinople nnder Reschid Pasha; it encountered Ibrahim at Konieh on December 21, and suffered at his hands a crushing reverse. Ibrahim advanced to Kutaya, and thence wrote to the Sultan asking permission to take up a still more threatening position at Bi'usa.

At this moment it looked as though Constantinople itself 'The would soon be at his mercy. But now, as so often, Turkey and the found in its military weakness diplomatic strength. In the Powers. summer of 1832 the Sultan had appealed to the Powers. Only the Tsar Nicholas was prompt in the offer of assistance; but to accept assistance from Russia alone was too risky a policy even in the hour of Turkey's extreme need. Yet where else was it to come from? England and Austria were unreservedly anxious to maintain the integrity of the Ottoman Empire, and Prussia followed humbly in the wake of Mettemich. England, however, was at the moment (1832) in the throes of a domestic revolution, and was still preoceupied with the affairs of Belgium. France had a traditional interest in Egypt, and in addition to this there had sprung up a curious but undeniable cult for Mehemet Ali, particularly among the Bonapartists, who regarded him as the disciple of Napoleon, almost as his apostolic successor in Egypt. Of all the Powers, therefore, Russia alone was at once anxious and able to go to the assistance of the Sultan in 1832. And not the most obtuse could be doubtful as to her motives. 
Turkey The Sultan, accordingly, made a desperate attempt to secure and England. the assistance of England. Stratford Canuing, in Constantinople, strongly urged the English ministry to accede to the Sultan's request for a naval expedition to the Syrian coast. Lord Palmerston, however, was in an unusually cautious mood, and, though generally in complete sympathy with the views of Stratford Canning was not, at the moment, willing to risk the breach with Russia and France, likely to arise from isolated action in the Levant.

Russia Russia, meanwhile, reiterated, with added empressement, and Turkey. her offers of assistance. In December, 1832, there arrived in Constantinople, simultaneously with the news of the disaster at Konieh, General Mouravieff on a special mission from the Tsar Nicholas. Mouravieff was charged to represent to the Sultan the fatal consequences likely to accrue to his empire from the phenomenal success of his Egyptian rassal, and to offer him a naval squadron for the protection of the capital. The Sultan still hesitated, however, to accept the offer, and Mouravieff, therefore, started off to Alexandria to attempt the intimidation of Mehemet Ali. The reasons for the Tsar's disquietude are not obscure. ${ }^{1}$ Not Turkey alone was threatened by the advance of Ibrahim. The rights secured to Russia by a succession of treaties were also directly jeopardized. The substitution of a virile Albanian dynasty at Constantinople in place of the effete Osmanlis was the last thing desired by the Power which wished, naturally enough, to command the gate into the Mediterranean.

Russia The most that Mouravieff could get out of Mehemet Ali and Me- . was that Ibrahim should not, for the moment, advance beyond Kutaya. ${ }^{2}$ The Sultan had, meanwhile, come to the conclusion that nothing but Russian aid could avert the ruin of his empire; he begged that not only a naval squadron might be sent to the Bosphorus, but that it might be followed by an army of 30,000 men.

1 They are fully set out in the instructions given to Mouravieff, which will be found in Serge Goriainow's valuable monograph, Le Bosphore et les Dardanelles, rp. :28-9.

${ }^{2} 150$ miles beyond Konieh, but 80 miles short of Brusa, Hall, op. cit., p. 158. 
Accordingly, on February 20, 1833, a powerful Russian Russian squadron sailed into the Bosphorus and anchored before fleet in Constantinople. Its appearance seriously alarmed both France phorus. and Great Britain, who brought pressure upon the Sultan to procure its withdrawal. The Tsar, however, refused to withdraw until Ibrahim and his army had recrossed the Taurns Mountains.

Until his demands were conceded Mehemet Ali would issue no such orders to Ibrahim. Those demands included the cession of the whole of Syria, part of Mesopotamia, and the very important port and district of Adana. In March the Sultan agreed to the cession of Syria, Aleppo, and Damascus, but the Pasha stood out for his pound of flesh.

The arrival of a second Russian squadron in the Bosphorus Convenand the landing of a Russian force at Scutari caused still tion of further alarm to the Western Powers, and did not perhaps diminish that of the Sultan. A prolongation of the crisis seemed likely to result in the permanent establishment of Russia at Constantinople. France and England, therefore, applied further pressure both to Mehemet Ali and his suzerain. At last the latter yielded, and on April 8, 1833, there was concluded the Convention of Kutaya, by which Mehemet Ali's terms were conceded in full.

But the drama was not yet played ont. Mehemet Ali had Treaty of been bought off; the debt to Russia remained to be discharged. SnkiarSo Russia took further security. On April 22 a third con- July 8, tingent of Russian troops arrived at Constantinople, and Russian engineers proceeded to strengthen the defences of the Bosphorus and the Dardanelles. Against what enemy? On the heels of the third Russian contingent came Count Alexis Orloff' to take up his appointment as 'AmbassadorExtraordinary to the Porte, and Commander-in-Chief of the Russian troops in the Ottoman Empire'. At the end of April Count Orloff made a State entry into his new kinglom,

1 The instructions given to Orloff aro of supreme interest. They are now printed, in extenso, in Goriainow, op. cit., p. 33 seq. Orloff was to (i) induce the Porte to confide absolutely in the support of Russia; (ii) combat Irench influence at Constantinople; (iii) conciliate the support of Austria and neutralize the perpetual ill will of England by making it 
and after two months of tiresome negotiations he received the title-deeds under the form of the Treaty of UnkiarSkelessi (July 8, 1833).

This famous treaty marked the zenith of Russian influence at Constantinople. In effect, it placed the Ottoman Empire under the military protectorship of Russia. The six public articles simply reaffirmed, in platonic terms, the relations of peace and friendship between the two empires, though the Tsar of Russia pledged himself, should circumstances compel the Sultan to elaim his help, to provide such military and naval assistance as the contracting parties should deem necessary. Reciprocal assistance was promised by the Sultan. The real significance of the treaty was contained in a secret article, which released the Sultan from any obligation to render assistance to Russia, save by closing the Dardanelles against the ships of war of any other Power. The precise meaning to be attributed to this stipulation was disputed at the time, and has been the subject of controversy ever since. But Count Nesselrode was clearly not guilty of an empty boast when he declared that the treaty 'legalized the armed intervention of Russia'. It did more. It guaranteed to Russia a free passage for her warships through the straits, and it closed the door into the Black Sea to every other Power. The day after the treaty was signed the Russian troops re-embarked, and the Russian nary sailed back to Sebastopol.

The The conclusion of this treaty excited the liveliest appre-

Powers and the Treaty. hensions in England and France. In Lord Palmerston's view its terms were inconsistent with the Anglo-Turkish Treaty of 1809 , by which 'the passage of ships of war through the straits is declared not allowable'.' The English fleet in the Levant, under the command of Sir Pulteney Malcolm, was reinforeed and sent up, with a French squadron, to Besika

clear that the sole object of Russian intervention was to preserve the Ottoman Empire; (iv) reserve to Russia complete independence of action, and resist any proposal for collective intervention; (v) keep the Russian forces at Constantinople until the conclusion of a definitive peace between 'i'urkey and Mehemet Ali, and, above all, convince Mahmud that in the support of Russia lay his one hope of salvation.

1 Palmerston to Temple, Oct. 8, ap. Bulwer, Lie, ii. 171. 
Bay. England and France presented identical notes at St. Petersburg and Constantinople protesting against the proposed violation of the neutrality of the straits, and things looked like war between the maritimes and Russia.

None of the Powers, however, lesired war. Metternich interposed his good offices, and the Tsar was induced to give a verbal assurance that he had no intention of enforcing the rights conferred upon him by the Treaty of Unkiar-Skelessi. For the moment the assurance was accepted, but Palmerston made up his mind that at the first convenient opportunity the treaty itself should be tom up.

In September a conference was held between the T'sar, Conventhe Austrian Emperor, and the Crown Prince of Prussia Yion of at Münchengrätz. Its outcome was a formal Convention grätz. (September 18, 18.33) between Russia and Austria, by which the two Powers mutually undertook to oppose any extension of the authority of the Egrptian Pasha over the European provinces of the Ottoman Empire, and agreed that, should their efforts fail to maintain the integrity of that empire, they would act in the closest concert in regard to future dispositions. The second provision, as Goriainow ${ }^{1}$ points ont, was studiously vague: the first was precise. Sultan Mahmud nearly proroked a renewal of the troubles by shuffling about the cession of Adana, but eventually gare way, and by the beginning of 1834 the first phase of the Egyptian crisis was at an end.

The diplomatic fires were only smouldering. Sultan Troubled Mahmud was eager to be revenged upon his detested situation rival in Egrpt, and in particular to recover Syria ; between England and France there was increasing suspieion and tension; while the Tsar Nicholas made no secret of his dislike for the Orleanist Monarehy in France, and his contempt for the policy pursued by its ministers. By 1838 events seemed hastening towards a renewed war in the Near East. The Sultan had invoked the help of Prussia in the reorganization of his army, and Prussia had lent him the services of a young officer, destined to fame as the conqueror of Austria and 
France, Helmuth von Moltke. By the conclusion (August 19, 1838) of a commercial treaty with England, the Sultan not only drew closer the ties between that country and himself, but at the same time, with consummate adroitness, deprived Mehemet Ali of much of the advantage derived from his commercial monopolies, and still further widened the breach between Egypt and England.

Turco- Mehemet Ali was, on his side, chafing under the reEgyptian strictions imposed upon him by the Convention of Kutaya, $(1839-41)$. and was restrained from declaring his formal independence only by the pressure of the Powers. In Syria, however, his rule proved to be as unpopular as it was tyrannical, a fact which encouraged the Sultan in his resolution to delay his revenge no longer. The Powers did their utmost to dissuade him; Moltke warned him that the army was not ready; but Mahmud wonld listen to no counsels of prudence, and in the spring of 1839 the war for the reconquest of Syria began. The issue was disastrous. In April, 1839, a large Turkish force crossed the Euphrates, and on June 24 it was routed by Ibrahim near Nessib, on the Syrian frontier. Nearly 15,000 prisoners were taken, and almost the whole of the Turkish artillery and stores fell into his hands. His victory was complete and conclusire.

Death of Before the news could reach Constantinople the old Sultan Sultan Mahmud. died (June 30), with rage in his heart and curses on his lips. He was succeeded by his son, Abdul Medjid, a youth of sixteen. Tothing could have been darker than the prospects of the new reign. Close upon the news of the disaster at Nessib came tidings of treachery in the fleet. The admiral, Ahmed Pasha, had carried off the Turkish fleet to Alexandria, and had surrendered it to Mehemet Ali.

The young Sultan promptly opened direct negotiations with the Egyptian Pasha. The latter demanded that the hereditary government of both Egypt and Syria should be secured to him, and the Sultan seemed disposed to acquiesce, when the Powers intervened.

Collective On July 27, 1839, the Powers presented a collective note Note of
July 27 . to the Porte, demanding the suspension of direct negotia- 
tions between the Sultan and the Pasha. To this the Sultan joyfully assented.

His assent only served to sow the seeds of discord be- Dissentween the members of the Concert. The soil was congenial. sions The government of Lonis-Philippe was lavish in encourage- l'owers. ments to Mehemet Ali. Firm alliance with the Egyptian adventurer seemed to open the prospect of a restoration of French prestige throughout the Near East. Strong in possession of Algeria, cordially united with Spain, France might even hope to convert the Mediterranean into a French lake; and, by cutting a canal through the isthmus of Suez, might neutralize the advantages secured to England by the possession of Cape Colony.

England, however, had in 1839 taken the precaution to occupy Aden, and, with the rest of the Powers, was not minded to permit the break-up of the Ottoman Empire and the substitntion of the rule of Mehemet Ali for that of a feeble youth at Constantinople. Hitherto England and France had acted in cordial co-operation in regard to the Near Eastem Question, and had to some extent succeeded in resisting the ambitions of Russia. The Tsar Nicholas now saw an opportunity of turning the tables upon the Western Powers, and in September, 1839, sent Baron Brmmow to London to make certain specific proposals to Lord Palmerston. The Treaty of Unkiar-Skelessi should be allowed to lapse; the straits be closed to all ships of war; Mehemet Ali should be restricted to the hereditary gorernment of Egypt; and Russia should go hand in hand with England towards a final solntion of the Near Eastern problem.

Lord Palmerston was naturally attracted by the prospect, Fngland, if only as a means of checking the ambitions of France. He Russia, was no more disposed to allow France to erect an exclusive France. protectorate over Egypt than he had been to sce Russia supreme at Constantinople. Of Lonis-Philippe he was at once contemptuous and mistrustful. His colleagues and his sovereign, on the other hand, were strongly averse to a rupture with France. Palmerston did not desire it; neither did he fear it. 'It is evident', he writes to Bulwer, 'the French Govermment will not willingly take the slightest step of cocrcion 
against Mehemet Ali ... anxious as we are to continue to go on with them, we are not at all prepared to stand still with them. They must therefore take this choice between three courses: either to go forward with us and honestly redeem the pledges they have given to us and to Europe; or to stand aloof and shrink from a fulfilment of their own spontaneous declaration; or lastly, to go right about and league themselves with Mehemet Ali, and employ force to prevent us, and those other Powers who may join us, from doing that which France herself is bound by every principle of honour and every enlightened consideration of her real interests, to assist us in doing, instead of preventing from being done.' ${ }^{1}$

As to the future of Turkey, Palmerston was far from pessimistic. 'All that we hear about the decay of the Turkish Empire, and its being a dead body or a sapless trunk, and so forth, is pure and unadulterated nonsense.' Given ten years of peace under European protection, coupled with interual reform, there seemed to him no reason why 'it should not become again a respectable Power'. For the moment two. things were essential : Mehemet must be compelled 'to withduaw into his original shell of Egypt', and the protection afforded to Turkey must be European, not exclusively Russian. These were the key-notes of Palmerston's policy in the Near East. Negotiations between the Powers were protracted, but Palmerston had the satisfaction of seeing his views prevail.

France, howerer, was excluded from the settlement. In February, 1840, Thiers had come into power in France. Thiers had always asserted the claims of France to supreme influence in the Near East with peculiar vehemence, and Palmerston soon convinced himself and the rest of the Powers that Thiers was playing exclusicely for his own hand. The policy adopted by Russia in 1833, and so recently repudiated, was to be precisely repeated on the part of France.

In order to avert a European war a sharp lesson had to be administered to Thiers. If he were allowed to persist in his course in regard to Egypt, Russia would resume her-

1 Sept. 1839. 
clains over Constantinople. The ultimate result would, therefore, be 'the practical division of the Ottoman Empire into two separate and independent States, whereof one would be a dependency of France and the other a satellite of Russia'. Only by a threat of resignation did Palmerston bring his colleagues into agrecment with himself, and on July 15, the four Powers-Russia, Prussia, Austria, and Great Britain-concluded with the Porte a 'convention for' the pacification of the Levant'.

Under this Convention the Sultan agreed to confer upon ConvenMehemet the hereditary Pashalik of Egypt, and, for his life, tion of the administration of southern Syria, including the fortress July 15, of St. Jean d'Acre, with the title of Pasha of Acre. Failing 1810. Mehemet's aeceptance within ten days, the latter part of the offer was to be withdrawn; failing acceptance within twenty days, the whole offer. The rest of the contracting Powers, Great Britain, Russia, Austria, and Prussia, agreed to force their terms upon Mehemet; to prevent sea-communication between Egypt and Syria, to defend Constantinople, and guarantee the integrity of the Ottoman Empire. ${ }^{1}$

It was, at the same time, expressly provided (Art. 4) that the naval protection of the straits against Mehemet Ali should be regarded as an exceptional measure, 'adopted at the express demand of the Sultan', and it was agreed 'that such measure should not derogate in any degree from the ancient rule of the Ottoman Empire, in virtue of which it has in all times been prohibited for ships of war of foreign Powers to enter the Straits of the Dardanelles and of the Bosphorus'.

The Treaty of Unkiar-Skelessi was torn into shreds. Two questions remained : would Mehemet Ali accept the terms to be offered to him by the Sultan? if not, could he count mpon the help of France in defying the will of Europe?

1 The full text of the Conrention in French is printed in an appendix to Bulwer's Lije of Palmeroton, ii. 420-7; also (in English) in Holland's European Concert in the Eastern Question, p1.90-7. The whole course of the preceding negotiations is described, with full references to the documents in Goriainow, op. cit., chapter $\mathrm{x}$-of course, from the Russian point of riew. 
England The Quadruple Treaty aroused profound indignation in and France.

France. For the best of reasons Palmerston had kept that country in the dark as to its impending conclusion. Had France known of it Mehemet Ali would undoubtedly have been encouraged to thwart the will of Europe, and a general war would have ensued. ${ }^{1}$

But Thiers was incensed no less at the substance of the Conrention than at the methods employed to secure it. The Citizen King and his subjects had undeniably been bowed out of the European Concert by Lord Palmerston. The will of Europe was imposed explicitly upon Mehemet Ali ; implicitly upon France. Thiers was all for defying the allied Powers. Warlike preparations were pushed on apace; the army and flect were strengthened, the fortification of Paris was begun, and for a moment it seemed probable that a great European conflagration would break out. Palmerston was quite unmored. He knew his man. He did not believe that Louis-Philippe was 'the man to run amuck, especially without any adequate motire'.2 Bulwer, therefore, was instructed to tell Thiers 'in the most friendly and inoffensive manner that if France throws down the gauntlet we shall not refuse to pick it up'. ${ }^{3}$ Palmerston's confidence in his own judgement was not misplaced. His diagnosis of the situation was accurate. LouisPhilippe knew that a European war would complicate the domestic situation in France, and might imperil his dynasty. The fiery Thiers was permitted to resign in October and was replaced by Guizot, who was at once friendly to England and anxious to preserve peace in Europe. Nehemet The task was not an easy one. In the Levant things had

the been moving fast since the signature of the Quadrilateral Powers. treaty. As a precautionary measure the British Mediterranean squadron had been ordered to cut off all communication by sea between Egypt and Syria, and a portion of it, with some Austrian frigates, appeared off Beyrout on August 11, 1840. Ibrahim was now in a dangerous position, and Mehemet Ali,

1 Palmerston's reasons are conclusively and exhaustively explained in a letter to Hobhouse printed in the English Historical Review for January, 1903.
2 'To Bulwer, July 21, 1840.
3 To Bulwer, Sept. 20, 1840. 
having virtually refused the terms required in the Convention of London, applied for protection to France. In September, therefore, the Sultan, with the approval of the four Powers, declared him to be deposed from all his governorships, and at the same time Sir Charles Napier bombarded and captured Beyrout, under the eyes of Ibrahim and the Egyptian army. Sidon was taken before the middle of October, and on November 3 the great fortress of St. Jean d'Acre, hitherto deemed impregnable, surrendered to Sir Charles Napier. Ibrahim himself had already been defeated by a force of British and Austrian marines, and Mehemet Ali at last realized that his hold upon Syria was gone for ever.

The British fleet then proceeded to Alexandria, and Mehemet Ali was compelled to yield to the will of the Powers. In return for the hereditary Pashalik of Egypt he agreed to surrender the Turkish fleet, which, since 1839, had been in his hands ; to evacuate Syria, Arabia, and Crete; and to comply with the terms set forth in the Convention of London. The Porte, now relieved of all anxiety, hesitated to fulfil its part of the bargain. Palmerston was consequently obliged to apply pressure at Constantinople, and on June 1, 1841, the Sultan issued a Firman by which, after an acknowledgement of the 'zeal and sagacity of Mehemet Ali', and a reference to the 'experience and knowledge which he had acquired in the affairs of Egypt', the government of Egypt, together with Nubia, Kordofan, Darfur, and Semnaar, was solemnly conferred upon him 'with the additional privilege of hereditary succession '. ${ }^{3}$

The Egyptian question was now settled. The European crisis was also successfully surmounted, thanks partly to the pacific disposition of Guizot and his bourgeois King, thanks even more to the incomparable self-confidence and undeviating firmness with which Lord Palmerston had conducted a series of difficult negotiations.

1 To the terms of the original Firman of Feb. 13 the Pasha had successfully objected.

2 The full text of a remarkable and historic document will he found in Holland, op. cit., pp. $110 \mathrm{~s} \mathrm{q}$. 
The

France was invited to re-enter the European Concert, and Treaty ( $f$ on July 13, 1841, a second Treaty of London was concluded
London, July 13, $18 \pm 1$. between England, Russia, Austria, Prussia, and France. The Porte recovered Syria, Crete, and Arabia; Mehemet was confirmed in the hereditary Pashalik of Egypt under the suzerainty of the Sultan; and the Powers agreed that the Dardanelles and the Bosphorus should be closed to all foreign ships of war so long as the Turkish Empire was at peace. Palmerston's triumph was complete. The claim of Russia to a protectorate over Turkey, that of France to a protectorate over Egypt was firmly repudiated; the Treaty of UnkiarSkelessi was set aside; Turkey was rescued both from the hostility of Mehemet Ali and from the friendship of Russia; the will of Great Britain was made to prevail ; the peace of Europe was secured.

With the conclusion of the Treaty of London Mehemet Ali disappears from the political stage on which for five-and-thirty years he had played so conspicuous a part. He lived until 1849, but some years before his death his mind gave way, and the actual government of Egypt was vested in Ibrahim. Ibrahim, howerer, died before his father, in 1848, and on his death the Pashalik passed to his son Abbas I.

Position The country which Mehemet had recreated became, subject of Egyl,to to the payment of an annual tribute to the Porte, completely autonomous in an administrative and economic sense. The Pasha was at liberty to conclude commercial, financial, and administrative conventions with foreign Powers; he could, by consent, vary the terms of the 'capitulations', raise loans, and set up any domestic institutions which seemed good to him. Yet the international position of Egypt was peculiar. Subject to an obligation to render military assistance when required to the suzerain, the Pasha was master of his own military establishment. With his African neighbours he could fight to his heart's content. He was prohibited from making war, without the Sultan's consent, upon any European Power ; but, obviously, no European Power could exact reparation, for any injury inflicted, from the Pasha, without a violation of international law, and offering a casus belli to the suzerain Power. The difficulties and contradic- 
tions involved in this situation were clearly revealed in the last decades of the nineteenth century, when Egypt again became the pirot of international politics.

A word seems to be required, before this chapter closes, Russis as to the relations of the two Powers which, apart from the and Ottoman Empire itself, were most intimately concerned in the events recorded in the preceding pages.

It was not until the outbreak of the Greek insurrection that Russia and Great Britain had come into contact in Near Eastern affairs. Camning laid down the principle that Russia must not be permitted to regard those affairs as her or'n exclusice concern. He, like his master Pitt, grasped the truth that Great Britain was not less interested than Russia, and much more interested than any other Great Power, in the fate of the Ottoman Empire. The Duke of Wellington, shocked by the 'untoward incident' of Navarino, deserted Camning's principles and dissipated the hard-won fruits of his diplomacy. The Tsar profited by Wellington's blunder in 1829, and was tempted to an even bolder experiment in 1833.

But Canning's mantle had fallen, in eren ampler folds, upon the shoulders of Palmerston. It was Palmerston, more definitely than Canning, who established the tradition that the actions of Russia in the Near East must be watched with ceaseless vigilance, not to say continuous jealousy. The lesson of Unkiar-Skelessi was always before his eyes. It. revealed, as he thought, the true mind of Russia. Her' real policy was not the annihilation of the Ottoman Empire, but its preservation in tutelage to herself. As a fact, Russian policy has throughont the nineteenth century halted between these two opinions.

As far back as 1802 Comt Victor placed the two alternatives clearly before his master, Alexander I: on the one hand, the policy of partition; on the other, the maintenance of a feeble power at Constantinople under a Russian protectorate.

This latter policy, as we have seen, attained the zenith of its success in the Treaty of Unkiar-Skelessi. But for the jealous vigilance of Palmerston the position then acquired 
by Russia might have been permanently consolidated. But if the lesson of 1833 sank deep into Palmerston's mind, so did that of 1840-1 make a profound impression upon the mind of the Tsar Nicholas.

Nicholas I The intellect of Nicholas may have been narrow, but it and Great was singularly acute. He frankly recognized that England
Britain. was hardly less interested than Russia in finding a satisfactory solution of the Near Eastern problem, and he endeavoured honestly, according to his lights, to assist her in the quest.

In the summer of 1844 the Tsar paid a visit to the English Court, and upon all with whom he came in contact his personality produced a pleasing impression. On public affairs, particularly those relating to the Eastern Question, he opened his mind freely to Lord Aberdeen, who was Foreign Secretary at the time, and to other statesmen in England, including the Prince Consort. The views expressed in conversation he was at pains to amplify and embody in a written memorandum. According to the account of it given by the Duke of Argyll, this singularly instructive document contained the following leading propositions: 'That the maintenance of Turkey in its existing territory and degree of independence is a great object of European policy. That in order to preserve that maintenance the Powers of Europe should abstain from making on the Porte demands conceived in a selfish interest, or from assuming towards it an attitude of exclusive dictation. That, in the event of the Porte giving to any one of the Powers just cause of complaint, that Power should be aided by the rest in its endeavours to have that cause removed. That all the Powers should urge on the Porte the duty of conciliating its Christian subjects, and should use all their influence, on the other hand, to keep those subjects to their allegiance. That, in the event of any unforeseen calamity befalling the Turkish Empire, Russia and England should agree together as to the course that should be pursued.' 1

'Nothing', as the Duke justly says, 'could be more reason-

1 Autobiography of the eighth Duke of Argyll,i.443. The Duke gives a vivid description of the Tsar. Cf. also Queen Victoricis Letters, ii. 13-23, for the impression produced on the $\mathrm{Comr}^{+}$. 
able, nothing more friendly and eren confidential towards us than this declaration of views and intentions of the Emperor of Russia.' The memorandum, so he tells us, remained in the Foreign Office, and 'was handed on by each minister to his successor', and he adds an expression of his own strong conviction that 'if the Emperor Nicholas had abided by the assurances of this memorandum, the Crimean War would never have arisen'.' Be that as it may there can be no doubt that the personal relations established by the Tsar in 1844 with English statesmen, and particularly with Lord Aberdeen, who in 1852 became Prime Minister, did predispose them to anticipate with a confidence, which was perhaps excessive, a peaceful issue to the difficulties which then arose. On the other hand, the Tsar had drawn from his conversations in London an inference, even more fatally erroneous: that under no circumstances, so long as Lord Aberdeen controlled its destinies, would Great Britain draw the sword. In these nutual misunderstandings we have, perhaps, a warning against 'amateur' diplomacy. That they were, in part, responsible for a most unhappy war cannot be denied.

With the antecedents and course of that war the next chapter will be concerned.

1 Autobiography of the eighth Duke of Argyll, i. 444.

For reference: C. de Freycinet, La Question d'Égypte (Paris, 1904) (presents the French point of riew with admirable lucidity and ample reference to documents); Major John Hall, England and the Orleans Monarchy (Smith, Eller \& Co., 1912: a valuable monograph; bien documentée); Serge Goriainow, Le Bosphore et les Dardanelles (written from the Russian documents by the Director of the Inperial Archires at St. Petersburg, and invaluable as presenting the Russian point of view); Dalling and Ashley, Life of Lord Palmerston (Bentley,1870; vol. ii consists almost entirely of original letters and documents of firstrate importance); T. E. Holland, European Concert in the Eastern Question (Clarendon Press, 1885) (invaluable for texts); Hertslet, as before. 


\section{CHAPTER $\mathbf{X}$}

\section{THE CRIMEAN WAR}

'Had it not been for' the Crimean War and the policy subsequently adopted by Lord Beaconsficld's Government, the independence of the Balkan States would never have been achieved, and the Russians would now be in possession of Constantinople.'-LORn Cromer.

'A war to give a few wretched monks the key of a Grotto.'-THIERs.

'The only perfectly useless modern war that has been waged.'Sir Robert Morier.

'The Turkish Empire is a thing to be tolerated but not to be reconstructed: in such a cause ... I will not allow a pistol to be fired.'-Tsar Nicholas.

The Near AfTER twenty years of continuous storms (1822-41) Eastern East (1841-52). Europe was permitted to enjoy a spell of unusual calm. It proved to be no more than an interlude between two periods of upheaval, but it lasted long enough (1841-52) to give the young Sultan, Abdul Medjid, an opportunity of putting his house in order.

Reforms in Turkey.

The leader of the reform party was Reschid Pasha, who had been Turkish ambassador at the Court of St. James's, and had imbibed, during his residence in London, many ideas as to the nature of political progress in the West. His efforts to apply to his own country the lessons learnt in England were warmly encouraged by Sultan Mahmud and by his successor Abdul Medjid.

The In 1839 all the grandees of the Ottoman Empire, viziers, scherif ulemas, dignitaries secular and ecclesiastical, with the of Gülhanè (1:39). diplomatic corps were summoned to the palace of Giilhanè ; prayer was offered up; the omens were consulted; a salute of a hundred and one guns was fired, and then the young Sultan proclaimed, with all possible solemnity, the issue of a Hatti-scherif, an organic Charter of Liberties, sometimes known in history as the Tansimat. The Sultan declared his fixed resolve to secure for the Ottoman Empirc the benefits 
of a reformed administration : security of life, honom, and property was to be guaranteed to every subject ; taxes were to be imposed and collected according to a fixed method; military service was to be regulated; the administration of justice was to be reformed, and something in the nature of a representative, though not an elected, council to be instituted.

The announcement of this comprehensive programme marks Army an epoch of no little significance in the history of the Otto- reform. man Empire. Nor was its execution delayed. $\Lambda$ large scheme of military reform was initiated in 1843. The army, recruited in European fashion, was henceforth to be divided into two parts: the $N$ isam, or active army, in which men were to serve for five years; and the Rerlif, or reserve, in which they were to serve for a further seven years.

Later on local government was reorganized, and a deter- Local mined attempt was made to put a stop to the farming of the Governtaxes and the gross abuses connected with that antiquated and Edufiscal system. The market for negro-slaves was abolished, cation. and the large profits accruing to the State therefrom were surrendered. Nor was education neglected. The ecclesiastical monopoly of education was restricted; a medical school and a military academy were established, and a great impulse was given to technical training by the institution of schools of commerce, science, and art.

Finally, the Sultan declared that there should be no discrimination between the several creeds: Moslems, Jews, and Christians were all to regard themselves as equally under the protection of the sovereign, children of the same father.

Sentiments so enlightened, especially when translated, however tentatively, into action, could not fail to excite alarm and proroke opposition among the obscurantist elements of the Sultan's Empire. Nor did the reactionaries lack either numbers or influence. The ulemas denounced Reschid as a giaour ; declared that the Almighty would not fail to risit with his wrath such a blasphemous violation of the Koran ; that the Hatti-scherif was contrary to the fundamental law of the Ottoman Empire, and that the attempt to put Moslem and Christian on an equality, so far from allaying discontent, 
would promote unrest among the subject populations and encourage perpetual agitation.

The latter prediction seemed, indeed, likely to be justified. Concession served to whet the appetite for reform. The war of creeds blazed out more fiercely than ever, and each sect in turn applied to its external protector : the Orthodox to the Tsar; the Catholics to France; the few Protestants to England. The quarrels of the Greeks and Latins were, as we shall see, not the least important among the many contributory causes which issued in the great European conflagration known to history as the Crimean War.

Origins of the Crimean War.

Napoleon III.

What Aristotle said of revolutions is true also of wars. The occasions may be trivial, the causes are always important. Emphatically was this the case with the Crimean War. It may be that the faggots were laid by the squabbles of the Greek and Latin monks in the Holy Land. Louis Napoleon may have applied the match to highly inflammable materials. The personalities of the 'Tsar Nicholas, of his ambassador Menschikoff, of Lord Stratford de Redcliffe, even, in another sense, of Lord Aberdeen, may have contributed to the outbreak. But to regard such things as the essential causes of the war implies a singularly superficial apprehension of the majestic and deliberate operation of historic forces. Kinglake wanted a villain for the central figure of his brilliant romance, and found him in the Emperor Napoleon. Much may be forgiven to a supreme artist, and something, as was hinted, to the disappointed suitor. ${ }^{1}$ But scientific history is compelled to look further and deeper.

That Louis Napoleon was the immediate firebrand is indisputable. In 1850 he took up with great zeal the cause of the Roman Catholics in the Near East. In 1852 M. de Iavalette, the French ambassador at Constantinople, was instructed to insist upon the claims of the Latin monks to the guardianship of the Holy Places in Palestine. 'Stated in bare terms', writes Kinglake, 'the question was whether for the purpose of passing through the building into their Grotto, the Latin monks should have the key of the chief door of the Church

1 Kinglitke is said to have been a suitor for the favours of Miss Howard, Napoleon's mistress: F. A. Simpson, Rise of Louis Napoleon, p. 162. 
of Bethlehem, and also one of the keys of each of the two doors of the sacred manger, and whether they shonld be at liberty to place in the sanctuary of the Nativity a silver star adorned with the arms of France.' 1 So stated, the question at issue seems puerile to the verge of criminal levity. But behind a question supcrficially trivial was the tradition of three hundred years of French diplomacy in the Levant. The privileged position bestowed upon France and its clients by Suleiman the Magnificent had, as we have seen, been specifcally renewed and guaranteed by the more formal Capitulations of May $28,1740 .^{2}$ Since 1740 the Latin monks had neglected their duties as custodians of the Holy Places, the Greeks had stepped into their shoes, with the tacit assent of France who had lost interest in the matter.

Louis Napoleon saw his chance. He was now on the brink of achieving his lifelong ambition. After two humiliating, but not futile, fiascoes ${ }^{3}$ the 'man of destiny' had come forward, at the precise psychological moment in 1848, and, declaring his name to be 'the symbol of order, nationality, and glory', had announced his candidature for the Presidency of the Second Republic established on the collapse of the July Monarchy. In the contest which ensued Lamartinc, the hero of February, received less than 18,000 votes; Cavaignac, who in the terrible 'days of June' had saved the State, received less than a million and a half ; the unknown man, who bore the name of Napoleon, receiver $5,434,226$. But Louis Napoleon had still to make good. He obtained a confirmation and prolongation of his Presidency by the coup détat of December, 1851, and after a second coup d'état in December, 1852, he transformed the Presidency into an hereditary empire. He relied for support fundamentally upon the peasants of France, but more immediatcly on the two highly organized forces in France, the Church and the Army. The Bourgeois Monarchy had failed to touch the imagination of France. 'La France s'ennuie', as Lamartine

1 Invasion of the Crimea, i. 46.

2 Arts. 33-6 and 82 deal specifically with Les Lieux saints.

3 At Strasburg (1836), at Boulogne (1840), the second followerl by six years' imprisonment.

$1: 24$ 
had sagaciously observed. Her prestige abroad had suffered severely from the conduct of foreign affairs under LouisPhilippe, particularly in that quarter as to which France was most sensitive-the Levant. Lord Palmerston had elbowed France out of the Concert in 1840, and had admitted her on sufferance in 1841.

France. Such a position was wholly inconsistent with the Napoleonic interpretation of 'la gloire'. That interpretation the new emperor was determined to revive. The traditions of French diplomacy dictated the direction. Nor was a personal motive lacking. With studied contempt Nicholas had refused to accord the successful conspirator the courtesy which prevailed between crowned heads: he had addressed him not as 'frère' but as 'bon ami'. The Greek monks at Bethlehem and Jerusalem were to pay for the affront put by the Tsar upon the protector of the Latins.

Russia. But if the prestige of France had suffered at the hands of Lord Palmerston, not less had that of Russia. Ever since the days of Peter the Great, Russia had set before herself two supreme objects : a virtual protectorate over the Christian subjects of the Sultan; and the domination of the Bosphorus and the Dardanelles. These objects had been practically attained when the Sultan, in 1833, signed the Treaty of Unkiar-Skelessi. That treaty Lord Palmerston had torn up.

England. For Great Britain, though tardy in realizing the significance of the Near Eastern Question to herself, was now deeply impressed with a sense of the danger to be apprehended whether from a French protectorate over Egypt or from a Russian protectorate over Turkey. To repudiate the exclusire pretensions of both Russia and France was, therefore, the key-note of English foreign policy throughout three-quarters of the nineteenth century.

Not that England asserted any exclusive claims on her own behalf. On the contrary, the principle to which she firmly adhered was that the problem of the Near East could be solved only by the Powers in Concert. That concert she has honestly endeavoured to maintain, and in maintaining it she has, to a large extent unconsciously, given room and 
opportunity for the growtl of a new and vitalizing principle, the principle of nationality.

In this diagnosis of the situation the modern reader will detect, or imagine that he has detected, a palpable onission. Yermany What, he will ask, was the attitude of the German Powers, Austria and Prussia, and of Italy? Austria was deeply interested, but preoccupied. The Habsburg dominions, German, Magyar, Bohemian, and Italian, had barely emerged from the crisis of 1848-9: the crisis which had displaced Metternich, and threatened with disruption the empire which he had so long governed. Only the intervention of the Tsar Nicholas had preserved Hungary to the Habsburgs, and though gratitude, as events were soon to prove, is not the most conspicuous attribute of the Austrian House, the policy of the young emperor was at the moment in complete accord with that of his preserver." Prussia had played no independent part in Eastern affairs since Metternich's accession to power. Italy had not yet come into being. But, as we shall see, the man destined to ereate it was no sooner in power than he firmly asserted that the Italy of the future had a vital interest in the solution of the Near Eastern Problem. For the moment, however, the game was in the hands of the Tsar Nicholas, Napoleon, and Great Britain.

The demands made, on behalf of the Latin monks, by The Holy Napoleon were supported by the other Roman Catholic powers: Austria, Spain, Sardinia, Portugal, Belgium, and Naples; and after some delay they were, in substance, conceded by the Sultan. The concession roused bitter resentment in the mind of the Tsar Nicholas, who demanded, from the Porte, its immediate rescission. Thus the Porte found itself, not for the first time, between the upper and the nether millstone; and, in order to escape from that embarrassing situation, the Sultan played an old diplomatic trick. His decision on the points at issue was embodied in a letter to the French chargé d'affaires, and in a Firman addressed to the Greek patriarch at Jerusalem. The language of the two documents was not identical : the letter laid stress upon

1 'When I speak of Russia I speak of Austria as well': Tsar Nicholas to Sir G. H. Seymour. Eastern Papers, Part V, $185 ̃$. 
the substantial concessions to France; the Firman dwelt upon the claims denied. In the upshot France was satisfied, Russia was not.

Menschi- Accordingly, in March, 1853, the Tsar dispatched to koff's Constantinople Prince Menschikoff, a rough and orerbearing

soldier, who was charged not only to obtain full satisfaction in regard to the Holy Places, but to demand from the Sultan a virtual acknowledgement, embodied in a formal treaty, of the Tsar's protectorate over all the Orthodox subjects of the Porte. On the question of the Holy Places the Tsar had a strong case; his claim to a protectorate over the Greek Church in Turkey was, on the contrary, an extravagant extension of the rague and indefinite engagements contained in the Treaty of Kainardji, and in subsequent conventions concluded between Russia and the Ottoman Empire.

This demand appeared to the British Government to be wholly inadmissible.

The atti- 'No sorereign,' wrote Lord Clarendon, 'having a proper' tude of Englani. regard for his own dignity and independence, could admit proposals so undefined as those of Prince Menschikoff, and by treaty confer upon another and more powerful sovereign a right of protection over a large portion of his own subjects. Howerer well clisguised it may be, yet the fact is that under the vague language of the proposed Sened a perpetual right to interfere in the internal affairs of Turkey would be conferred upon Russia, for gorerned as the Greek subjects of the Porte are by their ecclesiastical authorities, and looking as these latter wonld in all things do for protection to Russia, it follows that 14,000,000 of Greeks would henceforth regard the emperor as their supreme protector, and their allegiance to the Sultan would be little more than nominal, while his own independence would dwindle into vassalage.' 1

Inadmissible in substance, the Russian demand was urged upon the Sultan by Prince Menschikoff with insufferable insolence. But by this time Menschikoff himself had to reckon with an antagonist in whose skilful hands the blustering Russian was a mere child. On April 5 Lord Stratford de Redcliffe returned to Constantinople, and the whole 1 Lord Claremion to Lord Stratford, May 31, 1853. 
diplomatic situation quickly underwent a complete transformation. $^{1}$

The Tsar Nicholas had always, as we have seen, been Enyland anxious to maintain a cordial understanding with England and liusia. in regard to the Eastern Question, and early in the spring of 1853 he had a series of interviews with Sir Hamilton Seymour, then British ambassador at St. Petersburg. During these interviews he discussed, in the most friendly manner, the relations of their respective countries in the Near East. Recalling his personal friendship with the head of the new ministry, Lord Aberdeen, he insisted that the interests of England and Russia were 'upon almost all questions the same', and expressed his confidence that the two countries would continue to be on 'terms of close amity'. 'Turkey', he continued, 'is in a critical state . . the country itself seems to be falling to pieces... . we have on our hands a sick man-a very sick man : it will be, I tell you frankly, a great misfortune if, one of these days, he should slip away from us before all necessary arrangements were made.' In the Tsar's view it was therefore 'very important that England and Russia should come to a perfectly good understanding on these affairs, and that neither should take any decisive step of which the other is not apprised'. 'The Tsar further asserted that he had entirely abandoned 'the plans and dreams' of the Empress Catherine, but frankly admitted that he had obligations in regard to the Christian subjects of the Porte which treaties and national sentiment alike compelled him to fulfil. ${ }^{2}$ In his riew, however, the gorerning fact of the situation was that the Turk was in a state of hopeless decrepitude. 'He may suddenly die upon our hands: we cannot resuscitate what is dead; if the Turkish Empire falls, it falls to rise no more; and I put it to you, therefore, whether it is not better to provide beforehand for a contingency than to incur the chaos, confusion, and certainty of a European war, all of which must attend the catastrophe,

1 For the relations between the home Government and the ambassador in Constantinople during these critical montbs see Marwell's Life of Lord Clarendon, rol. ii, chap. xiii.

2 Eastern Papers. Part V (122 of 185t). 
if it should occur unexpectedly and before some ulterior system has been sketched.' England and Russia nust settle the matter. But neither England nor any other Great Power must have Constantinople. Nor would Russia take it permanently; temporarily she might have to oceupy it (cn dépositaire) but not en propriétaive. For the rest, the principalities might continue to be an independent State under Russian protection ; Serbia and Bulgaria might receive a similar form of government. To counterbalance these indirect advantages to Russia, England might annex Egypt and Crete. On one further point the Tsar was particularly insistent: 'I never will permit', he said, 'an attempt at the reconstruction of a Byzantine Empire, or such an extension of Greee as wonld render her a powerful State: still less will I permit the breaking up of 'Turkey into little Republican asylums for the Kossuths and Mazzinis and other revolutionists of Europe; rather than submit to any of these arrangements I would go to war, and as long as I have a man or a musket left wonld carry it on.'

The English ministers, who had been captivated by the personality of the 'Tsar in 1844, were aghast at the coolness and candour of the specific proposals which were submitted to them in 18.53 through the ordinary diplomatic channels. They refused to admit that the dissolntion of the sick man was imminent; they repudiated with some heat the idea of a possible partition of his inheritance; they pointed out, with unanswerable force, that 'an agreement in such a case tends very surely to hasten the contingency for which it is intended to provide; they urged the Tsar to act with forbearance towards the Porte; they objected to an agreement concluded behind the back of Austria and France; and, finally, they declined, courteously but very firmly, to entertain the proposals of the 'Tsar'.'

Those proposals were in form almost brutally eandid, but there is no reason to doubt that they were put forward with a genuine desire to find a solution for a hitherto insoluble problem. Nor was the Tsar's diagnosis of the case substantially

1 The correspondence briefly summarized above may be read in extenso in Eastern Papers, Part V (122 of 1854). 
inaccurate. It is tempting to speculate as to what would have happened had the Tsar's advances been accepted by the English Government ; but the temptation must be resisted. That they were refused was due largely to the mistrust inspired among ministers by the Treaty of Unkiar-Skelessi, much more to the popular detestation of Russia aroused by her treatment of the Poles, and most of all to the part played by the Tsar in the suppression of the Hungarian insurrection in 1849. Conversely, the Sultan was high in popular favour owing to the asylum he had chivalrously afforded to Louis Kossuth and other Hungarian refugees.

Still, none of these reasons, though potent in their appeal to popular passions, can in the dry light of historical retrospect be regarded as an adequate justification of a great European war.

Into that war, however, the Powers were now rapidly 'drifting'. The expression was Lord Aberdeen's, and to him and to several of his colleagues it was undeniably appropriate. To one Englishman it was not. Lord Stratford at Constantinople knew precisely where he was going, and where he intended to go. He was persuaded that there could be no real settlement in the Near East until the pretensions of Russia had been publicly repudiated and until the Tsar had sustained an ummistakable defeat either in diplomacy or in war. If without war so much the better, but by war if necessary.

Lord Stratford's first task was to persuade Menschikoff' to L.ord separate the question of the Holy Places from that of a stratford. general Russian protectorate over the Greek Christians. cliffe. This important object was attained with consummate adroitness, and Stratford then induced the Porte to give satisfaction to Russia on the former point. Before the end of $\Lambda_{\text {pril }}$ the dispute as to the Holy Places was settled. But the concession made by the Porte effected no improvement in the diplomatic situation. On the contrary, as the Porte became more conciliatory, Menschikoff became more menacing. But he was now on weaker gromul, on to which he had been lured by Lord Stratford's astuteness. The latter advised the Porte to refuse the protectorate elaimed by Russia, and on 
May 22, 1853, Menschikoff and the staff of the Russian Embassy quitted Constantinople. A week later the Porte addressed to the Powers a Note announcing that 'the question of the Holy Places had terminated in a manner satisfactory to all parties; that nevertheless the Prince Menschikoff, not satisfied with that, had demanded from the Porte a treaty to guarantee the rights and privileges of all kinds accorded by the Sultan to his Greek subjects'. 'However great', it contimed, 'may be the desire of the Porte to preserve the most amicable relations with Russia, she can never engage herself by such a gnarantee towards a foreign Government, either concluding with it a treaty or signing a simple official Note, without compromising gravely her independence and the most fundamental rights of the Sultan over his own subjects.' Despite all this the Porte, thongh bound to take measures of self-defence, did not abandon hopes of peace.

Palmer- The hopes became fainter day by day. A large Russian ston's polic 5 . army under Prince Gortschakoff had been mobilized in Bessarabia during the spring; on July 21 it crossed the Pruth and occupied the principalities. Russia thereupon announced to the Powers that the occupation was not intended as an act of war, but as a 'material guarantee' for the concession of her just demands. But while condescending to offer this explanation, the Tsar was not greatly concerned as to the attitude of the Westem Powers. He was confident that, if war really threatened, Anstria and Prussia would send an army to the Rhine and keep France quiet. His confidence was misplaced. Austria, forgetful of the debt she had recently incurred to the Tsar, was more jealous of Russia than of France, and more ready, therefore, to mobilize upon the Danube than upon the Rhine. Moreover, on the news of the impending occupation of the principalities the combined fleets of England and France had been sent into Besika Bay, and Palmerston believed that the only chance of now convincing Russia that we were in earnest and thus averting war would be to order them up to the Bosphorus and, if necessary, into the Black Sea. But Aberdeen still hung back, and the Sultan was advised, 
'in order to exhanst all the resources of patience', not to resist the Russian invasion by force.

Meanwhile, Austria, though unwilling to fight, was anxious 'The to avert the all but inevitable war. Accordingly, the repre- Vienna sentatives of England, France, Austria, and Prussia met at July 31. Vienua in July and agreed upon a 'Note' which it was hoped might satisfy both Russia and Turkey. The Note simply reaffirmed the adherence of the Porte to "the letter and spirit of the Treaties of Kainardji and Adrianople relative to the protection of the Christian religion'. 'The Note was accepted by Russia, though not, as subsequently appeared, in the sense intended by the mediator's. Turkey, like Russia, perceiving its ambiguities, insisted on amending it. For the words above quoted the Porte proposed to read: "To the stipulations of the Treaty of Kainardji, confimed by that of Adrianople, relative to the protection by the Sublime Porte of the Christian religion.' To a superficial view the amendment may appear a strangely inadequate reason for provoking a European war. But the addition of the words 'by the Sublime Porte' had revealed, in succinct epitome, the whole question at issue between Russia and Turkey. Did the Treaty of Kainardji give to Russia a general protectorate orer the Orthodox subjects of the Sultan? Since Russia claimed that it did, the Vienna Note was sufficient for her purpose. The diplonatists at Viemna were simple enough to imagine that they had discovered a formula which might, by studied ambiguity, postpone or even avert war. Lord Stratford, however, was quick to perceire the ambiguity, and by the addition of four words, seemingly unimportant, brought Russia out into the open. These words implicitly repudiated the Russian claim to a general protectorate over the Greek Christians. The latter were to be protected not by the Tsar but by the Sultan. Russia promptly refused to accept the amendment; Lord Stratford encouraged the sultan to insist upon it. 'No man', wrote the editor of the Edinburgh Revieu', 'ever' took upon himself a larger' amount of responsibility than Lord Stratford when he virtually overruled the decision of the four Powers, including his own Government, and acquiesced in-not to say cansed-the rejection of the 
Vienna Note by the Porte after it had been accepted by Russia. The interpretation afterwards put upon that Note by Count Nesselrode showed that he was right; but, nevertheless, that was the point on which the question of peace and war turned . . . Russia had formed the design to extort from Turkey, in one form or another, a right of protection over the Christians. She never abandoned that design. She thought she could enforce it. The Western Powers interposed, and the strife began.' '

Outbreak On October 5 the Porte demanded from Russia the

of war between Russia and Turkey. evacuation of the principalities within fifteen days, and on October 2:3 Turkey declared war. The British fleet had already been ordered up to the Bosphorus-an order of which Russia had some cause to complain as an infraction of the Treaty of $1841 .{ }^{2}$ Nevertheless, Russia and the Western Powers still remained at peace, and the Tsar declared that, despite the Turkish declaration of war, he would not take the offensive in the principalities. The Turks, howerer, attacked vigorously on the Danube, and on November 30 the Russian Black Sea fleet retaliated by the entire destruction of a Turkish squadron in the Bay of sinope.

The The 'massacre of sinope' aroused immense indignation massacre of Sinole. in England and France, and must be regarded as the immediate prelude to the European War. 'I have been', wrote Sir James Graham, 'one of the most strenuous adrocates of peace with Russia until the last moment; but the Sinope attack and recent erents have changed entirely the aspect of affairs. I am afraid that a rupture with Russia is inevitable."

The Cabinet decided that in consequence of the 'massacre'

1 Edinburgh Recien", April, 1863, p. 331. Special importanee attaches to this artiele. Written primarily as a review of the two first volumes of linglake by the then ectitor, Henry Reeve, it was earefully revised by Iord Clarendon himself, and may be taken as an authoritative apologia for the poliey pursued loy the Aberdeen Cabinet.

2 The Russian point of view on this important question is put with great elaboration and detailed reference to the doeuments in Goriainow, op. cit., Pp. 94 sqq.

3 Parker. Life of Giralem, ii. 226. 
of Sinope the allied fleets must enter the Black Sea. On The allien January 4, 1854, this momentous order was executed, and fleet in it was announced that the English and French admirals had sea, instructions to 'invite' all Russian ships in the Black Sea to January, withdraw into harbour. Even yet the Westem Powers were not at war, and on February 22 Austria, always anxious about the presence of Russian troops in the principalities, but not too straightforward in her diplomacy, intimated that if the Western Powers would present an ultimatum, demanding the evacuation of Moldavia and Wallachia before a given date, she would support them. England and France promptly acted on this suggestion, and on February 27 Lord Clarendon informed Count Nesselrode that Great Britain, having exhausted all the efforts of negotiation, was compelled to call upon Russia 'to restrict within purely diplomatic limits the discussion in which she has for some time been engaged with the Sublime Porte', and by return messenger to 'agree to the complete evacuation of the Prorinces of Moldavia and Wallachia by the 30th of April'.

Russia refused this ultimatum on March 19, and on the 27th and 28th the Western Powers declared war. It was then made manifest that Austria's promised support was only diplomatic ; Prussia-to the great indignation of Quecn Victoria-followed Austria's lead $;{ }^{1}$ the concert on which so much depended was broken, and England and France were left alone to sustain an exceptionally arduous struggle.

Can the Crimean War be justified before the tribunal of Was the impartial history? Retrospective criticism has tended to $\underset{\text { War }}{\text { Crimean }}$ the riew that the war, if not a crime, was at least a blunder, justified? and that it ought to have been and might have been avoided. Sir Robert Morier, writing in 1870, perhaps expressed the current opinion when he described it as 'the only perfectly useless modern war that has been waged '.2 Lord Salisbury, some twenty years later, enshrined in classical phrase the opinion that 'England put her money on the wrong horse'.

1 See the remarkable letters of Queen Victoria to the King of Prussia in March and June, 1854, Q. V.L. iii. 21, 39.

- Memoirs and Letters of Sir Robert Morier, by his daughter, Mrs. Wemyss, ii. 215. 
The Duke of Argyll, on the contrary, writing at the close of the century, confessed himself though one of the Cabinet responsible for the war 'to this day wholly umrepentant'. ' More recently Lord Cromer has reaffirmed his conviction that 'had it not been for the Crimean War and the policy subsequently pursued by Lord Beaconsfield the independence of the Balkan States would never have been achieved, and the Russians would now be in possession of Constantinople'.2 Kinglake has popularized the idea that England was an imnocent tool in the hands of an unscrupulous adventurer, anxious to establish a throne umrighteously attained, by a brilliant war causelessly provoked. But to suggest that either Stratford or Aberdeen was the dupe of Napoleon's ambition is grotesquely inaceurate.

Popular passions had, as we have seen, been aroused by recent events against the Russian Tsar. More reflective opinion inclined to the view that the time had come for a sustained effort to repel the secular ambition of his people. The bias of Russian policy during the last century and a half was ummistakable. From the Treaty of Azor to that of Unkiar-Skelessi the advance had been stealthy but contimuous. Was the dissolution of the sick man to be hastened now to satisfy the impatient avarice of the heir presumptive? Was the Tsar to be allowed to conrert the Black Sea into a Russian lake, and to establish an exclusive and dangerous domination in the eastern waters of the Mediterranean? Was Europe in general, and England in particular, prepared to permit Russia to force upon the Porte a 'diplomatic engagement which would have made her the sole protector of the Christian subjects of the Porte, and therefore the sole arbiter of the fate of Turkey'." Rightly or wrongly England came, slowly but steadily, to the conviction that the matter was one of vital concern to Europe at large and to herself in particular; that the Tsar was determined to assert his claims by force, and that only by force could they be repelled. Of

${ }^{1}$ Our Responsibilities for Turliey (1596), p. 10.

${ }^{2}$ Essays, p. 275.

s Argyll, op. cit.. p. 10 
this conviction the C'rimean War was the logical and inevitable result.

To the conduct of that war we must now turn. Early in The Thar 1854 a British fleet was sent to the Baltic, under the command $(15.54-6)$. of Sir Charles Napier, but though it captured Bomarsund the results of the expedition were disappointingly meagre, and contributed little to the ultimate issue of the war. On April 5 a British force under Lord Raglan, who had served both in the field and at the Horse Guards under the Duke of Wellington, landed at Gallipoli. It was preceded by a French army under Marshal Saint-Arnaud, the fellow conspirator of Napoleon III in the first coup) (l'etat.

The Russians had already crosserl the Danube (March 23) and had besieged Silistria. The prolonged defence of this weakly fortified town was due largely to two English rolunteers, Captain Butler and Lieutenant Nasmyth, and in order to support it the allied army mored up from Gallipoli to Varna. There on May 19 a conference was leeld between Raglan, Saint-Arnaud, and Omar Pasha. On June 23, however, the Russians raised the siege of Silistria, and in July they commenced the evacuation of the principalities. Their withdrawal was due partly to the arrival of the allies on the Black Sea littoral; partly, perhaps, to the hope of luring them on to a second Moscow expedition; but most of all to the pressure of Austria, who, with the support of Prussia, had called upon the Tsar to eracuate the principalities. As soon as that had been effected the principalities were occupied, under an arrangement with the Porte, by an Austrian army. That occupation, though perhaps dictated in the first instance by jealousy of Russia, proved in the long run of incomparable advantage to her.

$\mathrm{By}$ the end of the first week in August there was no longer a Russian soldier to the west of the Pruth; the ostensible and immediate object of the European intervention might seem, therefore, to have been attained. But the allies had already reached the momentous decision (June) to 'strike at the very heart of Russian power in the East-and that heart is at Sebastopol'.' On July 22 Lord Clarendon stated

1 The Times, June 24, 185 . 
explicitly that they would no longer be satisfied by the restoration of the Status quo ante bellum. They must at least secure guarantees on four points :

1. Russia must be deprived of the Treaty Rights in virtue of which she had occupied the principalities;

2. Turkey must be guarded against attack from the Russian navy in the Black Sea;

3. The navigation of the Danube must, in the interests of European commerce, be secured against the obstruction caused by Russia's ' uncontrolled possession of the principal mouth of the Danube'; and

4. The stipulations of the Treaty of Kainardji relative to the protection of the Christians must be amended, since that treaty 'has become by a wrongful interpretation the principal cause of the present struggle'.

Lord Clarendon's dispatch is of importance as defining at once the causes and the objects of the Crimean War.

'The War' in the Crimea.

On September 14, 1854, the allied army, more than 50,000 strong, disembarked in the Bay of Eupatoria to the north of Sebastopol. On the 19th the march towards Sebastopol began. On the 20th Menschikoff, in command of 40,000 Battle of troops, tried to stop the advance of the allies on the Almathe Alma. three hours of severe fighting the Russians were routed. The allies, though victorious, suffered heavily. But Raglan, clespite the lack of transport and the ravages of cholera, wanted to make an immediate assanlt upon Sebastopol. Had his advice been taken Sebastopol would almost infallibly have fallen. But Saint-Arnaud, in the grip of a mortal disease, vetoed the suggestion, and it was decided to march round the head of the harbour and approach Sebastopol from the south. This difficult operation was effected without resistance from Menschikoff who had withdrawn his main army into the interior, leaving the fortress under-garrisoned, and on the 26th Raglan occupied the harbour of Balaclava. Again Raglan wanted to assault, this time from the south, and was

1 Lord Clarendon to Lord Westmorland, Ambassador at Vienna, July 22, 1854._Eastern Papers. 
strongly seconded by Admiral Sir Edmund Lyons, who was commanding the fleet. Saint-A rnaud was now dying on board ship, ${ }^{1}$ and the command of the French force devolved upon General Canrobert, a man of great personal bravery, but devoid of the moral courage essential for high command. Canrobert was not less strongly opposed than Saint-Arnaud to the idea of assanlt, and the allied forces, therefore, encamped to the south of the fortress, and made slow preparations for a regular siege.

The hesitation of the allies gave the defenders of Sebastopol a chance which they seized with consummate adroitness and skill. They cleared the Russian ships of guns and men : sank some of the largest ships at the entrance to the harbourthus rendering the allied fleets comparatively useless-and mounted the guns on shore; Colonel ron Todleben, the great engineer, and Admiral Korniloff worked with such energy and enthusiasm that the town was rapidly placed in a posture of defence. On October 17 the bombardment began. The experience of the first day was sufficient to prove the inadequacy of the preparations for a siege. In order to arm three batteries the English Commander had to dismantle ships and employ seamen.

But no perceptible effect was produced upon the fortress, Battles of and on October 25 the allies were unpleasantly reminded Balaclava of the dangers to which their position was exposed by and InMenschikoff"s strategy. Reinforced from home Menschikoff', kerman at the head of 30,000 men, re-entered Sebastopol, while a large detachment under General Liprandi delivered from outside an attack on the position of the allies, hcping to catch them between two fires and drive them out of Balaclara.

The familiar story of the battle of Balaclara may not be retold; enough to say that the enemy, though repulsed in their attack upon Balaclara, retained their position on the heights above, and the besiegers were now, in fact, besieged, and ten days later were made to realize the fact.

For a regular investment of Sebastopol the allied forces

${ }^{1}$ He died on September 29. 
were hopelessly insufficient: for a bombardment the nary had been rendered useless by Menschikoff's ingenious device, and the army by itself could make little impression on a fortress which six weeks before might have been taken by assault, but was rendered every day more proof against a siege by the greatest engineer of his day. All that the allies could do was to await the arrival of reinforcements, and meanwhile hold their position on the bay of Balaclava and the ridges above it. From that position Menschikoff was determined to dislodge them. The attempt, known as the battle of Inkerman, was made on November 5, with the result that the Russians were compelled to retire with the loss of 10,000 men. Now, if ever, was the moment to storm the fortress. Raglan was in farour of it; Canrobert, however, again refused to concur ; and the opportunity of dealing a really effective blow at Menschikoff's army was lost. The great On November 14 a terrible disaster befell the allies. gale of November 1 t.

Siege of

Sebastopol.

A fierce hurricane, accompanied with storms of rain and sllow, sprang up, swept down the tents on shore, and destroyed much of the shipping in the roads. The Prince, a new steamer of 2,700 tons, was driven on the rocks and thirty other ships foundered in the gale. Stores to the value of $£ 2,000,000$ were lost, and the men were depriced of all that might have rendered tolerable the cruel Crimean winter.

The gale was the real beginning of the sufferings which hare made the 'Crimean Winter' a byword in the history of military administration. For many weary months the condition of the British force before Sebastopol was deplorable. After the great fight of Inkerman (November 5) there were no operations on a large scale in the field until the middle of February. Nevertheless, the intermission of fighting brought no cessation of toil or suffering to the unhappy soldiers.

Pence While the soldiers were thus toiling and suffering in the negotia- trenches, the diplomatists were busy at Vienna. Austria,
tions at Viemna. whose policy during this phase of the Eastern Question was consistently subtle, had set negotiations on foot towards the end of 1854, and on December 28 the allied Powers, in conjunction with Austria, presented to the Russian Pleni- 
potentiary a Memorandum embodying the 'Four Points'. They were as follows:

1. The exclusive protectorate exercised by Russia orer Moldavia, Wallachia, and Serbia was to cease, and the privileges accorded by the Sultan to the principalities were henceforward to be guaranteed colleetively by the five Powers ;

2. The navigation of the Danube was to be free;

3. The preponderance of Russia in the Black Sea was to be terminated ; and

4. Russia was to renounce all pretensions to a protectorate over the Christian subjects of the Porte; and the five Powers were to co-operate in obtaining from the Sultan the confirmation and observance of the religious privileges of all the varions Christian communities without infringing his dignity or the independence of his Crown.

The Conference formally opened on March 15, 1855, but before that date arrived two events had occurred, each, in its way, of profound significance. The first was the interrention of Sardinia ; the second the death of the Tsar Nicholas.

On January 26, 1855, Count Carour appended his signature Intervento a Convention with Great Britain and France, promising tion of the adherence of Sardinia to the alliance. Of good omen for January, the Western Powers, this step was incomparably the most momentous in the diplomatie history of modern Italy. On the face of it the resolution to take part in the war was at once cynical and foolhardy. What part or lot had the little sub-Alpine kingdom in the quarrel between Russia and the Western Powers? To Cavour the mere question seemed to imply 'a surrender of our hopes of the future'. Accordingly, despite bitter opposition at home, 18,000 Italians were by the end of April on their way to the Crimea, under the command of General Alfonso La Marmora. "You have the future of the country in your haversacks.' Such was Cavour's parting injunction to the troops. The response came from a soldier in the trenches, "Out of this mud Italy' will be made'. It was. 
Death of the 'Tsar' Nicholas, March 2, 1855.

('onference of Vienna.

rogress of the war.

The adhesion of Sardinia came as a timely encouragement to the allies. To all those who were longing and working for peace the death of the Tsar Nieholas seemed of still happier angury. Nicholas was unquestionably the prime author of the war ; he had sustained it with unflagging energy, and he was bitterly disappointed at his failure to bring it to a rapid and brilliant termination. What Russian arms failed to accomplish at the Alma, at Balaclava, and at Inkerman, 'Generals January and February' might be trusted to achieve. But, as Punch felieitously pointed out, 'General February turned traitor'. The 'Tsar was attacked by influenza, to which on March 2, 1855, he succumbed. The news of his death evoked profound emotion throughout Europe, more particularly at Vienna, where the Conference was in progress.

The accession of the new Tsar, Alexander II, did not, however, render the Russian Plenipotentiaries more pliable. The real crux lay in the proposed limitation of Russian naval preponderance in the Black Sea. To that point Palmerston in particular attached the greatest importance, and on it the negotiations, at the end of April, broke down. ${ }^{1}$

Notwithstanding the failnre of the diplomatists at Viemna the war was nearing its end. Still, there was a great deal of hard fighting round Sebastopol during the spring and summer of 1855. On February 17 a Russian force, 40,000 strong, made a determined effort to take Eupatoria by storm, but was gallantly repulsed by the Turks under Omar Pasha, supported by a French detachment and by five men-of-war in the roadstead. After four hours' continuous fighting the Russians retired with considerable loss. In March the Russians advanced the defensive works of Scbastopol into the allied lines by the seizure and fortification of a knoll known as the Mamelon Vert, and by the construction of a number of rifle pits. Desperate efforts were made by the allies to dislodge them from these advanced points, but without avail.

Towards the end of May, however, the allies planned and executed a diversion at the south-eastern extremity of the Crimea. A combined fleet, under Sir Edmund Lyons and

I 'The history of these negotiations may be followed in minute detail in Goriainow, op. cit., chap. xi. 
Admiral Bruat, with a considerable force of English, French, and Turkish troops left Sebastopol on May 22, and three days later captured Kertch and made themselves complete masters of the Straits of Yenikale, which lead from the Black Sea into the Sea of Azor. This expedition, brilliantly successful both in conception and execution, contributed in no slight degree to the general purpose of the campaign. The stores destroyed at Kertch were computed to amount to nearly four months' rations for 100,000 men-a very serious loss for the Russian army in the Crimea.

On May 16 Canrobert asked to be relieved of his command, and was succeeded by General Pélissier, who was not only a great soldier, but was possessed of the moral courage which Canrobert lacked. He soon infused fresh vigour into the operations before Sebastopol. On June 18 a tremendous assault was delivered by the allies upon the Russian position; the French directed their attack upon the Malakoff, the English upon the Redan, two formidable outworks on the east of the fortress. Both attacks were repulsed by the Russians with heary loss. The failure of the attack upon the Redan was a bitter disappointment to Lord Raglan, who, enervated Death of by anxiety and worn out by ceaseless toil, was carried Lord off by cholera on June 28. A braver soldier and a more gallant gentleman never breathed. The continuance of the French alliance was the best tribute to the extraordinary tact with which for two years he had eased the friction incidental to a difficult situation ; the fall of the great fortress was the posthumous reward of his persistency and courage. General James Simpson succeeded to the command, and reaped where Raglan had sown.

Slowly but surely the allied armies pushed forward their The Fall lines towards the Russian fortifications. Once more the of Sebascovering army, under the command of Prince Michael Gortschakoff, made a desperate and gallant effort to raise the siege. On the night of August 15-16 the Russians descended from the Mackenzie Heights upon the Tchernaya river, where the Sardinian contingent, under General La Marnora, got their first real chance. Nor did they miss it. Fighting with the utmost gallantry they contributed in no 
small degree to the decisive repulse of the Russian army. Thus were Cavour's calculations precisely fulfilled. In the waters of the Tchernaya the stain of Norara was wiped out for ever ; out of the mud of the Crimean trenches was modern Italy built up. Henceforward Cavour could speak with his enemies in the gate. The victory of the allies at the Tchernaya shattered the last hopes of the besieged from the army in the field. For three weeks the allies kept up a continuous and terribly destructive fire upon the devoted fortress, and on September 8 the attack which had been foiled in June was renewed. The British, with a force miserably inadequate, again attacked the Redan and were again with great loss repulsed, but the Malakoff-the real key of the position-was already in the hands of their allies.

The storming of the Malakoff cost the French 7,500 in killed and wounded, including fifteen generals, but it preluded the fall of Sebastopol. Within a few hours the Russians blew up the magazines, withdrew across the harbour to the north, and on September 9, after a siege of 349 days, the allies occupied the burning ruins of the fortress that had been. The Russian garrison was unwisely permitted to make good its retreat, and thus the fall of Sebastopol did not bring the war to an immediate conclusion.

Fall of On November 28 General Fenwick Williams was comKars. pelled to surrender the fortress of Kars. He had been sent to reorganize the Turkish forces in Armenia, and with a small T'urkish garrison had been holding Kars for nearly six months against orerwhelming odds. It was an heroic defence and it won for Fenwick Williams undying fame. A Turkish force had been dispatched too tardily to the relief of Kars, and before it arrived the little garrison was starved out. General Mouravieff's success at Kars was a slight set-off against the surrender of Sebastopol, and predisposed the mind of the Tsar Alexander to peace.

Treaty The Emperor Napoleon was even more anxious for it. of Paris, He had got all he could out of the war; the French army 1856 . had gained fresh lustre from its concluding passages; the English army had not. Napoleon's restless mind was already busy with the future disposition of Europe. He was looking 
towards Russia and towards Italy; for England he had no further use. Cavour too had got all he wanted. The main obstacle to peace was Lord Palmerston. He was gravely mistrustful of France, and still more so of Austria. And he had reason. The part played by Austria was crafty, selfish, and even treacherous. Her interest was concentrated upon the Principalities. She had induced England and France to pick the chestnuts out of the fire for her there. Russia having been induced to withdraw from the Principalities, not by the threats of Austria, but by the action of England and France, Austria had promptly oceupied them, and had thus enabled Russia to concentrate her efforts upon the Crimea. Finally, as soon as there was a chance of peace, Austria spared no effort to detach Napoleon from the English alliance. In this she nearly succeeded; but on January 16, 1856, the Tsar (at the instance of his brother-in-law the King of Prussia) accepted as a basis of negotiation the 'Four Points', including a stipulation for the neutralization of the Black Sea; on February 1 a protocol embodying these terms was concluded by the representatives of the five Powers at Viemna, and the definitive Peace was signed at Paris on March 30, 1856. The main terms were as follows:

1. The Sublime Porte was formally admitted, on the invitation of the six Powers (including the King of Sardinia), to 'participate in the public law and concert of Europe', and the Powers engaged severally to respect, and collectively to guarantee 'the independence and the territorial integrity of the Ottoman Empire'.

2. The Sultan, 'in his constant solicitude for the welfare of his subjects', announced to the Powers his intention to ameliorate their condition "without distinction of creed or race'; but the Powers, while recognizing 'the high value of this communication', expressly repudiated the "right to interfere, either collectively' or separately', in the internal aftairs of Turkey.

3. The Black Sea was neutralized, its waters and ports were to be open to the mercantile marine of erery

$$
1 \text { Cf. supra, r. } 211 .
$$


nation, but permanently 'interdicted to the flag of war' ; and there were to be no arsenals, either Russian or Turkish, on its coasts.

4. Kars was to be restored to the Turks, and the Crimea to Russia.

5. The navigation of the Danube was to be open on equal terms to the ships of all nations, under the control of an interuational commission.

6. Sonthern Bessarabia was to be ceded by Russia to Moldavia. The Principalities of Moldavia and Wallachia were to remain under the suzerainty of the Porte; Russia renonnced her exclusive protectorate over them, and the contracting Powers collectively guaranteed their privileges. They were to enjoy 'an independent and national administration with full liberty of worship, legislation, and commerce, and were to have 'a national armed force'. In each province a national Convention was to be held 'to decide the definitive organization of the Principalities'.

7. The liberties of Serbia were to be similarly guaranteed.

Conventions.

Treaty of Paris, April 15, 1856.

To the main Treaty of Paris there were annexed three Conventions of the same date. With one between England, France, and Russia respecting the Aland Islands we are not here concerned. A second, concluded between the six Powers on the one part and the Sultan on the other part, reaffirmed in the most specific manner the ancient rule of the Ottoman Empire according to which the Straits of the Dardanelles and of the Bosphorns are closed to foreign ships of war, so long as the Porte is at peace. A third, concluded between the Tsar and the Sultan, defined the force and number of light vessels of war which under Art. xiv of the main treaty they were authorized to maintain in the Black Sea, notwithstanding the neutralization of its waters and its ports, for the service of their coasts.

Under a separate treaty, concluded on April 15, Great Britain, Austria, and France agreed to guarantee, jointly and severally, the independence and the integrity of the Ottoman Empire; they pledged themselves to regard any infraction as a casus belli, and undertook to come to an 
understanding with the Sultan and with each other as to the measures necessary for rendering their guarantee effectual.

By an Addendum to the Treaty, known as the Declaration of DeclaraParis, it was agreed to abolish privateering, and to proclaim $\underset{\text { Pion of }}{\text { Par. }}$ as permanently accepted principles of maritime war the concessions in favour of neutrals made during the recent war by England and France: (1) a neutral flag was to cover an enemy's goods, except contraband of war; (2) neutral merchandise, except contraband, was not to be seized under an enemy's flag; and (3) a blockade must be 'effective', i. e. maintained by an adequate naval force. Such were the terms of the treaty which crowned the conclusion of the Crimean War.

What had the war achieved? In reference to one of the Results of most difficult and most interesting of the questions which the war. the war had forced to the front, the future of the Principalitics, nothing need now be said, as the subject will be considered in detail in the next chapter. So acute was the controversy on this point during the negotiations at Vienna and Paris that it was ultimately agreed that only the general principles of the settlement should be laid down in the formal treaty, and that their application should be left to be determined in a subsequent convention.

Of the other results of the war the most obvious was the The new lease of life secured to the Ottoman Empire. The Sultan Ottoman was to have his chance, free from all interference, friendly or otherwise, from his powerful neighbour, to put his house in order. He could enter upon his task with renewed self-respect, for was he not at last admitted to the most polite society of Europe? And his subjects should realize the spontaneity of his beneficence; if he chose to persecute, it was his affair: the Powers had expressly repudiated the right of interference; equally, if he chose to extend civil or religious liberty, the extension was the outcome of his own loving-kindness towards his people. Such was the formal position secured to the Ottoman Empire by the Treaty of Paris. Yet the Sultan, if he were wise, could not fail to observe that the guarantee of independence and integrity vouchsafed to him by the Powers imposed upon them a corresponding obligation. Morally, if not legally, they were bound to see to it that 
the Porte behaved in accordance with the unwritten rules of polite society. In repudiating the exclusive protectorship of Russia they assumed a responsibility for the good government of the Christian subjects of the Porte which the Sultan could ignore only at his peril. On this point much will, unfortunately, have to be said later on.

Russia. To Russia the Treaty of Paris involved, for the time being, a bitter disappointment, if not a profound bumiliation. For a century and a half she had pursued with singular consistency three main objects : to establish her naval and commercial supremacy on the waters and coasts of the Black Sea; to secure a free outlet to the Mediterranean; and to obtain from the Porte an acknowledgement of her position as champion of the liberties, political and ecclesiastical, of the Christian subjects of the Sultan. At times there had floated before the eyes of Russian rulers, notably those of the Tsarina Catherine, dreams even more ambitious. The Treaty of Paris not only dissipated completely all ideas of partition, but involved a disastrous set back to those more sober and prosaic aims which had inspired Russian policy from the days of Peter the Great to those of Alexander II.

The The neutralization of the Black Sea was of special concern Question. to England, as the leading Naval Power of the world. To the growth of the naval power of Russia, England, as we have seen, had become, in recent years, increasingly sensitive. The prolonged siege of Sebastopol had naturally made a profound impression upon the public mind. To allow Russia, in the complete security afforded by the closing of the straits, to build up a great naval force, and to convert the shores of the Black Sea into a great arsenal, seemed sheer madness to the Power which had large interests in the Near East and was paramount in the Far East.

Regarded from the Russian point of view the neutralization of the Black Sea was an insolent and intolerable interference in the domestic concerns of the Russian Empire, an attempt, inspired by petty jealousy, to arrest her natural and inevitable development. It was, therefore, absolutely certain that Russia would seize the first favourable opportumity to get rid of the shackles imposed upon her by the Treaty of Paris. 
The opportunity eame with the outbreak, in 1870, of the Bismarck Franco-German War. Bismarck owed Russia a very heavy and debt; the time had come to discharge it. Not that the obligations were all on one side. In the Crimean War the neutrality of Prussia was, as we have seen, more than benevolent towards Russia. During the Polish insurrection of 1863 Bismarck performed a signal service to the Tsar. For he not only kept a strict guard upon the western fronticr of Russian Poland, but warded off the possible interference of Austria and the Western Powers. Bismarck's assistance, however, was never given without precise caleulation. Each move in the great diplomatic game which he played during the next eight years was already in his mind, and in the course of that game Russia would be able to repay very amply any obligations incurred in 1863. Nor was Bismarek disappointed in the issue. The suceess of his policy in regard to the Danish Duchies in 1864, in regard to Austria and the Germanic Confederation in 1866, not least in regard to France in 1870, depended very largely upon the diplomatic goodwill of the Tsar, Alexander I. In 1864 Russia not only allowed the Treaty of London to be broken by Prussia, but declared herself ready to forgo her own claims upon Holstein and Oldenburg. In 1866 she avowedly regarded Prussia as 'the avenging instrument of Russian wrath' upon an ungrateful Austria. In 1870 it was Russia who kept Austria quiet while Bismarck worked his will upon France.

Such services demanded substantial requital. The means Russia were ready to hand. In October, 1870, Prince Gortschak off and the addressed to the Powers a circular denouncing on behalf of Russia the Black Sea clauses of the Treaty of Paris (1856), and declaring that the Tsar proposed to resume his "sovereign rights' in the Black Sea. The step, if not actually suggested, was certainly approved beforehand by Bismarck. In justification of the action of Russia Gortschakoff eynieally referred to the "infringements to which most European transactions have been latterly exposed, and in the face of which it would be difficult to maintain that the written law... retains the moral validity which it may have possessed at other times'. In plain English the Tsar saw no reason 
why he should observe treaties when other people broke them.

The Russian circular evoked strong opposition both in England and in Austria. Lord Granville expressed the 'deep regret' of his Government at 'an arbitrary repudiation of a solemn engagement', and declared that England 'could not possibly give her sanction'. Count Beust, the Austrian minister, expressed himself as 'painfully affected' by the behaviour of the Tsar, and found it 'impossible to conceal his extreme astonishment thereat'.

But Gortschakoff went on his way unheeding. Bismarck was behind him, and Bismarck was confident that though England might bark she would not bite.

He had leason for his confidence. Plainly there were but two courses open to Great Britain : either to acquiesce in the bold and cynical action of the T'sar, or, without allies, to fight him. To declare war upon Russia, at this juncture, would be to provoke the Armageddon which England was using all her endearours to avert. Was the game worth the candle? Lord Derby declared that 'he would fight for the neutrality of Egypt, but not for the neutrality of the Black Sea'.' And he expressed the general opinion on the subject. In face of that opinion Lord Granville had no option but to extricate lis country from a disagreeable situation with as little loss of prestige as possible. Accordingly, Bismarck was induced to invite the Great Powers to a conference to discuss the questions raised by Prince Gortschakoff's circular. Great Britain assented on condition that the conference met not at St. Petersburg but in London, and that it should not assume 'any portion of the Treaty to have been abrogated by the discretion of a single Power'. This assumption may be regarded as solemn farce; the conclusion was foregone; but Lord Granville was wisely attempting to put the best face upon an episode, somewhat discreditable to all parties. The conference met in London in December, 1870, and Lord Granville got all the satisfaction he could out of a solemn protocol, declaring it to be 'an essential principle of the law of nations

${ }^{1}$ Odo Russell to Granville, ap. Fitzmaurice, ii. 72. 
that no Power can liberate itself from the engagements of a Treaty ... unless with the consent of the contracting Powers by means of an amicable arrangement'. For the rest Russia got what she wanted. ${ }^{1}$

By the Treaty of London the Black Sea clauses (Arts. xi, Treaty of xiii, and xiv) of the Treaty of Paris were abrogated; but the London, Black Sea was to remain open to the mercantile marine of all 1871. nations as heretofore; at the same time the closing of the straits was confirmed with the additional proviso that the Sultan was empowered to open them in time of peace to the warships of friendly and allied Powers, if necessary, in order to secure the cxecution of the stipulations of the Treaty of Paris.

That English prestige suffered severely from the emasculation of that treaty can hardly be denied. To the Black Sea clauses she had attached great importance; from a selfish point of view she had little else to show for a heavy expenditure in men and money.

France had not much more. But though France gained France little by the Crimean War, Napoleon gained much. In 1853 Sardinia. his position in Europe was far from assured; the Crimean War established it; and until the advent of Bismarek his influence upon the Continent was almost orerwhelming. The war gained him, paradoxically, the friendship of Russia : the peace lost him the confidence of England.

The greatest gainer by the war, excepting the Porte, was Italy. Cavour's prudent calculations were precisely fulfilled. He took his place, despite the angry protest of Austria, at the Council Board in Paris, as the representative not merely of Sardinia but of Italy. In the name of Italy he denoumeed the misgovernment of the two Sicilies; for Italy he conciliated the sympathy of Great Britain and the active assistance of Napoleon. The intervention of Sardinia in the Crimean War gave to her a place in the Concert of Europe, and gave to her the right as well as the opportunity to champion the eause of Italian liberation. At the Congress of Paris Cavour and the Emperor Napoleon came to an understanding; it was

1 Cf. Holland, Europrean Concert in the Eastern Question (with texts in full), p. 272. 
sealed two years later by the pact of Plombières; it bore fruit in the war of 1859.

The Crimean War was, then, supremely significant in relation to the fortunes of more than one of the nations of modern Europe. A keen student of affairs has expressed his conviction that if the war had not been fought 'the two subsequent decades of the century would not have seen the formation of a United Italy and a United Germany, and all its consequences'. ${ }^{1}$ But it is as an epoch in the evolution of the Eastern Question that it must in these pages be considered. Some of its consequences, in that conmexion, were palpable even to contemporaries. To these attention has already been drawn. Other consequences neither were, nor could have been, perceived by the men of that day. And these were the more enduring. Subsequent chapters will disclose them.

${ }^{1}$ Lord Fitmmaurice, Life of the Second Earl Granville, i. 99.

Works for further reference. For documents: Eastern Papers, presented to Parliament, 1854-6. For texts: T. E. Holland, European Concert in the Eastern Question. Serge Goriainow (as before); Rambaud, History of Russia (trans.); Sir Herbert Maxwell, Life and Letters of the Fourth Earl of Clarendon; Duke of Argyll, Antobiography; Ashley, Life of Lord Palmerston; Martin, Life of Prince Consort; Letters of Queen Victoria (ed. Lord Esher and A. C. Benson); Morley, Life of Giladstone; Parker, Life of Sir James Graham; Lane Poole, Life of Lord Stratiord de Redcliffe; P. de la Gorce, Histoire du Second Empire; É. Ollivier, L'Empire Libéral; Debidour, Histoire diplomatique; Kinglake, Invasion of the Crimea; Sir E. B. Hamley, The War in the Crimea; Sir E. Wood, The Crimea in 1854 and 1894. For the Sardinian intervention: Thayer, Life of Carour, and Bolton King, History of Italian Unity. 


\section{CHAPTER XI}

\section{THE MAKING OF ROUMANIA}

'Cn ìlot latin au milieu de l'océan slave et finnois qui l'environne.'BARCN JEAN DE WITTE.

'La Roumanie est latine d'origine et d'aspirations : elle a constamment mis son orgueil à le dire et à le répéter. . . . Nous ne sommes ni Slaves, ni Germains, ni Turcs; nous sommes Roumains.'-Alexander Sturdza.

'La Dacie devint comme une Italie nouvelle. Ces Italiens du Danube et des Carpathes ont conservé dans l'histoire le nom des Romains qui leur' donnèrent leur sang, leur langue, leur civilisation; ils s'appellent les Koumains et leur pays la Roumanie.-G. LACOUR-GAYET.

The Crimean War was fought ostensibly to maintain the The independence and integrity of the Ottoman Empire. That Crimean principle reeeived its consecration in the Treaty of Paris. theBalkan The supreme purpose which inspired the Western Powers in nationalitheir joint enterprise was to repudiate the claims of Russia to an exclusive protectorate over the Christian subjects of the Porte, and to arrest her progress in the Black Sea and the narrow straits. That purpose was apparently achieved in 1856 .

But contemporaries were as usual slow to apprehend the things which really belonged unto their peace. Beneath the surface of Balkan polities there were fires smouldering, forces silently at work, which, in the middle of the nineteenth century, few people eould have perceived. Meanwhile the soldiers and diplomatists were working better than they knew. They set out to repel Russia and to sare Turkey. What they really saved was not the effete rule of the Ottoman Sultan, but the future of nations which were not yet reborn.

Of these the first to eome to the birth was that which we Rouma. know as the Kingdom of Roumania, but which figures in the nia. Treaty of Paris as the Principalities of Wallachia and Moldavia. The diplomatists at Paris were, however, content to lay down certain broad principles embodied in Articles $\mathbf{x x}$ to xxvii of the treaty, leaving it to a Special Commission at 
Bucharest to "investigate the present state of the principalities and to propose bases for their future organization'. A Divan ad hoc was also to be convoked in each of the two provinces to express the wishes of the people in regard to the definitive organization of the principalities. The results of this somewhat startling recognition of the right of a people to a voice in its own political destiny will be in due course recounted. It scems, in the meantime, desirable to preface the story of the making of the modern State of Roumania by a rapid sketch of the previous history of the principalities.

Sketch of the history of the principalities.

The Roumanians occupy, in more ways than one, a unique place among the Balkan peoples. A Latin people, surrounded by Slavs and Magyars, they were never really absorbed, like the Serbs, Bulgars, and Greeks, into the Ottoman Empire. About the year A.D. 101 Trajan, as we have seen, organized the province of Dacia, and a province of the Roman Empire it remained until the close of the third century. About the year 271 the Roman legions were withdrawn, and the colonists, in order to avoid the barbarian inroads, fled into the Carpathians. For the next thousand years Dacia was merely a highway for successive hosts of barbarian invaders. But they came and went, and none of them, except the Slars, left any permanent impress upon land or people. As the barbarian flood subsided the Daco-Roumans emerged from their mountain fastnesses, and towards the close of the thirteenth century established the Principality of Wallachia, and a century later that of Moldavia. The former was reduced to vassaldom by the Turks in 1412, the latter in 1512 ; but neither principality ever wholly lost the sense or the symbols of independence. Both paid tribute to the Sultan, but down to the eighteenth century they continued to elect their own rulers. Michael Towards the close of the sixteenth century there occurred (15951601). a brilliant interlude in the somewhat sombre history of the principalities. In the year 1593 Michael the Brave became Voyvode of Wallachia, and inaugurated his brief but brilliant reign by flinging down a challenge to the Ottomans, then hardly past the meridian of their fame. Engaged in their prolonged contest with the Habsburg Emperors the Turks 
quickly realized the importance of Michael's defection, and turned aside from the Hungarian campaign to inflict upon their revolted vassal the punishment due for so daring a defiance of their suzerainty. But Michael's forces, though hopelessly outnumbered, won at Kalougareni a decisive victory over the Ottoman army under Sinan Pasha (August 13, 1595). Strengthened by reinforcements from Transylvania and Moldavia, the victor pursued his advantage with such effect as to drive the Turks in headlong rout across the Danube. At a single stroke the independence of Wallachia was temporarily achieved.

Victorious over the Turks Michael then turned to the Union higher task of reuniting under one crown the whole of the Roumanian people. This also he achieved with singular success. Sigismund Báthory, Voyvode of Transylvania, suddenly resigned his crown to the Emperor Rudolph, and transferred to the latter such rights as he supposed himself to possess over Wallachia. Michael nominally accepted the suzerainty of the emperor, but the turn of events then gave him the opportunity of conquering Transylvania for himself. He eagerly embraced it, inflicted a crushing defeat upon a rival claimant at Schellenburg (October 28, 1599), and established himself as Voyvode of Transylvania. He then turned his attention to Moldavia. That also was reduced to submission, and thus for a brief space the whole Roumanian people were united under Michael 'the Brave'. It would be affectation to suggest that this achievement was regarded, at the time, as a triumph of the nationality principle. That principle had not yet emerged as a political force, and the sentiments of the Roumanians in Transylvania and Moldavia were entirely opposed to the rule of Michael. The significance of his achievement was wholly proleptic. Michael's reputation as a 'Latin hero' really results from the revival of national self-consciousness in the nineteenth century. The Roumans of Transylvania and Moldavia regarded him, in his own day, as a meddlesome usurper. The Roumanians of to-day look to him as the national hero, who, for a brief space, realized the unity of the Roumanian people. What Roumania was under Michael the Brave, the Greater Roumania may be 
again. Michael's, therefore, is the name with which to conjure among the Roumanian irredentists. The temporary union of the various Rouman provinces was, however, dissolved by the assassination of Michael in 1601, and with him died all hopes of unity or even of independence for more than two centuries. The eigh- The fortunes of the principalities touched the nadir in century. the eighteenth century. Suleiman the Magnificent had, in 1536, concluded an arrangement, by which the election of the ruling princes was left to the principalities themselves. But in 1711 even this remnant of independence was extinguished. The hospodarships of the two principalities were put up by the Porte to auction and were invariably knocked down to Phanariote Greeks. For one hundred and ten years, therefore (1711-1821), Moldaria and Wallachia were ruled by a rapid succession of Greek bureaucrats. The more rapid the succession the better for the Turks. Consequently, each hospodar, knowing that his tenure would be brief, ${ }^{1}$ had perforce to nuake hay while the sun shone, and the system was, as M. Xénopol has said, neither more nor less than 'organized brigandage'.

Habsburg Meanwhile, paradoxical as it may appear, the prospects of encroach- Roumania suffered from the weakening of Ottoman power
ments. and the disintegration of the Ottoman Empire. By the Treaty of Carlowitz the Turks were compelled, as we saw, to cede to the Habsburgs the whole of Hungary, except the Banat of Temesvar, together with the Roumanian Duchy of Transylvania. By the Treaty of Passarowitz (1718) the recovery of Hungary was completed by the cession of the Banat of Temesvar, while at the same time the Habsburgs acquired the whole of the territory known as Little Wallachia, that is the portion of the principality bounded by the river Aluta. The latter acquisition proved to be only temporary, for the Turks recovered it by the Treaty of Belgrade in 1739 . In 1775, however, the Habsburgs claimed and obtained from the Turks the Bukovina. The Moldavian boyards energeti-

1 In 110 years there were thirty-seven hospodars in Wallachia and thirty-three in Moldavia. Cf. Seignobos, Political History of Europe, ii. 640 . 
cally protested to the Porte against the cession of a district which was not merely an integral part of the principality but contained their ancient capital, the mausoleum of their kings, and other historical monuments and associations. The Porte, despite a strong hint that the Moldavians might find it to their interest to seek protection elsewhere, declined to reconsider its bargain with the emperor.

Had the Moldavians carried out their threat they would Russia not inave had to go far to find their new protector. Russia and the had begun, from the days of Peter the Great, to interest palities. herself in the affairs of the Danubian principalities. That interest was not ethmographical, but partly geographical and partly ecclesiastical. The appearance of Russia as a Black Sea Power raised an entirely new problem for the Roumanian peoples, while the geographical situation of the principalities suggested to the Russian strategists questions of the highest significance. Russia had temporarily occupied Moldavia during her war with the Turks, 1736-9, and both principalities were occupied during the war which was ended by the Treaty of Kainardji in 1774.

By that treaty, as we saw, Russia restored the principalities to the Porte, but only on condition of better government; and she formally reserved to herself the right of remonstrance if that condition was not observed. Five years later a Convention explicative (1779) stipulated that the tribute payable by the principalities to the Porte should be 'imposed with moderation and humanity'; a Russian consulate was, against the wishes of the Sultan, established at Bucharest, while the Prussian consul at Jassy complained of the activity of the Russian agents in Moldavia." Clearly the policy of peaceful penetration had begun.

The principalities occupied a noticeable place in the Catherine agreement concluded between the Tsarina Catherine II and princithe Emperor Joseph II in 1781. The two sovereigns then palities. decided that the time had arrived for the complete annihilation of Ottoman power in Europe, and for the partition of the dominions of the Sultan. Wallachia and Moldavia,

1 Miller, Ottoman Empire, p. 8. 
including Bessarabia, were to be erected into a new kingdom of Dacia, and the crown was to be conferred upon Catherine's favourite and minister, Count Potemkin. The grandiose scheme, of which this was only one, though by no means the least interesting feature, was not destined to materialize. Six years later, however, Catherine and Joseph II were again at war with the Porte, and when, in 1792, peace was concluded at Jassy, the Russian frontier was adranced to the Dniester, the Tsarina acquired the great fortress of Oczakov with the surrounding districts, while Moldavia was restored to the Sultan, but only on condition that the Porte fulfilled the stipulations of the Treaty of Kutschuk-Kainardji and the Conrention explieative.

Napoleon During the Napoleonic wars the principalities were reand the principalities. garded merely as a pawn in the game of diplomacy and of war. Thus in the war of the Second Coalition the Porte found itself in temporary alliance with Russia against France. Russia improved the occasion to obtain for her clients an important concession, and for herself a still stronger position as protectress. The Sultan agreed, in 1802, that henceforward the hospodars should hold office for a fixed term of seven years instead of at the good pleasure of the Porte, and that they should not be deposed without the assent of the Tsar. When, in 1806, Napoleon compelled the Sultan to declare war upon Russia, the latter retorted by an immediate invasion of the principalities. Before twelve months were over Napoleon had decided upon a new move in the diplomatic game, and agreed at Tilsit to divide the world with the Tsar Alexander. The Tsar's share was to include the Danubian principalitics. But the Tilsit concessions were never carried out, and in 1812 the Tsar, anxious to secure his left flank, agreed to evacuate the principalities, and to accept from the Porte in full settlement of all immediate claims the province of Bessarabia. This arrangement, reached through the mediation of England, was embodied in the Treaty of Bucharest.

Treaty of The Treaty of Bucharest was, for the Turks, a colossal Bucharest
(1812). Nor did it tend to assuage the bitter memory which the period of Russian occupation had implanted in the minds of the 
Roumanians. Though the Russians had come as 'liberators' there is no period in the history of their comntry to which the Roumanians look back with greater bitterness. More particularly do they resent the fact that by the dismemberment of Moldavia a population which now numbers two million Roumaniaus exchanged autonomy under the Sultan for absorption in the Empire of the T'sar.

At the general settlement in 1815 the Porte made desperate efforts to recover Bessarabia ; but Alexander was not likely to forgo the only, and as he might reasonably think the wholly inadequate, fruits of Russian diplomacy in the Near East, and Bessarabia remained in his hands.

The next scene in the drama of Roumanian history opens The Phaon the Greek revolution of 1821 . The selection of the nariote principalities for the initial rising, though intelligible, was, 1821 . as we saw, singularly unfortmate. The Rommanian nationalists detested the Phanariote Greeks, and neither felt nor displayed any enthusiasm for the Hellenic cause. Still, Hypsilanti's insurrection had one important result. It led immediately to the extinction of Phanariote rule in the principalities. Greek hospodars were no longer acceptable to the Porte, and from 1822 onwards the hospodars of both principalities were selected from the native nobility.

To the Roumanians, however, the change brought little The prinadvantage. It signified only a transference from one alien eipalities master to another. From 1822, until the outbreak of the Crimean War, the Russians enjoyed a virtual protectorate over the principalities. The Convention of Akerman guaranteed to them all their privileges "under the guardianship of the Cabinet of St. Petersburg'. The hospodars were to be clected for a term of seren years by the native boyards, and were not to be deposed by the Sultan without previous notice to Russia. The Treaty of Adrianople (1829) provided for the complete evacuation of the principalities by the Turks and conferred upon them practical autonony. They were to pay tribute, at a slightly enhanced rate, to the Porte, but were to be free from all requisitions for corn, corvées, and the like. No Moslems were henceforward to reside there, and those who owned real property were to sell it within eighteen s 2 
months. The hospodars were to hold office for life. Finally, the Turks undertook not to retain any fortresses on the left bank of the Danube, and to sanction the administrative regulations made during the Russian occupation. These regulations were embodied in a Règlement organique (1831) which the Russians bequeathed as a parting gift to the inhabitants when, in 1834, their occupation determined.

The In- In some respects the Russian administration of the prinsurrection cipalities had been excellent, but the material benefits which
of $18+8$. it conferred upon them were insufficient to counterbalance the loss of independence. Nor did Russian interference end with their formal evacuation. So bitter was the antiRussian feeling that in 1848 the people of the principalities appealed to their nominal suzerain, the Sultan, to deliver them from their 'liberators', and raised the standard of a national insurrection.

For Europe at large the year 1848 was essentially the 'year of revolution'; and nowhere did the fire burn more fiercely than in the heterogeneous empire which owned the Habsburgs as lords. Germans, Czechs, Magyars, Italians were all in revolt. But, while the Magyars of Hungary were in revolt against Vienua, they had themselves to confront a separatist movement within the borders which they regarded as their own. The feeling of Magyar against German was not more intense than the feeling of the Roumans of Transylvania against the Magyar. The nationalist fever had got into the blood of Europe, and, while the Transylvanian Roumans rose against Buda-Pesth, the CisCarpathian Roumans attempted once for all to throw off the yoke of St. Petersburg. Neither movement achieved any large measure of success. The Tsar Nicholas, as we have seen in another comnexion, went to the assistance of the young Emperor Francis Joseph and crushed the insurrections in Hungary and Transylvania, and, at the same time, in collusion with the Sultan, suppressed, without difficulty, the rising in the principalities. Ostensibly, the only result of the movement was the Convention of Balta Liman.

Conven- Under that Convention, concluded between the Sultan and tion of Balta the Tsar in May, 1849, the principalities were deprived of 
many of the privileges which they had previonsly enjoyed. Liman, The tenure of the hospodars was again limited to seven years; May 1, the representative assemblies were abolished, and they were replaced by Divans, nominated by the princes.

Here, as in Italy and elsewhere, the 'year of revolution' had come and gone, and to all outward seeming had left things worse than before. Not so, in reality. Good seed had been planted; the attempt to reap prematurely had failed; within a decade it was to fructify, and before the century closed was to yield an abundant harrest.

The growth was native, but the culture was French. French Ineffective as the movement of 1848 was, its inspiration was influence due to self-conscious nationalism. The nationalist spirit was mania. fostered in part by the spread of education at home, not less by the historical and juristic studies pursued then, as now, by the young nobles in Paris.

For to the French the Roumans hare persistently looked as the nearest of their blood relations; their natural allies in the secular struggle against Islamism on the one side and Pan-Slavism on the other. Nor can the modern history of Roumania be rightly apprehended unless this fact and all its many implications be kept steadily in view.

Modern Roumania is ' $u$ îlot latin au milieu de l'océan slare et finnois qui l'environne '. ${ }^{1}$ Roumanian historians love to recall the Roman origin of their race. ${ }^{2}$ But the primary debt, intellectual and political, acknowledged and emphasized by the modern Roumanian, is not to Italy but to France. 'Nous sommes Roumains,' writes M. Alexander Sturdza, the honoured bearer of an honoured Roumanian name, 'c'est-à-dire Latins; et parlant ethniquement apparentés à la France. La Roumanie moderne poursuit la réalisation d'une ouvre éminemment nationale, mais elle aime sa sœu' aînée, sa bienfaitrice, la France.'

The debt warmly acknowledged in Roumania is proudly claimed in France: 'C'est sous notre influence que la nation

1 De Witte, op. cit., p. 2.

2 Cf. for example the specch of the Roumanian historian, V. A. Urechia, in Rome: 'Nous sommes ici pour dire à tout le monde que Rome est notre mère' (cited by Mavrodin). 
roumaine s'est formée et a grandi ; ce sont les travaux de nos écrivains, de nos historiens, qui ont révélé sa véritable origine alors ignorée en Europe.' ${ }^{1}$

The prin- From France, then, came the spark which fired the incipalities

in the Crimean War. surrection of 1848 . The flame, for the moment, flickered out, but the fire was smouldering. It broke into flame again after the Crimean War. That war marks an epoch of great significance in the history of modern Roumania. On the first hint of trouble with Turkey the Tsar, as we have seen, sent a force, as usual, to occupy the principalities. But after their failure to take Silistria (June, 1854) the Russians retired across the Pruth, and Austria occupied the principalities; the Emperor Francis Joseph having pledged himself to protect them, during the war, and to restore them to the Sultan on the conclusion of peace.

The When the terms of that Peace came to be considered at Vienna, and afterwards in Paris, the future position of Moldavia and Wallachia proved to be a subject of acute controversy between the Powers. The question of frontiers was the least of the difficulties, and was settled by the restoration of the southern portion of Bessarabia to Moldavia. Three other points were quickly decided: the Russian protectorate was to be abolished; the suzerainty of the Sultan to be maintained; the principalities themselves were to be virtually independent. The Emperor Napoleon had, indeed, originally suggested that they should be handed over to Austria, in return for the cession of Lombardy and Venetia to Sardinia. This characteristic but over-ingenious scheme found no favour in any quarter; Austria had no mind for the bargain; Russia naturally opposed the idea; while the provinces themselves saw no advantage in getting rid of the Russians and the Turks in order to fall into the hands

1 de Witte, Quinze ans d'histoire,p.8. Cf.also M.Georges Lacour-Gayet's words: 'La France est certainement le pays, en delrors de la Roumanie, où les questions roumaines provoquent le plus de sympathie, ou les intérêts roumains sont le mieux sentis et le mieux compris'-ap. C. D. Mavrodin, La Roumanie contemporaine (p. $\mathrm{x}$ ); and of. also the elaborate studies of M. P. Éliade, L'Influence française sur l'esprit public en Roumanie (Paris, 1898); and Histoire de l'esprit public en Roumanie au XIX's siècle (Paris, 1905). 
of the Habsburgs. They ardently hoped to achieve not merely independence but union.

The former was virtually conceded in the Treaty of Paris, by which the Porte engaged to preserve to the principalities 'an independent and national administration as well as full liberty of worship, of legislation, of commerce, and of navigation'." The question as to the form of gorernment was postponed, and in order to ascertain the wishes of the inhabitants the Sultan undertook 'to convoke immediately, in each of the two provinces, a Diran ad hoc, composed in such a manner as to represent most closely the interests of all classes of society'.2

As to the wishes of the inhabitants there could be little doubt, and, in Napoleon, the champion of nationality, the Roumanians found a cordial supporter. Napoleon brought Russia round to his views. Austria, on the other hand, obstinate in her adherence to the policy Divide et Impera, and justly fearful of the operation of the nationality principle among her own subjects-particularly among the Roumans of Transylvania and the Bukovina-offered a strennous opposition. The Porte was naturally on the side of Austria, while the English Government, though not without considerable hesitation, eventually threw the weight of its influence into the same scale, on the ground that having fought to maintain the integrity of the Ottoman Empire, it could not logically support a project for its dismemberment. Persigny, the French ambassador in London, thought the entente with England much more important than the future of the principalities, and made no secret of his opinions. ${ }^{3}$ Thourenel, who represented France at Constantinople, was no less solicitous as to the maintenance of French influence over the Sultan, but behaved with greater discretion than his colleague in London. ${ }^{4}$

Under these circumstances much would obviously turn

1 Art. xxiii.

2 Art. xxiv.

3 Ollivier, L'Emtpire Libéral, iii. 411.

4 Cf. Louis Thouvenel, Trois Aus de la Question dOrient (1856-9), containing a number of important documents. 
upon the riews expressed by the Divans ad hoc. The elections were so manipulated by the provisional governors appointed by the Porte as to obtain the result desired by the Sultan. The scandal was so glaring that Thouvenel, supported by the ambassadors of Russia, Prussia, and Sardinia, entered an immediate protest, and, under the threat of a diplomatic rupture, compelled the Porte to cancel the results and hold the elections afresh.

Against this interference on the part of France and Russia the English Gorernment hotly protested. Lord Palmerston and Lord Clarendon were now deeply committed to the formula of 'the integrity of the Ottonan Empire'; still more deeply was Lord Stratford de Redcliffe concerned to maintain it. All three were profoundly suspicious of the good faith of Napoleon III, and gravely disquieted by his obrious rapprochement with Russia.

The

French

Emperor and Empress at Osborne.

In August, 1857, bowever, the French Emperor, accompanied by the Empress and by his Foreign Minister, Count Walewski, paid a visit to the English Court at Osborne. The question of the principalities was exhausticely discussed, and Napoleon urged very strongly that their 'union, by rendering those countries contented, and particularly if well governed by a European prince, would form an effectual barrier against Russia, whilst the present disjointed and unsatisfactory condition of those countries would make them always turn towards Russia. The union was, therefore, in the interest of Turkey'. As to the last point there may be a difference of opinion, but few people will now be found to deny that in his main contention the Emperor Napoleon was right, and the English statesmen wrong. Among the latter there were, howerer, one or two notable exceptions. The most notable was Mr. Gladstone, who, for once in his life, found himself in cordial agreement with Napoleon III, being drawn to the emperor's views by his warm sympathy with the nationality principle. He was not in office during the height of the crisis, but in May, 1858,

1 A record of this most important conversation, from the pen of the Prince Consort himself, will be found in Martin's Life of the Prince Consort, rol. iv, pu. $99 \mathrm{sq}$. 
he urged with characteristic vehemence that England ought to support the declared wish of the people of Wallachia and Moldavia. 'Surely the best resistance to be offered to Russia', he said, 'is by the strength and freedom of those countries that will have to resist her. You want to place a living barrier between Russia and Turkey. There is no barrier like the breast of freemen.' ${ }^{1}$ Mr. Gladstone carried with him into the division lobby not only Lord John Russell, but Lord Robert Cecil. They were unable, however, to prevail against the official view.

Meanwhile the diplomatic situation had become so grave as to threaten a renewal of war in the Near East. Napoleon III stoutly maintained his own views, and was supported by Russia, Prussia, and Sardinia. If war did not actually break out it was due partly to the sincere desire of the emperor to avoid any breach in the good relations between the English Court and his own ; partly to the natural reluctance of Russia and England again to draw the swords so lately sheathed; partly to English pre-occupation with the Sepoy mutiny in India ; but, above all, to the adroitness and tenacity of the prineipalities themselves.

Fresh elections having been held, the Disans ad hoc met in Jassy and Bucharest respectively (October, 1857). The Moldarian Assembly, by 80 rotes to 2, the Wallachian Assembly, without a dissentient roice, declared in farour of the 'union of the Principalities in a single nentral and autonomous State, subject to the suzerainty of the Sultan, and under the hereditary and constitutional government of a foreign prince'.

What were the Powers to do? Again they met in conference (May-August, 1858), and after nearly six months' deliberation resolved that the two principalities must remain politically separate : that each should have its own parliament and its own prince, to be elected by itself, but that affairs common to both should be entrusted to a joint commission of sixteen members, consisting of deputies from each parliament. 
This arrangement was both intrinsically clumsy and grossly insulting to the national sentiment of the Roumanians, who, with courage and ingenuity, resolved to cut the Gordian knot for themselres.

Election The National Assemblies duly met in the two capitals, and of Conza. both unanimously elected as their prince the same man, a native noble, Colonel Alexander Couza (January and February, 1859).

Union This flagrant defiance of the will of Europe caused concompleted.

Rule of Couza $(1861-6)$. siderable commotion in the Chancelleries; but the Powers eventually had the good sense to accept the accomplished fact; and on December 23, 1861, the union of the principalities was formally proclaimed. The new-born State was christened Roumania; and an agreement was reached, not without heart-burnings at Jassy, that the capital should be Bucharest. The united principalities did not provide a bed of roses for the prince of their choice; his brief reign sufficed to demonstrate the wisdom of the Roumanian leaders, who had, from the first, expressed a strong preference for a foreign hereditary dynasty. 'The accession to the throne of princes chosen from amongst us has', they declared, 'been a constant pretext for foreign interference, and the throne has been the cause of unending feud among the great families of this country.' Their misgivings were justified by the event.

Couza, though not conspicuous for domestic virtues, was a man of enlightened views, and anxiously desired to improve the social and economic condition of his people. Between 1862 and 1865 he carried through, despite much opposition from the 'feudal' party, a series of far-reaching reforms, mainly concerned with education and the agrarian problem.

Educa- The condition of education in Roumania was, indeed, tion. deplorable, but Couza made a serious effort to improve it. He founded two universities, one at Jassy and one at Bucharest; he established a number of secondary and technical schools, all of them free, and elementary education was made not only gratuitous but nominally compulsory. ${ }^{1}$ Despite

1 Since 1893, thanks to M. Take Jonescu, compulsion has been more than nominal. 
this fact the percentage of illiterates in Rommania is still very large. ${ }^{1}$ Couza then tackled the land question.

His first step was the secularization of monastic property. Agrarian Not less than one-fifth of the land of the country had passed reform. into the hands of the monks, who, to ensure themselves against spoliation, had affiliated their houses to the monasteries of Roumelia, Mount Athos, and Mount Sinai, and to the Patriarchies of Alexandria, Antioch, and Jerusalem. The device did not arail against the reforming zeal of Couza, who set aside over 27 million francs for the compensation of the patrons, but dissolved the monasteries, turned the abbots and monks adrift, seized their property for national purposes, and converted the houses themselves into hospitals and jails (1863).

The problem which confronted Couza was similar to that which, in the first years of the century, Stein and Hardenberg had faced and solved in Prussia. Roumanian feudalism was, in some respects, sui generis, but there, as elsewhere, the essential difficulty in modernizing a feudal land system was how, while respecting the rested interests of the 'lord' and the peasant owner respectively, to get rid of the legal and economic incubus of dual ownership.

Couza solved the problem, mutatis mutandis, much as it had been solved in Prussia. He abolished all dues, both in labour and kind, in return for an indemnity advanced to the lords by the State, to be repaid, in instalments, to the latter by the peasants; and he handed over one-third of the land in unshackled proprietorship to the peasants, leaving two-thirds in possession of the lords. That the compromise did not satisfy the peasants is proved by the fact that although some readjustment of the terms was effected in 1881, and again in 1889, the last thirty years have witnessed no less than fire insurrections among the Roumanian peasantry.

The path of the reformer is never easy, and in order to Coup overcome the opposition of the feudal and military parties, Ml'état of Couza was compelled, in May, 1864, to carry out a coup d'étct. 1864.

${ }^{1}$ Some authorities say sixty per cent. of people over seren. 
The army was employed to evict the deputies, and the prince demanded a plebiscite from his people for or against the policy which he propounded. The sole initiative in legislation was to belong to the prince; a Senate, nominated by him, was to be superadded to the Chamber, and the latter was to be elected by unirersal suffrage. The plebiscite gave the prince 682,621 votes against 1,307. Couza's action, compoumded of Cromwellianism and Bonapartism, subsequently received the sanction of the Powers.

Couza was now supreme, and the coup d'état was followed, appropriately enough, by the application of the Napoleonic codes - civil, criminal, and commercial - with slight modifications, to Roumania. That the coup d'état and its immediate results were generally approved by the people there can be no doubt, but the prince was assailed from many quarters: by the 'reds' who represented him as a pro-Russian dangerous to the peace of Europe; by the 'whites' who disliked his reforming activities; by the constitutionalists who denounced him as a bastard Bonaparte. Discontent reached a climax in August, 1865, when, during the prince's absence at Ems, a counter coup d'état was attempted at Bucharest. The Vicmua Fremdenblatt (August 5, 1865) detected in this coup) d'état the first signs of a revolutionary movement which would presently engulf not Rommania only, but Bosnia, Bulgaria, and Serbia as well. ' Couza hurried back to Roumania, but the movement against him rapidly gathered force; an association, comprising influential men from all parties, was formed with the object of substituting for him a foreign prince, and M. Jean Bratiano was sent abroad to find a suitable candidate. In Paris Conza was denounced as a Russian agent ; in St. Petersburg as the tool of Napoleon III.

Meanwhile, in February, 1866, the revolution had been quictly effected at Bucharest. Conza was deposed and deported, and a provisional government proclaimed as his successor Prince Philip of Flanders. ${ }^{2}$ This prince was promptly elected by the chambers, and their choice was ratified by plebiscite. Hardly a voice was raised for Couza; not a drop

1 Damé, La Roumanie contemporaine, p. 146.

${ }^{2}$ Father of King Albert of Belgium. 
of blood was shed on his behalf; he passed silently out of the land for which he had dared much, and seven years later he died in exile.

Prince Philip of Flanders promptly declined the proffered crown, which was thereupon offered to Prince Carol, the second son of the Prince of Hohenzollern-Sigmaringen, the elder and Catholic branch of the family ruling at Berlin.

A cousin of the King of Prussia, Prince Carol was, Prinee through his grandmother, connected with the Bonapartes. ${ }^{1}$ Carol of The Emperor Napoleon was sounded as to his candidature zollernthrough his intimate friend, Nadame Hortense Cornu, and Sigmaapproved it. King William of Prussia, dutifully consulted by his kinsman, was more doubtful ; but Bismarck, who was just about to phunge into war with Austria, perceived the advantage of having a Hohenzollern at Bucharest, and urged the prince to accept the offer, "if only for the sake of a piquant adventure'. The prince himself, if rumour be true, had never heard of Roumania when the offer reached him, but he took down an atlas, and, finding that a straight line drawn from London to Bombay passed through Roumania, exclaimed: 'That is a country with a future', and promptly decided to accept the crown."

The provisional offer was conveyed to him by John Bratiano on March 30 ; a plebiscite taken in April confirmed it ; and on May 22 the prince, having travelled in disguise to the frontier, made his formal entry into Bucharest.

A congress of the Powers at Paris had pronounced by four votes to three against the candidature of the Prince, but, like the Sultan himself, they ultimately accepted the accomplished fact, and a Hohenzollern prince, a Prussian dragoon, reigned over the principalities.

The outstanding features of his long, and, on the whole, Rule of prosperous, reign can here be indicated only in summary. Prince

His first act was to summon a constituent assembly which (1866drafted, on the Belgian nodel, a rery liberal Constitution. 1914).

1 His maternal grandmother was Stéphanie de Beaularnais, adopted daughter of Napoleon I, and his paternal granlmother was a Murat.

2 Carmen Sylva, wife of King Carol, tells the story (De Witte, op. cit., p. 7 ). 
A new Constitultion.

Accepted in 1866, and considerably amended in 1879 and 1884, that Constitution is still in force. Like its prototype, it is exceedingly meticulous, consisting of no less than 133 clauses. Alone among the Balkan States may Roumania be said to possess a monarchy which is genuinely 'constitutional' in the narrow English sense. The person of the king is, by article 92 , inviolable; his ministers are responsible, no act of the crown being valid unless signed by a responsible minister. Subject to this responsibility the crown enjoys the rights, and has to perform the duties, usually vested in the executive of a Constitutional State. ${ }^{1}$ The cabinet consists of nine members, who are responsible to the legislature. The latter is bicameral in form, but both chambers are elective. In each ease, however, the election is indirect, the elections being made throngh electoral colleges, composed of the taxpayers, who are divided into three colleges, according to the amount of taxes paid. The franchise is, however, higher in the case of the senatorial electors than in that of electors to the popular chamber. The senate consists of 120 members, who must be at least forty years of age and possess an income of $£ 376$ a year, and their term of office is for eight years. It enjoys a position not only of dignity but real power. The Chamber of Deputies consists of 183 members, who are elected for four years and must be at least fiveand-twenty years of age. ${ }^{2}$

The The Church has not played a part in the national evolution of Church. Roumania at all comparable to that which it played in Greece. And for a simple reason. Greek in its allegiance, the Church finds itself an alien institution among a Latin people. The people have always associated it, therefore, with foreign influences: with the Phanariote domination of the eighteenth century ; with the Church of their Russian 'protectors' in the first half of the nineteenth. Nevertheless, it was at once a symptom and a result of reviving national self-consciousness

1 The reality of the constitutional limitations upon the personal will of the sovereign was strikingly manifested, to the great advantage of the Entente, on the outbreak of the present war (1914).

2 The full text of the Constitution will be found in Dams, La Roumanie contemporaine, Appendice, pp. 425 sq. 
that the Roumanian Church should, in 1865, have declared its independence of the Greek Patriarchate of Constantinople. Since that time the Chureh has been virtually autocephalous, though its independence was not officially recognized by the Greek Patriarch until 1885.

From a social and economic standpoint the reign of Social and Prince Carol in Roumania has synchronized with the trans- Economic formation of a mediaeval into a modern State. One or two illustrations must suffice. In 1866 there did not exist a single railway in the State; in 1912 there were 3,690 kilometres of railways. The export of eereals, which, in 1866, was less than half a million tons, amounted, in 1913, to 1,320,235. Of petrol, the production at the earlier date was 5,915 tons; at the later about two million. A budget of 56 million francs sufficed for the country in 1866 ; it now exceeds 500 millions. In the war of 1877-9 the army numbered 40,000, and Roumania possessed not a single man-of-war ; the army now numbers more than a million, and there is an embryo fleet of thirty-one ships. Unlike most of the Balkan States Roumania possesses a powerful native aristocracy, but out of a population of seren and a half millions over one million are proprietor's, and most of the peasants own the land they cultivate. Industry derelops apace, but agriculture is still the main occupation of the people, only twenty per cent. of whom dwell in towns. The natality is said to be, next to that of Russia, the highest in Europe. The external trade of the country-consisting mainly in the export of oil and eereals-is now about fifty millions, and exeeeds that of all the other Balkan States together; but most of it is with the Central Empires. The imports from the United Kingdom are less than two millions ; from Germany and Austria-Hungary they are over thirteen.

The last figures indicate, eloquently enough, the new Foreign orientation of Roumanian policy. More and more since the policy. accession of Prince Carol was this Latin State drawn into the orbit of the Central-European Empires. Not unnaturally. 'Bien que je sois aujourd'hui prince de Roumanie,' so ran a telegram from Prince Carol to King William of Prussia in 1869 , 'je suis et je reste toujours un Hohenzollern.' The 
prince's marriage, in the same year, with the Princess Elizabeth of Wied, known to the world as the gifted Carmen Sylva, did nothing to diminish the force of his Teutonic sympathies.

The The Franco-German War revealed a serious clearage of

FrancoGerman Mar.

Position of Prince Carol. opinion between the prince and his subjects. When the war broke ont the prince wrote to King William to express his disappointment at not being able to "follow his beloved. Sovereign on to the field of battle, and at being compelled to the most rigorous reserve among a people whose sympathies were on the side of France'. The prince was not mistaken. It is true that since 1866 French influence at Bucharest had been waning, but from the hearts of the Roumanian people nothing could eradicate the sentiment of kinship with the people of France.

The position of a German prince at Bucharest, particularly when that prince's brother had been made the stalking-hor'se for the enmity between Germany and France, could not, during the war of 1870 , have been otherwise than difficult. In August, 1870, a serious émeute broke out at Ploïesti, a town about 60 kilometres north of Bucharest ; the 'Prussian prince' was denounced, and a republic proclaimed. The army remained loyal, and the insurrection was suppressed without difficulty, but it served to strengthen the disposition of the prince to abandon a thankless task. 'A German prince', so his father wrote to him on September 29, 'is made of stuff too precious to be wasted on such a useless job.' Financial complications, bitter discussions in parliament, insulting innuendos against the personal integrity of the prince, all tended to disgust Prince Carol with his position ; and in December, 1870, he appealed to the Powers to take into their consideration a revision of the Treaty of 1856.

The appeal came to nothing, and after the decisive victory of the Germans the excitement in Roumania tended to subside.

Only to be aroused, before long, and more acutely, over affairs nearer home. Already might be heard the distant rumblings of the storm, which, in 1875 , was to burst over the 
Balkans. From Montenegro, Bosnia, Herzegovina, Bulgaria, and Serbia came news which presaged the advent of a critical time for all the States and peoples actually or nominally subject to the Ottoman Sultan. Plainly it was not a moment to think of abdication, least of all for the prince who regarded himself as 'the extreme advance guard of civilization, the sentinel posted on the frontier of the East'.'

The part played by Roumania in the great drama of $1875-8$; the achierement of its independence (1878); its accession to the rank of a kingdom (1881); and its increasing inclination towards the Central European system, must receive notice in subsequent chapters.

$\mathrm{By}$ the close of the first decade of Prince Carol's reign the modern State of Roumania was fairly established. During the next few years the attention of the world was riretted upon other parts of the Ottoman Empire in Europe. On the eve of the great events of 1875 it may be well, therefore, to pause and examine the condition of the other peoples of the Balkans.

1 Prince Carol to Bismarck in 1871.

For further reference: A. D. Yénopol, Histoire des Roumains, and other works (translated into French from the Roumanian) (Paris, 1896); P. Éliade, Histoire de l'esprit public en Roumanie au $x I \mathrm{X}^{e}$ siècle (Paris, 1905), and L'Infuence française sur l'esprit public en Roumanie (Paris, 1898); F. Damé, Histoire de la Roumanie contemporaine, 18.21900 (Paris, 1900); Bon. Jehan de Witte, Quinze ans dhistoive, 1866-81 (Paris, 1905) ; C. D. Mavrodin, La Roumanie contemporaine (Paris, 1915) ; G. G. Giurgea, Données politiques et économiques sur la Roumanie moderne (Bucharest, 1913); R. W. Seton Watson, Roumania and the Great War (Constable \& Co., 1915); D. Mitrany, Roumania, in The Balkans (Clarendon Press, 1915); Ency. Brit. (11th edition), art. Roumania. 


\section{CHAPTER XII}

\section{THE BALKAN INSURRECTIONS}

The Southern Slavs. The Russo-Turkish War.

The Powers and the Eastern Question, 1856-78

'The Christian East has had enough of Turkish misrule. . . . High diplomacy will never solve the Eastern Question; it can be solved only in the East, in the theatre of war, with the co-operation of the peoples directly concerned.'-Prince Carol of Roumania.

'That Turkey is weak, fanatical, and miscoverned no one can honestly deny. ... The chief Powers of Christendom have all more or less an interest in the fortunes of an Empire which from heing systematically aggressive has become a tottering and untoward neighbour.'-LoRD Stratford de Redcliffe (1875).

Position Paradox is the eternal commonplace of the Eastern of Turkey Question. But even in the Near East paradox was nerer Crimean more triumphant than in the settlement which concluded the War. Crimean War. The Powers, as we have seen, expressly repudiated the right of interference, individual or collective, in the internal concerns of the Ottoman Empire. Yet the Treaty of Paris marks indisputably the point at which Turkey finally passed into a state of tutelage to the European Concert.

A fortnight after the signature of the general Treaty (March 30) a separate Treaty was, it will be remembered, concluded between Great Britain, France, and Austria guaranteeing 'jointly and sererally the independence and the integrity' of the Ottoman Empire (April 15, 1856). That guarantee imposed upon the Powers concerned a moral if not a legal responsibility of the gravest kind.

But this Treaty did not stand alone. At the moment when the Powers were negotiating their Treaties in Paris a conference was taking place in the British Embassy at Constantinople between the Turkish ministers and the representatives of the Powers. The ontcome of that conference 
was a charter of liberties which, as Lord Stratford de Redcliffe said, 'was made part of the general pacification under' an agreement that its insertion in the Treaty should not be made a pretext for the interference of any foreign Power in the internal affairs of Turkey'.1 The Firman of the Sultan was expressly described as 'emanating spontaneously from his sovereign will'; it was, however, 'communicated' to the contracting parties, and by them was 'ammexed' to the Treaty of Paris. Still, Turkey was to be entrusted with the fulfilment of her own promises.

Such was the paradoxical yet not unintelligible position in which matters were left by the Crimean War. The object of that war was, in the Prince Consort's words, 'the cancelling of all previous Russian treaties and the substitution of a European protectorate of the Christians, or rather of European protection for a Russian Protectorate'.2 That object was achiered. Plainly, howerer, there was a corollary. 'The Cabinet of Lord Aberdeen, while actively defending the independence of Turkey, felt that in objecting to the separate interference of Russia they were bound to obtain some guarantee for the security of the subjects of the Porte professing the Christian faith.' ${ }^{3}$ Thus, at a later date, Lord Russell. How far did the Turks fulfil their own promises? How far did the 'guarantee' obtained by the Powers prove effective for its purpose? It is the main purpose of this chapter to answer these questions.

While the Powers were concluding Peace in Paris, the The Sultan Abdul Medjid issued in February, 1856, a second Hatti-Huedition of the Tanzimat of Gulhaneh. Except in regard to Feb. 18, military refor'm the famous Tanzimat had remained a dead letter. The Christians, so far from obtaining the promised equality before the law, found themselves still treated as a despised and conquered people. Their word was not accepted in the courts; they were exposed to the extortions of every Moslem official, high or low; life, honour,

1 The Eastern Question, p. 14.

2 Martin, Lite, iii. 92.

3 Turkey, xvii, $187 \pi$, Y. 148 , p. 115, quoted by Duke of Argyll, Eastern Question, i, p. 34 . 
fortune was still at the mercy of the dominant race. But all this was now to be reformed. The Hatti-Humayoun of 1856 guaranteed to every subject of the Porte, without distinction of creed or class, personal liberty ; equality before the law; complete religious freedom; eligibility for office civil and military ; equality of taxation; equal representation in the communal and provincial councils and in the supreme Council of Justice ; and complete security of property. ${ }^{1}$ On paper nothing could have been more satisfactory. But practically nothing came of it.

Sultan In 1861 Sultan Abdul Medjid at last drank himself to Abdul Aziz death, and was succeeded by Abdul Aziz. At this fateful (1861-76). moment in its history, when the Western Powers had secured to it-on conditions-a reprieve, when its life depended upon a radical reform not merely of law but of administration, the Ottoman Empire was entrusted to the care of an amiable and well-intentioned but half-insane ruler. Abdul Aziz was sincerely minded to follow the prudent monitions of the Powers ; he did something to modernize and secularize the administration of the State; to initiate useful public works; to improve means of communication ; to exploit the natural resources of his empire; and to found a system of education, primary and secondary, free from ecclesiastical control and open to pupils of every creed. He set up a High Court of Justice, composed in equal numbers of Christians and Moslems, and in 1868 he crowned the administrative edifice by establishing a Council of State. The council was to have legislative as well as administrative functions ; it was to consist of Christians as well as Moslems, and, best of all, was to have as its first president Midhat Pasha, a statesman of enlightened views and strong character.

It was all to no purpose. The Ottoman Empire was and always had been a theocracy. It is impossible to secularize a theocracy : to reform law which rests upon an unchangeable religious sanction; or to secure good and equal government for men whose life, honour, and property were at the mercy of local officials, when those officials were in a few cases only

${ }^{1}$ The full text is printed in Holland, European Concert, pp. 329 sq. 
at once honest and eapable, in most cases were neither, and in all cases were beyond the reach or control of the energetic and well-intentioned reformers at Stamboul.

Here lay the root of the difficulty. To overcome it there was needed a man of exceptional strength of character, who was free to act without reference to the advice of more or less interested monitors; above all, a man who could rule, with a stern hand, his own political household.

Abdul Aziz had no such qualifications, and as his reign went on he plunged deeper and deeper into the grossest forms of personal extravagance. His incessant demands for money and more money afforded an exeuse for the rapacity of subordinates, and eren the best of the provincial Pashas were compelled to tighten the financial serew upon the peoples committed to their charge.

Nor were those peoples in a mood to submit to the exactions Political of the Turkish Pashas. A new spirit was beginning to stir the renais'dry bones' in the Balkan valleys. It was excited partly by the Balthe movement in the principalities; partly by the reforming kans. morement at Constantinople; partly by the deliberate PanSlavist propaganda of Russian agents, and not least by the memory of the Napoleonic rule in the 'Illyrian provinces'. Among the makers of United Germany and United Italy the first Napoleon already oceupies a conspicuous place. It may be that he is destined to a place not less conspicuous among the makers of the future Jugo-Slar Empire. This at least is certain, that the Jugo-Slars of to-day look back to the time, 1809-14, when, under the name of 'The Illyrian Provinees', Dalmatia, Istria, Trieste, Gorizia, Carinthia, Carniola, and part of Croatia were united under Napoleon's auspices, as the happiest and most fruitful period in the modem history of their race. The mere fact of union, though transitory and achieved under an alien ruler, was in itself an inspiration for the future, after the oppression and disumion of centuries; and the rule though alien was enlightened. In particular, the modern Jugo-Slavs recall with gratitude the fact that Napoleon reintroduced their natire tongue both as the medium of education and as the official language of the Illyrian State. Between 1830 and 1840 there was a renaissance of this 
'Illyrian' spirit, which was, however, sternly repressed by the Austrian administrators.

Serbia. Of the Southern-Slav movement Serbia was, throughout the nineteenth century, the most conspicuous and powerful champion. After a quarter of a century of struggle and vicissitude Serbia had, as we saw, become by 1829 an autonomous principality under the suzerainty of the Sultan, though the Turks continued to garrison the eight principal fortresses.

But only the first steps had been taken along the path of national regeneration. An immense task still awaited the Serbian people. They had, in the first place, to remake Serbia, in a territorial sense. What Serbia had been in the days of her greatness we have already seen. What she had been in the past she aspired again to be. The Serbia of 1830 included a very small portion of her ancient territory. The Turks were still in possession not only of Bosnia and the Herzegovina, but of the Sanjak of Novi-Bazar and the distriet of northern Macedonia known as Old serbia. To reunite with herself these territories was, and is, the minimum of Serbian aspirations.

In the second place, she had to work out her own constitutional salvation; to compose, if possible, the dynastic antagonisms which seemed so curionsly at variance with the genius of a Peasant-State; to devise an appropriate form of govermment, and to get rid of the last traces of Turkish sovereignty.

She had, lastly, and above all, to prepare herself by social, educational, and economic reform for the great part which she believed herself to be destined to play as the liberator of the Southern Slars, who were still under the heel of Habsburg and Turk, and as the centre and pirot of that Greater Serbia, the Jugo-Slav Empire, which is still in the future.

Serbia The period between 1830 and 1875 was largely ocenpied $(1830-75) \cdot$ by dyuastic alternations between the Obrenovićs and the Karageorgevićs which it would serve no useful purpose to follow in detail. The quarrel between the two families was not indeed really composed until the extinction of the former dynasty by the brutal though not undeserved assassination of 
King Alexander and his ill-omened consort Draga in 1903. Nothing could have been more disastrous for the infant State : not only was interual development seriously hampered, but, to an outside world ignorant of Serbia's great past, the impression was inevitably conveyed that the Serbia of the present consisted of half-civilized swineherds; and that it was perhaps unfortunate that these swineherds should have escaped from the control of the Ottoman Empire which had alone understood the best way of dealing with unruly savages. How false that impression was it has required a political martyrdom to prove to the world.

Apart from almost perpetual squabbles between the turbulent peasantry and their eleeted rulers, and between the rival chiefs, there are only two events, in the period between the attainment of autonomy (1829) and the outbreak of the Balkan insurrections (1875), which call for special mention.

The first is the achierement, in 1831, of ecelesiastical independence; the second is the evacuation of the Serbian fortresses by the Turks in 1867 .

As in Greece, so also in Serbia, the Orthodox Chmrch has The been throughout the ages the mursing mother of national inde- Serbian pendence. Founded and organized by St. Sava, the son of King Nemanja, the Serbian Church has been at once Orthodox and national. 'If the father (King Nemanja) endowed the Serbian State with a body, the son (St. Sava) gave it', ats Father Nicholas Velimirovic has eloquently and truly said, a 'soul. And later on, when the body of the Serbian state was destroyed by the Turkish invasion, the soul lived on through the centuries, and suffered, and nothing remained unconquered in this sonl but her faith, and the tradition of the freedom of the past. The monasteries were centres of trust and hope. The priests were the guides of the people, upholding and comforting them. The Patriarehs of Ipek were in truth patriarchs of the people, and, like the patriarchs of old, true representatives of the people and their protectors.' 1

The first act of the great Stephen Dushan had been, as we

\section{Religion and Nationality in Serbia, p. 7.}


saw, to summon an Ecclesiastical Council and to proclaim the Serbian Church a Patriarchate with its ecclesiastical capital at Ipek in Montenegro (1345). After the Ottoman conquest the Patriarchate of Ipek was abolished; the Serbian Church lost its independence; was subordinated to the Greco-Bulgar Archbishopric of Ochrida, and, for some two centuries, fell completely under the control of the Greeks. But in 1557 the Patriarchate of Ipek was revived. 'The revival of this centre of national life was momentous; through its agency the Serbian monasteries were restored, ecclesiastical books printed, and, more fortunate than the Bulgarian national Church, which remained under Greek management, it was able to focus the national enthusiasms and aspirations and keep alive with hope the flame of nationality among those Serbs who had not emigrated.' 1

Serbia suffered terribly at the hands of both Turks and Austrians during the wars of the seventeenth and eighteenth centuries, and in 1766 the Patriarchate of Ipek was finally abolished and the Serbian Church acknowledged the supremacy of the Greek Patriarch of Constantinople.

Ecclesiastical independence (1831).

Turkish evacuation of the fortresses.

With the revival of national self-consciousness in the nineteenth century came a renewed desire for ecclesiastical independence, and in 1831 Prince Miloš finally broke the chain which still bound the Serbian Church to the Patriarchate of Constantinople. Thus, at last, after many vicissitudes, Serbia obtained a national Church with a Metropolitan at Belgrade.

The year 1867 witnessed the completion of another stage on the long and toilsome journey towards national independence. The position of Serbia during the second quarter of the nineteenth century was more than usually paradoxical. Still subject to the sovereignty of the Sultan, she was really under the protectorship of Russia. But the Sultan possessed a tangible symbol of authority in the continued military occupation of the fortresses. Nor were the garrisons withdrawn even after the Crimean War. In that war Serbia took no part. The people inclined towards the Russian side, but 
the prince (Alexander Karageorgević) was under considerable obligations both to Turkey and to Austria. Nor could the prince forget the encouragement which Serbia had obtained from Lord Palmerston, who, for the first time, had sent a British consul to Belgrade in 1837, nor the support given to himself in 1843 by Lord Stratford de Redcliffe. By the Treaty of Paris Serbia, like the principalities, was tacitly excepted from the protectorate of Russia; she was to continue to enjoy an 'independent and national administration, as well as full liberty of worship, of legislation, of commerce and navigation', and her rights and immunities were 'placed thenceforth under the collective guarantee of the contracting powers'. An émeute at Belgrade in 1862 led to the withdrawal of the civilian Turkish population, and in 1867 Prince Michael Obrenovic III had the satisfaction of bringing about the final evacuation of the fortresses. Michael persuaded the Sultan that a grateful Serbia would be a far more effective barrier against an Austrian attack than a few isolated Turkish garrisons on the Danube and the Save; he persuaded Austria that a Serbian Belgrade would prove more neighbourly than a Turkish outpost; France, Russia, and Great Britain supported him ; the Porte gave way ; in May, 1867, the Turks finally eracuated Serbia, and Belgrade became, for the first time for many centuries, not merely the Serbian capital, but a Serbian city.

Independence was now virtually achieved, but the nominal suzerainty of the Sultan was not actually extinguished until the Turkish Empire had been broken by the Balkan insurrection of 1875 and the Russian War. To these erents we must now turn.

But for the foolish and brutal murder of Prince Michael in 1868 the great national uprisings of 1875 would have started more obviously under the leadership of serbia. That brilliant ruler had worked out an elaborate combination not only with the Southern Slavs of Montenegro, Bosnia, and the Herzegovina, but with the nationalist leaders in Croatia, with a Bulgarian patriotic society, and even with Greece. The Serbians have paid dearly for the dastardly crime, not the first nor the last of its kind, perpetrated in 1868. Had 
that crime not taken place the events of 1912-13 might possibly have been antedated by a whole generation; Serbia might have placed herself at the head of a great Southern-Slav Empire, while Austria was still reeling under the shock of Sadowa, when the German Empire had not yet come to the birth, when Bosnia and Herzegovina were still 'Turkish', and when Bulgarian aspirations were not yet formulated in opposition to those of the Southern Slars. The crime of 1868 robbed Serbia of a chance which, in its original form, can never recur.

Bosnia It was not Serbia then, but the Slav inhabitants of one and the remote village in the Herzegovina who, in the summer of Herzego-
rina. which quickly involved the whole of the Slav States in the Ottoman Empire; which, beforc it was quelled, led to another war between Russia and Turkey, and all but eventuated in a great European conflagration.

The primary canses of the original rising in Bosnia and the Herzegovina were not so much political as social and economic; they acquired strength less from the spirit of nationality than from the umbearable nature of the fiscal burdens imposed upon the peasantry by Turkish officials and native landowners.

Renegade Bosnia and the Herzegovina presented in several respects Nobles. a striking contrast to Serbia. It was against the powerful Empire of Serbia that the attack of the Ottoman Turks was first directed after their adrent into Europe. Bosnia, more remote and more obscure, managed to retain until 1463 independence. The Herzegovina until 1482. But when once conquered they were more completely absorbed into the Ottoman system than ever Serbia was. For another reason these provinces became more 'Turkish' than any other part of the Balkan peninsula except perhaps Bulgaria and the provinces immediately adjacent to Constantinople. Bosnia was a land of large landowners who, to save their property, abandoned their faith and "embraced Mohammedanism, not only with discretion, but with zeal.

Christian Nor was the Slav peasantry ecclesiastically homogeneous. Peasan- The najority adhered to the Orthodox Church, but mingled
try. 
with them was a very strong body of Roman Catholics, who leaned upon the Roman Catholic Slars of Croatia just as naturally as the Orthodox Bosuians looked to the Serbs. The aristocracy, who were exceptionally powerful in Bosnia, were Moslems to a man, and acknowledged in the Sultan not merely their political but their spiritual lord: sovereign and caliph in one. The Bosnian Moslems were indeed in every way 'more Turkish than the Turks', and in no quarter did the reforming party in Constantinople encounter more bitter or more sustained opposition than from the feudal renegades in Bosnia. The suppression of the Janissaries and the other reforms attempted by sultan Mahmud led to open revolt, and the policy embodied in the Tanzimat and the Hatti-Humayoun of 1856 was vicwed with the utmost disfarour.

It is not difficult, therefore, to understand why the condition of the Christian peasantry in these provinces should have been even less tolerable than elsewhere. Exposed on the one hand to the unregulated rapacity of the Ottoman tax-farmer ; ground down on the other by the labour services and burdensome dues demanded by their native fendal lords; the wretehed peasants found themselves between the hammer and the anvil.

But there were other ingredients in the restlessness of the PanBalkan Slavs which are less easy to discriminate. Ever Slarism. since the Crimean War missionaries of the new gospel of Pan-Slarism-mostly Russians-had been engaged in an unceasing propaganda among the peoples of their own faith and their own blood. In 1867 a great Pan-Slavist congress was held, under the thin disguise of a scientific meeting, at Moscow. It issued in the formation of a central Pan-Slavist committee with its head-quarters at Moscow, and a subcommittee sitting at Bucharest; books and pamphlets were circulated in the Balkans; young Slavs flocked to Russian universities, just as the Roumanian youths flocked to Paris; Serbia, Montenegro, Bosnia, and Bulgaria were honeycombed with secret societies.

Nor did the movement lack official support. Behind the popular propaganda were the forces of high diplomacy. 
Every Russian consul in the peninsula was a Pan-Slavist, and General Ignatieff, an enthusiast in the same cause, was appointed ambassador at Constantinople.

How far, at the precise moment of the outbreak, the incitement came from outside, how far it was a spontaneous explosion against political wrongs and fiscal oppression which had become intolerable, it is impossible to say. That both ingredients were present is beyond dispute; their proportions cannot, with accuracy, be determined.

The rising In July, 1875, the peasants of the Herzegovina suddenly in the Duchy. refused to pay their taxes or to perform their accustomed labour services, and, when confronted by a Turkish force, inflicted upon it a decisive defeat (July 24). Sympathizers flocked to their assistance from Serbia, Montenegro, and Dalmatia, and things began to look ugly when the consuls of the Powers intervened with an attempt to mediate between the Ottoman Government and its discontented subjects.

Consular For years past the British Government had been made Reports. aware by the reports of its consuls of the appalling condition of the Turkish provinces. As early as $1860 \mathrm{Mr}$. Holmes, the British consul in Bosnia, had warned the Foreign Office that "the conduct of the Turkish authorities in these provinces had been sufficient, in conjunction with foreign agitation, to bring Bosnia to the rery verge of rebellion, whilst the Herzegovina was in a state of war'. ${ }^{1}$ From Monastir, Janina, aud other parts came stories of almost inconceivable misgovernment, obscurantism, and tyranny: another batch of reports, containing further evidence, was laid before Parliament in 1867.2 In $1871 \mathrm{Mr}$. Holmes referred to 'the open bribery and corruption, the invariable and unjust farour shown to Ifussulmans in all cases between Turks and Christians' which was characteristic ' of what is called justice' throughout the Ottoman Empire. 'I do not hesitate to say', he wrote in April, that 'of all cases of justice, whether between Mrussulmans alone, or Turks and Christians, ninety out of a hundred are settled by bribery alone.' These reports testify not only

1 Reports on Condition of Christians in Turkey, 1860, presented to Parliament, 1861, p. 73 and passim.

$\because$ Reports, 1867. 
to the abuses of Turkish misgovernment, but to foreign interference. Thus in $1873 \mathrm{Mr}$. Holmes reported that Austrian and Russian agents were 'equally working to create difficulties'. ${ }^{1}$

Nor had the British Government neglected to warn the Porte of the ineritable outcome of the policy it was pursuing. Thus in 1861 Lord Russell, referring to the recent massacres in Syria, solemnly warned the Sultan that while Great Britain would resist 'a wanton violation of the rights or an unprovoked invasion of the territory of the Porte by any European sovereign', yet 'the public opinion of Europe would not approve of a protection accorded to the Porte in order to prevent the signal punishment of a Government' which should permit such atrocities to continne. ${ }^{2}$ Similarly, in 1870, Lord Granville instructed Sir Henry Elliot to impress upon Turkey 'that her' real safety will depend upon the spirit and feelings of the populations over which she rules'.

It is, however, unnecessary to multiply quotations. Writ large over the Papers presented at intervals to Parliament will be found orerwhelming testimony, on the one hand, to Turkish misgovernment; on the other to the Pan-Slavist agitation; and, above all, to the reiterated but unlieeded warnings addressed to the Ottoman Government.

In September, 1875, the insurgents themselves laid before Demands the European consuls in Bosnia a statement of their case of the inand an appeal for sympathy if not for help. They demanded freedom for their religion; the right to give eridence in the courts; the formation of a local Christian militia, and reforms in the imposition and collection of taxation; they declared that they would die rather than continue to suffer such slavery; they begged that the Powers would at least not obstruct their enterprise or assist their oppressors; and they concluded by suggesting alternative remedies: either (1) 'a corner of land' in some Christian state to which they might emigrate en masse; or (2) the formation of Bosnia and the Herzegovina into an autonomous state 'tributary to the Sultan with some Christian prince from somewhere, but

${ }^{1}$ Turkey, xri, 1877, No. 21.

${ }^{2}$ Turkey, xvii, $18 \pi 7$, No. 73. 
never from here'; or (3), as a minimum, a temporary foreign occupation.

In an Iradé published on October 2 the Porte promised prompt and general reform; but nevertheless the insurrection deepened and spread. In a Firman issued on December 12 the Sultan offered the immediate establishment of local elective councils, in which the Christians were to take part; and a local gendarmerie. The reply of the insurgents took the form of further defeats inflicted on the Turkish troops.

The The Powers could no longer refrain from interference, and Powers. their action was hastened by financial considerations.

It is one of the salutary paradoxes incidental to misgovernment that it is as ruinous to the sovereign as it is hurtful to the subject. The inherent extravagance of a bad system had combined with the peculation of officials to bring disaster upon Turkey, and on October 7, 1875, the Sultan was compelled to inform his creditors that he could not pay the full interest on the debt. Partial repudiation complicated an international situation already sufficiently embarrassing. Accordingly, the Sovereigns of Germany, Russia, and Austria took counsel together, and on December 30, 1875, the Austrian Chancellor, Count Andrassy, issued from Buda-Pesth the Note which bears his name.

The The Andrassy Note professed the anxiety of the Powers to Andrassy curtail the area of the insurrection and to maintain the peace
Note. of Europe; it drew attention to the failure of the Porte to carry out reforms long orerdue, and it insisted that pressure must be put upon the Sultan effectually to redeem his promises. In particular he must be pressed to grant complete religious liberty; to abolish tax-farming; to apply the direct taxes, locally levied in Bosnia and Herzegovina, to the local needs of those provinces; to improve the condition of the rural population by multiplying peasant owners; and, above all, to appoint a special commission, composed in equal numbers of Mussulmans and Christians, to control the execution not only of the reforms now proposed by the Powers, but also of those spontaneously promised by the Sultan in the Iradé of October 2 and the Firman of December 12. 
Finally, the three emperors required that the Sultan should, by a signed Convention, pledge himself to a prompt and effectual execution of the reforms; in default of which the Powers could not undertake to continue their efforts to restrain and pacify the insurgents. ${ }^{1}$ To this Note the British Government gave a general adhesion, though they pointed out that the Sultan had during the last few months promised to carry out the more important of the reforms indicated therein.

The Note was presented to the Porte at the end of January, 1876; and the Sultan, with almost suspicious promptitude, accepted four out of the five points ; the exception being the application of the direct taxes to local objects.

The friendly efforts of the diplomatists were foiled, however, by the attitude of the insurgents. The latter refused, not unnaturally, to be satisfied with mere assurances, or to lay down their arms without substantial guarantees. The Sultan on his side insisted, again not without reason, that it was impossible to initiate a scheme of reform while the provinces were actually in armed rebellion. Meanwhile the mischief was spreading. Bosnia threw in its lot with the Herzegorina; Serbia, Montenegro, and Bulgaria were preparing to do the same when, at the beginning of May, a fanatical Mohammedan outbreak at Salonica led to the murder of the French and German consuls. Drastic measures were obriously necessary if a great European conflagration was to be aroided.

On May 11 the Austrian and Russian Chancellors were The Berin conference with Prince Bismarck at Berlin, and deter- lin Nemomined to make further and more peremptory demands upon the Sultan. There was to be an immediate armistice of two months' duration, during which certain measures of pacification and repatriation were to be executed under the superintendence of the delegates of the Powers. A mixed Commission, composed of natives faithfully representing the two creeds of the country and presided orer by a native Christian, was to be appointed in Bosnia and the Herzegovina; and the

1 The full text of the Andrassy Note will be found in Hertslet, Iap of Europe by Treaty, rol. iv, pp. 2418-29. 
insurgents were to be permitted to remain under arms until the reforms promised by the Sultan in October and December, 1875, had been carried into effect. If by the expiry of the armistice the object of the Powers had not been attained, diplomatic action would have to be reinforced.

France and Italy assented to the Note, but the British Government regarded the terms as unduly peremptory; they resented, very naturally, the independent action of the three imperial Powers; they declined on May 19 to be a party to the Memorandum; and on the 24th ordered the fleet to anchor in Besika Bay. Accordingly, the proposed intervention was abandoned. The Moslem patriots replied in characteristic fashion to Christian menaces. On May 29 they deposed the Sultan Abdul Aziz as too feeble for their purposes, and on June 4 he was suicidé; his insane successor, Murad V, reigned only three months, being in turn (August 31) deposed to make room for his brother, Abdul Hamid, the cleverest Sultan Islam had known since the sixteenth century.

Attitude Mr. Disraeli's refusal to assent to the Berlin Memorandum of the English Government. created profound perturbation abroad, and evoked a storm of criticism at home. There can be no question that the European Concert, whatever it was worth, was broken by the action of Great Britain. If the latter had joined the other Powers, irresistible pressure would have been put upon the Porte, and some terrible atrocities might have been averted. On the other hand, it is indisputable that the Imperial Chancellors were guilty, to say the least, of grave discourtesy towards Great Britain ; nor can it be denied that, assuming a sincere desire for the preservation of peace, they committed an inexcusable blunder in not inviting the cooperation of England before they formulated the demands contained in the Berlin Memorandum.

Spread of Events were in the meantime moving rapidly in the the insur- Balkans. On June 30, 1876, Serbia formally declared war
rection. upon the Porte; Prince Milan being stimulated to action partly by irresistible pressure from his own people, and partly by fear of Peter Karageorgević, the representative of the rival dynasty. One day later Prince Nicholas of Montenegro followed his example. 
The tiny principality which thus came into the forefront Monteof Balkan politics has not hitlıerto elaimed much space in this negro. narrative. Serbs of the purest blood and subjects of the great Serbian Empire, the inhabitants of the Black Mountain had, on the dissolution of Dushan's Empire, proclaimed their antonomy. During the sixteenth and seventeenth centuries the Black Mountain was technically included in the Turkish province of Scutari, but the inhabitants, secure in fastnesses almost inaccessible, continued to be ruled by their Prince-Bishops, and never acknowledged the authority of the Ottoman Sultan.

In the eighteenth century they came forward as the champions of the Slar nationality; they received cordial encouragement from Russia, and played some part in the Turkish wars of the Empress Catherine. When, by the Treaty of Pressburg, Napoleon seized Dalmatia, the Montenegrins, with the support of the Tsar Alexander, occupied the splendid harbour known as the Bocele di Cattaro, and refused to evacuate it. The Bocche di Cattaro had belonged to them until the Treaty of Carlowitz (1699). That treaty had assigned the harbour to Venice, from whom in 1797 it was transferred to Austria. At Tilsit, howerer, Napoleon claimed it from Alexander, who deserted the Montenegrin cause. Half a century later the championship of that cause was assumed by Austria. Bishops of the Orthodox Church being celibate, the succession in Montenegro had always been collateral. But in 1851, on the death of the Prince-Bishop Peter II, his nephew and successor, Danilo, proposed to marry and to secularize the principality. With the approral of the Tsar and the assistance of Austria this change, though not withont a war with the Turks, was effected in 1852. Nowhere in the Balkans did the flame of Slar nationality, frequently revived by contests with the Turks, burn more pure, and the intervention of the little principality in 1876 was therefore according to expectation.

Nor was the unrest confined to Slars of the purest blood. Bulgaria. It spread even to Bulgaria, which of all the Balkan provinces had been most completely absorbed into the Ottoman system. For that reason we have heard nothing of Bulgaria since the last restiges of its independence were crushed out by 
the Ottoman victories in the closing years of the fourteenth century. ${ }^{1}$

During the great days of the Ottoman Empire the lot of the Bulgarians, as of other conquered peoples in the peninsula, was far from intolerable. As in Bosnia, many of the nobles embraced Mohammedanism, but the mass of the people adhered to their own creed, and, provided the tribute of children and money was punctually forthcoming, the Turks did not interfere with the exercise of Orthodox rites, nor with the ecclesiastical jurisdiction of the Orthodox priests. Some of the towns were permitted to retain their municipal privileges; a considerable measure of autonomy was conceded to the province at large; and the natives were allowed the free use of their own language.

Here, as elsewhere, the condition of the subject people deteriorated as the rule of the Ottoman Government became enfeebled. The Bulgarians suffered much from the passage of the Ottoman armies as they marched north against the Austrians, and later from that of the Russians when they began to threaten or to defend Constantinople. To Russia, however, Bulgaria began to look towards the end of the eighteenth century for protection. The stipulations for the better government of the principalities and the islands contained in the Treaty of Kainardji; the presence of a Russian ambassador at Constantinople; the privileges conceded, on Russia's demand, to the Christians, all tended in the same direction.

The Bul- In Bulgaria, as in Serbia, the Ottoman Sultan was not the Charch. only nor perhaps the most formidable foe to the spirit of independence and the sense of nationality. By the Sultan's side in Constantinople was the Greek Patriarch. Politically, Bulgaria was conquered and absorbed by the Turks ; socially and ecclesiastically, it was permeated by the Phanariote Greeks. The methods employed by the latter were parallel to, but even more thorough than, those which, as we have seen, were employed in Serbia: the independent Patriarchate of Tirnovo was in 1777 suppressed; all the higher ecclesiastical offices were monopolized by Phanariotes; the parish clergy,

1 Supra, chap. iii. 
even the schoolmasters, were Greek, and Greek became not only the language of 'society' but the sole medinm of instruction in the schools of the people. ${ }^{1}$ The first step towards a revival of Bulgarian nationality was therefore a restoration of ecclesiastical independence. The Porte promised to make certain concessions-the appointment of native bishops and the use of the native tongue in schools and churches-in 1856. But nothing was rone, and in 1860 the Bulgarians refused any longer to recognize the Patriarch of Constantinople. Not for ten years did the Porte give way, but in 1870 it agreed to the establishment of a separate Bulgarian Exarchate at Constantinople, with jurisdiction not only over Bulgarians in Bulgaria proper, but over those of Macedonia, and indeed over any community (millet) of Bulgarians in any part of the empire.

The demand for a Bulgarian Exarchate was symptomatic. The spirit which was moving the purer Slars of Serbia, Montenegro, Bosnia, and the Herzegorina was not leaving the Bulgar-Slars untouched. Nor were they less moved by the Pan-Slavist impulse from without. The Bulgarians, more even than the Serbs, were roused to a remembrance of their ancient greatness by the tramp of foreign soldiers in the peninsula. The march of the Russians upon Adrianople in 1828 naturally caused considerable exeitement eren among the phlegmatic peasants of Bulgaria; the presence of the allied armies at Varna in 1854 evoked emotions of a different but hardly less exciting character. At least these were signs of impending ehanges. Clearly, things were not going to be in the Balkans as for five hundred years they had been.

Nerertheless, it was not until May, 1876, that the name Bulgarian first beeame familiar on the lips of men. On the first day of the month, some of the Bulgarian Christians, imitating the peasants of Herzegovina, defied the orders of the Turkish officials, and put one hundred of them to death. The Herzegorina was relatively remote, but now

I 'Even forty years ago', wrote sir Charles Eliot in 1896 , 'the name Bulgarian was almost unknown, and every educated person coming from that country called himself a Greek as a matter of course' (op). cit., p. 314). 
the spirit of insubordination seemed to be infecting the heart of the empire. The Porte, already engaged in war with Serbia and Montenegro, was terrified at the idea of an attack upon the right flank of its army, and determined upon a prompt and terrible suppression of the Bulgarian revolt. A force of 18,000 regulars was marched into Bulgaria, and hordes of irregulars, Bashi-Bazouks, and Circassians were let loose to wreak the rengeance of the Sultan upon a peasantry unprepared for resistance and mostly unarmed. Whole villages were wiped out, and in the town of Batak only 2,000 out of 7,000 inhabitants escaped massacre.

Bulgarian On Jume 23 a London newspaper published the first acatrocities. count of the horrors alleged to have been perpetrated by the Turks in Bulgaria. How much of exaggeration there was in the tale of atrocities with which England and the world soon rang it was and is impossible to say. But something much less than the ascertained facts would be suffieient to account for the profound emotion which moved the whole Christian world. In July Mr. Walter Baring was sent by the British Government to Adrianople to ascertain, if possible, the truth. After careful investigation he came to the conclusion that in the initial outbreak 136 Moslems had been murdered, while, in the subsequent massacres, 'not fewer than 12,000 Christians' perished. ${ }^{1}$ His final report was not issued until September, but preliminary reports so far substantiated the accounts which had been published in the English Press as to move the conseience of England to its depths. In a dispateh ${ }^{2}$ to Sir Henry Elliot, British Ambassador to the Porte, Lord Derby gave expression, in language not the less strong by reason of its restraint, to the feelings of indignation aroused in England by the accounts of the Bulgarian atrocities, and instructed him to demand from the Sultan prompt and effective reparation for the rictims.

Mr. Glarl- But a voice more powerful than that of Lord Derby was stone's
pamphlet. already making articulate the feelings of his countrymen. To Mr. Gladstone the tale of atrocities made an irresistible

I M. Driault (op. cit., p. 214) puts the number much higher: 25,00030.000 .

- Sept. 21, 1876 . 
appeal. A pamphlet, published on September 6, was circulated by tens of thousands. ${ }^{1}$ With voice and pen he vehemently demanded that the Turks should be eleared ont 'bag and baggage ... from the province they have desolated and profaned'.

Meanwhile another complication had arisen. At the end Turcoof Jume Serbia and Nontenegro, as we have seen, had SerbWar. declared war upon the Porte. How far would that conflict extend? Could it be confined within the original limits? These were the serious questions with which diplomacy was now confronted. The Serbian army consisted largely of Russian volunteers and was commanded by a Russian general. How long would it be before the Russian Government became a party to the quarrel? The Serbian army, even reinforced by the volunteers, could offer but a feeble resistance to the Turk, and in Angust Prince Milan, acting on a hint from England, asked for the mediation of the Powers. ${ }^{2}$ England, thereupon, urged the Sultan to come to terms with Serbia and Montenegro, lest a worse thing should befall him. The Sultan declined an armistice, but formulated his terms, and intimated that if the Powers approved them he would grant an immediate suspension of hostilities. But to Lord Derby's chagrin Serbia would accept nothing less than an armistice, and, after six weeks' suspension, hostilities recommenced. Nerertheless, the English Government was untiring in its efforts to promote a pacification, and suggested to the Powers some heads of proposals (September 21): the status quo in Serbia and Montenegro; local or administrative autonomy for Bosnia and Herzegorina; guarantees against maladministration in Bulgaria, and a comprehensive scheme of reform, all to be embodied in a protocol concluded between the Porte and the Powers. Russia then proposed (September 26) that, in the event of a refusal from Turkey, the allied fleets should enter the Bosphorus, that Bosnia should be temporarily occupied by Austria, and Bulgaria by Russia. Turkey, thereupon, renewed her dilatory tactics,

1 The Bulgarian Horrors and the Question of the East.

¿ Turkey, 1877 (No. 1), p. 380. 
but Russia's patience was almost exhansted; General Ignatieff arrived at Constantinople, on a special mission from the Tsar, on October 15, and on the 30th presented his ultimatum. If an armistice were not concluded with Serbia within forty-eight hours, the Russian Embassy was to be immediately withdrawn. On November 2 the Porte gave way; Serbia was saved; a breathing space was permitted to the operations of diplomacy.

Confer-

The interval was utilized by the meeting of a Conference ence at
Constanti- of the Powers at Constantinople (December 23). The Powers nople, agreed to the terms suggested by Lord Derby in September, Dec. 23 , but the Porte was obdurate. Profuse in professions and
1876. promises of reform, the Porte, with delicions irony, selected this moment for the promulgation of a brand new and full-blown parliamentary constitution, but it stubbornly refused to allow Europe to superintend the execntion of the reforms. There was to be a Legislative Body of two Honses: a nominated Senate and an elected Chamber of Deputies; a responsible Executive; freedom of meeting and of the press; an irremovable judiciary and compulsory education. ${ }^{1}$ But though the Sultan was prodigal in the concession of reforms, on paper, no one but himself should have a hand in executing them. On this point he was inexorable. Therempon General Ignatieff, refusing to take further part in a solemn farce, withdrew from the Conference. The Tsar had already (November 10) announced his intention to proceed single-handed if the Porte refused the demands of the Powers, his army was already mobilized on the Pruth, and war appeared imminent.

The diplomatists, however, made one more effort to avert it. Their demands were reduced to a minimum: putting aside an extension of territory for Serbia or Montenegro, they insisted upon the concession of antonomy to Bosnia, to the Herzegovina, and to Bulgaria, under the control of an international commission. On January 20 the Sultan categorically refused, and on the 21st the Conference broke up. Great Britain, nevertheless, persisted in her efforts to preserve peace, and on March 31, 1877, the Powers signed in London

I The first Turkish Parliament was opener with due ceremony on March 19, 1877. 
a protocol proposed by Count Sehouvaloff. Taking cognizanee of the Turkish promises of reform, the Powers declared their intention of watching earefully "the mamer in which the promises of the Ottoman Govermment are carried into effect'. If, howerer, the condition of the Christian subjects of the Porte should again lead to a 'return of the complieations which periodically disturb the peace of the East, they think it right to declare that such a state of things would be incompatible with their interests and those of Europe in general'. The Turk, in high dudgeon, rejected the London Protocol (April 10), and on April 24 the Tsar, having secured the friendly neutrality of Austria, ${ }^{1}$ declared war.

Russia had behaved, in face of prolonged provocation, with commendable patience and restraint, and had shown a genuine desire to maintain the European Concert. The Turk had exhibited throughont his usual mixture of shrewdness and obstinaey. It is difficult to believe that he would have maintained his obstinate front but for expectations based upon the supposed goodwill of the British Government. The language of the Prime Minister" and the Foreign Seeretary had unquestionably given him some encouragement. So much so that before the break up of the Conference Lord Salisbury telegraphed" to Lord Derby from Constantinople: "The Grand Vizier' belieres that he can count upon the assistance of Lord Derby and Lord Beaconsfield.' The Turk, it is true, is an adept at diplomatic 'bluff', and 'assistance' went beyond the facts. But this much is certain. If the English Cabinet had, even in January, 1877, frankly and unambiguously gone hand in hand with Russia there would have been no war.

The armistice arranged in Norember between Turkey and RussoSerbia had been further prolonged on December 28, and on Turkish February 27 peace was concluded at Constantinople. But on June 12, Montenegro, encouraged by the action of Russia,

1 By the Agreement of Reichstadt (July $s, 1=76$ ), confirmed by definite treaty January 15, 187t. The terms of the Austro-Russian agreement have never lieen authoritatively revealed: (f. Rose, Derelopment of European Nations, 1. 180.

$\because$ e.g. at the Guildhall on November 9.

3 Jan. 8, 1877. 
recommenced hostilities, and on June 22 the Russian army effected the passage of the Danube.

No other way towards Constantinople was open to them, for the Russian navy had not yet had time since 1871 to regain the position in the Black Sea denied to it in 1856. The co-operation of Roumania was, therefore, indispensable, and this had been secured by a convention concluded on April 16, by which, in return for a free passage for his troops through the principalities, the Tsar engaged to 'maintain and defend the actual integrity of Roumania'. The Roumanian army held the right flank for Russia, but an offer of more active co-operation was declined with some hanteur by the Tsar. From the Danube the Russians pushed on slowly but successfully until their advanced guard suffered a serious check before Plevna on .July 30. On the following day Osman Pasha, strongly entrenched at Plerna, inflicted a very serious reverse upon them.

Siege of Instead of carrying Plerna by storm they were compelled Plerna. to besiege it, and the task proved to be a tough one. In chastened mood the Tsar accepted, in August, the contemned offer of Prince Carol, who was appointed to the supreme command of the Russo-Roumanian army. For five months Osman held 120,000 Russians and Roumanians at bay, inflicting meantime very heary losses upon them, but at last his resistance was worn down, and on December 10 the remnant of the gallant garrison-some 40,000 half-starred men-were compelled to surrender.

Re-entry Four days later Serbia, for the second time, declared war of Serbia into the war. upon the Porte, and recaptured Prisrend, the ancient capital of the kingdom. The Russians, meanwhile, were pushing the Turks back towards Constantinople; they occupied Sofia on January 5, and Adrianople on the 20th. In the Caucasus their success was not less complete; the great fortress of Kars had fallen on November 18 ; the Turkish Empire seemed to lie at their mercy, and in March Russia dictated to the Porte the Treaty of San Stefano.

Treaty of A basis of agreement had already been reached at San Stefano, Adrianople (January 31); the terms were now embodied in March, 1878 . a treaty signed, on March 3 , at a village not far from 
Constantinople. Montenegro, enlarged by the acquisition of some strips of Bosnia and the Adriatic port of Antivari, was to be recognized definitely as independent of the Porte; so also was Serbia, which was to acquire the districts of Nish and Mitrovitza; the reforms recommended to the Porte at the Conference of Constantinople were to be immediately introduced into Bosnia and the Herzegovina, and to be executed under the joint control of Russia and Austria; the fortresses on the Danube were to be razed ; reforms were to be granted to the Armenians ; Russia was to accuire, in lieu of the greater part of the money indemnity which she claimed, Batoum, Kars, and other territory in Asia, and part of the Dobrudja, which was to be exchanged with Roumania (whose independence was recognized by the Porte) for the strip of Bessarabia retroceded in 1856. The most striking feature of the treaty was the creation of a greater Bulgaria, which was to be constituted an autonomous tributary principality with a Christian gorernment and a national militia, and was to extend from the Danube to the Aegean, nearly as far sonth as Midia (on the Black Sea) and Adrianople, and to include, on the west, the district romd Monastir but not Salonica. ${ }^{1}$ The Ottoman Empire in Europe was practically amihilated. The proposed aggrandizement of Bulgaria aroused grave concern in the other Balkan States. How was this treaty regarded by Europe in general and in particular by Great Britain?

Lord Beaconsfield had come into power in $187 t$ with the Great deliberate purpose of giving to English foreign policy the $\begin{gathered}\text { Britain } \\ \text { and the }\end{gathered}$ new orientation imperatively demanded by the new conditions Eastern of the world.

Question.

'You have', he said, 'a new world, new influences at work, new and unknown objects and danger's with which to cope. ... The relations of England to Europe are not the same as they were in the days of Lord Chatham or Frederick the Great. The Queen of England has become the Sovereign of the most powerful of Oriental States. On the other side of the globe there are now establishments belonging to her,

1 See Turkey Papers, No. 22, 1878; Holland, European Concert, 1). $335 \mathrm{sq}$. 
teeming with wealth and population. . . . These are vast and novel elements in the distribution of power. . . . What our duty is at this critical moment is to maintain the Empire of England.'

Suez

Canal shares.

The

Roval

Titles

Bill.

The first indication given to the world of the "new Imperialism' was the purchase of the Khedive's shares in the Suez Canal. On the 25th of November, 1875, the world was startled by the news that the British Government had purchased from the Khedive for the sum of four million sterling his 176,000 shares in the Suez Canal. ${ }^{1}$ The success of this transaction, as a financial speculation, has long since been brilliantly demonstrated. As a political move, it marks a new departure of the highest significance. England, as preceding pages have shown, had been curiously blind to her interests in the Eastern Mediterranean; Disraeli, by a brilliant coup, opened her eyes. But to him the purchase of the Canal shares was no isolated speculation, but only the first move in a coherent and preconcerted plan.

His next more had a twofold object. During the winter of 1875-6 the Prince of Wales had undertaken an extended tour in India. The risit, which was without precedent in the history of the empire, proved an eminent success, and prepared the way for' a still more important departure. 'You can only act upon the opinion of Eastern nations through their imagination.' So Disraeli had spoken at the time of the Mutiny, and in Opposition. As first Minister of the Crown he gave effect to his convictions; and touched the imagination not only of India but of the world by making his sovereign Empress of India. A magnificent Durbar was held at Delhi in the closing days of the year 1876, and on January 1,1877 , a series of celebrations culminated in the proclamation of Queen Victoria as Empress of India in the presence of sixty-three ruling Chiefs, and amid the acclamations of the most brilliant assemblage ever brought together in British India.

1 The total shares were 400,000 . The idea of the purchase was sail to hare been suggested by Mr. Frederick Greenwood, a distinguished London jourualist. See The Times, Dec. 27, 1905, and Jan. 13, 1906. But there are now other claimants to the distinction. 
The purchase of the Canal shares, the assumption of the ReopenImperial Crown of India, were parts of a coherent whole. ing of the Disraeli's attitude towards the complex problems, roused Quetion. into fresh life by events in the Near East, was determined by precisely the same considerations. He never forgot that the queen was the ruler of Mohammedans as well as Christians, of Asiatics, Africans, Australians, and Americans as well as Europeans. It was therefore with the eyes of an oriental, no less than of an occidental, statesman that he watched the development of events in the Near East. Those events caused, as we have seen, grave disquietude in Great Britain. Before the Russian armies had crossed the Danube the Tsar undertook to respect English interests in Egypt and in the Canal, and not to occupy Constantinople or the Straits (June 8, 1877), but the Russian victories in the closing months of 1877 excited in England some alarm as to the precise fulfilment of his promises. Accordingly, in January, 1878, Lord Derby, then Foreign Secretary, deemed it at once friendly and prudent to remind the Tsar of his promise, and to warn him that any treaty conchuled between Russia and Turkey which might affect the engagements of 1856 and 1871 'would not be valid without the assent of the Powers who were parties to those Treaties'. (January 14.)

In order to emphasize the gravity of the warning the The Fleet, which had been at Besika Bay, was ordered to pass the English Dardanelles (January 23), and the Gorernment asked Parlia- Constantiment for a rote of credit of $\mathfrak{£} 6,000,000$. nople.

In moring the rote on January 28, the Chancellor of the Exchequer (Sir S. Northcote) made public the terms demanded by Russia, which, in addition to the points subsequently embodied in the Treaty of San Stefano, included 'an ulterior understanding for safeguarding the rights and interests of Russia in the Straits'. This was the point in regard to which Russia had already been warned by Lord Derby, and the situation became critical in the extreme. In the preliminary terms concluded between the combatants on January 31, this stipulation disappeared; but, in consequence of excited telegrams from Mr. Layard, the British ambassador in Constantinople, the Cabinet decided (February 7 ) 
to send a detachment of the Fleet into the Sea of Marmora for the protection of British subjects in Constantinople. Russia retorted that if British ships sailed up the Straits Russian troops would enter Constantinople for the purpose of similarly protecting the lives of Christians of every race. But the Sultan, equally afraid of friends and foes, begged the English fleet to retire, and it returned accordingly to Besika Bay.

The extreme tension was thus for the moment relaxed. The Austrian Government was already moving in the matter of a European Congress, and on March 4 Lord Derby informed Comnt Beust that Great Britain agreed to the suggestion, provided it were clearly understood that 'all questions dealt with in the Treaty of Peace between Russia and Turkey should be considered as subjects to be discussed in the Congress'. This had been throughout 'the keynote of our policy', 'the diapason of our diplomacy'. ${ }^{1}$ With regard to the Treaty of San Stefano the language of Lord Beaconsfield was emphatic: 'it abolishes the dominion of the Ottoman Empire in Europe ; it creates a large State which, under the name of Bulgaria, is inhabited by many races not Bulgarian ... all the European dominions of the Ottoman Porte are .. . put under the administration of Russia . . . the effect of all the stipulations combined will be to make the Black Sea as much a Russian lake as the Caspian.' ${ }^{2}$ Whether this description was exaggerated or no, there can be no question that, in every clause, the treaty was a 'deviation' from those of 1856 and 1871, and as such required the assent of the signatory Powers.

To the demand that the treaty in its entirety should be submitted to a congress Russia demurred. Great Britain insisted. Again peace hung in the balance. Apart from the dispute between England and Russia there was a great deal of inflammable material about, to which a spark would set light. Greece, Serbia, and, above all, Rommania, who with incredible tactlessness and base ingratitude had been

1 Lord Beaconsfield in the House of Lords, April 8, 1878, Speeches, ii. 163.

2 Ibid., p. 170. 
excluded from the peace negotiations, were all gravely dissatisfied with the terms of the Treaty of San Stefano. Greece had indeed actually invaded Thessaly at the beginning of February, and only consented to abstain from further hostilities upon the assmunce of the Powers that her claims should have farourable consideration in the definitive Treaty of Peace.

Lord Beaconsfield, however, was ready with his next move, Indian and, at this supremely critical moment he made it. On troops orApril 17 it was announced that he had ordered 7,000 Indian Italta. troops to embark for Malta. The coup was denounced as 'sensational', un-English, unconstitutional, ${ }^{1}$ even illegal." That it was dramatic none can gainsay ; but it was consonant with the whole trend of Lord Beaconsfield's policy : if it alarmed England it impressed Europe, and there can be no question that it made for peace.

The operation of other forces was tending in the same Russia, direction. The terms of settlement proposed by Russia Germany, were not less distasteful to Austria than to England. An Austria. Austrian army was mobilized on the Russian flank in the Carpathians, and on February 4 the Emperor Francis Joseph demanded that the terms of peace should be referred to a Congress at Vienna. Austria might well take a firm line, for behind Austria was Germany.

Bismarck had made up his mind. He would fain have Bispreserved in its integrity the Dreikaiserbund of 1872 ; he marck's was under deep obligations to Russia, and was only too glad to assist and even to stimulate her ambitions so long as they conflicted only with those of Great Britain or France. But when it came to a possible conflict between Russia and Germany matters were different. It was true that Russia had protected Prussia's right flank in 1864, and her left flank in 1866, and-highest service of all-had 'contained' Austria in 1870. The Tsar thought, not muaturally, that in the spring of 1878 the time had arrived for a repayment of the debt, and requested Bismarck to contain Austria. Bismarck was still anxious to 'keep open the wire between
1 e. g. by Mr. Gladstone.
2 e. g. by Lord Selborne. 
Berlin and St. Petersburg', provided it was not at the expense of that between Berlin and Vienna. He replied, therefore, to the Tsar that Germany must keep watch on the Rhine, and could not spare troops to contain Austria as well. The excuse was transparent. Bismarck had, in fact, decided to give Austria a free hand in the Balkans, and even to push her along the road towards Salonica. His attitude was regarded in Russia as a great betrayal, a dishonourable repudiation of an acknowledged debt. It is not, howerer, too much to say that it averted a European conflagration. The Tsar decided not to fight Austria and England, but, instead, to accept the invitation to a Congress at Berlin.

The On May 30 Lord Salisbury and Count Schouraloff came Treaty of to an agreement upon the main points at issue, and on June 13 the Congress opened at Berlin. Prince Bismarck presided, and filled his chosen rôle of 'the honest broker', but it was Lord Beaconsfield whose personality dominated the Congress. 'Der alte Jude, das ist der Mann' was Bismarck's shrewd summary of the situation.

Little time was spent in discussion; the treaty was signed on July 13. Russia's sole acquisition in Europe was the strip of Bessarabia which had been retroceded to Roumania in 18.56 and was now, by an act of grave impolicy and base ingratitude, snatched away from her by the Tsar. In Asia she retained Batoum, Ardahan, and Kars. Bosnia and the Herzegorina were handed over for an undefined term to Austria, who was also to be allowed to occupy for military, but not administrative, purposes the Sanjak of Novi Bazar. England, under a separate Convention concluded with Turkey on June 4, was to occupy and administer the island of Cyprus, so long as Russia retained Kars and Batoum. Turkey was to receive the surplus revenues of the island, to carry out reforms in her Asiatic dominions, and to be protected in the possession of them by Great Britain. France sought for authority to occupy Tunis in the future; Italy hinted at claims upon Albania and Tripoli. Germany asked for nothing, but was more than compensated for her modesty by securing the gratitude and friendship of the Sultan. Never did Bismarck make a better inrestment. 
Greece, with no false modesty, claimed the cession of Crete, Thessaly, Epirus, and a part of Macedonia, but for the moment got nothing. Roumania was ill compensater for the loss of southern Bessarabia by the acquisition of part of the Dobrudja, but seeured complete independence from the Porte, as did Serbia and Montenegro, who receired most of the districts promised to them at San Stefano.

Bulgaria did not. And herein lay the essential difference between the Treaty of Berlin and that of San Stefimo.

'Bulgaria', as defined at Berlin, was not more than a third of the Bulgaria mapped out at San Stefano. It was to consist of a relatively narrow strip between the Danube and the Balkans, and to be an independent State under Turkish suzerainty. South of it there was to be a province, Eastern Roumelia, which was to be restored to the Sultan, who agreed to place it under a Christian governor approved by the Powers. By this change the Sultan recovered 2,500,000 of population and 30,000 square miles of territory; Bulgaria was cut off from the Aegean; Macedonia remained intact.

Such were the main provisions of the famous Treaty of Berlin. They were criticized at the time, and from several points of view, with great acerbity. Lord Beaconsfield's claim that he had brought back to England 'Peace with Honour', though conceded by the mass of his fellow countrymen, eroked some derision among them. His statement that he had 'consolidated' the Ottoman Empire was received with polite scepticism both at home and abroad, a seepticism to some extent justified by the Cyprus Convention, to say nothing of the cession of Bosnia and the Herzegovina. With some inconsistency, however, he was simultaneously assailed for having replaced under the withering tyranny of the Sultan a Christian population which Russia had emancipated. The charge is, on the face of it, difficult to rebut. But it does not lie in the mouths of the Philhellenists and Philo-Serbs to make it. Had the Treaty of San Stefano been permitted to stand the ambitions both of Serbia and Greece would hare been seriously circmuscribed. It was not, indeed, of Serbia, or Greece, still less of Roumania, that Lord Beaconsfield was thinking at Berlin. The motive of 
his policy was that which had inspired Lord Palmerston and Mr. Canning. He definitely repudiated the claim of Russia to dictate by her sole voice and in her own interests the solution of a secular problem. It is only fair to Russia to say, that if at the time of the Berlin Memorandum Lord Beaconsfield had been at more pains to preserve the Concert of the Powers, the claim might never have been preferred. Once preferred it could not be admitted.

For a final judgement on the events recorded in this chapter the time has not yet arrived. During the generation which has followed the Congress of Berlin opinion has swung backwards and forwards, and the pendulum is not, even now, at rest. This much, however, may with confidence be affirmed: the diplomatists at Berlin were working better than they knew. The settlement outlined at San Stefano was both hasty and premature. That it should be submitted to the collective judgement of the Powers was only reasonable. Lord Beaconsfield must at least have the credit of haring secured for it that further scrutiny.

Rouma- Two of the Balkan States owe little gratitude to his nia. memory. At San Stefano Roumania had been treated by Russia with discourtesy and ingratitude. At Berlin it was treated no better. Both Germany and England, to say nothing of France, might have been expected to extend towards the principality something more than sympathy. But Bismarck, indifferent to the dynastic ties which united Prussia and Roumania, was not sorry to see Russia neglecting a golden opportunity for binding Roumania in gratitude to herself. A Roumania alienated from Russia woald be the less likely to quarrel with the Dual Monarchy and to press her claims to the inclusion of the unredeemed Roumanians in Transylvania and the Bukovina. Lord Beaconsfield professed much Platonic sympathy for the disappointment of their wishes in regard to Bessarabia, but frankly confessed that he could not turn aside from the pursuit of the larger issues to befriend a State in whose fortunes Great Britain was not directly interested. It was a gross blunder, the consequences of which are not yet exhausted. The Roumanian envoys left Berlin not only 
empty-handed, but deeply impressed by the eynicism of high diplomacy, and bitterly chagrined by the ingratitude of Russia and the indifference of Europe.

The sentiments of Bulgaria were not dissimilar. Against Bulgaria. Russia she had no cause of complaint; but in her view Germany and Great Britain had conspired to dash from her lips the cup proffered her by the Tsar. San Stefano had gone beyond the equities of the case, and had imperilled other interests not less important than those of Bulgaria. Berlin fell short of them. The barrier interposed between the Bulgarians of the new principality and those of Eastern Roumelia was not merely inequitable but manifestly absurd. Nor did it endure. The making of modern Bulgaria demands, however, and will receive, more detailed attention.

So also with the position of the Sonthern Slavs, to whom The the settlement of 1878 was profoundly disquieting. Serbia Southern gained some territory, but it was really at the expense of Bulgaria ; the Sanjak of Novi Bazar, garrisoned by Austria, but still gorerned by the Turks, serered the Serbs of Serbia from their brethren in Montenegro, while the Austrian occupation of Bosnia and the Herzegovina brought the Habsburgs into the heart of Balkan affairs and made a tremendous breach in the solidarity of the Jugo-Slav race.

The Treaty of Berlin is generally regarded as a great landmark in the history of the Eastern Question. In some respects it is; but its most important features were not those with which its author's were best pleased, or most concerned. They were preoccupied by the relations between the Sultan and the Tsar, and by the interest of Europe in defining those relations. The enduring significance of the treaty is to be found elsewhere: not in the remnant of the Ottoman Empire snatehed from the brink of destruction by Lord Beaconsfield, but in the new nations which were arising upon the ruins of that empire-nations which may look back to the 13th of July, 1878, if not as their birthday, at least as the date on which their charters of emancipation were signed and sealed.

For further reference: the Papers laid before Parliament in 1861, 1867, 1877 , and 1878, and referred to in the footnotes, are of great importance. 
They are usefully summarized by the Duke of Argyll in The Eastern Question (2 vols.). Lord Stratford de Redcliffe's Eastern Question, containing his letters to the Times in 1876-8, and other papers has great contemporary interest. Holland and Hertslet are, as before, invaluable for the texts of treaties.

For relations of Russia and Germany: T. Klaczko, The Two Chancellors (Gortschakoff and Bismarck); Busch, Our Chancellor; and Bismarck's Reminiscences.

On the Balkan movement: Marquis of Bath, Observations on Bulgarian Affairs, 1880; Duke of Argyll, as above; The Balkans (Clarendon Press, 1915) ; A. J. Evans, Through Bosnia and Herzegovina on Foot (1876); W. E. Gladstone, Bulgarian Horrors and the Question of the East (London, 1876); Iovanovitz, Les Serbes et la Mission de la Serbie dans l'Europe d'Orient (Paris, 1876); A. Gallenga, Two Years of the Eastern Question, 2 vols. (London, 1877); Hanotaux, Contemporary France.

For English policy: Lord Fitzmaurice, Life of Lord Granville; Lord Newton, Life of Lord Lyons ; Morley, Gladstone; Holland, Duke of Devonshire; Marriott, England since Waterloo; Paul, Modern England. The concluding volume of Monypenny and Buckle's Disraeli ought in this connexion to be of supreme interest.

Generally: Débidour, Histvire diplomatique; Driault, La Question l'orient. 


\section{CHAPTER XIII}

\section{THE BALKAN STATES, 1878-98}

\section{The Making of Bulgaria. Modfrn Greece (1832-98). The Cretan Probleni}

'These newly emancipated races want to breathe free air and not through Russian nostrils.'-SrR William White (1885).

'A Bulgaria, friendly to the Porte, and jealous of foreign influence, would be a far surer bulwark against foreign aggression than two Bulgarias, severed in administration, but united in considering the Porte as the only obstacle to their national devclopment.'-LORD SALISBURY (Dec. 23, 1885).

'It is next to impossible that the Powers of Christendom can permit the T'nrk, however triumphant, to cast his yoke again over the necks of any emancipated Provincials. . . There is much reason to think that a chain of antonomous States, though still, perhaps, tributary to the Sultan, might be extended from the Black Sea to the Adriatic with advantage to that potentate himself. But, at all events, the rery idea of reinstating any amount of Turkish misgovernment in places once cleared of it is simply revolting.'-LORD STRATFORd dE REDCLIFfe.

'Greece wants something more than the rules of political procedmre that are embodied in written constitutions in order to infuse better moral principles among her people whose social system has been cormpted by long ages of national servitude . . . until the people undergo a moral change as well as the government, national progress must be slow, and the surest pledges for the enjoyment of true liberty will be wanting.'--DR. GEORGE Finlay.

'Crete is an unexplored paradise in ruins, a political rolcano in chronic activity, a theatre on the boards of which rapine, arson, murder, and all manner of diabolical crimes are daily rehearsed for the peace, if not the delectation, of the Great Powers of peace-loving Christendom. Truly this is far and away the most grotesque political spectacle of the ninetcenth century.'-E. J. DilloN.

To pass from the Congress of Berlin to the early struggles The Balof the reborn Balkan States means more than a change of kans after temperature and environment. It iurolves an abrupt the Treaty tion from drab prose to highly coloured romance; from a problem play to transpontine melodrama; from the traditional methods of nineteenth century diplomacy to those 
of primitive political society. Transported to the Balkans we are in the midst of bouleversements and vicissitudes, political and personal; sudden elevations; sudden falls; democratic constitutions and antocratic coups d'état; plotting and counterplotting; the hero of yesterday, the villain of to-day, and again the hero of to-morrow; abductions, abdications, and assassinations; the formation and dissolution of parties; a strange medley of chivalry and baseness; of tragedy and comedy ; of obscurantism and progress.

Greece, The Treaty of Berlin meant the end of "Turkey in Europe" the Southern as the term had been understood by geographers for the last Slars, and four hundred years. The place of the provinces of the Rouma- Ottoman Empire is now taken by independent, or virtually
nia. independent, States: Greece, Roumania, Serbia, Montenegro, and Bulgaria. But although the Ottoman Empire is broken and crippled the new States are by no means fully fashioned. The garment woren at Berlin had many ragged edges. Greece got nothing at the moment, and had to wait three years before eren a portion of her claims upon Thessaly and Epirus were conceded; Crete remained in Turkish hands for another generation. Serbia was profoundly dissatisfied and with reason: the arrangement proposed at San Stefano would have divided the Sanjak of Novi-Bazar between herself and the sister State of Montenegro, thus bringing the two Slav States into immediate contact, and giving Serbia indirect access, through Montenegro, to the Adriatic. The crafty restoration of the Sanjak to Turkey; the retention of the great harbour of the Bocche di Cattaro by Austria, and the Austrian occupation of Bosnia and the Herzegovina inflicted a series of terrible blows upon the aspirations of the Southern Slavs, and kept open sores which might have been healed. The Habsburgs were, however, far too clever to allow their hopes of access to the Aegean to be frustrated by the interposition of a compact Jugo-Slav State, whether that State was unitary or federal. The disappointment of Serbia was the immediate disappointment of Montenegro, and ultimately the disappointment of Bosnia and the Herzegovina.

The Of the cruel blow to the legitimate hopes of Roumania Macedonian enough, for the moment, was said in the last chapter. But Problem. 
the fatal character of the blunder then committed by Russia, without protest, be it added, from any of the Powers, cannot be too strongly emphasized. Most significant of all, however, was the partition of the proposed Bulgaria. That partition not only served to keep the Balkans in ferment for the next thirty year's but introduced into European diplomacy, or at least into its vocabulary, a new problem, that of 'Macedonia'. Whether Serbia and Greece would or could have acquiesced in the San Stefano settlement is a question which must be reserved for subsequent discussion; but it is obvious that if Lord Beaconsfield had not torn that treaty into shreds the Macedonian problem would never have emerged in the shape with which the present generation is familiar. The Greater Bulgaria might ultimately have raised as many problems as it solved; but those problems would have been approached from a different angle and might have been solved with less friction and more satisfactory results.

As things were, it was upon the fortunes of Bulgaria that Bulgaria. the attention not merely of the Balkans but of Europe at large was concentrated during the twenty years succeeding the Congress of Berlin. To the affairs of Bulgaria a large section of this chapter must, therefore, be deroted.

In 1878 the Russian army was in occupation of the The Conprincipality which Russian diplomacy proposed to create. ${ }^{\text {stitution. }}$ The plans of the future edifice had been, it is true, profoundly modified at Berlin, but the task of executing them was committed to Russia.

The first business was to provide the new principality with a constitution. According to the Treaty of Berlin the 'Organic Law of the Principality' was to be drawn up 'before the election of the Prince' by an assembly of notables of Bulgaria conroked at Tirnovo; particular regard was to be paid to the rights and interests of the Turkish, Roumanian, Greek, or other populations, where these were intermixed with Bulgarians, and there was to be absolute equality between different religious creeds and confessions.

Until the completion of the Organic Law the principality 
was provisionally administered by a Russian Commissary, assisted by a Turkish Commissary and Consuls delegated ad hoc by the Powers. The Constituent Assembly, elected in December 1878, met on February 26, 1879, and duly drafted an Organic Law which was adopted on April 28. Mainly the work of the first ruler of the independent Bulgaria, Petko Karaveloff, ${ }^{1}$ this Law was amended in 1893 and again in 1911, but neither in its original nor amended form has it worked satisfactorily. It was said of modern Italy, perhaps with truth, that she was made too quickly. The saying is certainly true of Bulgaria. Her young men and old men were alike in a hurry. Without any training whatever in the most difficult of all political arts, that of self-government, Bulgaria adopted a form of constitution which presupposed a long political apprenticeship. Karaveloff was a sincere patriot, but he belonged to the worst type of academic radicals. The constitution reflected, in every clause, the work of the doctrinaire.

The Legislature was to consist of a Single Chamber, the Sobranje or National Assembly; any man over thirty years of age who could read and write, unless he were a clergyman, a soldier on active service, or had been deprived of civil rights, was eligible for election to it; all members were to be paid; the Assembly was to be elected on the basis of universal manhood suffrage, and each electoral district was to consist of 20,000 voters who were to return one member; unless dissolred by the prince (now the king) the Assembly was to sit for four years. Questions concerning the acquisition or cession of territory, a vacancy of the crown, regencies and constitutional revision were to be reserved from the competence of the ordinary Sobranje and to be referred to a Grand Sobranje, elected in the same manner by the same people but in double strength. The Executive was entrusted to a Council of eight ministers, to be nominated by the prince (king), but responsible to the Assembly."

Had this constitution been the outcome of a slow political evolution there would have been little to be said against it.

1 For an admirable portrait see Lavelẹe, The Balkan Peninsula, pp. $259 \mathrm{sq}$.

- For convenience the subsequent amendments are incorporated. 
Imposed upon a people totally inexperienced, it proved, as the sequel will show, unworkable.

Having drafted the Organic Law the Assembly proceeded The to the election of a prince. The Treaty of Berlin had pro- I'rince. vided that he was to be 'freely elected by the population, and confirmed by the Porte with the assent of the Powers, but no member of the reigning dynasty of a Great Power was to be eligible. The Tsar recommended and the Assembly elected (April 29, 1879) Prince Alexander of Battenberg, a scion, by a morganatic marriage, of the House of Darmstadt, a nephew by marriage of the Tsar, and an officer in the Prussian army.

Born in 1857 Prince Alexander was at this time a young Prince man of twenty-two, of fine presence, and with plenty of Alexcharacter and brains. A close observer described him as Batten'a wise statesman, a brave soldier, a remarkable man in every berg. respect'.' The description was perhaps partial, but the choice was unquestionably a good one, and if Prince Alexander had had a fair chance he would probably have done a great work for his adopted country. He was, however, hampered from the outset on the one hand by the jealousy and arrogance of the Russian officials by whom he was at first surrounded, and on the other by the opposition of the Sobranje, which was elected under the ridiculous provisions of the Organic Law.

Out of 170 members elected to the first Sobranje in 1879 The not more than thirty were supporters of the ministers appointed by the prince, and after a session which lasted only ten days it was dissolved. A second Sobranje, elected in 1880, was even less favourable to the prince and his ministers. The appointment of a new ministry, under the Russophil radicals Zankoff and Karaveloff, temporarily eased the situation, but in May, 1881, the prince suspended the Organic Law, and in July a new Assembly ratified his coup d'état and conferred upon him extraordinary powers for a period of seven years. In September, 1883, however, the prince was compelled by pressure from St. Petersburg to re-establish

1 Major A. von Huhn, The Struggle of the Bulgarians for Independence $(\mathbf{1 8 8 6 )}$, p. 6. 
the abrogated constitution. The new Tsar, Alexander III, ${ }^{1}$ was much less friendly than his father to the Prince of Bulgaria, and from this time onwards there was more or less arowed hostility between St. Petersburg and Sofia.

Union of the two

Bulgarias.

Eastern No less than ten articles of the Treaty of Berlin were Roumelia. devoted to the future organization of Eastern Roumelia, but these provisions proved to be so purely temporary that they need not detain us. Hardly was the ink on the treaty dry before the Russian agents, in both provinces, began to encourage the popular demand for remion. More particularly among the Bulgarians of 'Eastern Roumelia'. By the formation of 'athletic societies', the encouragement of national sports, and other methods common to the stimulation of nationalist movements, the youth of Eastern Roumelia were accustomed to the idea of association and discipline. By the year 1885, 40,000 of them were trained in the use of arms. When Sultan Hamid protested against these proceedings he was reminded that the Turkish indemnity to Russia was not yet paid.

Meanwhile, in the northern province, the unionist movement was making rapid progress, under the powerful leadership of Karaveloff, who was now Prime Minister, and of Stephen Stambuloff, who, in 1884, had become President of the Sobranje.

1 Succeeded in 1881 on the assassination of Tsar Alexander II. 
Among the makers of modern Bulgaria this remarkable stambuman holds, beyond dispute, the highest place. The son of loff. an innkeeper, Stephen Stambuloff was born at Tirnoro in 1854. Educated at Odessa, he was powerfully attracted towards the views of the nihilist party, but the consuming passion of his life was not Russian nihilism but Bulgarian nationalism. On his return from Odessa he plunged into the turbid waters of Bulgarian politics, and, on his election to the Sobranje, was almost immediately appointed l'resident of the Assembly. He ardently supported the morement for the union of the Bulgarias, and from the abdication of Prince Alexander to the days of his own dismissal by Prince Ferdinand he exercised an anthority which was virtually dictatorial. ${ }^{1}$

On September 18, 1885, Gavril Pasha, the Turkish Governor- Tnion of General at Philippopolis, was informed that his services were ${ }_{B \text { Bnl- }}^{\text {the tro }}$ no longer required, and he was conducted, with some con-garias. tumely, ont of the province. Resistance there could be none, for the Bulgarians were unanimous. Not so the Powers. What was their attitude? An answer to this question lands us once more in the realm of political paradox. To say that Russia frowned upon the enterprise thus launched at Philippopolis would be a ludicrous understatement. The attitude of Russia demands, however, and will repay, closer consideration. To the union of the two Bulgarias the Tsar was not, and could not be, in principle, opposed. Seren short years had passed since the Treaty of San Stefano was drafted. But the circumstances were radically different. In the spring of 1878 a victorious Russian army had just pierced the Balkans, and could, at any moment, thunder at the gates of Constantinople. Russia was virtually in occupation of all the comntry between the Danube and the Bosphorus. She could dictate the destinies of the Bulgarians.

It was otherwise in 1885 . The Bulgarians had found themselres. They had not learnt the art of parliamentary government, but what was more important they knew the meaning of 'nationality'. The arrogance of Russian officials

1 For Stambuloff's career cf. A. H. Beaman, M. Stambuloff (London, 1895). 
towards the Bulgarian peasants had, in the course of seven years, gone far to obliterate from their minds the remembrance of the mighty services rendered by their liberators in 1877. Neither 'the Battenberg', as Prince Alexander was contemptuously known at St. Petersburg, nor the quondam nihilist, Stambuloff, was inclined to be the pliant instrument of Russian influence in the principality.

The Tsar was not ill-disposed towards the union, provided it was effected on his own terms, on terms which would have brought the Bulgarians to heel. And the first indispensable condition was that Prince Alexander should yield his place to a Russian nominee. 'You remember', were the orders issued by the Foreign Office to the Russian ConsulGeneral at Rustchuk, 'that the union [of the two Bulgarias] must not take place until after the abdication of Prince Alexander.' 1 In other words, Russia was willing to see a Greater Bulgaria come into existence, but it must be as a Russian protectorate, not as a State, independent alike of the Sultan and the Tsar.

Attitude Did not the contention of the Tsar afford some posthumous of England. justification for the misgivings of Lord Beaconsfield in 1878? Plainly, there are two alternatice answers to this question. It may be urged, on the one hand, that Lord Beaconsfield would have done well to exhibit a more robust faith in Bulgarian nationality; on the other, that in 1878 the ambition of Russia was much more obvious than the independence of Bulgaria. Those Englishmen, who in 1878 favoured the creation of the Greater Bulgaria, were actuated much more by detestation of the Turk whom they did know, than love for the Bulgarian whom they did not know. They felt, with Lord Stratford de Redcliffe, that ' the rery idea of reinstating any amount of Turkish misgovernment in places once cleared of it is simply revolting'.

The policy of England in 1885 was inspired by a different motive. "If you can help to build up these peoples into a bulwark of independent States and thus screen the "sick man" from the fury of the northern blast, for God's sake do

1 Quoted by Rose (op. cit., p. 262), whose masterly analysis of the evidence should be consulted. 
it.' Thus wrote Sir Robert Morier from St. Petersburg to Sir William White in Constantinople at the height of the Bulgarian crisis in December, 1885. Bulgaria, it will be observed, was to come into bcing not as the catspaw of Russia, but as a barrier against her advance towards Constantinople. Could any one have foreseen such a possibility in 1878? It was too much to expect. But Lord Beaconsfield's colleague at Berlin was now a complete convert to the views of our ablest representatives abroad. 'A Bulgaria, friendly to the Porte', said Lord Salisbury in December, 1885 , 'and jealous of foreign influence, would be a far surer' bulwark against foreign aggression than two Bulgarias, severed in administration, but united in considering the Porte as the only obstacle to their national derelopment.' 1

Prince Alexander, without reference to the Powers, had Serboalready taken the plunge. He showed a moment's hesitation Bulgarian when the patriots of Philippopolis came to offer him the 1885, crown, but Stambuloff told him bluntly that there were only two paths open to him: "the one to Philippopolis and as far' beyond as God may lead ; the other to Darmstadt.' The prince's choice was soon made, and on September 20 he announced his acceptance of the throne of united Bulgaria.

Before his action could be ratified or repudiated by his suzerain or the Powers, Bulgaria was threatened with a new danger. If Russia began to see in a united Bulgaria a barrier in her advance towards the straits, Austria had no mind to see the multiplication of barriers between Buda-Pesth and Salonica.

On Norember 14 King Milan of Serbia, who, in 1882, had followed the example of Prince Carol of Roumania and assumed a royal crown, suddenly seized an obviously frivolous pretext to declare war upon Bulgaria.

Whether Austria actually instigated the attack it is at present impossible to say. Apart from Habsburg intrigues King Milan had his own reasons. Despite the new crown his own position was none too secure. An attempt upon his life in Belgrade indicated the fact that his enemies were 
alert: a marriage between Prince Peter Karageorgevié and a daughter of Prince Nicholas had lately strengthened the rival dynasty ; there were unsettled boundary questions and tariff questions between Serbia and Bulgaria; above all, the idea of a Balkan 'Balance of Power' was germinating. If Bulgaria was to be doubled in size, and more than doubled, Greece and Serbia, to say nothing of Roumania, would look for compensations. Serbia was the first actively to intervene. King Milan left his capital for the front amid enthusiastic cheers for 'the King of Serbia and Macedonia'. On November 14 the march towards Sofia began.

The chance to stab a friend and rival in the back was too tempting for a Balkan kinglet to refuse. The question of the union of the two Bulgarias, though answered with emphasis by the Bulgarian people, still hung in the diplomatic balance; the Bulgarian army, thanks to the aetion of the Tsar in the withdrawal of his Russian officers, was left at a eritical moment without instructors ; such officers as remained to it were raw and inexperienced; the prince's own position was exceedingly precarious.

But his peasant subjects rallied superbly to his support; Bulgarians from Macedonia flocked to the assistance of their kinsmen, and in a three days' battle at Slivnitza (November 17-19) they inflicted a decisive defeat upon the Serbians. The young Bulgarian army, emerging triumphant from its 'baptism of fire' at Slivnitza, promptly took the offensive and marehed on Pirot, which was captured on November 27. The Serbian ar'my seemed, to a close and eompetent observer, ${ }^{1}$ to lie at their mercy; but the short though significant war was over.

Interven- On November 28 Count Khevenhiiller, the Austrian tion of Austria. minister at Belgrade, arrived at Pirot, and imposed a truce upon Prince Alexander. The Bulgarians, flushed with victory, already dreaming of the absorption of Serbia into a Greater Bulgaria, were bluntly informed that if they advanced from

1 Major A. von Hubn, whose work, The Struggle of the Bulgarians for National Independence, translated from the German (Murray, 1886), contains much the best account known to me of these events. 
Pirot they would find themselves 'face to face no longer with Serbian but with Austrian troops'.

Serbia was saved: but so also was the union of the Bul-Attitude garias. The Battle of Slivnitza had decidled that question. of the

A peace signed at Bucharest (March 3, 1886) restored the stutus quo ante as between Bulgaria and Serbia; but the larger question had been settled at Constantinople. A conference of the Powers had met on November 5, and Great Britain had taken the lead in urging the Sultan to acquiesce in the alienation of Eastern Roumelia.

To the diplomatic reasons, already detailed, for the atti- Queen tude of Great Britain was now added a dynastic one. On Victoria. July 23, 1885, Princess Beatrice, the youngest daughter and constant companion of Queen Victoria, had become the wife of Prince Henry of Battenberg, the youngest brother of the Prince of Bulgaria. Queen Victoria's interest in the Battenberg family was not confined to her own son-in-law. His eldest brother, Prince Lonis, a distinguished officer in the English navy, had, in 1884, married the queen's granddaughter, Princess Victoria of Hesse, the eldest daughter of the Princess Alice, and in 1888 the queen interested herself keenly in a proposed marriage between another granddaughter, Princess Victoria of Prussia, and Prince Alexander. Before this time, however, much had happened to the prince and his people.

At Constantinople the will of Great Britain prevailed, and Recogniearly in 1886 Sultan Abdul Hamid formally recognized the $\begin{gathered}\text { tion of the } \\ \text { Union. }\end{gathered}$ union of the two Bulgarias, and appointed Prince Alexander to be 'Governor-General of Eastern Roumelia'.

He was not destined to enjoy his new honour long. On his Russian return from Pirot to Sofia he received an enthusiastic ${ }_{\text {Sofia }}^{\operatorname{con}}$ at welcome from his subjects. Their enthusiasm intensified the Angust, chagrin of Russia, and in August, 1886, the Tsar carried ont 1886. his counterstroke. Implacable in enmity against his cousin he determined to dethrone him by force. On the night of August 21 a band of liussian officers burst into the palace at Sofia, compelled the prince to sign an abdication, and carried him off a prisoner to Reni, near Galatz, in Russian territory. Thence he was dispatched under escort to Lemberg. But 
the Russian party in Bulgaria gained little by this melodramatic coup.

A provisional government was hastily set up at Sofia under Stambuloff, and their first act was to recall their kidnapped prince (August 29). On September 3 Prince Alexander re-entered his capital amid the enthusiastic plaudits of his people. But by his own act he had already rendered his position untenable.

On his arrival at Rustchuk he had been welcomed by the Consul-General for Russia, and in gratitude for this friendly act he was foolish enough, perhaps under the stress of the conflicting emotions produced by recent experiences, to send to the Tsar a telegram, which concluded with these words: 'Russia having given me my Crown I am ready to give it back into the hands of its Sorereign.' The Tsar promptly took advantage of this amazing indiscretion, and refused curtly to approve his restoration. The prince, in despair of overcoming the antipathy of his cousin, and genuinely anxious to do the best he could for his distracted country, at once announced his abdication, and on September 7 he left Bulgaria for erer. ${ }^{1}$

Prince Alexander had presided with dignity and some measure of success over the birth-throes of a nation; he left it, as he beliered, for its good; primarily, in order not to obstruct a rapprochement between Bulgaria and its 'natural' protector.

Before leaving Prince Alexander appointed a regency, consisting of Stambuloff, Karareloff, and Nikeforoff, to whom the Tsar sent as 'adviser' General Kaulbars. Haring done his best to raise the country against the regents, and failed ignominiously, Kaulbars was, howerer, recalled. The Government and the people alike refused to be browbeaten by the Russian agent. A Sobranje containing no less than 470 supporters of the regency against thirty Russophils was returned; it conferred a virtual dictatorship upon Stambuloff, and elected Prince Waldemar of Denmark. The latter, acting

1 He retired into private life, and, after the failure of Queen Victoria to obtain for him the hand of Princess Victoria, married an opera singer, and died in 1893. 
under family pressure exerted by the Tsar, declined the offer, and again Bulgaria had to look for a ruler. For the time being Stambuloff more than filled the place, but in July, 1887, after Bulgarian delegates had searched the European Courts for a candidate, the Sobranje, refusing the Tsar's nominee, the Prince of Mingrelia, elected Prince Ferdinand of Saxe-Coburg-Gotha, a son of Princess Clémentine of Orleans, and a grandson, therefore, of King Louis Philippe. Prince Ferdinand, who was a young ${ }^{1}$ and ambitious man, accepted the offer, and ascended the throne on August 14, 1887. Russia refused to recognize him, but strong in the support of Bismarck and the Emperor Francis Joseph, in whose army he had serred, the young prince defied the opposition of the Tsar and reaped his reward.

For the next seren years Bulgaria was ruled by Stephen StambuStambuloff. Prince Ferdinand wisely took time to feel his loff in way, and thus escaped much of the odium which no statesman (1857-94). worthy of the name could, during those difficult years, have aroided.

A double task awaited Stambuloff: on the one hand to emancipate his country from foreign tutelage; on the other to introduce internal order and discipline, and lay the foundations, as yet non-existent, of a modern civilized State. In both directions he succeeded beyond expectation, but not by 'rose water' 2 methods. The situation demanded strength rather than finesse, and it camnot be denied that Stambuloff' was compelled to have recourse to weapons which excited just resentment and even indignation. ${ }^{3}$ All through he had to fight for his political life, and more than once escaped actual assassination by a hair's-breadth, but he carried things through with a strong hand, to the infinite adrantage of his country and his prince. He has been called the Bismarck of the Balkans; but he lacked the finesse which that supreme diplomatist concealed under an affectation of bluntness ; in

1 Born in 1861.

2 The phrase, of course, is Carlyle's, and nsed by him in reference to Cromwell's work in Ireland.

${ }^{3}$ A notable example was the high-handed execution of a Major Panitza in 1890 . 
some respects he was Cromwellian rather than Bismarckian ; but essentially he was himself: a rough, coarse-grained peasant, of indomitable will, strong passions, and burning patriotism. Involved in domestic trouble in May, 1894, he sent in his resignation, little suspecting that it would be accepted. To his intense chagrin it was. Prince Ferdinand himself succeeded to the racant place.

Stambuloff bitterly resented his dismissal, and took no pains to hide the fact; it was, therefore, something of a relief to all parties when, in July, 1895, the fallen statesman was finally removed from the scene by assassination.

The people he had served so truly were stricken with grief at the news of the dastardly crime; but Prince Ferdinand was at last master in his own house.

Rap- The first use he made of his freedom was to effect a reconment with ciliation with Russia. The death of Alexander III in 1894 Russia. rendered the task easier. Ferdinand himself had married, in 1893, Princess Marie of the house of Bourbon-Parma, and when, in 1896, an heir was born to them, the young crown prince was baptized according to the rites of the Orthodox Church, and the Tsar Nicholas II acted as godfather. Two years later the reconciliation was sealed by a State visit paid by the Prince and Princess of Bulgaria to Peterhof.

Meanwhile, Ferdinand's international position was regularized when, in March, 1896, he was recognized by the Sultan as Prince of Bulgaria and Governor-General of Eastern Roumelia. His mother, the Princess Clémentine, who was at once exceedingly clever and exceedingly wealthy, devoted herself untiringly to the task of improving the dynastic and political position of her son. And not in vain. The development of Bulgaria, alike in European prestige, in political stability, and in all the economic and industrial appurtenances of a modernized society, was astonishingly rapid. Leaving it in this promising position we must turn our attention to other parts of the peninsula, or rather of the Ottoman dominions.

Armenian From 1894 to 1897 interest in the Eastern Question was massa- mainly concentrated upon the unhappy relations between
cres. the Sultan Abdul Hamid and the Armenian Christians. But 
this painful subject can be dealt with more conveniently in another comexion. ${ }^{1}$

Early in the year 1897 the outbreak of an insurrection in 'The Crete-the 'Great Greek Island' as the Grecks loved to Ifellenic call it-and the excitement caused thereby among the Greeks of the mainland once more brought into prominence the Hellenic factor in the Near Eastern problem.

In order to pick up the threads of the Hellenic question, it will be necessary to cast a brief retrospective glance upon Greek affairs since the formal achievement of independence in $1832 .{ }^{2}$

The protecting Powers, it will be remembered, had provided the new kingdom with a king in the person of a young German princeling, Otto of Bavaria.

The task committed to him wonld have tried the skill of The the most accomplished and experienced statesman; Otto Bavarian was a lad of seventeen, of indifferent natural capacity, devoid of any special aptitude for government, and entirely ignorant of the country and people whose fortunes were committed to his charge.

Manifold difficulties confronted him at the ontset of his reign, and most of them dogged his footsteps until its inglorious ending. His tender years necessitated a Regency, which was committed, perhaps, inevitably to Bavarians, and by Bavarians he was surrounded for the first ten years of his reign. An ex-minister of Bavaria, Count von Armansperg; General von Heideck, a typical German soldier; Dr. Maurer, a distinguished jurist-this was the incongruous triumvirate who were to rule the young kingdom in the young king's name. Less distinguished men might have bungled things less bally; they could hardly have bungled them worse.

A second difficulty arose from the niggardly and stupid Epirns fashion in which the northern frontiers were defined by and the Treaty of London (1832). The lino was then drawn from the Gulf of Arta on the west to the Gulf of Volo on the east. Beyond that line, in Epirus, Thessaly, and Macedonia,

1 Injra, p. 349.

2 supra, p. 199 
were a large number of Greeks who, ardently desiring reunion with their brethren in the kingdom, still remained subject to the rule of the Sultan. For half a century nothing whatever was done by the l'owers to remedy the sense of wrong which poisoned the minds of patriotic Greeks on both sides of the purely artificial frontier.

On the outbreak of the Crimean War the Greeks were anxious, not unnaturally, to take advantage of the preoccupation of the Turks and to acquire the long-coveted provinces of Epirus and Thessaly. Early in 1854 a large though ill-disciplined force of Greeks burst into the provinces; but the invasion was repelled by the Turks; the Western allies oceupied the Piraeus from May, 1854, until February, 1857 ; and King Otto was coerced into a highly distasteful neutrality. The only results of the ill-advised and inopportune invasion of Turkish territory were, therefore, the alienation of the best friends of Greece; an increase of her financial embarrassments ; and, worst of all, a damaging blow to her prestige and self-respect. At the Peace of Paris Greece got nothing.

The Russo-Turkish War of 1877-8 was, in a territorial sense, more productive. Though not immediately. In the war itself Greece had taken no part. There was a strong party in Greece which believed that the moment had come for taking by force of arms the great prize-Thessaly and Epirus-denied to her by diplomacy in 1856. But Trikoupis, who was Foreign Minister, unwisely preferred to trust to diplomacy and, in particular, to the goodwill of Great Britain, who, as in 1854, strongly opposed the intervention of Greece. Popular insurrections broke ont in Thessaly and Epirus as well as in Crete, but the peace between Greece and Turkey remained technically unbroken until February 2, 1878, when, at the acutest moment of the European crisis, Greece declared war upon the Porte. This most inopportune and not very courageous demonstration was at once suppressed by the Powers, and Greece acquiesced. Consequently Greece went to the Congress of Berlin as an outside suppliant, and, as might have been expected, came away emptyhanded. Lord Beaconsfield, jealous for the integrity of the 
Ottoman dominions, suggested that Greece was 'a country with a futmre, who could afford to wait'. Mr. Gladstone, an ardent Philhellene, scathingly contrasted the fate of Greece with that of the Balkan States which, relying upon Russia, had made war upon the Turk and harl reaped their appropriate reward. Greece, who had kept her sword in the scabbard and had relied upon English benevolenee, got nothing more than a passing sneer from Lord Beaconsfield. The Congress of Berlin did indeed invite the Sultan to grant to Greece such a rectification of frontiers as would include Janina and Larissa in Greek territory, but the Sultan, not unaturally, ignored the invitation.

Two years later (1880), when Mr. Gladstone himself had come into office, the Powers suggested to the Porte the cession of Thessaly and Epirus, and at last, in 1881, the tact and firmness of Mr. Goschen wrung from the unwilling Sultan one-third of the latter province and the greater part of the former. Macedonia was still left, fortunately for Greece, under the heel of the Snltan. Lord Beaconsfield did not exhibit much positive benevolence towards Greece, but negatively she, like Serbia, owes him a considerable debt. If he had not torn up the Treaty of San Stefano Bulgaria would have obtained a commanding position in Macedonia, Serbia would never have got Uskub and Monastir, Greece would still be sighing for Kavala and perhaps for Salonica.

Nearly twenty years earlier the Hellenic kingdom had been emriched by a gift even more romantic and hardly less prized than that of Thessaly and Epirus.

Ever since the Greek War of Independence the inhabitants The of the seven islands of the Ionian arehipelago-Corfu, Zante, Ionian Paxo, Ithaca, Cephalonia, Santa Maura, and Cerigo--had been restless under the British protectorate. To that protectorate they had, as we have seen, been confided after many vicissitudes by the Congress of Viemna (1815). But the arrangement did not work smoothly, and in 1858 Bulwer Lytton, then at the Colonial Office, persuaded Mr. Gladstone to undertake a special mission and to investigate the grievances of the islanders. The system of administration was such that, as Gladstone himself said, 'not Cherubim and 
Seraphim could work it'. The High Commissioner Extraordinary had a mixed reception in the islands, but everywhere he found one sentiment prevailing among the inhabitants, an ardent wish for immediate union with the Greek kingdom. To this step he was himself at the outset strongly opposed, believing that the surrender of the protectorate by England 'would be nothing less than a crime against the safety of Europe as connected with the state and course of the Eastern Question'. As a substitute he offered the islands constitutional reform, which they did not want. Within four years Mr. Gladstone had changed his mind; Lord Palmerston came round to the same opinion, and in the Queen's Speech of February, 1863, the offer of the islands to Greece was publicly announced. The National Assembly of the Hellenes gratefully accepted the gift on March 20, and the protocol concluded at London on June 5 contained a provision for the cession of the islands to Greece.

The cession of the Ionian Isles was in the nature of a christening present for the young Danish prince whom the Powers simultaneously presented to the Greeks. For by this time the rule of King Otto had reached its term.

The reign To follow in detail the course of events which eulminated of Otto in his enforced abdication would be both tedious and, in the (1833-62). present comnexion, impertinent. One or two outstanding causes must, however, be noted. The tactlessness of the Bavarian advisers of the king; the intrigues of innumerable parties which rapidly evolved during and after the War of Independence; discontent among the disbanded irregulars who had fought in the war; unrest among a people who found themselves under a highly centralized German bureaucracy deprived of that communal autonomy which they had enjoyed under the Turks, all contributed to the unpopularity of the unfortunate king. His ereed was another stumbling-block. The attempt of a Roman Catholic to rule a people who owed their political emancipation in large measure to Orthodox priests must, in any case, have led to some friction. It led to much more when the domestic relations between Crown and Church were complicated by the withdrawal of the Greek Church of the 
kingdom from the jurisdietion of the Patriarch of Constantinople.

We have already noted the significance of the movements Eccletowards ecclesiastical independence in Serbia and Bulgaria. siastical In those cases ecclesiastical preceded the achievement of dence. political independence. In Greece political emancipation came first. Consequently, the delicate task of adjusting relations with the Greek Patriarch of Constantinople fell to a German and a Roman Catholic. The Orthodox Church in Greece renounced obedience in 1833, and the renunciation was accompanied by a measure of domestic reorganization, by a reduction in the numbers of the episcopate, and by the dissolution of all the smaller monasteries. These measures exeited considerable opposition in Greece, and not until 1850 did the Church of the kingdom obtain formal recognition of its independence from the Patriarch.

In $1837 \mathrm{King}$ Otto came of age, and immediately assumed The Inthe reins of power. For a brief moment the hope was of $18 \pm 3$. entertained that he might prove to his people that the blunders which had thus far characterized his reign were those of his Bavarian ministers, not his own. They were; but unfortumately his own were worse. Otto, as Finlay pithily remarked, was neither ' respected, obeyed, feared, nor loved'.' The evils of the regency were if anything accentuated: a centralized administration of foreign type proved powerless to perform the elementary functions of government ; brigandage, 'an ineradicable institution' ' in Greece, grew steadily more and more intolerable; extravagant expenditme without appreciably beneficent results, but involving oppressive taxation, led ultimately to financial repndiation; the press was gagged ; the promised constitution was unaccountably withheld; worst of all, from the Greek point of view, the destruction of local self-govermment denied to the people those opportmities for discussion and debate so warmly cherished by every typical Greek and regarded as the only tolerable alternative to the other national sportguerrilla warfare. Denied the former, the Greeks resumed

1 Finlay, vii. 168.

2 Lowis Sergeant, New Greece, p. 104. 
the latter; and early in 184,3 armed insurrection in epidemic form broke out in many parts of the country. But though armed the insurrection of 1843 was bloodless. King Otto yielded at once to the demands of the insurgents, dismissed his Bavarian ministers, and agreed to accept a democratic constitution, with a bi-cameral legislature and a responsible executive. ${ }^{1}$

The constitution of 1844 .

The concession was popular; but it soon became erident that constitutional reform would not provide a permanent solution of the difficulties by which King Otto was confronted. The politicians amused themselves with a burlesque of parliamentary government; parties innumerable were formed, but the 'English', the 'French', and the 'Russian' parties were the only ones which had any correspondence with the realities of political affairs; debates interminable took place in 'Senate' and 'Chamber'; ministries, in rapid succession, were called to office and dismissed; the forms of a representative democracy were all carefully reproduced. There was no reality behind them. Unless indeed he were aiming at a reductio ad absurdum King Otto had begm at the wrong end. His people had asked for a 'constitution' based upon the rights of man, and other purely exotic ideas. What they wanted was a derelopment of indigenous local democracies. But this was precisely what they did not get. Otto was by no means entirely to blame. The Powers-England and France in particularmust bear a very large share of responsibility. It was the era of doctrinaire liberalism in the West. The same principles must be exported to the Near East. The Greeks were essentially democrats; but in the Swiss sense, not the French, still less the English.

If Otto had had the sense to build up a constitution from below instead of imposing it, in German method, from above he might have led his people-as difficult a people as ever a man had to lead-along the first halting steps on the path towards real self-government. It was in truth not to be

1 The text of this constitution, together with a detailed account of the revolution, will be found in British and Foreign State Papers, 1843-4, vol. xxxii, pp. 938 sq. 
expected of the king. But it was, in a constitutional sense, the only possible chance for his infant kingdom.

Otto's constitutional experiment lasted for nearly twenty years, but there is nothing to be gained from a detailed account of its vieissitudes. All that need here be said is that Otto, in his domestic policy, limentably failed to achieve the impossible.

In the domain of foreign relations the one really important The 'Dom episode of the reign was the rail into Epirus and Thessaly at P'acifico the opening of the Crimean War. To this episode reference has already been made. Another ineident, which at the time caused even more friction with England, was that associated with the name of Dom Pacifico. Two British subjects, Dr. George Finlay, the eminent historian, and Dom Pacifico, a Portuguese Jew born in Gibraltar, had suffered unquestionable wrong at the hands of the Greek Government. Dr. Finlay had tried in vain to recover damages for the loss of land illegally taken from him ; Dom Pacifico for the value of property destroyed by a mob with the connivance of the police. Dom Pacifico's own record was none of the best, but equally with Dr. Finlay he was a British subject, and for Lord Palmerston, who was then at the Foreign Office, that was enongh. Redress was insolently denied not merely to the sufferers, but to the British minister. Iord Palmerston, therefore, instrueted the British Admiral ' to take Athens on his way back from the Dardanelles'. Russia resented the pressure thus put upon King Otto, the enfant gâté ale l'absolutisme; the French President sulked, offended by the refusal of his offer of mediation, and withdrew his ambassador, Dronyn de Lhuys, from London. But Palmerston went on his way unheeding, and quickly achieved the desired end. The point at issue was trivial; the whole incident was intrinsieally unimportant except as illustrative of the stupidity displayed by King Otto and his ministers in their relations with other countries no less than with the Greek people.

By the year 1862 the patience of the Greeks, nerer their most conspicuous characteristic, was worn out, and they determined to get rid of their Bavarian king. The question 
of the succession to the throne brought matters to a crisis. The king and queen were childless, and no collateral member of the Bavarian House had qualified for the succession, according to the terms of the constitution, by embracing the Orthodox faith. Queen Amalia, an Oldenburg princess, was suspected of ambitious designs on her own account. The Greeks preferred to look elsewhere.

Revolution of 1862 .
In February, 1862, a military revolt broke out at Nauplia ; the insurrection spread rapidly; the king and queen found themselves excluded from their own capital ; in October, 1862, they embarked on an English gunboat, and from the Bay of Salamis the king issued a proclamation announcing that 'he had quitted Greece for a time in order to avoid plunging the country in civil war'.

They never returned. King Otto died in Germany in 1867; mean while the Greek people had proceeded to the election by plebiscite of a successor.

The protecting Powers acknowledged the right of the Greeks to decide the matter for themselres, but reiterated their resolution not to permit a scion of the reigning house of any of the great European Powers to accept the throne.

Search for The Greeks, howerer, were perversely determined, and a new liing. elected Prince Alfied, the second son of Queen Victoria. On a plebiscite, Prince Alfred obtained 230,016 rotes; the next candidate, the Duke of Leuchtenberg, got 2,400, Prince William George of Denmark was at the bottom of a long list with 6.

Prince Alfred, despite the waruing of the Powers that both he and the Duke of Leuchtenberg were disqualified, was accordingly proclaimed ling by the National Assembly (February 3, 1863).

The Powers, however, adhered to their resolution, ${ }^{1}$ and England was entrusted with the invidious task of providing the Greeks with a 'constitutional' king. For some months the crown was hawked round the minor Courts of Europe. It was first offered to and refused by a Coburg prince,

1 Cf. Joint Note of December 15, 1862 (State Papers, rol. Jviii, p. 1107), and translation ap. Hertslet, rol. iii, p. 2073. 
Ferdinand, the Ex-King-Consort of Portugal, and then, in succession, by two other Coburg princes.

The Greeks, in the meantime, being foiled in their attempt King to obtain the services of an English prince, tried to get an (ieorge of English statesman as their king. The offer of the crown was (1863actually made to and declined by Lord Stanley, and Mr. Gladstone's name was also mentioned, much to his own amusement in the same commexion. ${ }^{1}$ Ultimately, however, Great Britain secured for the Greeks the services of Prince William George of Denmark, who, in 1863, ascended the throne as King George I.

The disappointment of the Greeks was, as we have seen, mitigated by the cession of the Ionian Isles, a transaction which was tactfully included in the same protocol (London, Jume 5, 1863), which provided for the nomination of the Danish prince to the crown.

The definitive treaty was concluded between Great Britain, France, and Russia of the one part, and Denmark of the other part, on July 13, and its terms deserve attention. Article III runs as follows: 'Greece, under the Sovereignty of Prince William of Denmark and the guarantee of the three courts, forms a Monarchical, Independent and Constitutional State.'

The precise comnotation of the last epithet, 'Constitutional', was, and is, a matter of dispute. If the epithet implied anything more than a promise that the constitution should be embodied in a written document (Statuto), its implications must have varied considerably in the minds of the three protecting Powers-Great Britain, Imperial France, and Autocratic Russia.

King George, like his predecessor, was at the time of his Revision accession a youth of seventeen, and promptly proceeded to of the fulfil the promise of his sponsors. A Yational Assembly was tion. summoned, and the king urged upon it the importance of completing without delay the revision of the constitution.

1 'Though I do love the country and nerer laughed at anything else in connexion with it before, yet the seeing my own name, which was nerer meant to carry a title of any kind, placed in juxtaposition with that particular idea made me give way.' Mr. Gladstone to a friend, ap. Morles, Lije, i. 620. 
By the end of October, 1864, the work was accomplished; on Norember 28 the king took the oath to the constitution, and the Constituent Assembly was dissolved.

Constitu- The constitution thus inaugurated was frankly democratic. tion of $1 \approx 61$. The Senate, established in 1843, was abolished, and legislatire power was rested in a single chamber with an absolute veto reserved to the crown. The Boulé, as it is called, was to consist of not less than 150 deputies apportioned to the several provinces according to population. The deputies were to be elected for four years by direct and universal suffrage, and to receive payment for their services. Half the members, plus one, were required to form a quorum. A special procedure was ordained for constitutional revision. Minister's were to be responsible to the Chamber, but the means of asserting their responsibility were not defined until 1876. There was to be a Cabinet of seven nominated by the king, not necessarily from among members of the Bonlé. All ministers might speak in the Boulé, but could not vote unless they were members of it. ${ }^{1}$

Such were the main features of the constitution which continued practically unchanged down to 1911. In the latter year, the Council of State, a probouleutic body, was revived; soldier's were declared ineligible for seats in the Bonlé ; the quorum of the Boulé was reduced to one-third; and elementary education was made both compulsory and gratuitous. If parliamentary government has not hitherto proved a conspicuous success in Greece, it has not been for lack of meticulons constitutional definition. But the truth is that this particular form of polity postulates conditions which are not found in combination nearly so often as most Englishmen and some foreigners imagine. It demands, in the first place, a long and laborious apprenticeship in the art of self-govermment among the people; it demands in the elected representatives, as Cromwell perceived, substantial unanimity as regards the 'fundamentals' of government; it demands in the sorereign (if the polity be of the constitutional-

1 For details cf. Demombynes, Les Consitutions Européennes, rol. i, pp. $801 \mathrm{sq}$. The full text of the constitution of 1861 is printed in Appendix $\mathrm{V}$ to Finlay, op. cit., vol. vii. 
monarehical type) consummate tact and considerable political experience and education. It must frankly be admitted that these prerequisites have not invariably been fortheoming in the modern Hellenie State, and that the parliamentary constitution has been subjected, at not infrequent interrals, to a strain to which it is manifestly unequal.

With the establishment of the constitution of 1864 we may The leave, for a time, the domestic politics of Greece and turn to problcm the most pressing of its external problems.

Among these none appealed with such foree to the mass of ' the Greek people as the condition of their brethren, still under Turkish rule, in the 'Great Greek Island'. Crete, more definitely even than the Peloponnesus, presents the quintessence of Hellenism. The Cretans, as a Greek writer has said, 'are as pure Greeks as exist to-day ', ${ }^{1}$ and many of the foremost statesmen of the kingdom, including M. Venizelos himself, were born and bred in the island, and in the island served their political apprenticeship.

Crete was actually the last of the territorial acquisitions of the Ottoman Empire in Europe. Not until 1669 was it surrendered by the Republic of Venice to the Sultan. From the day of that surrender down to its rirtual mion with the Greek kingdom in October, 1912, Crete was the scene of perpetual revolts against Turkish tyranny. It was handed over by the Sultan to Mehemet Ali in 1830 as a reward for his services to his suzerain in the War of Independence, and for the next ten years it formed part of the Pashalik of Egypt. Under Mehemet Ali it enjoyed a species of local autonomy, but in 1840 it was restored by the Treaty of London to the Porte.

The biographer of M. Venizelos has comted no less than fourteen insurrections in the island since the year $1830 .^{2}$ To follow them in detail would be tedious; they were mostly of one pattern; and all were promoted with the same ultimate object, that of securing reunion with the Greeks of the mainland.

The domestic grierances of the Cretans were practically

1 D. J. Cassavetti, Hellas and the Balkan Tars (1914), p. 4.

2 Kerofilas, Eleftherios Venizelos, p. 47. 
the same as those with which we hare become familiar among other subject peoples in the Ottoman Empire: extortionate and irregular taxation; unequal treatment of Christians and Moslems; denial of justice in the courts ; the refusal to carry out the promises contained in the Tanzimat and the Hatti-Humayoun, and so forth. In 1866 the islanders broke into open rerolt, convoked a General Assembly at Sphakia, declared their independence of the Ottoman Empire, and proclaimed their union with the Hellenic kingdom (September 2). This declaration represented the Cretan reply to an offer made to them by the Sultan of reunion with the Pashalik of Egypt. The offer was indignantly repudiated, and from 1866 to 1868 the island was in a state of continuous revolt. The Turks were seriously embarrassed, and suppressed the revolt after three year's' fighting with considerable difficulty, and only by the assistance of Egyptian troops.

The

Organic Statute of 1868 .

In order to appease his troublesome subjects, whom he would gladly have handed over to the Khedive Ismail of Egypt, and to aroid, if possible, the expense and rexation of perpetual reconquests, the Sultan, in 1868, conceded a series of reforms which were embodied in the Organic Statute.

The Governor-General was henceforward to be assisted by two assessors, of whom one was to be a Christian ; similarly, the gorernor of each of the ten provinces into which the island was now divided was, if a Moslem, to have a Christian assessor, or if a Christian, a Moslem assessor; there was to be a central administrative council to advise the gorernor, and a similar local council in each province; the island as a whole was to have an elective general assembly; mixed tribunals were to be set up, and precautions were to be taken against religious persecution and oppressive taxation.

The new constitution proved entirely unworkable; it satisfied neither the pririleged Moslem minority nor the Christian majority, and in 1876 large modifications were demanded by the islanders. The outbreak of the RussoTurkish War in 1877 caused great excitement in Crete as in other Greek provinces still subject to the Sultan; a committee was formed to promote the complete autonomy of 
Crete, and, on the refusal of the Porte to grant their demands, an appeal was made to the l'owers. From the C'ongress of Berlin the Cretans got nothing, except a promise that the Organic Law should be strictly enforced and even enlarged; but they had had enongh of promises, and in despair they asked to be placed under the protectorate of Great Britain.

This privilege was denied to them, but by the good offices The Pact of the British Consul, Mr. Sandwith, a considerable amend- of Halépia, ment of the Organic Statute was secured from the Porte and 1878. was embodied in a pact which took its name from the suburb of Canea in which the consuls resided. The Judiciary was made nominally independent of the Executive ; there was to be a General Assembly, consisting of forty-nine Christians and thirty-one Moslems; natives were to have the preference for official appointments, and the official language, both in the assembly and in the courts, was to be Greek; the revenue was to be reorganized so as to provide a surplus for the promotion of much-needed public works; the issue of paper money was prohibited, and the press was to be free. For the moment the Cretans were satisfied, or rather were content to await a more favourable time for the achievement of their ultimate ambition.

The success of the Philippopolis revolution ${ }^{1}$ aroused among The Crisis the Greeks, as among the Southern Slars, much heartburning of 1886-9. and excitement. Serbia the naval Powers have never been able either to coerce or to assist. Greece is more-or lessfortunately situated. In 1882 there had come into power Charilaos Trikoupis, one of the two great statesmen whom modern Greece has produced. With brief intervals Trikoupis remained at the head of affairs until $1895 .^{2}$ Trikoupis had served a long apprenticeship to diplomacy in England, and had naturally seen much of English public life when, in an administrative sense, that life was perhaps at its best. No man was better qualified to introduce into the politics of his own country the qualities so sadly lacking: financial honesty and economy, with a high sense of public duty. In the years between 1882 and 1894 he did much to improve the financial

1 Supra, p. 313.

2 He was at the Greek Legation in London, 1852-63. 
and social condition of Greece ; order was introduced into the public service, and foreign capital, desperately needed for the development of the material resources of the country, was slowly but steadily attracted.

The crisis of 1885-6 unfortunately coincided, however, with one of the brief intervals of power enjoyed by his rival Theodore Delyannis. Delyannis, oblivious of the paramount necessity of husbanding the resources of Grcece, came in on the ery of a spirited foreign policy. Bulgaria had acquired Eastern Roumclia; Serbia was making a bid-though an unsuccessful one-for an equivalent; Greece could not afford to be left behind. The army and fleet were mobilized, and several collisions occurred between Turkish and Greek forces on the frontier.

Interren- But the Powers, strongly adverse to a reopening of the tion of the Eastern Question on a large scale, called upon Greece to
Powers. disarm. When Greece declined the Powers, despite the refusal of France to co-operate, established a blockade. The excitement on the mainland spread to Crete, where the Christians proclaimed their union with the kingdom. Thanks, however, to the presence of the European fleets things went no further. Delyannis was forced to resign; Trikoupis came back to power, and did his best to restore order at home and confidence abroad. In 1889, at the instance of the Porte, he persuaded the Cretans to acquiesce in the Turkish occupation of certain fortified places in the island, an act of complaisance characteristically rewarded by an abrogation of the Pact of Halépa. This gross breach of faith on the part of the Sultan not only evoked the liveliest indignation in the island, but fatally undermined the position of Trikoupis in the kingdom. In October, 1890, Delyannis came back to power, only, however, to give way again in 1892 to Trikoupis, who was recalled by the king, in the hope of arerting national bankruptcy. Even he proved unequal to the task withont recourse to a scaling down of interest on the debt, and when he ultimately resigned in 1895 Greece appeared to be plunging headlong towards financial ruin. ${ }^{1}$

A crisis of another kind was, however, rapidly maturing.

\section{1 'Trikoupis died in 1896.}


Temporarily gratified, in 1894, by the appointment of a Christian governor, the Cretans were greatly incensed by his recall in 1895. The bad faith of the Porte in financial and other matters intensificd the excitement, which was further stimulated by the rapid growth of the nationalist movement both in the island and in the kingrlom.

Of this movement there were many manifestations. Not The the least significant was the foundation, in 1894, of a secret Mthenike society known as the Ethnike Hetaireia (National Society). reia. Its objects were to stiffen the back of the Government in regard to the nationalist movement, both on the mainland and in the islands; to repudiate international intervention which in 1854, in 1878, and in 1886 had, as the young patriots imagined, denied to Greece its reasonable share in the spoils of the Ottoman Empire; to improve the military organization of the kingdom ; to stimulate the 'Greek' movement in Macedonia, and thus avert absorption by Bulgaria; and, not least, to promote reunion between the Greeks of the island and the kingdom.

In the spring of 1896 the islanders were again in arms. Cretan inCivil war broke out between Moslems and Christians in $\begin{gathered}\text { surrection } \\ (1896-7)\end{gathered}$ Canea, and the Powers, to prevent the spread of disturbances, put pressure upon the Sultan to make concessions. The latter accordingly agreed to renew the Pact of Halépa, to grant an amnesty, to summon a National Assembly, and to appoint a Christian governor. On September 4 Gcorge Berovic, who had been 'Prince of Samos', was appointed to the post. But neither Moslems nor Christians took the Sultan's promises scriously, and in February, 1897, war again broke out at Canea, and the Christians again proclaimed union with Grecce.

No power on earth could now hare prevented the Greek patriots from going to the assistance of the islanders. Prince George, the king's second son, was accordingly sent (February 10) with a torpedo-boat flotilla to intercept Turkish reinforcements, and three days later an army was landed under Colonel Vassos. The admirals of the Powers then occupied Canea with an international landing party, and compelled the insurgents to desist from further fighting. 
Meanwhile diplomacy got to work, and, on March 2, presented identical notes at Athens and Constantinople. Greece was to withdraw her army and navy ; the Turks were not to be allowed to send reinforcements to the island; Crete was (1) not at the moment to be annexed to Greece; (2) 'in no circumstances to revert to the rule of the Sultan'; and (3) to enjoy autonomy under the suzerainty of the Porte. To the ears of the Greeks these proposals had a painfully familiar sound. The Greck Government refused to abandon the Christian Cretans to their Moslem enemies, or to withdraw their forces until the islanders had been allowed to decide for themselves, by plebiscite, the future of their own land. The insurgents themselves declined to lay down their arms. The admirals accordingly established a blockade of the island (March 20) and bombarded the Christian insurgents at Malaxa, ${ }^{1}$ occupied the ports, and issued a formal declaration to the effect that henceforward the island was under European protection, and that its autonomy was assured.

The Interest then shifted to the mainland. The young patriots

'Thirty Days' leagued in the Ethnitie Hetaireia believed that the moment War,' April 17 for decisive action had come. King George yielded, in May 20 , 1897. words, to the warlike sentiment of his people, believing, it was said, that the Powers would intervene, as they had intervened in 1854, in 1878, and in 1886, to prevent war. ${ }^{2}$ But if the Greek hot-heads wanted war, the Sultan was prepared for it, and his august ally at Berlin urged him to put to the test the new weapon which Germany had forged for him, and, once for all, teach the insolent Greeks their place.

'Greek' irregulars were already pouring over the frontiers of Thessaly, and accordingly, on April 17, the Sultan declared war. The 'Thirty Days' War' ensued. It was all over before the end of May. Greece was quite isolated. Russia had warned her friends in the Balkans that there must be no intervention. The European admirals policed the Levant. The Greeks made no use of their superior sea-power, and on land they were quickly pushed back orer their own frontiers.

1 For details cf. Dr. E. J. Dillon's article 'Crete and the Cretans' in the Fortnightly lieview for June, 1897.

2 Miller, Ottoman Empire, p. 435. 
The Turkish army under Edhem Pasha occupied Larissa, and won two decisive victories at Pharsalos and Domokos. So disorganized were the Greek forces that Athens became alarmed for its own safety, and turned saragely upon the king. The Powers, howerer, having no mind to embark, for the third time, upon the tedious task of providing the Greeks with a king, imposed an armistice upon the combatants (May 20). The definitive peace was signed in December.

The war was nothing less than disastrous to Greece: it discredited the dynasty; it involved the retrocession of a strip of Thessaly ; and it imposed upon a State, already on the verge of bankruptcy, the burden of a considerable war indemnity. Nor was Greece spared the further humiliation of International Control, exercised by means of a mixerl Conmission, over her external finance. On the other hand, Crete obtained final, though not formal, emancipation.

With the Cretan imbroglio the Powers had still to deal. The They dealt with it not the less effectually because they had Powers ceased to be unanimous. For reasons which the next chapter will disclose Germany and Austria-Hungary retired from the Concert, and withdrew their ships from the naval blockade. Great Britain, France, Russia, and Italy went forward and completed the task. There were many factors in a difficult problem: the antagonism of Christian and Moslem in the island itself; the wider rivalry of which Crete was the microcosm between Hellenes and Ottomans; the mutual suspicions of the Great Powers. At the very moment when the English and French admirals were co-operating cordially in Crete the two nations were brought to the brink of war by the Fashoda incident. ${ }^{1}$ But all the difficulties were by patience orercome. Each of the four Powers occupied a coast-town; the English holding Candia, and Canea being held by a joint force. In these towns the Moslems were concentrated, while the open country was left to the Christians. Colonel Vassos and the Greek troops had already withdrawn, and a characteristic incident presently

${ }^{1}$ Kitchener won his rictory at Omdurman on September 2, 1898, and occupied Khartoum on the 4th. Major Marchand planted the French flag at Fashoda on the Upper Nile on July 12 of the same year. 
led to a demand for the recall of the Turks. On September 18 the Moslems in Candia, having burnt the British vice-consul in his own housc, proceeded to massacre all the Christians they could reach. The Porte was thereupon required to recall all its troops and all its civil officials, and by the end of November the last of the Turks had left the island. The admirals were now in sole and supreme control. But on November 26 the four Powers invited Prince George of Greece to act as their High Commissioner in Cretc for a period originally of three years, but subsequently prolonged to eight. This ingenious arrangement was accepted by Greece, and on December 21, 1898, the prince landed at Suda Bay. Before the end of the year the naval squadrons withdrew, though the troops remained to police the island.

Autonomy achieved.

In April, 1899, a Constituent Assembly was summoned, and approved a new constitution on liberal lines. That constitution had been drafted by a young Cretan lawyer, destined to fill a conspicuous place not merely in Greek but in European politics, M. Eleftherios Venizelos. Thanks mainly to him Crete for the first time enjoyed real self-government. Owing to the international occupation, which was prolonged only long enough to restore order in the island, the experiment started under the happiest auspices. Unfortunately, however, friction soon developed between the prince and M. Venizelos. The latter retired from the Council, and when in 1905 a revolution broke out the leadership of the movement was by general consent confided to him.

The sole object of the rising was to hasten the day of reunion with the kingdom. By the Greeks of the island the appointment of Prince George as High Commissioner had been interpreted, not unnaturally, as a sign that the Powers had made up their minds to union, and only desired that it should be brought about with the least possible offence to the Sultan, and without raising difficult questions elsewhere. The High Commissionership of a royal prince was in fact accepted as a step to union.

But years passed, nothing was done; the term of the prince's appointment was prolonged, and at last in August, 
1904, the prince was formally requested to 'inform the Great Powers of the firm resolution of Crete, and urging them not to postpone its union with Greece'. No action followed, and in 1905 the islanders, led by M. Venizelos, attempted to take the matter into their own hands, and proclaimed the union of Crete with the Hellenic kingdom. The Powers, thereupon, again intervened; Prince George resigned; the king, by permission of the Powers, nominated M. Zaimis to succeed him, and for the next three year's the island was policed by an international military force. The exciting events of 1908 : the proclamation of Bulgarian independence; the 'Young Turks" revolution at Constantinople; above all, the annexation of Bosnia and the Herzegovina by Austria, produced an uncontrollable outburst of feeling in Crete, and again the islanders demanded annexation to Greece. A provisional government was set up with M. Venizelos as Minister of Justice and Foreign Affairs. The Powers, while refusing formally to recognize the provisional government, entered into administrative relations with it. If, at this crisis, Greece had acted with courage and promptitude, the Cretan problem would probably have been solved there and then; but in fear of the Turk on the one hand, and on the other of the Powers, the Greeks allowed the farourable opportunity to slip. Not until the whilom rebel M. Venizelos had become Prime Minister of the kingdom was the union actually achieved. The recital of the events which led to that long and ardently desired consummation must, however, be deferred. In the meantime there had entered into the problem of the Near East a new factor which must be subjected to close analysis. That analysis will occupy the next chapter.

The best authorities are the Papers presented to Parliament under the head of 'Bulgaria' and 'T'urkey'.

For further reference: Dr. J. Holland Rose's masterly essay on The Making of Bulgaria (The Development of the European Nations, chap. x); E. Dicey, The Peasant State; A. H. Boaman, Life of Stambulotf,

; J. Sammelson, Bulgaria Past and Present (18s8); Major A. von Huhn, The Struggle of the Bulgariaus for National Independence (Eng. trans., 1886), The Kidnapping of Prince Alexander (1887); Marquis of Bath, Observations on Bulgarian Affairs (1880); A. G. Drandal, Cinq 
Ans de Règne de Prince Alexandre de Battenberg en Bulgarie (Paris, 1884); E. de Laveleye, The Balkan Peninsula; Encyclopedia Britannica (11th edition); V. Bérard, Les Affaires de Crìte; Kolmar Fr. von der Goltz, Der Thessalische Krieg und die Türkische Armee (Berlin, 1898); D. J. Cassavetti, Hellas and the Balkan Wars (1914); Dr. C. Kerofilas, Eleftherios Venizelos (1915); Victor Bérard, La Turquie et l'Hellénisme contemporain (1904); G. Isambert, LiIndépendance grecque et l'Europe (Paris, 1900). 


\section{CHAPTER XIV}

\section{A NEW FACTOR IN THE PROBLEM}

\section{German Policy in the Near East, 1888-1908}

'The attempt to dominate the East forms the keystone of German Weltpolitik:'-G. W. Prothero.

'Ce qui modifie l'évolution de la question d'Orient, ce qui bouleverse complètement les données du problème et par conséquent sa solution possible, c'est la position nouvelle prise par l'Allemagne dans l'Empire ottoman. . . . Hier, l'influence de l'empereur allemand à Constantinople n'était rien, aujourd'hui elle est tout; silencieusement ou avec éclat, elle joue un rôle prépondérant dans tout ce qui se fait en 'Turquie.'André Chéradame (1903).

'I never take the trouble even to open the mail bag from Constantinople.' 'The whole of the Balkans is not worth the bones of a single Pomeranian grenadier.'-Prixce Bismarck.

'The 300,000,000 Mohammedans who, dwelling dispersed throughout the East, reverence in H.M. the Sultan Abdul Hamid their Khalif, may rest assured that at all times the German Emperor will be their friend.'Speech of the German Emperor at Damascus in 1898.

'We have carefully cultivated good relations with Turkey. ... These relations are not of a sentimental nature. . . . For many a year Turkey was a useful and important link in the chain of our political relations.'-PRIxCs BERNHARD VON BÜLOW.

'La politique utilitaire de l'Allemagne, si odieuse soit-elle au sentiment européen, est au moins une politique; elle gagne à l'empereur Guillaume les sympathies du monde musulman, ouvre les voies au commerce et impose un certain respect. . . . L'Orient ne respecte que la force.'-GAULIS.

ON November 1, 1889, the German imperial yacht, the Emperor Hohensollern, steamed through the Dardanelles with the WilliamEmperor William II and his Empress on board. They were stantion their way to pay their first ceremonial visit to a European nople. capital and a European sorereign. ${ }^{1}$ The capital selected for this distinguished honour was Constantinople; the ruler was the Sultan Abdul Hamid.

1 The emperor and empress had recently attended the marriage at Athens of the present King and Queen of Greece. 
It was precisely seren hundred years, as the German colony in Constantinople reminded their sovereign, since a German emperor had first set foot in the imperial city. But Frederick Barbarossa had come sword in hand; the Emperor William came as the apostle of peace; as the harbinger of economic penetration; almost, as was observed at the time, in the guise of a commercial traveller. The reception accorded to him in Constantinople was in every way worthy of a unique occasion; he and his empress were the recipients not only of the grossest flattery but of superb and costly gifts. But such attentions were not bestowed without the hope of reward. Sultan Abdul Hamid was one of the shrewdest diplomatists that ever ruled the Ottoman Empire. He was well aware that the State risit of the emperor and empress to Constantinople meant the introduction of a new factor into an immemorial problem. 'The East is waiting for a man.' So spake the Emperor William ten years later. His adrent was foreshadowed in 1889. Rarely has a ceremonial visit been productive of consequences more important.

Hwhen\%olleris prolicy in the Near lisist.

The ostentatious advances thus made by the Emperor William to Abdul Hamid marked an entirely new departure in Hohenzollern policy. Until the conclusion of the alliance with Holland and Great Britain in 1788 the Eastern Question had never come into the orbit of Prussian diplomacy. Nor can it be pretended that solicitude for the fortunes of the Ottoman Turks had much weight in bringing Frederick William II into the triple alliance. Just before the meeting of the emperors at Tilsit, Hardenberg, the Prussian minister, did, as we have seen, amuse himself by adding one more to the many schemes for the partition of the Ottoman Empire. But Hardenberg was clutching at straws to arert disaster nearer home. From the Congress of Vienna down to the advent of Bismarck Berlin took its orders as to foreign policy from Vienna. ${ }^{1}$ No Prussian diplomatist was at all a match for Metternich or Schwarzenberg.

1 If the Zollverein is deemed to belong to foreign policy one exception to this rule would have to be admitted; but the Zollverein was primarily a comestic measure. 
During the first ten years of his official career Bismarck was Bismarck far too much occupied in fighting Denmark, Austria, the Ger- $\begin{aligned} & \text { and the } \\ & \text { Eastern }\end{aligned}$ manic Confederation, and France to pay much heed to the Question. Eastern Question, even had the question been acute. But, as a fact, the years between 1861 and 1871 coincided with one of the rare periods of its comparative quiescence. Yet Bismarck lost no opportunity of turning the Near East to account as a convenient arena in which to reward the services of friends or to assuage the disappointment of temporary opponents without expense to Prussian pockets or detriment to Prussian interests.

Two illustrations of this policy will suffice. In 1866 Bismarck not only turned Austria out of Germany but, in order to secure the assistance of Victor Emmanuel, he depriced the Habsburgs of the last remnant of their heritage in Italy. He had, however, no desire to see Austria unnecessarily humiliated, still less permanently disabled. Provided it were clearly understood that henceforward she had no part or lot in German affairs, Austria might regard him as a friend and ally.

Two results ensued. The new frontier of Italy was drawn The with a most niggardly hand. The assistance rendered by the Drang Italian forces on land and sea during the Seren Weeks' War Osten of had not indeed been such as to entitle her to an ounce more the Hat. than the promised pound of flesh. And Bismarck, though true to the letter of his bond, took good care that the weight was not exceeded. On the contrary, 'Venetia' was interpreted in the narrowest possible sense. The northern frontier of Italy was defined in such a way as to deprive Italy of a compact mass of 370,000 Italians; to exclude the industrial products of these Italian people from their natural market in north Italy, and to thrust into the heart of an Italian province the military outpost of an unfriendly neighbour. From the boundary definition of 1866 has arisen the Trentino problem of to-day.

But that was not the only, nor, from our present standpoint, the most important, feature of the readjustment of 1866.

Italian though the Trentini are in race, in language, and 
The

Arliatic jroblem.

in sympathies, the Trentino had nerer formed part of the kingdom of Italy, except for five years (1809-14), when it was annexed to his Italian kingdom by Napoleon. Nor was it ever politically united to Venetia except during the periods 1797-1805 and 1815-66, when Venice itself was under Habsburg rule. The same is true of Trieste. But it was otherwise with the Venetian provinces to the east of the Adriatic, Istria and Dalmatia, which Austria also retained in 1866. For four centuries at least the Venetian commonwealth had been dominant on the eastern coast of the Adriatic, and ardent Italians to-day base their claims upon an even earlier title. But be that as it may, a great opportunity was lost by Italy in 1866 . Had Venice been wrung from Austria by Italy's strong right arm, instead of being accepted from Bismarck as the price of a diplomatic bargain, and in spite of a dubious success on land and a disastrous defeat at sea, there might be no 'Adriatic Problem' to-day.

To Trieste and Fiume Italy cannot adrance any historical claim, and however strong her strategic or political claims may be they do not concern our present theme. What is important in this connexion is the problem of the Dalmatian coast. To its possession there are two claimants who can advance strong arguments, historical, racial, strategical, and commercial, in support of their respective claims : Italy and the Southern Slars. If Bismarck had really been animated in 1866 by friendly feelings towards Italy, he would unquestionably have insisted, without any nice regard for ethnography, upon the transference to the Italian kingdom of the whole of the Venctian inheritance, including Istria and Dalmatia.

Bismarck, however, was concerned much less with the future of Italy than with the future of Austria-Hungary, and he deliberately encouraged the Drang nach Osten, which, from 1866 onwards, became a marked feature of Habsburg policy. Istria and Dalmatia, therefore, were retained by Austria. Thus did Bismarck conciliate a temporary enemy and a potential ally.

Four years later he took the opportunity of rewarding 
the services of a most constant friend. The Black Sca Bismarck clauses of the Treaty of Paris were, as we have seen, torn liussia. up in favour of Russia. That transaction was not, of course, inspired entirely by benerolence towards Russia. Bismarck's supreme object was to keep Russia at arm's length from France, and, what was at the moment more important, from England. Nothing was more likely to conduce to this end than to encourage the pretensions of Russia in the Near East, and, indeed, in the Further East. The Black Sea served his purpose in 1870; the 'Penjdeh incident' was similarly utilized in 1885.

Another critical situation arose in 1877. Since 1872 the The Dreikaiserbund had formed the pivot of Bismarck's foreign crisis of policy. But the interests of two out of the three emperors were now in sharp conflict in the Balkans. It is true that in July, 1876, the Emperors of Russia and Austria had met at Reichstadt, and that the Emperor Francis Joseph had agreed to give the Tsar a free hand in the Balkans on condition that Bosnia and the Herzegovina were guaranteed to Austria. But by 1878 Russia was in occupation of Bulgaria and Roumelia, and in less complaisant mood than in 1876 ; an immense impulse had been giren to the idea of Pan-Slavism by recent erents; the Southern Slars were beginning to dream of the possibility of a Jugo-Slav empire in the west of the peninsula. Bosnia and the Herzegovina might easily slip, under the new circumstances, from Austria's grip ; the Drang nach Osten might receive a serious set-back; the road to the Aegean might be finally barred; eren access to the Adriatic might be endangered. Thus Bismarck had virtually to choose between his two friends. At the Berlin Congress he played, as we saw, the rôle of the 'honest broker'. For aught he cared Russia might go to Constantinople, a move which would have the advantage of embroiling her with England; but Austria must have Bosnia and the Herzegovina. Austria got them, and the road to Salonica was kept open.

Apart from any sinister design on the part of a Mittel-Austrian europa party in Germany or Austria-Hungary there was occupaa great deal to be said for the arrangement. Not least from Bosnia the English point of view. To the England of 1878 Russia and the govina. 
was the enemy, Pan-Slavism the bugbear. An Austrian wedge thrust into the heart of the incipient States under Russian protection was, as Lord Beaconsfield thought, distinctly advantageous to equilibrium in the Near East. To the fate of the Balkan peoples, as has been shown above, Lord Beaconsfield was indifferent. Even from a selfish point of view it is now possible to view the matter in a clearer light. We can perceive that 'the occupation of Bosnia and Herzegovina ... was the prelude to the attempted strangulation of Serbian nationality' ${ }^{1}$ and we can see also that the strangulation of that nationality was an essential preliminary to the realization of Central European ambitions in the Balkan Peninsula.

In the future of the Christian subjects of the Ottoman Empire Bismarck took as little interest as Lord Beaconsfield. It is said that on the morrow of the signature of the Treaty of Berlin Bismarck sent for the Turkish representatives and said : 'Well, gentlemen, yon ought to be very much pleased; we have secured you a respite of twenty years; you have got that period of grace in which to put your house in order. It is probably the last chance the Ottoman Empire will get, and of one thing I'm pretty sure-you won't take it.' The story may be apocryphal, but it accords well enough with Bismarck's sardonic humour.

The

Triple

Prince Gortchakoff never forgave his pupil for the rupture Alliance of the Dreikaiserbund. Russia and Germany drifted further apart; and in 1882 Bismarck formed a fresh diplomatic combination. Italy joined Germany and Austria in the Triple Alliance; and, a year later, the Hohenzollern King of Roumania was introduced into the firm as 'a sleeping partner'. The 'Battenberger' was no favourite at Berlin, but the election of a 'Coburger' to the Bulgarian throne in 1887 decidedly strengthened Teutonic influence in the Balkans.

Bismarck, however, to the end of his career, regarded Balkan politics as outside the immediate sphere of Berlin. Ten years he devoted to the task of creating a united Germany under the hegemony of Prussia. The next twenty

1 Professor Ch. Andler, Pan-Germanism-a brilliant summary. 
were given to the consolidation of the position he had acquired. But Bismarck's course was nearly run.

In 1888 the direction of German policy passed into other hands. Like his great-great-uncle, George III, the young Emperor William mounted a throne quite determined 'to be king'. In the English executive there was no room for both George III and the elder Pitt; Pitt had to go. In the higher command of German politics there was no room for William II and Bismarck; the pilot was soon dropped.

The young emperor was by no means alone in his anxiety to initiate a new departure in the Near East. The visit to Constantinople in 1889 was the first overt intimation to the diplomatic world of the breach between the young emperor and his veteran Chancellor. The mission of Bismarck was, in the eyes of the younger generation, already accomplished. The past belonged to him, the future to the emperor. 'Bismarck', wrote one of the younger school, 'merely led us to the threshold of German regeneration.' ${ }^{1}$

The man who more than any one else persuaded the Kaiser A racancy to the new enterprise, and in particular to the effusive at Condemonstration of 1889, was Count Hatzfeld, who had been nople. German ambassador to the Sublime Porte in the early eighties. Count Hatzfeld was quick to perceive, during his residence in Turkey, that there was a vacancy at Constantinople. From the days of Suleiman the Magnificent down to the first Napoleonic Empire, France, as we have seen, occupied a unique position at Constantinople. From the beginning of the nineteenth century that position was threatened by England, and from the days of Canning to those of Beaconsfield England was a fairly constant and successful suitor for the beaux yeux of the Sultan.

England's popularity at Constantiuople did not long survire the conclusion of the Cyprus Convention (1878). It was further impaired by Mr. Gladstone's return to power in 1880 .

Mr. Gladstone was the recoguized friend not of the Turks but of the 'subject peoples'; and his accession to office was

1 F. Lange, Reines Deutschtum, p. 210 (quoted by Andler, op. cit., p. 23). 
signalized by the rectification of the Greek frontier at the expense of the Porte in 1881. The occupation of Egypt (1882) was the final blow to a traditional friendship.

The vacancy thus created at Constantinople the young German Emperor determined to fill. The way had been prepared for his advent in characteristic Prussian fashion. Von Moltke had been sent on a mission to Constantinople as far back as 1841, and had formed and expressed very clear views on the situation he found there. Forty years later a military mission was dispatched from Berlin to avert, if possible, the disruption which Moltke had prophesied. The head of the mission was the great soldier-scholar, who, in 1916, laid down his life in the Caucasus. Baron von der Goltz devoted twelve years to the task of reorganizing the Turkish army, and the results of his teaching were brilliantly demonstrated in the brief but decisive war with Greece in 1897. In the wake of Prussian soldiers went German traders and German financiers. A branch of the Deutsche Bank of Berlin was established in Constantinople, while German commercial travellers penetrated into every corner of the Ottoman Empire. The contemporary situation was thus diagnosed by a brilliant French journalist: 'Dans ce combat commercial l'Allemagne poursuit l'offensive, l'Angleterre reste sur la défensive et la France commence à capituler.' Monsieur Gaulis further suggests reasons for the phenomenal success of the German traders : even ambassadors do not deem it beneath their dignity to assist by diplomatic influence the humblest as well as the greatest commercial enterprises; consular agents abroad keep the manufacturers at home constantly and precisely informed as to demands of customers, and above all the German manufacturer is adaptable and teachable. Instead of attempting to force upon the consumer something which he does not want-' l'article démodé' - he supplies him with the exact article which he does want. And what the Eastern generally does want to-day is something cheap and nasty. The result may be learnt from a conversation with a typical Turk recorded by M. Gaulis :

'Mon grand-père a acheté sa sacoche à un Français; il l'a payée deux livres; elle était en cuir. Mon père l'a achetée 
à un Anglais; il l'a payée une livre ; elle était en toile cirée. Moi, je l'ai achetée à un Allemand; je l'ai payée deux medjidiés (huit francs) ; elle est en carton verni.'

If German diplomatists have not disdained to act as commercial agents they have only followed a still more exalted example. The commercial aspect of the question did not escape the shrewd eyes of the empcror in 1889.

The second visit paid by the emperor to the Sultan, in The em1898, was even more productive in this respect. But the peror's promotion of the commercial interests of Germany was not age to the its primary object. The moment was chosen with incompar- East in able felicity. No crowned head ever stood more desperately in need of a friend of unimpeachable respectability than did Abdul Hamid in the year 1898.

For the last four years Christendom had been resounding The with the heartrending cries of the Armenian Christians, butchered in their thousands to make a Sultan's holiday. (1894_o). The story of the Armenian massacres has been told by many competent pens. Pamphlets, articles in contemporary reviews, political speeches, and substantial volumes go to make up a vast literature on the subject. ${ }^{2}$ Not the least impressive account is that which is to be found in the papers presented to Parliament in 1895 and $1896 .^{3}$ Stripped of all exaggeration and rhetoric the story is one of the most horrible, and, for the Christian nations, the most humiliating in the long history of the Eastern Question. The present narrative is, however, concerned with it only so far as it reacted upon the diplomatic situation in the Near East, and the relations of the European Powers to the Sultan and to each other.

Some parts of the story are still obviously incomplete; much of it is obscure; the whole of it is difficult and confusing. But the points essential to our present purpose emerge with terrible distinctness.

The Armenian Church claims to be the oldest of all the Armenia national churches, having been founded by St. Gregory the and the nians.

1 Gaulis, La Ruine d"un Empire, p. 143.

2 See bibliographical note at the end of this chapter.

${ }^{3}$ Under the head of Turkey. 
Illuminator in the third century. It is not in communion with the Orthodox Greck Church, and its appeals, therefore, have always left the Russians cold; and only since the abandonment of the monophysite heresy in the fifteenth century has a portion of the Armenian Church been accepted as 'Catholic'. Armenia itself is an ill-defined geographical area lying between the Caspian, the Black Sea, the Caucasus, and Kurdistan, partitioned between the Empires of Russia, Turkey, and Persia. But while 'Armenia' has no official geographical existence in the gazetteer of the Ottoman Empire, the Armenians have been for centuries among the most important sections of Turkish society. 'To the Albanians the sword ; to the Armenians belongs the pen.' The familiar proverb indicates with sufficient accuracy their characteristic place and function. These 'Christian Jews', as they have been called, are apt, above all other subjects of the Sultan, in all that pertains to money and finance. Bankers, financiers, and merchants in the higher grades of society; moneychangers and hucksters in the lower, they have performed a useful function in the Ottoman Empire, and many of them have amassed large fortunes. Wealth acquired by finance has, it would seem, in Turkey as elsewhere, a peculiarly exasperating effect upon those who do not share it, and the Armenian Christians have always excited a considerable amount of odium even in the cosmopolitan society of Constantinople. Still, it is only within the last quarter of a century that their lot has been rendered unbearable.

Three reasons must be held mainly responsible for the peculiar ferocity with which the Armenians were assailed by Abdul Hamid: the unrest among hitherto docile subjects caused by the nationalist movements in Bosnia, Serbia, and Bulgaria ; the intervention of the European Powers ; and, not least, the palpable jealousies and dissensions among those Powers.

The primary motive which animated Abdul Hamid was beyond all question not fanaticism but fear. Greeks, Roumanians, Serbians, and Bulgarians; one after another they had asserted their independence, and the Ottoman Empire was reduced to a mere shadow of its former self. 
That these events had caused unrest among the Armenians, even though Armenia was not, like Roumania or Bulgaria, a geographical entity, it would be idle to deny. Abdul Hamid was terrified.

He was also irritated. The Powers had interested themselves in the lot of the Armenians. Article LXI of the Treaty of Berlin ran as follows:

'The Sublime Porte undertakes to carry ont, without further delay, the improvements and reforms demanded by local requirements in the provinces inhabited by the Armenians, and to guarantee their security against the Circassians and Kurds.

'It will periodically make known the steps taken to this effect to the Powers, who will superintend their application.'

But if the Powers in general were disposed to interfere, Great Britain, in particular, had imposed a special obligation upon the Sultan, and had herself assumed a peculiar responsibility. The first Article of the Cyprus Conrention contained, it will be remembered, a promise, a condition, and a territorial deposit.

'If', it ran, 'Batoum, Ardahan, Kars, or any of them shall be retained by Russia, and if any attempt shall be made at any future time by Russia to take possession of any further territories of his Imperial Majesty the Sultan in Asia, as fixed by the Definitive Treaty of Peace, England engages to join his Imperial Majesty the Sultan in defending them by force of arms.

'In return, His Imperial Majesty the Sultan promises to England to introduce necessary reforms, to be agreed upon later between the two Powers, into the government, and for the protection, of the Christian and other subjects of the Porte in these territories; and in order to enable England to make necessary provision for executing her engagement, His Imperial Majesty the Sultan further consents to assign the Island of Cyprus to be occupied and administered by England.'

From 1878 onwards the Sultan lived, therefore, under the perpetual apprehension of intervention while his Armenian subjects could repose in the comfortable assurance that they were under the special protection of their fellow Christians throughout the world.

Gradually, however, it dawned upon the shrewd Sultan that the apprehension was groundless, while the miscrable 
Armenians were soon to discorer that the assurance was not worth the paper upon which it was written.

If the Sultan was frightened, so also was the Tsar, Alexander III. The nihilist spectre was always before his eyes. His father, the emancipator of the serfs, had fallen a victim to a nihilist conspiracy in 1881. Nihilism had shown itself among the Turkish Armenians, and had led to an outbreak, easily suppressed, in 1885. Bulgaria, too, had proved a terrible disappointment to Russia. After being called into being by the Tsar it was manifesting its independence in most disquieting fashion. Instead of opening the way to Constantinople, Bulgaria, with unaccountable forgetfulness of past favours, was actually closing it. 'We don't want an Armenian Bulgaria,' said the Russian Chancellor, Prince Lobanoff. If the road to Constantinople is closed, all the more reason for keeping open the roads to Bagdad and Teheran. Nothing could be more inconrenient to the Tsar than a 'nationality' movement in Armenia. The Tsar's disposition was well known at Constantinople, and the Sultan soon drew the inference that, if he chose to work his will upon the Armenians, he had little to fear from St. Petersburg. He had much less to fear from Berlin ; while Paris and London were kept apart by Egypt.

The Here, then, was an opportunity; and from 1894 to 1896 massacres not a moment was wasted. The Powers should be taught the imprudence of intervening between an Ottoman Sultan and his rightful subjects; the Armenians should learn -or the remnant of them who escaped exterminationthat they had better trust to the tender mercies of their own sovereign than confide in the assurances of the European Concert.

His crafty calculations were precisely fulfilled. In the year 1893 there seems to have been some recrudescence, among the Armenians, of the revolutionary propaganda which had been suppressed in 1885 . The Kurds, halfpublicans, half-police, wholly irregulars, were encouraged to extort more and more taxes from the Armenian highlanders. The Armenians forcibly, and in some cases effectually, resisted their demands. Supported by Turkish 
regulars the Kurds were then bidden to stamp out the insurrection in blood.

They soon got to work, and the massacre of August, 1894, The was the result. Sereral villages in the Sassoun district were $\begin{gathered}\text { Sassoun } \\ \text { masacre }\end{gathered}$ pillaged and burnt, and about 900 people were killed.' The (1894). news of these massacres, the extent of which was at first grossly exaggerated, sent a thrill of horror throughout Christendom, and as a result the Sultan was obliged to consent to a Commission of Inquiry, consisting of English, French, and Russian consuls, together with certain Turkish officials. The Commission inquired, but the massacres went on. In the spring of 1895 a scheme of reform was presented to the Sultan, and after alternate pressure and delay was accepted by him in the autumn. The Sultan had, however, some reason to hope that before the reforms could be executed the Armenians would be exterminated. All through the year 1895 the massacres went on, and by December the rictims probably numbered at least $50,000,{ }^{2}$ not to mention the thousands who perished from the ravages of disease and from exposure. The massacres were accompanied by deeds of 'the foulest outrage and the most devilish cruclty'. Great Britain laboured assiduously to induce the Concert to interrene, but Russia, for reasons already suggested, resolutely refused, and Great Britain hesitated to act alone. Our responsibility was heary; that of Russia was still hearier, for she could act directly in Armenia; we could act only at Constantinople, and there only in conjunction with unwilling allies.

Still the massacres went on; whole rillages were wiped out; the cry of the rictims rose to heaven; the Powers looked on in impotence; the 'red Sultan' was glceful, but his appetite for blood was even yet unsated.

In August, 1896, the interest of the scene shifted from Armenia to Constantinople. On the 26th the Armenians of

1 The original reports put the numbers at $7,000-8,000$; official inquiries reduced them to 900 : see Eliot, op. cit., p. 406.

2 An American estimate put it at 75,000 .

3 The phrase is the Duke of Argyll's, Our Responsibilities for Turkey, p. 87.

1984

A a 
the capital, frenzied by the appeals of their brethren in Armenia, and despairing of help from the Powers, rose in rebellion, and attacked and captured the Ottoman Bank in Galata. Something desperate must be done to make the world listen. But the recoil upon their own heads was immediate and terrible. Within the next twenty-four hours 6,000 Armenians were bludgeoned to death in the streets of the capital. But though the aggregate was appalling the Sultan was precise and discriminating in his methods. Only Gregorian Armenians were butchered; hardly a Catholic was touched. ${ }^{1}$ In Constantinople the Armenians were the aggressors; the Turks were plainly within their rights in suppressing armed insurrection; the Powers could only, as before, look on; all the cards were in the Sultan's hands; the rubber was his.

Still, his hand was bloodstained. No respectable sorereign could grasp it without loss of self-respect. That consideration did not deter the German Emperor. The more socially isolated the Sultan the greater his gratitude for a mark of disinterested friendship.

The In the midst of the massacres it was forthcoming. On the Sultan's birthday, in 1896, there arrived a present from Sultan.

Berlin. It was carefully selected to demonstrate the intimacy of the relations which subsisted between the two Courts, almost, one might say, the two families; its intrinsic value was small, but the moral consolation which it brought to the recipient must have been inestimable : it consisted of a signed photograph of the emperor and empress surrounded by their sons. That was in 1896 . In 1897 came the TurcoGreek War. 'The success of von der Goltz's pupils in Thessaly afforded a natural excuse for a congratulatory risit on the part of von der Goltz's master to Constantinople.

In 1898 the visit was paid; but it was not confined to the Bosphorus. From Constantinople the German Emperor, accompanied by the Empress, went on to the Holy Land.

The pilgrimage, which was personally conducted by Messi's. Thos. Cook \& Co., ${ }^{2}$ extended from Jaffa to Jeru-

1 Eliot, op. cit., p. 411.

2 'Des caisses, des malles, des sacs portant l'inscription "Voyage de 
salem, and from Jerusalem back to Damascus. The avowed purpose of the emperor's visit to the Holy Land was the inauguration of a Protestant Church at Jerusalem. Down to 1886 the Protestant bishop in Palestine was appointed in turn by England and by Prussia, though the bishop was under the jurisdiction of the See of Canterbury. The German Protestants have, however, shown remarkable activity in mission work in Palestine, and the emperor's visit was intended primarily to set the seal of imperial approval upon these activities and to mark the emancipation of the German mission from Anglican control. But the German Emperor is lord not only of Protestants but of Catholics. To the Catholics, therefore, in the Holy Land he also gare proof of his special farour. Nor must the Moslems be ignored. True, he could not count Moslems among his own subjects as yet. But who knows what the future may have in store? At Jerusalem Protestants and Catholics had claimed attention. But the emperor, as M. Gaulis wittily observed, varied his parts as quickly as he changed his uniforms. At Damascus he was an under-study for the Caliph, and the Mohammedans got their turn. Of all the emperor's speeches that which he delivered at Damascus, just before quitting the Holy Land, on November 8, 1898, was perhaps the most sensational and the most impudent. It contained these words: 'His Majesty the Sultan Abdul Hamid, and the three hundred million Mohammedans who reverence him as Caliph, may rest assured that at all times the German Emperor will be their friend.' Well might those who listened to this audacious utterance hold their breath. Was it intoxication or cool calculation?

'Ceux qui ont vu, comme moi', writes M. Gaulis, 'le pèlerin et son cortège dans leurs trois a ratar's successifs : protestant, catholique et musulman, restent un peu abasourdis sur le rivage. Quel est le sens de cette grande habileté qui, voulant faire à chacun sa part, jette un défi aux passions

S.M. l'empereur d'Allemagne à Jérusalem; Thos. Cook \& Co." Deux royautés dans une phrase. Celle de Cook est ineontestée en Palestine.' Gaulis, in whose work, La Ruine d'un Empire, pp. 156_242, will be found an entertaining and illuminating account by an eyewitness of the Kiaser's pilgrimage. 
religienses de l'Orient? L'Allemagne, nous le savons bien, est venue tard dans la politique orientale. Comme toutes les places y étaient prises elle a jugé qu'elles étaient toutes bounes à prendre. Elle s'est mise alors à jouer le rôle d'essayiste, tâtant le terrain de tous les côtés, guettant toutes les proies et ouvrant la succession des vivants avec une andace souvent heureuse. Mais ce n'est plus de l'audace, c'est de la candeur, tant le jeu en est transparent, lorsqu'elle offie dans la même quinzaine un hommage à Jésus-Christ et un autre à Saladin, un sanctuaire à l'Eglise évangélique et un antre au pape.'

But if Frenchmen marvelled at the audacity of the performance, other reflections occurred to the applauding Germans. Among those who were present at the banquet at Damascus was Pastor Friedrich Naumann, the author of a work which has to-day made his name famous throughout the world. ${ }^{1}$ Side by side with the impressions of the French publicist it is instructive to read those of the German philosopher. Pastor Nammann discerned in the emperor's speech a secret calculation of 'grave and remote possibilities'.

(1) 'It is possible that the Caliph of Constantinople may fall into the hands of the Russians. Then there would perhaps be an Arab Caliph, at Damascus or elsewhere, and it would be advantageous to be known not only as the friend of the Sultan but as the friend of all Mohammedans. The title might give the German Emperor a measure of political power, which might be used to counteract a Russophil Ottoman policy.

(2) 'It is possible that the world war' will break out before the disintegration of the Ottoman Empire. Then the Caliph of Constantinople would once more uplift the Standard of a Holy War. The Sick Man would raise himself for the last time to shout to Egypt, the Sondan, East Africa, Persia, Afghanistan, and India "War against England". . . I It is not unimportant to know who will support him on his bed when he rises to utter this cry.' ${ }^{2}$

German railway development

But the Kaiser had not undertaken a personal mission to the Near East merely to patronize the disciples of various creeds in the Holy Land; nor even to congratulate his friend

${ }^{1}$ Mitteleuropa, by Friedrich Naumann (Berlin, 1915; Eng. trans., London, 1916).

2 Asia (1899) quoted by Andler, op. cit., p. 57. 
Abdul Hamid upon a partial extermination of the Armenians. His sojourn at Constantinople coincided with the concession of the port of Haidar-l'asha to the 'German Company of Anatoliau Railways'.

That concession was supremely significant. German diplomacy in the Near East has been from first to last largely 'railway-diplomacy', and not its least important field has been Asia Minor and Mesopotamia. The idea of directing German capital and German emigration towards these regions was of long standing. The distinguished economist, Roscher, suggested as far back as 1848 that Asia Minor would be the natural share of Germany in any partition of the Ottoman Empire. After 1870 the idea became more prevalent and more precisely defined. In 1880 a commercial socicty was founded in Berlin, with a capital of fifty million marks, to promote the 'penetration' of Asia Minor. Kiepert, the prince of cartographers, was employed systematically to survey the country. About 1886 Dr. A. Sprenger, the orientalist, and other savants called attention to the favourable opening for German colonization in these regions.

"The East is the only territory in the world which has not passed under the control of one of the ambitious nations of the globe. Yet it offers the most magnificent field for colonization, and if Germany does not allow this opportunity to escape her, if she seizes this domain before the Cossacks lay hands upon it, she will have secured the best share in the partition of the earth. The German Emperor would have the destinies of Nearer Asia in his power if some hundreds of thousands of armed colonists were cultivating these splendid plains; he might and would be the guardian of peace for all Asia.'

Ten years later the Pan-German League published a brochure with the suggestive title, Germany's Claim to the Turkish Inheritance, and in the editorial manifesto wrote as follows :

'As soon as events shall have brought about the dissolution of Turkey, no power will make any serious objections if the

1 A. Sprenger, Babylonien das reichste Land in der Vorzeit und das lohnendste Kolonisationsfeld für die Gegenwart (1886). Quoted bJ Andler, op. cit., p. 40. 
German Empire claims her share of it. This is her right as a World-Power, and she needs such a share far more than the other Great Powers because of the hundreds of thousands of her subjects who emigrate, and whose nationality and economic subsistence she must preserve.' 1

English schemes in Meso. potamia.

The

Bagdad-

hahn.

The field in Asia Minor was open to them alike for commercial penetration and for railway construction. But it was not for lack of warning on the part of clear-sighted Englishmen. The question of establishing a steam route to the Persian Gulf and India by way of Mesopotamia had been again and again raised in this country. In the early forties the fashionable idea was the establishment of steam navigation up the Euphrates; in 1856 a private company did actually obtain a concession from the Porte for the construction of a line of railway from the mouth of the Syrian Orontes to Koweit, but the scheme was insufficiently supported and never materialized; a committee of the House of Commons reported favourably upon a similar scheme in 1872 , but the report was coldly received in parliament ; finally, an abortive Euphrates Valley Association was formed in 1879 under the presidency of the Duke of Sutherland. But after 1880 attention in this country was concentrated upon Egypt and the Canal route; not unnaturally, but in so far as it excluded consideration of the alternative possibilities of Asia Minor and Mesopotamia, with very questionable wisdom. ${ }^{2}$

England's indifference was Germany's opportunity. In 1880 an Anglo-Greek syndicate had obtained from the Porte certain rights for railway construction in Asia Minor; in 1888 all these rights were transferred on much more favourable terns to the Deutsche Bank of Berlin and the Württembergische Vereinsbank of Stuttgart, and in 1889 the Ottoman Company of Anatolian Railways was promoted under the same auspices. Further concessions were obtained between that time and 1902, and in the latter year the convention for the construction of a railway from Constantinople to Bagdad was

\footnotetext{
1 Quoted by Andler, op. cit., p. 38. See also Chéradame, La Question d'Orient, pp. 5-7.

2 Cf. a most informing article by Mr. D. G. Hogarth, National Review, vol. xxxix, pp. 462-73.
} 
finally concluded. This railway it need hardly be said was only one link in a much longer chain stretching from Hamburg to Vienna, and thence by way of Buda-Pesth, Belgrade, and Nish to Constantinople, with an ultimate extension from Bagdad to Basra. Thus would Berlin be connected by virtually continuous rail with the Persian Gulf.

It was, and it remains, a great conception worthy of a scientific and systematic people. Should it materialize it will turn the flank of the great Sea-Empire, just as, in the fifteenth century, Portugal, by the discovery of the Cape route to India, turned the flank of the Ottoman Turks.

That a line should be constructed from the Bosphorus to the Persian Gulf is in the political and social interests of one of the richest regions of the world; it is in the economic interests of mankind. But there are alternative routes from Western Europe to Constantinople. ${ }^{1}$ Not all these routes are controlled from Berlin or even from Vienna. Which of them will ultimately be selected? The answer to this question is one of the many which depend upon the issue of the present war. $^{2}$

For the first twenty years of his reign all went well with Checks to the policy of the Kaiser in the Near East. But everything German depended upon the personal friendship of the Sultan Abdul Hamid, and upon the stability of his throne. In 1908 his throne was threatened; in 1909 it was overturned. The triumph of the Young Turk revolution imposed a serious check upon German policy; but, to the amazement of European diplomacy, the check proved to be only temporary. Enver Pasha quickly succeeded to the place in the circle of imperial friendship vacated by his deposed master. Bosnia and the Herzegovina were definitely annexed by Austria. Bulgaria finally declared her independence. Russia was suecessfully defied by Germany. Once again the Kaiser was supreme at Constantinople.

It now seemed as if one thing, and one thing only, could interpose a final and effective barrier between Mitteleuropa

${ }^{1}$ Cf., for instance, Sir Arthur Evans's exceedingly interesting suggestion of a route via Milan and the Save valley to Constantinople.

2 Written in 1916. 
and its ambitions in the Near East-a real union between the Balkan States. In 1912 that miracle was achieved. Again the Kaiser's schemes appeared to be finally frustrated. Again the check was only temporary. The brilliant success of the Balkan League in 1912 was followed, in 1913, by the disruption of the League and by fratricidal war. Once more had German diplomacy triumphed. But the crowded events of these fateful years must be reserved for treatment in the next chapter.

For further reference: Paul Dehn, Deutschland und der Orient (1884), and Deutschland nach Osten (1888); Karl Kaeger, Klein-Asien ein deutsches Kolonisationsfeld (1892); F. Lange, Reines Deutschtum (1904); Paul Rohrbach, Der deutsche Gedanke in der Welt: die Bagdadbahn; Albrecht Wirth, Türkei, Oesterreich, Deutschland (1912); Count von Reventlow, Die auswärtige Politik Deutschlands, 1888-1913 (Berlin); J. L. de Lanessan, L'Empire Germanique sous Bismarck et Guillaume II; Bismarck, Reflections and Reminiscences; G. W. Prothero, German Policy before the War (1916); Klaczko, Two Chancellors; André Cheradame, La Question d'Orient (1903), and Le Plan Pangermaniste démasqué (1916).

For Armenia: Lord Bryce, Transcaucasia (1896); E. M. Bliss, Turkey and the Armenian Atrocities (1896); W. E. Gladstone, The Armenian Question (1905); H. F. B. Lynch, Armenia: Travels and Studies, 2 vols. (1901); Saint-Martin, Mémoire historique et géographique sur l'Arménie (Paris, 1818). 


\section{CHAPTER XV \\ THE MACEDONIAN PROBLEM \\ Habsburg Policy in the Balkans. The Young TURK Revolution}

'The history of the last fifty years in South-Eastern Europe is to a great extent the history of the disentanglement of the Slavonie races from Greeks and 'Turks, and to this is now suceeeling the disentanglement of the Slavonic races from one another.'-SiR CHARLES ELIOT.

'La Macédoine est vraiment le fondement de l'Hellade unie et grande, la Macédoine est le boulevard de la liberté greeque, le gage de son avenir.'Kallostypt (in 1886).

"Macedonia has for two thousand years been the "dumping ground" of different peoples and forms, indeed a perfeet ethnographic museum.'LUigi Villari.

'Voilà un siècle que l'on travaille à résoudre la question d'Orient. Lo jour où l'on croira l'avoir résolue l'Europe verra se poser inévitablement la question d'Autriche.'-Albert Sorel.

MACEDONIA is the microcosm of the Balkan problem. In The Macedonia we can see simultaneously, and in compact and Maceconcentrated form, all the different elements which, on a problem. larger scale and in successive phases, have combined to make up the Eastern Question.

There we see in the forefront the Turk; heary-handed The in extortion; in all other matters careless and indifferent; Turks. impotent to absorb the various races and creeds; but determined to prevent their fusion. There we see exemplified not only his attitude towards his own subjects, Moslem and Christian, but his relations to the concerted Powers of Europe: there, as elsewhere, we see him ever prodigal of promises but tardy in fulfilment.

The presence of the Turk is, however, the least perplexing of the problems which confront us in Macedonia. The country with its ill-defined boundaries and its kaleidoscopic medley of races is in itself a problem. And the problem has 
been intensified by the demarcation of the Balkan nations in the last half-century. For Macedonia is a 'no man's land'; or rather it is an all men's land. It is the residuum of the Balkans. Moslems, Jews, Albanians, Bulgars, Serbs, KutzoVlachs, Greeks-all are to be found here cheek by jowl; only the ronghest territorial discrimination is possible.

The The Greeks have always desired to see Macedonia 'HelGreeks. lenized', and an Hellenized Macedonia is plainly an indispensable preliminary to the realization of the dream of a revived Hellenic Empire with Constantinople as its capital. Yet to Macedonia itself the Greeks have, on ethnographic grounds, no overpowering claim. Greeks are numerous on the coast and in most of the towns; they form a preponderant element in the south-western part of the vilayet of Monastir and in the south of that of Salonica, but they are outnumbered by the Spanish Jews in the city of Salonica, and in the aggregate they are far inferior to the Slavs.

The Greek claim to a Hellenized Macedonia rests partly upon a Byzantine past, and partly upon the possibility of a Byzantine future; but in the present it is mainly ecclesiastical. 'Hellenism', writes a close observer, 'claims these (Macedonian) peoples, because they were civilized by the "Greek Orthodox" Church.... To the Greek Bishops all Macedonians are Greeks because they are by right the tributaries of the Patriarch. True, they are at present in schism, but schism is an offence against the order of the Universe.' 1 This purely ecclesiastical claim is buttressed by a 'spiritual' claim. Macedonia may not be Hellenic in speech or in race, but its spiritual (or, as the Germans would say, kultural) affinities are, so the Greeks urge, incontestable. Macedonia being Hellenic in spirit must eventually, therefore, form part of the Greater Greece.

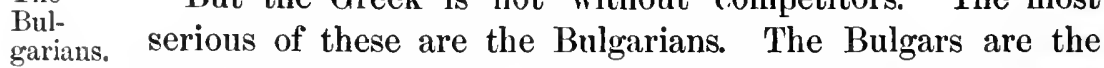
more detested by the Greeks since their rivalry is of recent date. Down to 1870 all the Bulgarians in Macedonia, as elsewhere, were, according to the official nomenclature of the Ottoman Empire, Greeks. Creed being the only differentia ${ }^{1}$ H. N. Brailsford, Macedonia, pp. 195, 196. 
acknowledged by the Turk, all members of the Orthodox Church were in the same category. The establishment of an independent Bulgarian exarchate ${ }^{1}$ was the first blow to the Greek monopoly in Macedonia. But although Bulgaria eame into existence as an ecclesiastical entity in 1870, it was not until 1878 that its existence was acknowledged in a political sense.

The conclusion of the Treaty of San Stefano appeared to deal a death-blow to Hellenic ambitions in Macedonia. Lord Beaconsfield's intervention was a godsend to the Greeks. But the success of the Philippopolis revolution in 1875 and the subsequent union of Eastern Ronmelia and Bulgaria again rendered acute the Macedonian situation. The events of 1885 seemed once more to bring within the sphere of practical politics the realization of the dream of the Greater Bulgaria actually defined at San Stefano. For some years after 1885 the Bulgarians entertained the hope that it might be realized. Geologically and geographically ${ }^{2}$ Bulgaria is drawn towards the Aegean. So long as Constantinople and the Straits are in hands potentially hostile, a good commercial harbour on the Aegean is essential to the full economic derelopment of Bulgaria.

Ethnographically also her claims are strong. It is perhaps rather too much to say, with a distinguished American authority, that 'the great bulk of the popnlation of Macedonia is Bulgarian', ${ }^{3}$ but it is undeniable that Macedonia has, 'by the educational efforts of the Bulgar people, been to a very large extent Bulgarized in its sympathies' in recent years. The people have 'for a quarter of a century been educated as Bulgars; have fought as Bulgars in 1895, 1903, and 1912 ; were amexed to Bulgaria by the Russians in 1878, and by the Serbs in 1912; were assigned to the Bulgar Church by the Turks in 1872 and 1897 ; and are to-day, many of them, perhaps most of them, protesting against being treated other than as Bulgars.' 4

1 Supra, p. 291.

${ }^{3}$ H. A. Gibbons, New Map of Europe, p. 167.

4 Nationalism and War in the Near East, by A Diplomatist (Clarendon Press, 1915). 
Bulgarian The policy of Bulgaria in regard to Macedonia has passed policy in through two phases and into a third during the last thirty donia. years. For some years, as was said, it aimed at the realization of the Greater Bulgaria, mapped out at San Stefano. Gradually abandoning this idea as outside the domain of practical politics the Bulgarians deroted their energies to the emancipation of Macedonia. Their arowed hope was that, as an autonomous principality under a Christian governor, Macedonia, possibly enlarged by the addition of the vilayet of Adrianople, might become a powerful independent State and the nucleus of a Balkan Federation. ${ }^{1}$

Always practical, however, Bulgaria, while surrendering the dream of political annexation, has pursued a policy of peaceful penetration; perhaps with a view to the ultimate partition which would now seem to be the least unhopeful of the many schemes which hare been propounded for the pacification of Macedonia.

Mean while, the Bulgarians have incurred the bitter hostility not only of the Turks but of the other Christian races in Macedonia. The Turks here, as elsewhere, have proceeded on the formula: Divide et impera. In the south of Macedonia, as Dr. Tatarcheff (not without a strong Bulgarian bias) writes: 'The Turks support the Greek propaganda; in the north they encourage the Serbian propaganda; and everywhere they persecute the Bulgarian Church, schools, and nationality.' 2 In the latter task they have undoubtedly derived much assistance from the Greeks, and some perhaps from the Serbians.

The The latter have their own claims to substantiate. EthnoSerbians. graphically those claims are incontestable in northern Macedonia; historically they extend much further. It was from Serbians, not from Greeks or Bulgars, that the greater part of Macedonia was originally conquered by the Ottoman Turks. The historical self-consciousness of the Serbs is not less intense than that of the Greeks. If, therefore, the hold of the Turks upon Macedonia be relaxed, it is to

1 Cf. Tatarcheff, ap. Villari, Balkan Question, chap. vi.

${ }^{2}$ Op. cit., p. 171. 
those who represent the empire of Stephan Dushan that, in the Serbian view, the country shonld revert. But present politics are more potent in Nacedonia than past history, and Serbian pressure towards the south is due rather to the denial of access to the Adriatic than to the hope of reviving Dushan's empire. 'To this point, however, we shall have, in another connexion, to return.

Two other races claim a share in the Macedonian heritage, Illyrians and though numerically inferior to the rest, are incom- and parably superior in antiquity. They are the Illyrians, cians. represented by the modern Albanians, who are numerous in the extreme west, and the Thracians, who, as KutzoVlachs or Roumanians, are to be found in scattered 'pockets' throughout Macedonia, but are nowhere concentrated in any compact mass. The Roumanians elaim that their countrymen in this 'all men's land' number half a million; less sympathetic analysts give them a fifth of that sum. In any case, Roumania cannot, for obvious geographical reasons, adrance any territorial claims in Macedonia, though the unquestionable existence of a Roumanian element in the population might possibly help Roumania, when the time arrives for a final partition of the Balkans, towards a favourable deal with Bulgaria in the Dobrudja.

The rough outline sketch presented above would sufficiently The demonstrate the complexity of the Macedonian problem even Powers if it did not contain other factors. But Macedonia is not donia. only the residuum of Balkan races; it is not only the cockpit of competing Balkan nationalities; it has been for years the farourite arena for the international rivalries of the great European Powers.

We have seen that international jealousies were largely responsible for the immunity enjoyed by Abdul Hamid in the perpetration of the Armenian massacres, and for the mishandling of Crete ; the same cause operated to prolong the agony of Macedonia. Two Powers in particular-Russia and AustriaHungary-have looked with a jealous eye upon Macedonia; and the other Powers have, in a sense, tacitly admitted the validity of their superior claims. If Russia had been per- 
mitted to carry out her plans in 1878 the Macedonian question would have been settled in favour of Bulgaria. At that time Europe was quite unconscious of the existence of a Macedonian problem. Indeed, in the sense in which we have understood it in this chapter, that problem did not exist. The growing self-consciousness of the Balkan nations, and the demarcation of their respective frontiers served, if not to create, at least to accentuate and define it. So soon as the problem was defined there would seem to have been only three possible solutions : an autonomous Macedonia under European protection; Turkish reform under European control ; or partition between Greece, Bulgaria, Serbia, and Albania. The jealousy of the Powers was effectual to prevent the adoption of either of the first two, and has practically wrecked the third.

Meanwhile, the condition of the Macedonian peoples, to whatever race they might belong, was nothing short of deplorable. For five hundred years the Ottomans had been undisputed lords of Macedonia. They began to plant colonies in Macedonia, eren before they attempted the conquest of the Balkan Peninsula. They have been systematically colonizing it afresh since the shrinkage of their empire in Europe. But at no time have Turkish Moslems formed a majority of the population in Macedonia. There, as elsewhere, many of the upper classes apostatized to Mohammedanism, and were rewarded in the usual fashion. Those who refused to do so shared the common lot of the subject Christian populations in other parts of the peninsula.

With the nature of their grievances we have become, in the course of this narrative, only too familiar. There is, indeed, a painful monotony in the tale of Turkish misgoverument. Here, as elsewhere, the toiling peasantry were subject to a cross-fire of exactions, and extortions, and persecutions. They suffered at the hands of the Moslems because they were Christians; they were exposed to the lawless depredations of the brigands, frequently of Albanian race, by whom the country was infested; they had to meet the demands, both regular and irregular, of Moslem beys and official tax-farmers; they could obtain no redress in the courts of law ; life, property, honour were all at the mercy of the ruling creed. 
For some years after the conclusion of the Treaty of Berlin Insurrecthese things were patiently endured in the hope that the tions 1893 Powers would fulfil the promises of reforms contained in that document. But from 1893 to 1903 there were sporadic insurrections in varions parts of Macedonia, organized by the secret revolutionary committees which quickly came into existence as the hope of reform faded. In 1895 Bulgaria stood forth as the avowed champion of the oppressed peasantry of Macedonia. In that year the 'supreme MacedoAdrianopolitan Committee' was formed at Sofia, and armed bands poured over the Bulgarian frontiers. Bulgarian intervention effected little good, though it served to stimulate a movement in Macedonia itself which had for its object the creation of an autonomous province under Turkish suzerainty.

The outbreak of the 'Three Weeks' War' between Turkey and Greece in 1897 naturally aroused considerable enthusiasm in Macedonia. But the hopes it raised were destined to disappointment, for, in 1898, Austria and Russia concluded an agreement to maintain the status quo. In 1899, however, the Macedonian Committee, which was attempting from Sofia to organize a reform movement, addressed a memorial to the Powers in favour of an 'autonomous Macedonia', with its capital at Salonica, to be placed under a governor-general belonging to the 'predominant nationality'. Nothing came of it, and from 1900 to 1903 Macedonia was in a state of chronic insurrection, which culminated in the autumn of 1903 in general risings in the Monastir district and in Thrace.

Meanwhile, in 1901, a band of brigands, acting, there is no doubt, under the orders of the Sofia Committee, captured Miss Stone, an American missionary, and held her to ransom. The object of the capture was twofold : moncy and publicity. In order to obtain Miss Stone's release a very large sum$£ 16,000$ - had to be paid to her captors; while the excitement caused by the ontrage made Europe for the first time generally aware that there was a 'Macedonian question'. Having at last realized the existence of a 'problem', the Powers confided to Austria and Russia the task of solving it. By this time the Porte was becoming seriously alarmed, 
and in the autumn of 1902 Abdul Hamid himself produced an elaborate scheme of reform, and appointed Hilmi Pasha as inspector-general to supervise its execution. Austria and Russia, which for some years had acted in close concert in Macedonia, were not to be burked in their benerolent intentions, and early in 1903 they presented to the Porte an independent reform programme.

Macedonian insurrection of 1903.

The Mcanwhile the Tsar Nicholas and the Emperor Francis Mrörzteg Joseph met at the castle of Miurzteg, near Vienna, and the gramme. two sovereigns sanctioned the immediate initiation of a scheme of reform known as the Miirzteg Programme.

Acting as the 'mandatories' of Europe they recommended that Hilmi Pasha, the inspector-general of reforms, should be assisted in the work of pacifying Macedonia by two civil assessors, one a Russian and the other an Austrian, and that the gendarmerie should be reorganized and put under the command of a foreign general and a staff of foreign officers. Germany stood ostentatiously aloof, but the other five Powers each took a district and attempted to maintain order within it. Under their well-meant but misdirected efforts Macedonia sank deeper and deeper into the slough of anarchy. The Powers might put pressure upon the Sultan, but 'bands' of Greeks and Bulgarians made life intolerable for the mass of the population. The ciril assessors had no administrative powers, and it soon became plain that much 
more drastic measures would have to be taken if any good were to be effected.

But long before Europe had made up its mind to effective action a rapid series of dramatic events had revolutionized the whole situation in the Near East.

In 1905 Great Britain, France, Italy, and Germany combined to secure the appointment of an international commission to control Macedonian finance. This touched the Turk on his tenderest spot, and the Sultan showed every disposition to prevent the action of the Powers. But the latter presented a firm front; their combined squadrons occupied Mytilene and sailed through the Dardanelles, and, in December, 1905, the Sultan, at last realizing that they meant business, gave way. The commission did useful work within a limited sphere, but the essential difficulties of the Macedonian situation were untouched. Nor did the Mürzteg Programme solve them more effectually.

Early in 1908 the two parties to that agreement fell out. In January Baron von Aerenthal announced that AustriaHungary had applied for permission to survey the ground for a line of railway to connect the terminus of the Bosnian railway with the line running from Mitrovitza to Salonica. The implication was obvious, and the announcement created a great sensation. Russia, in particular, regarded it, and naturally, as a denunciation of the condominium, which, with Austria-Hungary, she had been commissioned by the Powers to exercise over Macedonia.

Baron von Aerenthal did not question the correctness of the inference. On the contrary, he declared that the 'special task of Austria and Russia [in Macedonia] was at an end'. Plainly, the Dual Monarchy had made up its mind to play its own hand. Momentous events compelled it to play without delay.

In the long history of the Eastern Question there is no The year period more pregnant with startling developments than the ${ }^{1908 .}$ last six months of the year 1908.

On July 24 the 'Committee of Union and Progress'better known as the 'Young Turks'-effected a bloodless revolution in Constantinople; on October 5 Prince 
Ferdinand proclaimed the independence of Bulgaria; on the 7 th the Emperor Francis Joseph announced the formal annexation of Bosnia and the Herzegovina to the Habsburg Empire; on the 12th the Cretan Assembly voted the union of the island with the kingdom of Greece. At least two of these developments will demand detailed treatment. The last, as the least complicated, may be disposed of forthwith.

Crete: M. Zaimis, who was appointed High Commissioner of union with Crete in 1907, had speedily reduced the island to order. The Greece. protecting Powers, anxious to lay down their invidious task at the earliest moment compatible with its fulfilment, informed M. Zaimis that as soon as an effective native gendarmerie had been organized and the High Commissioner could guarantee the maintenance of order, and more particularly the security of the Moslem population, they would eracuate the island.

In March, 1908, M. Zaimis formally drew the attention of the Powers to the fact that their conditions had been fulfilled. In July the evacuation began. But the news from Bosnia and Bulgaria created intense excitement in Crete, and on October 12, just a week after the Tsar Ferdinand's proclamation at Tirnovo, the Assembly at Canea once more voted the union of the island with the Hellenic kingdom. M. Zaimis happened to be absent on a holiday, and the Assembly therefore appointed a Provisional Government of six members to gorem the island in the name of the King of the Hellenes.

The Moslems, in great alarm, thereupon invoked the protection of the British Government; but the latter, while promising protection to the Moslems, declined either to recognize or to repudiate the union. The Young Turk Govermment at Constantinople contented itself with a formal protest against the dismemberment of the inheritance upon which it had so lately entered. In July, 1909, the protecting Powers finally withdrew their forces from the island, while at the same time they announced that four ships of war would be stationed off Crete in order to guarantee the safety of the Moslem population and to 'safeguard' the 
rights of the Ottoman Empire. Those rights were, however, already virtually extinguished, and the Balkan War of 1912 brought the solemn farce to an end.

The circumstances attending the completion of Bulgarian Bulgarian independence demand only brief attention. Prince Ferdinand's indepenmove, like that of the Cretan Assembly, was directly attributable to the astonishing success of the Young Turks.

It had long been Ferdinand's ambition to sever the last ties which bound the principality to its suzerain and to assume the ancient title of Tsar of Bulgaria. So long, however, as the Ottoman Empire was manifestly in a condition of decadence there was no immediate necessity for a step likely to arouse the susceptibilities of the Powers which had signed the Treaty of Berlin. The revolution at Constantinople put another aspect on the matter. Ferdinand could no longer afford to postpone the contemplated step. If the Young Turks succeeded in effecting a real reform at Constantinople the opportunity for the declaration of Bulgarian independence might never recur. A slight offered to the Bulgarian representative at Constantinople in September afforded a pretext for his recall, and on October 5 the independence of Bulgaria was proclaimed. The principality was converted into a kingdom, and the king, by a solemm act performed in the Church of the Forty Martyrs in the ancient capital of Timovo, assumed the title of Tsar. Two reasons were assigned for the violation of the Berlin Treaty: first that the Bulgarian nation, though practically independent, was 'impeded in its normal and peaceful development by ties the breaking of which will remove the tension which has arisen between Bulgaria and Turkey'; and, secondly, that 'Turkey and Bulgaria, free and entirely independent of each other, may exist under conditions which will allow them to strengthen their friendly relations and to devote themselves to peaceful internal development'.

This hypocritical explanation did not tend to mitigate the Sultan's wrath, but the real significance of Ferdinand's action was to the Porte financial rather than political. The new government at Constantinople demanded compensation for the loss of the tribute which Bulgaria had been accustomed B b 2 
to pay. Tsar Ferdinand bluntly refused to provide it; Turkey and Bulgaria were brought to the brink of war, but Russia stepped in to facilitate a financial composition, and on April 19, 1909, the Turkish Parliament formally recognized the independence of Bulgaria.

Austria- Much more serious alike in its immediate and its remoter Hungary and the consequences was the action taken by Austria-Hungary in Balkans. regard to Bosnia and the Herzegovina. So serious, indeed, that this would seem to be the appropriate occasion for a summary analysis of Austro-Hungarian policy in the Near East.

Of all the great European Powers Austria-Hungary is most closely, if not most vitally, concerned in the solution of that problem. England's interest is vital, but remote, and nay be deemed to have been secured by the anmexation of Egypt and Cyprus, and by her financial control over the Canal. Russia's interest also is vital. On no account must any Power, potentially hostile, be in a position to close the straits against her. But the interests of Austria-Hungary while not less vital are even more immediate and direct. For England it is mainly a question of external policy, except in so far as the fate of the European Moslems reacts upon the hopes and fear's of British subjects in Egypt and India. For Russia too, apart from the waning idea of Pan-Slavism and from the position of the Orthodox Church, the question is mainly though less exclusively an external one.

For Austria-Hungary the external question is hardly if at all less vital than it is to Russia, and more vital than it is to England, while internally the whole position of the Dual Monarchy may be said, without exaggeration, to depend upon the form in which the Balkan problem is ultimately solved. M. Albert Sorel writing as far back as 1889, exhibited the prescience of a great publicist no less than the acumen of a brilliant historian when he predicted, in words which have lately become familiar, that the moment the Eastern Question was solved Europe would find itself confronted with an Austrian question. As a fact, the Habsburgs have deemed it imprudent to await the final 
solution of that question before flinging the Austrian apple of discord into the diplomatic arena. It becomes necessary, therefore, at this point to define with some precision the nature and extent of Austro-Hungarian interests in the problem under consideration.

No words are needed to emphasize the vital importance External to Russia of a free passage through the Bosphorus and the interests. Dardanelles. Her dominant interest in the future of the straits is now generally recognized. It is less commonly realized that the external problem for Austria-Hungary is almost precisely parallel to that of Russia. Deprive the Habsburgs of Trieste, Pola, Fiume, and Dalmatia-and her enemies would do it, if they could, to-morrow-and the position of Austria-Hungary would be identical with that of Russia, or worse. The Danube alone would then give them access to the sea, and with Constantinople in hostile hands the advantages eren of that access would be cancelled.

Trieste is the Liverpool of the Dual Monarchy; Pola its The Portsmouth. If Trieste be adjudged to Italy, and Istria and Adriatic. Fiume either to Italy or to the new Jugo-Slavia, the naval and commercial position of Austria-Hungary would indeed be desperate. But even assuming that there is no dismemberment of the existing Habsburg Empire her position on the Adriatic will still be exceedingly precarious. Secure in the possession of Brindisi and Valona, Italy would find little difficulty in barring the access of Austria-Hungary to the Mediterranean. The Straits of Otranto are only forty-one miles broad; small wonder, then, that Albania is regarded with jealous eyes by the statesmen of the Ballplatz.

Italy, however, is not the only potential rival of AustriaHungary in the Adriatic. Montenegro has already gained access to its waters, though her coast-line is less than thirty miles in extent. If the dreams of a Jugo-Slav Empire are realized even partially, the Greater Serbia, possessed of Dalmatia and absorbing Bosnia-to say nothing of Croatia and part of Istria-would at once neutralize, in considerable degree, the importance of Trieste, Fimme, and Pola.

These considerations enable us to appreciate the significance 
of the Habsburg monarchy's Drang nach Süd-Osten. If egress from the Black Sea and the Adriatic were denied to her, or even rendered precarious, Salonica would become not merely valuable but indispensable to her existence. Hence the persistent and increasing hostility manifested by Austria towards the development of Serbia and the consolidation of the Southern Slavs.

'The new departure in Habsburg policy.

Position of Serbia.

The Habsburgs have, in Bismarck's phrase, been gravitating towards Buda-Pesth ever since the virtual destruction of the Holy Roman Empire in the Thirty Years' War (1618-48). As a fact, gravitation was for many years equally perceptible towards the Adriatic and the Lombard plain. But the new departure in Habsburg policy really dates, as I have attempted to show in another connexion, not from the Treaty of Westphalia but from the Treaty of Prague (1866). When Bismarck turned Austria simultaneously out of Germany and out of Italy he gave her a violent propulsion towards the south-east. The calculated gift of Bosnia and the Herzegovina, supplemented by the military occupation of the Sanjak of Novi-Bazar, increased the momentum. Novi-Bazar not only formed a wedge between the Slavs of Serbia and those of Montenegro but seemed to invite the Habsburgs towards the Vardar valley and so on to Salonica.

For twenty-five years Serbia appeared to be acquiescent. Had Serbia been in a position at the Congress of Berlin to claim Bosnia, or even Novi-Bazar, Balkan politics would have worn a very different aspect to-day. But Serbia had not yet found her soul, nor even her feet. Her geographical position as defined in 1878 was, as we have seen, a hopeless one. Nor did she lack other troubles. Prince Milan assumed a royal crown in 1882, but his policy was less spirited than his pretensions; he took his orders from Vienna, a fact which widened the breach between himself and the Queen Natalie, who, being a Russian, had strong Pan-Slavist sympathies. But Queen Natalie had grievances against Milan as a husband no less than as a king, and court scandals at Belgrade did not tend to enhance the reputation of Serbia in European society.

The disastrous war with Bulgaria (1885) still further lowered 
her in public estimation. The grant of a more liberal constitution in 1888 did little to improve the situation of a country not yet qualified for self-gorernment, and in 1889 King Milan abdicated.

His son, King Alexander, was a child of thirteen at his accession, and though not deroid of will he could not give Serbia what she needed, a strong ruler. In 1893 he suddenly declared himself of age, arrested the regents and ministers, and abrogated the prematurely liberal constitution of 1888. This act, not in itself unwise, threw the country into worse confusion, which was still further increased when in 1900 the headstrong young man married his mother's ladyin-waiting, a beautiful woman but a divorcée, and known to be incapable of child-birth. The squalid story reached a tragic conclusion in 1903, when the king, Queen Draga, and the queen's male relations were all murdered at Belgrade with every circumstance of calculated brutality.

This ghastly crime sent a thrill of horror through the courts and countries of Europe. ${ }^{1}$ Politically, however, it did not lack justification. Serbia gained immeasurably by the extinction of the decadent Obrenovic dynasty, and the reinstatement of the more virile descendants of Karageorgerić; the pro-Austrian bias of her policy has been corrected; and under King Peter she has regained selfrespect and has resumed the work of national regeneration.

That work was watched with jealous eyes at Vienna, and Austriastill more at Buda-Pesth, and not without reason. The develop- Hungary ment of national self-consciousness among the Southern Slars Southern seriously menaced the whole structure of the Dual Monarchy. Expelled from Germany in 1866, the Emperor Francis Joseph came to terms with his Magyar subjects in the Ausgleich of 1867. Henceforward the domestic administration of Austria and her dependencies was to be entirely separate from that of Hungary; even the two monarchies were to be distinct, but certain matters common to the Austrian Empire and the Hungarian kingdom-foreign policy, army administration,

1 There is more than a suspicion that it was plotted in Vienna and earried out with Austrian connivance; for Alexander was less in tutelage to Vienna than Milan. 
and finance-were committed to a joint body known as the 'Delegations'. But the essential basis of the formal reconciliation thus effected between Germans and Magyars was a common hostility to the third racial element in the Dual Monarchy, the element which outnumbers both Magyars and Germans, that of the Slavs.

Out of the 51,000,000 subjects of the Emperor Francis Joseph about 10,000,000 are Magyars-these form a compact mass in Hungary; about 11,000,000 are German; about $26,000,000$ are Slavs. Of the latter, about 7,000,000 belong to the Serbo-Croatian or Southern Slav branch of the great Slav family.

Since 1867 it has been the fixed policy of the leading statesmen, of both Viemna and Buda-Pesth, to keep the Slav majority in strict subordination to the German-Magyar minority. The inclusion of Bosnia and Herzegovina, with a compact population of nearly 2,000,000 Slars, has rendered this policy at once more difficult, and, at least in the eyes of the timorous minority, more absolutely imperatire. In proportion, however, as Habsburg methods have become more drastic, the annexed provinces have tended to look with more and more approbation upon the Jugo-Slav propaganda emanating from Belgrade. To meet this danger the Austrian Gorernment has promoted schemes for the systematic German colonization of Bosnia in much the same way as Prussia has encouraged colonization in Poland. But neither the steady progress of colonization nor the material benefits unquestionably conferred upon Bosnia by German administration have availed to win the hearts of the Bosnian Serbs, nor to repress the growing intimacy between Serajevo and Belgrade.

Trialism This fact, too obtrusive to be ignored, has led some of the Dualism. more thoughtful statesmen of the Ballplatz to advocate a new departure in Habsburg policy. To maintain, in perpetuity, the German-Magyar ascendancy over the Slavs seemed to them an impossibility. But was there any alternative, consistent, of course, with the continued existence of the Habsburg Empire? Only, it seemed to them, one: to substitute a triple for the dual foundation upon which for half a century the Habsburg Empire had rested; to bring 
in the Slav as a third partuer in the existing GermanMagyar firm.

On one detail of their programme the 'trialists' were not unanimous. Some who favoured 'trialism' in principle wished to include only the Slavs who were already subject to the Dual Monarchy; others, with a firmer grip upon the nationality idea, adrocated a bolder and more comprehensive policy. To them it seemed possible to solve by one stroke the most troublesome of the domestic difficulties of the Habsburg Empire, and the most dangerous of their external problems. The Jugo-Slav agitation had not, at that time, attained the significance which since 1912 has attached to it. Serbo-Croat unity was then a distant dream. While the nationality sentiment was still comparatively weak, the religious barriers between Orthodox Serbs and Roman Catholic Croats were proportionately formidable. Whether eren then the Slars could have been tempted by generous terms to come in as a third partner in the Habsburg Empire it is impossible to say; but from the Habsburg point of view the experiment was obviously worth making, and its success would have bcen rightly regarded as a superb political achievement. With Serbia and Montenegro added to Bosnia, and the Herzegovina to Dalmatia and Croatia-Slavonia, the Habsburgs would not only have been dominant in the Adriatic; the valley of the Morava would have been open to them, and Salonica would have been theirs whenever they chose to stretch out their hands and take it. Greece would certainly have protested, and might have fought, but at that time there would have been Crete and Epirus, and even western Macedonia to bargain with. Bulgaria might easily have been conciliated by the cession of western Macedonia, including, of course, Kavala, and perhaps the vilayet of Adrianople. The Macedonian problem would thus have been solved with complete satisfaction to two ont of the three principal claimants, and to the incomparable advantage of the Habsburg Empire.

If it be true that the heir to the throne, the late Arch- The Archduke Franz Ferdinand, had identified himself with this large duke scheme of policy, it would go far to stamp him as a great Ferdistatesman; it would also go far to explain the relentless nand. 
hostility with which he was pursued by the party of GermanMagyar ascendancy.

1903. Things seemed to be shaping, in the first years of the present century, in that direction. Serbia, distracted by domestic broils, was in the slough of despond; a generous offer from the Habsburgs might well have seemed to patriotic Serbs the happiest solution of an inextricable tangle. Austria, on the other hand, had reached at that moment the zenith of her position in the Balkans. The year which witnessed the palace revolution at Belgrade witnessed also the brilliant culmination of Habsburg diplomacy in the conclusion of the Miirzteg agreement. Russia was on the brink of the Japanese War. Great Britain had just emerged with seriously damaged prestige from the war in South Africa. The brilliant diplomacy of King Edward VII had not yet succeeded in bringing England and France together, still less in laying the foundations for the Triple Entente between the Western Powers and Russia.

The moment was exceptionally favourable for a bold coup on the part of the Habsburgs in the Balkans. The Miirzteg agreement seemed almost to imply an interuational invitation to attempt it. But the opportunity was lost. What were the forces which were operating against the Trialists? At many of them we can, as yet, only guess. But there are some indications which are as sinister as they are obscure. In 1909 a corner of the curtain was lifted by a cause célebre. In December of that year the leaders of the Serbo-Croat Coalition brought an action for libel against a well-known Austrian historian, Dr. Friedjung of Vienna. Dr. Friedjung had accused the Croatian leaders of being the hirelings of the Serbian Government, but the trial revealed the amazing fact that a false accusation had been based upon forged documents supplied to a distinguished publicist by the Foreign Office. Dr. Friedjung was perhaps the imnocent. victim of his own nefarious government; the real culprit was Count Forgach, the Austrian minister at Belgrade, a diplomatist whose ingenuity was rewarded by an important post at the Ballplatz. Incidents of this kind showed to the world the direction of the prevailing wind. The archduke 
was already beaten. Baron von Aerenthal was in the saddle.

During six critical years the direction of the external Baron ron policy of the Habsburg Empire lay in the hands of this $\begin{gathered}\text { Aerenthal } \\ (1906-1 \%)\end{gathered}$ masterful diplomatist. The extinction of the Obrenovic dynasty in Serbia was a considerable though not a fatal blow to Habsburg pretensions. The tragedy itself was one of several indicative of the growth of an anti-Austrian party. The bad feeling between the two States was further accentuated by the economic exclusiveness of the Habsburg Government, which threatened to strangle the incipient trade of Serbia, and in particular to impede the export of swine upon which its commercial prosperity mainly depended. The friction thus generated culminated in the so-called 'Pig-war' of 1905-6, which convinced even the most doubting of Serbian politicians that no free economic derelopment was possible for the inland State until she had acquired a coastline either on the Adriatic or on the Aegean. The latter was hardly in sight; only two alternatives were really open to Serbia. The Albanian coast is with reference to the hinterland of little economic value. Besides, the Albanians are not Serbs; nor have they ever proved amenable to conquest. Unless, therefore, Serbia were content to resign all hope of attaining the rank eren of a third-rate European State, one of two things was essential, if not both. Either she must have some of the harbour's of Dalmatia, preeminently a Slas country, or she must obtain access to the Adriatic by union with Bosnia and the Herzegovina.

All hope of the latter solution was extinguished by Aeren- Annexithal's abrupt annexation of these Slar provinces in 1908. $\begin{aligned} & \text { tion of } \\ & \text { Bosnia }\end{aligned}$ Austria-Hungary had been in undisputed occupation since and the 1878 , and no reasonable person ever supposed that she would Hovina. voluntarily relax her hold. But so long as the Treaty of Berlin remained intact, so long as the Habsburg occupation was technically provisional, a glimmer of hope remained to the Pan-Serbians. Aerenthal's action was a declaration of war. In the following year he did indeed throw a sop directly to the Turks, indirectly to the Serbs, by the evacuation of NoriBazar. He took to himself great credit for this generosity 
and the step was hailed with delight in Serbia. We now know that it was dictated by no consideration for either Turkish or Serbian susceptibilities; it was taken partly to conciliate Italy, the third and most restless member of the Triple Alliance; but mainly because the Austrian general staff had come to the conclusion that the Morava valley offered a more convenient route than the Sanjak to Salonica. Feeling in Could Serbia hope to shut and lock both these doors
Serbia. against the intruding Habsburgs? That was the question which agitated every Chancellery in Europe at the opening of the year 1909. In Belgrade the action of Austria-Hungary excited the most profound indignation, and the whole Serbian people, headed by the Crown Prince, clamoured for war. Feeling in Montenegro was hardly less unanimous. The Serbian Government made a formal protest on October 7, and appealed to the Powers for ' justice and protection against this new and flagrant violation, which has been effected unilaterally by force majeure to satisfy selfish interests and without regard to the grievous blows thus dealt to the feelings, interests, and rights of the Serbian people'. Finally, in default of the restoration of the status quo, they demanded that compensation should be given to Serbia in the Sanjak of Novi-Bazar.

The Powers were not unsympathetic, but urged Serbia to be patient. Upon the most acute of English diplomatists the high-handed action of Austria had made a profound impression. No man in Europe had laboured more assiduously or more skilfully for peace than King Edward VII. Lord Redesdale has recorded the effect produced upon him by the news from the Balkans.

'It was the 8th of Oct. that the King received the news at Balmoral, and no one who was there can forget how terribly he was upset. Never did I see him so moved. . . . The King was indignant. . . . His forecast of the danger which he communicated at the time to me showed him to be possessed of the prevision which marks the statesman. Every word that he uttered that day has come true.' 1

The peace of Europe depended upon the attitude of Russia. Her Balkan partnership with Austria-Hungary had been

1 Lord Redesdale, Memories, i. 178-9. 
dissolved, and in 1907 she had concluded an agreement respecting outstanding difficulties with Great Britain. That agreement virtually completed the Triple Entente, the crown of the diplomacy of King Edward VII. In June, 1908, King Edward and the Tsar Nicholas met at Réral, and a further programme for the pacification of Macedonia was drawn up. Whether the Réval programme would have succeeded in its object any better than the Miirzteg agreement, which it replaced, the Young Turks did not permit Europe to learn. But at least it afforded conclusive evidence that a new era in the relations of Russia and Great Britain had dawned.

In the Balkan question Russia was, of course, profoundly interested. To her the Serbians naturally looked not merely for sympathy but for assistance. Russia, howerer, was not ready for war. She had not regained her breath after the contest with Japan. And the fact was, of course, well known at Potsdam. All through the autumn and winter (1908-9) Serbia and Montenegro had been feverishly pushing on preparations for the war in which they beliered that they would be supported by Russia and Great Britain. Austria, too, was steadily arming. With Turkey she was prepared to come to financial terms: towards Serbia she presented an adamautine front. Towards the end of February, 1909, war seemed inevitable. It was averted not by the British proposal for a conference but by the 'mailed fist' of Germany. In melodramatic phrase the German Emperor announced that if his august ally were compelled to draw the sword, a knight 'in shining armour' would be found by his side. At the end of March Russia was plainly informed that if she went to the assistance of Serbia she would have to fight not Austria-Hungary only but Germany as well. Russia, conscious of her unpreparedness, immediately gave way. With that surrender the war of 1914 became inevitable. Germany was intoxicated by her success; Russia was bitterly resentful. The Serbs were compelled not merely to acquiesce but to promise to shake hands with Austria. The Powers tore up the twenty-fifth Article of the Treaty of Berlin. Turkey accepted $£ 2,200,000$ from Austria-Hungary as compensation for the loss of the Serbian provinces, and in April, 1909, 
formally assented to their alienation. Bulgaria compounded for her tribute by the payment of $£ 5,000,000$. $^{1}$ Thus were the 'cracks papered over', and Europe emerged from the most serious international crisis since 1878 .

The

Turkish revolu-

We must now return, after this prolonged parenthesis, to tion. the fons et origo of the whole commotion. It was, as we saw, the sudden move of the Macedonian 'Committee of Union and Progress' which set a light to the conflagration, the slow burning down of which we have just witnessed. The fire was not burnt out. The ashes smouldered, to blaze out again more fiercely in 1914.

Few single erents in the whole history of the Near Eastern Question have caused a greater sensation or evoked more general or generous enthusiasm than the Turkish revolution of 1908. The Committee which organized it with such complete and amazing success had been in existence for several years, and was itself the descendant of a party which was first formed in Constantinople after the disastrous conclusion of the Greek War of Independence (1830). It was in that year that the High Admiral, Khalil Pasha, said: 'I am convinced that unless we speedily reform ourselves on European lines we must resign ourselves to the necessity of going back to Asia.' ${ }^{2}$ Those words indicate the genesis of the Young Turk party, and might have been taken as its motto. To transform the Ottoman Empire for the first time into a modern European State; to gire to Turkey a genuine parliamentary constitution; to proclaim the principle of religious and intellectual liberty; to emancipate the press; to promote intercourse with the progressice nations of the world; to encourage education; to promote trade; to eradicate the last relics of mediaevalism-such was the programme with which the Young Turks astonished and deluded Europe in the summer of 1908 .

Composed mainly of young men who had acquired a veneer of Western-particularly Gallic-ideas the Committee was originally formed at Geneva in 1891. Thence it transferred its operations to Paris, and, in 1906, established its head-

¿ Of which Russia provided $£ 1,720,000$.

2 Driault, p. 135. 
quarters at Salonica. Its first object was to secure the army, more particularly the third army corps then stationed in Macedonia. The sporadic outbreaks in the early part of July in Macedonia, the assassination of officers known to be well affected towards the Hamidian régime indicated the measure of its success. On July 23 the Committee proclaimed at Salonica the Turkish constitution of 1876, and the third army corps prepared to march on Constantinople.

Abdul Hamid, however, rendered the application of foree superfluous. He protested that the Committee harl merely anticipated the wish dearest to his heart; he promptly proclaimed the constitution in Constantinople (July 24); summoned a parliament; he guaranteed personal liberty and equality of rights to all his subjects irrespective of race, creed, or origin; he abolished the censorship of the press; and dismissed his army of 40,000 spies.

The Turkish revolution was welcomed with cordiality in Counterall the liberal States of Europe and with peculiar effusive- revoluness in Great Britain. The foreign officers of the Macedonian Constant;gendarmerie were recalled; the International Commission nople. of Finance was discharged. But the brightness of a too brilliant dawn soon faded. The new grand vizier, Kiamil Pasha, was compelled to resign in February. His successor, Hilmi Pasha, the late inspector-general in Macedonia, was replaced in April by Tewfik Pasha. The army, meanwhile, gave signs of grave dissatisfaction. There was unrest, too, in Arabia and Anatolia. The Young Turks soon learnt that the introduction of a European system into an empire essentially Asiatic is less easily accomplished than they had supposed. The Sultan, Abdul Hamid, was even more acutely conscious of this truth, and on April 13 he felt himself strong enough to effect, with the aid of the army, a counterrevolution.

But his triumph was short-lired. The Young Turkish Depositroops, conmanded by Mahmud Sherket, marehed from tion of Salonica, and on April 24 entered and oceupied Constanti-Hamid. nople. On the 27th Abdul Hamid was formally deposed by a unanimous rote of the Turkish National Assembly, and his younger brother was proclaimed Sultan in his room, under' 
the title of Mohammed V. On the 28th the ex-Sultan was deported to Salonica, and interned there. Hilmi Pasha was reappointed grand vizier; the new Sultan expressed his conviction that 'the safety and happiness of the country depend on the constant and serious application of the constitutional régime which is in conformity with the sacred law as with the principles of civilization'.

'Turkifica- A new era appeared to have dawned for the Ottoman tion.

Empire. It soon became clear, however, that the Young Turks, so far from turning their backs upon the traditions of their race, were Osmanlis first and reformers afterwards. Abdul Hamid's brief triumph had been marked characteristically by fresh massacres of Armenians at Adana and in other parts of Anatolia. His deposition, so far from staying the hands of the assassins, tended rather to strengthen them. An eyewitness of the massacres has declared that in the last fortnight of April, 1909, 30,000 Christians perished in Asia Minor, and that the murderers went unpunished under the new régime. ${ }^{1}$

In Macedonia, as in Asia Minor, the lot of the Christians, so far from being ameliorated by the reformers, became steadily worse. There, as elsewhere, the keynote of Young Turk policy was unrelenting 'Turkification'. The same principle inspired their ecclesiastical policy. At the name of Allah every knee was to bow. The obeisance was to be enforced by every form of outrage and persecution. 'They treat us', said the Greek Patriarch, 'like dogs. Never under Abdul Hamid or any Sultan have my people suffered as they are suffering now. But we are too strong for them. We refuse to be exterminated.' ${ }^{2}$ But the power of the Young Turks was unequal to their ambition ; their deeds, though as brutal as might be wherever they were strong, were less potent than their words. Their denunciation of tyranny was all sonnd and fury; in effect it signified nothing. Their promises of reform were empty.

Still, one possibility remained. Enver Pasha and his crew were bent on making Turkey a nation of Turks. One virtue

1 Gibbons, op. cit., pp. 178 sq.

2 Idem, p. 189. 
at least the Turk was supposed to possess. He was believed to be a born fighter. True, most of his battles had been won by the Moslemized Christians. But they had fought in the Ottoman name. If the Yommg liurks conld effect but one reform, a real reorganization of the army, their régime might still justify itself:

It was not long before the army was bronght to the test. On September 29, 1911, Italy declared war upon the ()ttoman Empire. That war opened the latest chapter in the history of the Eastern Question.

For further reference: the Anmual lieffister, 1907-10; The Romnd Table, 1911 onwards; Natiomelism and War in the Near East, hy a Diplomatist (Oxford, 1915); Sir C. Eliot (as before) ; C. R. Buxton, Turkey in Revolution, 1 vol. (London, 1909); Sir W. R. Ramsay, Revolution in Turkey and Constantinople (London, 190!)); II. A. Gibbons, Nex líay' of Europe (London, 1915); Victor Bérard, La liécolution Turque (1'iris, 1909), La Turquie et l'Hellénisme contemponain (6th ed., Taris, 1911) Lu Macédoine (Paris, 1900), Pro Macedomin (Paris, 1:04); H. N. Brailsford, Macedonia, its Races and thrir Future (London, 1906): L. Villari (ed. and others), The Ballien Question (London, 1904); E. F. Knight, The Awakening of Turkey (London, 1909): Rene Pinon, LEurope of la Jeure 'Turquie (1911); Virginio Gayda, Modern Austria (Eng. trans., London, 1915) ; Louis Léger, L'Autriche-Hougrie (Paris, 1879); B. Anerbach, Les Races et les Nationalités en Autriche-IIongrie (Paris); R. Chamaty, Oesterreichs innere Geschichte, 18 \& 1909. 2 vols. (Tenher): A. Chinadante, L'Allemagne, la France, et la question d' Autriche (Paris). L'Europe ot. la question "l Autriche au seuil du XXme siècle (I’aris); (A. Drage, Austria-Hungary; D. A. Fomnier, thie wir $\approx u$ Bosnien lamen (Vienna, 1909): 'Scotus Viator' (R. W. Seton-Watson), The. Future of AustrictHungary (London, 1907), Racial Prohlems in IIungary (1908); li. W. Seton-Watson, The Southern Slav Question and the Hapsburg Monarchy (1911); H. W. Steed, The Hapsburg Monarchy (London, 1913). 


\section{CHAPTER XVI}

\section{THE BALKAN LEAGUE AND THE BALKAN WARS}

'The pr'oblem now is not how to keep the Turkish Empire permanently in being . . . but low to minimize the shock of its fall, and what to substitute for it.'-Viscount Bryce.

'The war of the Coalition can claim to have heen both progressive and epoch-making. The succeeding War of Partition was rather predatory and ended no epoch, though possibly it may have begun one: it is interesting not as a settlement but as a symptom.'- 'Diplomatist', Nationalism and War in the Near East.

'The Turks, who have always been strangers in Europe, have shown conspicnous inability to comply with the elementary requirements of European civilization, and have at last failed to maintain that military efficiency which has, from the days when they crossed the Bosphorus, been the sole mainstay of their power and position.'-Lord CROMER.

The

I'owers

and the

African

shore of

the Merli-

terranean.

Is October, 1909, the diplomatic world was startled to learn that the Tsar Nicholas was abont to pay a ceremonial visit to the King of Italy. The incident proved to be of considerable significance; it was the prologue to the last act in the drama of the Near East. At that moment Russia was smarting under the hmmiliation imposed upon her by the Paladin of Potsdam, who in his shining armour stood forth ostentationsly by the side of Austria and Hungary. The poverty not the will of Russia had consented to the annexation of Bosnia and the Herzegovina by Austria-Hungary. Italy, too, regarded with increasing uneasiness the advance of the Habsburgs in the Balkans. Consequently, after 1909, Italy and Russia tended to draw together.

France And not only Russia and Italy. Bismarck's constant, and and Italy. on the whole successful, endeavour was to throw apples of discord anong the members of the European family. Thus in 1881 he had tossed Tunis to France, not from any love of France, but because, as he well knew, Italy had long had a reversionary interest in that country. But in 1896 France 


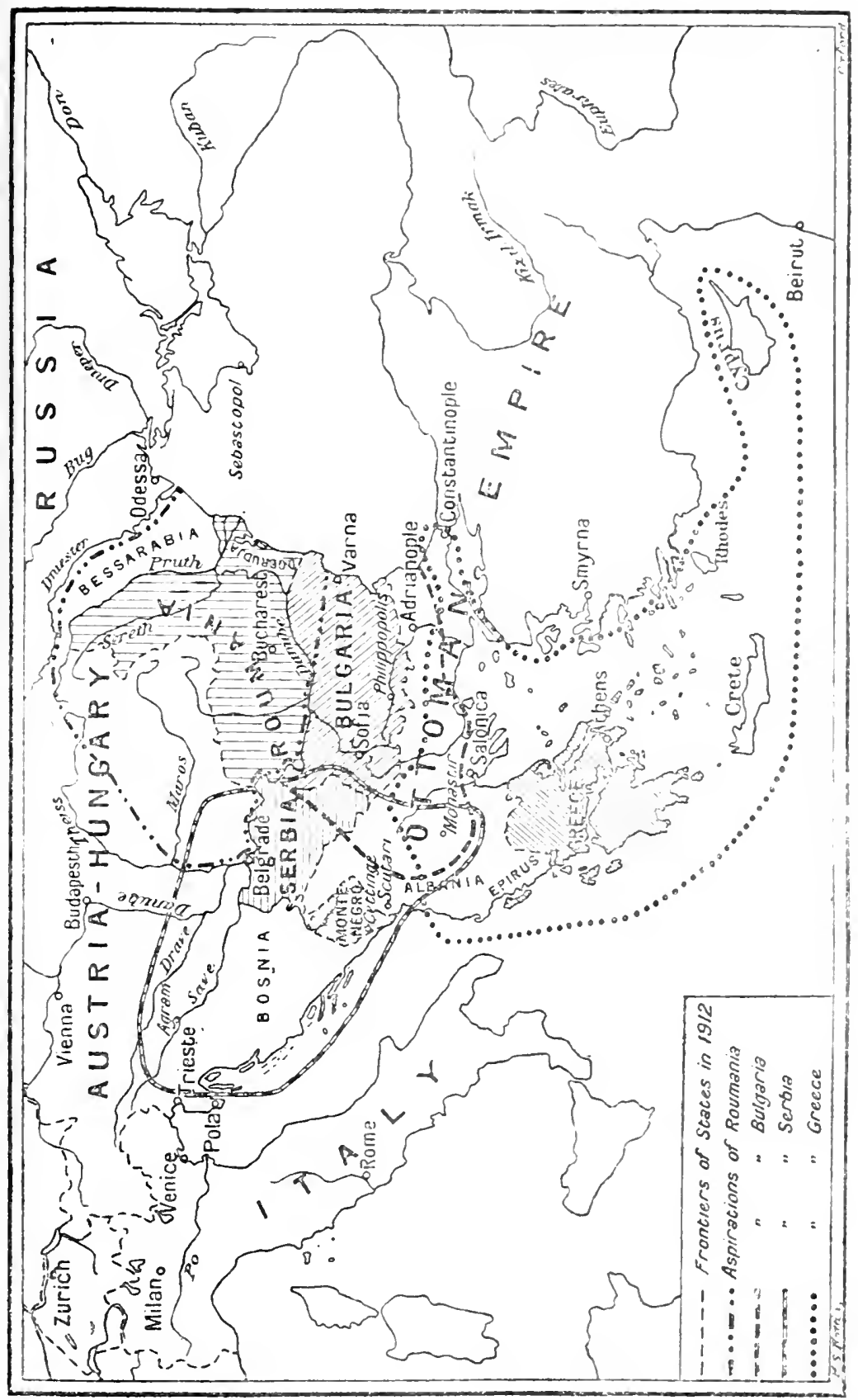


and Italy concluded a convention which finally closed a long series of disputes arising out of the French protectorate in Thnis. ${ }^{1}$

England The same thing was happening in regard to Anglo-French

and

France.

Tripoli. France had been in undisputed possession of Algeria ever since 1844. Consequently, of all the dominions of the Ottoman Empire on the African shore of the Mediterranean Tripoli alone remained. As far back as 1901 France, in return for the concessions in regard to Tunis, had agreed to give Italy a free land in Tripoli; and, from that time onwards, there was a general understanding among the European Chancelleries that when the final liquidation of the Ottoman estates was effected Tripoli would fall to the share of Italy. Her reversionary rights were tacitly recognized in the Anglo-French agreement of 1904, and again at Algeciras in 1906.

Those rights were now menaced from an unexpected quarter. The Kaiser's visit to Tangier in March, 1905, had resulted chiefly in a strengthening of the Anglo-French alliance; the attempted coup at Agadir in July, 1911, had a similar effect. But German intervention in the western Mediterranean was merely for demonstration purposes; to assist her 'national credit'; to indicate to the Western Powers that she could not be treated as a quantité négligeable-even in fields relatively remote. But the scientific interest which German geologists and archaeologists had lately developed in Tripoli

1 Cf. Albin, Grands Traités politiques, p. 290. 
was otherwise interpreted at Rome; and the descent of the Panther upon Agadir convinced Italy that, miless she was prepared to forgo for all time her reversionary interests in Tripoli, the hour for claiming them had struck.

For many years past Italy had pursued a policy of economic The and commercial penetration in Tripoli, and had pursued it Italians in without any obstruction from the Turks. But there, as elsewhere, the revolution of 1908 profoundly modified the situation. The Yomng Turks were as much in Tripoli as in Macedonia opposed to Christians. At every turn the Italians found themselres thwarted. It might be merely the Moslem fanaticism characteristic of Young Turk poliey. But the suspicion deepened that between Moslem fanaticism and Teutonic zeal for scientific research there was more than an accidental connexion. Be this as it might, ltaly deemed that the time had come for decisive action.

That action fell, nevertheless, as a bolt from the blue. TurcoOn September 27 Italy suddenly presented to Turkey an Italian ultimatum demanding the consent of the Porte to an Italian Sept. 2!4, occupation of Tripoli under the sovereignty of the Sultan, 1911-(1).t. and subject to the payment of an ammual tribute. A reply was required within forty-eight hours, but already the Italian transports were on their way to Tripoli, and on September 29 war was declared.

The details of the war do not concern this narrative. It Italy and must suffice to say that even in Tripoli Italy had no easy the J'orte. task. She occupied the coast towns of Tripoli, Bengazi, and Derna without difficulty, but against the combined resistance of Turks and Arabs she could make little progress in the interior. The Turks, trusting that the situation would be relieved for them by international complications, obstinately refused to make any concessions to Italy. But between her two allies Germany was in a difficult position. She was indignant that one ally should, without permission from Berlin, have ventured to attack the other ally at Constantinople; but, on the other hand, she had no wish to throw Italy into the arms of the Triple Entente. Italy, however, was determined to wring consent from the Porte, and in the spring of 1912 her navy attacked at several points; a couple of 
Turkish warships were sunk off Beirut; the forts at the entrance to the Dardanelles were bombarded on April 18; Rhodes and the Dodecanese Archipelago were occupied in May. To the bombardment of the Dardanelles Turkey retorted by closing the Straits. This proved highly inconvenient to neutrals, and after a month they were reopened. Throughout the summer the war went languidly on, entailing much expense to Italy, and very little either of expense or even inconvenience to the Turks.

In two ways the war was indeed decidedly advantageous to the policy of the Young Turks. On the one hand, 'by reconciling Turk and Arab in a holy war in Africa, tle Tripoli campaign healed for a time the rumning sore in Arabia which had for years drained the resources of the Empire'. ${ }^{1}$ On the other, the naval operations of Italy in the Aegean aroused acute friction between the Italians and the Greeks, whose reversionary interests in the islands were at least as strong as those of Italy upon the African littoral. That friction would be likely to increase, and in any case could not be otherwise than advantageous to the Turk.

Treaty of But suddenly a new danger threatened him. The Tripoli Lausanne. canpaign was still dragging its slow length along, and seemed likely to be protracted for years, when the conflagration blazed up to which the Tripoli War had applied the first match. In view of the more immediate danger the Porte at last came to terms with Italy, and the Treaty of Lansanne was hastily signed at Ouchy on October 18. The Turks were to withdraw from Tripoli; Italy from the Aegean islands; the Khalifal authority of the Sultan in Tripoli was to remain intact; he was to grant an amnesty and a good administration to the islands ; Italy was to assume responsibility for Tripoli's share of the Ottoman debt. The cession of Tripoli was assumed but sub silentio. The withdrawal of the Italian troops from the islands was to be subsequent to and consequent upon the withdrawal of the Turkish troops from Africa. Italy has contended that the latter condition has not been fulfilled, and she remains, therefore, in Rhodes 
and the Dodecanese. Her continued occupation has not injured the Turks, but it has kept out the Greeks.

On the same day that the Treaty of Lausanne was signed Greece declared war upon the Ottoman Empire. This time she was not alone. The miracle had occurred. The Balkan States had combined against the common enemy. The circumstances which had conduced to this astonishing and unique event demand investigation.

The idea of a permanent alliance or even a confederation the among the Christian States of the Balkaus was frequently laalkan canvassed after the Treaty of Berlin. But the aggrandizement of Bulgaria in 1885, and the war which ensued between Bulgaria and Serbia, shattered the hope for many years to come. M. Trikoupis, at that time Prime Minister of Greece, made an effort to revive it in 1891, and with that object paid a visit to Belgrade and Sofia. The Serbian statesmen welcomed his advances, but Stambuloff, who was then supreme in Bulgaria, was deeply committed to the Central Powers and throngh them to the Porte, and frowned upon the project of a Balkan League.

The real obstacle, howerer, to an entente between the DiffiBalkan Powers arose, as the previous chapter has shown, $\begin{gathered}\text { culties in } \\ \text { Nlace- }\end{gathered}$ from their conflicting interests in Macedonia. Bulgaria donia. consistently favoured the policy of autonomy, in the not unreasonable expectation that autonomy would prove to be the prelude to the union of the greater part if not the whole of Macedonia with Bulgaria. Neither Serbia nor Greece could entertain an equally capacious ambition, and from the first, therefore, advocated not autonomy but partition.

Each of the three neighbouring States was genuinely concerned for the unhappy condition of its co-nationals in Macedonia, but the bitter rivalry between them prevented anything approaching to cordial co-operation for a general improvement. The Young Turk revolution brought matters to a head. That revolution, as a close and shrewd observer has said, was 'in fact a last effort of the Moslem minority to retain its ascendancy in the face of growing resistance on the part of subject races and impending European intervention'. The revival of the constitution was 
little more than an ingenious device for appeasing Liberal sentiment abroad while furnishing a pretext for the abrogation of the historic rights of the Christian nationalities at home. That the subject peoples would combine in defence of their rights, and that their reconciliation would react on the kindred States across the frontier, was not foreseen by the inexperienced but self-confident soldiers and politicians who now directed the destinies of the Turkish Empire. ${ }^{1}$

The triumphant success of the Committee of Union and Progress so far from improving the condition of Macedonia served only to accentuate its sufferings. The Bulgarians of the kingdom were deeply stirred by them. They saw with indignation and alarm that the Young Turks were bent upon exterminating such Bulgarians as they could not compel to emigrate. M. Shopoff; the Bulgarian consul-general at Salonica, stated in 1910 that the Bulgarian population had in fifteen years been reduced by twenty-five per cent.; the number of refugees was becoming a serious problem in Bulgaria, while the terrible massacres at Ishtib and Kotchani, the 'murders, pillaging, tortures, and persecutions' compelled 'the most peaceful Bulgarian statesmen' to ask themselves 'if all this was not the result of a deliberate plan on the part of the Young Turks to solve the Macedonian and Thracian problem by elearing those two provinces of their Bulgarian and Christian inhabitants. ${ }^{2}$

'The Entente in the Balbins.

Between 1910 and 1912 there were various indications of some improvement in the mutual relations of the Balkan States. In 1910 the Tsar Ferdinand, the shrewdest of all the Balkan diplomatists, paid a visit to Cettinje to take part, together with the Crown Prince of Serbia and the Crown Prince of Grecee, in the celebration of King Peter's Jubilee. At Easter, 1911, some three hundred students from the Uni-

1 The Ballan League: a series of articles contributed to The Times in June, 1913, by their 'own correspondent in the Balkan Peninsula'. 'To these admirable articles I desire to make specific acknowledgement of my obligations. No individual did more than the writer of them to bring into being the League which he so brilliantly chronicled.

${ }^{2}$ Gueshoff, The Balkan League, p. 8. The reader may be reminded that M. Gueshoff, Prime Minister of Bnlgaria in 1912, was educated at the Owens College (now the Victoria University of), Manchester. 
versity of Sofia received a cordial welcome at Athens. In April of the same year M. Venizelos made a proposal to Bulgaria for a definite alliance, through the intermediation of Mr. J. D. Bourchier, The Times correspondent in the Balkan Peninsula. In May the Greek Patriarch and the Bulgarian Exarch so far forgot their secular animosity as to combine in a protest to the Sultan against the persecution of his Christian subjects. In July the T'sar Ferdinand obtained a revision of the Bulgarian constitution, under which the executive was anthorized to conclude secret political treaties without communication to the Legislature. In October M. Gueshoft, Prime Minister of Bulgaria, had an exceedingly confidential interview with M. Milanovanic, the Prime Minister of Serbia. ${ }^{1}$ In February, 1912, the several heirs apparent of the Balkan States met at Sofia to celebrate the coming of age of Prince Boris, heir to the Tsardom of Bulgaria.

All these things, the social gatherings patent to the world, the political negotiations conducted in profoundest secrecy, pointed in the same direction, and were designed to one end.

A favourable issue was not long delayed. On March 13, Serbo1912, a definite treaty was signed between the kingdoms Bulgarian of Serbia and Bulgaria. This was in itself a marvel of March 13, patient diplomacy. Not since 1878 had the relations between 1912 . the two States been cordial, nor were their interests or their antagonisms identical. To Serbia, Austria-Hungary was the enemy. The little land-locked State, which yet hoped to become the nucleus of a Jugo-Slav Empire, was in necessary antagonism to the Power which had thrust itself into the heart of the Balkans, and which, while heading the Slavs off from access to the Adriatic, itself wanted to push through Slav lands to the Aegean. Bulgaria, on the other hand, had no special reason for enmity against Vienna or Buda-Pesth. The 'unredeemed' Bulgarians were subjects not of the Emperor Francis Joseph but of the Ottoman Sultan, and while the antagonisms of the two States differed their mutual interests clashed. To Thrace and eastern Macedonia

${ }^{1}$ See Gueshoff, op. cit., pp. 15 sq. 
Serbia could of course make no claim. Bulgaria could not dream of acquiring Old Serbia. But there was a considerable intermediate zone in Macedonia to which both could put forward substantial pretensions. The treaty concluded in March, 1912, reflected these conditions.

By that treaty the two States entered into a defensive alliance; they mutually guaranteed each other's dominions and engaged to take common action if the interests of either were threatened by the attack of a Great Power upon Turkey ; at the same time they defined their respective claims in Macedonia should a partition be effected: Old Serbia and the Sanjak of Novi-Bazar, that is, all the territory north and west of the Shar Mountains, was to go to Serbia, the territory east of the Rhodope Mountains and the river Struma to Bulgaria; the intermediate regions of Macedonia 'lying between the Shar Mountains and the Rhodope Mountains, the Archipelago, and the Lake of Ochrida' were, if possible, to be formed into the autonomous province long desired by Bulgaria; but if such an organization of this territory appeared to the two parties to be impossible it was to be dirided into three zones: Bulgaria was to have the region round Ochrida; Serbia was to get an additional strip in northern Macedonia, while the unassigned residuum was to be subject to the arbitration of the Tsar of Russia.

Military In order to give the treaty additional solemnity it was convention. signed not only by the ministers but by the sorereigns of the two States, and at the end of April the Tsar notified his acceptance of the difficult function assigned to him under its provisions. A separate military convention was concluded at Varna on May $29^{1}$; and a further agreement between the general staffs was signed in June. It is noticeable, however, that there was a marked difference of military opinion as to the 'principal theatre of war', the Bulgarian staff pronouncing, as was natural, for the valley of the Maritza, the Serbians for the Vardar valley.

Greco- Two months after the signature of the Serbo-Bulgarian Pulgarian Treaty an arrangement was reached between Greece and May 10 , 1912.

1 The full texts of all these important treaties will be found in Appendices to Gueshoff, op. cit. 
Bulgaria. It differed in one important respect from that concluded between the latter and Serbia. Between Greeks and Bulgarians nothing was said as to the partition of Macedonia. Further, it was expressly provided that if war broke out between Turkey and Greece on the question of the admission of the Cretan deputies to the Greek Parliament, Bulgaria, not being interested in the question, should be bound only to benevolent neutrality.

There was good reason for this proviso. The Cretan diffi- The culty had become acute, and, indeed, threatened to involve Cretan the kingdom in revolution. The accession of the Young Turks had only intensified the confusion in regard to the great Greek island. They were by no means disposed to acquiesce in its alienation from the Ottoman Empire. The Greek Cretans were absolutely determined to unite themselves to the kingdom of Greece. The Powers were impartially anxious to prevent the extermination of the Moslem population by the Greeks, or the Greek population by the Turks, but they were eren more concerned to prevent this inflammable island from lighting a wider conflagration. As soon as the foreign contingents had left the island (July, 1909) the Cretans hoisted the Greek flag. A month later the Powers returned and lowered it. The hesitation of King George's Government in the face of these events precipitated a military revolt in Athens, and all but led to the overthrow of the dynasty. The revolt of the army in August was followed by the mutiny of the nary at the Piraeus in September, and the condition of Greece appeared to be desperate.

It was saved by the adrent of a great statesman. M. Veni- Elefzelos had already shown his capacity for leadership in Crete $\stackrel{\text { therios }}{\text { Venizelos. }}$ when, in February, 1910, he was summoned to Athens to advise the Military League. Having come to Athens to advise the League be remained to advise the king. In October the League orerturned the Dragoumis ministry, and King George invited the Cretan statesman to form a Cabinet. M. Venizelos accepted the difficult task, effected a nuchneeded revision of the constitution, and propounded an extensive programme of domestic reforms.

But the execution of such a programme predicated peace, 
internal and external, and in addition a certain basis of financial stability and commercial prosperity.

The Young Turks were quite determined that neither condition should be satisfied. They imposed upon Greek commerce a boycott so strict as all but to reduce to ruin that nation of seafarers and traders. A further obstacle to the commercial development of Greece was interposed by the Young Turks when they declined to sanction the linking-up of the Greek railway system with that of Macedonia. These manifestations of the extreme and persistent hostility of the 'New Moslems', combined with their refusal to acquiesce in the alienation of Crete, at last drore Greece into the 'impossible' alliance with Bulgaria.

(ireco- The defensive alliance signed in May was followed in SepBullitary tember, as in the case of Serbia, by a detailed nilitary consonvention, Sept. 2., 1912 .

vention. Bulgaria was to supply at least 300,000 men to operate in the vilayets of Kossovo, Monastir, and Salonica. If, however, Serbia should come in, Bulgaria was to be 'allowed to use her forces in Thrace'. Greece was to supply at least 120,000 men; but the real gain to the alliance was of course the adhesion of the Greek fleet, whose 'chief aim will be to secure naval supremacy over the Aegean Sea, thus interrupting all communications by that route between Asia Minor and European Turkey'. How efficiently Greece performed that part of the common task the immediate sequel will show.

The For the crisis was now at hand. It was forced generAlbanian ally by the condition of Macedonia, and in particular by the
factor. revolt of the Albanians. In no direction had the Young Turks mishandled the affairs of the empire more egregiously than in regard to Albania. It might, indeed, have been expected that a party which set out with the ideal of 'union and progress' would have dealt sympathetically and successfully with this perennial problem. The Albanian factor, like every other in the complex problem of the Near East, is double-edged, external and internal. On the one hand, Albania is an object of desire to Austria-Hungary, to Italy, and to Greece, to say nothing of Serbia; on the other, the Albanians, though a source of considerable strength to the 
personnel of the Ottoman Empire, have never shown themselres susceptible of conquest or absorption. They are, indeed, too far lacking in political integration either to conquer or to be conquered. 'A barbarons country', as Caesar' observed long ago, 'is less easily conquered than a civil.' The highland tribesmen of Albania have defied, in turn, every would-be conqueror, by reason not of their strength, but by reason of their weakness. It is easier to kill a lion than a jelly-fish.

The almost incredible fatuity of Young Turk policy promised, however, to give to the Albanians a coherence which they had hitherto lacked, and their successful rising in the spring of 1912, still more the spread of the revolt to Macedonia, precipitated, in more ways than one, the Balkan crisis.

To the rising in northern Albania the Young Turks wonld Albanian probably hare paid no more heed than had the Old Turks on rising. a dozen similar occasions, but for the intrusion of a novel phenomenon. The fact that the Turkish troops made common cause with the Albanian insurgents compelled the notice of Constantinople. But there was worse to come. In June the troops at Monastir broke out into mutiny, and demanded the overthrow of the Young Turk ministry. In July the strongest man of the party, the man who had suppressed the counter-revolution in April, 1909, Mahmud Sherket Pasha, the minister of war, resigned, and was replaced by one of the strongest opponents of the Young Turk régime, Nazim Pasha. In August Hilmi Pasha followed Sherket into retirement.

Things were, in the meantime, hastening to a crisis in Albanian Macedonia. Both Greece and Serbia were becoming seriously demands. alarmed by the unexpected success achieved by the Albanians, who were now openly demanding the cession to them of the entire rilayets of Monastir and Uskub. Unless, therefore, the Balkan League interposed promptly, Greece and Serbia might find the ground cut from under their feet in Macedonia. Bulgaria was less directly interested than her allies in the pretensions put forward by the Albanians, but she was far more eoncerned than they in 
the terrible massacre of Macedonian Bulgars at Kotchana and Berana.

Bulgaria and the l'orte.

On August 14 a great popular demonstration, representative of all parts of the Bulgarian kingdom, was organized at Sofia to protest against the massacres at Kotchana; to demand immediate autonomy for Macedonia and Thrace, or, in default, immediate war against the Porte. Ten days later a congress, representing the various brotherhoods of the Macedonian and Thracian districts, opened its sessions at Sofia. The resohtions of the congress were identical with those of the popular demonstration. In the midst of the excitement aroused by these meetings there arrived from Cettinje a proposal for immediate action. None of the Balkan States was more whole-hearted in the Balkan cause than Nontenegro, and none was so eager for a fight. In April an arrangement had been arrived at between her and Bulgaria; the proposal which now reached Sofia was the outcome of it. On August 26 the dic was cast; Bulgaria agreed that in Oetober war should be declared.

The While the Turks and the Balkan States were mobilizing,

powers Ballians. the Powers put out all their efforts to maintain the peace. In September the States of the Balkan League appealed to the Powers to join them in demanding an immediate and radical reform in Macedonia: a Christian governor, a local legislature, and a militia recruited exclusively within the province. The Powers nrged concession upon the Porte and patience upon the Balkan League. It was futile to expect either. Nothing but overwhelming pressure exerted at Constantinople could at this moment have averted war. Instead of taking that course the Powers presented an ultimatum simultaneously at Sofia, Belgrade, Athens, and Cettinje. In brief, the Powers will insist upon the reforms adumbrated in the Treaty of Berlin; but the Balkan States must not fight; if they do, the Powers will see that they get nothing by it.

Outbreak This masterpiece of European diplonacy was presented at of war. the Balkan capitals on Oetober 8,1912 . On the same day King Nicholas of Montenegro declared war at Constantinople. The other three States presented their ultimatum on the 14th. 
On the 18th the Porte declared war upon Bulgaria and Serbia; and on the same day Greece declared war upon the Porte.

Then, as M. Gueshoff writes, 'a miracle took place. . . . The War Within the brief space of one month the Balkan Alliance of the demolished the Ottoman Empire, four tiny countries with Oct.-Dec., a population of some $10,000,000$ souls defeating a great ${ }^{1912}$. Power whose inhabitants numbered 25,000,000'. Each of the allies did its part, though the brunt of the fighting fell upon the Bulgarians.

Bulgaria was, however, from the outset in a false position. Bulgaria's Its true political objective was Salonica; its purpose the ${ }^{\text {part. }}$ emancipation of Macedonia. Military considerations compelled it to make Constantinople its objective, and Thrace its campaigning ground. The greater, therefore, its military success, the more certain its political disappointment.

The success of the Bulgarians in the autumn campaign was, indeed, phenomenal. On October 18 a large and finely equipped army crossed the Thracian frontier under General Savoff. Its first impact with the Turks was on the 22nd at Kirk Kilisse, a position of enormous strength to the north-east of Adrianople. After two days' fighting the Turks fled in panic, and Kirk Kilisse was in the hands of their enemies. Then followed a week of hard fighting, known to history as the Battle of Lule Burgas, and at the end of it the Turks were in full retreat on Constantinople. One Bulgarian army was now in front of the Tchataldja lines, another was investing Adrianople. On Norember 4, after a campaign of less than a fortnight, the Porte appealed to the Power's for mediation. Bulgaria refused to accept it ; but no progress was, thereafter, made either towards Constantinople or towards the taking of Adrianople. Bulgaria had shot its bolt; it had won an astonishing victory orer the Turks, but politically had already lost ererything which it had set out to attain. On November 19 orders came from Sofia that the attack upon the Tchataldja lines must be suspended. What did that order import? Was it the cholera which had broken out in Constantinople, and which protected the city from attack more effectually than the Young Turks? Was 
it pressure from the Powers? And more particularly from St. Petersburg? We learn from M. Gueshoff that M. Sazonoff had wired to Sofia on November 9 that Serbia must not be allowed to seek any territorial acquisitions on the Adriatic coast $^{1}$; but M. Gueshoff is silent as to any orders respecting Bulgarian access to the Bosphorus. The explanation must be sought elsewhere. Before we seek it we must turn to the achievements of Serbia.

Serbia's Hardly less astonishing, though on a smaller scale than part. the victories of Butgaria, were the equally rapid victories of the Serbs. On October 18 King Peter issued a proclamation to his troops declaring that the object of the Balkan League was to secure the welfare and liberty of Macedonia, and promising that Serbia would bring liberty, fraternity, and equality to the Christian and Moslem Serbs and Albanians with whom for thirteen centuries Serbia had had a common existence. Splendidly did the army vindicate King Peter's words. The Serbian forces, which were about 150,000 strong, were divided into three armies. One marched into Novi-Bazar, and, after a week's stiff fighting, cleared the Turks out of that no man's land. Having done that a portion of this army was dispatched down the Drin valley into Albania.

A second army occupied Pristina (October 23), while the third and main army, under the crown prince, made for Uskub. The Turks barred the way to the ancient capital of the Serbs by the occupation of Kumanovo, and there on the $22 \mathrm{nd}$ of October the two armies met. Three days of fierce fighting resulted in a complete victory for the Serbs. At last, on that historic field, the stain of Kossovo was wiped out. Patiently, for five hundred years, the Serbs had waited for the hour of revenge; that it would some day come they had never doubted; at last it was achieved. Two days later the Turks evacnated Uskub, and on October 26 the Serbs entered their ancient capital in triumph. Now came the supreme question. Should they press for the Aegean or the Adriatic? Europe had already announced its decision that under no circumstances should Serbia be allowed to

1 Gueshoff, op. cit., p. 63. 
retain any part of the Albanian coast. But was the will of diplomacy to prevail against the intoxicating military successes of the Balkan League?

Forty thousand Serbian troops were sent off to Adrianople to encourage their Bulgarian allies to a more vigorous offensive in Thrace, and help was also sent in Greek vessels to the Montenegrins, who were making slow progress against Scutari. Meanwhile the main body of the Serbs flung themselves upon the Turks at Prilep and thrust them back upon Monastir; from Monastir they drove them in utter confusion upon the guns of the advancing Greeks. The capture of Ochrida followed upon that of Monastir.

Serbia, having thus cleared the Sanjak of Novi-Bazar, Old Serbia, and western Macedonia, now turned its attention to Albania, and, with the aid of the Montenegrins, ocenpied Alessio and Durazzo before the end of Norember.

On December 3 the belligerents accepted an armistice Armistice proposed to them by the Powers, but from this arnistice the Greeks were, at the instance of the League, expressly excluded. The League could not afford to permit the activity of the Greek fleet in the Aegean to be, even temporarily, interrupted.

On land the part played by the Greeks, though from their The own standpoint immensely significant, was, in a military sense, Greck $^{\text {prt. }}$ relatively small. They fought an engagement at Elassona on October 19, and they occupied Grevena on the 31st and Prevesa on November 3. Their march towards Salonica was not indeed seriously contested by the Turks. Whether the withdrawal of the latter was due, as was at the time widely believed, to the advice tendered at Constantinople by the German ambassador, or whether the Turks were actuated exclusively by military considerations cannot with certainty be determined. The Turks offered some resistance at Yenidje on November 3, but they were completely routed, and three days later the Greeks entered Salonica.

If the Turks were indeed animated by a desire to estrange Salonica. the Bulgarians and the Greeks their manœurre was only executed just in time. For hardly had the Greck troops occupied Salonica when the Bulgarians arrived at the gates. 
Only after some demur did the Greeks allow their allies to enter the city, and from the outset they made it abundantly clear not only that they had themselves come to Salonica to stay but that they would permit no divided authority in the city which they claimed exclusively as their own. From the outset a Greek governor-general was in command, and the whole administration was in the hands of Greeks. In order still further to emphasize the situation, the King of the Hellenes and his court transferred themselves to Salonica.

The Meanwhile, at sea, the Greek fleet had, from the outset (treek fleet.

The

Adriatic coast. of war, established a complete supremacy: practically all the islands, except Cyprus and those which were actually in the occupation of Italy, passed without resistance into Greek hands. But Greece looked beyond the Aegean to the Adriatic. On December 3 the Greek fleet shelled Avlona, where its appearance caused grave concern both to Italy and to Austria-Hungary. Both Powers firmly intimated to Greece that though she might bombard Avlona she would not be permitted to retain it as a naval base.

Austria-Hungary had already made similar representations to Serbia in respect to the northern Albanian ports. It was obvious, therefore, that the forces of European diplomacy were beginning to operate. But the military situation of the Turks was desperate, and when the armistice was concluded on December 3 the Turks remained in possession only of Constantinople, Adrianople, Janina, and the Albanian Scutari. Outside the walls of those four cities they no longer held a foot of ground in Europe. 'The Lon- The centre of interest was now transferred, however, from ferences, Dec. 1912 the Balkans to London. Ten days after the conclusion of the armistice delegates from the belligerent States met in Jan. 1913. London. Side by side with the conference of delegates sat a second conference composed of the ambassadors accredited to the Court of St James's by the five Great Powers. The latter sat continuously under the presidency of the English Foreign Secretary from December 1912 down to August 1913. ${ }^{1}$

1 The reasons for this arrangement and the course of negotiations were 
From the outset the negotiations betwcen the representatives of the Ottoman Turk and those of the Balkan allies were exceedingly diffieult, and nothing but the tact and patience of Sir Edward Grey, combined with an occasional plain and strong word in season, could have kept the negotiator's together so long.

Turkey held out for the retention of the four cities which at the moment represented all that was left of the Ottoman Empire in Europe: Constantinople, Adrianople, Seutari, and Janina. As to the first there was no dispute; the main obstacle to peace was presented by the question of Adrianople and Thrace. A secondary diffieulty arose from the claim put in by Roumania to a readjustment of the boundaries of the Dobrudja as compensation for her neutrality. By January 22, 1913, both difficulties had been more or less overeome, and Turkey had agreed to aceept as the boundary between herself and Bulgaria a line drawn from Midia on the Black Sea to Enos at the mouth of the Maritza on the Aegean, thus surrendering Adrianople.

But Europe was reckoning without the Young Turks. On Enver's January 23 Enver Bey, at the head of a military deputa- coup d'étut, tion, burst into the chamber where the Council was sitting Jan. 29 . in Constantinople, denounced the proposal to surrender Adrianople, insisted on the resignation of the grand vizier, Kiamil Pasha, and shot Nazim Pasha the Turkish commanderin-chief.

Enver's coup d'état brought the London negotiations to an abrupt conclusion, and on February 1 the Conference broke up. Mahmud Sherket Pasha, the hero of 1909, replaced Kiamil as grand vizier; but the Young Turks proved themselves quite incapable of redeeming the military situation. It was indeed beyond redemption.

The armistice was denounced by the allies on January 29, Resumpand on February 4 the Bulgarians resumed the attack upon war. Adrianople. Not, however, until Narch 26 did the great fortress fall, and the Bulgarians had to share the eredit of taking it with the Serbians. Meanwhile the Greeks had explained to the House of Commons hy Sir Edward Grey on August 12, 1913, in a speech of great historic importance.-Hansard, vol. Ivi, 1. 2283.

D d 2 
won a brilliant and resounding victory. On March 6 the great fortress of Janina, the lair of the 'Lion' and hitherto deemed impregnable, fell to their assault ; the Turkish garrison, 33,000 strong, became prisoners of war, and 200 guns were taken by the victor's. The completeness of the Greek victory did not, however, make for harmony among the allies, and it was of sinister import that the day which witnessed the entry of the Greeks into Janina was marked by an encounter of desperate and sanguinary character between Greek and Bulgarian troops near Salonica.

Scutari. Adrianople and Janina gone, there remained to the Turks, outside the walls of Constantinople, nothing but Scutari in Albania. Already (March 2) the Porte had made a formal request to the Powers for mediation. On the 16th the Balkan League accepted 'in principle' the proposed mediation of the Powers, but stipulated for the cession of Scutari and all the Aegean islands as well as the payment of an indemnity.

Albania. Scutari was indeed the key of the diplomatic situation. Montenegro, the tiny State on whose behalf Mr. Gladstone had evoked so much.passionate sympathy in England, was determined to take Scutari whatever the decision of the European Powers. The latter had indeed decided, as far back as December, 1912, that Scutari must remain in the hands of Albania. The latter was to be an autonomous State under a prince selected by the Great Powers, assisted by an international commission of control and a gendarmerie under the command of officers drawn from one of the smaller neutral States.

Whence came this interest in the affairs of Albania? On the part of Austria and Italy it was no new thing. An autonomous Albania was an essential feature of Count Aerenthal's Balkan policy, and upon this point Austria-Hungary was supported by Italy and Russia. Italy's motives are obvious and have been already explained; those of Russia are more obscure.

Germany There was, however, another Power supremely interested, and the

Balkan though in a different way, in the future of Albania. Nothing League. which concerned the future position of Austria-Hungary on 
the Adriatic could be a matter of indifference to Berlin. But Germany had a further interest in the matter. If the argument of the preceding chapter be accepted as sound, little pains are needed to explain the action of Germany. The Young Turk revolution of 1908 had threatened to dissipate the carefully garnered influence of Germany at Constantinople. That danger had, however, been skilfully overcome. Abdul Hamid himself had not been more esteemed at Berlin than was now Enver Bey. Far more serious, however, was the set back to German ambitions threatened by the formation of the Balkan League. Still more by its rapid and astonishing victories in the autumn of 1912.

Hardly had the League entered upon the path of victory when Serbia received a solemn warning that she would not be permitted to retain any ports upon the Adriatic. This was a cruel blow to her natural ambitions ; but it was something more. It was a diplomatic move of Machiavellian subtlety and skill. If Serbia could be effectually headed off from the Adriatic; if the eastern boundaries of an autonomous Albania could be drawn on sufficiently generous lines, Serbia would not only be deprived of some of the accessions contemplated in her partition treaty with Bulgaria (March, 1912), ${ }^{1}$ but would be compelled to seek access to the sea on the shores of the Aegean instead of the Adriatic. A conflict of interests between Serbia and Bulgaria would almost certainly ensue in Macedonia; conflict between Serbia and Greece was not improbable. Thus would the solidarity of the Balkan League, by far the most formidable obstacle which had ever intervened between Mitteleuropa and the Mediterranean, be effectively broken. How far this motive did consciously inspire the policy of Germany and AustriaHungary at this momentous crisis it is not yet possible to say with certainty; but the subsequent course of crents has rendered the inference almost irresistible. In the light of those events, the words of Sir Edward Grey on August 12, 1913 , his congratulations upon the achievement of an autonomous Albania, have a ring either of irony or of innocence.

1 Supra, p. 394. 
But to return to Scutari. With or without the leare of the Powers Montenegro was determined to have it, and on February 6, 1912, the town was attacked with a force of 50,000 men, of whom Serbia contributed 12,000-14,000. But Scutari resisted every assault and inflicted heary losses upon its assailants. On March 24 the Montenegrins so far yielded to the representations of the Powers as to allow the civil population to leave the town, but as for the possession of the town and the adjoining territory that was a matter between Montenegro and the Porte, with which the Powers had no right to interfere.

Fall of The Powers, however, were not to be denied. On April 4 Scutari. an international squadron appeared off Antivari and proceeded to blockade the Montenegrin coast between Antivari and the Drin ricer. Still Montenegro maintained its defiance, and at last, after serere fighting, Scutari was starved into surrender (April 22). The Turkish garrison, under Essad Pasha, was allowed to march out with all the honours of war and to take with them their arms and stores, and on April 26 Prince Danilo, Crown Prince of Montenegro, entered the town in triumph. But his triumph was brief. The Powers insisted that the town should be surrendered to them; King Peter at last yielded, and Scutari was taken orer by an international force landed from the warships. The pressure thus put upon Montenegro in the interests of an autonomous Albania had an ugly appearance at the time, and subsequent events did not tend to render it less unattractive. To these events we shall refer presently. Attention must for the moment be concentrated upon Constantinople. Treaty of A few days before the fall of Scutari an armistice was May 30 , 1913. concluded between Turkey and the Balkan League, and the next day (April 21) the League agreed to accept unconditionally the mediation of the Powers, but reserved the right to discuss with the Powers the questions as to the frontiers of Thrace and Albania, and the future of the Aegean islands. Negotiations were accordingly reopened in London on May 20, and on the 30th the Treaty of London was signed. Ererything beyond the Enos-Midia line and the island of C'rete was ceded by the Porte to the Balkan allies, while the 
question of Albania and of the islands was left in the hands of the Powers.

The European Concert congratulated itself upon a remarkable achievement: the problem which for centuries had confronted Europe had been solved; the clouds which had threatened the peace of Europe had been dissipated; the end of the Ottoman Empire, long foreseen and long dreaded as the certain prelude to Armageddon, had come, and come in the best possible way; young nations of high promise had been brought to the birth; the older nations were united, as never before, in bonds of amity and mutual goodwill. Sinch was the jubilant tone of contemporary criticism.

Yet in the midst of jubilation there sounded notes of warn- The ricing and of alarm. Nor were they, unfortunately, without tors and justification. Already ominous signs of profound disagreement between the rictors as to the disposal of the spoils were apparent. As to that, nothing whaterer had been said in the Treaty of London. Whether the temper which already prevailed at Sofia, Belgrade, and Athens would have permitted interference is very doubtful : the Treaty of London did not attempt it. In effect the belauded treaty had done nothing but affix the common seal of Europe to a deed for the winding-up of the affairs of the Ottoman Empire in Europe. How the assets were to be distributed among the creditors did not concern the official receivers. Yet here lay the real crux of the situation.

The problem was in fact intensified by the sudden collapse of the Ottoman Empire and the unexpected success achiered by each of the allies. The Balkan League might have held together if it had been compelled to fight rather harder for its victory. Greece and Serbia in particular were intoxicated by a success far greater than they could have dared to anticipate. Bulgaria's success had been not less emphatic; but it had been achiered at greater cost, and in the wrong direction. The Bulgarians were undisputed masters of Thrace; but it was not for Thrace they had gone to war. The Greeks were in Salonica; the Serbs in Uskub and Monastir. For the victorious and war-wom Bulgarians the situation was, therefore, peculiarly exasperating. 
Dissen- Bulgaria's exasperation was Germany's opportunity. To sions Allies.
among the fan the fires of Bulgarian jealonsy against her allies was not
Aermany spared no effort in the performance of this sinister task. The immediate sequel will demonstrate the measure of her success. Bulgaria and Greece had appointed a joint commission to delimit their frontiers in Macedonia on April 7 ; it broke up without reaching an agreement on May 9. Roumania, too, was tugging at Bulgaria in regard to a rectification of the frontiers of the Dobrudja. On May 7 an agreement was signed by which Bulgaria assented to the cession of Silistria and its fortifications, together with a strip of the Dobrudja. Notwithstanding this agreement a military convention was concluded between Serbia, Greece, and Roumania, and on May 28 Serbia demanded that the treaty of partition concluded between herself and Bulgaria in March, 1912, should be so amended as to compensate her for the loss of territory due to the formation of an autonomous Albania. The demand was not in itself umreasonable. It was impossible to deny that the formation of an autonomous Albania had profoundly modified the situation, and had modified it to the detriment of Serbia in a way which had not been foreseen by either party to the treaty of March, 1912. On the other hand the demand was peculiarly irritating to Bulgaria, who found herself bowed out of Macedonia by Greece.

Interven- The situation was highly critical when, on June 8, the Tsar tion of the Tsar Nicholas. of Russia offered his services as arbitrator. Taking advantage of the position assigned to and accepted by him in the treaty of March, 1912, the Tsar appealed to the Kings of Serbia and Bulgaria not to 'dim the glory they had earned in common' by a fratricidal war, but to turn to Russia for the settlement of their differences; and, at the same time, he solemnly warned them that 'the State which begins war would be held responsible before the Slav cause', and he reserved to himsclf 'all liberty as to the attitude which Russia will adopt in regard to the results of such a criminal struggle'.

Serbia accepted the Tsar's offer ; but Bulgaria, though not actually declining it, made various conditions ; attributed all the blame for the dispute to Serbia, and reminded the Tsar 
that Russia had long ago acknowledged the right of Bulgaria to protect the Bulgarians of Macedonia.

Events were plainly hurrying to a catastrophe. Greece The War had made up its mind to fight Bulgaria, if necessary, for of l'artiSalonica; Serbia demanded aceess to the Aegean. 'Bulgaria is washed by two seas and grudges Serbia a single port.' So ran the order of the day issued at Belgrade on July 1. Meanwhile, on June 2, Greece and Serbia concluded an offensive and defensive alliance against Bulgaria for ten years. Serbia was to be allowed to retain Monastir. The Greeks dirl not like the surrender of a town which they regarded (as did Bulgaria) as their own in reversion, but Venizelos persuaded them to the sacrifice, on the ground that unless they made it they might lose Salonica. Bulgaria, in order to detach Greece from Serbia, offered her the guarantee of Salonica, but M. Venizelos had already giren his word to Serbia, and he was not prepared to break it.

On the night of June 29 the rupture occurred. Acting, according to M. Gueshoff, ${ }^{1}$ on an order from head-quarters, the Bulgarians attacked their Serbian allies. M. Gueshoff himself describes it as a 'criminal act', but declares that the military authorities were solely responsible for it; that the Cabinet was ignorant that the order had been issued, and that as soon as they learnt of it they begged the Tsar to intervene. We cannot yet test the truth of this statement, but M. Gueshoff is a man of honour, and it is notorious that the army was in a warlike mood. But wherever the fault lay the allies were now at each other's throats ; the war of partition had begun.

It lasted only a month ; but the record of that month is full both of horror and of interest. The Serbs and Greeks, attacking in turn with great ferocity, drore the Bulgarians before them. Serbia wiped out the stain of Slivnitza; the Greeks, who had not had any real chance for the display of military qualities in the earlier war, more than redeemed the honour tarnished in 1897. In the course of their retreat the Bulgarians inflicted hideous cruelties upon the Greek population of Macedonia; the Greeks, in their adrance, retaliated in 
CHAP.

kind. But the Bulgarians had not only to face Serbs and Greeks. On July 9 Roumania intervened, seized Silistria, and marched on Sofia. Bulgaria could offer no resistance and wisely bowed to the inevitable. Three days later (July 12) the Turks came in, recaptured Adrianople (July 20), and marched towards Tivnovo. Bulgaria had the effrontery to appeal to the Powers against the infraction of the Treaty of London ; King Carol of Roumania urged his allies to stay their hands; on July 31 an armistice was concluded, and on August 10 peace was signed at Bucharest. Treaty of Bulgaria, the aggressor, was beaten to the earth and could rest, Ang. not hope for mercy. By the Treaty of Bucharest she lost to 10, 1913. Roumania a large strip of the Dobrudja, including the important fortress of Silistria ; she lost also the greater part of Macedonia which she would almost certainly have received under the Tsar's award, and had to content herself with a narrow strip giving access to the Aegean at the inferior port of Dedeagatch. Serbia obtained central Macedonia, including Ochrida and Monastir, Kossovo, and the eastern half of Novi-Bazar ; the western half going to Montenegro. Greece obtained Epirus, southern Macedonia, Salonica, and the seaboard as far east as the Mesta, thus including Kavala.

Bulgaria and T'urkey.
But the cup of Bulgaria's humiliation was not yet full. She had still to settle with the Porte, and peace was not actually signed between them until September 29. The quarrel between the allies put the Ottoman Empire on its feet again. The Turks were indeed restricted to the EnosMidia line, but lines do not always run straight even in Thrace, and the new line was so drawn as to leave the Ottoman Empire in possession of Adrianople, Demotica, and Kirk Kilisse. Having been compelled to surrender a large part of Macedonia to her allies, Bulgaria now lost Thrace as well. Even the control of the railway leading to her poor acquisition on the Aegean was denied to her. ${ }^{1}$ The terms dictated by the Porte were hard, and Bulgaria made an attempt by an appeal to the Powers to evade payment of the bill she had run up. The attempt though natural was futile. The

1 Gibbons, op. cit., p. 325. 
Powers did go so far as to present a joint note to the Porte, urging the fulfilment of the Treaty of London, but the Sultan was well aware that the Powers would never employ force to compel Turkey to satisfy a defeated and discredited Bulgaria, and the joint note was ignored.

For the loss of Adrianople, Demotica, and Kirk Kilisse, Bulgaria therefore, Bulgaria blamed the Powers in general and and EngEngland in particular. It was believed at Sofia that England was induced to consent to a variation of the Enos-Midia line by Turkish promises in regard to the Bagdad railway. There was no ground for the suspicion, but it was one of several factors which influenced the decision of Bulgaria in 1915.

We may now briefly summarize the results of the two Results of Balkan Wars. The two wars were estimated to have cost, the Balin money, about $£ 245,000,000$, and in killed and wounded, 348,000 . The heariest loss in both eategories fell upon Bulgaria, who sacrificed 140,000 men and spent $\mathfrak{£} 90,000,000$; the Turks, 100,000 men and $£ 80,000,000$; the Serbians 70,000 , and $£ 50,000,000$; while the Greeks, whose gains were by far the most conspicuous, acquired them at the relatively trifling cost of 30,000 men and $\pm 25,000,000$.

In territory and population Turkey was the only loser. Before the war her European population was estimated to be $6,130,200$, and her area 65,350 square miles. Of population she lost 4,239,200, and she was left with only 10,882 square miles of territory. Greece was the largest gainer, increasing her population from 2,666,000 to 4,363,000, and her area from 25,014 to 41,933 square miles. Serbia increased her population from just under three millions to four and a half, and nearly doubled her territory, increasing it from 18,650 to 33,891 square miles. Roumania added 286,000 to a population which was and is the largest in the Balkans, now amounting to about seren and a half millions, and gained 2,687 square miles of territory, entirely, of course, at the expense of Bulgaria. The net gains of Bulgaria were only 125,490 in population and 9,663 square miles; while Montenegro raised her population from 250,000 to 480,000 , and her area from 3,474 to 5,603 square miles. ${ }^{1}$

1 Robertson and Bartholomew, Historical Atlas, p. 24. 
The significance of the changes effected in the map of 'Turkey in Europe' camnot, however, be measured solely by statistics.

Greece. The settlement effected in the Treaty of Bucharest was neither satisfactory nor complete. Of the recent belligerents Greece had most cause for satisfaction. To the north-east her territorial gains were not only enormous in extent, but of the highest commercial and strategic importance. The acquisition of Salonica was in itself a veritable triumph for the Greek cause, and Greece would have been well advised to be content with it. The insistence upon Kavala, whatever her ethnographic claims may have been, is now recognized as a political blunder. To have conceded Kavala to Bulgaria would have gone some way towards satisfying the legitimate claims of the latter in Macedonia, without in any way imperilling the position of Greece. If Greece had followed the sage advice of Venizelos the concession would have been made. To her undoing she preferred to support the hotheaded demands of the soldiers and the king. On the northwest, Greece acquired the greater part of Epirus, including. the great fortress of Janina, but she was still unsatisfied. For many months she continued to urge her claims to portions of southern Albania, assigned by the Powers to the new autonomous State. But to press them would have brought Greece into conflict with Italy. 'Italy', said the Marquis di San Giuliano, 'will even go to the length of war to prevent Greece occupying Valona ; on this point her decision is irrevocable.' 1 On that side Greece, therefore, remained unsatisfied. There remained the question of the islands. Of these, incomparably the most important was, of course, Crete. Crete was definitively assigned to Greece, and on December 14, 1913, it was formally taken over by King Constantine, accompanied by the crown prince and the Prime Minister, M. Venizelos. Thus was one long chapter closed. The question as to the rest of the islands was reserved to the Powers, who ultimately awarded to Greece all the islands of which the Porte could dispose, except Imbros and Tenedos,

1 Kerofilas, Venizelos, p. 155. 
which were regarded as essential for the safeguarding of the entrance to the Dardanelles, and were, therefore, left to Turkey. The Sporades, including Rhodes, remained in the occupation of Italy. Greece, therefore, had reason for profound satisfaction. Not that even for her the settlement was complete. Some 300,000 Greeks are said to remain under Bulgarian rule in Thrace and eastern Macedonia, while in the Ottoman Empire-mainly, of course, on the Asiatic side of the Straits-Greece still claims some 3,000,000 ' unredeemed' co-nationals. But no settlement can achieve ethnographic completeness, least of all one which is concerned with the Balkans, and Greece had little cause to quarrel with that of 1913.

Nor had Roumania. In proportion to her sacrifices her Roumagains were considerable, but for the satisfaction of her larger nia. claims the Balkan Wars afforded no opportunity. The ' mmredeemed' Roumanians are the subjects either of AustriaHungary or of Russia. Transylvania, the Bukovina, and Bessarabia are the prorinces to which, in any large settlement on ethnographic lines, Roumania will be able to prefer a strong claim. But the time is not yet.

Of Bulgaria's position in 1913 it is not, at the moment, ${ }^{1}$ Bulgaria. easy to write with detachment and impartiality. Bulgaria is at present fighting on the side of the enemies of Great Britain. Whether she would be found in those ranks if the diplomacy of the Quadruple Entente, and in particular of England, had been more skilful, is a question which it is not, at the moment, possible to answer. Wherever the fault may lie Bulgaria is to-day in the enemy camp. Moreover, the misfortunes of Bulgaria in 1913 were largely of her own making, not the less so if her shrewd German lking was pushed on to the destruction of his country by subtle suggestions from Vienna and Berlin. When the Treaty of London was signed in May fate seemed to hold for Bulgaria the promise of a brilliant future. Despite the secular hostility of the Greeks and the rivalry of the Latins, Bulgaria was then first favourite for the hegemony of the Balkans. 
The Bulgarians lacked some of the cultural qualifications of their neighbours; they were the latest comers into Balkan society, but they had given proof of a virile and progressive temper and were advancing rapidly in the arts of both peace and war. Then suddenly, owing, if not solely to their own intemperate folly, then to their inability to resist subtle temptation or to restrain the impatience of their co-nationals, they flung away in a short month the great position secured to them by the patient labours of a generation. Had they but been able to resist provocation and to await the award of the Russian Tsar, the greater part of central as well as eastern Macedonia must have fallen to them. As it was, they got an area relatively circumscribed, with a wretched coast-line bounded by the Mesta, and in Dedeagatch a miserable apology for an Aegean port; above all they lost the coveted districts of Ochrida and Monastir. The impartial judgement of history will probably incline to the view that in defining so narrowly the share of Bulgaria, Greece and Serbia alike showed short-sightedness and parsimony. Even on the admission of Philhellenists Greece blundered badly in pressing her claims against Bulgaria so far. The latter ought at least to have been allowed a wider outlet on the Aegean littoral with Kavala as a port. Nothing less could reconcile Bulgaria to the retention of Salonica by Greece.

Serbia. Serbia, too, showed herself lacking in prudent generosity. But while Greece was without excuse Serbia was not. What was the Serbian case? It may be stated in the words of the general order issued by King Peter to his troops on the eve of the second war (July 1, 1913). 'The Bulgarians, our allies of yesterday, with whom we fought side by side, whom as true brothers we helped with all our heart, watering their Adrianople with our blood, will not let us take the Macedonian districts that we won at the price of such sacrifices. Bulgaria doubled her territory in our common warfare, and will not let Serbia have land not half the size, neither the birthplace of our hero king, Marco, nor Monastir, where you covered yourself with glory and pursued the last Turkish troops sent against you. Bulgaria is washed by two seas, and grudges Serbia a single port. Serbia and her 
makers-the Serbian army-cannot and must not permit this.' 1

The gains of Serbia were, as we have seen, very considerable. The division of Novi-Bazar between herself and Montenegro brought her into immediate contact with the Southern Slavs of the Black Mountains, while the aequisition of Old Serbia and central Macedonia earried her territory southwards towards the Aegean. But Serbia's crucial problem was not solved. She was still a land-locked country; deprived by the subtle diplomacy of the German Powers of her natural access to the Aegean, and pushed by them into immediate conflict with the Bulgarians, perhaps into ultimate conflict with Greece. Disappointed of her dearest ambition, flushed with victory, duped by interested advice, Serbia can hardly be blamed for having inflicted humiliation upon Bulgaria, and for having yielded to the temptation of unexpected territorial acquisitions.

Montenegro shared both the success and the disappoint-Montement of her kinsmen, now for the first time her neighbours. ${ }^{\text {negro. }}$ To Scutari Montenegro could advance no claims consistent with the principles either of nationality or of ecelesiastical affinity. But King Nicholas's disappointment at being deprived of it was acute, and was hardly compensated by the acquisition of the western half of Novi-Bazar. His position as regards seaboard was less desperate than that of Serbia, but he too had an account to settle with the European Concert.

To have kept the harmony of that Concert unbroken was The a very remarkable achievement, and the credit of it belongs Powers primarily to the English Foreign Secretary. Whether the Albania. harmony was worth the trouble needed to preserve it is an open question. There are those who would have preferred to see it broken, if necessary, at the moment when the German Powers vetoed the access of the Serbs to the Adriatic. It must not, however, be forgotten that this masterpiece of German diplomacy could hardly have been achiered had it not appeared to coincide with the dominant dogma of English policy in the Near East, the principle of nationality. Mace-

${ }^{1}$ Gueshoff, op. cit., p. 102. 
donian autonomy had so long been the watchword of a group of English politicians and publicists that little pains were needed to excite them to enthusiasm on behalf of an autonomous Albania.

Albania. Macedonia, as we have seen, was a hard nut to crack. Albania was, in a sense, even harder. That the idea of autonomy was seductive is undeniable. Such a solution offered obvious adrantages. It might stifle the incipient pretensions of Italy and Austria-Hungary ; it might arrest the inconrenient claims of Greece upon 'northern Epirus' ; it might interpose a powerful barrier between the Southern Slars and the Adriatic; it might, above all, repair the havoc which the formation of the Balkan alliance had wrought in German plans in regard to the Near East. Nor was it the least of its advantages that it could be commended, without excessive explanation of details, by democratic ministers to the progressive democracies of Western Europe.

Of the conditions which really prevailed in Albania little was or is accurately known. But it was decreed that it should be autonomous, and on November 23 Prince William of Wied, a German prince, a Prussian soldier, a nephew of the Queen of Roumania, was selected for the difficult task of ruling orer the wild highlanders of Albania. On March 7, 1914, he arrived at Durazzo, where he was welcomed by Essad Pasha, the defender of Scutari, and himself an aspirant to the crown. Prince William of Wied never had a chance of making good in his new principality. The ambitious disloyalty of Essad Pasha; the turbulence of the Albanian tribesmen, among whom there was entire lack of coherence or of unity ; the intrigues of more than one interested Power, rendered his position from the first impossible. The prince and his family were compelled to take refuge temporarily on an Italian warship on May 24, and in September they left the country. The government then fell into the hands of a son of the ex-Sultan Abdul Hamid, Bushan Eddin Effendi, who appointed Essad Pasha grand vizier and commander-inchief. When the European War broke out no central authority existed in Albania. The authority of Essad Pasha was recognized at Durazzo; the Greeks took possession of 
southern Albania or northern Epirus; the Italians promptly occupied Valona. For the rest there were as many rulers in Albania as there are tribes.

Besides Albania two other questions were left outstanding Armenia. after the Peace of Bucharest. The settlement of the Aegean islands has already been described. That of Armenia demands a few words. If 'autonomy' be a word to conjure with in regard to Albania, why not also in regard to Armenia? But the former has at least one advantage over the latter. Albania exists as a geographical entity; Armenia does not. Nor is there, as Mr. Hogarth has pointed out, any 'geographical unit of the Ottoman area in which Armenians are the majority. If they cluster more thickly in the vilasets of Angora, Sivas, Erzeroum, Kharput, and Van, i. e. in easternmost Asia Minor, than elsewhere, ... they are consistently a minority in any large administrative district '. $\quad$ Where, then, as he pertinently asks, is it possible to constitute an autonomous Armenia? The question remains unanswered. In February, 1914, the Porte agreed to admit to the Ottoman Parliament seventy Armenian deputies, who should be nominated by the Armenian Patriarch, and to carry out various administrative and judicial reforms in the Anatolian vilayets inhabited largely by Armenians. But the outbreak of the European War afforded the Ottoman Government a chance of solving a secular problem by other and more congenial methods. Massacres of Armenian Christians have been frequent in the past; but the Turks have been obliged to stay their hands by the intervention of the Powers. That interference was no longer to be feared. An unprecedented opportunity presented itself to the Turks. Of that opportunity they are believed to have made full use. A policy of extermination was deliberately adopted, and has been consistently pursued. It is at least simpler than autonomy.

For the conclusion of peace atBucharest one Power in Europe Mitteltook special credit to itself. No sooner was it signed than the europa Emperor William telegraphed to his cousin, King Carol of Peace of Roumania, his hearty congratulations upon the successful Bucha-

1 The Balkans, p. 384. 
issue of his ' wise and truly statesmanlike policy'. 'I rejoice', he added, 'at our mutual co-operation in the cause of peace.' Shortly afterwards King Constantine of Greece received at Potsdam, from the emperor's own hands, the bâton of a Field-Marshal in the Prussian army.

If the Kaiser had been active in the cause of peace his august ally at Vienna had done his utmost to enlarge the area of war. On August 9, 1913, the day before the signature of peace at Bucharest, Austria-Hungary communicated to Italy and to Germany 'her intention of taking action against Serbia, and defined such action as defensive, hoping to bring into operation the casus foederis of the Triple Alliance'.' Italy refused to recognize the proposed aggression of AustriaHungary against Serbia as a casus foederis. Germany also exercised a restraining influence upon her ally, and the attack was consequently postponed; but only for eleven months. Germany was not quite ready : on November 22, however, II. Jules Cambon, the French ambassador at Berlin, reported that the German Emperor had ceased to be 'the champion of peace against the warlike tendencies of certain parties in Germany, and had come to think that war with France was inevitable'."

France, therefore, would have to be fought: but the eyes of the German Powers, and more particularly of AustriaHungary, were fixed not upon the west but upon the southeast.

Attack Serbia had committed two unpardonable crines: she had upon Serbia. strengthened the barrier between Austria-Hungary and Salonica; and she had enormously enhanced her own prestige as the representative of Jugo-Slav aspirations. Serbia, therefore, must be annihilated.

But Serbia did not stand alone. By her side were Greece and Roumania. The association of these three Balkan States appeared to be peculiarly menacing to the Habsburg Empire. Greece, firmly planted in Salonica, was a fatal obstacle to the

1 Telegram from the Marquis di San Giuliano to Signor Giolitti : quoted by the latter in the Italian Chamber, Dec. 5, 1914 (Collected Diplomatic Documents, p. 401).

- Collected Diplomatic Documents, p. 142. 
hopes so long cherished by Austria. The prestige acquired by Serbia undoubtedly tended to create unrest among the Slavonic peoples still subject to the Dual Monarehy. And if Jugo-Slav enthusiasm threatened the integrity of the Dual Monarchy upon one side, the ambitions of a Greater Roumania threatened it upon another. The visit of the Tsar Nicholas to Constanza in the spring of 1914 was interpreted in Vienna as a recognition of this fact, and as an indication of a rapmochement between St. Petersburg and Bucharest.

If, therefore, the menace presented to 'Central Europe' by The the first Balkan League had been effectually dissipated, the Ferman menace of a second Balkan League remained. One crumb and the of consolation the second war had, however, brought to the Ottoman German Power's : the vitality and power of recuperation manifested by the Ottoman Turk. So long as the Turks remained in Constantinople there was no reason for despair. The key to German policy was to be found upon the shores of the Bosphorus.

Constantinople and Salonica were then the dual objectives of Austro-German ambition. Across the path to both of them lay Belgrade. At all hazards the Power which commanded Belgrade must be crushed.

How was it to be done? The military problem was, of course, easy of solution ; not so the diplomatic. The time has not yet come for unrarelling the tangled skein of erents which will render memorable the history of the months which preceded the outbreak of the Great European War in August, 1914. Attention must, however, be drawn, briefly and simply, to certain unquestionable facts which bear directly upon the theme of this book.

On June 12, 1914, the German Emperor, accompanied by The Grand Admiral von Tirpitz, risited the Archduke Franz $\underset{\text { Emperor }}{\text { German }}$ Ferdinand and his wife, the Duchess of Hohenberg, at their and the castle of Konopisht in Bohemia. What passed between the Archaugust visitor and his hosts must be matter for conjecture. A responsible writer has, however, given currency to a story that the object of the Emperor William's visit was to provide an inheritance for the two sons of the Duchess of Hohenberg, 
and at the same time to arrange for the eventual absorption of the German lands of the House of Habsburg into the German Empire. ${ }^{1}$

The Archduke Franz Ferdinand was heir to the Dual Monarchy, but his marriage was morganatic, and his children were portionless. Both he and his wife were the objects of incessant intrigue alike at Vienna and at Buda-Pesth, where the archduke was credited with pro-Slav sympathies.

Assassina- On June 28 the archduke and his wife were assassinated tion of the in the streets of the Bosnian capital, Serajevo. None of the Franz Ferdinand, June 28, 1914. usual precautions for the safety of royal visitors had been taken. On the contrary, the police of Serajevo received orders that such precautions were unnecessary, as the military authorities were to be responsible for all arrangements. As the inperial visitors drove from the station a bomb was thrown at the carriage by the son of an Austrian police official. On arriving at the Town Hall the archduke is said to have exclaimed: 'Now I know why Count Tisza advised me to postpone my journey.' ${ }^{2}$ Still no precautions were taken to safeguard the archduke, though the town was known to be full of conspirators. On their way from the Town Hall to the hospital, the archduke and his wife were mortally wounded by three shots deliberately fired by a second assassin. It is reported that the archduke, in his last moments, exclaimed: "The fellow will get the Golden. Cross of Merit for this.' True or not the story points to a current suspicion. The assassin though not a Serbian subject was a Serb, but by whom was he employed? No steps were taken to punish those who had so grossly neglected the duty of guarding the archduke's person, though the canaille of Serajevo were let loose among the Serbs, while the Austrian police stood idly by. The funeral accorded to the archduke served to deepen the mystery attending his death. Prince Arthur of Connaught was appointed to represent King George, but he did not leave London. The

1 Cf. The Pact of Konopisht, by H. Wickham Steed, Nineteenth Century and After, February, 1916, but other stories are current.

2 Stated by Mr. Steed on the authority of The Times correspondent at Serajero. 
German Emperor announced his intention of being present, but when the time came he was indisposed. The funeral of the heir to the Dual Monarchy was 'private'. The satisfaction which prevailed in certain quarters in Vienna and Buda-Pesth was hardly concealed.

Nevertheless, the Serbians were to be chastised for a Austrian dastardly crime planned in Belgrade. ${ }^{1}$ Accordingly, on UltimaJuly 23, the Austro-Hungarian Government addressed to Serbia, Serbia the following ultimatum :July 23 .

' On the 31st March, 1909, the Servian Minister in Vienna, on the instructions of the Servian Gorernment, made the following declaration to the Imperial and Royal Government :-

" "Servia recognizes that the fait accompli regarding Bosnia has not affected her rights, and consequently she will conform to the decisions that the Powers may take in eonformity with article 25 of the Treaty of Berlin. In deference to the advice of the Great Powers, Servia undertakes to renounce from now onwards the attitude of protest and opposition which she has adopted with regard to the annexation since last autumn. She undertakes, moreover, to modify the direction of her policy with regard to Austria-Hungary and to live in future on good neighbourly terms with the latter."

'The history of recent years, and in particular the painful events of the 28th June last, have shown the existence of a subversive movement with the object of detaching a part of the territories of Austria-Hungary from the Monarchy. The movement, which had its birth under the eye of the Servian Government, has gone so far as to make itself manifest on both sides of the Servian frontier in the shape of acts of terrorism and a series of outrages and murders.

' Far' from carrying out the formal undertakings contained in the declaration of the 31st March, 1909, the Royal Servian Government has done nothing to repress these movements. It has permitted the criminal machinations of various societies and associations directed against the Monarchy, and has tolerated unrestrained language on the part of the press, the glorification of the perpetrators of outrages, and the partici-

1 The Serbian Government challenged proof, never afforded, of its connivance in the crime. It also pointed out that it had previously offered to arrest the assassins, but the Austrian Government had deprecated the precautionary step. 
pation of officers and functionaries in subversive agitation. It. has permitted an unwholesome propaganda in public instruction; in short, it has permitted all manifestations of a nature to incite the Servian population to hatred of the Monarchy and contempt of its institutions.

'This culpable tolerance of the Royal Servian Government had not ceased at the moment when the events of the 28th June last proved its fatal consequences to the whole world.

'It results fiom the depositions and confessions of the criminal perpetrators of the outrage of the 28th June that the Serajevo assassinations were planned in Belgrade; that the arms and explosives with which the murderers were provided had been given to them by Servian officers and functionaries belonging to the Narodna Odbrana ; and finally, that the passage into Bosnia of the criminals and their arms was organized and effected by the chiefs of the Servian frontier service.

'The above-mentioned results of the magisterial investigation do not permit the Austro-Hungarian Government to pursue any longer the attitude of expectant forbearance which they have maintained for years in face of the machinations hatched in Belgrade, and thence propagated in the territories of the Monarchy. The results, on the contrary, impose on them the duty of putting an end to the intrigues which form a perpetual menace to the tranquillity of the Monarchy.

'To achieve this end the Imperial and Royal Government see themselves compelled to demand from the Royal Servian Government a formal assurance that they condemn this dangerous propaganda against the Monarchy; in other words, the whole series of tendencies, the ultimate aim of which is to detach from the Monarchy territories belonging to it, and that they undertake to suppress by every means this criminal and terrorist propaganda.

'In order to give a formal character to this undertaking the Royal Servian Government shall publish on the front page of their "Official Journal" of the 13/26 July the following declaration :-

" "The Royal Government of Servia condemn the propaganda directed against Austria-Hungary-i.e., the general tendency of which the final aim is to detach from the AustroHungarian Monarchy territories belonging to it, and they sincerely deplore the fatal consequences of these criminal proceedings.

" The Royal Gorernment regret that Servian officers and 
functionaries participated in the above-mentioned propaganda and thus compromised the good neighbourly relations to which the Royal Government were solemnly pledged by their declaration of the 31st March, 1909.

" "The Royal Government, who disapprove and repudiate all idea of interfering or attempting to interfere with the destinies of the inhabitants of any part whatsoever of Austria-Hungary, consider it their duty formally to wa'n officers and finctionaries, and the whole population of the kingdom, that henceforward they will proceed with the utmost rigour against persons who may be guilty of such machinations, which they will usc all their efforts to anticipate and suppress."

'This declaration shall simultaneously be communicated to the Royal army as an order of the day by His Majesty the King and shall be published in the "Official Bulletin" of the Army.

'The Royal Servian Government further undertake :

' 1 . To suppress any publication which incites to hatred and contempt of the Austro-Hungarian Monarchy and the general tendency of which is directed against its territorial integrity ;

'2. To dissolve immediately the society styled "Narodna Odbrana", to confiscate all its means of propaganda, and to proceed in the same manner against other societies and their branches in Servia which engage in propaganda against the Austro-Hungarian Monarchy. The Royal Government shall take the necessary measures to prevent the societies dissolved from continuing their activity under another name and form ;

' 3 . To eliminate without delay from public instruction in Servia, both as regards the teaching body and also as regards the methods of instruction, everything that serves, or might serve, to foment the propaganda against AustriaHungary ;

'4. To remove from the military service, and from the administration in general, all officers and functionaries guilty of propaganda against the Austro-Hungarian Monarchy whose names and deeds the Austro-Hungarian Government reserve to themselves the right of communicating to the Royal Government ;

' 5 . To accept the collaboration in Servia of representatives of the Austro-Hungarian Government for the suppression of the subversive movement directed against the territorial integrity of the Monarchy;

' 6 . To take judicial proceedings against accessories to the 
plot of the 28th June who are on Servian territory ; delegates of the Austro-Hungarian Government will take part in the investigation relating thereto ;

' 7. To proceed without delay to the arrest of Major Voija Tankositch and of the individual named Milan Ciganovitch, a Servian State employé, who have been compromised by the results of the magisterial inquiry at Serajevo ;

' 8 . To prevent by effective measures the co-operation of the Servian authorities in the illicit traffic in arms and explosives across the frontier, to dismiss and punish severely the officials of the frontier service at Schabatz and Ložnica guilty of having assisted the perpetrators of the Serajevo crime by facilitating their passage across the frontier;

'9. To furnish the Imperial and Royal Government with explanations regarding the unjustifiable utterances of high Servian officials, both in Servia and abroad, who, notwithstanding their official position, have not hesitated since the crime of the 28th June to express themselves in interviews in terms of hostility to the Austro-Hungarian Government; and, finally,

'10. To notify the Imperial and Royal Government without delay of the execution of the measures comprised under the preceding heads.

'The Austro-Hungarian Government expect the reply of the Royal Government at the latest by 6 o'clock on Saturday evening, the 25th July.

'A memorandum dealing with the results of the magisterial inquiry at Serajevo with regard to the officials mentioned under heads (7) and (8) is attached to this note.'

Forty-eight hours only were permitted for a reply to this ultimatum which was communicated, together with an explanatory memorandum, to the Powers, on July 24.

Diplomacy, therefore, had only twenty-four hours in which to work. The Serbian Government did its utmost to avert the war, plainly pre-determined by the German Powers. It replied promptly, accepting eight out of the ten principal points and not actually rejecting the other two. No submission could have been more complete and even abject. To complete the evidence of Serbia's conciliatory attitude it is only necessary to recall the fact that she offered to submit the whole question at issue between the two Governments, either to the Hague Tribunal or to the Great Powers, which took part in the drawing up of the declaration made by the 


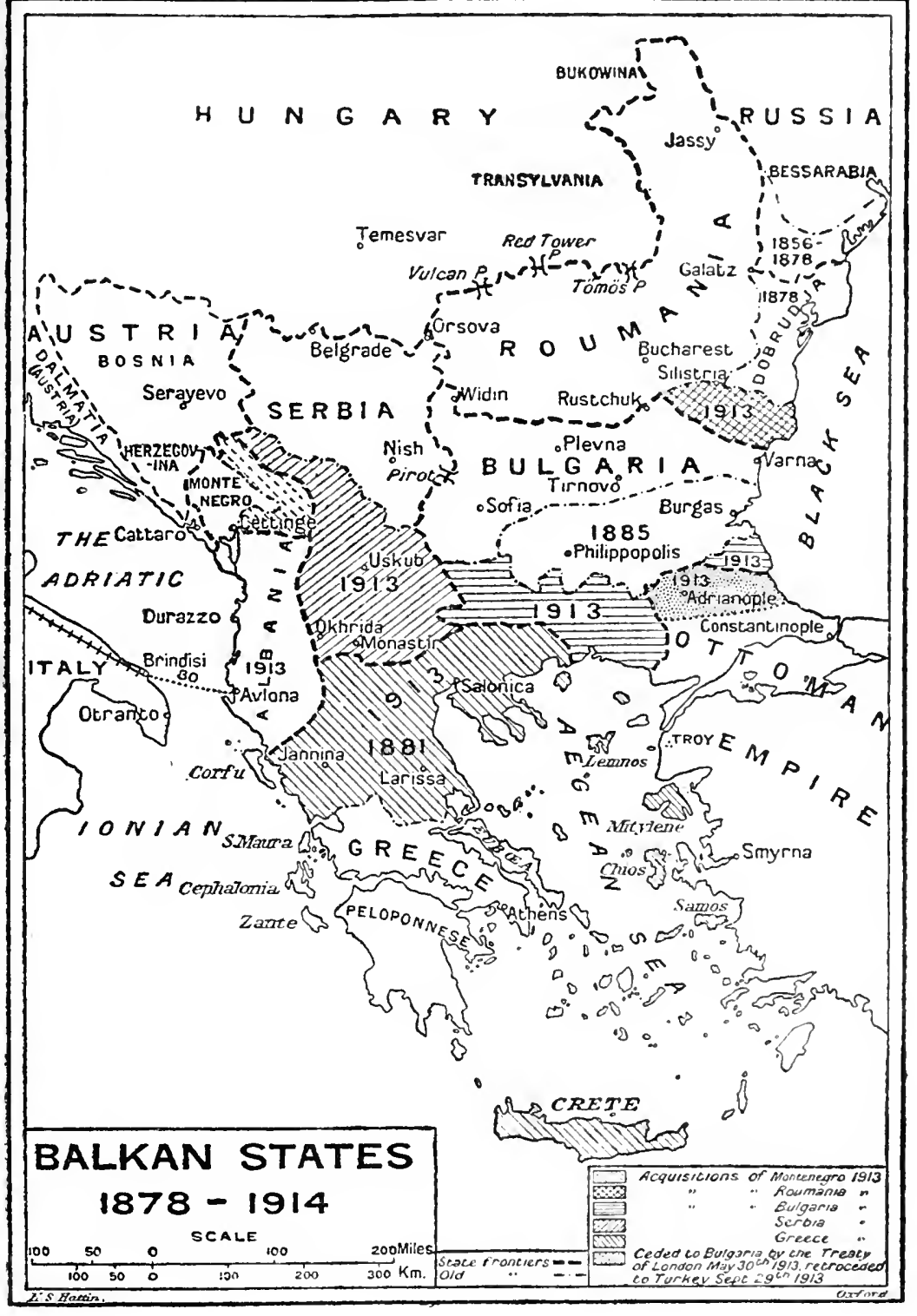


Serbian Government on the 18th (31st) March, 1909. ${ }^{1}$ But nothing could avail to avert war. The German Powers were ready and they had struck.

Austria From the mass of the diplomatic correspondence two not and Salonica. insignificant, but almost casual, remarks may be unearthed. On July 25, Sir Rennel Rodd, British ambassador at Rome, telegraphed to Sir Edward Grey: 'There is reliable information that Austria intends to seize the Salonica Railway'.2 On the 29th, the British chargé d'affaires at Constantinople telegraphed: 'I understand that the designs of Austria may extend considerably beyond the Sanjak and a punitive occupation of Serbian territory. I gathered this from a remark let fall by the Austrian ambassador here, who spoke of the deplorable economic situation of Salonica under Greek administration, and of the assistance on which the Austrian army could count from Mussulman population discontented with Serbian rule':"

The old and the new Rome were equally awake to the fact that Austria was looking beyond Serbia to Salonica.

The Euro- Austria declared war upon Serbia on July 28; Germany pean War. declared war upon Russia on Angust 1, and upon France on August 3; Germany invaded Belgium on August 4, and on the same day Great Britain declared war on Germany.

Once more the problem of the Near East, still unsolved, apparently insoluble, had involved the world in war.

1 British Diplomatic Correspondence, No.39, 1914(Collected Documents, p. 31).
¿ Idem, No. 19.
3 Idem, No. 82.

For further reference: I. E. Gueshoff, The Balkan League (Eng. trans., London, 1915 : contains many original documents of first-rate importance); C. Kerofilas, Eleftherios Verizelos (Eng. trans., London, 1915: popular but useful); Annual Register for the years 1912-14; Collected Diplomatic Documents relating to the outbreak of the European Har (London, 1915: contains British, French, Belgian, Serbian, German, and AustroHungarian official correspondence); Nationalism and War in the Near East, by a Diplomatist (Clarendon Press, 1915); J. G. Schurman, The Balkan Wars, 1912-13 (Clarendon Press, 1915); D. J. Cassaretti, Hellas and the Balkan Wars; Jean Pélissier, Dix Mois de Guerre dans les Balkans (Oct. 1912-Aug. 1913) (Paris, 1915); H. Barby, Les Victoires Serbes (Paris, 1915), L'Épopée Serbe (Paris, 1915); Balcanicus, La Bulgarie 
(with documents) (Paris, 1915) ; Songeon, Histoire de la Bulgare, 485-1913 (Paris, 1914); Gabriel Hanotaux, La Guerre des Ballans et l'Europe (Paris, 1914).

The contemporary rolumes of the Edinburgh Review, the Quarterly, the Round Table, the Nineteenth Century and After, the Fortuightly, and other Reviews are also of great value for the history of this as of other recent periods. 


\title{
EPILOGUE
}

\author{
$1914-16$
}

'Le plan pangermaniste constitue la raison unique de la guerre. Il est, en effet, la cause à la fois de sa naissance et de sa prolongation jusqu'à la victoire des Alliés indispensable à la liberté du monde.'-AxDRÉ Chéradaue (1916).

'The war comes from the East; the war is waged for the East; the war will be decided in the East.'-ERnst J ̈̈ckn in Deutsche Politik (Dec. 22, 1916). (Quoted in The New Europe, Feb. \&, 1917.)

Origins of THE Great War, initiated by the events which have been pean War. ment. As these pages go to press the war is in its thirty-first month. Each month that has passed has rendered it more and more clear that the clue to the attack launched, in August, 1914, by the Hohenzollern and the Habsburgs upon their unprepared and unoffending neighbours must be sought and will be found in the Balkan Peninsula.

When the storn cloud burst upon Europe in July, 1914, the minds of men were bewildered by the appalling suddenness of the catastrophe. Opinion as to the origin of the crisis and the scope of the resulting conflict would seem to have passed since those days through three distinct phases. Before the actual outbreak of war, and while diplomacy was still at work, there was a disposition to regard the SerboAustrian-Hungarian dispute as merely a fresh manifestation of the saecular problem of the Near East. It was hoped that the area of conflict might, by the efforts of diplomacy, be again localized as it had been in 1912-13. That the Central Empires in striking at Serbia were really challenging the whole position of Great Britain in the Near East and in the Further East was, to say the least, very imperfectly realized even in the most responsible quarters in this country. Why should Great Britain concern herself with the chastisement inflicted by Austria-Hungary upon a nation of assassins and 
pig-merchants? Such was the thought commonly entertained and not infrequently expressed.

Then came the attack upon Belgium and France. The public mind, incapable of grasping more than one aspect of the question at a time, rushed to the conclusion that the quarrel fastened upon Serbia was merely the occasion, not the cause, of the European War. The Central Empires had found in Serbia a pretext for the attack-long contemplated and prepared for-upon France, Russia, and Great Britain.

Gradually, as men have had time to reflect upon the essential causes of the conflict and to reconstruct the recent past in the light of the present, opinion has hardened into conviction that the assault upon the peasant State of Serbia was not merely the occasion of the world-war, but a revelation of it, the fundamental cause. That assault was, in fact, the outcome of ambitions which have dominated the mind of the German Emperor, and have dictated the main lines of his diplomacy, ever since his accession to the throne. Bismarck had long ago perceived the gravitation of the Habsburgs towards Buda-Pesth. He attempted to console them for their expulsion from Germany, and at the same time to involve them in perpetual hostility to Russia, by the gift of the Southern Slav provinces of Bosnia and the Herzegovina. That gift suggested to the Habsburgs the idea of opening up a road between Vienna and the Aegean. But the way to Salonica was barred by Belgrade. An independent Serbia, still more a Greater Serbia of which the Sonthern Slars had long dreamt, blocked the path not only of the Habsburgs to Salonica but of the Hohenzollern to Constantinople. The Jugo-Slars alone stood between the Central Empires and the realization of their dream of a Mitteleuropa, stretching from Hamburg to Constantinople. Nor was Constantinople the ultimate goal. From Constantinople a highway was in building which should carry German traders and German soldiers to the Persian Gulf. Once established on the Persian Gulf what was to hinder a further adrance? The flank of the Great Sea-Power had been turned; there was no longer any insuperable obstacle between Germany and the dominion of the East. 
There were, however, one or two intermediate steps to be taken. Behind the Southern Slars stood Russia; Russia, therefore, must be crushed. In close alliance with Russia stood France; a swift descent upon France, the occupation of Paris, a peace dictated to the French, on sufficiently lenient terms, should precede the annililation of Russia. True, Great Britain would regard with grave concern a German victory over France; but what could Great Britain, rendered impotent by domestic dissensions, do to avert it, even if she would.

Such were the calculations which determined the method and the moment of the world-war. The dominating motives of that war were the realization of the dream of a great Central-European Empire stretching from the German Ocean to the shores of the Bosphorus, and the extension of German influence in those Asiatic lands, of which, for a land-power, Constantinople, as of old, still holds the key.

If this diagnosis be correct, the successive symptoms which, in the course of the disorder of the last three years, have manifested themselves, appear not merely intelligible but inevitable.

Whether by a timely display of force the Turk could have been kept true to his ancient comnexion with Great Britain and France; whether by more sagacious diplomacy the hostility of Bulgaria could have been arerted, and the cooperation of Greece secured ; whether by the military intervention of the Entente Powers the cruel blow could have been warded off from Serbia and Montenegro; whether the Dardanelles expedition was faulty only in execution or radically unsound in conception; whether Roumania came in too tardily or moved too soon, and in a wrong direction: these are questions of high significance, but the time for answering them has not yet come.

Meanwhile, it may be convenient to summarize the events of the last two and a half years, so far as they have reacted upon the problems discussed in the preceding pages.

Turkey On the outbreak of the European War (August, 1914) the and the Porte declared its neutrality - a course which was followed,
War. in October, by Greece, Roumania, and Bulgaria. The allied 
Powers of Great Britain, France, and Russia gave an assurance to the Sultan that, if the Ottoman Empire maintained its neutrality, the independence and integrity of the Empire wonld be respected during the war, and provided for at the peace settlement. That many of the most responsible statesmen of the Porte sincerely desired the maintenance of neutrality cannot be doubted; but the forces working in the contrary direction were too powerful. The traditional enmity against Russia; the chance of recovering Egypt and Cyprus from Great Britain; the astute policy which for a quarter of a century Germany had pursued at Constantinople ; the German training imparted to the Turkish army; above all the powerful personality of Enver Bey, who, early in 1914, had been appointed Minister of War-all these things impelled the Porte to embrace the cause of the Central Empires. Nor was it long before Turkey gave unmistakable indications of her real proclivities. In the first week of the war the German cruisers, the Goeben and the Breslau, having eluded the pursuit of the allied flect in the Mediterranean, reached the Bosphorus, were purchased by the Porte, and commissioned in the Turkish navy. Great Britain and Russia refused to recognize the transfer as valid, but the Porte took no notice of the protest. Meanwhile, Germany poured money, munitions, and men into Turkey ; German officers were placed in command of the forts of the Dardanelles ; a German General, Liman Pasha, was appointed Commander-in-Chief of the Turkish army, and on October 28 the Turkish fleet bombarded Odessa and other unfortified ports belonging to Russia on the Black Sea. To the protest made by the ambassadors of the allied Powers the Porte did not reply, and on Norember 1 the ambassadors demanded their passports and quitted Constantinople. A few days later the Dardanelles forts were bombarded by English and French ships, Akaba in the Red Sea was bombarded by H.M.S. Minerva, and on November 5 Cyprus was formally annexed by Great Britain. For the first time Great Britain and the Ottoman Empire were really at war.

Left to themselves the Ottoman Turks might possibly have remained true to their traditional policy; but considerable 
irritation had been aroused against England by the detention of two powerful battle-ships which were being built in English yards, and the arrival of which at the Bosphorus had been impatiently awaited by a large body of patriotic subscribers. That irritation supplied the spark utilized at the last moment to set fire to the combustible materials which had been steadily accumulated by German foresight at Constantinople. The Pan- The German anticipation unquestionably was that by Plan. means of the Turkish alliance she would be able to exploit Mesopotamia, to penetrate Persia commercially and politically, to deliver a powerful attack upon the British position in Egypt, and to threaten the hegemony of Great Britain in India. For all these ambitious schemes Constantinople was to be an indispensable base. ${ }^{1}$

It cannot, at the moment of writing (February, 1917), be said that all danger in these diverse directions has been dissipated. Nor can it yet be accurately known how serious during the last two years has been the German threat to British world-power. But at least it may be said that none of these designs has been actually achieved. Still, German authority is as yet unchallenged in Constantinople; a pathway has been hewn from Hamburg and Berlin to the Bosphorus, and from the Bosphorus to Bagdad the Turco-German position is still unassailed. On the other hand, the attacks upon Egypt have thus far ignominiously failed, and, although British arms suffered a serious reverse in Mesopotamia in 1916, speedy and effective measures are in progress towards a reassertion of British supremacy in the middle-East.

Serbia. In the Balkans, however, German influence is, at present, predominant. In the autumn of 1914 Austria-Hungary launched a terrific attack upon Serbia, and after four months of sanguinary fighting succeeded (December 2) in capturing Belgrade. But their triumph was short-lived. By an heroic effort the Serbians, three days later, recaptured their capital ; the Habsburg assault was repelled, and for the first half of 1915 Serbia enjoyed a respite, from the attacks of external enemies. An epidemic of typhus

1 Cf. a powerful speech by Earl Curzon of Kedleston in the House of Lords, Feb. 20, 1917. 
ferer in its most virulent form wrought terrible havoc, howerer, upon an exhausted, ill-fed, and, in certain parts, congested population. From this danger Serbia was reseued by the heroism of English doctors and Luglish nurses, warmly seconded by American and other volunteers. Had the methods of English diplomacy been as energetic and effective as those of the English Medical Service, Serbia might still have escaped the terrible fate in store for her. Judged by results, and as yet we have no other materials for judgement, nothing could have been more inept than the efforts of allied English diplomacy in the Balkans throughont the year 1915.

One diffieulty that arose eamnot, in fairness, be attributed Italy to the diplomacy of England and her allies. It was inherent and the in the situation. In May, 1915, Italy threw in her lot with the Triple Entente. She had declined in 1914 to regard the Austro-German attack upon their neighbours as a cusus foederis, and on February 12, 1915, she informed Austria that any further action in the Balkans, on the part of Austria-Hungary, would be regarded by Italy as an unfriendly act. That her action contributed to the respite enjoyed by Serbia camnot be gainsaid. Germany was very anxious to avoid a rupture with Italy, and offered large concessions, of course at the expense of her ally; but early in May Italy denounced the Triple Alliance, and on the twenty-third declared war upon Austria-Hungary.

Italy was determined to seize the opportunity for completing the work of the Risorgimento, for rectifying her frontier on the side of the Trentino, for securing her naval ascendaney in the Adriatic, and for 'redeeming' the islands of the Dalmatian archipelago and those districts on the eastern littoral of the Adriatic, which had for centuries formed part of the historic Republic of Venice. Her quarrel, therefore, was not primarily with the Hohenzollern, but with the Habsburgs, who since 1797 had been in almost continuous occupation of these portions of the Venetian inheritance.

The pretensions of Italy, howerer well justified politically Italy and and historically, introduced a considerable complication into Serbia. 
the diplomatic situation. In particular they aroused grave perturbation among the Southern Slavs and especially in Serbia. In the eastern part of the Istrian Peninsula, and along the whole coast from Fiume to Albania, the population is predominantly Slav. The dream of a Greater Serbia would be firustrated were Italy to acquire the Dalmatian coast and islands. Rather than see Italy established there, the Serbs would prefer to leave Austria-Hungary in occupation. The situation was an embarrassing one for the Triple Entente, and, in the event of their victory, may again become acute. Southern Slav opinion was strongly roused by the rumour which gained credence in May, 1915, that in order to secure the adhesion of Italy the Powers of the Triple Entente had conceded her claims to Northern Dalmatia and several of the islands of the archipelago. Be this as it may, Italy, as we have seen, adhered to the alliance of which Serbia forms an integral part. The Dar- The Triple Entente needed all the friends they could expedition. muster in south-eastern Europe. In February the world learnt that an English fleet, assisted by a French squadron, was bombarding the forts of the Dardanelles, and high hopes were entertained in the allied countries that the passage of the Straits would be quickly forced. Nothing would have done so much to frustrate German diplomacy in southeastern Europe as a successful blow at Constantinople. But the hopes aroused by the initiation of the enterprise were not destined to fulfilment. It soon became evident that the navy alone conld not achieve the task entrusted to it. Towards the end of April a large force of troops was landed on the Gallipoli Peninsula; but the end of May came, and there was nothing to show for the loss of nearly 40,000 men. On Angust 6th a second army, consisting largely of Australians, New Zealanders, and English Territorials, was thrown on-to the peninsula. The troops displayed superb courage, but the conditions were impossible; Sir Ian Hamilton, who had commanded, was succeeded by Sir C. C. Munro, to whom was assigned the difficult and ungrateful task of evacuating an untenable position. To the amazement and admiration of the world a feat, deemed 
almost impossible, was aceomplished before the end of December, without the loss of a single man. How fur the expedition to the Dardanelles may have arerted dangers in other directions it is impossible, as yet, to say; but, as regards the accomplishment of its immediate aims, the enterprise was a ghastly though a gallant failure.

The failure was apparent long before it was proclaimed by the abandonment of the attempt. Nor was that failure slow to react upon the situation in the Balkaus.

On the outbreak of the European War Greece had pro-Greece. claimed its neutrality, though the Premier, M. Venizelos, at the same time declared that Greece had treaty obligations in regard to Serbia, and that she intended to fulfil them. But in Greece, as elsewhere in the Near East, opinions if not sympathies were sharply dirided. The Greek kingdom owed its existence to the Powers comprising the Triple Entente ; the dynasty owed its crown to their nomination; to them the people were tied by every bond of historical gratitude. No one realized this more clearly than M. Venizelos, and no one could have shown himself more determined to repay the debt with compound interest. Moreorer, M. Venizelos believed that the dictates of policy were identical with those of gratitude. The creator of the Balkan League had not abandoned, despite the perfidious conduct of one of his partners, the hope of realizing the dream which had inspired his policy in 1912. The one solution of a secular problem at once feasible in itself and compatible with the claims of nationality was and is a Balkan Federation. A German hegemony in the Balkans, an Ottoman Empire dependent upon Berlin, would dissipate that dream for ever. To Greece, as to the other Balkan States, it was essential that Germany should not be permitted to establish herself permanently on the Bosphorus. If that disaster was to be averted mutual concessions would have to be made, and Venizelos was statesman enough to make them. Early in 1915 he tried to persuade his sovereign to offer Kavalla and a slice of 'Greek' Macedonia to Bulgaria. He was anxions also to co-operate in the attack upon the Dardanelles with allies who had offered to Greece a large territorial con- 
cession in the Smyrna district. To neither suggestion would King Constantine and his Hohenzollern consort listen. Venizelos consequently resigned.

Poliey of If Venizelos desired harmony among the Balkan States, so the Allies also, and not less ardently, did the allies. Macedonia still Ballans. remained the crux of the situation. Hohenzollern-Habsburg diplomacy had, as we have seen, thrown oil upon the flames of inter-Balkan rivalries in that region. Bulgaria, the willing cat's-paw of the Central Empires, had in 1913 drawn down upon herself deserved disaster, but that she would permanently acquiesce in the terms imposed upon her by the Treaty of Bucharest ${ }^{1}$ was not to be expected. Venizelos was quick to recognize this truth. Had his advice been followed Bulgaria would have gained a better outlet to the Aegean than that afforded by Dedeagatch. Serbia possessed no statesman of the calibre of Venizelos. But the situation of Serbia was in the last degree hazardous, and under the pressure of grim necessity Serbia might have been expected to listen to the voice of prudence. How far that voice reached her ears in the early summer of 1915 we cannot yet know for certain. Almost anything can be believed of the diplomacy of the Entente at that period, and many things can be asserted on the authority of Sir Edward Carson, who in October resigned his place in the Cabinet as a protest against the Balkan policy of his colleagues. But the time for a full investigation has not yet come, and, in the meantime, it must suffice to record results.

13ulgaria. Not until August, 1915, was Serbia induced to offer such concessions in Macedonia to Bulgaria as might possibly have sufficed, in May, to keep Bulgaria out of the clutches of the Central Empires. In Bulgaria, as elsewhere, opinion was sharply divided. Both groups of Great Powers had their adherents at Sofia. Had the Russian advance been maintained in 1915; had the Dardanelles been forced; had pressure been put by the Entente upon Serbia and Greece to make r'easonable concessions in Macedonia, Bulgaria might

1 Supra, p. 410. 
not have yielded to the seductions of Cerman gold and to the wiles of German diplomacy. But why should a German king of Bulgaria have thrown in his lot with P'owers who were apparently heading for military disaster; whose diplomacy was as incpt as their arms were feeble? What more natmal than that when the German avalanche descended upon Serbia in the autumn of 1915 Bulgaria should have co-operated in the discomfiture of a detested rival?

Yet the Entente built their plans npon the hope, if not the expectation, that Bulgaria might possibly be induced to enter the war on the side of the allies against Turkey. ${ }^{1}$ Serbia was anxions to attack Bulgaria in September, while her mobilization was still incomplete. It is generally believed that the allies intervened to restrain the Serbian attack; hoping against hope that a concordat between the Balkan States might still be arrived at. To that lope Serbia was sacrificed. ${ }^{2}$

A great Austro-German army, under the command of Field- The chasMarshal von Mackensen, concentrated upon the Serbian tisement frontier in September, and on the 7 th of October it crossed the Danube. Two days later Belgrade surrendered, and for the next few weeks ron Mackensen, descending upon the devoted comtry in orerwhelming strength, drove the Serbians before him, until the whole country was in the occupation of the Austro-German forces. The Bulgarians captured Nish on November 5 and effected a junction with the army under von Mackensen ; Serbia was amnihilated; a remnant of the Serbian army took refuge in the mountains of Montenegro and Albania, while numbers of deported civilians sought the hospitality of the allies. On November 28 Germany officially declared the Balkan campaign to be at an end. For the time being Serbia had ceased to exist as a Balkan State.

What had the allies done to succour her? On Septem- Balkim ber $28 \mathrm{Sir}$ Edward Grey, from his place in the House of policy

1 Cf. Speech of Sir Edward Grey in House of Commons, Oct. 14, 1915. Entente

2 Cf. The Times, Nov. 22, 1915: but for a contrary view of. Dr. E. J. Dillon-no apologist for English diplomacy-ap. Fortnightly Reriew, Jan., 1916. 
Commons, uttered a grave, though not unfriendly, warning to Bulgaria, and declared that Great Britain was determined, in concert with her aliies, to give to her friends in the Balkans all the support in her power in a manner that would be most welcome to them 'without reserve and without qualification'. How was this solemn promise fulfilled? Russia was not, at the moment, in a position to afford any effective assistance, but on October 4 she dispatched an ultimatum to Bulgaria, and a few days later declared war upon her. On October 5 the advance guard of an Anglo-French force, under General Sarrail and Sir Bryan Mahon, began to disembark at Salonica. The force was miserably inadequate in numbers and equipment, and it came too late. Its arrival precipitated a crisis Wing Con- in Greece. As a result of an appeal to the country in June, stantine King Constantine had been reluctantly compelled to recall V'enizelcs. Venizelos to power in September. Venizelos was as determined as ever to respect the obligations of Greece towards Serbia, and to throw the weight of Greece into the scale of the allies. But despite his parliamentary majority he was no longer master of the situation. The failure of the Dardanelles expedition, the retreat of Russia, the impending intervention of Bulgaria on the Austro-German side, the exhortations and warnings which followed in rapid succession from Berlin, above all, the knowledge that von Mackensen was preparing to annihilate Serbia, had stiffened the back of King Constantine. Venizelos had asked England and France whether, in the event of a Bulgarian attack upon Serbia, the Western Powers would be prepared to send a force to Salonica to take the place of the Serbian contingent contemplated by the Greco-Serbian treaty. The landing of the Anglo-French force in October was the practical response of the allies to the 'invitation' of Venizelos. Technically, however, the landing looked like a violation of Grcek neutrality, and Venizelos was compelled by his master to enter a formal protest against it. But the protest was followed by an announcement that Greece would respect her treaty with Serbia, and would march to her assistance, if she were attacked by Bulgaria. That announcement cost Venizelos his place. He was promptly dismissed by King Constantine, who, flouting 
the terms of the Constitution, effected what was virtually a monarchical coup détat.

The king's violation of the Hellenic Constitution was the opportunity of the protecting Powers. They failed to seize it, and King Constantine remained master of the situation. From an attitude of neutrality professedly 'benevolent', he passed rapidly to one of hostility almost openly arowell. That hostility deepened as the year 1916 advanced. On May 25, in accordance with the terms of an agreement secretly concluded between Greece, Germany, and Bulgaria, King Constantine handed over to the Bulgarians Fort Rupel, an important position which commanded the flank of the French army in Salonica. A few weeks later a whole division of the Greek army was instructed to surrender to the Germans and Bulgarians at Kavalla. Kavalla itself was occupied by King Constantine's friends, who carried off the Greek division, with all its equipment, to Germany. Nearly the whole of Greek Macedonia was now in the hands of Germany and her allies, and the Greek patriots, led by Venizelos, were reduced to despair. In September a Greek Committee of National Defence was set up at Salonica, and in October Venizelos himself arrived there.

By this time, however, the Balkan situation had been Roumafurther complieated by the military intervention of Roumania vian interon the side of the allies. In Roumania, as elsewhere, opinion was, on the outbreak of the war, sharply divided. The sympathies of King Carol were, not unnaturally, with his Hohenzollern kinsmen, and, had he not been, in the strict sense of the term, a constitutional sovereign, his comntry would have been committed to an Austro-German alliance. Nor was the choice of Rommania quite obriously dictated by her interests. If the coveted districts of Transylvania and the Bukovina were in the hands of the Habsburgs, Russia still kept her hold on Bessarabia. A 'Greater Roumania', corresponding in area to the ethnographical distribution of population, would involve the aequisition of all three provinces. Could Roumania hope, either by diplomacy or by war, to achieve the complete reunion of the Rommanian people? 
In October, 1914, the two strongest pro-German forces in Roumania were removed, almost simultaneously, by death : King Carol himself, and his old friend and confidant Demetrius Sturdza. Roumania had already declared her neutrality, and that neutrality was, for some time, scrupulously observed. The natural affinities of the Roumanians attract them, as we have seen, towards France and Italy, and it was anticipated that Italy's entrance into the war would be speedily followed by that of Roumania. But not until August, 1916, was the anticipation fulfilled. On August 27 Roumania declared war and flung a large force into Transylvania. The Austrian garrisons were overwhelmed, and in a few weeks a considerable part of Transylvania had passed into Rommanian hands. But the success, achieved in defiance of sound strategy, and also, it is said, in complete disregard of warnings addressed to Roumania by her allies, was of brief duration. In September Mackensen invaded the Dobrudja from the south, entered Silistria on September 10, and, though checked for awhile on the Rasova-Tuzla line, renewed his advance in October and captured Constanza on the twenty-second.

Meanwhile, a German army, under General von Falkenhayn, adranced from the west, and on September 26 inflicted a severe defeat upon the Roumanians at the Rothen Thurm pass. The Roumanians, though they fought desperately, were steadily pressed back; at the end of Norember Mackensen joined hands with Falkenhayn, and on December 6 the German armies occupied Bucharest.

Thus another Balkan State was temporarily crushed. From Belgrade to Constantinople, from Bucharest to the valley of the Vardar, the Central Empires are in undisputed command of the Balkan Peninsula. A corner of Greek Macedonia is still held by the Anglo-French force under General Sarrail, and towards the end of Norember a Serbian army, reformed and re-equipped, had the gratification of (iermany reoccupying Monastir. But the German successes in the (ireece. north-east of the peninsula naturally emboldened their friends in the south-west, and the increasing hostility of the Athenian Government rendered the position of the allies in 
Salonica exceedingly precarious. The patience with which the vagaries of King Constantine have been treated by the allied governments has tended to eroke contempt rather than gratitude in Athens. We may not even hazard a conjecture as to the obstacles which have impeded the dealings of the allies with the Hellenic Gorermment. Whaterer the nature of those obstacles the results have been disastrous. We have discouraged our friends and put heart into onr enemies. King Constantine, obviously playing for time, was allowed to gain it. The attitude of his partisans in $A$ then towards the allies grew daily more insolent, until it culminated (December 1-2, 1916) in a dastardly attuck upon a small Franco-British force which Admiral de Fournet deemed it prudent to land at the Piraens. For that outrage the Hellenic Govermment has formally apologized, and has consented to withdraw the Greek army from Thessalya position which obriously menaced the security of the allical force in Salonica.

But the whole position in Greece is, from the point of view of Great Britain and her allies, pre-eminently unsatisfactory. Venizelos, the elected lcader of the Greek people, is an exile from the capital, and is powerless to influence the course of his nation's policy. Power is rested in a king, who has hitherto taken his orders from Berlin, and whose position rests not upon the support of his people but upon that of his army. By means of a blockade the allicd Power's have enforced the acceptance of their modest terms, and have cxtorted some measure of respect for their flags and their representatives. But the diplomatic position is one of unstable equilibrium, and its maintcnance from day to day depends wholly upon the issue of the military struggle elsewhere.

This narrative must therefore be brought to an abrupt The Peare end ; it cannot pretend to reach a conclusion. The problem settlewhich this book was designed to unravel appear's for the and the time being more than ever insoluble. All the Balkan States Fastem have been thrown into the witches' cauldron, and what may issuc therefrom no man can tell. But the allied gorernments have, with admirable perspicacity, enunciated principles which, if they be accepted as the basis of a European settlement, 
must have far-reaching consequences in the lands once subject to the Ottoman Empire. 'No peace', the allies have declared, 'is possible so long as they have not secured . . . the recognition of the principle of nationalities and of the free existence of small states.' ${ }^{1}$ These principles are inconsistent with the continued presence of the Ottoman Turk in Europe. Turkey has forfeited its claim to the protection of the allied Powers. 'A Turkish Gorernment, controlled, subsidized, and supported by Germany, has been guilty of massacres in Armenia and Syria more horrible than any recorded in the history even of those unhappy countries. Evidently the interests of peace and the claims of nationality alike require that Turkish rule over alien races shall if possible be brought to an end.' ${ }^{2}$ From the day when the Ottomans first made themselves masters of the Balkan Peninsula down to the present hour their rule has been that of an alien tyrant. They have never even attempted the task of assimilating the subject peoples; they have been content to establish and to maintain in European lands a military encampment. Depending from the first upon the power of the sword, and upon that alone, they are now destined to perish by the sword. The allied governments are pledged beyond recall to "the setting free of the populations subject to the bloody tyranny of the Turks; and the turning out of Europe of the Ottoman Empire as decidedly foreign to Western cirilization'. ${ }^{3}$

The task thus indicated was all but accomplished by the States of the Balkan League in 1912. The formation of that League, and still more the astonishing success achieved by its arms, constituted a serious set-back to the realization of Pan-German hopes in the Near East. At all hazards the unity of the League had to be broken; the remnant of Ottoman Power upon the Bosphorus had to be saved. Both objects were successfully attained by German diplomacy. The Balkan allies were precipitated into a suicidal conflict; the Sultan recovered Adrianople, and the terms of peace were so arranged

1 Allies' Reply to German Peace Orertures, Dec. 31, 1916.

2 Mr. Balfour's Dispatch to the British Ambassador at Washington. The Times, Jan. 18, 1917.

${ }^{3}$ Allies' Reply to President Wilson, Jan. 10, 1917. 
as to render practically certain an early renewal of the contest between the Balkan States. The German Emperor congratulated his Hohenzollern kinsman in Rommania upon the conclusion of the Treaty of Bucharest. The congratulations were due rather to Berlin. From the first moment of his accession to the throne the Emperor William had spared no pains to bind the Ottoman Sultan in ties of gratitude to himself. Of the $300,000,000$ Moslems throughout the world he had proclaimed himself the ehampion and friend. Their Khalif still reigned at Constantinople. The gate to the East was still guarded by the ally of the Habsburg and the friend of the Hohenzollern.

Not upon these lines can any permanent solution of the Eastern Question be reached. The peoples who were submerged by the oncoming of the Ottoman flood have now again reappeared as the waters have subsided. If the principles solemnly proclaimed by the allies are to prevail ; if the new map of Europe is so drawn as to respect them, the Balkan lands will be divided among the Balkan peoples. But the geographical distribution of those peoples is so complex, the ethnographical demarcation is so disputable, that the mere enunciation of the nationality principle will not suffice to secure a satisfactory settlement. Greeks, Bulgars, Albanians, Roumanians, and Southern Slavs will have to learn to live side by side in the Balkan Peninsula on terms, if not of precise mathematical equality, at least of mutual forbearance and goodwill.

Otherwise there can be no peace for them or for Europe at large. Ever since the advent of the Turk the Balkans have been one of the main battle-grounds of Europe. For at least a century the storm centre of European politics has lain in the Balkans. The struggle for Hellenic independence; the ambition of Mehemet Ali; the rivalry of Russia and Great Britain at Constantinople; the jealonsies of Great Britain and France in Egypt; the inclusion of Jugo-Slavs in the conglomerate Empire of the Habsburgs; the determination of the Hohenzollern to extend Pan-German domination from Berlin to Belgrade, from Belgrade to the Bosphorus, from the Bosphorus to Bagdad, from Bagdad to Basra-these have 
been the main causes of unrest in Europe from the overthrow of Napoleon to the outbreak of the European War. In an unsolved Eastern Question the origin of that war is to be found. For that secular problem the Peace must propound a solution. Should it fail to do so, the Near East will in the future, as in the past, afford a nidus for international rivalries, and furnish occasions for recurring strife. 


\section{APPENDIX A}

\section{LIST OF OTTOMAN RULERS}

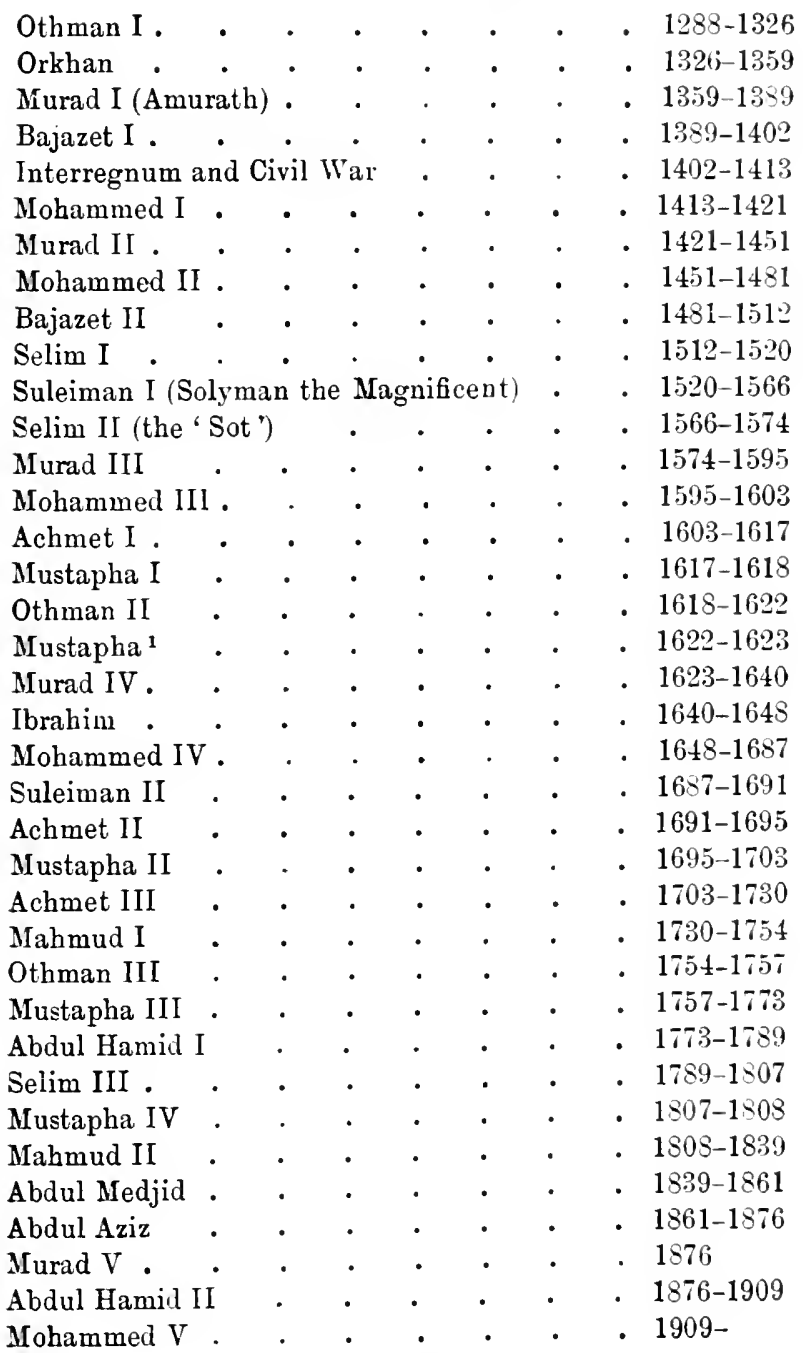

1 Sometimes omitted from the list. 


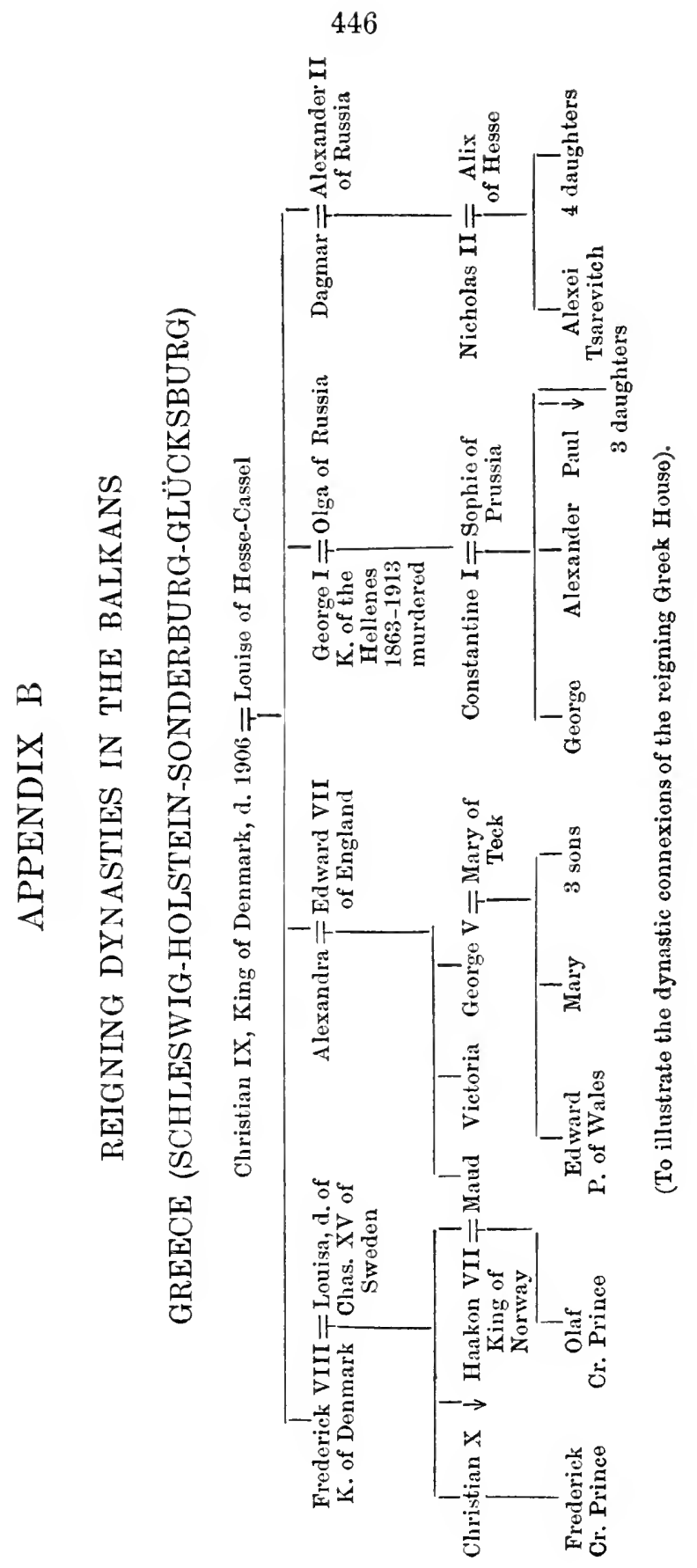




\section{MONTENEGRO}

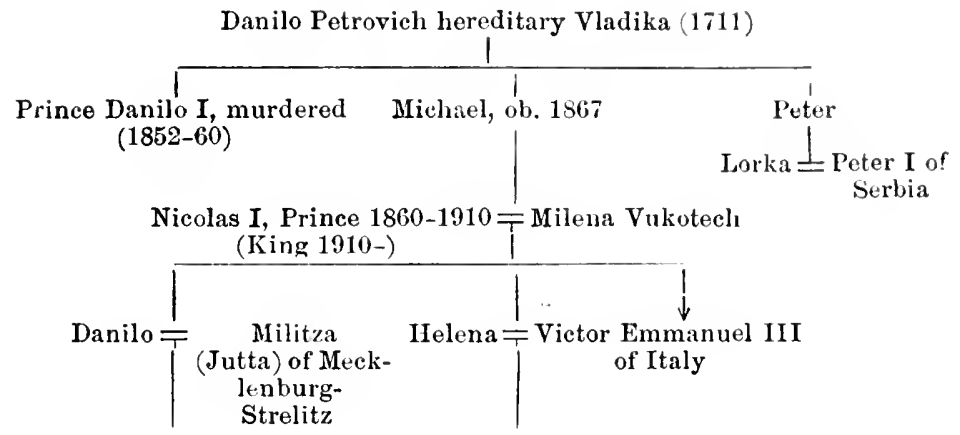

\section{SERBIA (OBRENOVIĆ)}

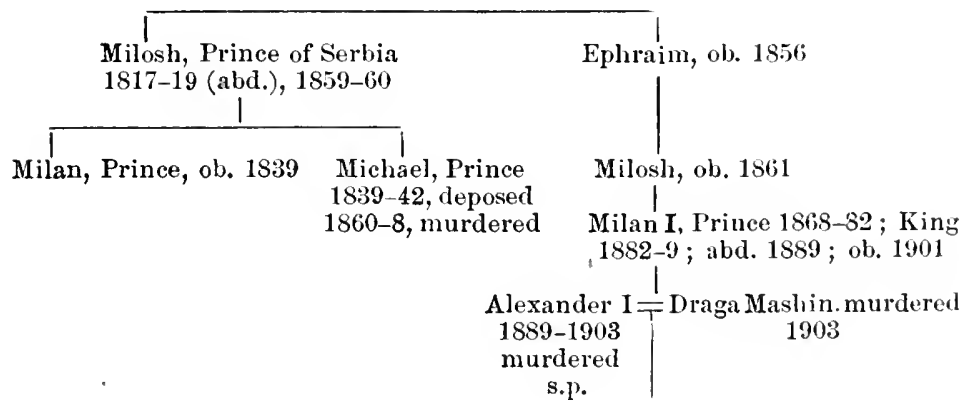

\section{SERBIA (KARAGEORGEVIĆ)}

George Petrovich (Kara George), murdered 1817

Alexander I, Prince 1842-59 deposed, ob. 1885.

Peter I, $=$ Lorka of Montenegro King 1903 


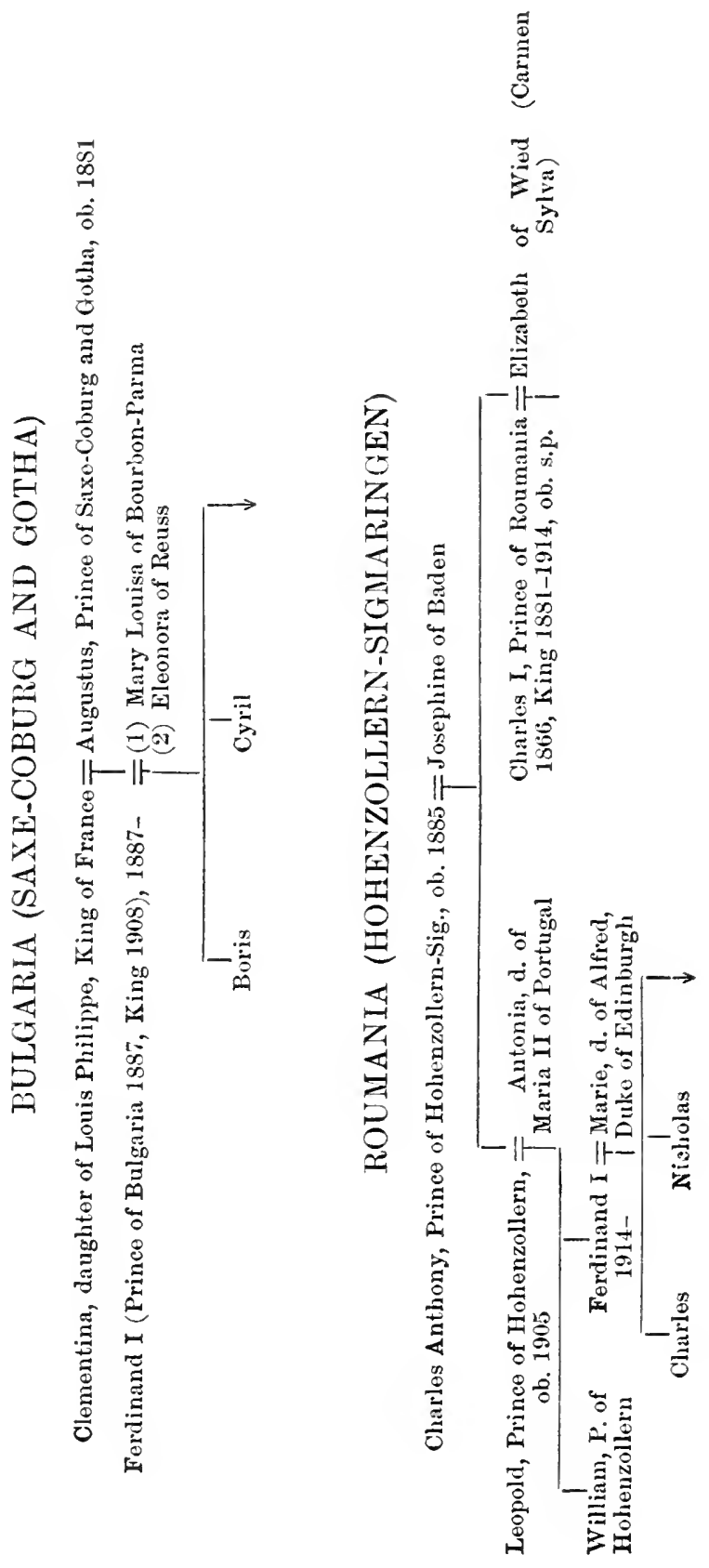




\section{APPENDIX C}

SHRINKAGE OF THE OTTOMLAN EMPIRE IN EUROPE DURING THE LAST HUNDRED YEARS

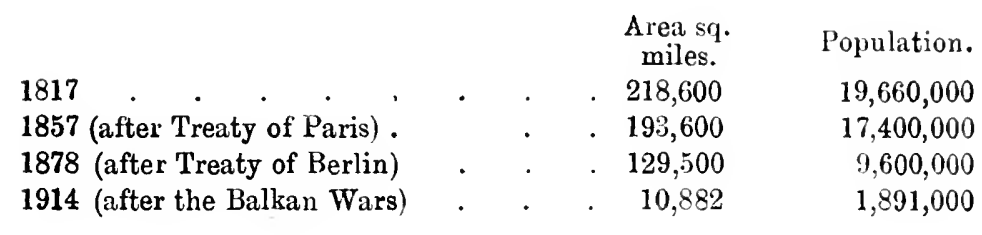




\section{INDEX}

Abdul Aziz, 276.

Abdul Hamid, Sultan, 16, 317, 342, $349,354,357,368,383$.

Abdul Medjid, 212, 222, 275.

Abercromby, Sir Ralph, 154.

Aberdeen, 4th Earl of, 220.

Achmet I, Sultan, 96.

Achmet II, Sultan, 97.

Achmet III, Sultan, 97.

Acre, 217 ; siege of, 152.

Adana, 211.

Aden, 82, 213.

Adrianople, 39, 401, 403; Ottoman capital, 57.

Adriatic, the, 16,170 ; problem of, 344.

Aegean, the. 26.

Aerentlial. Baron von, 369, 379.

Agadir, 388.

Albania, 43, 72, 182, 396, 404, 415.

Alberoni, Cardinal, 5.

Albert, Prince of Saxe-Coburg, 220.

Aleaddin, Seljukian Sultan, 37.

Alexander I, Tsar, 5, 155, 165, 169, $175,184,189$.

Alexander II, Tsar, 242.

Alexander III, Tsar, 312, 352.

Alexander I of Serbia, 375.

Alexandria, 202.

Algiers, 82, 201.

Ali Pasha of Janina, 182.

Anatolia, 75.

Andrassy Note, 286.

Arabia, 218; conquered by Turks, 77.

Argyle, 8th Duke of, quoted, 220, 236.

Armenia, 350 seq., 417.

Armenian Church, 349.

Armenian Massacres, 320, 349, 384.

Armenians, 16.

Asia Minor, Turks in, 37, 38.

Athens, 186, 189.

Augustus III of Poland, 130.

Aurelian, Emperor, 44.

Ausgleich, the, 375 .

Austria, 134, 344, 359; and the Adriatic, 170, 373; and the
Aegean, 15; and the Balkans, 345, 372; and Bosnia, 15; and Crimean War, 235, 245; and Herzegovina, 15; and Salonica, 426 ; and Serbia, 418, 421; and the Slavs, 376 seq.

Austria-Hungary, races in, 376 .

Azov, 75, 112, 119, 125, 135.

Bagdad, 19, 82, 432 .

Bagdad Railway, 15, 21, 358.

Bajazet, Sultan, 58.

Balkan League, the, 16, 32, 391 seq., 394.

Balkan Wars : first (1912), 398 seq. ; the second, 409 seq.; results of, 411.

Balkans, physical features of, 22.

Balta Liman, convention of, 261 .

Baltic, the, British Fleet in, 237.

Bar, Confederation of, 131.

Barbarossa, Khaireddin, 82, 85.

Basil II, Emperor (Bulgaroktonos), 49.

Basra, 19.

Battenberg, Prince Alexander of, 311.

Battles:

Aboukir, 152.

Alma, 238.

Angora, 61 .

Austerlitz, 156.

Balaclava, 239.

Baphaeon, 38.

Dragashan, 176 .

Friedland, 165.

Hermanstadt, 62.

Hohenlinden, 153.

Inkerman, 239.

Jena, 156.

Khoczim, 106.

Kirk Kilisse, 399.

Konieh, 207.

Kossovo, 58.

Kumanovo, 400.

Lepanto, 2, 4, 99.

Lule Burgas, 399.

Marengo, 153. 
Mohacz (1687), 79, 112.

Navarino, 196.

Nessib, 212.

Nikopolis, 59 .

Peterwardein, 121.

Pultawa, 119.

St. Gothard, 4, 104.

Slivnitza, 316.

Tchernaya, 243.

Trafalgar, 156.

Varna (1444), 63.

Zenta, 114.

Bayezid II, Sultan, 76 .

Beaconsfield, Benjamin Disraeli, Earl of, 14, 236, 29.5, 300, 302, $346,363$.

Belgrade, 23, 34, 43, 112, 121, 281 . $419,429,432$.

Belgrade, conquered by Turks, 78 .

Berlin Memorandum, 287. See also Treaties.

Bessarabia, 169, 246, 259.

Bismarck, Count Otto von, 13, 15 . 249, 301, 343, 386, 429.

Black Sea, 75, 117, 123, 125, 136, 234, 242, 245, 248, 431; Russia and, $2,5$.

Boniface IX, Pope, 59.

Bosnia, 13, 165, 278, 282, 302, 359, $376,378,429$.

Bosphorus, the, 11, 246.

Bourchier, Mr. J. D., 393.

Brankovic, George, 62, 72 .

Bratiano, M. Jean, 268.

Brunnow, Baron, 213.

Brusa, 38.

Bucharest, 440.

Buda Pesth, conquered by Turks, 81.

Bukovina, the, 138, 256, 439 .

Bulgaria, 13, 25, 33, 43, 165, 289 seq., 303, 305, 309 seq., 430, 435, 436, 438; Church of, 290 ; constitution of, 310 ; independence of, 359,371 ; in $1913,413$.

Bulgaria and Macedonia, 362.

Bulgarian atrocities, 292.

Bulgarian Empire: the First, 47 ; the Second, 49.

Bulgarian Exarchate, 291.

Bulgarians, the, 46.

Bulgarias, union of, 317 .

Buonaparte. See Napoleon I.

Byron, Lord, 183, 187; and Greece, 9.

Byzantine Empire, 41.
Cabot, John Sebastian, 20.

Candia, siege of, 101.

Canning, feorge. 9, 187, 190, 192. 194. 195; and Russia, 10.

Canning, Stratford, 191, 196, 20ऍ. see also Lord Stratford de Redeliffe.

Canrobert, General, 239.

Cantacuzenos, John, :39.

Cupitulutions: of 1535,6 . of 1740,225 .

French. 8:, 127.

Capo d'lstria, Count, 175, 185, 200.

Castlereagh, Viscount, 9.

Castriotis, George, 73.

Catherine II, Tsarina of Pussia, 6, 129,182 ; and Joseph 1I, 18\%, 141 ; and Roumania. 257.

Cattaro, Bocche di, 166.

Cavour, Count, 241. 245.

Charles IV, Duke of Lorraine. 109.

Charles V, Emperor, 79, 83, 85.

Charles XII of Sweden, 119.

Charles of Hohenzollern-Sigmaringen, Prince, 269.

Chios, 186.

Choiseul, Duc de, 131.

Church. General. 183.

Clarendon, 4th Earl of, 137. 228.

Clementine. Princess of Orleans, 319.

Coalition, war of second (1798), 15\%.

Codrington, Admiral sir Edward, 196.

Columbus, Christopher, 20.

Comnenos, House of. 41.

Comnenus David, Emperor, 75.

Constantine, Emperor, 41.

Constantine, King of (ireece. $4: 36$. $438,439,441$.

Constantinople, 19, 33. 34, 42, 117 , $165,166,429,430,432,443$; capture of, by the Turks, 64 ; conference at (1876), 294; conquest of, 20 ; Germany and, 15.

Couza, Colonel Alexander. 266.

Crete, 10, 12,13,78,103, 188,201,206, $218,308,321,331$ seq., $370,395$.

Crimea, the, 75, 112, 140. 246.

Crimean War, p. 12, chap. $x$, passim.

Croats, the, 51 .

Cromer, Earl of, 296.

Crusade, Fourth, 41.

Cyprus, 99, 302, 431.

Cyprus Convention, 351.

Czartoryski, Prince Adam, 155.

Czartoryskis, the, 130. 
Dacia, 44, 254.

Dalmatia, 24, 156, 170. 344.

Danilo, Prince of Montenegro, 289.

Danube, river, 25 ; navigation of, 246.

Danubian Principalities, 232, 246. See Moldavia, Wallachia, and Roumania.

Dardanelles, 11, 430, 431, 434.

D'Argenson, Marquis of, 6 .

Delyanuis, Theodore, 334.

Demotika, battle of, 39 .

Derby, 15th Earl of, 293, 299.

Doria, Andrea, 83.

Draga, Queen of Serbia, 375.

Dreikaiserbund, 345.

Driault, Édouard, quoted, 2.

Duckworth, Admiral, 157.

Durazzo, 416.

Dushan, Stephen, 53.

Eastern Question defined, 1-3, 444. Edinburgh, Alfied, Duke of, 328.

Edinburgh Review, quoted, 234.

Edward VII, King, 378, 380.

Egypt, 34, 139, 218, 348, 431, 432 ; conquered by Turks. 77 ; England and, 12, 388; France and, 6, 7; Napoleon and, 150.

Elphinstone, Admiral, 133.

England and Balkan insurrections, 293 ; and Eastern Question, 6, 12, 143, 428; and Egypt, 12, 388; Philhellenism in, 187; relations of, with Russia, 1, 133, 143, 219, (1839) 213, (1853) 229.

Enver Bey, 359, 403, 431.

Ertogrul, 37, 38.

Essad Pasha, 406, 416.

Eugene of Savoy, Prince, 114, 121.

Eupatoria, 242.

European War (1914), 426, 428.

Evans, Sir Arthur, quoted, 18.

Falkenhayn, General von, 440.

Ferdinand I, Emperor, 80.

Ferdinand, Prince of Saxe-CoburgGotha, 319.

Ferdinand I, Tsar of Bulgaria, 370, 392.

Finlay, Dr. George, 327.

Fiume, 344.

Flanders, Baldwin, Count of, 41.

Fox, Charles James, and Russia, 145.

France and Eastern Question, 6,
429 ; and Roumania, 261; and Turkey, 83, 124, 126; diplomacy of, 124; intervention of, in Morea, 198.

Francis Joseph, Emperor, 368, 375.

Francis I, King of France, 6, 83, 85.

Franks, the, 42.

Franz Ferdinand, Archduke, 377. $419,420$.

Frederick II of Prussia, 131, 132.

Freeman, E. A., quoted, 70.

Gallipoli, 39, 434 .

Gaulis, quoted, 348, 355.

George, Prince of Greece, 335, 338.

George I, King of Greece, 329.

Germany and Asia Minor, 357 ; and the Balkans, 15; and Balkan Wars, 405, 442; and Turkey, 16, $419,431$.

Gibbons, H. A., quoted, 42, 69.

Gladstone, Wm. Ewart, 292, 329, 347.

Goltz, General von der, 354.

Goriainow Serge, quoted, 209.

Gortschakoff, Prince, 232, 243, 249, 346.

Granville, 2nd Earl, 250.

Greco-Turkish War (1897), 336.

Greece, 33, 165, 303, 321 seq., 430, 435.

Greece and Macedonia, 16, 362; conquered by Turks, 60,74 ; constitution of 1844 , 326; constitution of 1864,330 ; independence of, 10 ; independent kingdom of, 199 ; insurrection of 1843,325 ; in 1913,412 ; kingdom of, chap. viii, passim; revolution of, 1862 , 327; War of Independence, 2,28 , chap. viii, passim.

Greek Church, relations of, with Turks, 68 .

Greek (Orthodox) Church, 180.

Greeks, the, 43.

Grey, Sir Edward, 403, 405, 437.

Gueshoff, M., 393, 400.

Gülhanè, Hatti-Scherif of, 222.

Gustavus III, 142.

Habsbur'gs, the, and Eastern Question, 15.

Halépa, Pact of, 333.

Hardenberg, Count, scheme for partition of Turkey, 165 .

Hatti-Humayoun, the, 275. 
Hatzfeld, Count, 347.

Hilmi Pasha, 368, 383.

Henry II, King of France, 86.

Herzberg, Count, 143.

Herzegovina, the, 13, 278, 282,302, 359.

Hetaireia Philike, 18 ?.

Hogarth, D. G., quoted, 18.

Holy Alliance, 174.

Holy League, (1570) 98, (1684) 103.

Holy Places, 224.

Hungary, 105, 107; conquered by Turks, 81, 114.

Hunter, Sir W. W., quoted, 18.

Hunyadi, John Corvinus, 62, 72 .

Hypsilanti, Prince Alexander, $₫$, 175.

Ibrahim Pasha, 188, 196, 206.

Ibrahim I, Sultan, 97.

Iconium (Konia), 41.

Ignatieff, General, 294.

Illyria, 170, 277.

Illyrians, the, 43.

India, 432.

Ionian Isles, 6, 7, 149, 154, 168, $170,323$.

Istria, 156, 170,344 .

Italy and Adriatic, 27, 373,433; and Dalmatia, 24; and Tripoli, 388 ; war with Turkey (1911), 16.

Iran the Terrible, 118.

\section{Janina, 404.}

Janissaries, the, 90, 102, 161, 192 ; abolition of, 192.

John, Don of Austria, 99.

John V, Emperor, 57.

Joseph II, Emperor, 6, 135.

Jugo-Slavs, the, $277,305,345$; and Adriatic, 373, 379, 405.

Kabardas, the, 135.

Kaminyi, John, 104.

Karageorgević, Prince Alexander, 281.

Karageorgević, Peter, 288.

Karaveloff, 311 .

Kars, 244, 246, 296.

Kaulbars, General, 318.

Karala, 410, 412, 414, 435, 439.

Khalifate, the, 77 .

Khartoum, 206.

Kiamil Pasha, 383, 403.

Kinglake, A. W., quoted, 224.

Kiuprili, Acbmet, 102.
Kiuprili, Mohammed, 102.

Kiuprili II I, Mustapha, 113.

Kiuprilis, the, 4, 97.

Knights of St. John, 43, 7 8 .

Koraes, Adamantios, 181.

Kordofan, 206.

Korniloff, Admiral, 239.

Kutaya, 208; convention of, 209.

Ladislas, King of Hungary, 63.

Laibach Circular, 174.

La Marmora, General, 241, 243.

Latin Empire of Constantinople, 41.

Lavalette, M. de, 224.

Leczynski, Stanislaus, 125.

Leopold I, Emperor, 107.

Lesseps, MI. de, 21.

Lewis, King of Hungary, 80.

Lewis the Great of Hungary, 4?, $54,57$.

Liman Pasha, 431.

Lissa, 168.

London Conference of 1912, 402.

London Convention of 1840, 214.

London, Treaties of. See Treatic:

Louis Philippe, King of France. $213,226$.

Louis XIV, 102, 104, 107.

Lyons, Admiral Sir Fdmund, afterwards Lord, 239.

Macedonia, 13, 14, 32, 309, 391. chap. xi, passim; physical features, 26.

Mackensen, Field Marshal ron, 437,440 .

IIahmud II, Sultan, 163, 192, 212

Malcolm, Sir Pulteney, 210.

Malta, $78,87,154,170$.

Mamelukes, the, 205.

Maria Theresa, Queen, 133.

Naritza river, 26.

IIaximilian II, Emperor, 82, 99.

Nehemet Ali, 10, 158, 188, 135 . chap. xi, passim.

Menschikoff. Prince, 228, 231, 238.

Mesopotamia, 34, 432; England and, 358 .

Metternich, Count, 174, 190, 211 ; and Greek Insurrection, 184.

Michael the Brave, 254.

Milan, Prince of Serbia, 288.

Milan I. King of Serbia, 315, 374.

Miller, Dr. William, quoted. 2.

Missolonghi, 186, 188.

Mitteleuropa, 21, 429. 
Mloguls, the, 37 .

Mohammed I, Sultan, 61.

Mohammed II, Sultan, 63 ; death of, 75 .

Mohammed III, Sultan, 96 .

Mohammed V, Sultan, 384 .

Moldavia, 8, 122, 125, 134, 135, 137, 139, 157, 165, 167, 199.

Moltke, Count Helmuth von, 212, 348.

Monastir, 401, 440.

Montecuculi, Marshal, 104.

Montenegro, $13,72,289,373$; in $1913,415,430$.

Montesquieu, quoted, 126.

Morea, the, 121, 134, 183; Ibrahim in, 188 ; Venetian rule in, 103.

Morier, Sir Robert, 235.

Morley, Viscount, of Blackburn, quoted, 2.

Morocco, 388.

Mouravieff, General, 208, 244.

Münchengrätz, convention of, 211.

Münnich, Marshal. 129.

Murad I, Sultan, 57.

Murad II, Sultan, 61.

Murad III, Sultan, 96.

Murad IV, Sultan, 96.

Mürzteg Programine, 368.

Mustapha Kara, 106, 110.

Mustapha I, Sultan, 96.

Mustapha II, Sultan, 97.

Mustapha IV, Sultan, 16.

Napier, Sir Charles, 217, 237.

Napoleon I, 149, 153, 277; and Alexander I, 167; and Egypt, 150 ; and India, 154; and Near East, 6: and Paul 1, 153; and Persia, 158; and Turkey, 157, 167 ; in Syria, 152.

Napoleon III, Emperor, 224, 236, 245 ; and houmania, 262.

Nationality, principle of, in Balkans, 14.

Naumann, Dr. Friedrich, 356.

Nelson, Lord, 156.

Nesselrode, Count, 235.

Newbiggin, Miss, quoted, 34 .

Nice, truce of, 85 .

Nicea, $38,41$.

Nicholas, King of Montenegro, 398.

Nicholas, Prince, of Montenegro, 288.

Nicholas I, Tsar, 12, 190, 207, 213, $220,229,242$.

Nicholas II, Tsar, 320, 368, 381.
Nicomedia, 38.

Nihilism, Russian, 352.

Northcote, Sir S. (Earl of Iddesleigh), 299.

Novi-Bazar, Sandjak of, 278, 380, 400.

Obrenović, Prince Michael, 281.

Obrenović, Milan, 163.

Obrenović, Milosh, 163.

Oczakov, 126, 139, 142, 145, 146.

Oglou, Passwan, 161.

Omar Pasha, 237, 242.

Orkhan, Sultan, 38.

Orloff, Count Alexis, 133, 209.

Osman, Sultan, 38.

Othman II, Sultan, 96.

Otto of Bavaria, King of Greece, 199.

Otto, King of Hellenes, 321.

Ottoman Empire, 431, 442; decay of, 92 .

Ottomans, characteristics of, 67 seq. ; first settlement in Europe, 39 ; origins of, 37 .

Ottoman Turks, 3.

Pacifico, Don, 327.

Palaeologi, the, 39.

Palaeologus, Emperor Nichael, 42.

Palmerston, Viscount, 11, 12, 208. $210,213,226,327$.

Pan-Slavism, 283, 345.

Paris, Declaration of $1856,247$.

Paul I, Tsar, 153.

Pélissier, General, 243, 432.

Persia, 82.

Peter the Great, Tsar, 5, 112, 117; will of, 138.

Peter III, Tsar, 130.

Peter, King of Serbia, 375.

Petrović, George (Kara George). 162.

Phanariotes, the, 68, 178, 256.

Philip II, King of Spain, 87.

Pitt, William, the younger, 7, 127, $143,145$.

Pius V, Pope, 98.

Plevna, siege of, 296.

Plombières, 252.

Poland, 130, 149, 165.

Poland, Turkish war with (1672), 105.

Poniatowski, Stanislas, 130.

Potemkin, Count, 258.

Prilep, 401.

Prussia and Crimean War, 235. 
Raglan, 1st Baron, 237.

Ragusa, 170.

Railways in Balkans, 30 .

Rákóczy II, George, 102.

Reschid Pasha, 222.

Rhegas, 181.

Rhodes, 75 ; conquered by Turks, 78.

Roman roads in Balkans, 30.

Rosetta, 203.

Rounania, 18, 25, 33, 34, chap. xi, passim, 296, 303, 304, 410,430, 439 ; constitution of, 270 ; king. dom of, 273 ; in 1913,413 . See also Danubian Principalities, Moldavia, and Wallachia.

Roumanians, the, 44, 254.

Roumelia, 165.

Roumelia, Eastern, 312.

Roxalana, Sultara, 88.

Russia, 103, 429; and the Greek Church, 136; and Serbia, 381; and Turkey, 5, 117.

Russo-Turkish Wars: (1736) 124 ; (1768) 132 ; (1827) 197 ; (1877) 13,295 .

St. Arnaud, Marshal, 237.

St. Petersburg, Protocol of, 191.

Salisbury, 3rd Marquis of, 235, 302.

Salonica, 15, 23, 287, 345, 369, 419, $429,438,439,441$; Austria and, 374; Greeks in, 401.

Sardinia and Crimean War, 241, 251.

Schouvaloff, Count, 295, 302.

Scutari, 404, 406.

Sebastiani, Colonel, 154.

Sebastopol, 146, 238, 244.

Selim I, Sultan, 77.

Selim III, Sultan, 144, 159.

Selim the Sot, Sultan, 96.

Seljukian Turks, 37, 41; Empire of, 75 .

Serajevo, 420 .

Serbia, 13, 16. 18, 23, 33, 165, 170, $246,278,374,428,430,432,433$, 437 ; and Adriatic, 27 ; and $\mathrm{Ma}$ cedonia, 364; Church of, 279 ; Greater, 17; Mediaeval Empire of, $42,52-5$; Old, 278 ; rising of $1804,160-4$.

Serbo-Bulgarian War 188.5): 315.

Serbs, the, 51.

Sèves, Colonel (Suleiman Pasha), 204.

Seymour, Sir Hamilton, 12, 229.
Sigismund, King of Hungary, 59.

Silistra, 237.

Simeon the Great, 47 .

Simpson, General, 243.

Sinope, 234.

Slars, Southern, 42 ; independence of, extinguished, 72 .

Slovenes, the, 51 .

Smith, Sir Sidney, 152.

Sobieski. John, King of Poland, $4,5,106,109$.

Sököli, 118.

Stahremberg, Count, 109.

Stambouloft, Stephen, 313, 317, $319,391$.

Stephen the Great, Voyvode of Moldavia, 46.

Stratford de Redcliffe, Lord, 228 , 231 (see Canning).

Sudan, the, 206.

Suez Canal, 6, 21.

Suez Canal shares, 298.

Suez, Isthmus of, 213.

Suleiman I, Sultan, 78, 256; Empire of, 89 .

Suleiman II, 97.

Suleiman, the Magnificent, 4, 6 .

Suleiman Pasha, 39.

Suvaroff, Marshal, 142.

Syria, 34, 139, 206, 217, 218; conquered by Turks, 77 ; France and, 6 ; Napoleon and, 152.

Tanzimat, the 222.

Tchataldja, 399 .

Temesvar, 121.

Tewfik Pasha, 383.

Thiers, A., 214.

Thracians, the, 44.

Timour the Tartar, 60 .

Tirnovo, Patriarchate of, 290.

Todleben, Colonel von, 239.

Tököli, Emmerich, 108.

Trade rontes, ancient, 19.

Trajan, Emperor, 44, 254.

Transylvania, 105, 114, 439; conquered by Turks, 81 .

Treaties:

Adrianople, 10, 164, 199.

Akerman. 164, 194.

Amiens, 154.

Azor, 5.

Belgrade, 125, 256.

Berlin, (1878) 13, 302.

Bucharest, (1812) 6, 169, 258;

(1913) 33, 51, 410 .

Carlowitz, 4, 114, 256. 
Constantinople, (1479) 74.

Crespy, 86.

Finkenstein, 158.

Jassy, 6, 146.

Kutschuk-Kainardji, 6, 135, 228.

Lausanne, (1912) 390.

London, (1827) 194 ; (1832) 10, 199 ; (1840) 11 ; (1841) 11, 21 ; (1863) 329 ; (1871) 251 ; (1913) $33,406$.

Paris, (1856) 245.

Passarowitz, 121, 256.

Pressburg, 156.

Pruth, 119.

San Stephano, 13, 296, 363.

Sistova, 146.

Sitvatorok, 100.

Szegeddin, 62.

Tilsit, 165.

Unkiar-Skelessi, 11, 209, 215, 219.

Vasvar, 104.

Vienna, (1815) 170.

Westphalia, 101.

Zurawno, 106.

Trebizond, 75 ; Empire of, 42.

Trentino, 344 .

Trieste, 170, 344 .

Trikoupis, Charilios. 322, 333, 391.

Triple Alliance (1788), 6, 143.

Triple Alliance (1882), 346.

Tripoli, 388.

Tunis, 386.

Turco-Egyptian War (1832), 206.

Turco-Egyptian War (1839), 212.

Turco-Italian War (1911), 389.

Turco-Serb War (1876), 293.

Turkey, reforms in (1839), 222 ; scheme for partition of (1781), 139.

Ukraine, the, 106.

Ukraine, Cossacks of the, 105.
Urosh, Stephen, 52.

Uskub, 400 .

Valona, 412.

Varna, 237. See Battles.

Vasco de Gama, 20.

Vassos, Colonel, 335, 337.

Venetian Republic, 42, 74, 76, 85, 98.

Venice, 120,156 ; rule of, in Morea, 181; war with Turks (1645-1718), 101.

Venizelos, Eleftherios, 338, 393, 395, $409,435,438,441$.

Vergennes, 131 .

Victoria, Queen, 235, 317 ; Empress of India, 298.

Vienna, note (1853), 233 ; 'Four Points of', note, 241 ; siege of, (1529) 80 ; (1683) 110.

Villencuve, Marquis de, 125.

Wahabites of Arabia, 205.

Wallachia, 122, 125, 134, 135, 137, 139, 157, 165, 199.

War, European, of $1914,17$.

Wellington, Duke of, 10, 190, 191, 197.

Wied, Prince William of, 416.

William II, German Emperor, 15, $342,347,419,429,443$.

William Il at Constantinople, 354 .

William II at Damascus, 355.

William II at Jerusalem, 355.

Williams, General Fenwick, 244.

Yenishehr, 38.

Young Turks, 16, 359, 369.

Young Turks, revolution, 382.

Zaimis, M., 339, 370.

Zapolya, John, 80.

Zips, County of, 133. 



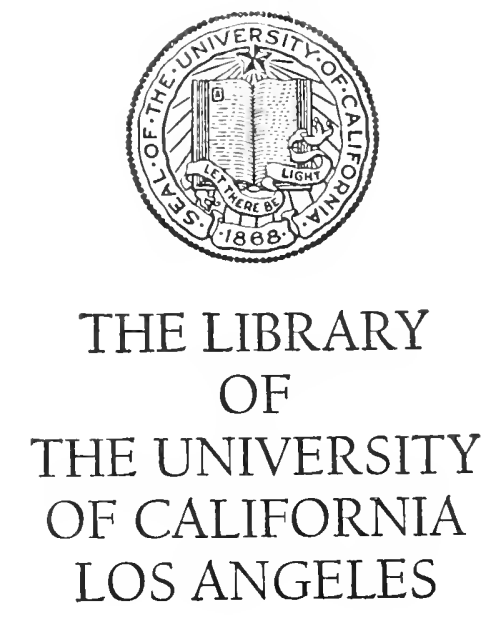

FROM THE LIBRARY OF

FRANK J. KLINGBERG

I'armiott, J.A. P.

The Fastern Guevtion Uxford

oJarendon Tress, 1917

$456 \mathrm{pp}$. 
